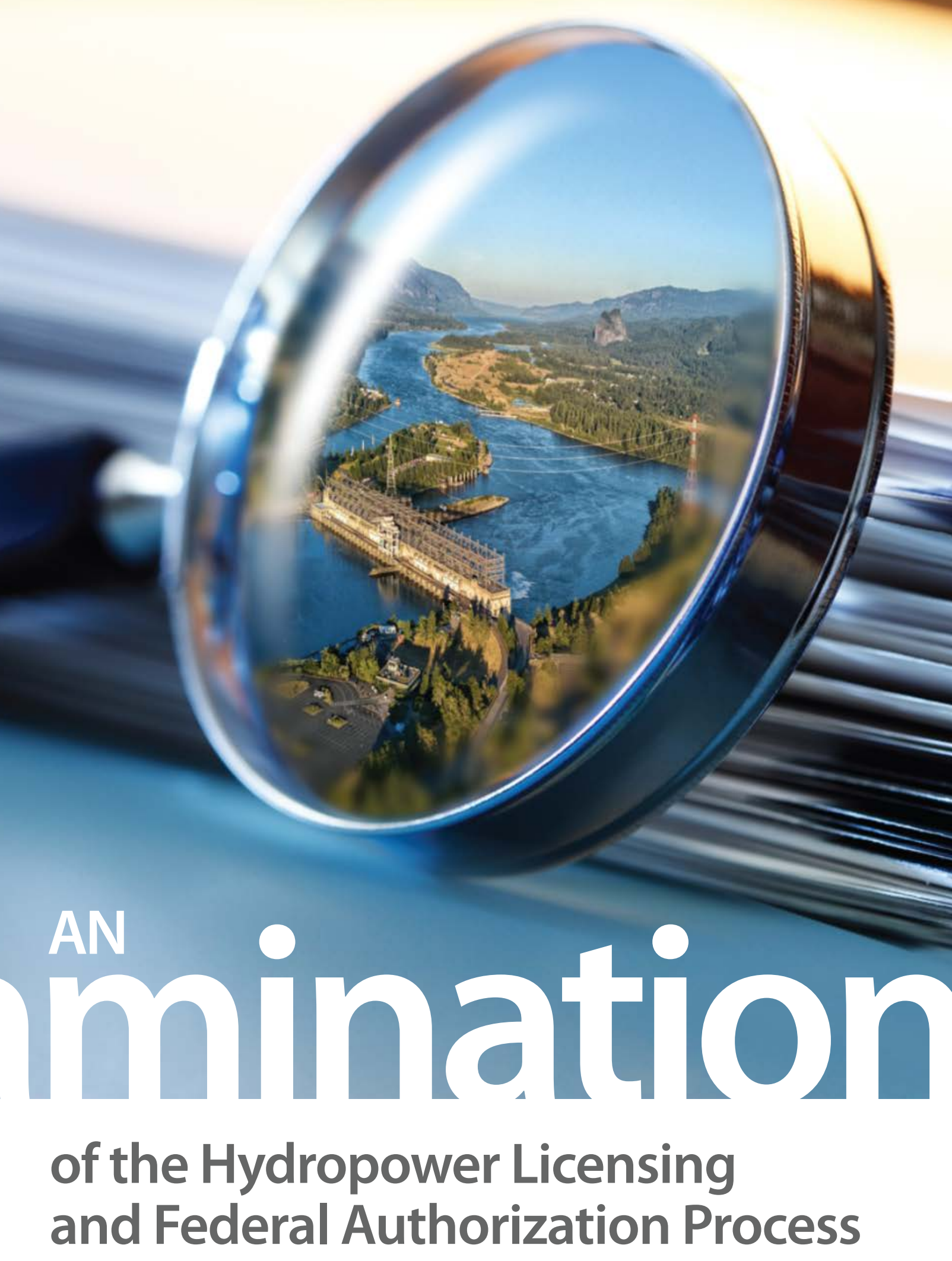




\title{
An Examination of the Hydropower Licensing and Federal Authorization Process
}

\author{
Aaron Levine, ${ }^{1}$ Brenda Pracheil, ${ }^{2}$ Taylor Curtis, ${ }^{1}$ \\ Ligia Smith, ${ }^{1}$ Jesse Cruce, ${ }^{1}$ Matt Aldrovandi, ${ }^{2}$ \\ Christa Brelsford, ${ }^{2}$ Heather Buchanan, ${ }^{1}$ Emily Fekete, ${ }^{1}$ \\ Esther Parish, ${ }^{2}$ Rocio Uria-Martinez, ${ }^{2}$ Megan Johnson, ${ }^{2}$ \\ and Debjani Singh ${ }^{2}$
}

1 National Renewable Energy Laboratory

2 Oak Ridge National Laboratory

\author{
Suggested Citation \\ Levine, Aaron, Brenda Pracheil, Taylor Curtis, Ligia Smith, Jesse Cruce, Matt Aldrovandi, \\ Christa Brelsford, Heather Buchanan, Emily Fekete, Esther Parish, Rocio Uria-Martinez, \\ Megan Johnson, and Debjani Singh. An Examination of the Hydropower Licensing and \\ Federal Authorization Process. Golden, CO: National Renewable Energy Laboratory. \\ NREL/TP-6A20-79242. https://www.nrel.gov/docs/fy22osti/79242.pdf.
}

NREL is a national laboratory of the U.S. Department of Energy Office of Energy Efficiency \& Renewable Energy Operated by the Alliance for Sustainable Energy, LLC
Technical Report

NREL/TP-6A20-79242

October 2021

This report is available at no cost from the National Renewable Energy Laboratory (NREL) at www.nrel.gov/publications. 


\section{NOTICE}

This work was authored in part by the National Renewable Energy Laboratory, operated by Alliance for Sustainable Energy, LLC, for the U.S. Department of Energy (DOE) under Contract No. DE-AC36-08GO28308. Funding provided by the U.S. Department of Energy Office of Energy Efficiency and Renewable Energy Water Power Technologies Office. The views expressed herein do not necessarily represent the views of the DOE or the U.S. Government.

This report is available at no cost from the National Renewable Energy Laboratory (NREL) at www.nrel.gov/publications.

U.S. Department of Energy (DOE) reports produced after 1991 and a growing number of pre-1991 documents are available free via www.OSTI.gov.

NREL prints on paper that contains recycled content. 


\section{Foreword}

To provide insights on project methodology and gather perspectives on our research findings and analysis, we worked extensively with a Stakeholder Working Group (SWG). The SWG comprised hydropower licensing experts representing a cross section of stakeholder groups with often diverse perspectives reflective of their role in the authorization process.

SWG member selection was based on the following criteria:

- Knowledge of the organization and the interests they represent

- Direct hydropower licensing experience

- Commitment to consider the other diverse interests involved in hydropower licensing.

The following is a list of SWG member agencies and organizations that participated in this project:

- Federal Energy Regulatory Commission

- National Oceanic and Atmospheric Administration Fisheries

- National Park Service

- United States Army Corps of Engineers

- United States Fish and Wildlife Service

- United States Forest Service

- Natural Resources Defense Council, Inc.

- Association of Clean Water Administrators

- Idaho Governor's Office of Energy and Mineral Resources

- Association of Fish and Wildlife Agencies

- California State Water Resources Control Board

- New York State Department of Environmental Conservation

- North Carolina Wildlife Resources Commission

- Penobscot Nation

- Bureau of Indian Affairs

- Natural Resources Defense Council, Inc.

- Hydropower Foundation

- Hydropower Reform Coalition

- American Whitewater

- Water and Power Law Group PC

- National Hydropower Association

- Gomez and Sullivan

- Pacific Gas and Electric

- Southern Company

- Eagle Creek Renewable Energy

- Rye Development

SWG members participated in a series of in-person meetings and webinars during the 3-year course of this project. SWG members had the following review responsibilities: research methodology, key findings of the report, and draft chapters as they were developed. Most 
importantly, the SWG members provided important input and strategic guidance as results were presented and drafted throughout the project. Although SWG perspectives are captured in this report as appropriate, the analyses, conclusions, and key messages presented herein are solely those of the National Renewable Energy Laboratory and Oak Ridge National Laboratory and not based on SWG consensus.

The National Renewable Energy Laboratory and Oak Ridge National Laboratory thank the SWG members for their time and contributions to the project. 


\section{Acknowledgments}

The authors gratefully acknowledge the U.S. Department of Energy Office of Energy Efficiency and Renewable Energy Water Power Technologies Office for its funding support. We thank Kearns \& West for their guidance and stakeholder facilitation support. We also thank the following reviewers and editors for their time and expertise: Alejandro Moreno, Jennifer Garson, Tim Welch, Corey Vezina (U.S. Department of Energy); Al LiVecchi, Gian Porro, Dan Bilello, Kristen Ardani, Sheri Anstedt, Kelly Dwyer, John Frenzl (National Renewable Energy Laboratory); Paul Matson, Carly Hansen, and Brennan Smith (Oak Ridge National Laboratory). 


\section{List of Acronyms}

ACHP

AIR

ALP

BA

BIA

BLM

$\mathrm{BO}$

BOR

CAA

cfs

CRMP

CWA

CZMA

DEC

DEQ

DNR

DOD

DOE

DOI

EA

ECPA

EIS

EPA

ESA

EU

FERC

FONSI

FPA

FWCA

GAO

HPMP

IAA

IFIM

ILP

IOU

MPE

NEPA

NGO

NHPA

NOAA Fisheries

NOI

NPS

NPDES

NRC

NREL
Advisory Council on Historic Preservation additional information request

Alternative Licensing Process

biological assessment

Bureau of Indian Affairs

U.S. Bureau of Land Management

biological opinion

U.S. Bureau of Reclamation

Clean Air Act

cubic feet per second

cultural resources management plan

Clean Water Act

Coastal Zone Management Act

Department of Environmental Conservation

Department of Environmental Quality

Department of Natural Resources

U.S. Department of Defense

U.S. Department of Energy

U.S. Department of the Interior

environmental assessment

Electric Consumers Protection Act of 1986

environmental impact statement

U.S. Environmental Protection Agency

Endangered Species Act

European Union

Federal Energy Regulatory Commission

finding of no significant impact

Federal Power Act

Fish and Wildlife Coordination Act

U.S. Government Accountability Office

Historic Properties Management Plan

Impact Assessment Act [Canada]

instream flow incremental methodology

Integrated Licensing Process

investor-owned utility

Ministry of Petroleum and Energy [Norway]

National Environmental Policy Act of 1969

non-governmental organization

National Historic Preservation Act

National Oceanic and Atmospheric Administration Fisheries

notice of intent

National Park Service

National Pollutant Discharge Elimination System

Nuclear Regulatory Commission

National Renewable Energy Laboratory 
NVE

OLA

ORNL

PA

PAD

PME

REA

RHA

ROW

SARA

SEC

SHPO

SPLAT

SWRCB

THPO

TLP

TERA

USACE

USFS

USFWS

VANR

VNRC

WDE

WQC

WVDEP
Norwegian Water Resources and Energy Directorate

off-license agreement

Oak Ridge National Laboratory

programmatic agreement

pre-application document

protection, mitigation, and enhancement

ready for environmental analysis

Rivers and Harbors Act of 1899

right-of-way

Species At Risk Act [Canada]

Swedish Environmental Code

State Historic Preservation Office

Stanislaus Planning Action Team

State Water Resources Control Board [California]

Tribal Historic Preservation Office

Traditional Licensing Process

tribal energy resources agreement

U.S. Army Corp of Engineers

U.S. Forest Service

U.S. Fish and Wildlife Service

Vermont Agency of Natural Resources

Vermont Natural Resources Council

Washington Department of Ecology

water quality certification

West Virginia Department of Environmental Protection 


\section{Executive Summary}

Permitting and regulation are necessary to ensure hydropower projects (both original and relicensed) comply with statutory requirements and address multiple stakeholder priorities that consider a range of factors, including water quality, species protection, cultural resource impacts, and recreation. Although hydropower projects provide benefits to society, they also have impacts on freshwater ecosystems and the communities that depend on them, which must be taken into account during the licensing process. The time involved in acquiring a license for an individual hydropower project can be highly variable and lead to increased project licensing costs, risks, and uncertainties. In part, this variability is the result of a regulatory structure that has evolved over time to include multiple approvals and compliance requirements administered by the Federal Energy Regulatory Commission (FERC), U.S. Army Corp of Engineers, federal land management agencies, federal and state resource agencies, and Indian tribes.

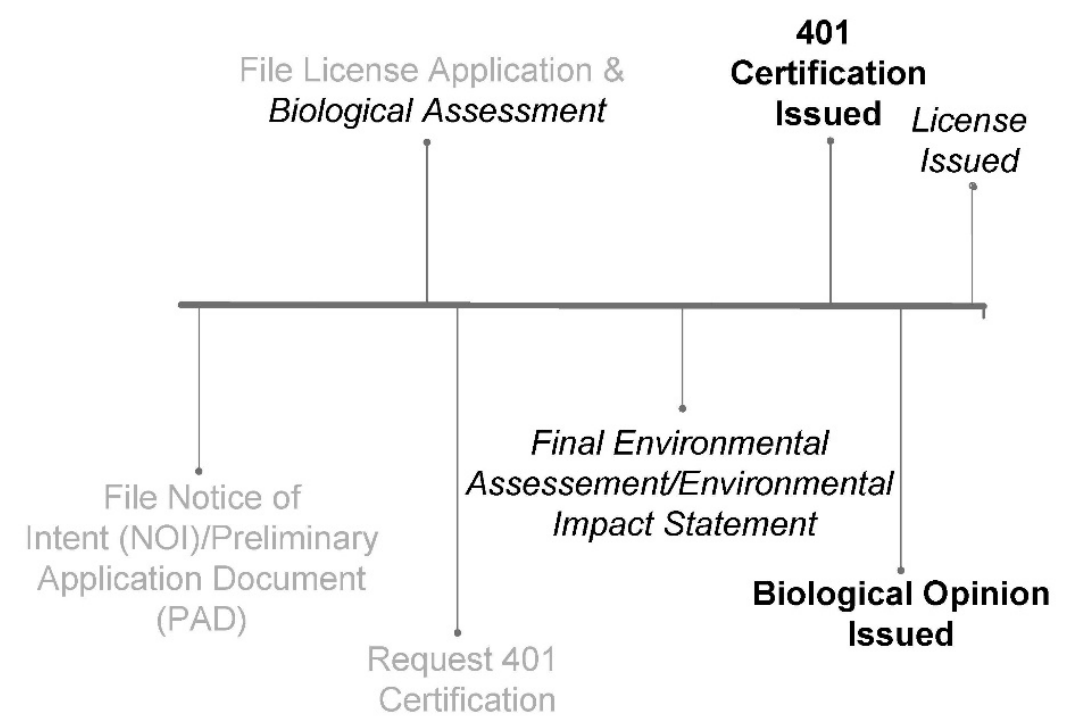

Figure ES1. Simplified hydropower licensing timeline including steps initiated by the license applicant (gray), steps initiated by the Federal Energy Regulatory Commission (black italics), and steps completed by other federal or state agencies (black bold). The license applicant requests the Clean Water Act Section 401 Certification, but the state water quality authority analyzes the water quality impacts and issues the certification. Where threatened or endangered species are potentially impacted, under the Endangered Species Act, the U.S. Fish and Wildlife Service and/or NOAA Fisheries analyze species impacts and issue a Biological Opinion and Incidental Take Statement stating whether the project is likely to jeopardize a federally listed species or result in the destruction or adverse modification of critical habitat of a listed species.

For context, as used in this report, a license to construct and operate an unconstructed (or previously unlicensed) hydropower project is referred to as an original license, while a license to continue operating an existing hydropower project is referred to as a new license (hereinafter relicense) (FERC 2017). FERC hydropower licenses may be issued for a term of 30-50 years; however, in 2017 FERC issued a policy statement setting 40 years as the default license term length for most hydroelectric projects under FERC's jurisdiction (16 U.S.C. 808(e); 161 FERC 61,078). ${ }^{1}$ Hydropower licensing begins with the pre-filing stage prior to a license applicant filing

\footnotetext{
${ }^{1}$ For projects located at or that use the head created by federal dams, the default licensing terms is 50 years.
} 
a final license application (FERC 2017). The pre-filing stage varies by license process type, but generally requires some level of stakeholder engagement to identify issues and gather information, which informs the eventual final license application and associated National Environmental Policy Act (NEPA) review process (FERC 2017). The first formal filing required as part of the hydropower licensing process is a notice of intent (NOI) that the license applicant intends to file a license application and a pre-application document (PAD) ${ }^{2}$ that describes the project and its potential effect on environmental, cultural, and recreational resources (FERC 2017). When relicensing an existing project, the licensee must file the NOI and PAD between 5 and 5.5 years of the current license's expiration date (FERC 2017). Beginning in July 2005, the default FERC licensing process is the Integrated Licensing Process (ILP) (18 C.F.R. § 5.3(a)(2)). However, at the same time as the NOI/PAD filing, the license applicant may also request to use one of the non-default license process types - either the Traditional Licensing Process (TLP) or the Alternative Licensing Process (ALP) (FERC 2017; 18 C.F.R. § 5.3(a)(2)). FERC must approve the request to use the TLP or the ALP before the license applicant can use a non-default licensing process (18 C.F.R. $\S 5.3(\mathrm{a})(2)$ ). A complete description of the hydropower licensing and federal authorization process, including the roles and responsibilities of each of these stakeholders, is included in Chapter 2.

This report presents the results of our examination of the hydropower licensing and federal authorization process, including quantitative and qualitative analyses of licensing and approval timelines, project attributes that may influence those timelines, and their combined effect on costs and risks to developers. In addition, this report highlights the positive outcomes that result from these processes, specifically the environmental measures (i.e., the protection, mitigation, and enhancement [PME] measures) that result from the licensing and federal authorization process. This study will support policymakers and regulators at the federal and state levels as well as other hydropower industry stakeholders (e.g., utilities, developers, consultants, trade associations, non-governmental organizations [NGOs]) by informing discussions helpful to individual license proceedings and policies affecting efficiencies within the hydropower licensing and federal authorization process. This report does not propose any specific recommendations to alter the current hydropower licensing and authorization process. Instead, it provides an evaluation of the current federal regulatory process to allow decision makers to identify areas that need reform.

Although the authors of this study are indebted to the project's Stakeholder Working Groupmade up of hydropower stakeholders with a cross section of perspectives who provided valuable feedback - the conclusions and analysis provided herein are those of the National Renewable Energy Laboratory and Oak Ridge National Laboratory and not those of the Stakeholder Working Group.

\footnotetext{
2 The PAD requirement was added by a rule published August 25, 2003, that went into effect October 23, 2003 (Hydroelectric Licensing Under the Federal Power Act, 68 Fed. Reg. 51070, 51075 (Aug. 25, 2003) (codified at 18 C.F.R. pts. 2, 4, 5, 9, 16, 375, and 385)).
} 
The report is divided into the following series of chapters, which provide both quantitative and qualitative analysis:

- Chapter 1 introduces the study; provides varied perspectives on the hydropower licensing process from industry, agency, and NGO stakeholders; and includes descriptions of previous studies analyzing hydropower licensing timelines and costs.

- Chapter 2 provides a comprehensive overview of the hydropower licensing and federal authorization process, including the jurisdictional roles of federal, state, and tribal agencies under federal law. In addition, Chapter 2 includes a comparison of the U.S. hydropower regulatory framework and other types of energy and water infrastructure in the United States, and a comparison between the U.S. hydropower licensing process to those in three other top hydropower-producing countries: Canada, Norway, and Sweden. Key findings of this chapter include:

- All infrastructure project types reviewed in the United States and in other western countries aim to protect the same resource concerns and potential impacts (e.g., water quality, species, cultural resources, recreation).

- Hydropower licensing under the Federal Power Act (FPA) is unique compared to other infrastructure projects in the United States in that FPA Section 4(e) requires equal consideration of developmental and non-developmental values.

- United States hydropower licensing involves more agencies and stakeholder engagement requirements than other types of infrastructure in the United States or hydropower projects in other western countries.

- Chapter 3 describes the length of licensing timelines from beginning to end and the factors that influence licensing timeline length. Key findings of this chapter include:

- Overall, the average time from the beginning to the end of the licensing process was 6.7 years.

- Projects obtaining original licenses had less sensitive or complex cultural, social, and natural resource issues and had shorter licensing timelines than projects being relicensed by an average of 2.6 years.

- Chapter 4 examines the hydropower licensing process impact on costs, including a statistical analysis of factors related to costs that parallels the timeline analysis from Chapter 3. Chapter 4 also includes a summary of applicant submitted licensing cost information in final license application documents to analyze these licensing costs and compare these costs against other project attributes (e.g., license process type, license type, size, presence of endangered species). Key findings of this chapter include:

- Relicensing had higher reported licensing costs than original licenses.

- Longer timelines are related to higher reported costs for a relicense but there was no relationship between timeline and cost for original licenses.

○ The licensing process selected by the applicant influenced the reported licensing costs. Projects using the ALP had the highest mean costs and the highest variability, followed by projects using the ILP and then the TLP. 
- Despite larger projects having higher licensing costs overall, smaller projects on average had higher licensing costs under a costs/kilowatt $(\mathrm{kW})$ metric.

- Chapter 5 summarizes environmental measures that result from the hydropower licensing process. The descriptions of environmental measures outline the environmental license conditions included in hydropower licenses that are designed to address potential impacts to cultural, social, recreational, and natural resources. Key findings of this chapter include:

- Species protection measures including biodiversity, fish passage, habitat, and water quality measures were most commonly listed in the database, accounting for $48 \%$ of PME measures.

- Hydrology PME measures accounted for $29 \%$ of the measures in the database.

- Non-ecological benefit PME measures accounted for $23 \%$ of measures in the database.

- Chapter 6 summarizes stakeholder perspectives on the licensing process. These perspectives were obtained through email elicitations and phone interviews from stakeholders involved in hydropower licensing with project development and social, cultural, and environmental interests. Key findings of this chapter include:

○ Stakeholders from across sectors (e.g., federal and state agencies, tribes, NGOs, development interests) identified the length and complexity of the licensing process as challenges.

- Across sectors, the relevance, accuracy, and availability of scientific data on project impacts were reported across sectors as the source of most disagreements during the licensing process.

- There is a lack of trust among some stakeholders, particularly where each sector views stakeholders with other perspectives as using the licensing process to forward their agenda without the intent to compromise.

- Chapter 7 compares the findings of this report to those of previous studies on hydropower licensing timelines and costs identified during our literature review.

- Both the statistical timeline analysis and the FERC 603 report found the Clean

Water Act 401 Water Quality Certification process was a driver of longer hydropower licensing timelines.

$\circ$ Both the statistical analysis and the FERC 603 report found settlement agreements to be associated with longer licensing timelines.

- The FERC 603 report included criteria not specifically analyzed in this report, including the association between additional information requests, National Historic Preservation Act Section 106 timelines, and timeliness of mandatory conditions from other agencies.

- Chapter 8 discusses the results from Chapters 2-7 in order to synthesize the findings and provide key takeaways regarding the U.S. hydropower licensing and federal authorization process. 


\section{Key Report Findings}

The key findings of our report are synthesized in Chapter 8 and, at a high level, include the following:

\section{Length and Complexity of the Licensing Process Is Challenging for All Stakeholder Sectors, Including Regulatory Agencies}

The average length of an original $(5.0+2.9$ years $)$ or relicense $(7.6+3.3$ years $)$ process constitutes a relatively long-term time and monetary investment by all sectors of the hydropower community. ${ }^{3}$ Responses to email elicitations and phone interviews with stakeholders from all sectors point to turnover and limited bandwidth among state and federal agency staff and NGOs as primary sources of these challenges. Specifically, these responses indicated that new or inexperienced staff taking over in the middle of a licensing/authorization process; agencies not having adequate staff resources to complete work in a timely fashion; and NGOs, especially those with a local focus, not having adequate staff bandwidth or technical expertise to stay engaged throughout the licensing process.

Some states noted that they waived Clean Water Act 401 authority due to inadequate funding/staff bandwidth and cited duplicity of this process with other authorization processes needed for hydropower licensing.

\section{Longer Licensing Timelines Are Associated With Greater Environmental Complexity}

The potential for environmental impacts from hydropower development and operation to significant or sensitive cultural or natural resources, endangered species, critical habitat, and recreation may require more time and consideration to determine how best to evaluate and mitigate these impacts. Indicators of environmental complexity such as larger dams, longer Clean Water Act Section 401 certifications or Endangered Species Act Section 7 consultations, the presence of endangered species, the need for an environmental impact statement NEPA document, and the presence of a settlement agreement can all prolong the process. In addition, projects that have not been relicensed since the passage of environmental protection legislation, such as amendments to the FPA, tend to have longer NOI/PAD to license issuance timelines.

Moreover, our analyses found that relicensing timelines were 2.6 years longer than those for original licenses. We have interpreted shorter original licensing timelines as an effect of reduced environmental complexity at these sites because projects with original licenses included in the timeline analyses only rarely had the indicators of environmental complexity listed above. Projects being relicensed, in contrast, often had one or more indicators of environmental complexity. This suggests that the site selection process for original licenses involves choosing sites where hydropower development will have fewer impacts, which played an important role in reducing their licensing timelines.

\footnotetext{
${ }^{3}$ For context, per FERC regulations (18 C.F.R. $\left.\S 5.5\right)$ the anticipated time for relicensing a project is 5 to 5.5 years, as determined by when a licensee must file the NOI/PAD to relicense the hydropower project.
} 


\section{Licensing Costs Generally Disproportionately Impact Both Smaller Projects and Projects Seeking Original Licenses}

The burden of costs associated with licensing disproportionately impacts smaller projects, even though regression analyses showed that smaller projects have shorter timelines. Despite larger projects having higher licensing costs overall, smaller projects on average had higher licensing costs under a costs $/ \mathrm{kW}$ metric, likely due to fixed costs associated with various aspects of license application development and associated studies. The lower costs/kW associated with the licensing process for larger projects suggests that these larger projects can absorb licensing costs through economies of scale in a way that is not possible for smaller projects.

In addition, although the costs are higher and the timelines are longer for projects being relicensed than for those seeking original licenses, projects being relicensed can continue to generate electricity during the licensing process. Projects seeking original licenses, in contrast, must wait until the license is issued and the project is constructed before generating electricity/revenue. There may also be a viability component for projects seeking original licenses in that projects exceeding a certain cost are not viable and are abandoned during the licensing process. Approximately $90 \%$ of projects seeking original licenses abandon pursuit of a license prior to license issuance, but how the environmental complexity and/or costs associated affected abandonment of these projects is not known (Uria-Martinez et al. 2020). However, protracted relicensing proceedings for existing hydropower projects can also drive up costs and increase project economic uncertainty through compounding interest costs over long time periods coupled with an unclear risk profile.

\section{Environmental Study Negotiations Are a Source of Stakeholder Disagreement in the Licensing Process}

Stakeholders from across sectors described the process of determining project impacts and deciding how to study them as a primary source of disagreement in the licensing process. There are frequent and sometimes protracted disagreements on what environmental impacts are relevant to the project and whether existing information or studies conducted by outside organizations are appropriate to inform protection, mitigation, enhancement, or other measures. License applicants feel that the value of existing studies is often too quickly discounted, while agencies feel that existing information presented by license applicants may not be current or does not use the best available science. License applicants also expressed frustration when agencies proposed new studies because the applicants believed the time and money spent on those studies could be better spent planning and executing mitigation measures. NGO stakeholders felt disadvantaged relative to other stakeholders in the licensing process because of limited access to information or expertise.

Stakeholders from all sectors described a lack of trust among stakeholders with different perspectives, particularly during the study negotiation process. Stakeholders from across sectors suggested that other stakeholders involved in the study negotiation process used positional bargaining to achieve their sector or group mission without any real intent to compromise. This lack of trust can lead to further communication breakdowns that can prolong study negotiations. 
Incomplete and/or Inadequate Information for Authorization Processes Results in Longer Licensing Timelines and Disagreements Among Some Stakeholders

State water quality authorizations required in the hydropower licensing process are completed within statutorily required time frames in $64 \%$ of the case studies, while $17 \%$ of state water quality certifications took longer than 2 years. Anecdotal information suggests that incomplete and/or inadequate information is one reason for longer timelines in this process. Similarly, documentation provided by National Oceanic and Atmospheric Administration Fisheries and the U.S. Fish and Wildlife Service states that receipt of incomplete packages of information needed to begin the Endangered Species Act Section 7 Consultation process leads to additional months to years added to licensing proceedings. However, it is important to note that what constitutes complete and adequate information for these authorizations is also a source of disagreement between agencies and some license applicants.

\section{The ILP Had the Shortest and Least Variable Timeline of the Three Licensing Processes}

The ILP may minimize the time spent in the licensing process and provide less variability, which equates to greater timeline certainty compared to other licensing processes. Specifically, although there was no statistical difference in the NOI/PAD to license issuance timeline among the three license processes (alternative licensing process: $6.7+2.8$ years, ILP: $6.0+1.5$ years, traditional licensing process: $6.9+4.0$ years; values mean + standard deviation), the ILP has significantly shorter post-filing timelines $(2.6+0.2$ years $)$ than projects using the TLP $(4.2+0.4$ years) as well as overall greater certainty (i.e., lower standard deviation values) in the licensing timeline compared to the alternative licensing process and the traditional licensing process. The ILP "schedule-driven" process keeps the licensing timeline from taking longer than necessary and may be advantageous to projects seeking original licenses or those proposing new construction that may not begin until the license is issued. On the other hand, the schedule of the ILP can create challenges related to tight timelines and turnaround times for comments and the meeting of other licensing milestones.

\section{Compared to Other Types of Energy and Water Infrastructure, Both Nationally and Internationally, the U.S. Licensing Process Includes More Federal and State Agencies As Well As Opportunities for Stakeholder Engagement}

In comparing the statutory and regulatory frameworks governing hydropower development to other energy and non-energy infrastructure project types, all of the infrastructure projects we analyzed required the consideration of project impacts to biological resources, cultural resources, and the environment (including water quality as applicable) prior to project construction and operation. Although most infrastructure projects must consider potential impacts to the environment through applicable resource protection statutes and the NEPA review process, hydropower licensing is distinct from other types of infrastructure projects (including nuclear energy and interstate natural gas pipelines) in that the FPA requires additional opportunities for federal and state agencies to weigh into the licensing process, specifically through Sections 4(e), 10(a), 10(j), and 18. In addition, Section 4(e) requires FERC to give equal consideration to the benefits of development and environmental concerns, a standard that other infrastructure projects included in this review were not subject to. 
Some members of our Stakeholder Working Group highlighted that, in part, these differences between how other types of energy and non-energy infrastructure projects are regulated may be attributed to river systems being a public trust resource and the scale of impacts associated with hydropower development compared to the other infrastructure project types analyzed in this report. See Appendix A for a description of common environmental impacts associated with each type of energy and non-energy infrastructure project analyzed in this report based on a review of NEPA documents.

In comparing the statutory and regulatory framework for hydropower projects in the United States, Canada, Norway, and Sweden, we found that all require that a project proponent to consider project impacts on biological resources, water quality, cultural resources, and the general environment. However, as noted above, the United States hydropower licensing and authorization process requires the participation and engagement of up to 11 federal agencies as well as state agencies throughout the licensing and authorization process. By comparison, the other countries analyzed in this report only required a handful of federal agencies to participate in the authorization process (e.g., the authorization process in Norway may involve the participation of 5-6 federal agencies) or their authorization processes were primarily delegated to provincial or local jurisdiction with minimal federal involvement. Again, the distinction with respect to the number of agencies involved in the United States hydropower authorization process is due in part to FPA requirements under Sections 4(e), 10(a), 10(j), and 18.

In addition, although Canada, Sweden, and Norway all provide some opportunities for agency, tribal, and public engagement within their hydropower licensing processes, in the United States, the hydropower authorization process includes more opportunities for tribal and public engagement through built-in statutory requirements (e.g., NEPA and the FPA require federal and state agency participation as well as tribal and public engagement). By contrast, in Sweden and Norway, the public may participate informally or formally by consulting with a project proponent or engaging in stakeholder meetings, hearings, or appeal processes. Recent amendments to Canadian federal statutes require that project proponents engage with the public and Aboriginal peoples throughout the environmental assessment process. This distinction may result from the fact that in the United States, multiple statutes involved in the hydropower licensing process require agency, tribal, and public engagement.

\section{Environmental Measures Resulting From the Licensing Process Are Important to Ecosystems and Stakeholders}

The hydropower licensing and federal authorization process can lead to improved environmental outcomes and stakeholder relationships. Settlement agreements may result in greater environmental benefits than would have been otherwise realized, such as expanded fish passage across dams in a watershed, increased protections for species of concern, improvements in recreational facilities, and other benefits that are difficult to quantify in a statistical analysis. Examples of common protection, mitigation, and enhancement measures are summarized here and presented more fully in Chapter 5 and the case studies in Appendix C. 


\section{Table of Contents}

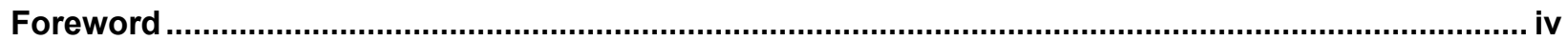

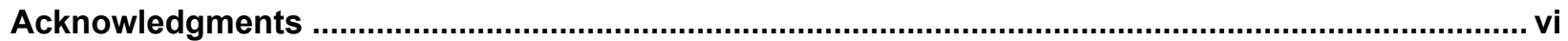

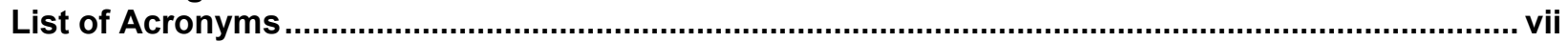

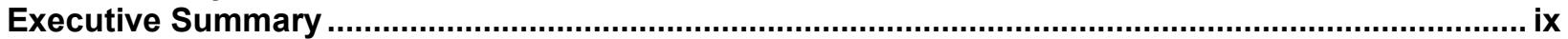

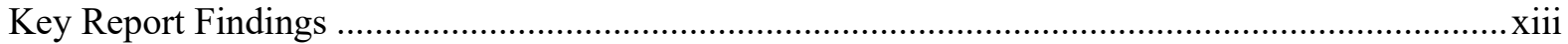

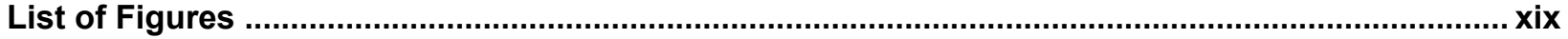

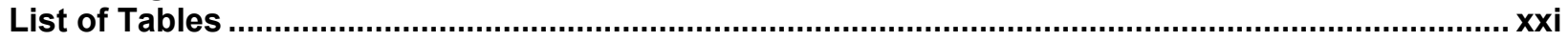

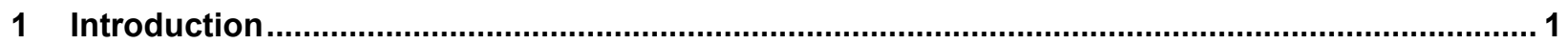

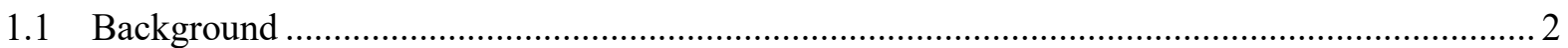

1.2 Road Map for Remaining Chapters of the Report.......................................................... 6

2 Hydropower Regulatory Overview and Comparison ............................................................. 8

2.1 U.S. Hydropower Licensing and Federal Authorization Overview .......................................... 9

2.2 Summary of the Hydropower Licensing Process ............................................................... 9

2.3 Hydropower Project Potential Environmental Impacts ........................................................... 13

2.4 Required Licenses, Permits, and Authorizations to Construct and Operate Non-Federal

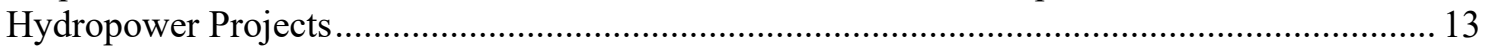

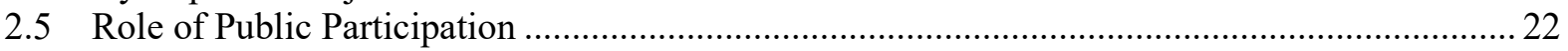

Role of Settlement Agreements in Hydropower Licensing Process..................................................... 22

2.6 Comparison of Hydropower Regulation to Other Types of Infrastructure Projects in the United

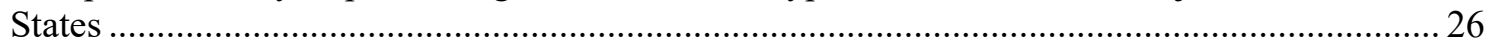

2.7 Comparison of Hydropower With Other Infrastructure Projects .......................................... 32

2.8 Comparison of Hydropower Regulation in the United States to International Jurisdictions ...... 35

2.9 International Hydropower Comparison Discussion ............................................................. 39

3 Statistical Description and Analysis of Hydropower Licensing Timelines ............................... 41

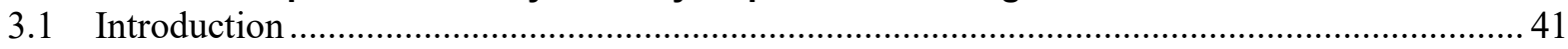

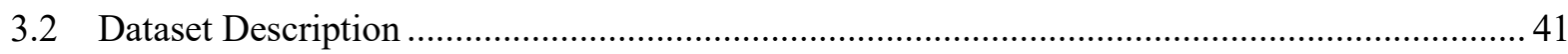

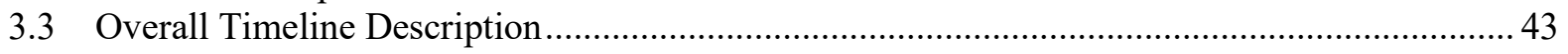

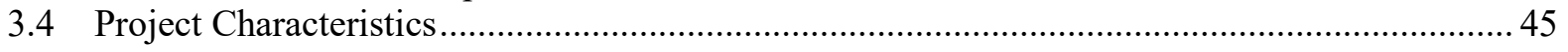

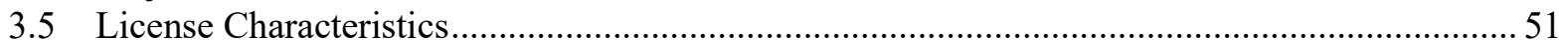

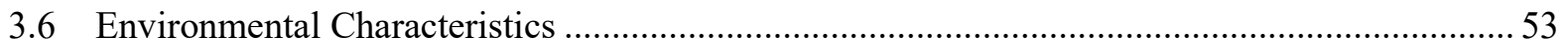

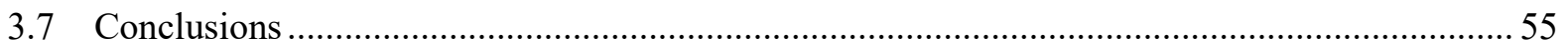

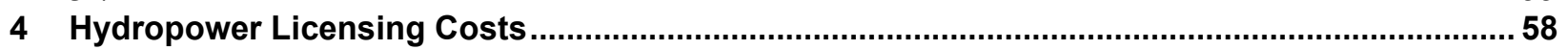

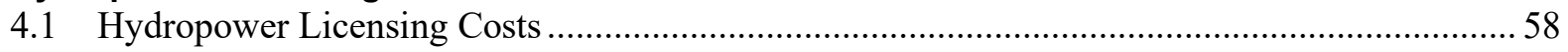

5 Environmental Measures Resulting From the Hydropower Licensing and Federal Authorization

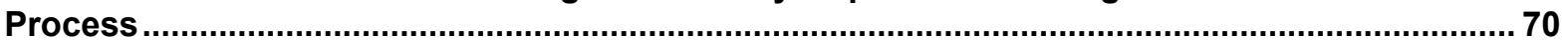

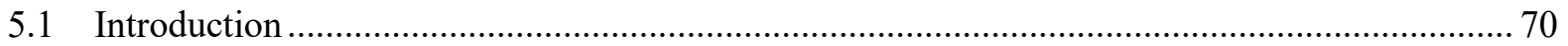

5.2 Summary of Existing Information on Mitigation Measures.................................................... 70

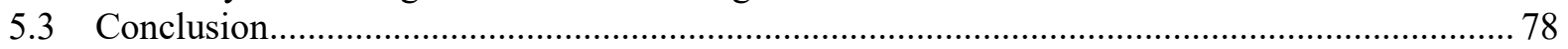

6 Stakeholder Elicitations on Licensing Process Challenges ….................................................... 79

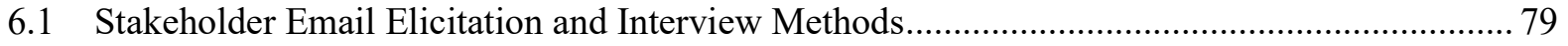

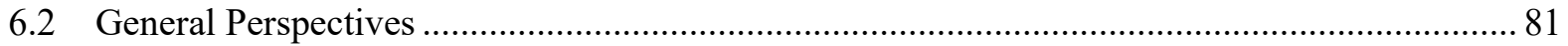

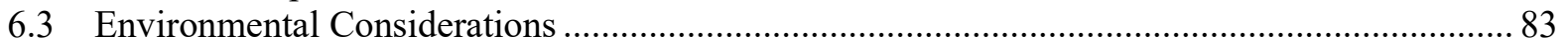

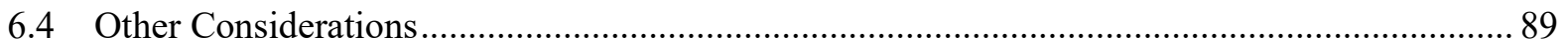

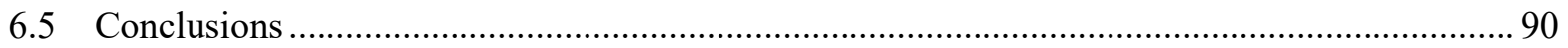

7 Comparison to Previous Reports Analyzing the Hydropower Licensing and Federal

Authorization Process ............................................................................................................. 92

7.1 Summary of Previous Federal Energy Regulatory Commission Licensing Reports.................. 92

7.2 Summary of Other Hydropower Licensing Reports.............................................................. 97

7.3 Comparison of Previously Published Federal Energy Regulatory Commission, Academic, and

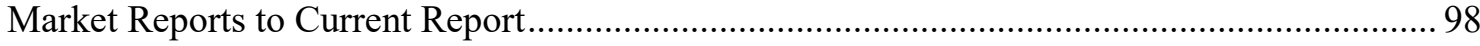


8 Hydropower Licensing and Federal Authorization Process: Conclusions and Discussion .... 100

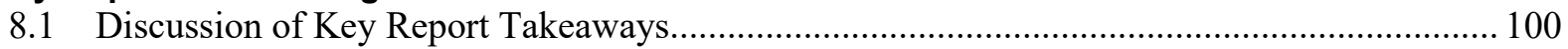

8.2 Future Focus Areas for Additional Research and Collaboration............................................. 105

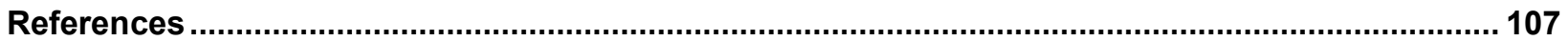

Appendix A.1. Infrastructure Project Review: Environmental Impacts and Regulatory Approvals for Infrastructure Projects in the United States ...................................................................... 120

Appendix A.2. International Hydropower Project Review: Regulatory Approvals for Hydropower

Projects in Canada, Sweden, and Norway ...................................................................... 146

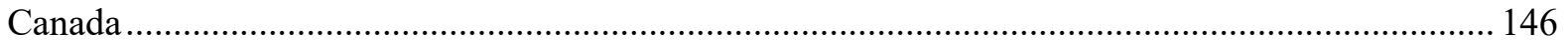

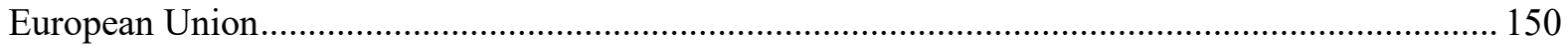

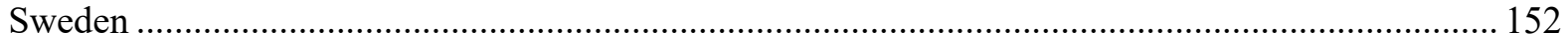

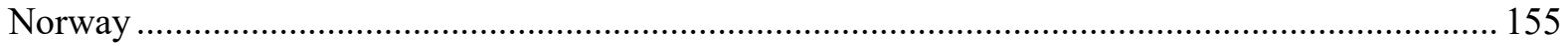

Appendix B. Supplemental Information and Results for Statistical Analyses Used in Timeline and

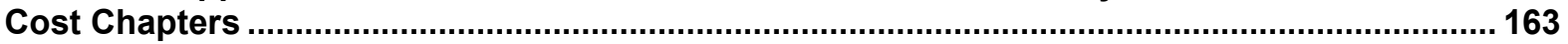

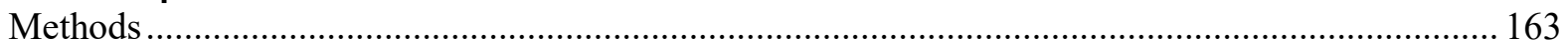

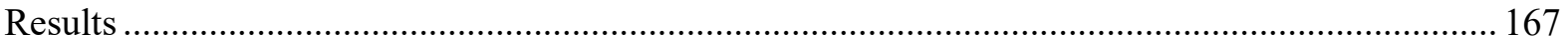

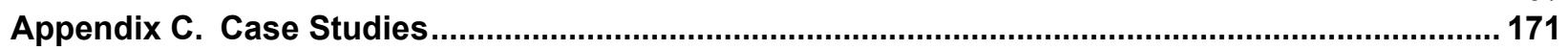

A-Drop Hydroelectric Project, Hydrodynamics, Inc. - P-12549 Case Study ................................. 172

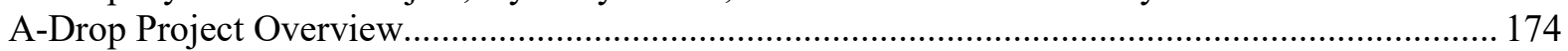

Badger-Rapide Croche Hydroelectric Project - P-2677 (Relicensing) Case Study …....................... 178

Badger-Rapide Croche Project Overview ................................................................................. 179

Carver Falls Hydroelectric Project - P-11475 (Licensing) Case Study ........................................... 186

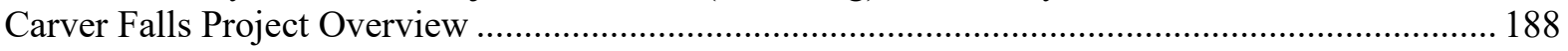

Emeryville Project—P-2850 (Relicensing) Case Study ............................................................ 196

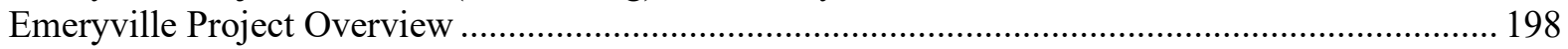

Loup River Hydroelectric Project - P-1256 (Relicensing) Case Study .......................................... 203

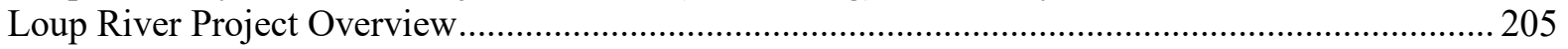

Merwin Hydroelectric Project - P-935 (Relicensing) Case Study ................................................. 212

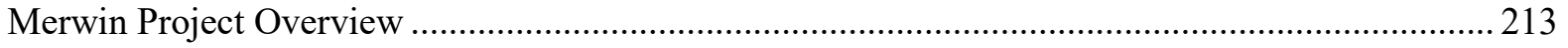

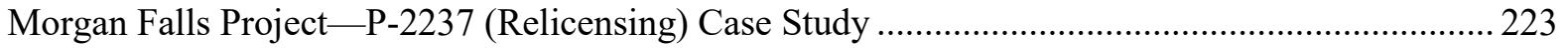

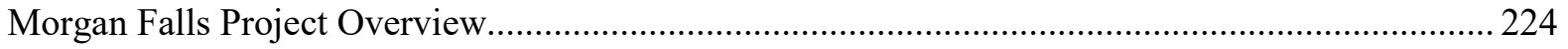

City of Wadsworth, Ohio - RC Byrd Hydroelectric Project - P-12796 Case Study ......................... 230

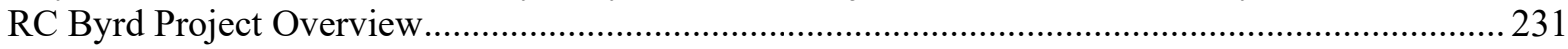

Spring Gap- Stanislaus Project—P-2130 (Relicensing) Case Study ............................................. 239

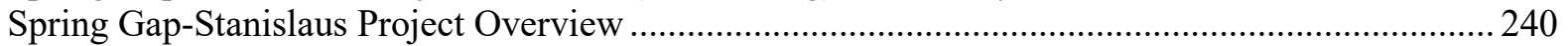

Waterbury Hydroelectric Project - P-2090 (Relicensing) Case Study .............................................. 249

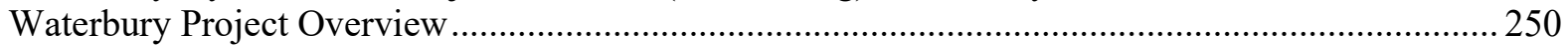

Appendix D. Detailed Mitigation Measure Information From Environmental Measures Chapter... 256 Appendix E. Summary and Overview of the Federal Energy Regulatory Commission's Legislative,

Regulatory, and Policy Recommendations From the 2001603 Report .................................... 261 


\section{List of Figures}

Figure ES1. Simplified hydropower licensing timeline including steps initiated by the license applicant (gray), steps initiated by the Federal Energy Regulatory Commission (black italics), and steps completed by other federal or state agencies (black bold). The license applicant requests the Clean Water Act Section 401 Certification, but the state water quality authority analyzes the water quality impacts and issues the certification. Where threatened or endangered species are potentially impacted, under the Endangered Species Act, the U.S. Fish and Wildlife Service and/or NOAA Fisheries analyze species impacts and issue a Biological Opinion and Incidental Take Statement stating whether the project is likely to jeopardize a federally listed species or result in the destruction or adverse modification of critical habitat of a listed species.

Figure 1. Example alternative, integrated, and traditional licensing process timelines. License applicants are responsible for milestones in black text, other stakeholders are responsible for milestones in green text, and FERC is responsible for milestones in blue text........................ 12

Figure 2. Federal hydropower authorization roles ....................................................................21

Figure 3. Locations of each individual facility in the 107 projects in the licensing timeline dataset from the Existing Hydropower Assets Database (Johnson et al. 2021)

Figure 4. Example timeline showing relative order of licensing milestones for hypothetical projects using the a) alternative, b) integrated, and c) traditional licensing processes where the license applicant is responsible for milestones in black text, other stakeholders are responsible for milestones in green text, and FERC is responsible for milestones in blue text.

Figure 5. Boxplot summarizing the time taken by segments of the hydropower licensing and federal authorization process for the dataset of 107 projects. Segments include filing of the notice of intent/pre-application document to license issuance (NOI to $\mathrm{LI}$ ), filing of NOI/PAD to final license application (NOI to LA), LA to LI, LA to ready for environmental analysis (REA), REA to final National Environmental Policy Act environmental impact statement or environmental analysis (EIS), FERC request for Section 7 Consultation to issuance of biological opinion or letter of concurrence, licensee request for state 401 water quality certification to issuance or waiver of water quality certification. Box boundaries show first and third quartiles, the band inside the box shows the median, vertical lines show largest and smallest values within 1.5 times the interquartile range, and dots show points larger than 1.5 times the interquartile range.

Figure 6. Mean \pm standard deviation of notice of intent (NOI) to license issuance timelines for projects used in this study in the eastern and western United States. Orange dots represent the location of hydropower facilities from the dataset of 107 projects and the size of the dot represents the length of the NOI to license issuance timeline.

Figure 7. Scatterplot of project nameplate capacity (MW) versus timeline from license NOI filing to license issuance for original (orange) and relicensed (blue) projects. No relationship exists between project size (nameplate capacity) and license timeline length without considering license type.

Figure 8. Boxplots summarizing the time taken by segments of the hydropower licensing and federal authorization process for the 107 projects in our dataset. Segments include filing of the notice of intent/pre-application document to license issuance (NOI to $\mathrm{LI}$ ), filing of NOI/PAD to final license application (NOI to LA), and license application to license issuance (LA to LI). Boxplot components are described in Figure 4.

Figure 9. Scatterplots showing time (years) from (from top down) final license application (LA) to ready for environmental analysis (REA), REA to final NEPA document, ESA Section 7 Consultation, and CWA Section 401 water quality certification versus time (years) between notice of intent/pre-application document (NOI/PAD) and license issuance for projects seeking a relicense (blue) or original license (orange). Vertical line in $\mathbf{4 0 1}$ plots denote the 1-yr requirement for issuance of the $\mathbf{4 0 1}$ certificate by the state water quality authority..

Figure 10. (a; left) Log-log scale scatterplots of reported licensing costs in $2019 \$$ and project generating capacity in $\mathrm{kW}$. (b; right) The size-agnostic $\$ / \mathrm{kW}$ metric and project generating capacity. 
Note: The three high-cost outliers are circled in red in both plots; the low-cost/high $\$ / \mathrm{kW}$ outlier is not visible on either plot (i.e., at $0.25 \mathrm{~kW}|\$ 5,400| \$ 21,600 / \mathrm{kW}$ ). Non-generating projects that reported licensing costs are also not shown.

Figure 11. Map showing Tier 1 mitigation measure categories from the Schramm, Bevelhimer, and DeRolph (2016) database by FERC licensing region. Bars show the relative numbers of mitigations for each mitigation category and region. Actual numbers of mitigations depicted in bars are in Table 1.

Figure 12. Bull trout (Salvelinus confluentus), Cougar Reservoir. Photo from Garth Wyatt, DOE ......

Figure 13. Freedom Falls Hydropower Project, Freedom, Maine. Photo from Andy Baumgartner, DOE.

Figure 14. Salmon fishing in front of Wanapum Dam, Columbia River, Washington. Photo from Dave Dempsey, DOE

Figure 15. Stakeholder elicitation process and timeline showing Waves $A$ through $D$ and the structure of Rounds 1, 2, and 3 of each wave

Figure $\mathrm{C} 1$. Timeline of some major licensing milestones..

Figure C2. Map indicating major landmarks and features mentioned in project license. Arrow indicates direction of flow.

Figure C3. Timeline of some major licensing milestones.

Figure C4. Map indicating major landmarks and features mentioned in project license. Arrow indicates direction of flow.

Figure C5. Timeline of some major licensing milestones.

Figure C6. Map indicating major landmarks and features mentioned in project license. Arrow indicates direction of flow.

Figure C7. Timeline of some major licensing milestones.

Figure C8. Map indicating major landmarks and features mentioned in project license. Arrow indicates direction of flow.

Figure C9. Timeline of major points in relicensing of Loup River Hydroelectric Project P-1256 ... 204

Figure C10. Map of Loup River Hydroelectric Project P-1256 showing the bypassed reaches of the Loup and Platte rivers in Nebraska and the Loup River Power Canal. All hydropower generation takes place within the Loup River Power Canal. The area of inset map shows the location of the project in reference to the continental United States. Arrows indicate direction of flow.

Figure C11. Timeline of some major licensing milestones

Figure C12. Map indicating major landmarks and features mentioned in project license. Arrow indicates direction of flow.

Figure C13. Timeline of some major licensing milestones....................................................... 223

Figure C14. Map indicating major landmarks and features mentioned in project license. Arrow indicates direction of flow.

Figure C15. Timeline of some major licensing milestones

Figure C16. Map indicating major landmarks and features mentioned in project license. Arrow indicates direction of flow.

Figure C17. Timeline of some major licensing milestones.

Figure C18. Map indicating major landmarks and features mentioned in project license. Arrow indicates direction of flow.

Figure C19. Timeline of some major licensing milestones

Figure C20. Map indicating major landmarks and features mentioned in project license. Arrow indicates direction of flow. 


\section{List of Tables}

Table 1. Regulatory and Permitting Requirements for Hydropower Licensing and Authorization in the United States

Table 2. Regulatory and Permitting Requirements Across Energy Infrastructure Project Types in the United States

Table 3. Regulatory and Permitting Requirements Across Energy Infrastructure Project Types in

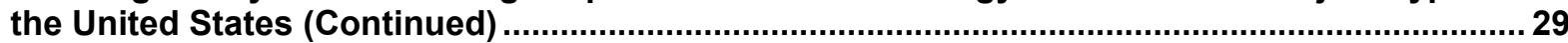

Table 4. International Hydropower Development Summary Table .................................................. 36

Table 5. Years from Beginning to End of Step in Licensing Process ................................................ 46

Table 6. Mean + Standard Deviation (N) Years From Notice of Intent/Preapplication Document to License Issuance

Table 7. Hydropower Projects Being Relicensed for Which FERC Has Determined That Section 401 Water Quality Certification or Endangered Species Act Section 7 Consultation Have Been Pending for 1 Year as of August 2019

Table 8. Application Development Cost Estimate Reporting ........................................................ 59

Table 9. Statistical Results for the Entire Sample Dataset, With Outliers Removed .........................61

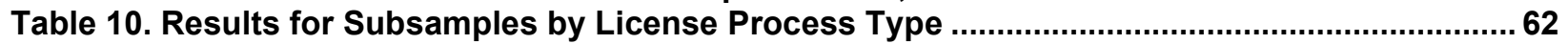

Table 11. Results for Subsamples by License Type: Original or Relicense .....................................62

Table 12. Results for Subsamples by Whether the Project Licensing Used a Settlement Agreement or Not

Table 13. Results for Subsamples by Whether Endangered Species Were Present and Thus Required Additional Protection Measures and/or Studies.

Table 14. Results for Subsamples by National Environmental Policy Act Review Type (Environmental Assessment [EA] or Environmental Impact Statement [EIS])

Table 15. Results for Subsamples by Project Type...................................................................65

Table 16. Results for Subsamples by Whether the Project Included Fishway Prescriptions or Not 66

Table 17. Results for Subsamples by Licensee Type: Investor-Owned Utility, Private Non-Utility, or Publicly Owned Utility

Table 18. Summary of Reported Licensing Cost Variability Across Licensing Process Attributes Outliers are excluded from these results. Total $\mathrm{N}=82$ for each category.

Table 19. Tallies of Tier-1 (gray highlight) and Tier-2 (bold) Protection, Mitigation, and Enhancement Measures from FERC Licenses From the Database Described by Schramm, Bevelhimer, and DeRolph (2016) by FERC Licensing Region, As Described in Chapter 3........71

Table 20. Taxonomy of Stakeholder Sectors

Table 21. Total Number of Respondents Including All Three Rounds in Each Wave by Geographic Region.

Table 22. Summary of Respondents for Each Wave by Stakeholder Sector ...................................81

Table 23. Characteristics of Projects Licensed or Exempted From Licensing in More Than 2 Years and 2 Years or Less

Table A1. Infrastructure Comparison Table ................................................................................. 135

Table A2. International Hydropower Development Comparison Table ........................................... 160

Table B1. A Priori Hypotheses and Predicted Direction of Effect of Variables on FERC Licensing Timelines

Table B2. Variables Extracted from Licensing Documents From 107 U.S. Federal Energy Regulatory Commission (FERC) Licensed Projects Used in Analyses Including the Variable Name and Variable Description. Italicized Variables Are Response Variables and Bolded Variables Are Included as Predictor Variables in Linear Regression Analyses.

Table B3. Summary of Results of Regression Analyses for Factors Hypothesized to be Related to NOI/PAD to License Issuance Timelines. All Models Also Included a Term for License Type. Model p-values Shown Have Been Adjusted for Multiple Comparisons Using the BenjaminiHochberg Procedure.

Table B4. Summary of Results of Regression Analyses for Factors Hypothesized to be Related to Licensing Costs Based on Variables Hypothesized to Influence Licensing Timelines. Model pvalues Shown Have Been Adjusted for Multiple Comparisons Using the Benjamini-Hochberg (B-H) Procedure. The B-H p-values Presented here Only Included Analyses Conducted for the 
Cost Chapter Including Regressions With Cost and Cost/kW.

Table C1. Description of Project Key Characteristics and Timeline Lengths..................................172

Table C2. Description of Project Key Characteristics and Timeline Lengths.................................. 178

Table C3. Description of Project Key Characteristics and Timeline Lengths................................ 186

Table C4. Description of Project Key Characteristics and Timeline Lengths................................. 196

Table C5. Description of Project Key Characteristics and Timeline Lengths...................................203

Table C6. Description of Project Key Characteristics and Timeline Lengths.................................212

Table C7. Description of Project Key Characteristics and Timeline Lengths....................................223

Table C8. Description of Project Key Characteristics and Timeline Lengths................................ 230

Table C9. Description of Project Key Characteristics and Timeline Lengths................................... 239

Table C10. Description of Project Key Characteristics and Timeline Lengths ................................. 249

Table D1. Tallies of Tier-1 (Gray Highlight and Bold), Tier-2 (Blue Highlight and Italics), and Tier-3

(Bold) Protection, Mitigation, and Enhancement Measures from FERC Licenses From the

Database Described by Schramm, Bevelhimer, and DeRolph (2016) by FERC Licensing

Region As Described in Chapter 3 and Are As Follows: Mid-Atlantic (MA), Midwest (MW), New

England (NE), Northwest (NW), South, and West.

Table D2. Number of Mitigation Measures by Tier 1 Category for Species Mentioned in FERC

Licenses 259

Table E1. FERC's 2001 Legislative Recommendations 261

Table E2. FERC's 2001 Regulatory and Policy Recommendations 


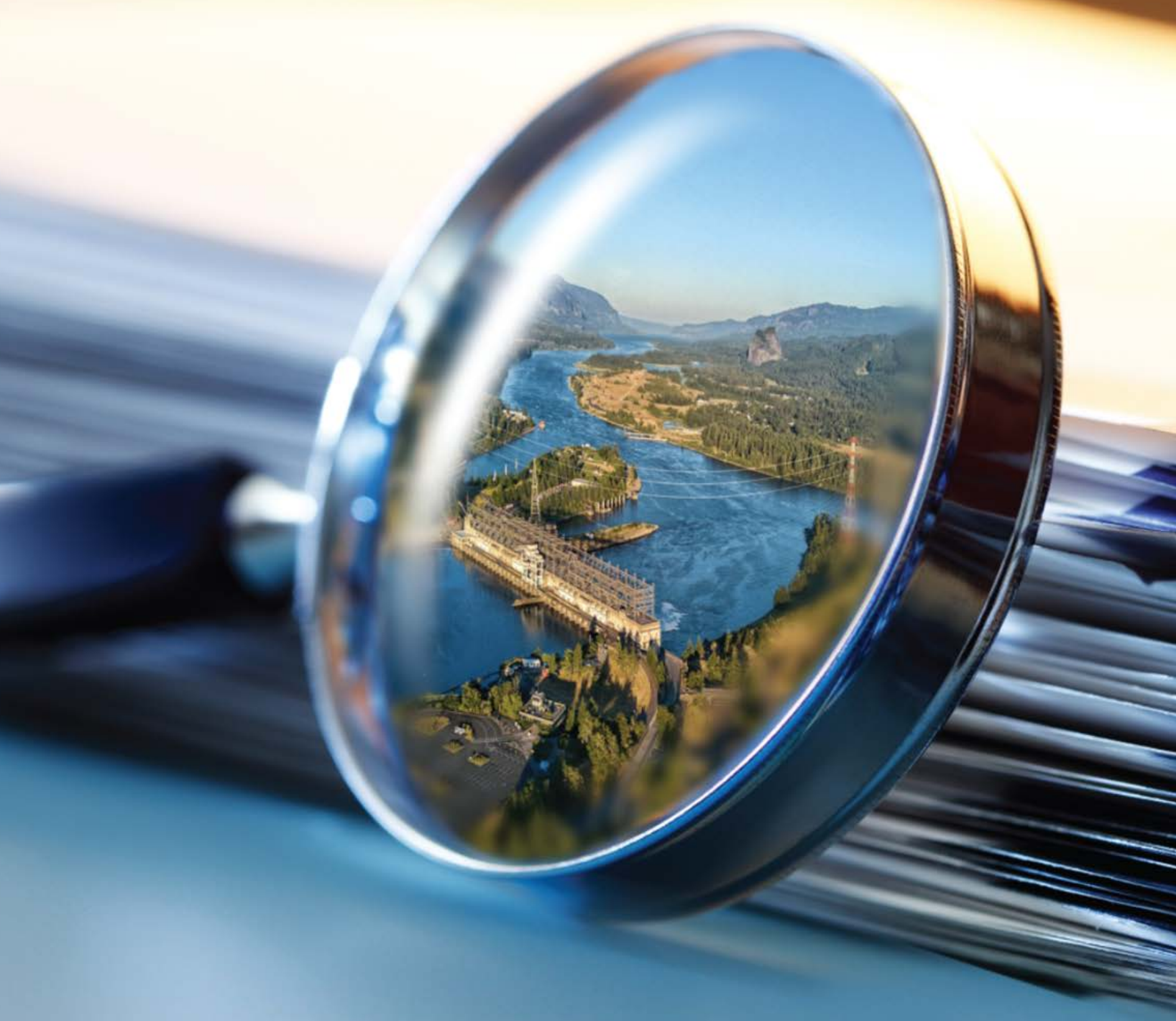

AN EXAMINATION OF THE HYDROPOWER LICENSING AND FEDERAL AUTHORIZATION PROCESS

\section{Introduction}




\section{Introduction}

Permitting and regulation are necessary to ensure hydropower projects (both original and relicensed) comply with statutory requirements and address multiple stakeholder priorities that consider a range of factors, including water quality, species protection, cultural resource impacts, and recreation. Although hydropower projects have benefits to society, they also have impacts on freshwater ecosystems and the communities that depend on them, which must be taken into account during the licensing process. However, the time involved in acquiring a license for an individual hydropower project can be highly variable and lead to increased project licensing costs, risks, and uncertainties. In part, this variability is the result of a regulatory structure that has evolved over time to include multiple approvals and compliance requirements administered by the Federal Energy Regulatory Commission (FERC), U.S. Army Corp of Engineers (USACE), federal land management agencies, federal and state resource agencies, and Indian tribes.

The hydropower industry has expressed concern that uncertainty and variability within the U.S. hydropower licensing and federal authorization process may create risks, specifically those related to time and cost (Kern 2018; Sensiba, Swiger, and White 2018). Representatives of the hydropower industry, including staff and members of the National Hydropower Association (NHA), have opined on the impact of hydropower licensing costs and risks associated with timeline uncertainty. As one industry member stated in 2017 congressional testimony “...private investors in the power generation space find the length and complexity of hydropower's timeline difficult to manage" (Swaminathan 2017). For new hydropower projects, the costs associated with the engineering and construction are already expensive and delays in licensing a project that increase costs further could discourage future investment in hydropower (Kern 2018; Sensiba, Swiger, and White 2018). When faced with these factors, many investors choose to invest in other forms of generation with far shorter timelines and clearer risk assessments (Swaminathan 2017).

Protracted relicensing proceedings for existing hydropower projects can also drive up costs and increase project economic uncertainty through compounding interest costs over long time periods coupled with an unclear risk profile (Swaminathan 2017). According to the NHA in their 2017 congressional testimony, owners of small hydropower projects, particularly those in the northeast United States, expressed concern that the costs of relicensing may render some projects uneconomic and lead to additional hydropower license surrenders (Leahey 2017). On the other hand, some have suggested that although prolonged licensing decisions create additional costs and uncertainties, they also provide the benefit to licensees of postponing the implementation of new costly licensing requirements (Kosnik 2006). These new licensing requirements, such as installation of fish ladders, water quality improvements, and other conditions may lead to increased operating costs after FERC issues the new license (Kosnik 2006). However, these new licensing requirements may also produce beneficial outcomes for environmental, cultural, and recreational interests.

While multiple perspectives may exist among resource agencies and non-governmental organizations (NGOs), some have expressed a desire to improve the efficiency of the hydropower licensing and federal authorization process, while also preserving resource agency's 
statutory authority and environmental protection objectives. At a 2018 congressional hearing focused on improving the hydropower licensing process, the then principal deputy director of the U.S. Fish and Wildlife Service (USFWS) expressed a desire to make the licensing process more efficient, while making sure that conservation objectives for fish, wildlife, and habitat are taken into account (Sheehan 2018). Specifically, the USFWS viewed the licensing process as an opportunity to improve instream flow conditions at existing projects, protect fish from projectinduced injury and mortality, conserve threatened and endangered species, and provide fish passage (Sheehan 2018). However, the USFWS recognizes that to avoid delays, federal and state agencies must maximize their coordination and efficiency (Sheehan 2018). NGOs, including American Rivers, have also expressed a desire to improve hydropower licensing, but have opposed any changes viewed as limiting the application of the Endangered Species Act (ESA), Clean Water Act (CWA), or other measures limiting state or tribal sovereignty and the protection of fish, wildlife, or other natural resources (Irvin 2017). However, American Rivers acknowledged that there are improvements that can be made to a process that can be long and complex (Irvin 2017). Instead of curbing the authority of federal and state resource agencies and tribes, American Rivers has focused on increased communication and cooperation as the greatest area for improvement in the hydropower licensing process (Irvin 2017).

The lack of publicly available research and rigorous analysis into the cost, time, and risks associated with obtaining a FERC hydropower license may increase the issues of uncertainty and variability within the process. In addition, the environmental benefits associated with the outcomes of the licensing and federal authorization process warrant documentation to provide context to the cost and time associated with obtaining a hydropower license. As a result, this report analyzes the time, cost, benefits, and associated risks and uncertainties associated with obtaining a non-federal hydropower license and related federal authorizations to inform decision makers on the full range of issues and perspectives involved in the process.

\subsection{Background}

In the United States, non-federal hydropower development is governed primarily by the Federal Power Act (FPA), which authorizes FERC to issue preliminary permits, ${ }^{4}$ licenses, and exemptions from licensing ${ }^{5}$ (FERC 2017). FERC issues licenses to construct, operate, and maintain certain dams, water conduits, reservoirs, powerhouses, transmission lines, or other project works necessary and convenient for the development and improvement of navigation and for the development, transmission and use of power across, along, from, or in navigable waters of the United States (16 U.S.C. $§ 797(\mathrm{e})$ ). The authority provided to FERC under the FPA applies to all non-federal projects, regardless of who owns or manages the surrounding surface land (e.g., federal, state, private). A license to construct and operate an unconstructed

\footnotetext{
${ }^{4}$ Preliminary permits allow the permit holder to have priority for a hydroelectric site over any other applicants for four years, during which time the permit holder can conduct feasibility and environmental studies of the project site as well as prefiling stakeholder consultations (18 C.F.R. $\S 4.80$; FERC 2017a). During the term of the preliminary permit, which may be extended for up to four additional years with permission from FERC, the permit holder must submit 12-month progress reports to FERC that show progress and preparation toward filing a license application (18 C.F.R. $§ 4.80$; FERC 2017a). Preliminary permits are outside the scope of this report.

${ }^{5}$ Under certain specified criteria, a project may receive an exemption from FERC licensing as a qualifying conduit hydropower facility, a small conduit hydroelectric facility, or a small hydroelectric facility (16 U.S.C. $\S 832 \mathrm{a}(\mathrm{a}), 16$ U.S.C. $\S 823 \mathrm{a}(\mathrm{b}), 16$ U.S.C. $\S 2705)$. Exemptions from licensing are outside the scope of this report.
} 
hydroelectric power project or to operate a constructed but previously unlicensed hydroelectric power project is called an original license; a license to continue operating an existing hydropower project after the expiration of the initial license term is called a new license (hereinafter relicense) (FERC 2017). FERC hydropower licenses may be issued for a term of 30 50 years, but in 2017, FERC issued a policy statement setting 40 years as the default term length for most hydropower projects under FERC's jurisdiction (16 U.S.C. 808(e); 161 FERC 9 61,078). In addition to FERC, a number of other federal land management agencies, federal and state resource agencies, tribes, and members of the public play significant roles both directly in the FERC licensing process through issuance of mandatory terms and conditions or license recommendations as well as through other approvals required under federal law (e.g., ESA Section 7 Consultation, CWA Section 401 WQC [water quality certification]). A complete description of the hydropower licensing and federal authorization process, including the roles and responsibilities of each of these stakeholders, is included in Chapter 2.

The stakeholder-driven hydropower licensing and federal authorization process can be complex. Federal and state resource and land management agencies, Indian tribes, and the public may require or propose operational or environmental conditions for inclusion in the FERC license related to protection, mitigation, and enhancement (PME) of resources (e.g., energy, economic, societal, environmental) through the FPA and other regulatory processes (e.g., FPA, CWA 401 WQC, ESA Section 7 consultation), public comment, and negotiations. These PME measures may be incorporated as conditions to a FERC license through FERC's powers under the FPA or as required by federal statute. Under the FPA, FERC must balance energy and non-energyrelated values of measures recommended by stakeholders, as required by the Electric Consumers Protection Act of 1986 (ECPA). ECPA, among other changes to the FPA, amended Section 4(e) of the FPA to require FERC to give "equal consideration to the purposes of energy conservation; the protection, mitigation of damages to, and enhancement of, fish and wildlife (including related spawning grounds and habitat); the protection of recreational opportunities; and the preservation of other aspects of environmental quality" (16 U.S.C. $§ 797($ e) as amended). In addition, ECPA amended the FPA to require FERC to consult with affected federal and state resources agencies and Indian tribes.

Specifically, ECPA amended Section 10(a) of the FPA to provide an opportunity for resource agencies and affected Indian tribes to provide recommendations on how to make a hydropower project consistent with federal and state comprehensive plans for improving, developing, or conserving waterways affected by the project. ECPA also added Section 10(j) to provide an opportunity for the USFWS, the National Oceanic and Atmospheric Administration's National Marine Fisheries Service (NOAA Fisheries), and state fish and wildlife agencies to provide recommendations under the Fish and Wildlife Coordination Act to protect, mitigate damages to, and enhance fish and wildlife affected by development and operation of the hydropower project (16 U.S.C. $\S 803(a)$ and (j)). In this way, the hydropower licensing and federal authorization process offers an opportunity for a diverse suite of stakeholders such as development interests (e.g., project developers, utilities), NGOs, and representatives from federal, state, and tribal regulatory authorities and governments to work together towards mutually beneficial power and non-power objectives. 


\subsubsection{Previous Studies on Hydropower Licensing Timelines}

As is discussed in greater detail in Chapter 7, previous studies on hydropower licensing timelines are limited to specific criteria (e.g., relicensing, non-powered dam development, specific license process types) or are dated, which may limit the value of these studies for contemporary decision-making. However, a study dating back to the early 2000s highlighted a growing trend of more extended hydropower relicensing timelines (Kosnik 2006).

In 2006, Kosnik reviewed 222 hydropower relicensing proceedings from 1982-1998 and found that $27 \%$ of hydropower relicenses were not issued within a 5 -year period (assumed by Kosnick to be the anticipated length for licensing a project). Kosnik found that project size indicators, such as dam height, capacity in megawatts (MW), gross storage, and drainage area, correlate to longer relicensing timelines (Kosnik 2006). Kosnik also observed several reasons for longer relicensing timelines based on a FERC public docket review focused on intervenor comments, including indicators of "regulatory delays" from both power interests (i.e., licensees, power intervenors) and some (quasi) environmental interests (i.e., sportfishing and historical intervenors).

A 2017 "U.S. Hydropower Market Report" analyzed the length of time between license application and license issuance, but only reported statistics for non-powered dam projects. The study analyzed 53 non-powered dam projects with FERC dockets opened between 2000 and 2016 and found those projects had a median number of years from license application to license issuance of 2.5 years, but that time period ranged from 6 months to 7 years across the sample (Uría-Martínez et al. 2018).

Another 2017 study analyzed 24 hydropower projects (pumped storage, run of river, and conventional dams) relicensed between 2007 and 2012 using the Alternative Licensing Process (ALP) or Integrated Licensing Process (ILP). That study analyzed the impact of stakeholder collaboration on relicensing timelines but found no relationship between the two ${ }^{6}$ (Ulibarri 2017). Ulibarri found the mean timeline for the 24 projects to be approximately 5.9 years with a standard deviation of 1.5 years. In addition, Ulibarri found a positive association (i.e., longer timelines) between timeline length and the presence of aquatic endangered species as well as a positive association between timeline length and increased project size (i.e., megawatt capacity) (Ulibarri 2017).

Finally, FERC itself has reported on hydropower licensing timelines as part of congressionally mandated reports. Section 603 of the Energy Act of 2000 required FERC to undertake a comprehensive review of the FERC licensing procedures for hydroelectric projects to determine how to reduce the cost and time of obtaining a license under the FPA. Overall, FERC found that on average, the licensing process took 43 months (approximately 3.6 years) from the date of the filing of the final license application to receiving a license. In addition, FERC determined that the major sources of delay in licensing were a result of statutory procedures, which disperse decision-making responsibilities for required permits and authorizations among federal and state agencies independent of FERC proceedings. FERC noted that untimely processing of state WQC

\footnotetext{
${ }^{6}$ Timelines were measured using the notice of intent/pre-application document submittal date, the final license application submittal date, and the issuance of the license date.
} 
required by the CWA was the most common cause of delayed licensing proceedings (FERC 2001). Specifically, FERC staff analyzed the effect of untimely receipt of WQC in licensing delays by reviewing applications for WQCs filed between 1994 and 2000 (FERC 2001). FERC determined that $39 \%$ of applications $(65 / 167)$ filed during this period experienced WQC delays. Of the 39\%, 19 WQCs were eventually issued after a period exceeding 1 year had passed, 5 applications were dismissed for WQC related issues, and 41 had pending applications as of 2001. FERC noted that out of 129 licensing cases pending at the time of the report, 73 were held up from normal processing, and, of those 73, 71\% were held up by WQC issues (FERC 2001).

To determine the general factors influencing the timeliness of hydropower licensing and relicensing, FERC compared application processing timelines for license applications filed between 1980 and 1992 to applications filed between 1993 and 2000 (FERC 2001). FERC ultimately found that for applications filed between 1993 and 2000, the median time from application to issuance took 13 months longer than for applications filed between 1980 and 1992. FERC determined that the increased processing was attributable to the following factors: 1) a greater volume of applications, 2) post-application disputes over the scope of necessary studies, 3) FERC efforts to promote settlements, 4) a 1993 policy requiring the issuance of draft environmental assessments (EAs) for comment, 5) a 1994 policy requiring additional scoping procedures, 6) an increased number of joint National Environmental Policy Act of 1969 (NEPA) documents with other federal agencies, and 7) increased issuance of state WQC as opposed to waiver of certification (FERC 2001).

More recently, in 2017, FERC authored a second congressionally mandated report, the Report on the Pilot Two-Year Hydroelectric Licensing Process for Non-Powered Dams and Closed-Loop Pumped Storage Projects and Recommendations Pursuant to Section 6 of the Hydropower Regulatory Efficiency Act of 2013 (FERC 2017b). FERC's report reviewed 83 projects that received original licenses or small hydropower project exemptions ${ }^{7}$ from licensing as well as the 2-year pilot project being undertaken by FERC at the time, which had completed both pre and post-filing activities and received either an original license or an exemption from licensing between 2003 and 2016. The FERC report included 52 Traditional Licensing Processes (TLPs), 7 ILPs, and 4 ALPs and comprised 64 licenses, 19 exemptions, and the 2-year pilot project. FERC reported that the median time from notice of intent (NOI)/pre-application document (PAD) filing to license issuance was 3.34 years $^{8}$; the median time to receive an exemption was 1.86 years. In addition, FERC noted that $27 \%$ of the projects within the report received a license or exemption in 2 years or less, all of which used the TLP or ALP.

The 2017 FERC report also reviewed a number of project characteristics that may correlate with project licensing timelines, including project capacity (i.e., nameplate capacity in megawatts), CWA Section 401 compliance, ESA Section 7 compliance, NEPA compliance, National Historic Preservation Act (NHPA) compliance, and application quality as determined by the need for

\footnotetext{
${ }^{7}$ Under certain specified criteria, a project may receive an exemption from FERC licensing as a qualifying conduit hydropower facility, a small conduit hydroelectric facility, or a small hydroelectric facility (16 U.S.C. $§ 832 \mathrm{a}$ (a), 16 U.S.C. $\S 823 \mathrm{a}(\mathrm{b}), 16$ U.S.C. $\S 2705)$.

${ }^{8}$ FERC also reported on interim time frames, reporting that the median time from NOI/PAD filing to the final license application filing was 1.55 years and final license application filing to license issuance was 1.79 years (FERC 2017).
} 
additional information requests (AIRs) after filing the final license application. FERC found that $87 \%$ of the projects licensed in 2 years or less were $5 \mathrm{MW}$ or smaller, and all projects licensed in 2 years or less were smaller than $10 \mathrm{MW}$. Conversely, $40 \%$ of the projects with licensing timelines longer than 2 years were greater than $5 \mathrm{MW}$ and $25 \%$ were greater than $10 \mathrm{MW}$.

FERC reported that all of the projects licensed in 2 years or less (post-filing licensing time) received a WQC or waiver within 1 year; only $80 \%$ of the projects with licensing timelines longer than 2 years received a WQC or waiver within 1 year. FERC also found that $70 \%$ of projects licensed in less than 2 years required no ESA consultation (with only one project requiring formal consultation), but $53 \%$ of projects with licensing timelines greater than 2 years required ESA informal or formal consultation. FERC also reported that only $23 \%$ of projects licensed in less than 2 years had adverse effects on historic properties requiring a programmatic agreement (PA) or memorandum of agreement under the NHPA, but $37 \%$ of projects with licensing timelines longer than 2 years had adverse effects on historic properties. FERC determined that $100 \%$ of projects licensed in less than 2 years met all FERC-set deadlines for providing FPA 4(e) and/or Section 18 Fishway Prescriptions, but only 33\% of projects with licensing timelines longer than 2 years met FERC-set 4(e) deadlines and only $78 \%$ met FERC-set Section 18 Fishway Prescription deadlines. FERC found that the average NEPA EA took approximately 4 months for projects licensed in 2 or less years; EAs for projects with licensing timelines longer than 2 years averaged approximately 10 months.

Finally, FERC reviewed "application quality," as defined by the number of AIRs after license application filing, finding that $65 \%$ of projects licensed in 2 years or less had at least one AIR and $43 \%$ of projects required an AIR due to an application deficiency. Conversely, $87 \%$ of projects with licensing timelines longer than 2 years had at least one AIR and $67 \%$ of projects required an AIR due to an application deficiency.

\subsubsection{Previous Studies on Hydropower Licensing Costs}

We failed to identify any complete studies on hydropower licensing cost during our historical literature review. In the Section 603 Report, FERC touched on the costs associated with hydropower licensing, including license processing costs (FERC 2001). FERC determined that the cost to prepare TLPs compared to ALPs were approximately the same, with average application cost being about $\$ 2.3$ million. FERC noted that the costs of preparing a license application and implementing terms and conditions were relatively greater for smaller projects than large projects.

Another attempt to study licensing costs, which was completed by the U.S. Government Accountability Office (GAO) in 2001, found cost data inadequate, particularly as they pertain to costs by participant, project, and process step (GAO 2001). In addition, the $2001 \mathrm{GAO}$ report identified a need to identify why certain projects take longer and cost more to license than other projects, as well as why the time and costs to complete different steps in the licensing process vary by project or groups of similar projects (GAO 2001).

\subsection{Road Map for Remaining Chapters of the Report}

The analysis contained within this report could provide federal and state policymakers, federal and state regulators, and other hydropower industry stakeholders (e.g., utilities, developers, consultants, trade associations, NGOs) with quantitatively rigorous information to facilitate 
discussions and policy related to the licensing process, interagency coordination and collaboration, and increased efficiencies throughout the process. This report does not propose any specific recommendations to alter the current hydropower licensing and authorization process. Instead, this report seeks to provide an objective evaluation of the current federal regulatory process, timelines, costs, and benefits related to hydropower licensing and permitting approvals.

The remainder of this report is divided into a series of chapters, which provide both quantitative and qualitative data and analysis.

Chapter 2 includes a comprehensive overview of the hydropower licensing and federal authorization process. Chapter 2 includes federal, state, and tribal agency jurisdictional roles in hydropower licensing and regulatory authorizations under federal law.

In addition, Chapter 2 includes a comparison of the U.S. hydropower regulatory framework to other types of energy and water infrastructure in the United States and a comparison between the U.S. hydropower licensing process and the processes in three other top hydropower-producing countries: Canada, Norway, and Sweden.

Chapter 3 provides a statistical analysis of factors related to licensing timelines including information on licensing and federal authorization milestones and characteristics such as project attributes (e.g., type, size, mode of operation, number of facilities), license process type, various steps and authorizations in the licensing process, geopolitical variables (e.g., state, FERC licensing region), and environmental characteristics and complexity (e.g., presence of settlement agreement, EA, or environmental impact statement [EIS], presence of ESA species).

Chapter 4 examines hydropower licensing process on costs. Chapter 4 includes a summary of applicant submitted licensing cost information in final license application documents to analyze these licensing costs and compare these costs against other project attributes (e.g., license process type, license type, size, presence of ESA species).

Chapter 5 provides examples of common non-power benefits that result from the hydropower licensing process. Within the scope of this report, non-power benefits were determined to be the PME measures included in hydropower licenses and settlement agreements designed to address potential impacts to water quality, biological resources, cultural resources, and recreational opportunities among other more nuanced protective measures.

Chapter 6 summarizes stakeholder perspectives on the licensing process. These perspectives were obtained through email elicitations and phone interviews from stakeholders involved in hydropower licensing with project development and social, cultural, and environmental interests.

Chapter 7 compares the findings of this report to those of previous studies on hydropower licensing timelines and costs identified during our literature review.

Chapter 8 discusses the results from Chapters 2-7 in order to synthesize the findings and provide key takeaways regarding the U.S. hydropower licensing and federal authorization process. 


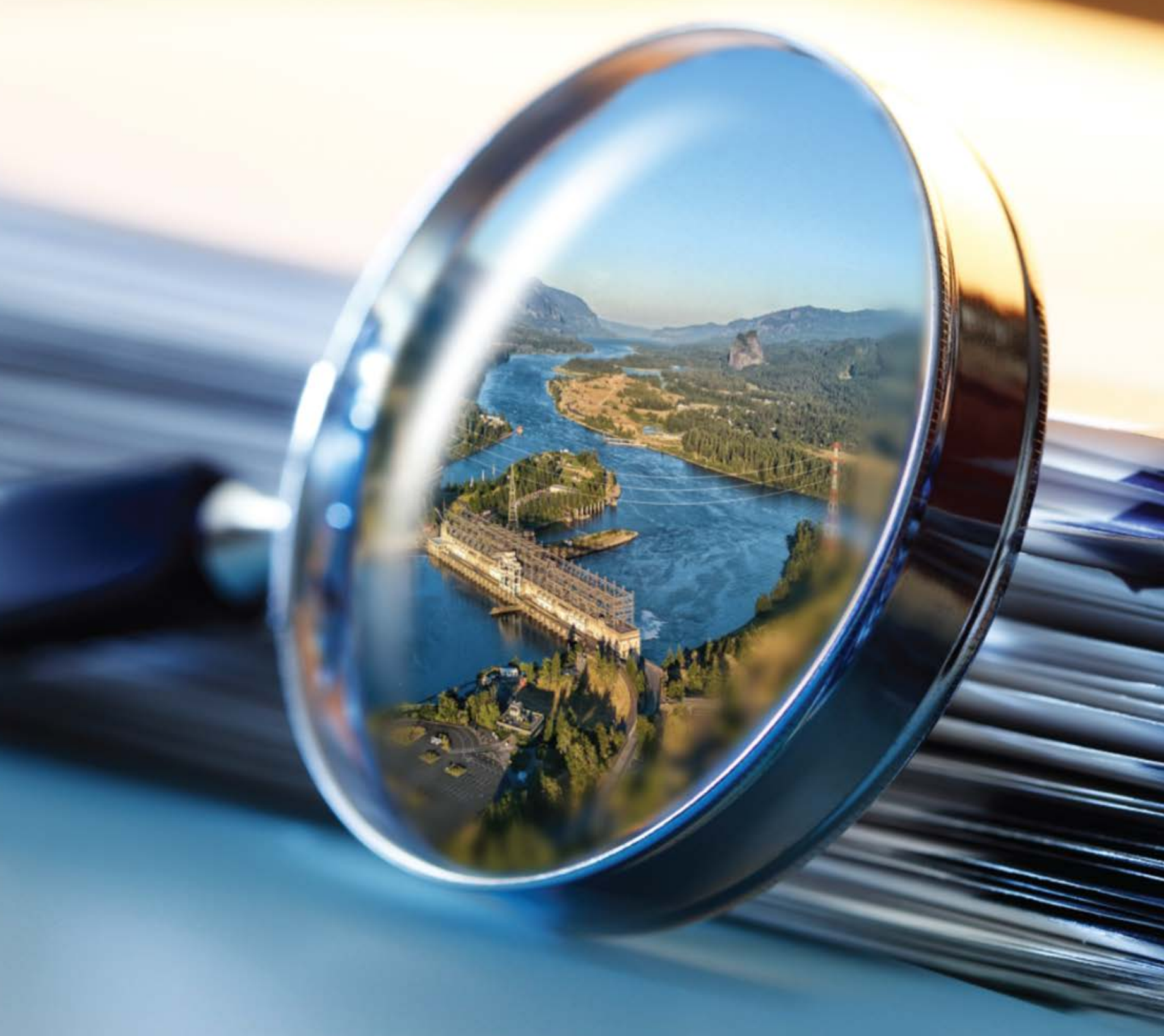

AN EXAMINATION OF THE HYDROPOWER LICENSING AND FEDERAL AUTHORIZATION PROCESS

\section{Hydropower Regulatory Overview and Comparison}




\section{Hydropower Regulatory Overview and Comparison}

This chapter provides an overview of the non-federal hydropower licensing and federal authorization process (i.e., hydropower projects not developed directly by the federal government), including the roles and responsibilities of regulatory agencies, tribes, and the public within this process; a comparison of the hydropower regulatory framework in the United States to the regulatory framework of other infrastructure projects in the United States; and a comparison of the U.S. hydropower licensing process to those of the hydropower regulatory frameworks across a selection of other countries.

Section 2 of this chapter begins by providing a brief overview of the FERC hydropower licensing process. Thereafter, this section describes the potential environmental impacts associated with developing a hydropower project and the required licenses, permits, and approvals associated with developing a non-federal hydropower project. This section also provides a description of the federal, state, and tribal jurisdictional roles in the hydropower licensing and federal authorizations process.

Section 3 of this chapter compares the U.S. hydropower regulatory framework to other types of energy and water infrastructure in the United States, including non-hydropower water infrastructure, wind, solar, geothermal, bulk electric transmission, natural gas pipelines and power plants, nuclear power plants, and coal power plants. As discussed further in Section 3, the U.S. hydropower licensing and federal authorization process shares similarities with approval processes for other infrastructure project types, such as requirements related to the protection of biological resources, cultural resources, water quality, and environmental review requirements. However, other characteristics of the U.S. hydropower licensing and federal authorization process may have notable differences compared with other types of infrastructure project approval processes, including the:

- The licensing framework and required authorizations

- The jurisdictional reach of federal regulators' authority

- Term length of the authorization (e.g., license, permit, or lease)

- Stakeholder engagement requirements

- Equal consideration of development and non-development values within the licensing/approval process (as required under FPA 4(e)).

Section 4 of this chapter compares the U.S. hydropower licensing process to the hydropower licensing/approval processes in three other top hydropower-producing countries: Canada, Norway, and Sweden. As discussed further in Section 4, although all of the countries share some similarities, areas where U.S. hydropower licensing is distinct from other countries include the:

- Licensing framework and the allocation of regulatory authority at different levels (e.g., federal/national, state/province, regional, local)

- Term length of the licenses/approvals

- Opportunities afforded to stakeholders and the public to engage with and participate in the licensing process. 


\subsection{U.S. Hydropower Licensing and Federal Authorization Overview}

In the United States, non-federal hydropower development is governed primarily by the FPA, which authorizes FERC to issue preliminary permits, ${ }^{9}$ licenses, and exemptions from licensing ${ }^{10}$ (FERC 2017). FERC issues licenses to construct, operate, and maintain certain dams, water conduits, reservoirs, powerhouses, transmission lines, or other project works necessary and convenient for the development and improvement of navigation and for the development, transmission, and use of power across, along, from, or in navigable waters of the United States (16 U.S.C. § 797(e)). The authority provided to FERC under the FPA applies to all non-federal projects, regardless of who owns or manages the surrounding surface land (e.g., federal, state, private).

This section includes:

- An overview of the process required to obtain a FERC hydropower license

- The potential environmental impacts associated with developing a hydropower project

- The required licenses, permits, and authorizations required to construct a non-federal hydropower project

- The role of the public in the federal hydropower licensing and authorization process.

\subsection{Summary of the Hydropower Licensing Process}

For context, as used in this report, a license to construct and operate an unconstructed hydroelectric project is referred to as an original license, while a license to continue operating an existing hydropower project is referred to as a new license (hereinafter relicense) (FERC 2017). FERC hydropower licenses may be issued for a term of 30-50 years; however, in 2017 FERC issued a policy statement setting 40 years as the default license term length for most hydroelectric projects under FERC's jurisdiction (16 U.S.C. 808(e); 161 FERC $\uparrow$ 61,078). ${ }^{11}$

Hydropower licensing begins with the pre-filing stage prior to a license applicant filing a final license application (FERC 2017). The pre-filing stage varies by license process type, but generally requires some level of stakeholder engagement to identify issues and gather information, which informs the eventual final license application and associated NEPA review process (FERC 2017). The first formal filing required as part of the hydropower licensing process is an NOI that the license applicant intends to file a license application and a PAD $^{12}$ that

\footnotetext{
${ }^{9}$ Preliminary permits allow the permit holder to have priority for a hydroelectric site over any other applicants for 3 years, during which time the permit holder can conduct feasibility and environmental studies of the project site and pre-filing stakeholder consultations (18 C.F.R. $§ 4.80$; FERC 2017). During the term of the preliminary permit, which may be extended for up to 2 additional years with permission from FERC, the permit holder must submit 6month progress reports to FERC that show progress and preparation toward filing a license application (18 C.F.R. $\S$ 4.80; FERC 2017). Preliminary permits are outside the scope of this report.

${ }^{10}$ Under certain specified criteria, a project may receive an exemption from FERC licensing as a qualifying conduit hydropower facility, a small conduit hydroelectric facility, or a small hydroelectric facility (16 U.S.C. § 832a(a), 16 U.S.C. $\S 823 a(b), 16$ U.S.C. $§ 2705)$. Exemptions from licensing are outside the scope of this report.

${ }^{11}$ For projects located at or that use the head created by federal dams, the default licensing terms is 50 years.

${ }^{12}$ The PAD requirement was added by a rule published August 25, 2003, that went into effect October 23, 2003 (Hydroelectric Licensing Under the Federal Power Act, 68 Fed. Reg. 51070, 51075 (Aug. 25, 2003) (codified at 18 C.F.R. pts. 2, 4, 5, 9, 16, 375, and 385)).
} 
describes the project and its potential effect on environmental, cultural, and recreational resources (FERC 2017). When relicensing an existing project, the licensee must file the NOI and PAD between 5 and 5.5 years of the current license's expiration date (FERC 2017). Beginning in July 2005, the default FERC licensing process is the ILP (18 C.F.R. § 5.3(a)(2)). However, at the same time as the NOI/PAD filing, the license applicant may also request to use one of the nondefault license process types - either the TLP or the ALP (FERC 2017; 18 C.F.R. § 5.3(a)(2)). FERC must approve the request to use the TLP or the ALP before the license applicant can use a non-default licensing process (18 C.F.R. $\S 5.3(\mathrm{a})(2))$.

The pre-filing steps vary most among the three license process types, although the post-filing ${ }^{13}$ steps are more comparable, with the exception of scoping occurring in the TLP post-filing (see Figure 1) (FERC 2017). According to FERC, the ILP is suitable for projects with complex issues and study needs because there is more oversight by FERC during the pre-filing stage (FERC 2017). In addition, the ILP requires set schedules and time frames during the pre-filing stage, which increases the predictability of the process (FERC 2017). The ALP has less FERC oversight during pre-filing and emphasizes collaboration among stakeholders, demonstrated by the collaboratively determined pre-filing schedule communication protocol (FERC 2017). The TLP has the least oversight by FERC during pre-filing and may be most appropriate for projects with less complex issues and study needs (FERC 2017). The TLP has no set time frames and is referred to as a "paper-driven process" (FERC 2017). The pre-filing stage ends with the filing of the final license application (FERC 2017).

Once the license applicant submits a final license application, FERC checks that the application package is complete and adequate for processing. If the application is not complete, FERC will issue either a deficiency letter or an AIR. The license applicant has 90 days ${ }^{14}$ to correct the deficiencies or FERC may dismiss their application. If the application is complete, then FERC must determine whether the application is ready for environmental analysis (REA). If so, FERC will issue a public notice that requests formal agency and stakeholder comments and motions to intervene. Agency and stakeholder comments can include recommendations, prescriptions, terms, or conditions, depending on the jurisdiction (FERC 2017).

Unlike the ALP and ILP, under the TLP ${ }^{15}$ FERC conducts a scoping meeting and publishes a scoping document(s) for environmental issues associated with the proposed project after filing

\footnotetext{
${ }^{13}$ In 2019, FERC established the Expedited Licensing Procedure (ELP) for issuing original licenses for qualifying facilities at existing nonpowered dams and for closed-loop pumped storage projects (18 C.F.R. $\S \S 7.1-7.9$ ) The goal of the ELP is to ensure that a final licensing decision on qualifying facilities is issued no later than two years after FERC receives a completed license application. Any license applicant that develops and files an application for an original license for a qualifying facility under the ILP, TLP, or ALP procedures may request to use the ELP procedure for the post-filing phase of licensing.

14 This deadline may vary depending on the nature of the deficient information (FERC 2017).

${ }^{15}$ Under the ILP and the ALP, the scoping process occurs before the license applicant submits their final license application (i.e., during the pre-filing phase) (18 C.F.R. Parts 4 and 5; Levine and Flanagan 2019). Under the ALP, the license applicant also submits a draft EA/EIS with their final license application for FERC to consider before FERC drafts the final EA/EIS (Carter 2015; Levine and Flanagan 2019).
} 
the final license application (18 C.F.R. Part 4). ${ }^{16}$ Once FERC makes a determination of REA, FERC conducts NEPA review, which concludes with the publication of an environmental review document (i.e., EA or EIS) (18 C.F.R. Part 4; Levine and Flanagan 2019). Stakeholders are also given the opportunity to provide comments on a draft EA or EIS before the document is finalized (18 C.F.R. Part 4; Levine and Flanagan 2019).

The license applicant must also request a WQC pursuant to Section 401 of the CWA from any applicable state or authorized tribe or the EPA (18 C.F.R. Parts 4 and 5). If any state agency with jurisdiction denies a WQC, FERC may not issue a license for the project (33 U.S.C. $\S$ 1341(a)(1); Curtis and Buchanan 2019). Where a state issues a WQC, the conditions become terms of the FERC license.

During the post-filing phase, if FERC (and the license applicant) determine that the proposed activity is likely to affect a listed species, then FERC must also consult USFWS and NOAA Fisheries to ensure that the proposed project will not jeopardize the continued existence of any threatened or endangered species or result in destruction or adverse modification of a threatened or endangered species' habitat pursuant to the ESA (16 U.S.C. $\S \S 1531-1544)$. FERC may designate the license applicant as the non-federal representative for FERC during the ESA informal consultation process (FERC 2017). If the project may affect a threatened or endangered species, FERC must prepare a biological assessment (BA) that addresses any potential effects on the species (FERC 2017). Based on the results of the BA, the project may require formal consultation pursuant to Section 7 of the ESA, after which the service(s) with authority over the affected species must submit a biological opinion (BO) that outlines the measures needed to avoid jeopardizing or adversely modifying the habitat of the affected species (FERC 2017).

In addition, during the post-filing phase FERC will receive mandatory conditions and license recommendations from federal and state agencies under FPA Sections 4(e), 10(a), 10(j), and 18 for inclusion and/or consideration in the final license.

Once there is compliance with all the required authorizations discussed below in Section 2.3 (e.g., FPA, NEPA, CWA, ESA, NHPA), FERC may issue the final license order based on all the documents in the public record for the proposed project (FERC 2017). The final license order includes any mandatory terms and conditions that the project must comply with (FERC 2017).

\footnotetext{
${ }^{16}$ Under the ILP and the ALP, the scoping process occurs before the license applicant submits their final license application (i.e., during the pre-filing phase) (18 C.F.R. Parts 4 and 5; Levine and Flanagan 2019). Under the ALP, the license applicant also submits a draft applicant-prepared EA/EIS with their final license application for FERC to consider before FERC drafts the final EA/EIS (Carter 2015; Levine and Flanagan 2019).
} 

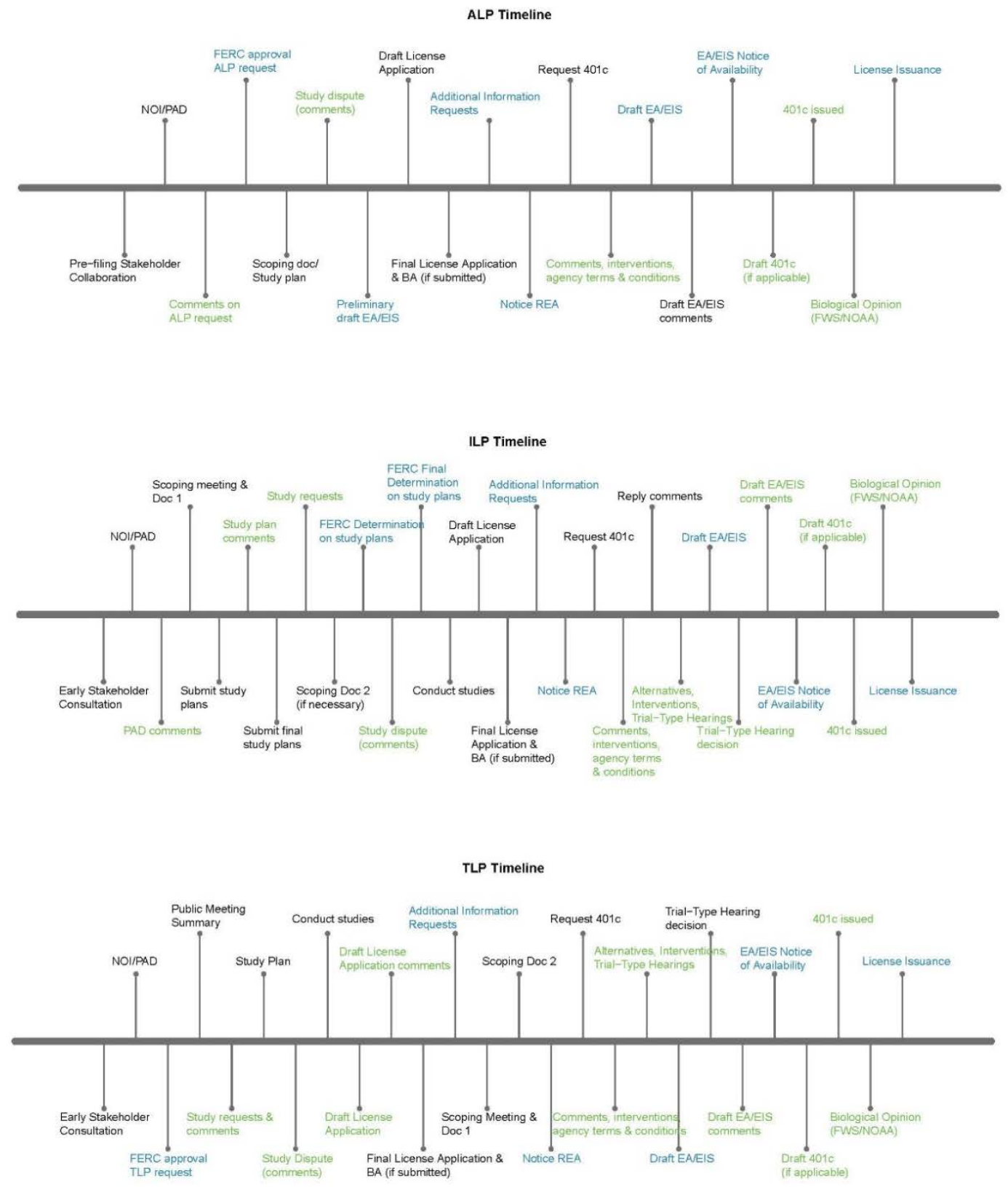

Figure 1. Example alternative, integrated, and traditional licensing process timelines. License applicants are responsible for milestones in black text, other stakeholders are responsible for milestones in green text, and FERC is responsible for milestones in blue text. 


\subsection{Hydropower Project Potential Environmental Impacts}

A hydropower project raises potential environmental issues ${ }^{17}$ that may require permitting and/or regulatory approvals from federal and state agencies. Potential environmental impacts associated with hydropower development include but are not limited to:

- Potential impacts to water quality (e.g., dissolved oxygen levels, increased water temperatures, sediment buildup) due to altered flow rates, water loss due to evaporation, and interruption of natural sediment flows during construction activities and operation

- Potential impacts to groundwater composition, quality, and hydrology as a result of changes to water flow during operation

- Potential impacts to recreation activities (e.g., boating, swimming, fishing, and camping activities) due to altered reservoir and flow conditions from construction and operation activities

- Potential impacts to fish (including eel) and other aquatic species populations due to turbine entrainment and inhibited migratory patterns during construction and operation

- Potential impacts to aquatic wildlife due to loss of habitat after land inundation and altered surface water hydrology, including permanent removal or alteration of habitat during construction activities and operation

- Potential impacts to near-surface cultural resources from topographic or hydrological pattern changes or from soil movement or disturbance (e.g., removal, erosion, sedimentation, excavation) during construction and operation activities

- Potential impacts to rivers, streams, and other bodies of water due to alterations made during construction of intakes and dams

- Potential impacts to scenic and aesthetic qualities of landscapes and rivers due to construction activities and addition of permanent operation structures.

\subsection{Required Licenses, Permits, and Authorizations to Construct and Operate Non-Federal Hydropower Projects}

FERC is the primary licensing authority, and works with other federal agencies as well as state, local, and tribal governments and the public to issue licenses for non-federal hydropower projects. The following permits, licenses, and authorizations are required under federal law ${ }^{18}$ for hydropower project construction and operation.

\subsubsection{Federal Energy Regulatory Commission Hydropower License}

As discussed above, the FPA authorizes FERC to issue licenses to construct, operate, and maintain non-federal hydropower projects. Non-exempt ${ }^{19}$ hydropower projects must complete

\footnotetext{
${ }^{17}$ For more information on how the authors determined applicable regulatory and permitting requirements and common potential environmental impacts associated with non-federal hydropower projects, see Section 3.

${ }^{18}$ This chapter does not include a detailed discussion of regulatory and permitting requirements solely under state or local law. In addition, to the specific regulatory and permitting requirements discussed in this chapter, a hydropower developer may need to comply with other regulatory requirements or receive approvals from a state or local authority.

${ }^{19}$ Under certain specified criteria, a project may receive an exemption from FERC licensing as a qualifying conduit hydropower facility, a small conduit hydroelectric facility, or a small hydroelectric facility (16 U.S.C. § 832a(a), 16 U.S.C. $\S 823 \mathrm{a}(\mathrm{b}), 16$ U.S.C. $\S 2705)$.
} 
the FERC hydropower licensing process using one of FERC's three licensing processes-ILP, TLP, or ALP. ILP is the default licensing process under the FPA; however, a hydropower license applicant may request permission from FERC to use the TLP or ALP. ${ }^{20}$

\subsubsection{Federal Energy Regulatory Commission Hydropower Project License Procedures and Prerequisites}

Under the FPA, prior to FERC issuing a license, the project must comply with the following processes and obtain the following certifications, approvals, permits, and authorizations from the relevant authority with jurisdiction:

- 401 Water Quality Certification

- ESA Section 7 Consultation Process

- Essential Fish Habitat Consultation Process

- Coastal Zone Management Act Consistency Determination

- National Environmental Policy Act of 1969 Environmental Review Process

- National Historic Preservation Act Section 106 Consultation Process

- Wild and Scenic River Section 7 Consultation (if applicable).

In addition, to mitigate potential impacts to resources and ensure that hydropower projects are consistent with agency land and resource management plans, the FPA authorizes federal agencies with jurisdiction to issue mandatory conditions and federal agencies, state agencies, and Indian tribes with jurisdiction to issue recommendations for inclusion in a FERC license. The following agency license conditions and/or recommendations may be issued in addition to or in lieu of certain permits, authorizations, or other approvals described in Section 3 of this chapter:

- FPA Section 4(e) Mandatory Conditions: Federal agencies with jurisdiction over federal reservations (i.e., Bureau of Indian Affairs [BIA], U.S Bureau of Reclamation [BOR], USFWS, National Park Service [NPS], Bureau of Land Management [BLM], and USFS [U.S. Forest Service]) may prescribe mandatory Section 4(e) conditions for inclusion as conditions to a FERC license to ensure that the project will not interfere or be inconsistent with the purpose of any reservation and ensure adequate protection and utilization of the reservation (16 U.S.C. $\S 797(\mathrm{e})$ ). In addition, Section 4(e), as amended by the ECPA, requires FERC to give "equal consideration to the purposes of energy conservation; the protection, mitigation of damages to, and enhancement of, fish and wildlife (including related spawning grounds and habitat); the protection of recreational opportunities; and the preservation of other aspects of environmental quality" (16 U.S.C. $\S 797($ e) as amended). This "equal consideration" clause requires FERC to balance developmental and non-developmental values when making a decision on licensing a non-federal hydropower project. The licensee or any other party to the FERC licensing

\footnotetext{
${ }^{20}$ In 2019, FERC established the ELP for issuing original licenses for qualifying facilities at existing nonpowered dams and for closed-loop pumped storage projects. (18 C.F.R. $\S \S 7.1-7.9)$. The goal of the ELP is to ensure that a final licensing decision on qualifying facilities is issued no later than 2 years after FERC receives a completed license application. Any license applicant that develops and files an application for an original license for a qualifying facility under the ILP, TLP, or ALP procedures may request to use the ELP procedure for the post-filing phase of licensing.
} 
proceeding may also file alternative mandatory 4(e) conditions with the relevant land management agency (16 U.S.C. $§ 823 d(a)$ ).

- FPA Section 10(a) Recommendations: Federal agencies (i.e., BIA, BOR, BLM, USFWS, NPS, USACE, NOAA Fisheries, and USFS) and state resource agencies exercising administration over flood control, navigation, irrigation recreation, cultural, and other relevant resources of the state in which the project is located as well as Indian tribes affected by the project may provide Section 10(a) license recommendations for inclusion as conditions to a FERC license to ensure that a hydropower project will be best adapted to a comprehensive plan for improving or developing a waterway for the use or benefit of interstate or foreign commerce; the improvement and use of water power development; and the adequate PME of fish and wildlife and for other public uses (16 U.S.C. $\S$ 803(a)(1); (2)(B)).

- FPA Section 10(j) Recommendations: USFWS, NOAA Fisheries, and state fish and wildlife agencies may provide Section 10(j) license recommendations for inclusion as conditions to a FERC license to adequately and equitably protect, mitigate damages to, and enhance fish and wildlife (including related spawning grounds and habitat) affected by the development, operation, or management of the project (16 U.S.C. $\S 803(j)(1) ; 16$ U.S.C. $\S 661$ et seq.).

- FPA Section 18 Mandatory Fishway Prescriptions: USFWS and NOAA Fisheries may prescribe Section 18 mandatory fishway prescriptions for inclusion as a condition to a FERC license during the operation and maintenance of a hydropower project (16 U.S.C. $\S 811$ ). Section 18 fishway prescriptions are limited to: physical structures, facilities, or devices necessary to maintain all life stages of such fish; and project operations and measures related to structures, facilities, or devices, which are necessary to ensure the effectiveness of such structures, facilities, or devices for such fish (Energy Policy Act $1992 \S 1701(\mathrm{~b}))$. The licensee or any other party to the FERC licensing proceeding may also file alternative Section 18 fishway prescriptions with NOAA Fisheries and/or USFWS (16 U.S.C. $\S 823 \mathrm{~d}(\mathrm{~b})$ ).

\subsubsection{Town Sites and Power Development Act (Lease of Power Privilege)}

A FERC licensed hydropower project may require a lease of power privilege from the Bureau of Reclamation to use a BOR asset for electric power generation pursuant to the Town Sites and Power Development Act of 1906 (43 U.S.C. $\$ 485 \mathrm{~h}(\mathrm{c})$ ) when one asset is within BOR's jurisdiction and a second asset is within FERC's jurisdiction. This circumstance may apply to non-federal pumped storage hydropower projects (FERC and BOR 1992).

\subsubsection{Rivers and Harbors Act Section 14 Authorization ("Section 408" Authorization)}

A FERC licensed hydropower project may require a "Section 408" authorization from USACE for a FERC licensed hydropower project to use or alter USACE infrastructure (e.g., dam, conduit) pursuant to Section 14 of the Rivers and Harbors Act of 1899 (RHA) (33 U.S.C. $\S$ 408(a)). Section 408 grants USACE the authority to authorize the alteration or use of any USACE infrastructure when it will not be injurious to the public interest or impair the infrastructure's usefulness (33 U.S.C. § 408(a)). 


\subsubsection{Fish and Wildlife Coordination Act Consultation}

A license applicant for a FERC licensed hydropower project must consult with the USFWS and/or NOAA Fisheries and the relevant state resource agency before proposing or authorizing any project that will cause a stream or other body of water to be impounded, diverted, the channel deepened, or otherwise controlled or modified for any purpose pursuant to the Fish and Wildlife Coordination Act (FWCA) (16 U.S.C. § 662(a)). Generally, this requirement is satisfied through FPA Section 10(j).

\subsubsection{Land Access Rights-of-Way, Easements, Leases, and Other Approvals}

A FERC licensed hydropower project may require one or more of the following rights-of-way, easements, leases, or other approvals under federal law from the appropriate agency with jurisdiction to obtain land access through, under, or over federally or tribally managed land and resources. Land access is a key consideration for siting hydropower projects. Agencies with jurisdiction have authority to grant the following land access rights-of-way, easements, leases and other approvals for hydropower projects so long as the proposed use is compatible with the agency managed land or resource and the public interest:

- Bureau of Land Management Right-of-Way: A hydropower developer may need a right-of-way (ROW) from the Bureau of Land Management to access BLM-managed lands. The Federal Land Policy and Management Act of 1976 gives the BLM authority to grant ROWs for a term of years appropriate for the life of the project (43 U.S.C. $\S$ 1761(a)).

- U.S. Department of Defense Enhanced Use Lease: A hydropower developer may need an enhanced use lease from the U.S. Department of Defense (DOD) to use real or personal property that is under the control of a military department. DOD has authority to grant an enhanced use lease for a term of 5 years or longer if DOD determines a longer lease period is in the public interest (10 U.S.C. § 2667(a)).

- Military Land Rights-of-Way: A hydropower developer may need a ROW from DOD to gain access to public lands permanently withdrawn or reserved for the use of the military department. DOD has authority to grant a military land ROW for any term of years that the DOD considers appropriate (10 U.S.C. § 2668(a)).

- National Park System Right-of-Way: A hydropower developer may need a ROW from the National Park Service to obtain access over, across, or through a National Park System Unit. NPS may grant a National Park System ROW for a maximum term of 50 years (43 U.S.C. $§ 959 ; 54$ U.S.C. $\S \S 100902(a)-(b) ; 54$ U.S.C. $§ 100501) .{ }^{21}$

- National Wildlife Refuge Right-of-Way or Easement: A hydropower developer may need a ROW from the USFWS to access areas within the National Wildlife Refuge System. The USFWS has authority to grant a National Wildlife Refuge ROW for a term of years that the USFWS considers appropriate (16 U.S.C. $\S 668 \mathrm{dd}(\mathrm{d})(1)(\mathrm{B})$ ). The USFWS may not initiate or permit a new use of a refuge or expand, renew, or extend an existing use of a refuge unless they have determined that the use is a compatible use and that the use is not inconsistent with public safety (16 U.S.C. $\S 668 \mathrm{dd}(\mathrm{d})(3)(\mathrm{A})(\mathrm{i}))$.

\footnotetext{
${ }^{21}$ For non-federal hydropower projects, a National Park System ROW applies only to land or water regulated by NPS, other than a National Park or Monument.
} 
- Special Use Authorization: A hydropower developer may need a special use authorization from the U.S. Forest Service to access USFS-managed lands (e.g., national forest system lands, other than those designated as wilderness areas). Pursuant to the Federal Land Policy and Management Act of 1976, the USFS may grant special use authorizations for a term that the USFS deems appropriate and reasonable, with a recommended maximum term of 30 years (43 U.S.C. $\S 1761(\mathrm{a}),(\mathrm{d})$ ); 36 C.F.R. $\S$ 251.52(1); USFS 2003, Chapter 2771; USFS 2011). ${ }^{22}$

- Tribal Land Right-of-Way: A hydropower developer may need a ROW from the BIA to access any lands held in trust by the United States for individual Indians or Indian tribes, communities, bands, or nations, or any lands now or hereafter owned. The BIA may grant ROWs on tribal land for any term of years an Indian tribe deems reasonable. For individually owned Indian land, the BIA may grant a ROW for a maximum term of 20 years for oil and gas purposes and 50 years for any other purpose (25 U.S.C. $\S 323 ; 25$ C.F.R. $\S 169.201)$.

- Tribal Energy Resources Agreement Right-of-Way: A hydropower developer may need a tribal energy resources agreement (TERA) ROW from the Indian tribe with jurisdiction to access land pursuant to a TERA with BIA approval. An Indian tribe may grant a TERA ROW for a maximum term of 30 years (25 U.S.C. $\S 2218(a)$ ).

\subsubsection{Biological, Cultural, Water, and Other Environmental and Natural Resource Permits, Approvals, and Requirements}

Hydropower projects may require a permit, authorization, or other approval under federal law from the appropriate resource agency with jurisdiction if a project impacts biological, cultural, water, or other environmental and natural resources. Hydropower projects may impact these resources during project construction and operation. In addition, site-specific factors such as a hydropower project's proximity to cultural artifacts, endangered or threatened species and/or critical habitats, migratory bird nests, and water resources may require that a hydropower developer mitigate or offset potential project impacts through compliance with resource agency permits, authorizations, or other approvals.

\subsubsection{Biological Resource Considerations and Requirements}

A hydropower developer must consider the potential impacts of their projects on biological resources and habitat pursuant to federal laws including the ESA, Migratory Bird Treaty Act, Bald and Golden Eagle Protection Act, Magnuson-Stevens Fishery Conservation and Management Act, and Marine Mammal Protection Act (MMPA). Accordingly, a non-federal hydropower project may require one or more of the following permits, authorizations, or other approvals:

\footnotetext{
${ }^{22}$ For FERC licensed projects in existence on October 24, 1992, a license applicant is required to obtain a special use authorization from USFS under the following circumstances:

- Projects with a FERC license, or with an amended license, issued between October 21, 1976, and July 6, 1980, where the USFS advised the license holder to obtain a special use authorization, or where a special use authorization was actually issued

- $\quad$ Projects with a FERC license, or with an amended license, issued after July 6, 1980.
} 
- Eagle Non-Purposeful Take Permit: A hydropower developer may need an eagle nonpurposeful take permit from the USFWS for any incidental take of bald or golden eagles pursuant to the Bald and Golden Eagle Protection Act (16 U.S.C. $\S \S 668-668 d ; 50$ C.F.R. $\S 22.26)$.

- Essential Fish Habitat Consultation: A hydropower developer must consult with the NOAA Fisheries with respect to any action authorized, funded, or undertaken or proposed to be authorized, funded, or undertaken by such agency that may adversely affect any essential fish habitat pursuant to the Magnuson-Stevens Fishery Conservation and Management Act (16 U.S.C. § 1855(b)(2)).

- ESA Section 7 Consultation: A federal agency (potentially with assistance of a designated non-federal representative) must consult or confer with USFWS and/or NOAA Fisheries if an agency action is likely to jeopardize the continued existence of any listed endangered or threatened species or result in the destruction or adverse modification of designated critical habitat pursuant to the ESA Section 7 (16 U.S.C. $\S$ 1536(a)(2)). ESA Section 7 consultation may result in the issuance of a BO from the USFWS or NOAA Fisheries containing an incidental take statement.

- Marine Mammal Incidental Take Authorizations: A hydropower developer may need an incidental take authorization from USFWS and/or NOAA Fisheries if a project may result in the incidental take (e.g., harassment) of marine mammals for a year or less pursuant to the MMPA. A hydropower developer may need an incidental take letter authorization from USFWS and/or NOAA Fisheries if a project may result in the incidental take (e.g., harassment) of marine mammals for more than a year or the serious injury of marine mammals pursuant to the MMPA (16 U.S.C. $\S 1371(a)(5)(A)-(D) ; 50$ C.F.R. $\S 216.106 ; 50$ C.F.R. $\S \S 18.2$, 18.27(f)).

- Migratory Bird Special Purpose Permit: A hydropower developer may need a special purpose permit from USFWS to conduct an activity that results in the take, possession, import, export, sale, purchase, barter, or offer for sale, purchase, or barter of any migratory bird or their parts, nests, or eggs pursuant to the Migratory Bird Treaty Act (16 U.S.C. $\S \S 703-712 ; 50$ C.F.R. $\S 21.11$ ).

\subsubsection{Cultural Resource Considerations and Requirements}

Federal agencies must consider the potential impacts of hydropower projects on cultural and tribal resources pursuant to NHPA. Accordingly, a hydropower project may need to comply with:

NHPA Section 106 Consultation Process: A federal agency must consider the effect of a federal undertaking ${ }^{23}$ on historic properties or resources that are either eligible for listing or are listed on the National Register of Historic Places pursuant to Section 106 of the NHPA (54 U.S.C. § 306108). NHPA Section 106 consultations may result in a memorandum of agreement containing a summary of the views of consulting parties and the public as well as an evaluation of any measures considered to avoid or minimize the project's effects on historic properties (36

\footnotetext{
23 "Federal undertaking" means a project, activity, or program funded in whole or in part under the direct or indirect jurisdiction of a federal agency, including those carried out by or on behalf of an agency; those carried out with federal financial assistance; those requiring a federal permit, license, or approval; and those subject to state or local regulation administered pursuant to a delegation or approval by a federal agency (54 U.S.C. § 300320).
} 
C.F.R. $\S 800.6($ b)-(c)). State agencies or tribes with jurisdiction may be required to consult on culturally or historically important state or tribal sites, respectively, that may be affected by a hydropower project (54 U.S.C. § 306108).

\subsubsection{Water Quality Resource Considerations and Requirements}

Hydropower project developers must consider the potential impacts of hydropower projects to water quality and water resources pursuant to the CWA. Accordingly, a hydropower project that discharges materials or pollutants ${ }^{24}$ into navigable waters ${ }^{25}$ of the United States may require one or more of the following permits:

- Clean Water Act Section 401 Water Quality Certification: A hydropower developer will need a 401 Water Quality Certification from the state and/or authorized tribe where the project is located (or in some limited circumstances EPA) to evaluate impacts on state water quality when applying for a federal license or permit to conduct any activity including, but not limited to, the construction or operation of facilities that may result in any discharge into the navigable waters of the United States pursuant to the CWA (33 USC 1341(a)(1).

- Clean Water Act Section 402 National Pollutant Discharge Elimination Permit: A hydropower developer must obtain a Section 402 National Pollutant Discharge Elimination System (NPDES) permit from a state agency and/or tribe with EPA delegated authority or, in limited circumstances the EPA, to discharge a pollutant or any combination of pollutants into navigable waters of the United States pursuant to the CWA (33 U.S.C. $\S 1342(a)(1))$.

- Clean Water Act Section 404 Dredge and Fill Permit: A hydropower developer must obtain a Section 404 Dredge and Fill Permit from USACE to discharge dredged or fill material into navigable waters of the United States pursuant to the CWA (33 U.S.C. $\S$ $1344(\mathrm{a}))^{26}$

\subsubsection{Preexisting Land Use and Natural Resource Protection Considerations and Requirements}

Hydropower project developers must consider preexisting land uses pursuant to the Coastal Zone Management Act (CZMA) and Wild and Scenic River Act (WSRA). Accordingly, a hydropower project, which may impact preexisting uses present at or surrounding a project site, may need to comply with one or more of the following:

- Coastal Zone Management Act Consistency Determination: A hydropower developer must obtain a Coastal Zone Management Plan Consistency Determination from the relevant state agency if a federal activity (e.g., permit, license, or approval) may affect

\footnotetext{
24 "Pollutant" means dredged spoil, solid waste, incinerator residue, sewage, garbage, sewage sludge, munitions, chemical wastes, biological materials, radioactive materials, heat, wrecked or discarded equipment, rock, sand, and cellar dirt as well as industrial, municipal, and agricultural waste discharged into water (33 U.S.C. § 1362 (6)).

25 "Navigable waters" means waters that are subject to the ebb and flow of the tide and/or are presently used, or have been used in the past, or may be susceptible for use to transport interstate or foreign commerce (33 C.F.R. § 329.4 ).

${ }^{26}$ The states of Florida, Michigan, and New Jersey have assumed the 404 program from USACE, and projects in those states will need to obtain a Section 404 permit from the appropriate state agency.
} 
any land, water use, or natural resource of a state coastal zone pursuant to the CZMA (16 U.S.C. $\S \S 1456$ (c)(1)(A) \& (C)).

- Wild and Scenic River Act Section 7 Consultation and Compliance: A hydropower developer ${ }^{27}$ must consult with BLM, NPS, USFWS, or USFS to evaluate potential project effects on agency-managed designated wild and scenic rivers and congressionally authorized study rivers to protect the free-flowing condition and environment of those designated and congressionally authorized study rivers pursuant to the WSRA (16 U.S.C. $\S 1278(\mathrm{a})-(\mathrm{b}))$. The WSRA provides for the protection of designated free-flowing rivers and their immediate environments by prohibiting certain federally sponsored or assisted projects, including the construction of any dam, water, conduit, reservoir, powerhouse, transmission line, or other project works on or directly affecting designated rivers and congressionally authorized study rivers (16 U.S.C. $§ 1278(a)-(b))$. Projects upstream, downstream, or on a tributary of a designated river are evaluated to ensure they do not invade or unreasonably diminish the fish, wildlife, recreation, or aesthetic river values (16 U.S.C. 1278(a)). Projects upstream, downstream, or on a tributary of a congressional study river are evaluated to ensure they do not invade or diminish the fish, wildlife, recreation, or aesthetic river values (16 U.S.C. 1278(b)).

Note that, unlike other infrastructure projects, RHA Section 10 Construction Permits are not applicable to non-federal FERC licensed hydropower projects. See Scenic Hudson Preservation v. Callaway, 370 F. Supp. 162 (S.D.N.Y. 1973) (holding that the FPA preempts authority of USACE under the RHA to grant permits for the construction of hydroelectric plants and vesting sole licensing authority to FERC).

\subsubsection{Other Environmental Review Requirements}

Hydropower projects, which constitute major federal actions, must comply with an environmental review process to take into account project impacts on human health and the environment (e.g., impacts to natural resources, cultural resources, biological resources, socioeconomic resources) prior to project construction pursuant to NEPA (42 U.S.C. $\S 4332(2)(C)$ ). Major federal actions include new and continuing activities, including projects and programs entirely or partly financed, assisted, conducted, regulated, or approved by federal agencies (40 C.F.R. $\S \S 1506.8,1508.17)$.

- National Environmental Policy Act of 1969 Environmental Review Process: A federal agency must evaluate the impact of major federal actions significantly affecting the quality of the human environment pursuant to NEPA (42 U.S.C. § 4332(2)(C)). The purpose of NEPA is to establish a national environmental policy and goals for the

\footnotetext{
${ }^{27}$ FERC may not license the construction of any dam, water conduit, reservoir, powerhouse, transmission line, or other project works under the FPA on or directly affecting any river designated as a component of the national wild and scenic rivers system or a congressionally-authorized study river (16 U.S.C. $§ 1278(a)-(b)$ ). However, FERC may issue a new license (relicense) to any dam, water conduit, reservoir, powerhouse, transmission line, or other project works under the FPA located on any river that was subsequently designated as a component of the national wild and scenic river system or a congressionally-authorized study river after the issuance of the original FERC license if the river administering agency (BLM, NPS, USFWS, or USFS) with jurisdiction has made a Section 7 determination that the FERC licensed hydropower project will not have a direct and adverse effect on the free flow, water qualities, and other river values (16 U.S.C. § 1278(a)-(b)).
} 
protection, maintenance, and enhancement of the environment and provide a process for implementing these goals. NEPA review is managed by a lead federal agency, which is responsible for preparing the main NEPA document analyzing project impacts and alternatives and coordinating review with any other cooperating agencies ( 40 C.F.R. $\S$ 1508.16). NEPA review may result in a NEPA document (e.g., an EA or EIS), which analyzes the impacts of a project and any project alternatives. It may also provide measures to avoid and/or mitigate any impacts to resources ( 40 C.F.R. $\S 1508.16)$. The level and scope of NEPA review varies depending on the nature of the project.

Environmental impact evaluations result in either a categorical exclusion (and in some cases a record of consideration), a final EA and finding of no significant impact, or a final EIS and record of decision.

- State Environmental Review Process: In certain states, a state agency must evaluate the impacts of its actions or discretionary decisions to fund, permit, or otherwise issue project approvals (e.g., California Environmental Quality Act, Washington State Environmental Policy Act). State environmental review processes may be required for state implemented programs under federal statutes (e.g., CWA).

See Figure 2 for a high-level summary of federal agency, state agency, and tribe hydropower authorization roles.

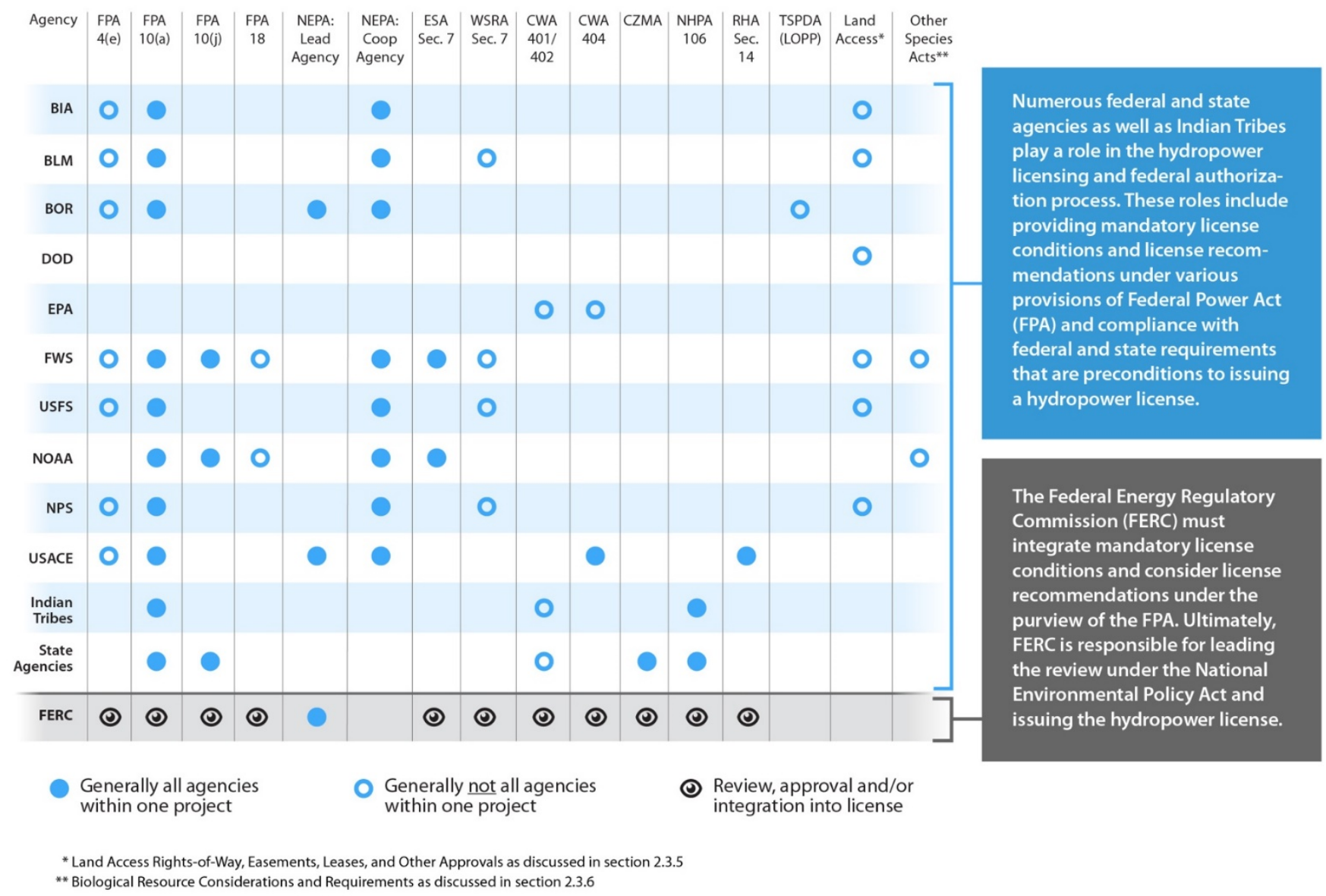

Figure 2. Federal hydropower authorization roles 


\subsection{Role of Public Participation}

In the United States, the public plays a key role in the licensing process for non-federal hydropower projects. The public may participate formally or informally in the hydropower licensing process by consulting with the project proponent, providing public comment, and engaging in stakeholder meetings, hearings, or appeal processes. For example, the FPA and FERC regulations require the project proponent to consult with the public and also provide the public with an opportunity to comment on the studies a project proponent must conduct prior to project approval. In addition, other federal statutes that a non-federal hydropower project proponent must comply with also provide multiple opportunities for the public participation (e.g., ESA, NEPA).

\section{Role of Settlement Agreements in Hydropower Licensing Process}

Settlement agreements can help resolve disputes among stakeholders who may have differing perspectives about license terms and conditions for the construction and operation of a nonfederal hydropower project. Stakeholders may hold informal and formal settlement agreement conferences, during which stakeholders can explain their position and interest in the outcome of the licensing proceeding. Conferences may result in a settlement offer, which participants may submit to FERC at any time prior to the issuance of a final license order. FERC must review the settlement agreement and determine which portions of the agreement it may incorporate into the final license order (FERC 2006a; Levine, Curtis, and Shields 2018). Settlement agreements can be broad or narrow in scope and do not require the support of all participants. In fact, a single licensing proceeding can result in multiple settlement agreements that resolve distinct sets of issues (Levine, Curtis, and Shields 2018).

See Table 1 for a high-level summary of the regulatory and permitting requirements for hydropower projects. 
Table 1. Regulatory and Permitting Requirements for Hydropower Licensing and Authorization in the United States

\begin{tabular}{|c|c|c|c|c|}
\hline Infrastructure Type & $\begin{array}{l}\text { Required Permits, } \\
\text { Approvals, and } \\
\text { Authorizations }\end{array}$ & Agency & $\begin{array}{c}\text { Common Potential } \\
\text { Environmental Impacts }\end{array}$ & Regulatory Considerations \\
\hline $\begin{array}{l}\text { Non-Federal } \\
\text { Hydropower }\end{array}$ & $\begin{array}{l}\text { Land Access } \\
\text { BLM ROW } \\
\text { DOD Enhanced Use } \\
\text { Lease } \\
\text { Military Land ROW } \\
\text { National Park System } \\
\text { ROW } \\
\text { National Wildlife } \\
\text { Refuge ROW } \\
\text { Special Use } \\
\text { Authorization } \\
\\
\text { Biological Resources } \\
\text { Eagle Non-Purposeful } \\
\text { Take Permit } \\
\text { Essential Fish Habitat } \\
\text { Consultation } \\
\text { ESA Section } 7 \\
\text { Consultation } \\
\text { Marine Mammal } \\
\text { Incidental Take } \\
\text { Authorizations } \\
\text { Migratory Bird Special } \\
\text { Purpose Permit } \\
\text { FWCA Consultation } \\
\end{array}$ & $\begin{array}{l}\text { Uiological Resources } \\
\text { USFWS } \\
\text { NOAA Fisheries/USFWS } \\
\text { NOAA Fisheries/USFWS } \\
\text { USFWS } \\
\text { USFWS/NOAA } \\
\text { Fisheries/State Agency }\end{array}$ & $\begin{array}{l}\frac{\text { Biological Resources }}{\text { Impacts }} \\
\text { Fish, eel, and other } \\
\text { aquatic species affected } \\
\text { by turbine entrainment } \\
\text { and inhibited migratory } \\
\text { patterns } \\
\text { Wildlife and nesting bird } \\
\text { habitat inundated due to } \\
\text { altered hydrology } \\
\text { Habitat and species } \\
\text { fragmentation due to } \\
\text { addition of permanent } \\
\text { structures } \\
\text { Cultural Resources Impacts }\end{array}$ & $\begin{array}{l}\text { Land Access } \\
\text { - } \\
\text { USFS may waive special } \\
\text { issue FPA Section 4(e) } \\
\text { condition for inclusion in a } \\
\text { FERC hydropower license } \\
\text { Tribal land ROWs are not } \\
\text { applicable to FERC licensed } \\
\text { hydropower projects, instead } \\
\text { BIA issues FPA Section 4(e) } \\
\text { conditions (as applicable) for } \\
\text { inclusion in a FERC } \\
\text { hydropower license } \\
\text { Tribal energy resources } \\
\text { agreements are not } \\
\text { applicable to FERC licensed } \\
\text { hydropower projects. } \\
\text { Biological Resources } \\
\text { Essential fish habitat } \\
\text { consultation is a prerequisite } \\
\text { to a FERC hydropower } \\
\text { license } \\
\text { ESA Section } 7 \text { Consultation } \\
\text { is a prerequisite to a FERC } \\
\text { hydropower license when } \\
\text { listed species or critical } \\
\text { habitats will be affected by } \\
\text { the proposed activity. } \\
\text { Cultural Resources }\end{array}$ \\
\hline
\end{tabular}




\begin{tabular}{|c|c|c|c|c|}
\hline Infrastructure Type & $\begin{array}{l}\text { Required Permits, } \\
\text { Approvals, and } \\
\text { Authorizations }\end{array}$ & Agency & $\begin{array}{l}\text { Common Potential } \\
\text { Environmental Impacts }\end{array}$ & Regulatory Considerations \\
\hline & $\begin{array}{l}\text { NHPA Section } 106 \\
\text { Consultation Process } \\
\text { Water Quality } \\
\text { CWA Section } 401 \\
\text { Water Quality } \\
\text { Certification } \\
\text { CWA Section } 402 \\
\text { NPDES Permit } \\
\text { CWA Section } 404 \\
\text { Dredge and Fill Permit } \\
\\
\text { Preexisting Land Use } \\
\text { CZMA Consistency } \\
\text { Determination } \\
\text { Wild and Scenic River } \\
\text { Act Section } 7 \\
\text { Consultation }\end{array}$ & $\begin{array}{l}\text { State Historic } \\
\text { Preservation Officer, } \\
\text { Tribal Historic } \\
\text { Preservation Officer, } \\
\text { Advisory Council on } \\
\text { Historic Preservation } \\
\\
\text { Water Quality } \\
\text { State/Tribe/EPA } \\
\text { State/Tribe/EPA } \\
\text { USACE/Michigan/New } \\
\text { Jersey }\end{array}$ & $\begin{array}{l}\text { - } \begin{array}{l}\text { Cultural resources } \\
\text { damage due to } \\
\text { hydrological and } \\
\text { topographical pattern } \\
\text { changes }\end{array} \\
\text { Water Quality Impacts: } \\
\text { Reduced reservoir } \\
\text { elevations affecting } \\
\text { groundwater quality } \\
\text { Flow rate changes } \\
\text { leading to dissolved } \\
\text { oxygen levels, water } \\
\text { loss, sediment buildup, } \\
\text { increased temperatures } \\
\text { to surface water } \\
\\
\text { Preexisting Land Use } \\
\text { Impacts } \\
\text { Construction and } \\
\text { operation of intakes, } \\
\text { dams, and other project } \\
\text { facilities affecting } \\
\text { recreation, habitat, and } \\
\text { scenic and aesthetic } \\
\text { qualities of rivers and } \\
\text { streams }\end{array}$ & $\begin{array}{l}\text { - NHPA Section } 106 \\
\text { consultation is a prerequisite } \\
\text { to a FERC hydropower } \\
\text { license } \\
\text { Water Quality } \\
\text { - } 401 \text { Water Quality } \\
\text { Certification is a prerequisite } \\
\text { to a FERC hydropower } \\
\text { license } \\
\\
\text { - } \\
\text { Preexisting Land Use } \\
\text { Determination is a } \\
\text { prerequisite to a FERC } \\
\text { hydropower license } \\
\text { RHA Section } 10 \\
\text { Construction Permits are not } \\
\text { applicable to FERC licensed } \\
\text { hydropower projects } \\
\end{array}$ \\
\hline
\end{tabular}




\section{Required Permits, \\ Approvals, and \\ Authorizations}

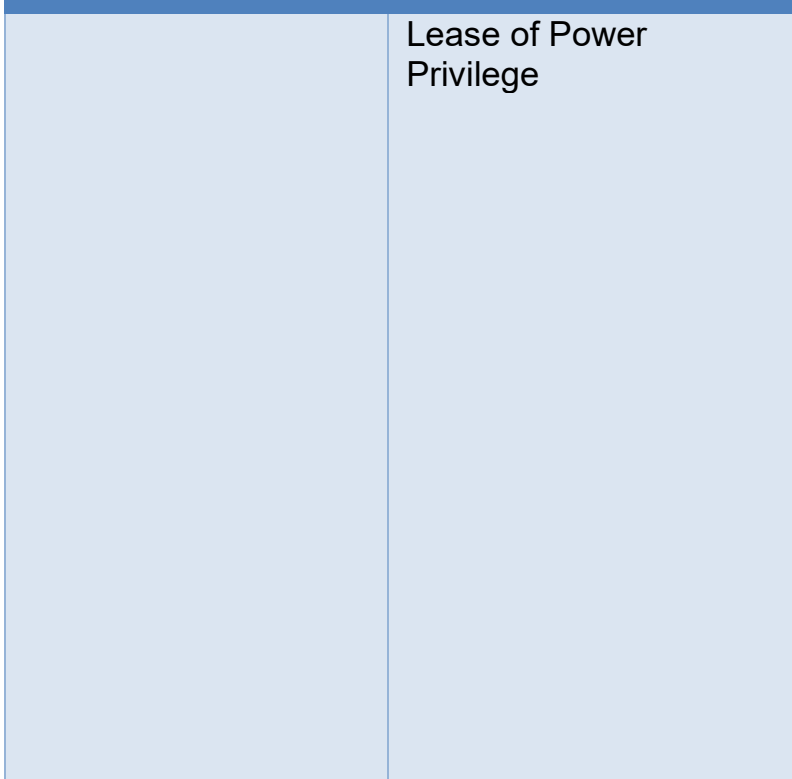

- $\quad$ FERC hydropower licenses subject to 30-50 year term; 40-year default term

- FERC must give equal consideration to

developmental and nondevelopmental value when making a license determination.

- FERC's authority under the Federal Power Act is not limited by surface owner or manager.

- The FWCA requires consultation with NOAA Fisheries/USFWS, which is generally satisfied through recommendations provided under FPA Section 10(j). 


\subsection{Comparison of Hydropower Regulation to Other Types of Infrastructure Projects in the United States}

This section provides a high-level comparison between regulatory and permitting requirements associated with non-federal hydropower and those of other types of infrastructure projects in the United States. The other types of infrastructure projects included in this comparison are:

- Non-hydropower water infrastructure projects

- Nuclear energy projects

- Geothermal power projects

- Land-based wind power projects

- Solar power projects

- Bulk electric transmission projects

- Natural gas pipeline projects

- Natural gas power plant

- Coal power plant projects.

To determine applicable regulatory and permitting requirements and common potential environmental impacts associated with different infrastructure projects, National Renewable Energy Laboratory (NREL) staff reviewed and analyzed approximately 10 NEPA documents per each project type (86 total), including a relatively even distribution of EAs and EISs, to identify potential environmental impacts associated with construction and operation activities of each of the nine aforementioned infrastructure project types. In addition, NREL staff analyzed the NEPA documents to identify relevant permits, authorizations, and approvals required under federal law for each type of infrastructure project. Upon completion of review, NREL staff compiled associated data, including:

- Common potential environmental impacts associated with construction and operation activities of each infrastructure project type

- Each relevant federal permit, authorization, or approval identified during the NEPA document literature review

- Relevant federal statutory authority and enabling act associated with each permit, authorization, or approval

- Relevant federal and state agencies and actors relevant to each permit, authorization, or approval

- A list of all infrastructure project types subject to each identified permit, authorization, or approval under federal law.

For an overview of the regulatory and permitting requirements and common potential environmental impacts associated with each of these types of infrastructure projects, see Appendix A.1. See Table 3 for a high-level summary of the requirements across other infrastructure project types. 
Table 2. Regulatory and Permitting Requirements Across Energy Infrastructure Project Types in the United States

\begin{tabular}{|c|c|c|c|}
\hline \multirow{2}{*}{ Infrastructure Туре } & \multicolumn{3}{|c|}{ Regulatory and Permitting Requirements by Category } \\
\hline & Infrastructure Specific & Preexisting Land Use & Land Access \\
\hline Hydropower & $\begin{array}{l}\text { - FERC Hydropower License } \\
\text { - Lease of Power Privilege } \\
\text { - RHA Section } 408 \text { Authorization }\end{array}$ & $\begin{array}{l}\text { - CZMA Consistency Determination } \\
\text { - WSRA Section } 7 \text { Consultation }\end{array}$ & $\begin{array}{l}\text { - BLM ROW } \\
\text { - DOD Enhanced Use Lease } \\
\text { - Military Land ROW } \\
\text { - National Park System ROW } \\
\text { - National Wildlife Refuge ROW } \\
\text { - Special Use Authorization } \\
\text { - Tribal Land ROW } \\
\text { - Tribal Energy Resources Agreement } \\
\text { Land ROW }\end{array}$ \\
\hline Non-Hydropower Water Infrastructure & - RHA Section 408 Authorization & $\begin{array}{l}\text { - RHA Section } 10 \text { Construction Permit } \\
\text { - CZMA Consistency Determination } \\
\text { - Wild and Scenic River Act Section } 7 \\
\text { Consultation }\end{array}$ & $\begin{array}{l}\text { - BLM ROW } \\
\text { - Military Land ROW } \\
\text { - National Park System ROW } \\
\text { - National Wildlife Refuge ROW } \\
\text { - Special Use Authorization } \\
\text { - Tribal Land ROW }\end{array}$ \\
\hline Nuclear Energy & $\begin{array}{l}\text { - Combined Nuclear License } \\
\text { - Notice of Proposed Construction or } \\
\text { Alteration }\end{array}$ & $\begin{array}{l}\text { - RHA Section } 10 \text { Construction Permit } \\
\text { - CZMA Consistency Determination }\end{array}$ & NA \\
\hline Geothermal Power & $\begin{array}{l}\text { - Underground Injection Control Permit } \\
\text { - Geothermal Lease } \\
\text { - NOI to Conduct Geothermal Resource } \\
\text { - Exploration Operations } \\
\text { - Geothermal Drilling Permit } \\
\text { - Geothermal Utilization (i.e., Construction } \\
\text { Permit, Site License, and Commercial Use } \\
\text { Permit) }\end{array}$ & - CZMA Consistency Determination & $\begin{array}{l}\text { - BLM ROW } \\
\text { - DOD Enhanced Use Lease } \\
\text { - National Park System ROW } \\
\text { - National Wildlife Refuge ROW } \\
\text { - Special Use Authorization } \\
\text { - Tribal Land ROW } \\
\text { - Tribal Energy Resources Agreement } \\
\text { Land ROW }\end{array}$ \\
\hline
\end{tabular}




\begin{tabular}{|c|c|c|c|}
\hline \multirow{2}{*}{ Infrastructure Tуре } & \multicolumn{3}{|c|}{ Regulatory and Permitting Requirements by Category } \\
\hline & Infrastructure Specific & Preexisting Land Use & Land Access \\
\hline Land-Based Wind Power & $\begin{array}{l}\text { - BLM Wind and Solar Lease } \\
\text { - Notice of Proposed Construction or } \\
\text { Alteration }\end{array}$ & - CZMA Consistency Determination & $\begin{array}{l}\text { - BLM ROW } \\
\text { - DOD Enhanced Use Lease } \\
\text { - National Park System ROW } \\
\text { - National Wildlife Refuge ROW } \\
\text { - Special Use Authorization } \\
\text { - Tribal Land ROW } \\
\text { - Tribal Energy Resources Agreement } \\
\text { Land ROW }\end{array}$ \\
\hline Solar Power & - BLM Wind and Solar Lease & - CZMA Consistency Determination & $\begin{array}{l}\text { - BLM ROW } \\
\text { - DOD Enhanced Use Lease } \\
\text { - National Park System ROW } \\
\text { - National Wildlife Refuge ROW } \\
\text { - Special Use Authorization } \\
\text { - Tribal Land ROW } \\
\text { - Tribal Energy Resources Agreement } \\
\text { Land ROW }\end{array}$ \\
\hline Natural Gas Pipeline & $\begin{array}{l}\text { - FERC Certificate of Public Convenience } \\
\text { and Necessity }\end{array}$ & $\begin{array}{l}\text { - CZMA Consistency Determination } \\
\text { - RHA Section } 10 \text { Construction Permit }\end{array}$ & $\begin{array}{l}\text { - BLM ROW } \\
\text { - Military Land ROW } \\
\text { - National Park System ROW } \\
\text { - National Wildlife Refuge ROW } \\
\text { - Special Use Authorization } \\
\text { - Tribal Land ROW } \\
\text { - Tribal Energy Resources Agreement } \\
\text { Land ROW }\end{array}$ \\
\hline Natural Gas and Coal Power Plants & NA & - CZMA Consistency Determination & $\begin{array}{l}\text { - BLM ROW } \\
\text { - Military Land ROW } \\
\text { - National Park System ROW } \\
\text { - National Wildlife Refuge ROW } \\
\text { - Special Use Authorization } \\
\text { - Tribal Land ROW } \\
\text { - Tribal Energy Resources Agreement } \\
\text { Land ROW }\end{array}$ \\
\hline
\end{tabular}


Table 3. Regulatory and Permitting Requirements Across Energy Infrastructure Project Types in the United States (Continued)

Infrastructure Type Regulatory and Permitting Requirements by Category

Air Quality Biological Resources Cultural Resources Environmental Review Water Quality

\begin{tabular}{|c|c|c|c|c|c|}
\hline Hydropower & NA & $\begin{array}{l}\text { - Eagle Non-Purposeful Take } \\
\text { Permit } \\
\text { - Essential Fish Habitat } \\
\text { Consultation } \\
\text { - Marine Mammal Incidental Take } \\
\text { Authorizations } \\
\text { - Migratory Bird Special Purpose } \\
\text { Permit } \\
\text { - ESA Section } 7\end{array}$ & $\begin{array}{l}\text { - NHPA Section } 106 \\
\text { Consultation }\end{array}$ & $\begin{array}{l}\text { - NEPA Environmental } \\
\text { Review }\end{array}$ & $\begin{array}{l}\text { - CWA Section } 401 \text { Water } \\
\text { Quality Certification } \\
\text { - CWA Section } 402 \\
\text { NPDES Permit } \\
\text { - CWA Section } 404 \text { Dredge } \\
\text { and Fill Permit }\end{array}$ \\
\hline $\begin{array}{c}\text { Non-Hydropower Water } \\
\text { Infrastructure }\end{array}$ & NA & $\begin{array}{l}\text { - Eagle Non-Purposeful Take } \\
\text { Permit } \\
\text { - Essential Fish Habitat } \\
\text { Consultation } \\
\text { - ESA Section } 7 \text { Consultation } \\
\text { - Marine Mammal Incidental Take } \\
\text { Authorizations } \\
\text { - Migratory Bird Special } \\
\text { Purpose Permit } \\
\text { - FWCA Consultation }\end{array}$ & $\begin{array}{l}\text { - NHPA Section } 106 \\
\text { Consultation }\end{array}$ & $\begin{array}{l}\text { - NEPA Environmental } \\
\text { Review }\end{array}$ & $\begin{array}{l}\text { - CWA Section } 401 \text { Water } \\
\text { Quality Certification } \\
\text { - CWA Section } 404 \text { Dredge } \\
\text { and Fill Permit }\end{array}$ \\
\hline Nuclear Energy & $\begin{array}{l}\text { - Clean Air Act Title } \\
\text { V Operating Permit } \\
\text { - Acid Rain Permit }\end{array}$ & $\begin{array}{l}\text { - Eagle Non-Purposeful Take } \\
\text { Permit } \\
\text { - Essential Fish Habitat } \\
\text { Consultation } \\
\text { - ESA Section } 7 \text { Consultation } \\
\text { - Marine Mammal Incidental Take } \\
\text { Authorizations } \\
\text { - Migratory Bird Special } \\
\text { Purpose Permit }\end{array}$ & $\begin{array}{l}\text { - NHPA Section } 106 \\
\text { Consultation }\end{array}$ & $\begin{array}{l}\text { - NEPA Environmental } \\
\text { Review }\end{array}$ & $\begin{array}{l}\text { - CWA Section } 401 \text { Water } \\
\text { Quality Certification } \\
\text { - CWA Section } 402 \\
\text { NPDES Permit } \\
\text { - CWA Section } 404 \text { Dredge } \\
\text { and Fill Permit }\end{array}$ \\
\hline
\end{tabular}




\begin{tabular}{|c|c|c|c|c|c|}
\hline \multirow{2}{*}{ Infrastructure Туре } & \multicolumn{5}{|c|}{ Regulatory and Permitting Requirements by Category } \\
\hline & Air Quality & Biological Resources & Cultural Resources & Environmental Review & Water Quality \\
\hline Geothermal Power & NA & $\begin{array}{l}\text { - Eagle Non-Purposeful Take } \\
\text { Permit } \\
\text { - Essential Fish Habitat } \\
\text { Consultation } \\
\text { - Migratory Bird Special Purpose } \\
\text { Permit } \\
\text { - ESA Section } 7 \text { or Section } 10 \\
\text { Consultation }\end{array}$ & $\begin{array}{l}\text { - NHPA Section } 106 \\
\text { Consultation }\end{array}$ & $\begin{array}{l}\text { - NEPA Environmental } \\
\text { Review }\end{array}$ & $\begin{array}{l}\text { - CWA Section } 401 \text { Water } \\
\text { Quality Certification } \\
\text { - CWA Section } 404 \text { Dredge } \\
\text { and Fill Permit }\end{array}$ \\
\hline Land-Based Wind Power & NA & $\begin{array}{l}\text { - Eagle Non-Purposeful Take } \\
\text { Permit } \\
\text { - Essential Fish Habitat } \\
\text { Consultation } \\
\text { - Marine Mammal Incidental Take } \\
\text { Authorizations } \\
\text { - Migratory Bird Special Purpose } \\
\text { Permit } \\
\text { - ESA Section } 7 \text { or Section } 10 \\
\text { Consultation }\end{array}$ & $\begin{array}{l}\text { - NHPA Section } 106 \\
\text { Consultation }\end{array}$ & $\begin{array}{l}\text { - NEPA Environmental } \\
\text { Review }\end{array}$ & $\begin{array}{l}\text { - CWA Section } 401 \text { Water } \\
\text { Quality Certification } \\
\text { - CWA Section } 404 \text { Dredge } \\
\text { and Fill Permit }\end{array}$ \\
\hline Solar Power & NA & $\begin{array}{l}\text { - Eagle Non-Purposeful Take } \\
\text { Permit } \\
\text { - Essential Fish Habitat } \\
\text { Consultation } \\
\text { - Migratory Bird Special Purpose } \\
\text { Permit } \\
\text { - ESA Section } 7 \text { or Section } 10 \\
\text { Consultation }\end{array}$ & $\begin{array}{l}\text { - NHPA Section } 106 \\
\text { Consultation }\end{array}$ & $\begin{array}{l}\text { - NEPA Environmental } \\
\text { Review }\end{array}$ & $\begin{array}{l}\text { - CWA Section } 401 \text { Water } \\
\text { Quality Certification } \\
\text { - CWA Section } 404 \text { Dredge } \\
\text { and Fill Permit }\end{array}$ \\
\hline
\end{tabular}




\begin{tabular}{|c|c|c|c|c|c|}
\hline \multirow{2}{*}{ Infrastructure Туре } & \multicolumn{5}{|c|}{ Regulatory and Permitting Requirements by Category } \\
\hline & Air Quality & Biological Resources & Cultural Resources & Environmental Review & Water Quality \\
\hline $\begin{array}{l}\text { Bulk Electric } \\
\text { Transmission }\end{array}$ & NA & $\begin{array}{l}\text { - Eagle Non-Purposeful Take } \\
\text { Permit } \\
\text { - Essential Fish Habitat } \\
\text { Consultation } \\
\text { - Marine Mammal Incidental Take } \\
\text { Authorizations } \\
\text { - Migratory Bird Special Purpose } \\
\text { Permit } \\
\text { - ESA Section } 7 \text { or Section } 10 \\
\text { Consultation }\end{array}$ & $\begin{array}{l}\text { - NHPA Section } 106 \\
\text { Consultation }\end{array}$ & $\begin{array}{l}\text { - NEPA Environmental } \\
\text { Review }\end{array}$ & $\begin{array}{l}\text { - CWA Section } 401 \text { Water } \\
\text { Quality Certification } \\
\text { - CWA Section } 404 \text { Dredge } \\
\text { and Fill Permit }\end{array}$ \\
\hline Natural Gas Pipeline & NA & $\begin{array}{l}\text { - Eagle Non-Purposeful Take } \\
\text { Permit } \\
\text { - Essential Fish Habitat } \\
\text { Consultation } \\
\text { - ESA Section } 7 \text { Consultation } \\
\text { - Marine Mammal Incidental Take } \\
\text { Authorizations } \\
\text { - Migratory Bird Special Purpose } \\
\text { Permit }\end{array}$ & $\begin{array}{l}\text { - NHPA Section } 106 \\
\text { Consultation }\end{array}$ & $\begin{array}{l}\text { - NEPA Environmental } \\
\text { Review }\end{array}$ & $\begin{array}{l}\text { - CWA Section } 401 \text { Water } \\
\text { Quality Certification } \\
\text { - CWA Section } 404 \text { Dredge } \\
\text { and Fill Permit }\end{array}$ \\
\hline $\begin{array}{l}\text { Natural Gas and Coal } \\
\text { Power Plants }\end{array}$ & $\begin{array}{l}\text { - Clean Air Act Title } \\
\text { V Operating Permit } \\
\text { - Acid Rain Permit } \\
\text { - Minor New Source } \\
\text { Review Permit } \\
\text { - National Emission } \\
\text { Standard for } \\
\text { Hazardous Air } \\
\text { Pollutants Approval } \\
\text { - New Source } \\
\text { Performance } \\
\text { Standards } \\
\text { - Non-attainment } \\
\text { New Source Review } \\
\text { Permit } \\
\text { - Prevention of } \\
\text { Significant } \\
\text { Deterioration Permit }\end{array}$ & $\begin{array}{l}\text { - Eagle Non-Purposeful Take } \\
\text { Permit } \\
\text { - Essential Fish Habitat } \\
\text { Consultation } \\
\text { - Marine Mammal Incidental Take } \\
\text { Authorizations } \\
\text { - Migratory Bird Special Purpose } \\
\text { Permit } \\
\text { - ESA Section } 7 \text { or Section } 10 \\
\text { Consultation }\end{array}$ & $\begin{array}{l}\text { - NHPA Section } 106 \\
\text { Consultation }\end{array}$ & $\begin{array}{l}\text { - NEPA Environmental } \\
\text { Review }\end{array}$ & $\begin{array}{l}\text { - CWA Section } 401 \text { Water } \\
\text { Quality Certification } \\
\text { - CWA Section } 402 \\
\text { NPDES Permit } \\
\text { - CWA Section } 404 \text { Dredge } \\
\text { and Fill Permit }\end{array}$ \\
\hline
\end{tabular}




\subsection{Comparison of Hydropower With Other Infrastructure Projects}

Infrastructure project types can differ in their potential environmental impacts and regulatory requirements based on factors including the spatial and temporal scope and the footprint on the landscape. As presented in Appendix A.1, most of the infrastructure project types included in this review have similar responsibilities related to biological resources, cultural resources, water quality, and environmental review. As such, the discussion in this section focuses on several distinctions between hydropower and other infrastructure project types, including:

- Comprehensive licensing/permitting structures and prerequisite authorizations

- Federal jurisdiction over infrastructure projects

- Term length of authorizations

- Stakeholder engagement requirements

- Consideration of development and non-development values.

\subsubsection{Comprehensive Licensing/Permitting Structures and Prerequisite Authorizations}

FERC licensed hydropower projects are subject to a comprehensive licensing process, which requires that a license applicant obtain various certifications, approvals, and/or permits as a prerequisite to obtaining a FERC license. These prerequisites include obtaining a 401 Water Quality Certification from a state resource agency as well as conducting consultations with federal and state entities regarding project impacts to endangered and threatened species, essential fish habitat, and cultural resources. In addition, the FPA provides opportunities for mandatory conditioning authority from federal agencies with jurisdiction over federal reservations (i.e., FPA Section 4(e) and mandatory fishway prescriptions from the USFWS or NOAA Fisheries (i.e., FPA Section 18) as well as recommendations for inclusion in a hydropower license related to comprehensive plans (i.e., FPA Section 10(a)) and PME of fish and wildlife (i.e., FPA Section 10(j)) pursuant to the FWCA. ${ }^{28}$

Similarly, nuclear energy projects are also subject to a comprehensive licensing process, requiring a license applicant to obtain various certifications, approvals, and/or permits as a prerequisite to receiving a combined nuclear license. These prerequisites include obtaining a 401 Water Quality Certification from a state resource agency as well as conducting consultations with federal and state entities regarding project impacts to endangered and threatened species, essential fish habitat, and cultural resources. By comparison, although other infrastructure project types analyzed in this chapter may require various permits and approvals at different times prior to construction and/or operation, they are not subject to the same type of comprehensive licensing scheme requiring the extent of coordination and prerequisite certifications, approvals, and/or permits as non-federal hydropower or nuclear licensing.

In comparison to other infrastructure project types, which do not have comprehensive licensing/authorization processes, licensing timelines for non-federal hydropower projects may be impacted by the time it takes to receive prerequisite approvals from other federal and state

\footnotetext{
${ }^{28}$ The FWCA was unique to hydropower and other water infrastructure projects because it only applies to projects that will cause a stream or other body of water to be impounded, diverted, the channel deepened, or otherwise controlled or modified for any purpose.
} 
resource agencies, which are built into the FERC licensing process. For example, FERC licensed hydropower projects require that a license applicant obtain a 401 Water Quality Certification from a state resource agency with EPA delegated authority (or from EPA in limited circumstances). State requirements for obtaining a 401 Water Quality Certification may vary by jurisdiction (e.g., the scope of review, the number of studies required) and not be limited to strictly water quality considerations. In addition, although 401 Water Quality Certifications for FERC licensed hydropower projects are subject to a 1-year time frame under the CWA, historically, this time frame had not been interpreted strictly as from the date of initial request

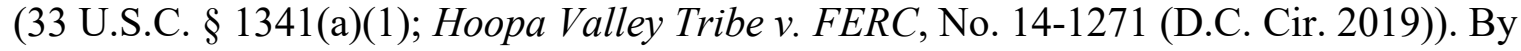
comparison, other infrastructure projects (e.g., solar, wind, or bulk transmission projects) may require an Individual 404 Dredge and Fill Permit from USACE, which also requires 401 Water Quality Certification from a state resource agency. However, absent special circumstances, USACE regulations provide that state resource agencies have 60 days to act on a request for a 401 Water Quality Certification. USACE has authority to extend the 60-day time frame; however, as mandated by the CWA, an extension must not exceed 1 year. (33 C.F.R. $\S$ 325.2(b)(ii)).

\subsubsection{Federal Jurisdiction Over Infrastructure Projects}

The infrastructure projects included in this analysis vary considerably on when a federal license, permit, or authorization is required for project construction and operation. Although some resource protection approvals, such as ESA consultation and CWA permits, may apply broadly across all project types regardless of location, that was not the case for all license, permit, and authorizations included in this review. A number of infrastructure project approvals, including hydropower licenses; nuclear licenses; interstate natural gas certificates of public convenience and necessity (CPCNs); and RHA Section 10 permits and air quality permitting for nuclear, natural gas, and coal-fired power plants apply across all jurisdictions, regardless of whether the project is sited on federal, state, or private land. However, other infrastructure projects included in this analysis predominately required approvals based on the location of the project being situated on federally-managed land or using an existing federal asset. This was the case for geothermal, solar, and wind authorizations as well as transmission line siting and development or alteration of water infrastructure using federal assets. These infrastructure projects generally required a lease or ROW from the BLM or applicable land management agency or a 408 Authorization from USACE.

\subsubsection{Term Length of Authorizations}

FERC licensed hydropower projects are subject to a 30-50 year licensing term (with a 40-year default licensing term) for original and new (re)licenses, after which the licensee must apply to FERC for relicensing (16 U.S.C. 808(e); 161 FERC 9 61,078) ${ }^{29}$ Similarly, nuclear energy projects with a combined nuclear license are subject to a 40-year licensing term, after which a nuclear project operator may apply for a 20 -year relicensing term from the U.S. Nuclear Regulatory Commission (NRC) (10 C.F.R. $\S \S 51.1$ - 51.125; 10 C.F.R. $\S \S 54.1-54.43$ ). Although other infrastructure projects may be subject to leases and other land access authorizations (e.g., ROWs and easements; BLM geothermal, solar, and wind leases) of variable

\footnotetext{
${ }^{29}$ During the relicensing process, a prospective license applicant may compete against the incumbent licensee for an existing project pursuant to the FPA (16 U.S.C. $\S 808(a)(1)$; Levine, Curtis, and Kazerooni 2017).
} 
lengths of time as prescribed by the federal agency with jurisdiction, generally lessees have the option to extend the lease/ROW without additional reviews and approvals or to dismantle the infrastructure project in accordance with a previously developed reclamation plan without the need for additional approvals.

\subsubsection{Stakeholder Engagement Requirements}

Depending on which FERC hydropower licensing process is used (i.e., ALP, ILP, or TLP), the licensing process requires varying degrees of early stakeholder engagement and participation from a variety of stakeholders including federal and state agencies, Indian tribes, NGOs, and the public. Stakeholders involved in the FERC hydropower licensing process must interact and coordinate with one another as well as complete agency consultations to develop comprehensive environmental study plans and project timelines early in the licensing process. By comparison, other infrastructure projects may be subject to review processes, such as NEPA environmental review, which require stakeholder coordination and public engagement (e.g., scoping, public meetings, notice and comment on draft or final review documents), but does not require the same level of stakeholder engagement or as many opportunities to participate in the process as the FERC hydropower licensing process.

\subsubsection{Consideration of Developmental and Non-Developmental Values}

One aspect unique to hydropower licenses is the FPA 4(e) requirement to give "equal consideration to the purposes of energy conservation; the protection, mitigation of damages to, and enhancement of, fish and wildlife (including related spawning grounds and habitat); the protection of recreational opportunities; and the preservation of other aspects of environmental quality." This balancing of developmental and non-developmental values in licensing hydropower projects is distinct from all other infrastructure projects included in the review. In part, this could be because public river systems are public trust resources, which should be available to all members of the public for a variety of uses. ${ }^{30}$ The most analogous review criteria are related to FERC's approval of interstate pipeline CPCNs under the Natural Gas Act. In the case of interstate natural gas pipelines, FERC must balance the public benefit of developing the pipeline against the potential adverse consequences of the proposed pipeline by evaluating economic, public, and environmental factors. However, this standard does not specifically require that FERC equally consider the benefits of energy development with respect to wildlife, recreation, and environmental quality. The other infrastructure projects included within this review do not require any balancing or equal consideration, but instead would only require analysis of the environmental impacts of the project if subject to NEPA (which also applies to FERC CPCNs and hydropower licenses). Although NEPA does require the federal agency to evaluate the environmental impacts of the proposed action and generally consider various alternatives to the proposed action (including a no-action alternative), NEPA does not require a federal agency to balance these considerations. Rather, NEPA only requires a federal agency to consider the environmental impacts of the proposed action but does not mandate environmental protection requirements.

\footnotetext{
${ }^{30}$ It is important to note that public lands are also a public trust resource in which competing values and uses must be balanced (e.g., the Federal Land Policy and Management Act requires that public lands be managed "on the basis of multiple use and sustained yield" (43 U.S.C. $§ 1701(a)(7))$.
} 


\subsection{Comparison of Hydropower Regulation in the United States to International Jurisdictions}

This section provides a comparison of the statutory and regulatory frameworks governing hydropower development in Canada, Sweden, and Norway (which are among the world's top producers of hydroelectric power internationally) to that of the United States (Myers 2015). Furthermore, because Sweden is a member state of the European Union and Norway is part of the European Economic Agreement, this section also considers European Union directives related to hydropower development. What follows in this section is a summary table that compares the statutory and regulatory frameworks governing hydropower development within these countries and a comparative discussion focused on:

- National versus local authority over hydropower development

- Term length of hydropower authorizations

- Resource protection requirements

- Public stakeholder engagement.

For a more detailed overview of the statutory and regulatory frameworks governing hydropower development in Canada, Sweden, and Norway, see Appendix A.2. See Table 4 for a high-level summary of these countries' hydropower requirements. 
Table 4. International Hydropower Development Summary Table

\begin{tabular}{|c|c|c|c|}
\hline Country & Statutes & Agencies & Public Participation \\
\hline \multirow[t]{7}{*}{ Canada } & $\frac{\text { Land Access }}{\text { Crown land tenure }}$ & $\frac{\text { Land Access }}{\text { Provincial/territorial agency }}$ & \multirow{7}{*}{$\begin{array}{l}\text { Appeals } \\
\text { Consultation } \\
\text { Comment }\end{array}$} \\
\hline & $\begin{array}{l}\text { Energy Facility Licensing } \\
\text { Provincial/territorial process }\end{array}$ & $\begin{array}{l}\text { Energy Facility Licensing } \\
\text { Provincial/territorial agency }\end{array}$ & \\
\hline & $\frac{\text { Environmental Review }}{\text { Impact Assessment Act }}$ & $\begin{array}{l}\text { Environmental Review } \\
\text { Impact Assessment Agency }\end{array}$ & \\
\hline & $\begin{array}{l}\text { Biological Resources Protection } \\
\text { Species At Risk Act } \\
\text { Migratory Birds Convention Act } \\
\text { Fisheries Act }\end{array}$ & $\begin{array}{l}\text { Biological Resources Protection } \\
\text { Department of Environment and Climate } \\
\text { Change Canada } \\
\text { Parks Canada Agency } \\
\text { Department of Fisheries and Oceans } \\
\text { Canada }\end{array}$ & \\
\hline & $\frac{\text { Cultural Resources Protection }}{\text { Impact Assessment Act }}$ & $\frac{\text { Cultural Resources Protection }}{\text { Impact Assessment Agency }}$ & \\
\hline & $\frac{\text { Water Quality }}{\text { Canadian Navigable Waters Act }}$ & $\frac{\text { Water Quality }}{\text { Transport Canada }}$ & \\
\hline & $\begin{array}{l}\text { Other Development Restrictions } \\
\text { Wildlife Act }\end{array}$ & $\begin{array}{l}\text { Other Development Restrictions } \\
\text { Department of Environment and Climate } \\
\text { Change Canada }\end{array}$ & \\
\hline \multirow[t]{3}{*}{ Sweden } & $\frac{\text { Land Access }}{\text { Regional process }}$ & $\begin{array}{l}\frac{\text { Land Access }}{\text { Land Court }} \\
\text { County Board }\end{array}$ & \multirow[t]{3}{*}{$\begin{array}{l}\text { Consultation } \\
\text { Comment } \\
\text { Hearings }\end{array}$} \\
\hline & $\begin{array}{l}\text { Energy Facility Licensing } \\
\text { Swedish Environmental Code }\end{array}$ & $\begin{array}{l}\text { Energy Facility Licensing } \\
\text { Land Court } \\
\text { County Board }\end{array}$ & \\
\hline & $\frac{\text { Environmental Review }}{\text { Swedish Environmental Code }}$ & $\begin{array}{l}\text { Environmental Review } \\
\text { County Board }\end{array}$ & \\
\hline
\end{tabular}




\begin{tabular}{|c|c|c|c|}
\hline Country & Statutes & Agencies & Public Participation \\
\hline & $\begin{array}{l}\text { Biological Resources Protection } \\
\text { Regulations in development }{ }^{a}\end{array}$ & $\frac{\text { Biological Resources Protection }}{\text { County Board }}$ & \\
\hline & $\frac{\text { Cultural Resources Protection }}{\text { Regulations in development }}$ & $\begin{array}{l}\text { Cultural Resources Protection } \\
\text { County Board }\end{array}$ & \\
\hline & $\begin{array}{l}\text { Water Quality } \\
\text { Regulations in development }\end{array}$ & $\frac{\text { Water Quality }}{\text { County Board }}$ & \\
\hline & $\frac{\text { Other Development Restrictions }}{\text { Swedish Environmental Code }}$ & 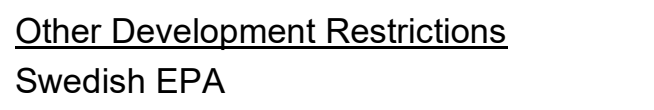 & \\
\hline & $\begin{array}{l}\text { aAt the direction of the European Union, } \\
\text { Sweden is currently in the process of } \\
\text { developing a more comprehensive } \\
\text { hydropower licensing procedure, which } \\
\text { takes into account project impacts to } \\
\text { biological, wildlife, and cultural resources } \\
\text { and establishes a license review and } \\
\text { renewal procedure (SwAM 2019a, 2019b; } \\
\text { Rudberg et al. 2015). }\end{array}$ & & \\
\hline \multirow[t]{4}{*}{ Norway } & $\frac{\text { Land Access }}{\text { N/A }}$ & $\frac{\text { Land Access }}{\text { N/A }}$ & \multirow{4}{*}{$\begin{array}{l}\text { Consultation } \\
\text { Comment } \\
\text { Meetings } \\
\text { Hearings } \\
\text { Appeals }\end{array}$} \\
\hline & $\begin{array}{l}\text { Energy Facility Licensing } \\
\text { Watercourse Regulation Act } \\
\text { Water Resources Act } \\
\text { Waterfall Rights Act }\end{array}$ & $\begin{array}{l}\text { Energy Facility Licensing } \\
\text { King in Council } \\
\text { Norwegian Water Resources and Energy } \\
\text { Directorate }\end{array}$ & \\
\hline & $\begin{array}{l}\text { Environmental Review } \\
\text { Planning and Building Act }\end{array}$ & $\begin{array}{l}\text { Environmental Review } \\
\text { Norwegian Water Resources and Energy } \\
\text { Directorate } \\
\text { Ministry of Local Government and } \\
\text { Modernization } \\
\text { Local government bodies }\end{array}$ & \\
\hline & Biological Resources Protection & Biological Resources Protection & \\
\hline
\end{tabular}




\begin{tabular}{|l|l|l|}
\hline \multicolumn{1}{|l|}{$\begin{array}{l}\text { Statutes } \\
\text { Country }\end{array}$} & $\begin{array}{l}\text { Agencies } \\
\text { Nature Diversity Act }\end{array}$ & $\begin{array}{l}\text { Norwegian Water Resources and Energy } \\
\text { Directorate } \\
\text { Ministry of Climate and the Environment }\end{array}$ \\
\hline $\begin{array}{l}\text { Cultural Resources Protection } \\
\text { Cultural Heritage Act }\end{array}$ & $\begin{array}{l}\text { Cultural Resources Protection } \\
\text { Directorate of Cultural Heritage }\end{array}$ \\
\hline $\begin{array}{ll}\text { Water Quality } \\
\text { Pollution Control Act }\end{array}$ & $\begin{array}{l}\text { Water Quality } \\
\text { Ministry of the Environment }\end{array}$ \\
\hline $\begin{array}{l}\text { Other Development Restrictions } \\
\text { Svalbard Environmental Protection Act } \\
\text { Protection Plan for Watercourses }\end{array}$ & $\begin{array}{l}\text { Other Development Restrictions } \\
\text { Ministry of Climate and Environment } \\
\text { Parliament }\end{array}$ \\
\hline
\end{tabular}




\subsection{International Hydropower Comparison Discussion}

\subsubsection{National vs. Local Authority Over Hydropower Development}

In comparing the regulatory structure of each country, the United States and Canada regulate hydropower development through a cooperative federal, state, and local process. However, in the United States, the federal government, through FERC, has primary licensing authority for nonfederal hydropower development. By comparison, in Canada, provinces have primary licensing authority and play the central role in hydropower project development. In contrast, hydropower development in Sweden is regulated primarily at the regional level with minimal federal involvement, and in Norway hydropower development is regulated through a centralized, national system.

\subsubsection{Term Length of Hydropower Authorizations}

The United States and Norway have regulatory frameworks in place that establish term lengths for hydropower licenses. In the United States, pursuant to the FPA, FERC hydropower licenses may be issued for a term of 30-50 years; however, FERC's 2017 policy statement establishes a 40-year default licensing term for new and original hydropower licenses. Similarly, in Norway, hydropower licenses issued by the King-in-Council are subject to a term of 30-50 years pursuant to the Watercourse Regulation Act. By contrast, in Canada license terms may vary by province, with some provinces establishing hydropower licensing terms (e.g., in Manitoba, hydropower licenses may be issued for a term of 30-50 years pursuant to the Water Power Act) while other provinces grant hydropower licenses in perpetuity (e.g., in Quebec, hydropower licenses are granted in perpetuity pursuant to the Hydro-Quebec Act). In Sweden, all existing hydropower licenses are granted in perpetuity; however, Sweden is currently in the process of drafting hydropower legislation that would establish licensing terms for new hydropower licenses.

\subsubsection{Resource Protection Requirements}

The United States, Canada, Norway, and Sweden all have regulatory frameworks in place that require project proponents to analyze a hydropower project's potential impacts on biological resources, cultural resources, and the environment more generally. For example, similar to the United States ESA Section 7 consultation process, in Canada and Norway, the hydropower licensing process requires that project proponents consult with multiple resource protection agencies to analyze project impacts on listed endangered species. Sweden, a member state of the European Union, is currently developing a more comprehensive hydropower authorization procedure that takes into account impacts relating to biological, wildlife, and cultural resources so that it is more closely aligned with European Union environmental directives. However, in terms of the number of stakeholders involved in the authorization process, the United States is distinct from several of the other countries analyzed in this report. In the United States, up to 11 federal agencies may participate in the hydropower licensing process. In addition, the participation of state water quality and wildlife resource agencies with jurisdiction as well as tribal and public engagement is required. By contrast, Norway has a more consolidated approach, which may involve the participation of between 5-6 federal governmental agencies (i.e., ministries and/or parliament) in addition to local governmental bodies. By comparison, in Canada and Sweden, hydropower authorization processes generally fall under provincial or local jurisdiction. Specifically, in Canada, hydropower authorization processes may only require the 
participation of federal agencies if the project exclusively impacts federal land or resources. However, similarly to the United States, many Canadian provinces and territories require consultation and engagement with Aboriginal peoples during the hydropower authorization process.

\subsubsection{Public Stakeholder Engagement}

The public plays a key role in the licensing process of hydropower projects in the United States, Canada, Sweden, and Norway. In the United States and Norway, the public may participate formally or informally in the hydropower licensing process by consulting with the project proponent; providing public comment; and engaging in stakeholder meetings, hearings, and appeal processes. Similarly, in Sweden the public may participate in the hydropower licensing process by consulting with the project proponent, providing public comment, and engaging in approval hearings. In Canada, recent amendments to Canadian federal statutes have increased public participation in hydropower development and require that project proponents engage with the public and Aboriginal peoples throughout EA processes. 


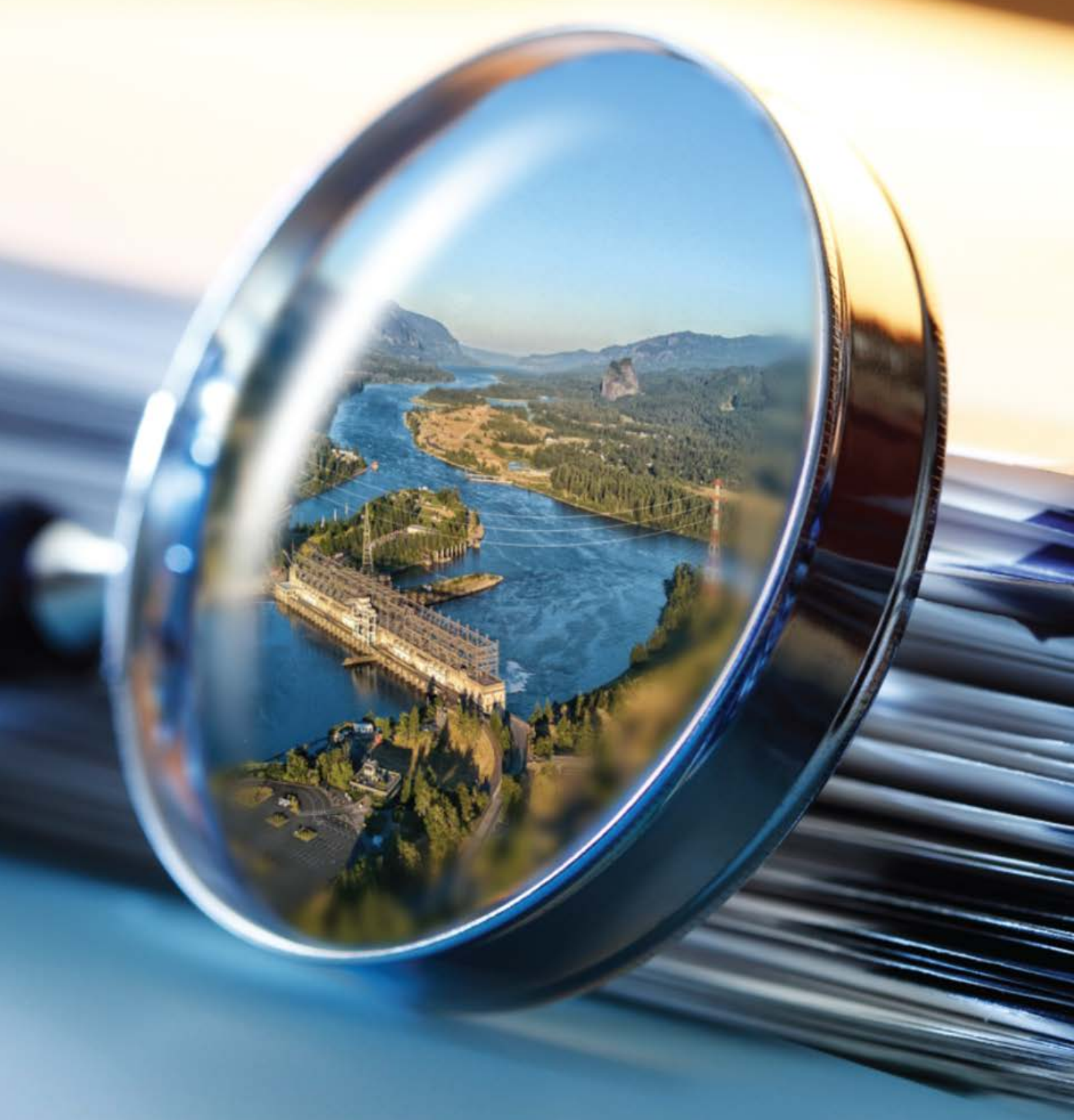

AN EXAMINATION OF THE HYDROPOWER LICENSING AND FEDERAL AUTHORIZATION PROCESS

3

Statistical Description and Analysis of
Hydropower Licensing Timelines

OAK RIDGE 


\section{Statistical Description and Analysis of Hydropower Licensing Timelines}

\subsection{Introduction}

Issuance of the 30-50-year licenses required for most non-federal hydropower projects involves many steps that can lead to variability in the licensing timeline for a project. The variability in timelines from the filing of the initial documents to issuance of the license can be very large, with some projects taking months while others take decades. This uncertainty in licensing timelines can have impacts on the cost and time investment for all stakeholders involved and can impact the length and cost of project development and financing, particularly for projects seeking original licenses (Uria-Martinez, Johnson, and O'Connor 2018; see also Chapter 4 in this report). There are limited quantitative data on the factors that may be influencing the length of these timelines and on where challenges in the licensing process may occur (FERC 2001; UriaMartinez, Johnson, and O'Connor 2018). As a result, the U.S. Department of Energy's (DOE's) Water Power Technologies Office funded this study to analyze the hydropower licensing process and gain insights into process uncertainties. This chapter seeks to quantitatively identify factors associated with licensing timeline length, determine where challenges may occur in the process, and point out the greatest sources of uncertainty in the hydropower licensing and federal authorization process.

\subsection{Dataset Description}

To understand factors that influence hydropower licensing timelines, a dataset of dates and characteristics of original and relicensed hydropower project licenses was created by extracting information from FERC hydropower licensing documents such as license orders and NEPA and BO documents. Steps in the licensing process and hypothesized influential factors included in analyses presented in this chapter were informed by the project Stakeholder Working Group.

The project team examined information from 150 projects, randomly selecting 129 projects from a FERC-maintained list of the 296 projects that had licenses issued since October 1, 2005. This group represented $44 \%$ of all licensed projects in the study period, which is a large sample relative to the total number of projects licensed during the study period. Another 21 projects were from a FERC-maintained list of annual licenses, described below.

The resulting dataset of 107 conventional hydropower projects (Figure 3) consisted of projects that remained from the 129 randomly selected projects after excluding projects that did not fit study criteria (https://hydrosource.ornl.gov/dataset/hydropower-licensing-timeline-and-costdataset). The 22 excluded projects included transmission line projects, pumped storage projects, and projects with multiple types of hydropower facilities (e.g., pumped storage and conventional). This cutoff date was chosen because October 1, 2005, was the beginning date of the ILP, although projects using all three license processes were included in the dataset of 107 projects. The final dataset included 44 original licenses and 63 relicenses. More details on the sample sizes of projects with specific characteristics such as project type, mode of operation, and license process are provided in Table 5 and Table 6. 
To the extent possible, licensing milestone dates were retrieved from FERC license orders (Figure 4). Other documents such as NEPA documents, BOs, and study determination letters (from ILP projects) were also mined for information on licensing milestone dates when information could not be found in the license order. Information on the date when NOAA Fisheries and USFWS received complete Section 7 Consultation packages were provided by those agencies. Some project characteristics and locations for mapping were obtained from the Oak Ridge National Laboratory (ORNL) Existing Hydropower Assets Database (Johnson et al. 2020). In cases where there was a discrepancy between information reported in the license order and the ORNL Existing Hydropower Assets Database or another document, information from the license order was used.
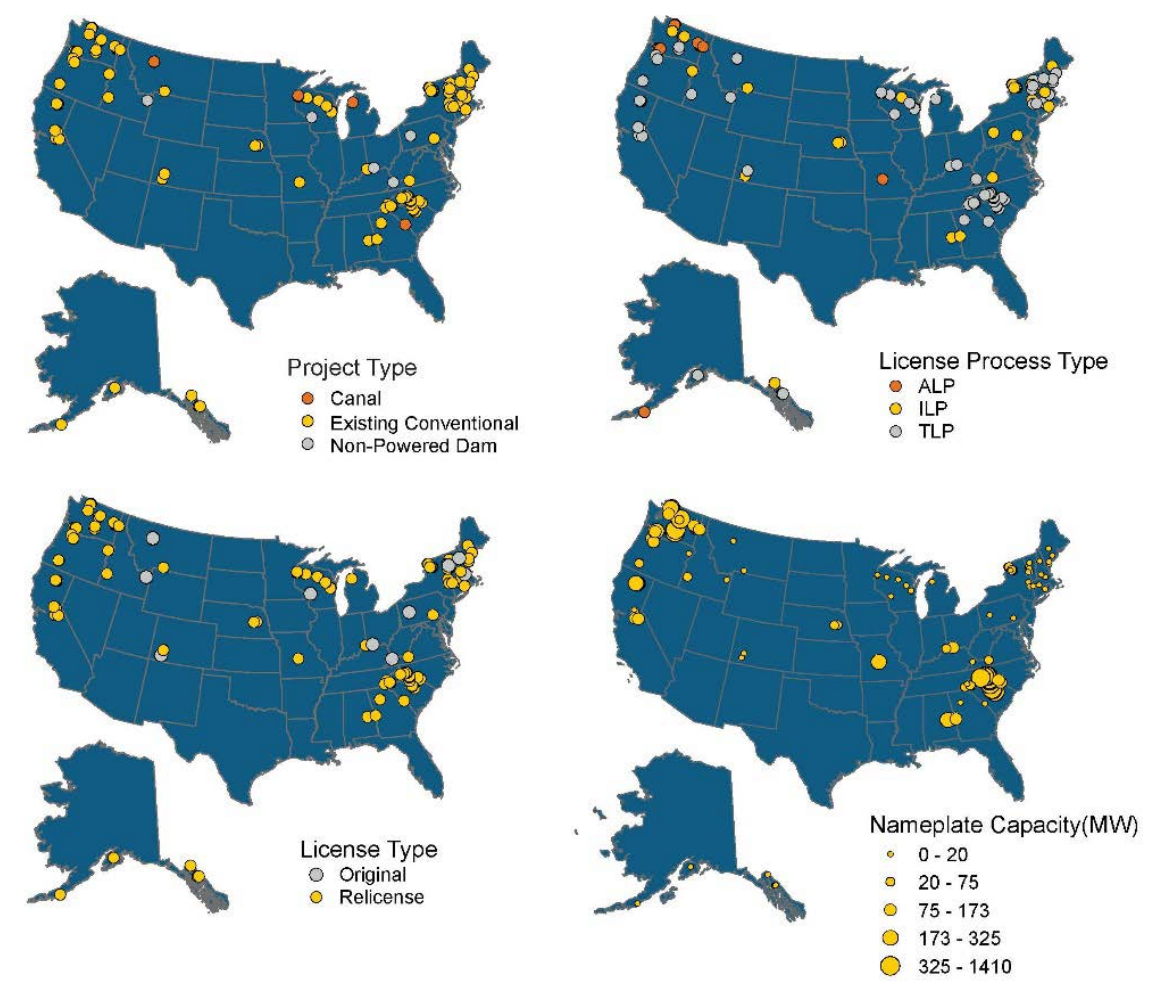

Figure 3. Locations of each individual facility in the 107 projects in the licensing timeline dataset from the Existing Hydropower Assets Database (Johnson et al. 2021)

Qualitative analysis was conducted of FERC-published information on hydropower projects being relicensed that have completed the NEPA process and had either CWA Section 401 Water Quality Certifications or ESA Section 7 Consultations pending for more than 1-year. FERC has included this information on its website since 2017 and versions of this list accessed in August 2019 and February 2020 were qualitatively compared to determine how many projects from the 2019 list are still on the 2020 list and how many projects not on the 2020 list have been licensed (Table 7).

Average values reported in this chapter are mean \pm standard deviation unless otherwise noted. Additional methods for data collection and detailed analysis methods and results are provided in Appendix B. 


\subsection{Overall Timeline Description}

The overall mean length of time from filing of the NOI/PAD to license issuance across the sample of 107 projects was 6.6 years (Table 5). The range of NOI/PAD to license issuance timelines recorded in our dataset was 1.1 years to 19.5 years. The mean timeline length during the pre-filing period (filing of NOI/PAD to filing of final license application) was 2.7 years and was shorter than the mean timeline length of the post-filing period (filing of license application to license issuance) of 3.8 years (Figure 5).

Each hydropower project has a unique licensing story, but examples of the types and characteristics of hydropower projects representing short, average, and long NOI to license issuance timelines in our sample of 107 may provide insight into challenges encountered by stakeholders in the hydropower licensing and federal authorization process. Boxes 1-3 were highlighted from the case studies to illustrate examples of project licensing stories that represent relatively short (Box 1), average (Box 2), and long (Box 3) NOI to license issuance timelines with respect to the sample of 107 projects. 

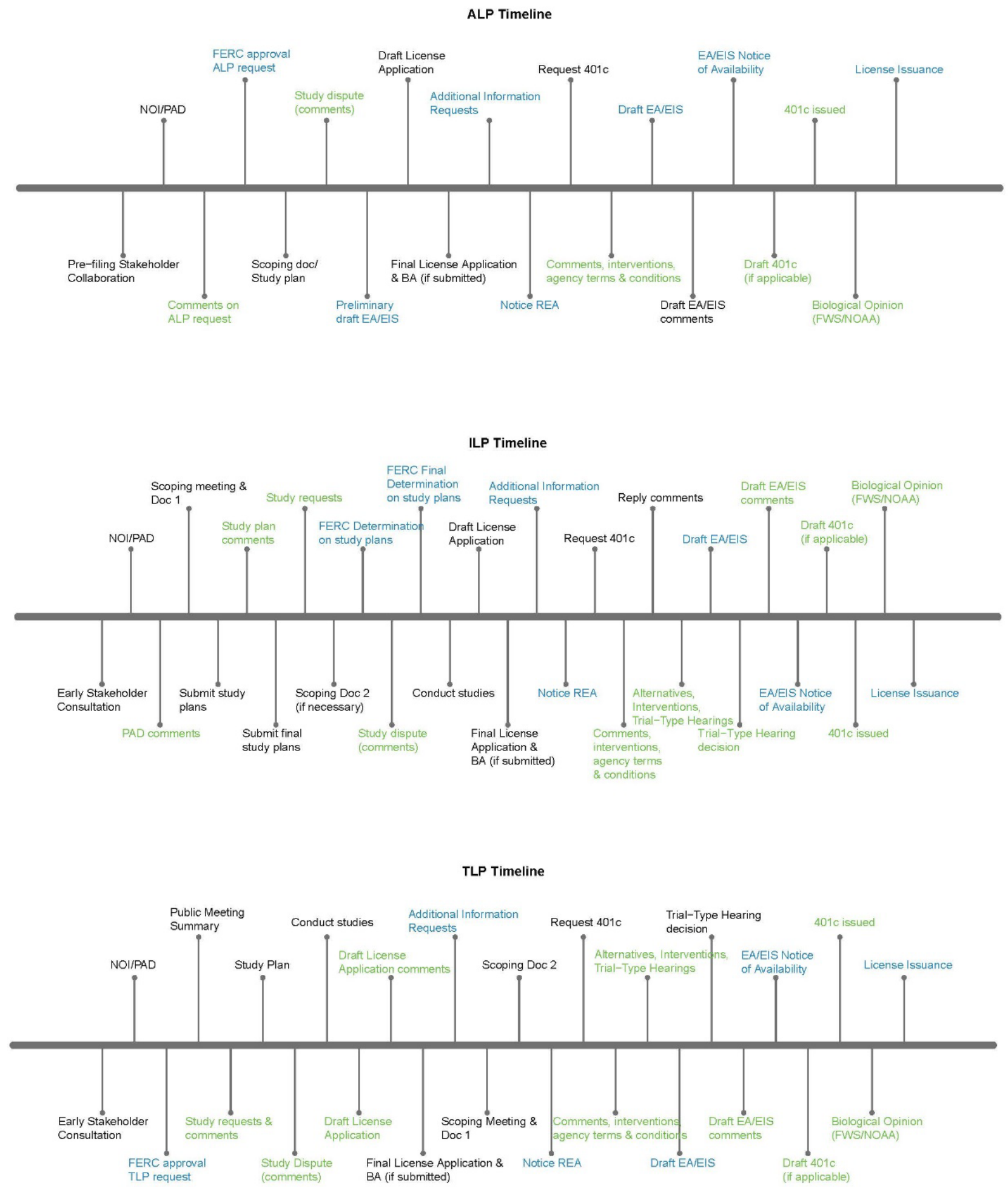

Figure 4. Example timeline showing relative order of licensing milestones for hypothetical projects using the a) alternative, b) integrated, and c) traditional licensing processes where the license applicant is responsible for milestones in black text, other stakeholders are responsible for milestones in green text, and FERC is responsible for milestones in blue text. 


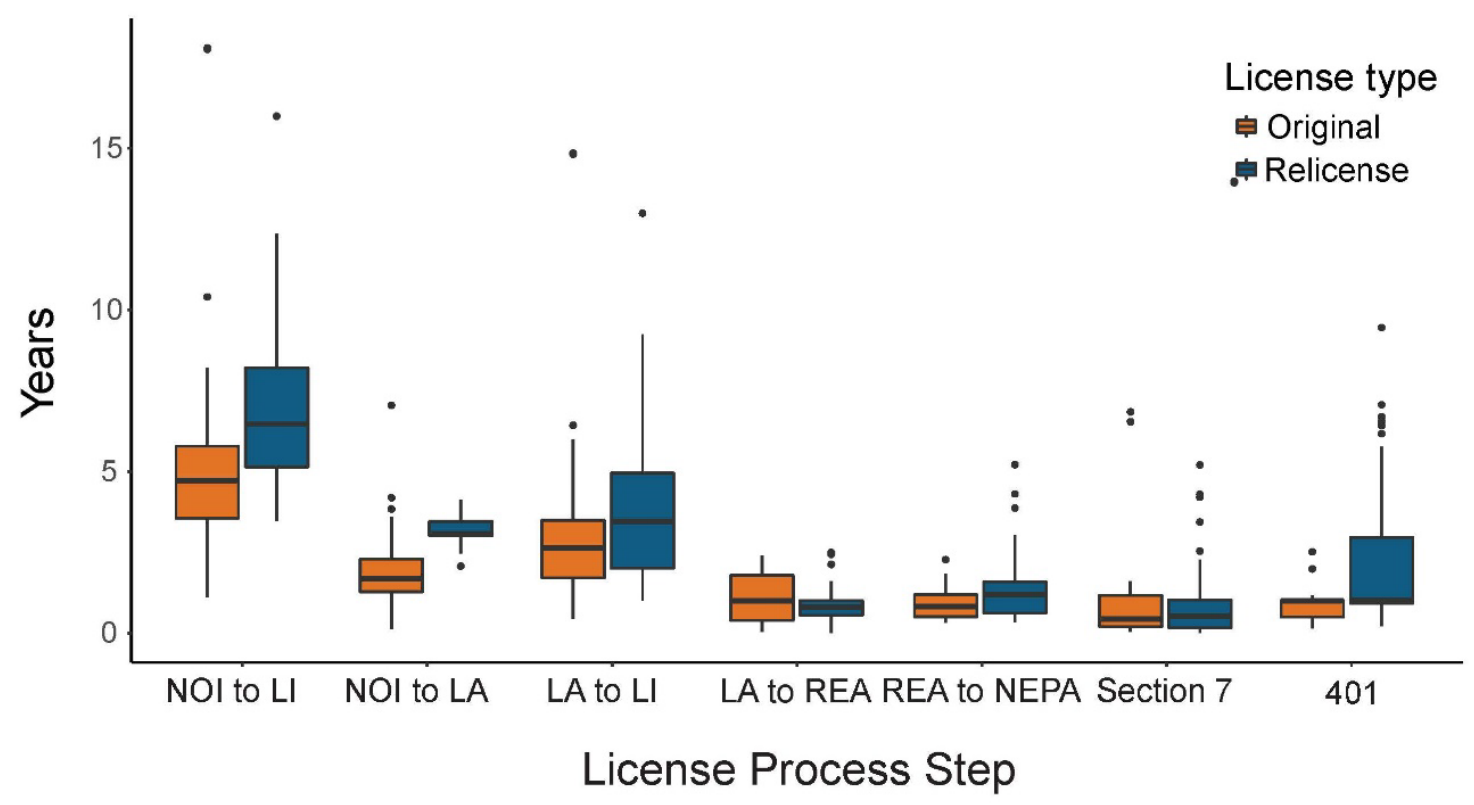

Figure 5. Boxplot summarizing the time taken by segments of the hydropower licensing and federal authorization process for the dataset of 107 projects. Segments include filing of the notice of intent/pre-application document to license issuance (NOI to LI), filing of NOI/PAD to final license application (NOI to LA), LA to LI, LA to ready for environmental analysis (REA), REA to final National Environmental Policy Act environmental impact statement or environmental analysis (EIS), FERC request for Section 7 Consultation to issuance of biological opinion or letter of concurrence, licensee request for state 401 water quality certification to issuance or waiver of water quality certification. Box boundaries show first and third quartiles, the band inside the box shows the median, vertical lines show largest and smallest values within 1.5 times the interquartile range, and dots show points larger than 1.5 times the interquartile range.

\subsection{Project Characteristics}

The dataset of 107 projects contained four types of projects: existing conventional (hydropower dams already in operation), in-canal conventional (conventional hydropower projects in an irrigation or other man-made canal), new development (construction of new dam and hydropower facilities), and non-powered dam retrofit (existing dams being retrofitted with hydropower infrastructure; Table 6). Of note among these projects were four existing conventional hydropower projects receiving original licenses. These projects included two approximately $2 \mathrm{MW}$ facilities in Vermont that had not been previously licensed (NOI/PAD to license issuance timeline of approximately 18 years each), one historic mill in Massachusetts that was not required to have a license until the facility was upgraded to $8 \mathrm{MW}$ (NOI/PAD to license issuance timeline of 2.9 years), and one facility with generation capacity of $<0.05 \mathrm{MW}$ that powers a backpacking hut and is not connected to the grid (no NOI was filed and license application to license issuance timeline was 0.6 years). The facility powering the backpacking hut is owned by the Appalachian Mountain Club and was installed using funding from of a 1981 DOE demonstration grant. It received expedited licensing because of close coordination with federal agencies in preparing the license application. 


\section{Box 3.1 Timeline of a Project With a Shorter-Than-Average Timeline}

This box provides an example of the licensing process for one project with a relatively short timeline (e.g., in the lowest quartile of timelines in the dataset of 107 projects) using the A-Drop Project (P-12549; nameplate capacity: $1 \mathrm{MW}$; NOI/PAD-License Issuance: 2.3 years) as an example. Although this project was issued a license, it was not constructed. More complete details on this license are available in case studies detailed in Appendix C.

The A-Drop Project was a conventional hydropower project to be constructed on the Greenfields Main Canal, which is part of the BOR's Sun River Irrigation Project in Teton County, Montana. This project proposed to install a new inflatable weir that would divert water from the canal into a new powerhouse. The new tailrace would have been buried to discharge flows back into the drop structure's stilling pool. This project would have operated strictly as a run-of-release project, would not occupy any federal lands, and would not have impounded water. The project EA was issued in 0.3 years with a finding of no significant impact (FONSI) with no impacts on endangered species. The CWA Section 401 certification was waived by the Montana Department of Environmental Quality and there was determined to be no adverse effects to historic properties due to the project. PME measures included those on species protection for Arctic grayling that may be entrained into the canal and implementation of an Historic Properties Management Plan (HPMP).

Table 5. Years From Beginning to End of Step in Licensing Process

\begin{tabular}{lllll}
\hline $\begin{array}{l}\text { Timeline of Licensing Process } \\
\text { Steps }\end{array}$ & Original & Relicense & Total \\
\hline NOI/PAD to License Issuance & $5.0 \pm 2.9$ & $7.6 \pm 3.3$ & $6.6 \pm 3.4$ \\
& $(36)$ & $(62)$ & $(98)$ \\
\hline NOI/PAD to Final License Application & $1.9 \pm 1.3$ & $3.2 \pm 0.3$ & $2.7 \pm 1.0$ \\
& $(36)$ & $(62)$ & $(98)$ \\
\hline Final License Application to License & $2.9 \pm 2.3$ & $4.4 \pm 3.3$ & $3.8 \pm 3.0$ \\
Issuance & $(45)$ & $(62)$ & $(107)$ \\
\hline Application to NEPA (Final License & $1.1 \pm 0.7$ & $0.8 \pm 0.5$ & $0.9 \pm 0.6$ \\
Application to REA) & $(45)$ & $(62)$ & $(107)$ \\
\hline NEPA (REA to Final NEPA) & $0.9 \pm 0.5$ & $1.3 \pm 0.9$ & $1.2 \pm 0.8$ \\
& $(45)$ & $(62)$ & $(107)$ \\
\hline 401 CWA Certification (First & $1.2 \pm 2.4$ & $2.8 \pm 3.3$ & $2.2 \pm 3.1$ \\
application to 401 issuance) & $(34)$ & $(51)$ & $(85)$ \\
\hline Section 7 (FERC Request to BO/LOC) & $1.2 \pm 2.0$ & $1.2 \pm 1.6$ & $1.2 \pm 1.7$ \\
\hline USFWS Section 7 (Applicant Complete & $(19)$ & $0.5 \pm 0.8$ & $(38)$ & $(57)$ \\
Info to BO/LOC) & $(13)$ & $1.0 \pm 1.7$ & $0.8 \pm 1.5$ \\
\hline NOAA Section 7 Consultation & 0.8 & $(28)$ & $(41)$ \\
(Applicant Complete Info to BO/LOC) & $(1)$ & $1.7 \pm 1.4$ & $1.5 \pm 1.3$ \\
\hline
\end{tabular}

Note: All values are mean + SD $(\mathrm{N})$. The calculated $\mathrm{N}$ for each statistic only includes the number of observations with notice of intent/pre-application document (NOI/PAD) to license issuance values, which were not available for all projects so total $\mathrm{N}$ may be $<107$. 


\section{Box 3.2 Timeline of an Average Sized Project With an Average Length Timeline}

Based on the project dataset $(\mathrm{N}=107)$, the median nameplate capacity is $6.4 \mathrm{MW}$ and takes $6.7 \pm$ 3.4 (mean \pm standard deviation) years to receive a license. This box provides an example of the licensing process for one project of approximately median size with an approximately average timeline using the Badger-Rapide-Croche Project (P-2677; nameplate capacity: 9.8 MW; NOI/PAD - LI: 6 years) as an example. More complete details on this license are available in case studies detailed in Appendix C.

The Badger-Rapide-Croche Project consists of two facilities on the Fox River, Wisconsin: the Badger Development located in the City of Kaukauna at the USACE Kaukauna Dam and the Rapide-Croche Development located in the Town of Buchanan at the USACE Rapide-Croche Dam. The Kaukauna Dam is approximately 4.5 miles downstream of the Badger Dam and both dams are operated for navigation, recreation, water quality, and flood control purposes. This project obtained an original 50-year license in 1977 with a term that was retroactively dated to begin in 1938, was relicensed for 30-years in 1989, and was most recently relicensed again in 2011 for 30-years. The project EA was issued in 1.4 years with a Finding of No Significant Impact and the project was determined to cause no adverse impacts on endangered species. The CWA Section 401 certification from the Wisconsin Department of Natural Resources was issued in 1.9 years and resulted in 14 conditions in the license. Protection, Mitigation, and Enhancement measures included those on species protection, water quality, instream flow, and improved recreation access and educational information.

\section{Table 6. Mean + Standard Deviation (N) Years From Notice of Intent/Preapplication Document to License Issuance}

\begin{tabular}{|c|c|c|c|}
\hline $\begin{array}{l}\text { NOI/PAD to License Issuance Timeline } \\
\text { Predictor Variables }\end{array}$ & Original & Relicense & Total \\
\hline \multicolumn{4}{|l|}{ Project Type } \\
\hline Existing Conventional & $\begin{array}{l}13.0 \pm 8.8 \\
(3)\end{array}$ & $\begin{array}{l}7.4 \pm 3.0 \\
(59)\end{array}$ & $\begin{array}{l}7.7 \pm 3.6 \\
(62)\end{array}$ \\
\hline In-Canal Conventional & $\begin{array}{l}3.4 \pm 2.4 \\
(3)\end{array}$ & $\begin{array}{l}6.2 \pm 1.9 \\
(3)\end{array}$ & $\begin{array}{l}4.9 \pm 2.4 \\
(9)\end{array}$ \\
\hline New Development & $\begin{array}{l}5.0 \pm 2.5 \\
(3)\end{array}$ & (0) & $\begin{array}{l}5.0 \pm 2.5 \\
(3)\end{array}$ \\
\hline Non-Powered Dam Retrofit & $\begin{array}{l}4.7 \pm 1.9 \\
(27)\end{array}$ & (0) & $\begin{array}{l}4.7 \pm 1.9 \\
(27)\end{array}$ \\
\hline \multicolumn{4}{|l|}{ Mode of Operation } \\
\hline Run-of-River & $\begin{array}{l}5.0 \pm 2.2 \\
(30)\end{array}$ & $\begin{array}{l}7.3 \pm 3.2 \\
(26)\end{array}$ & $\begin{array}{l}6.0 \pm 2.9 \\
(56)\end{array}$ \\
\hline Peaking/Storage & $\begin{array}{l}7.1 \pm 7.4 \\
(3)\end{array}$ & $\begin{array}{l}8.0 \pm 3.2 \\
(24)\end{array}$ & $\begin{array}{l}7.8 \pm 3.8 \\
(27)\end{array}$ \\
\hline \multicolumn{4}{|l|}{ License Process } \\
\hline ALP & $\begin{array}{l}3.6 \pm 2.5 \\
(3)\end{array}$ & $\begin{array}{l}7.8 \pm 2.5 \\
(8)\end{array}$ & $\begin{array}{l}6.7 \pm 3.2 \\
(11)\end{array}$ \\
\hline ILP & $\begin{array}{l}6.2 \pm 2.7 \\
(4)\end{array}$ & $\begin{array}{l}5.9 \pm 1.1 \\
(22)\end{array}$ & $\begin{array}{l}6.0 \pm 1.5 \\
(26)\end{array}$ \\
\hline TLP & $\begin{array}{l}5.2 \pm 3.1 \\
(29)\end{array}$ & $\begin{array}{l}8.5 \pm 3.8 \\
(32)\end{array}$ & $\begin{array}{l}6.8 \pm 3.8 \\
(61)\end{array}$ \\
\hline \multicolumn{4}{|l|}{ Settlement Agreement } \\
\hline Yes & $\begin{array}{l}6.2 \pm 3.4 \\
(4)\end{array}$ & $\begin{array}{l}8.3 \pm 2.8 \\
(32)\end{array}$ & $\begin{array}{l}8.4 \pm 3.3 \\
(36)\end{array}$ \\
\hline
\end{tabular}




\begin{tabular}{|c|c|c|c|}
\hline $\begin{array}{l}\text { NOI/PAD to License Issuance Timeline } \\
\text { Predictor Variables }\end{array}$ & Original & Relicense & Total \\
\hline No & $\begin{array}{l}5.1 \pm 3.0 \\
(32)\end{array}$ & $\begin{array}{l}6.4 \pm 2.9 \\
(30)\end{array}$ & $\begin{array}{l}5.6 \pm 3.0 \\
(62)\end{array}$ \\
\hline \multicolumn{4}{|l|}{ NEPA Document } \\
\hline EA & $\begin{array}{l}5.3 \pm 3.7 \\
(35)\end{array}$ & $\begin{array}{l}6.8 \pm 3.0 \\
(46)\end{array}$ & $\begin{array}{l}6.2 \pm 3.4 \\
(90)\end{array}$ \\
\hline EIS & $\begin{array}{l}6.1 \\
(1)\end{array}$ & $\begin{array}{l}9.0 \pm 2.2 \\
(16)\end{array}$ & $\begin{array}{l}8.8 \pm 2.2 \\
(17)\end{array}$ \\
\hline \multicolumn{4}{|l|}{ ESA } \\
\hline Yes & $\begin{array}{l}6.7 \pm 4.9 \\
(17)\end{array}$ & $\begin{array}{l}7.8 \pm 2.4 \\
(38)\end{array}$ & $\begin{array}{l}7.5 \pm 3.3 \\
(55)\end{array}$ \\
\hline No & $\begin{array}{l}4.2 \pm 1.5 \\
(19)\end{array}$ & $\begin{array}{l}6.6 \pm 3.7 \\
(24)\end{array}$ & $\begin{array}{l}5.6 \pm 3.1 \\
(43)\end{array}$ \\
\hline \multicolumn{4}{|l|}{ Licensee Type } \\
\hline Investor-Owned Utility & $\begin{array}{l}11.4 \pm 9.5 \\
(2)\end{array}$ & $\begin{array}{l}8.6 \pm 3.8 \\
(31)\end{array}$ & $\begin{array}{l}8.8 \pm 4.1 \\
(33)\end{array}$ \\
\hline $\begin{array}{r}\text { NOI/PAD to License Issuance Timeline } \\
\text { Predictor Variables }\end{array}$ & Original & Relicense & Total \\
\hline Private Non-Utility & $\begin{array}{l}4.4 \pm 1.5 \\
(33)\end{array}$ & $\begin{array}{l}6.3 \pm 3.0 \\
(15)\end{array}$ & $\begin{array}{l}5.1 \pm 6.1 \\
(48)\end{array}$ \\
\hline Publicly Owned Utility & $\begin{array}{l}5.1 \pm 3.0 \\
(10)\end{array}$ & $\begin{array}{l}6.7 \pm 1.3 \\
(15)\end{array}$ & $\begin{array}{l}6.1 \pm 2.1 \\
(25)\end{array}$ \\
\hline \multicolumn{4}{|l|}{ Fishway Prescription } \\
\hline Yes & -- & $\begin{array}{l}7.9 \pm 2.4 \\
(18)\end{array}$ & $\begin{array}{l}7.9 \pm 2.4 \\
(18)\end{array}$ \\
\hline No & $\begin{array}{l}5.3 \pm 3.7 \\
(36)\end{array}$ & $\begin{array}{l}7.1 \pm 3.2 \\
(44)\end{array}$ & $\begin{array}{l}6.4 \pm 3.5 \\
(80)\end{array}$ \\
\hline
\end{tabular}

Note: Calculated $\mathrm{N}$ for each statistic only includes projects with notice of intent/preapplication document (NOI/PAD) to license issuance dates, so total $\mathrm{N}$ may be $<107$. 


\section{Box 3.3 Timeline of a Project With a Longer-Than-Average Length Timeline}

This box provides an example of the licensing process for a project with a relatively long timeline (e.g., in the highest quartile of timelines in the dataset of 107 projects) using the Waterbury Hydroelectric Project (P-2090; nameplate capacity: 5.5 MW; NOI/PAD-License Issuance: 19.5 years) as an example. More complete details on this license are available in case studies detailed in Appendix C.

The Waterbury Hydroelectric Project consists of one dam that creates one reservoir on the Little River in Washington County, Vermont. From the project area, the Little River flows in a southerly direction for about 2.5 miles before joining the Winooski River. From its confluence with the Little River, the Winooski River flows about 90 miles in a northwesterly direction to Lake Champlain, which is located on the border of New York and Vermont. The Waterbury Project was originally licensed in 1954 for a 50-year term, effective in 1951. The relicensing process for the licensing documented in this project began in 1996 proposing no major modifications to the existing infrastructure using TLP. The project EA was issued in 2.9 years with a FONSI and the project was determined to cause no adverse impacts on endangered species. The CWA Section 401 certification from the Vermont Department of Environmental Conservation was issued in 15.3 years and resulted in 11 conditions in the license including provisions for flow alteration, dissolved oxygen, fish passage, construction and maintenance water protection, and recreation. PME measures included those on water quality, flow alteration, instream flow, and fish passage. 


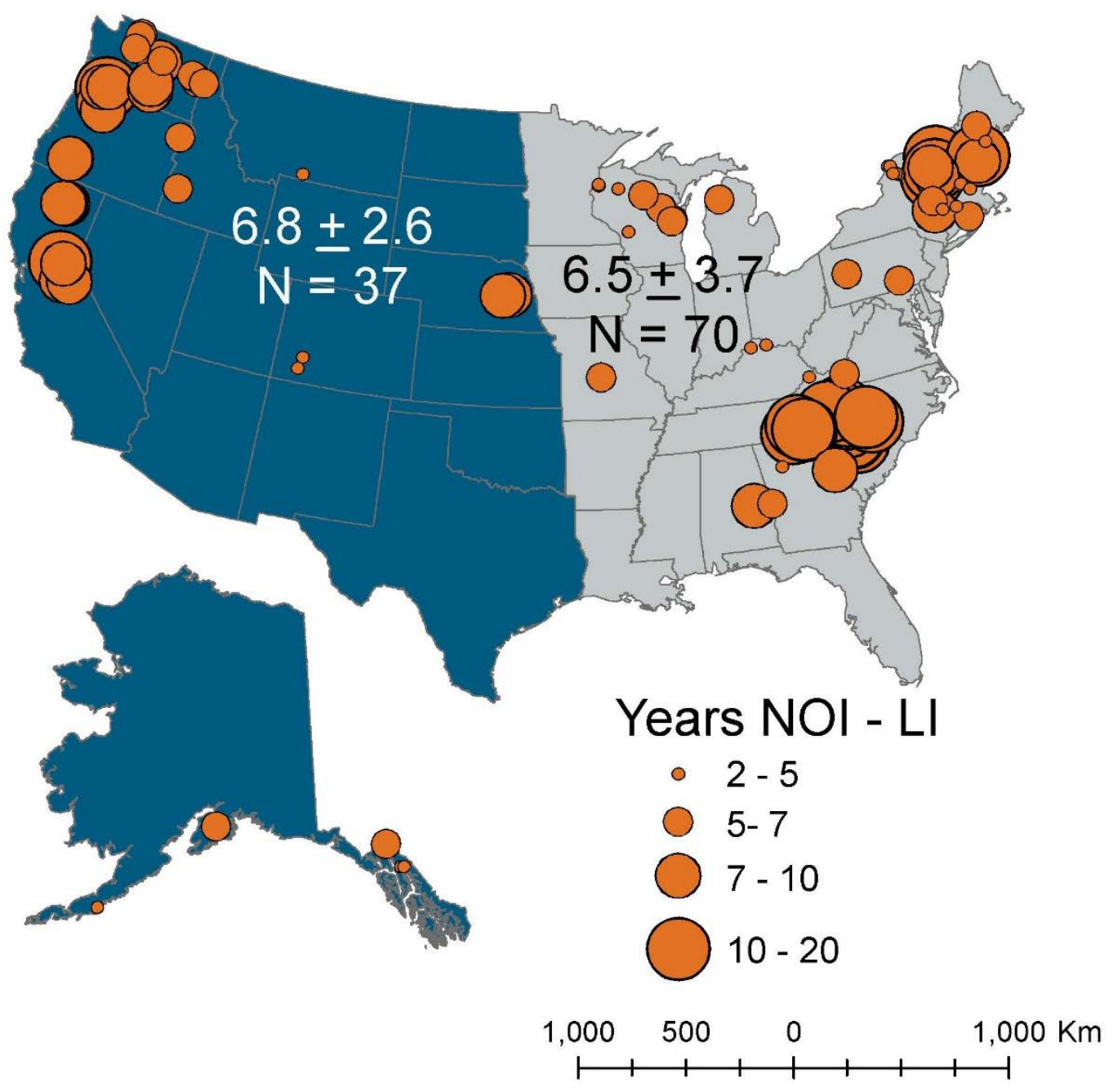

Figure 6. Mean \pm standard deviation of notice of intent (NOI) to license issuance timelines for projects used in this study in the eastern and western United States. Orange dots represent the location of hydropower facilities from the dataset of 107 projects and the size of the dot represents the length of the NOI to license issuance timeline.

There were nearly twice as many projects in the East $(\mathrm{N}=70)$ as in the West $(\mathrm{N}=37$; Figure 6$)$. No differences in timelines were found among licensee types (i.e., public, private, public/private) or between regions (i.e., east versus west; Table 6). Larger projects (higher megawatt nameplate capacity) had statistically longer license timelines, but only when incorporating license type (Figure 7), although there was no statistically significant relationship between number of facilities in a project and NOI/PAD to license issuance timelines.

There was no statistically significant difference between NOI/PAD to license issuance timelines among project type or for projects with peaking versus run-of-river mode-of-operation regardless of license type. All projects that received original licenses for adding power to non-powered dams were listed as operating in run-of-river or run-of-release mode. Projects being relicensed had similar average and standard deviations of NOI to license issuance timelines for run-of-river and peaking/storage projects. Original licenses for in-canal conventional, new development (i.e., 
development of greenfield site), and non-powered dam retrofits were shorter than original or relicenses for existing conventional projects (Table 6).

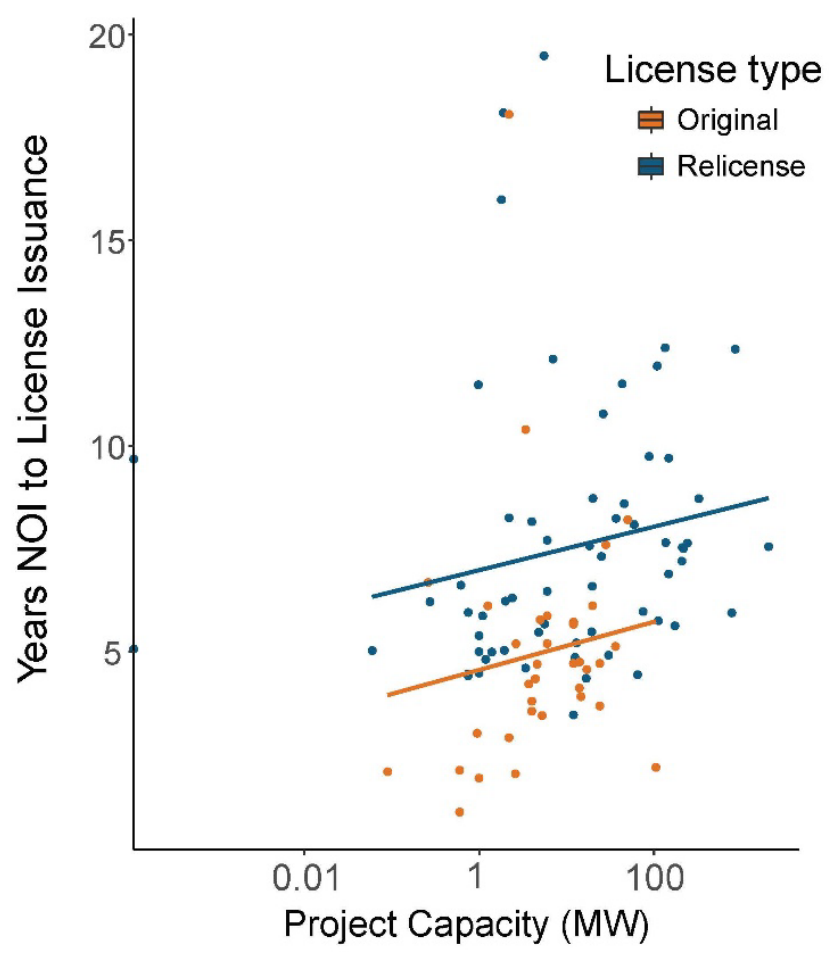

Figure 7. Scatterplot of project nameplate capacity (MW) versus timeline from license NOI filing to license issuance for original (orange) and relicensed (blue) projects. No relationship exists between project size (nameplate capacity) and license timeline length without considering license type.

\subsection{License Characteristics}

Original licenses had statistically shorter NOI/PAD to license issuance timelines than relicenses with original licenses averaging $5.0 \pm 2.9$ years and relicenses averaging $7.6 \pm 3.3$ years (Table 5; Figure 5). Projects seeking original licenses also had shorter pre-filing and post-filing timelines than projects seeking relicenses. Both original and relicenses have certain minimum time requirements for filing licensing documentation. The average licensing proceeding for original and relicenses lasts longer than the minimum required time for filing documents, suggesting that other factors than filing requirements are influencing timelines. Projects being relicensed must file their NOI/PAD 5-5.5 years prior to license expiration and must file their license application no less than 2 years prior to license expiration. 


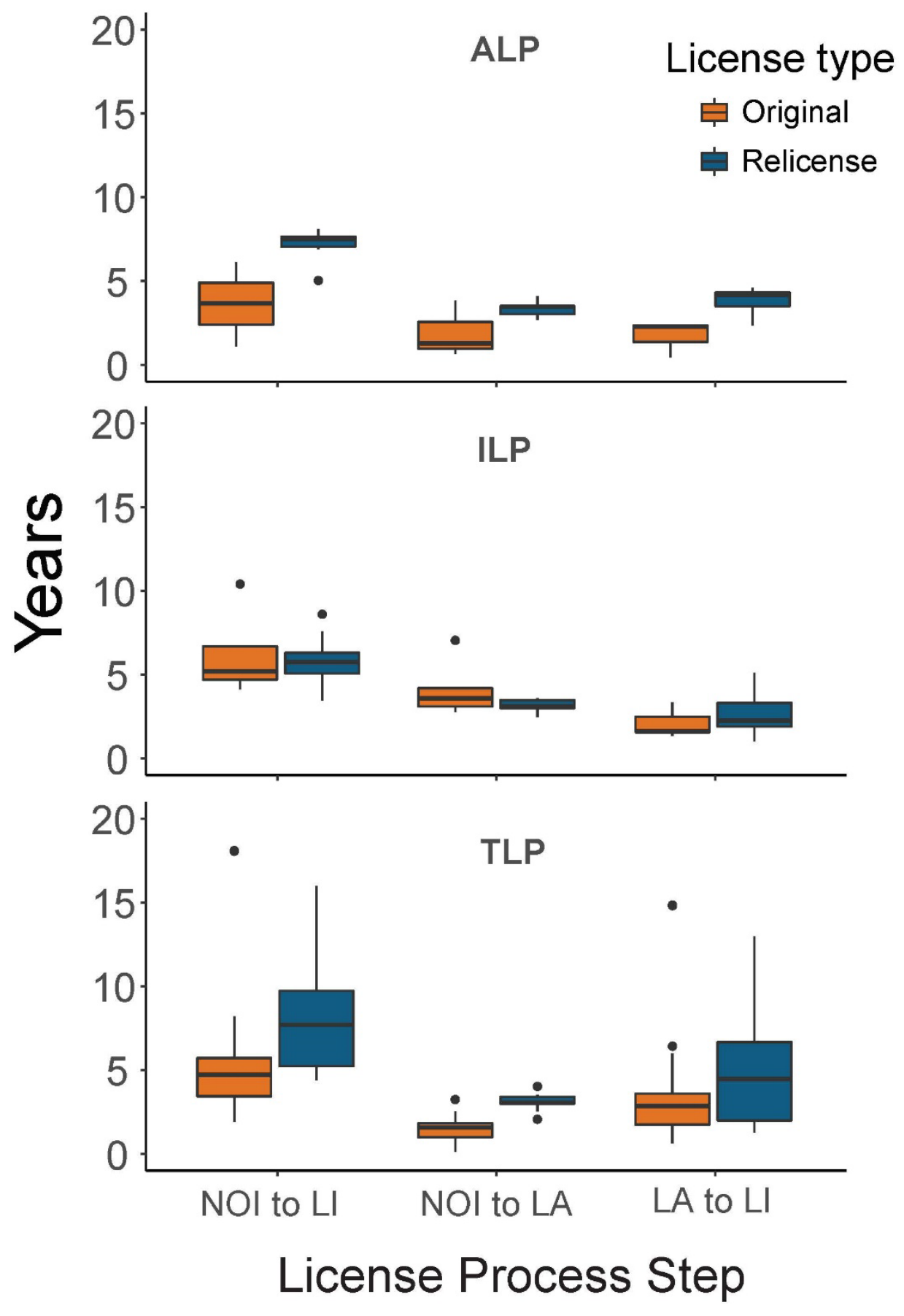

Figure 8. Boxplots summarizing the time taken by segments of the hydropower licensing and federal authorization process for the 107 projects in our dataset. Segments include filing of the notice of intent/pre-application document to license issuance (NOI to LI), filing of NOI/PAD to final license application (NOI to LA), and license application to license issuance (LA to LI). Boxplot components are described in Figure 5. 
There were no statistically significant differences in NOI/PAD to license issuance timelines among license processes, ${ }^{31}$ although the post-file timeline for the ILP $(2.6 \pm 0.2$ years $)$ was statistically shorter than the post-file timeline for the TLP $(4.2 \pm 0.4$ years; Table 5 ; Figure 8 ; Appendix B). The post-file timeline for the ALP $(3.7 \pm 0.7$ years $)$ was not statistically different from either the ILP or TLP. Most projects included in the study dataset used the TLP which had a larger standard deviation in NOI to license issuance timelines and a larger number of projects compared to projects using ALP or ILP licenses processes (Table 6). Most projects that were issued licenses over the study period used the TLP, so the large percentage of TLP projects is representative of projects licensed during this time period. The ILP was designed to help create more predictable timeline lengths; as more projects are licensed using the ILP, future studies may want to reexamine timeline length by license process.

Projects with longer timelines from the final license application to REA also had significantly longer NOI/PAD to license issuance timelines (Table 5; Figure 8). Unlike most other variables examined in this study, there was no significant difference in license application to REA timelines between projects seeking original versus relicenses. Proceeding forward in the licensing process to the NEPA review depends on FERC issuing the Notice REA (Figure 4), thus longer timelines between filing of the final license application and issuance of the notice REA would lead to longer NOI/PAD to license issuance timelines.

\subsection{Environmental Characteristics}

Projects with greater environmentally complexity, that is, projects with significant effects based on the NEPA analysis including projects with larger dams, projects that involve longer CWA Section 401 certifications or ESA Section 7 consultations, and/or projects that have not been relicensed since passage of environmental protection legislation such as amendments to the FPA tend to have longer NOI/PAD to license issuance timelines than those with less environmental complexity. Projects with more disputed studies and more of those disputed studies required in Study Determination Letters had statistically longer NOI/PAD to license issuance timelines. There was no relationship between the number of disputed studies that were rejected and NOI to license issuance timelines.

Environmental complexity may also be a factor in differences between NOI/PAD to license issuance timelines where relicenses have longer timelines than original licenses. For example, projects seeking an original license had shorter CWA Section 401 certification timelines, lower likelihood of endangered species and/or shorter than average ESA Section 7 consultation timelines, and shorter than average NEPA timelines. This suggests that project developers seeking an original license may have shorter licensing timelines because they develop new projects in less environmentally sensitive areas or in areas that are already impacted such as canals or non-powered dams. This is supported by the dataset of 107 projects where only three of 45 original licenses involved constructing a hydropower dam at an undeveloped site.

\footnotetext{
${ }^{31}$ For more information on the three FERC hydropower license processes see Levine and Flannagan 2019.
} 


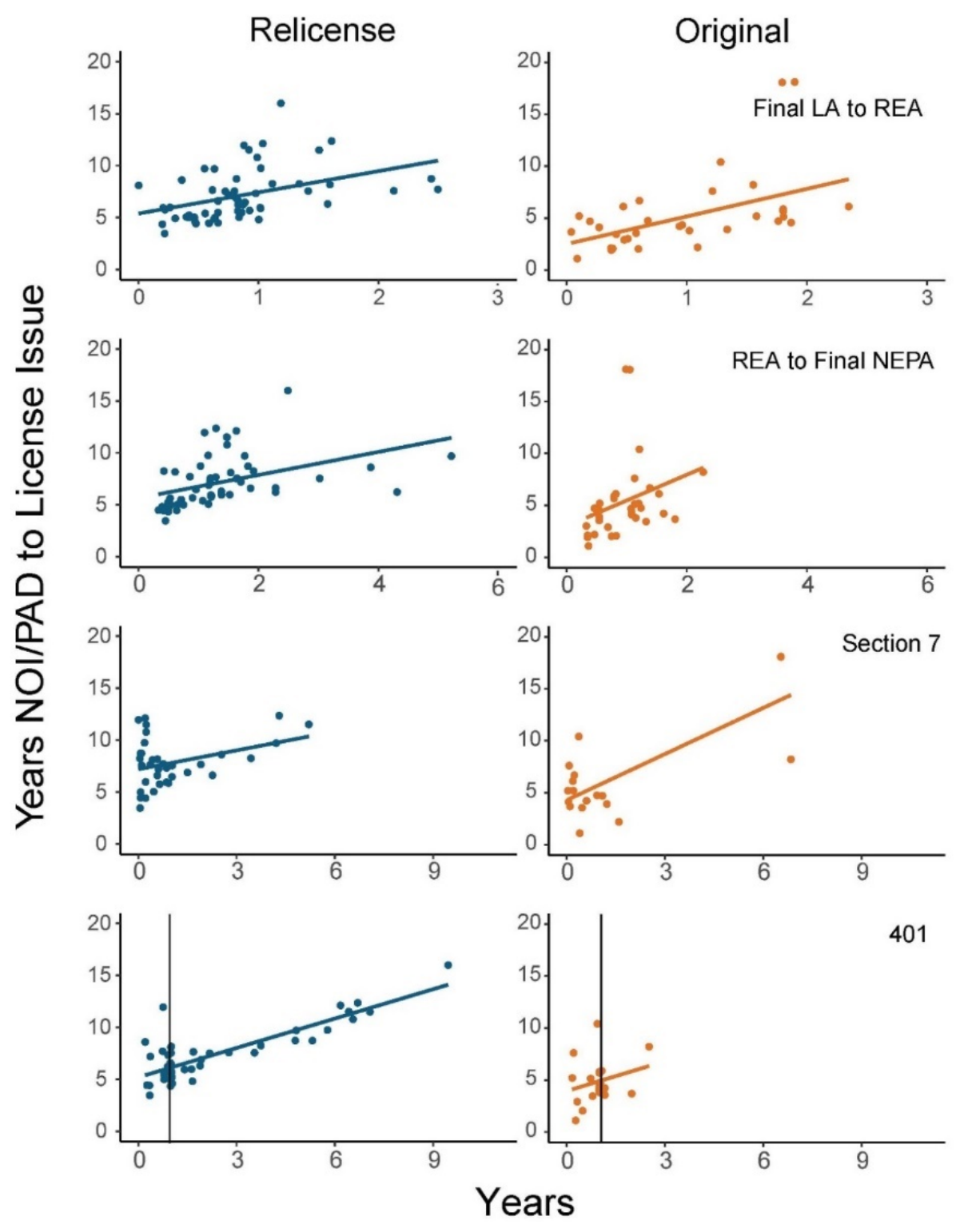

Figure 9. Scatterplots showing time (years) from (from top down) final license application (LA) to ready for environmental analysis (REA), REA to final NEPA document, ESA Section 7

Consultation, and CWA Section 401 water quality certification versus time (years) between notice of intent/pre-application document (NOI/PAD) and license issuance for projects seeking a relicense (blue) or original license (orange). Vertical line in 401 plots denote the 1-yr requirement for issuance of the $\mathbf{4 0 1}$ certificate by the state water quality authority.

The remaining 42 projects with original licenses were projects that were already impacted, including 32 original licenses seeking to add power to a non-powered dam.

According to the CWA, the Section 401 certification process is required to be completed within a 1-year time frame; however, historically this has been interpreted differently among states. Although the 1-year timeline requirement for the CWA Section 401 certification is not new, prior to the Hoopa Valley Tribe v. FERC D.C. Circuit Court decision, which includes all projects in the dataset of 107 projects, withdrawal, and refiling of CWA Section 401 certification 
application as the end of the 1-year timeline approached was common. The timeline from the date the first time the CWA Section 401 was requested to the date of issuance shows that $73 \%$ (78 of 107) of CWA Section 401 certifications were waived (22 of 78) or completed (56 of 78) within or around the 1-year required time frame ( $<400$ days) and $84 \%$ (90 of 107) within or around 2 years ( $<800$ days; Figure 9$)$. State water quality authorities frequently cite incomplete CWA Section 401 certification applications as a primary reason for longer timelines for issuing WQCs. Unfortunately, our license review was unable to document incomplete submission of application materials or other reasons for variability in 401 timelines because this information is generally not included in the FERC record.

The ESA specifies that USFWS and NOAA Fisheries must have a complete package of information before consultation can be initiated. This information will generally include any requirements of a CWA Section 401 certificate and a complete description of the proposed action and any mitigation measures analyzed in the NEPA document. This complete package of information allows the consulting agency to have a full understanding of impacts and mitigations to consider as they create the BO and Incidental Take Statement. FERC may request formal consultation but neither consulting agency will consider consultation initiated until all the required information has been provided by the applicant through FERC. The agencies then have a 135-day period in which to complete the Section 7 Consultation, unless otherwise extended. Incomplete Section 7 Consultation application packets can add an average of $123 \pm 263(\mathrm{~N}=39)$ days for USFWS and $316 \pm 395(\mathrm{~N}=14)$ days for NOAA Fisheries. There was no statistically significant relationship between the length of time from receipt of complete information to issuance of either the $\mathrm{BO}$ or Letter of Concurrence to NOI to license issuance timeline.

Projects with settlement agreements had statistically longer timelines than projects without. These projects often have complex environmental issues, potentially involving multiple jurisdictions or significant or rare cultural, recreational, biological, or ecological resources that require increased time and attention during licensing. These agreements are negotiated among project stakeholders and may lead to greater environmental or other benefits than would have been otherwise possible, such as increased generation capacity at some dams in exchange for added recreational amenities, dam removal somewhere else in the watershed, or improved fish passage in addition to building positive stakeholder relationships. Given the potential complexity of issues for a project where a settlement agreement has been negotiated, it is possible that the settlement agreement prevented an even lengthier process that may be influenced by the number of controversial issues that were dealt with inside versus outside of the settlement agreement process.

Ten of the 21 projects on the 2019 version of the FERC list of projects with incomplete ESA Section 7 Consultations or Section $401 \mathrm{CWA}$ certifications lasting $>1$ year were no longer on the list in 2020 (Table 7; Figure 9). Of the remaining 11 projects from the 2019 list that were also on the 2020 list, all but one was awaiting conclusion of Section 7 Consultation.

\subsection{Conclusions}

Although there have been anecdotal reports of why some segments of the regulatory process take longer than others, this was the first statistical analysis of a large suite of factors in the licensing process that aimed to flesh out factors associated with licensing timeline length. This chapter addressed this knowledge gap by creating and analyzing a dataset of hydropower milestones and 
timelines created from 107 randomly selected FERC licensed projects to quantify and understand the effects of various licensing, project, and environmental characteristics on regulatory timelines.

The average NOI to license issuance timeline for a project in this study was $6.6 \pm 3.4$ years, although project licensing timeline variability is linked to factors related to license type (original, relicense), license process (TLP, ILP, ALP), and environmental complexity. License type was the primary predictor of NOI to license issuance timelines where projects being relicensed had longer timelines $(7.6 \pm 3.3$ years $)$ than projects seeking original licenses $(5.0 \pm 2.9$ years $)$. In fact, license type was a "master variable" and nearly all variables analyzed had significantly longer timelines for relicensed projects than for projects seeking original licenses. Among other project and license characteristics analyzed for this report (e.g., project region, type, mode of operation, license process) only project size (MW) was found to be statistically related to overall (NOI to license issuance) licensing timelines. Although there were no statistically significant differences in NOI to license issuance timelines among license processes, projects using the ILP had significantly shorter license application to license issuance timelines than projects using either the ALP or TLP, likely due to the deadline driven pre-filing structure of the ILP. Projects with greater environmental complexity (e.g., EIS rather than EA, presence of endangered species, presence of Settlement Agreement, longer 401 process) had longer NOI/PAD to license issuance timelines than projects with less environmental complexity.

Table 7. Hydropower Projects Being Relicensed for Which FERC Has Determined That Section 401 Water Quality Certification or Endangered Species Act Section 7 Consultation Have Been Pending for 1 Year as of August 2019

\begin{tabular}{|c|c|c|c|c|c|c|c|c|}
\hline $\begin{array}{l}\text { FERC } \\
\text { Docket }\end{array}$ & Project & State & $\begin{array}{l}\text { Date NEPA } \\
\text { Issued }\end{array}$ & $\begin{array}{l}\text { Pending } \\
\text { Requirement } \\
\text { Type }\end{array}$ & $\begin{array}{l}\text { On } \\
2020 \\
\text { List? }\end{array}$ & $\begin{array}{l}401 \\
\text { Issued or } \\
\text { Waived? }\end{array}$ & $\begin{array}{l}\text { BO/LOC } \\
\text { Issued? }\end{array}$ & $\begin{array}{l}\text { License } \\
\text { Issued? }\end{array}$ \\
\hline 2086 & $\begin{array}{l}\text { Vermilion } \\
\text { Valley }\end{array}$ & CA & $5 / 4 / 2004$ & ESA/401 & $\mathrm{N}$ & $\mathrm{Y}$ & $\mathrm{Y}$ & $\mathrm{N}$ \\
\hline 2174 & Portal & CA & $4 / 27 / 2006$ & ESA/401 & $\mathrm{N}$ & $Y$ & $Y$ & $\mathrm{~N}$ \\
\hline 67 & $\begin{array}{l}\text { Big Creek } \\
\text { Project 2A }\end{array}$ & CA & $3 / 13 / 2009$ & ESA/401 & $\mathrm{N}$ & $Y$ & $Y$ & $\mathrm{~N}$ \\
\hline 120 & $\begin{array}{l}\text { Big Creek } \\
\text { Project } 3\end{array}$ & CA & $3 / 13 / 2009$ & ESA/401 & $\mathrm{N}$ & $Y$ & $Y$ & $\mathrm{~N}$ \\
\hline 2085 & $\begin{array}{l}\text { Mammoth } \\
\text { Pool }\end{array}$ & $C A$ & $3 / 13 / 2009$ & ESA/401 & $N$ & $Y$ & $Y$ & $N$ \\
\hline 2175 & $\begin{array}{l}\text { Big Creek } \\
\text { Project } 1 \& \\
2\end{array}$ & $\mathrm{CA}$ & $3 / 13 / 2009$ & ESA/401 & $\mathrm{N}$ & $Y$ & $Y$ & $\mathrm{~N}$ \\
\hline 2106 & $\begin{array}{l}\text { McCloud- } \\
\text { Pit }\end{array}$ & $C A$ & $2 / 25 / 2011$ & 401 & $N$ & $Y$ & NA & $N$ \\
\hline 2079 & $\begin{array}{l}\text { Mid-Fork } \\
\text { American }\end{array}$ & $C A$ & $2 / 22 / 2013$ & ESA/401 & $\mathrm{N}$ & $Y$ & $Y$ & $\mathrm{~N}$ \\
\hline 848 & Trout Creek & NV & $12 / 19 / 2017$ & 401 & $N$ & $Y$ & NA & $Y$ \\
\hline 2337 & $\begin{array}{l}\text { Prospect } \\
\text { Number } 3\end{array}$ & OR & $4 / 16 / 2018$ & 401 & $\mathrm{~N}$ & $Y$ & NA & $Y$ \\
\hline
\end{tabular}




\begin{tabular}{|c|c|c|c|c|c|c|c|c|}
\hline $\begin{array}{l}\text { FERC } \\
\text { Docket }\end{array}$ & Project & State & $\begin{array}{l}\text { Date NEPA } \\
\text { Issued }\end{array}$ & $\begin{array}{l}\text { Pending } \\
\text { Requirement } \\
\text { Type }\end{array}$ & $\begin{array}{l}\text { On } \\
2020 \\
\text { List? }\end{array}$ & $\begin{array}{l}401 \\
\text { Issued or } \\
\text { Waived? }\end{array}$ & $\begin{array}{l}\text { BO/LOC } \\
\text { Issued? }\end{array}$ & $\begin{array}{l}\text { License } \\
\text { Issued? }\end{array}$ \\
\hline 2105 & $\begin{array}{l}\text { Upper N. } \\
\text { Fork } \\
\text { Feather } \\
\text { River }\end{array}$ & CA & $11 / 10 / 2005$ & 401 & $Y$ & $Y$ & NA & $\mathrm{N}$ \\
\hline 11810 & $\begin{array}{l}\text { Augusta } \\
\text { Canal }\end{array}$ & SC & $9 / 22 / 2006$ & ESA & $Y$ & NA & $\mathrm{N}$ & $\mathrm{N}$ \\
\hline 1971 & $\begin{array}{l}\text { Hells } \\
\text { Canyon }\end{array}$ & ID/OR & $8 / 31 / 2007$ & ESA/401 & $Y$ & $Y$ & $\mathrm{~N}$ & $\mathrm{~N}$ \\
\hline 199 & $\begin{array}{l}\text { Santee } \\
\text { Cooper }\end{array}$ & SC & $10 / 26 / 2007$ & ESA & $Y$ & NA & $Y$ & $\mathrm{~N}$ \\
\hline 2088 & $\begin{array}{l}\text { South } \\
\text { Feather } \\
\text { Power }\end{array}$ & CA & $6 / 4 / 2009$ & ESA & $Y$ & $Y$ & $\mathrm{~N}$ & $N$ \\
\hline 803 & $\begin{array}{l}\text { DeSabla- } \\
\text { Centerville }\end{array}$ & CA & $7 / 24 / 2009$ & ESA & $Y$ & NA & $\mathrm{N}$ & $\mathrm{N}$ \\
\hline 516 & Saluda & SC & $7 / 20 / 2010$ & ESA & $Y$ & NA & $\mathrm{N}$ & $N$ \\
\hline 2179 & $\begin{array}{l}\text { Merced } \\
\text { River }\end{array}$ & CA & $12 / 4 / 2015$ & ESA/401 & $Y$ & $Y$ & $N$ & $N$ \\
\hline 2467 & $\begin{array}{l}\text { Merced } \\
\text { Falls }\end{array}$ & CA & $12 / 4 / 2015$ & ESA/401 & $Y$ & $\mathrm{Y}$ & $\mathrm{N}$ & $\mathrm{N}$ \\
\hline 12532 & $\begin{array}{l}\text { Pine Creek } \\
\text { Mine }\end{array}$ & CA & $2 / 12 / 2018$ & ESA/401 & $Y$ & $\mathrm{~N}$ & NA & $N$ \\
\hline 2615 & Brassua & $\mathrm{ME}$ & $9 / 14 / 2011$ & 401 & $Y$ & $Y$ & $Y$ & $Y$ \\
\hline
\end{tabular}

Note: This table notes the date the project EA or EIS was issued, the pending requirement of $>1$ year (as determined by FERC), whether a project was included again on the 2020 list (published in February 2020), whether the 401 certification had been issued or waived by time of publication of the 2020 list, whether a BO or letter of concurrence had been issued, and whether a license had been issued.

The high-level statistical analysis of the licensing and federal authorization process presented in this chapter was not designed to provide detailed analysis of factors underlying longer or shorter licensing proceedings or extensive comparisons of environmental outcomes that result from longer or shorter licensing timelines. For example, results of statistical analysis presented in this chapter showed that projects with settlement agreements have longer NOI to license issuance timelines than projects without settlement agreements but did not quantify environmental benefits or improvements in stakeholder relations that may result from settlement agreements. Also, projects going through relicensing have statistically longer timelines than projects seeking original licenses. Based on the environmental characteristics of these two groups, developers that are constructing new hydropower facilities in need of original licenses likely are developing sites with relatively less environmental complexity that will have relatively fewer environmental impacts such as adding power to a non-powered dam or constructing a hydropower dam in a man-made canal. Reasons for state CWA 401 certifications timeline variability prior to the DC Circuit's ruling in Hoopa Valley Tribe v. FERC are also not incorporated into our statistical analysis and may have been a result of factors such as receipt of incomplete certification application materials or application withdrawal and resubmittal under the previously accepted practice at the request of the license applicant or the state agency. 


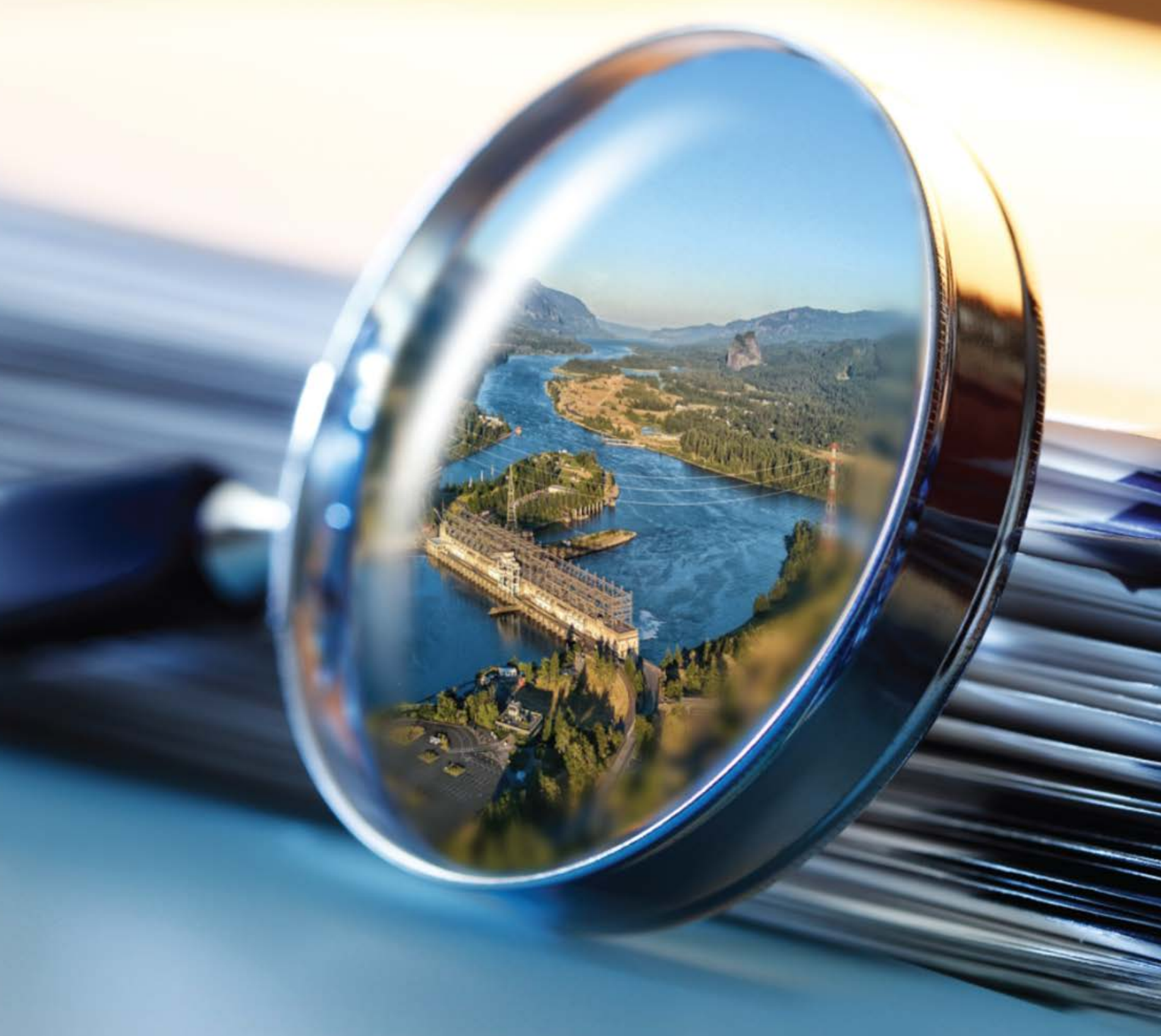

AN EXAMINATION OF THE HYDROPOWER LICENSING AND FEDERAL AUTHORIZATION PROCESS

\section{Hydropower Licensing Costs}




\section{Hydropower Licensing Costs}

This chapter explores the costs associated with preparing a hydropower license application as reported to FERC in applicant prepared license application documents. Additional costs within the hydropower licensing process, such as the costs to federal and state agencies or NGOs, are not included in this report. Further, other economic impacts, such as project financing and associated financial risk related to timeline variability, are not presented in this chapter (see Chapter 3 for a discussion of timeline variability, which may impact project financing and associated financial risk to hydropower license applicants). Although obtaining project financing may create challenges for new hydropower project development or the relicensing of existing projects, quantifying these impacts is challenging and was not rigorously explored.

\subsection{Hydropower Licensing Costs}

This section describes the analysis of hydropower licensing costs as reported by license applicants in final application documents to FERC. Sources and methods for determining these costs are presented, along with analysis methods and results for the sample and for subsamples of projects delineated by FERC licensing process attributes.

\subsubsection{Reported Licensing Costs}

FERC regulations require license applicants to submit a final license application that includes numerous requirements depending on whether the project is a major project (greater than 5 $\mathrm{MW}$ ), ${ }^{32}$ a minor project, ${ }^{33}$ or a major project between 1.5 and $5 \mathrm{MW}$ (see 18 CFR $\S 4.41,18 \mathrm{CFR}$ $\S 4.51$, and $18 \mathrm{CFR} \S 4.61$ ). For major projects, FERC regulations require the license applicant to submit an "Exhibit D," which is a statement with details on costs and financing for the project (18 CFR $\S 4.41(\mathrm{e}) ; 18 \mathrm{CFR} \S 4.51(\mathrm{e})$ ). As part of the list of required cost and financing filings, FERC regulations require the license applicant to submit "an estimate of the cost to develop the license application" (18 CFR $\S 4.41(\mathrm{e})(9))$. Minor projects and major projects between 1.5 and 5 MW do not require an Exhibit D (FERC 2017), but some of these hydropower license applications still include licensing cost estimates as part of "Exhibit A."

For each of the 107 projects included in the sample for this report, the FERC eLibrary Docket Search tool was used to obtain final license application documents (including Exhibit A and Exhibit D) to identify the reported estimated cost of developing the license application (see Chapter 3 for more information on the methodology for selecting the 107 projects included in the project sample; https://hydrosource.ornl.gov/dataset/hydropower-licensing-timeline-and-costdataset). Of the 59 major projects in the sample, 47 reported an estimated cost of developing the license application in Exhibit D, and 12 did not report the estimated licensing cost at all. In some minor projects, the estimated cost of developing the license application was included under Exhibit A, which focuses on the overall project description. Of the 48 minor projects in the sample, 33 reported an estimated cost of developing the license application in Exhibit A, 2

\footnotetext{
${ }^{32}$ Major projects are defined as major unconstructed or major modified projects greater than 5 MW and major projects on existing dams greater than 5 MW (FERC 2017).

${ }^{33}$ Minor projects are defined as projects $1.5 \mathrm{MW}$ or less (FERC 2017).
} 
reported the estimated cost in Exhibit D, and 13 did not report the estimated licensing cost at all. Thus, a total of 82 projects reported licensing costs for analysis. See Table 8 for more details.

Table 8. Application Development Cost Estimate Reporting

\begin{tabular}{|l|c|}
\hline Category & Count \\
\hline Major Project with Cost Estimate Reported in Exhibit D & 47 \\
\hline Major Project with Cost Estimate Not Reported & 12 \\
\hline Minor Project with Cost Estimate Reported in Exhibit A & 33 \\
\hline Minor Project with Cost Estimate Reported in Exhibit D & 2 \\
\hline Minor Project with Cost Estimate not Reported & 13 \\
\hline Total Projects & $\mathbf{1 0 7}$ \\
\hline Total Projects Reporting Costs & $\mathbf{8 2}$ \\
\hline
\end{tabular}

Although most projects reported a cost estimate for developing the license application, the estimates may not report in a uniform manner. FERC does not have specific guidance on how to report these cost estimates, resulting in a wide range of inclusions in the overall reported licensing cost. For some projects, a detailed list of items included in the estimate is provided in the exhibit, such as administrative and general salaries; office supplies and meeting expenses; and costs associated with conducting required studies and/or developing settlement agreements and management plans. Other projects simply list the estimated cost itself with no explanation of which components were included in the cost estimate. This lack of guidance on which inclusions are appropriate for the licensing cost estimate may also result in a wide range of quantitative responses, ranging from tens of thousands to tens of millions of dollars. For example, one project included licensing costs, studies, and document preparation, but explicitly left out specific legal services, along with other studies and grants required to attempt to obtain additional study and licensing funds for the project. This project reported an estimated cost to develop the license of $\$ 50,000$. Another project reported cost estimates to be more than $\$ 40$ million, and included planning, consultation, and studies developed and completed for relicensing during a 10-year period. Both projects were clear about what was included into their cost estimate, yet the reported estimates emphasize the potential variation within the sample.

\subsubsection{Licensing Cost Methodology}

The variability in reported licensing costs was assessed across the entire sample and for different licensing process attributes - e.g., project size/generating capacity, license type, presence of endangered species, type of NEPA review, etc. All reported costs were updated to 2019 dollars using the Consumer Price Index, based on the year that the final license application was submitted (original cost years ranged from 1994 to 2017). To reduce order-of-magnitude effects on licensing costs due to project size, an additional metric of comparison was created by dividing the indexed cost $(2019 \$)$ by the project generating capacity (kilowatts [kW]), thus giving a relatively size-agnostic metric in $\$ / \mathrm{kW}$.

Given the significant ranges in the licensing cost data, the sample was checked for outliers using a two-tailed p-value test. The three highest-cost projects were found to be outliers, with yearindexed costs ranging from $\$ 22$ million-\$56 million (originally reported as $\$ 15.7$ million- $\$ 40.5$ 
million). A single small, low-cost project $(\$ 5,400$ and $0.25 \mathrm{~kW})$ was deemed an outlier in the $\$ / \mathrm{kW}$ metric (at $\$ 21,600 / \mathrm{kW}$, an order of magnitude higher than the next highest project). Three other projects were possible outliers for the $\$ / \mathrm{kW}$ metric (at $\$ 2,300-\$ 2,500 / \mathrm{kW}$ ) but were left in the sample for analysis because they were not outliers in reported licensing costs.

Variability in reported licensing costs, project sizes, and the $\$ / \mathrm{kW}$ metric was assessed by determining the quartiles (median, first, and third), mean, and standard deviation for each. The statistics were calculated both with and without the outliers. The analysis was conducted for the entire project sample and for subsamples of projects delineated by licensing process attributes. The licensing process attributes evaluated included:

- $\quad$ License process type (ALP, ILP, TLP)

- License type (original, relicense)

- Whether a settlement agreement was reached (yes, no)

- Whether endangered species were present (yes, no)

- Which NEPA review was conducted (EA, EIS)

- Project type (canal, existing conventional, new stream reach, non-powered dam)

- Whether the licensing included fishway prescriptions (yes, no)

- Licensee type (investor-owned, private non-utility, publicly owned).

\subsubsection{Licensing Cost Results}

The following sections present the main results of interest for the entire sample and the subsamples by licensing process attribute. Full analysis results are available in Appendix F.

\subsubsection{All Projects}

The ranges in reported licensing costs and cost metrics compared to project generating capacities (i.e., $\$ / \mathrm{kW}$ ) are shown in Figures $10 \mathrm{a}$ and 10b. Given the order-of-magnitude ranges in reported licensing costs and generating capacities, both figures are presented on a log-log scale. As shown in Figure 10a, larger generating projects tend to also report higher licensing cost and the trend appears somewhat linear on the log-log scale. However, Figure 10b, which shows the $\$ / \mathrm{kW}$ metric, also suggests an economy-of-scale trend that benefits these larger projects on a capacityproportional basis. This economy of scale is not surprising, given that many of the components that go into the licensing process, such as developing an EA or EIS, are relatively fixed in development costs regardless of the project size. Thus, higher-capacity projects can spread these fixed costs over their larger generation potential, as demonstrated by the $\$ / \mathrm{kW}$ metric. It is also of note that although the three highest-cost projects were deemed outliers on a reported-cost basis (circled in red), they are much closer to the middle of the range of the $\$ / \mathrm{kW}$ metric. The low-cost/high $\$ / \mathrm{kW}$ outlier is outside of the ranges shown in the graphs (at $0.25 \mathrm{~kW}|\$ 5,400|$ $\$ 21,600 / \mathrm{kW})$. 

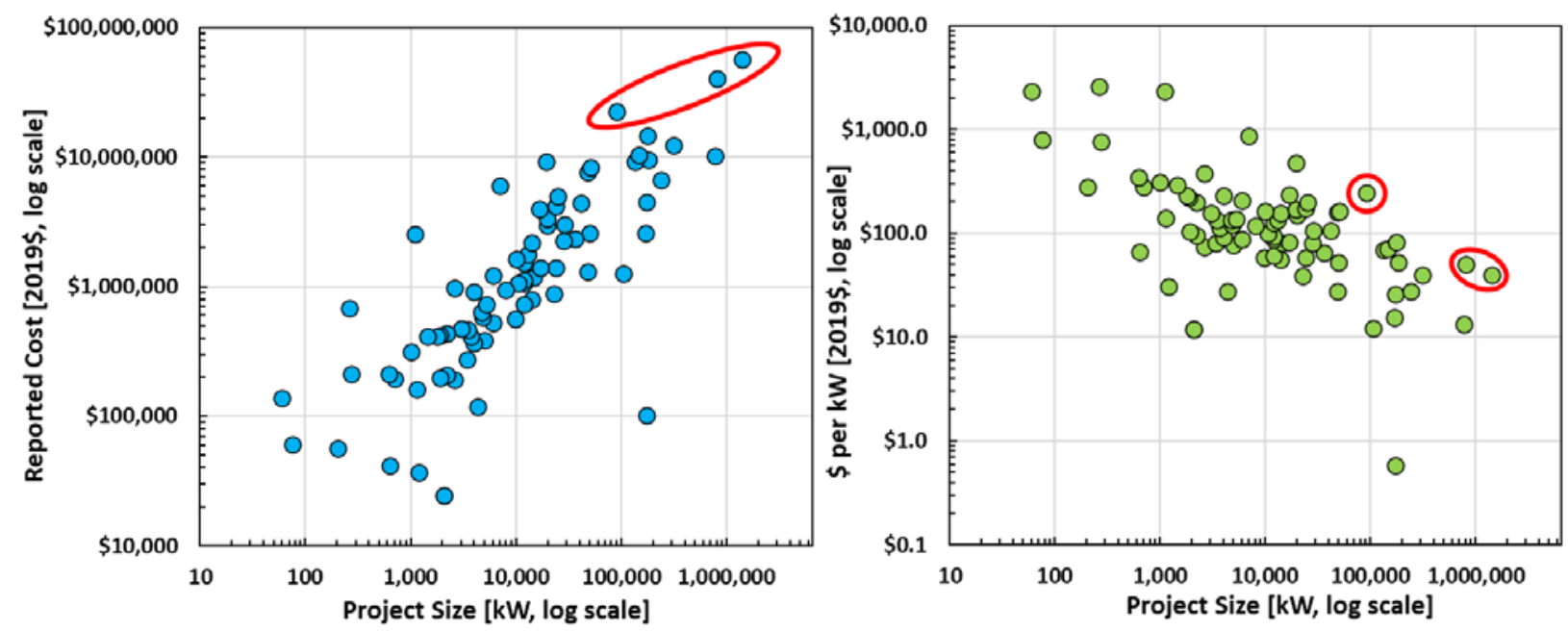

Figure 10. (a; left) Log-log scale scatterplots of reported licensing costs in $2019 \$$ and project generating capacity in $\mathrm{kW}$. (b; right) The size-agnostic $\$ / \mathrm{kW}$ metric and project generating capacity.

Note: The three high-cost outliers are circled in red in both plots; the low-cost/high $\$ / \mathrm{kW}$ outlier is not visible on either plot (i.e., at $0.25 \mathrm{~kW}|\$ 5,400| \$ 21,600 / \mathrm{kW}$ ). Non-generating projects that reported licensing costs are also not shown.

Basic statistics were calculated to examine the variability in reported licensing costs, project sizes, and the $\$ / \mathrm{kW}$ metric for all projects in the sample dataset. Results - namely quartiles, medians, means, and standard deviations — are shown with outliers removed in Table 9. The differences between the mean and median as well as between the quartiles and standard deviation for these metrics suggest a skew in the data towards higher licensing costs. This skew is not surprising, however, given the order-of-magnitude ranges in scales of reported licensing costs and particularly project sizes. Removing the outliers decreased some of the variability in the results; the standard deviation for licensing costs and project sizes both decreased by a factor of 2 (down from $\$ 8,180,000$ and $200,000 \mathrm{~kW}$, respectively) and for the $\$ / \mathrm{kW}$ metric by a factor of 4 (down from $\$ 2,433 / \mathrm{kW}$ ). The mean for all metrics similarly decreased by a factor of 1.5 to 2 (down from $\$ 3,681,000 ; 69,000 \mathrm{~kW}$; and $\$ 503 / \mathrm{kW}$, respectively).

Table 9. Statistical Results for the Entire Sample Dataset, With Outliers Removed

\begin{tabular}{|c|c|c|c|c|c|} 
Metric & Q1 & Median & Q3 & Mean & $\begin{array}{c}\text { Standard } \\
\text { Deviation }\end{array}$ \\
\hline $\mathbf{\$}$ & 373,000 & 960,000 & $2,610,000$ & $2,345,000$ & $3,243,000$ \\
\hline $\mathbf{k W}$ & 2,100 & 8,900 & 25,000 & 43,000 & 104,000 \\
\hline $\mathbf{\$} / \mathbf{k W}$ & 64 & 107 & 199 & 241 & 473 \\
\hline
\end{tabular}

\subsubsection{License Process Type}

The results for projects delineated by license process type (ALP, ILP, or TLP) are shown in Table 10. All four outliers were TLP projects. The differences in reported licensing costs for the three process types appear to be most strongly driven by differences in project sizes rather than the license process type. For example, size $(\mathrm{kW})$ quartiles for TLP projects are half those for ILP projects, while those for ALP projects are an order-of-magnitude bigger. However, the $\$ / \mathrm{kW}$ 
metric, which reduces project size effects on cost, shows that there is no strong correlation between proportional costs and license process type.

\section{Table 10. Results for Subsamples by License Process Type}

All four outliers were traditional licensing process (TLP) projects and are excluded from the results. Total $\mathrm{N}=82$.

\begin{tabular}{|c|c|c|c|c|c|c|c|}
\hline $\begin{array}{c}\text { License } \\
\text { Process } \\
\text { Type }\end{array}$ & $\begin{array}{c}\text { \# of } \\
\text { Projects }\end{array}$ & Metric & Q1 & Median & Q3 & Mean & $\begin{array}{l}\text { Standard } \\
\text { Deviation }\end{array}$ \\
\hline \multirow[t]{3}{*}{ ALP } & 9 & $\$$ & $2,970,000$ & $6,632,000$ & $9,207,000$ & $6,479,000$ & $4,509,000$ \\
\hline & & $\mathrm{kW}$ & 24,000 & 134,000 & 170,000 & 106,000 & 85,000 \\
\hline & & $\$ / k W$ & 69 & 83 & 160 & 341 & 743 \\
\hline \multirow[t]{3}{*}{ ILP } & 23 & $\$$ & 624,000 & $1,311,000$ & $3,194,000$ & $2,589,000$ & $2,949,000$ \\
\hline & & $\mathrm{kW}$ & 3,200 & 12,000 & 25,700 & 60,700 & 163,000 \\
\hline & & $\$ / k W$ & 64 & 135 & 196 & 342 & 693 \\
\hline \multirow[t]{3}{*}{ TLP } & 46 & $\$$ & 201,000 & 556,000 & $1,300,000$ & $1,414,000$ & $2,407,000$ \\
\hline & & $\mathrm{kW}$ & 1,800 & 4,800 & 14,500 & 21,500 & 53,100 \\
\hline & & $\$ / k W$ & 65 & 95 & 199 & 172 & 199 \\
\hline
\end{tabular}

\subsubsection{Original/Relicense}

Results for projects by license type (original or relicense) are shown in Table 11. The three highcost outliers were relicensed projects while the $\$ / \mathrm{kW}$ outlier was an original project. Again, the strongest correlations are likely driven more strongly by project size than by license type; relicensed projects are generally larger than original projects in the project sample, so would be expected to report generally higher costs. However, the interquartile ranges for the $\$ / \mathrm{kW}$ metric may indicate somewhat greater variability and/or somewhat higher proportional costs for relicensed projects - original projects have a range across a factor of about 2 , while relicensed projects have a range of more than 4 and have higher proportional costs at the median and above.

\section{Table 11. Results for Subsamples by License Type: Original or Relicense}

The three high-cost outliers were relicensed projects while the $\$ / \mathrm{kW}$ outlier was an original project. Outliers are excluded from the results. Total $\mathrm{N}=82$.

\begin{tabular}{|c|c|c|c|c|c|c|c|}
\hline $\begin{array}{l}\text { License } \\
\text { Type }\end{array}$ & $\begin{array}{c}\text { \# of } \\
\text { Projects }\end{array}$ & Metric & Q1 & Median & Q3 & Mean & $\begin{array}{l}\text { Standard } \\
\text { Deviation }\end{array}$ \\
\hline \multirow[t]{3}{*}{ Original } & 36 & $\$$ & 346,000 & 724,000 & $1,300,000$ & 996,000 & 952,000 \\
\hline & & $\mathrm{kW}$ & 2,200 & 5,600 & 14,200 & 12,800 & 19,300 \\
\hline & & $\$ / k W$ & 71 & 93 & 157 & 196 & 432 \\
\hline \multirow[t]{3}{*}{ Relicense } & 42 & $\$$ & 417,000 & $1,416,000$ & $5,763,000$ & $3,500,000$ & $4,001,000$ \\
\hline & & $\mathrm{kW}$ & 1,600 & 12,500 & 50,000 & 68,600 & 136,000 \\
\hline & & $\$ / \mathrm{kW}$ & 56 & 131 & 246 & 281 & 509 \\
\hline
\end{tabular}




\subsubsection{Settlement Agreement}

Results for projects that did or did not include a settlement agreement are shown in Table 12. The three high-cost outliers used settlement agreements (i.e., "Yes"), while the $\$ / \mathrm{kW}$ outlier did not. Again, settlement agreements were generally more likely for larger projects, at least at or above the median project sizes for each category. Thus, again, differences may be more strongly correlated with project size than licensing attribute, especially given the economy-of-scale trend in the $\$ / \mathrm{kW}$ metric previously discussed.

Table 12. Results for Subsamples by Whether the Project Licensing Used a Settlement Agreement or Not

The three high-cost outliers used settlement agreements, while the $\$ / \mathrm{kW}$ outlier did not. Outliers are excluded from the results. Total $\mathrm{N}=82$.

\begin{tabular}{|c|c|c|c|c|c|c|c|}
\hline $\begin{array}{l}\text { Settlement } \\
\text { Agreement }\end{array}$ & $\begin{array}{c}\text { \# of } \\
\text { Projects }\end{array}$ & Metric & Q1 & Median & Q3 & Mean & $\begin{array}{l}\text { Standard } \\
\text { Deviation }\end{array}$ \\
\hline \multirow[t]{3}{*}{ Yes } & 22 & $\$$ & 446,000 & $3,894,000$ & $8,789,000$ & $4,871,000$ & $4,470,000$ \\
\hline & & $\mathrm{kW}$ & 4,500 & 35,000 & 172,000 & 110,000 & 174,000 \\
\hline & & $\$ / k W$ & 43 & 106 & 168 & 151 & 191 \\
\hline \multirow[t]{3}{*}{ No } & 56 & $\$$ & 346,000 & 756,000 & $1,433,000$ & $1,353,000$ & $1,881,000$ \\
\hline & & $\mathrm{kW}$ & 1,700 & 5,100 & 14,200 & 16,500 & 32,700 \\
\hline & & $\$ / k W$ & 67 & 120 & 217 & 278 & 545 \\
\hline
\end{tabular}

\section{Endangered Species}

Results for projects based on whether endangered species were present are shown in Table 13. The three high-cost outliers had endangered species, while the $\$ / \mathrm{kW}$ outlier did not. The presence of endangered species would require projects to incur additional costs for their protection, including possible additional studies, mitigation measures, and licensing approvals. However, again, project size appears to have a stronger correlation on cost results than endangered species alone. The size quartiles for projects with endangered species were $2-5$ times higher than the sizes of projects without them, and the previous economy-of-scale discussion suggests that larger size outweighs the cost impacts of endangered species, as seen by the somewhat lower $\$ / \mathrm{kW}$ metric values for these projects. 
Table 13. Results for Subsamples by Whether Endangered Species Were Present and Thus Required Additional Protection Measures and/or Studies

The three high-cost outliers were "Yes," the $\$ / \mathrm{kW}$ Outlier was "No." Outliers are excluded from the results. Total $\mathrm{N}=82$.

\begin{tabular}{|c|c|c|c|c|c|c|c|}
\hline $\begin{array}{l}\text { Endangered } \\
\text { Species }\end{array}$ & $\begin{array}{c}\text { \# of } \\
\text { Projects }\end{array}$ & Metric & Q1 & Median & Q3 & Mean & $\begin{array}{l}\text { Standard } \\
\text { Deviation }\end{array}$ \\
\hline \multirow[t]{3}{*}{ Yes } & 41 & $\$$ & 417,000 & $1,522,000$ & $4,447,000$ & $3,188,000$ & $3,799,000$ \\
\hline & & $\mathrm{kW}$ & 3,400 & 14,600 & 50,000 & 66,200 & 135,000 \\
\hline & & $\$ / \mathrm{kW}$ & 39 & 95 & 164 & 288 & 622 \\
\hline \multirow[t]{3}{*}{ No } & 37 & $\$$ & 369,000 & 584,000 & $1,311,000$ & $1,411,000$ & $2,180,000$ \\
\hline & & $\mathrm{kW}$ & 1,800 & 4,800 & 12,000 & 16,900 & 39,900 \\
\hline & & $\$ / k W$ & 80 & 135 & 226 & 185 & 180 \\
\hline
\end{tabular}

\subsubsection{National Environmental Policy Act: Environmental Assessment or Environmental Impact Statement}

Results for projects based on their NEPA review type (EA or EIS) are shown in Table 14. The three high-cost outliers required an EIS, while the $\$ / \mathrm{kW}$ outlier only required an EA. The development of an EIS is more comprehensive, longer, and includes more extensive public comment periods, and thus would be expected to result in higher costs. However, again, the effects of the NEPA review costs on the overall licensing cost variability is masked by the difference in project sizes for each category. EIS projects in our sample are significantly larger than projects requiring only an EA, so they report higher licensing costs but benefit from the economy of scale afforded by their larger size. Table 14. Results for Subsamples by National Environmental Policy Act Review Type
(Environmental Assessment [EA] or Environmental Impact Statement [EIS])

The three high-cost outliers required an EIS while the $\$ / \mathrm{kW}$ outlier only required an EA. Outliers are excluded from the results. Total $\mathrm{N}=82$.

\begin{tabular}{|c|c|c|c|c|c|c|c|}
\hline $\begin{array}{l}\text { NEPA } \\
\text { Type }\end{array}$ & $\begin{array}{c}\text { \# of } \\
\text { Projects }\end{array}$ & Metric & Q1 & Median & Q3 & Mean & $\begin{array}{l}\text { Standard } \\
\text { Deviation }\end{array}$ \\
\hline \multirow[t]{3}{*}{ EA } & 67 & $\$$ & 335,000 & 724,000 & $1,573,000$ & $1,717,000$ & $2,693,000$ \\
\hline & & $\mathrm{kW}$ & 1,900 & 5,000 & 16,900 & 19,200 & 36,500 \\
\hline & & $\$ / k W$ & 73 & 113 & 205 & 257 & 501 \\
\hline \multirow[t]{3}{*}{ EIS } & 11 & $\$$ & $3,155,000$ & $6,021,619$ & $9,377,000$ & $6,171,000$ & $3,789,000$ \\
\hline & & $\mathrm{kW}$ & 22,400 & 170,000 & 211,000 & 187,000 & 219,000 \\
\hline & & $\$ / k W$ & 21 & 52 & 160 & 145 & 247 \\
\hline
\end{tabular}

\subsubsection{Project Type}

Results for projects by project type are shown in Table 15. All outliers were existing conventional projects. The small sample sizes for canal and new stream reach projects does not allow accurate comparisons for these categories. For the other project types, not only were nonpowered dams generally smaller than existing conventional projects, but they also report lower 
proportional $\$ / \mathrm{kW}$ costs, suggesting there may be some correlation between project type and licensing costs. The lower $\$ / \mathrm{kW}$ for non-powered dam projects could be tied to the fact that these projects are developed on existing infrastructure, which may limit the number of new project impacts and related studies.

Table 15. Results for Subsamples by Project Type

All outliers were existing conventional projects. Outliers are excluded from results. Total $\mathrm{N}=82$.

\begin{tabular}{|c|c|c|c|c|c|c|c|}
\hline Project Type & $\begin{array}{c}\text { \# of } \\
\text { Projects }\end{array}$ & Metric & Q1 & Median & Q3 & Mean & $\begin{array}{l}\text { Standard } \\
\text { Deviation }\end{array}$ \\
\hline \multirow[t]{3}{*}{ Canal } & 2 & $\$$ & * & 116,000 & * & 116,000 & * \\
\hline & & $\mathrm{kW}$ & * & 950 & * & 950 & * \\
\hline & & $\$ / k W$ & * & 155 & * & 155 & * \\
\hline \multirow{3}{*}{$\begin{array}{c}\text { Existing } \\
\text { Conventional }\end{array}$} & 45 & $\$$ & 417,000 & $1,311,000$ & $4,987,000$ & $3,303,000$ & $3,935,000$ \\
\hline & & $\mathrm{kW}$ & 1,900 & 10,600 & 48,000 & 64,300 & 133,000 \\
\hline & & $\$ / \mathrm{kW}$ & 62 & 122 & 210 & 267 & 493 \\
\hline \multirow{3}{*}{$\begin{array}{l}\text { New Stream } \\
\text { Reach }\end{array}$} & 2 & $\$$ & * & $1,825,000$ & * & $1,825,000$ & * \\
\hline & & $\mathrm{kW}$ & * & 10,000 & * & 10,000 & * \\
\hline & & $\$ / k W$ & * & 1,373 & * & 1,373 & * \\
\hline \multirow{3}{*}{$\begin{array}{c}\text { Non- } \\
\text { Powered } \\
\text { Dam }\end{array}$} & 29 & $\$$ & 386,000 & 788,000 & $1,395,000$ & $1,047,000$ & 948,000 \\
\hline & & $\mathrm{kW}$ & 3,700 & 6,000 & 14,600 & 14,600 & 20,900 \\
\hline & & $\$ / k W$ & 65 & 88 & 155 & 130 & 144 \\
\hline
\end{tabular}

\subsubsection{Fishway Prescriptions}

The results for projects based on whether fishway prescriptions were included as part of the licensing process are shown in Table 16. Outliers were found in both categories. Generally, projects with fishway requirements were much larger and thus reported higher licensing costs, though there is not strong correlation in the proportional $\$ / \mathrm{kW}$ metric. 
Table 16. Results for Subsamples by Whether the Project Included Fishway Prescriptions or Not

The outliers were found in both categories. Outliers are excluded from the results. Total $N=82$.

\begin{tabular}{|c|c|c|c|c|c|c|c|}
\hline $\begin{array}{c}\text { Fishway } \\
\text { Requirements }\end{array}$ & $\begin{array}{c}\text { \# of } \\
\text { Projects }\end{array}$ & Metric & Q1 & Median & Q3 & Mean & $\begin{array}{l}\text { Standard } \\
\text { Deviation }\end{array}$ \\
\hline \multirow[t]{3}{*}{ Yes } & 13 & $\$$ & 446,000 & $3,894,000$ & $8,789,000$ & $4,871,000$ & $4,470,000$ \\
\hline & & kW & 4,500 & 35,000 & 172,000 & 110,000 & 174,000 \\
\hline & & $\$ / k W$ & 43 & 106 & 168 & 151 & 191 \\
\hline \multirow[t]{3}{*}{ No } & 65 & $\$$ & 346,000 & 756,000 & $1,433,000$ & $1,353,000$ & $1,881,000$ \\
\hline & & $\mathrm{kW}$ & 1,700 & 5,100 & 14,200 & 16,500 & 32,700 \\
\hline & & $\$ / \mathrm{kW}$ & 67 & 120 & 217 & 278 & 545 \\
\hline
\end{tabular}

\subsubsection{Licensee Type}

The results for projects by license type are shown in Table 17. The high-cost outliers were both investor-owned utilities (IOUs) and public utilities while the $\$ / \mathrm{kW}$ outlier was a private nonutility. Although IOU projects report the highest licensing costs by a significant margin, they also represent much larger projects, so the proportional $\$ / \mathrm{kW}$ costs are actually much lower than for other licensee types. These data further highlight the disproportionate licensing costs for smaller hydropower projects compared to larger hydropower projects.

\section{Table 17. Results for Subsamples by Licensee Type: Investor-Owned Utility, Private Non-Utility, or Publicly Owned Utility}

The high-cost outliers were both IOUs and public utilities while the $\$ / \mathrm{kW}$ outlier was a private non-utility. Outliers are excluded from the results. Total $\mathrm{N}=82$.

\begin{tabular}{|c|c|c|c|c|c|c|c|}
\hline $\begin{array}{l}\text { Licensee } \\
\text { Type }\end{array}$ & $\begin{array}{c}\text { \# of } \\
\text { Projects }\end{array}$ & Metric & Q1 & Median & Q3 & Mean & $\begin{array}{l}\text { Standard } \\
\text { Deviation }\end{array}$ \\
\hline \multirow[t]{3}{*}{ IOU } & 21 & $\$$ & $1,065,000$ & $3,952,000$ & $6,632,000$ & $4,688,000$ & $4,287,000$ \\
\hline & & kW & 8,000 & 25,000 & 173,000 & 88,000 & 96,900 \\
\hline & & $\$ / k W$ & 52 & 101 & 136 & 246 & 512 \\
\hline \multirow[t]{3}{*}{ Private } & 38 & $\$$ & 373,000 & 581,000 & $1,290,000$ & 943,000 & 895,000 \\
\hline & & $\mathrm{kW}$ & 1,800 & 4,400 & 13,500 & 8,700 & 9,500 \\
\hline & & $\$ / k W$ & 80 & 124 & 177 & 205 & 385 \\
\hline \multirow[t]{3}{*}{ Public } & 18 & $\$$ & 227,000 & 734,000 & $3,782,000$ & $2,695,000$ & $3,559,000$ \\
\hline & & kW & 1,200 & 11,900 & 48,000 & 64,200 & 179,000 \\
\hline & & $\$ / k W$ & 56 & 141 & 278 & 318 & 600 \\
\hline
\end{tabular}

\subsubsection{Licensing Cost Discussion}

Overall, the results suggest several possible correlations. First, larger projects with higher generating capacities tend to also report higher licensing costs, with most projects of more than $10 \mathrm{MW}$ reporting licensing costs of more than $\$ 1$ million and half of projects of more than 100 MW reporting costs of around $\$ 10$ million or more (median reported cost is just under $\$ 1$ million, thus most projects less than $10 \mathrm{MW}$ report costs lower than this). However, when costs 
are proportionalized to project size using the $\$ / \mathrm{kW}$ metric, larger projects show a strong economy-of-scale trend, which allows them to spread these licensing costs over a larger generating capacity. For example, projects of more than $100 \mathrm{MW}$ have a median of $\$ 15 / \mathrm{kW}$ and a third quartile of $\$ 52 / \mathrm{kW}$, compared with a median of $\$ 107 / \mathrm{kW}$ and first quartile of $\$ 59 / \mathrm{kW}$ for the entire sample. Conversely, smaller projects, particularly those less than about $1 \mathrm{MW}$, report significantly higher proportional licensing costs, with most reporting costs of more than $\$ 200 / \mathrm{kW}$ (the third quartile for the entire sample), and several reporting costs 4-10 times higher than that quartile (i.e., $\$ 800$ to more than $\$ 2,000 / \mathrm{kW}$ ).

Several project attributes have a correlation with higher licensing costs, specifically for projects that use the ALP process, have settlement agreements, have endangered species, require an EIS, require fishway prescriptions, or are associated with an IOU. However, these project attributes also share a commonality that is a likely contributor to their higher licensing costs, namely that they all tend to be associated with larger projects. For example, median project generating capacities $(\mathrm{kW})$ across these higher-cost attributes are generally at least an order of magnitude higher than the medians for the other attributes. The $\$ / \mathrm{kW}$ metrics for these higher-cost attributes confirms this trend, given that larger projects tend to benefit from economies of scale that lead to similar or lower $\$ / \mathrm{kW}$ metrics for these higher-cost project attributes (especially at the medians and third quartiles) than for attributes associated with lower licensing costs and smaller projects. The exception is relicensing projects, which show higher $\$ / \mathrm{kW}$ costs (and greater variability in them) than original projects, despite being more common for larger projects. Table 18 provides a summary of licensing costs across all project attributes reviewed in this study.

The licensing timeline variability discussed in Chapter 3 may also impact project licensing costs and overall project economics and risk. Increased timeline variability, more so than longer timelines alone, may contribute to greater uncertainty for projects, which may increase financing risk and/or overall hydropower project costs. 
Table 18. Summary of Reported Licensing Cost Variability Across Licensing Process Attributes Outliers are excluded from these results. Total $\mathrm{N}=82$ for each category.

\begin{tabular}{|c|c|c|c|c|c|c|c|c|}
\hline Category & Туре & $\begin{array}{c}\text { \# of } \\
\text { Projects }\end{array}$ & Metric & Q1 & Median & Q3 & Mean & $\begin{array}{l}\text { Standard } \\
\text { Deviation }\end{array}$ \\
\hline \multirow{9}{*}{$\begin{array}{c}\text { License } \\
\text { Process } \\
\text { Type }\end{array}$} & ALP & 9 & $\$$ & $2,970,000$ & $6,632,000$ & $9,207,000$ & $6,479,000$ & $4,509,000$ \\
\hline & & & $\mathrm{kW}$ & 24.000 & 134.000 & 170,000 & 106,000 & 85,000 \\
\hline & & & $\$ / k W$ & 69 & 83 & 160 & 341 & 743 \\
\hline & ILP & 23 & $\$$ & 624,000 & $1,311,000$ & $3,194,000$ & $2,589,000$ & $2,949,000$ \\
\hline & & & kW & 3,200 & 12,000 & 25,700 & 60,700 & 163,000 \\
\hline & & & $\$ / k W$ & 64 & 135 & 196 & 342 & 693 \\
\hline & TLP & 46 & $\$$ & 201,000 & 556,000 & $1,300,000$ & $1,414,000$ & $2,407,000$ \\
\hline & & & $\mathrm{kW}$ & 1,800 & 4,800 & 14,500 & 21,500 & 53,100 \\
\hline & & & $\$ / \mathrm{kW}$ & 65 & 95 & 199 & 172 & 199 \\
\hline \multirow[t]{6}{*}{ License Type } & Original & 36 & $\$$ & 346,000 & 724,000 & $1,300,000$ & 996,000 & 952,000 \\
\hline & & & $\mathrm{kW}$ & 2,200 & 5,600 & 14,200 & 12,800 & 19,300 \\
\hline & & & $\$ / k W$ & 71 & 93 & 157 & 196 & 432 \\
\hline & Relicense & 42 & $\$$ & 417,000 & $1,416,000$ & $5,763,000$ & $3,500,000$ & $4,001,000$ \\
\hline & & & $\mathrm{kW}$ & 1,600 & 12,500 & 50,000 & 68,600 & 136,000 \\
\hline & & & $\$ / k W$ & 56 & 131 & 246 & 281 & 509 \\
\hline \multirow{6}{*}{$\begin{array}{l}\text { Settlement } \\
\text { Agreement }\end{array}$} & Yes & 22 & $\$$ & 446,000 & $3,894,000$ & $8,789,000$ & $4,871,000$ & $4,470,000$ \\
\hline & & & $\mathrm{kW}$ & 4,500 & 35,000 & 172,000 & 110,000 & 174,000 \\
\hline & & & $\$ / \mathrm{kW}$ & 43 & 106 & 168 & 151 & 191 \\
\hline & No & 56 & $\$$ & 346,000 & 756,000 & $1,433,000$ & $1,353,000$ & $1,881,000$ \\
\hline & & & $\mathrm{kW}$ & 1,700 & 5,100 & 14,200 & 16,500 & 32,700 \\
\hline & & & $\$ / \mathrm{kW}$ & 67 & 120 & 217 & 278 & 545 \\
\hline \multirow{6}{*}{$\begin{array}{c}\text { Endangered } \\
\text { Species }\end{array}$} & Yes & 41 & $\$$ & 417,000 & $1,522,000$ & $4,447,000$ & $3,188,000$ & $3,799,000$ \\
\hline & & & kW & 3,400 & 14,600 & 50,000 & 66,200 & 135,000 \\
\hline & & & $\$ / k W$ & 39 & 95 & 164 & 288 & 622 \\
\hline & No & 37 & $\$$ & 369,000 & 584,000 & $1,311,000$ & $1,411,000$ & $2,180,000$ \\
\hline & & & kW & 1,800 & 4,800 & 12,000 & 16,900 & 39,900 \\
\hline & & & $\$ / \mathrm{kW}$ & 80 & 135 & 226 & 185 & 180 \\
\hline \multirow[t]{5}{*}{ NEPA Type } & EA & 67 & $\$$ & 335,000 & 724,000 & $1,573,000$ & $1,717,000$ & $2,693,000$ \\
\hline & & & $\mathrm{kW}$ & 1,900 & 5,000 & 16,900 & 19,200 & 36,500 \\
\hline & & & $\$ / \mathrm{kW}$ & 73 & 113 & 205 & 257 & 501 \\
\hline & EIS & 11 & $\$$ & $3,155,000$ & $6,021,619$ & $9,377,000$ & $6,171,000$ & $3,789,000$ \\
\hline & & & $\mathrm{kW}$ & 22,400 & 170,000 & 211,000 & 187,000 & 219,000 \\
\hline
\end{tabular}




\begin{tabular}{|c|c|c|c|c|c|c|c|c|}
\hline Category & Type & $\begin{array}{c}\text { \# of } \\
\text { Projects }\end{array}$ & Metric & Q1 & Median & Q3 & Mean & $\begin{array}{l}\text { Standard } \\
\text { Deviation }\end{array}$ \\
\hline & & & $\$ / k W$ & 21 & 52 & 160 & 145 & 247 \\
\hline \multirow[t]{12}{*}{ Project Type } & Canal & 2 & $\$$ & * & 116,000 & * & 116,000 & * \\
\hline & & & $\mathrm{kW}$ & * & 950 & * & 950 & * \\
\hline & & & $\$ / \mathrm{kW}$ & * & 155 & * & 155 & * \\
\hline & $\begin{array}{c}\text { Existing } \\
\text { conventional }\end{array}$ & 45 & $\$$ & 417,000 & $1,311,000$ & $4,987,000$ & $3,303,000$ & $3,935,000$ \\
\hline & & & $\mathrm{kW}$ & 1,900 & 10,600 & 48,000 & 64,300 & 133,000 \\
\hline & & & $\$ / k W$ & 62 & 122 & 210 & 267 & 493 \\
\hline & $\begin{array}{l}\text { New stream } \\
\text { reach }\end{array}$ & 2 & $\$$ & * & $1,825,000$ & * & $1,825,000$ & * \\
\hline & & & $\mathrm{kW}$ & * & 10,000 & * & 10,000 & * \\
\hline & & & $\$ / k W$ & * & 1,373 & * & 1,373 & * \\
\hline & $\begin{array}{l}\text { Non- } \\
\text { Powered } \\
\text { Dam }\end{array}$ & 29 & $\$$ & 386,000 & 788,000 & $1,395,000$ & $1,047,000$ & 948,000 \\
\hline & & & $\mathrm{kW}$ & 3,700 & 6,000 & 14,600 & 14,600 & 20,900 \\
\hline & & & $\$ / k W$ & 65 & 88 & 155 & 130 & 144 \\
\hline \multirow{6}{*}{$\begin{array}{c}\text { Fishway } \\
\text { Prescriptions }\end{array}$} & Yes & 13 & $\$$ & 446,000 & $3,894,000$ & $8,789,000$ & $4,871,000$ & $4,470,000$ \\
\hline & & & kW & 4,500 & 35,000 & 172,000 & 110,000 & 174,000 \\
\hline & & & $\$ / k W$ & 43 & 106 & 168 & 151 & 191 \\
\hline & No & 65 & $\$$ & 346,000 & 756,000 & $1,433,000$ & $1,353,000$ & $1,881,000$ \\
\hline & & & $\mathrm{kW}$ & 1,700 & 5,100 & 14,200 & 16,500 & 32,700 \\
\hline & & & $\$ / k W$ & 67 & 120 & 217 & 278 & 545 \\
\hline \multirow{9}{*}{$\begin{array}{l}\text { Licensee } \\
\text { Type }\end{array}$} & IOU & 21 & $\$$ & $1,065,000$ & $3,952,000$ & $6,632,000$ & $4,688,000$ & $4,287,000$ \\
\hline & & & $\mathrm{kW}$ & 8,000 & 25,000 & 173,000 & 88,000 & 96,900 \\
\hline & & & $\$ / k W$ & 52 & 101 & 136 & 246 & 512 \\
\hline & Private & 38 & $\$$ & 373,000 & 581,000 & $1,290,000$ & 943,000 & 895,000 \\
\hline & & & $\mathrm{kW}$ & 1,800 & 4,400 & 13,500 & 8,700 & 9,500 \\
\hline & & & $\$ / k W$ & 80 & 124 & 177 & 205 & 385 \\
\hline & Public & 18 & $\$$ & 227,000 & 734,000 & $3,782,000$ & $2,695,000$ & $3,559,000$ \\
\hline & & & $\mathrm{kW}$ & 1,200 & 11,900 & 48,000 & 64,200 & 179,000 \\
\hline & & & $\$ / \mathrm{kW}$ & 56 & 141 & 278 & 318 & 600 \\
\hline
\end{tabular}

*Quartile not calculated due to low project count 


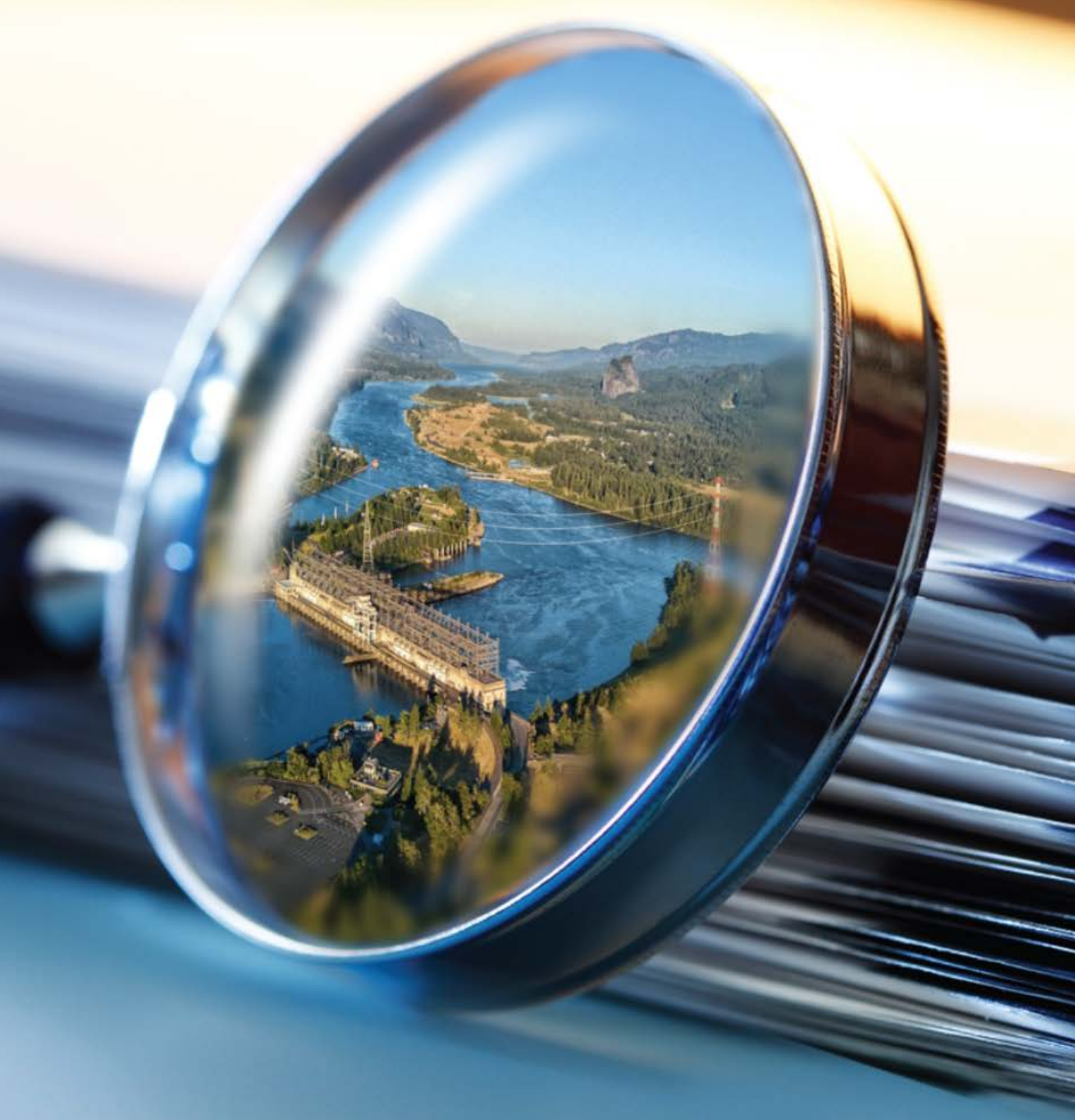

AN EXAMINATION OF THE HYDROPOWER LICENSING AND FEDERAL AUTHORIZATION PROCESS

\begin{abstract}
Environmental Measures Resulting From the Hydropower Licensing and Federal Authorization Process
\end{abstract}




\section{Environmental Measures Resulting From the Hydropower Licensing and Federal Authorization Process}

\subsection{Introduction}

Prescriptions, conditions, and PME for aquatic and terrestrial resources resulting from hydropower licensing and federal authorization processes are included in licenses to mitigate project impacts on these resources. Although passage requirements for anadromous fishes may be the most conspicuous of these PME measures, upstream fish passage provides only a small fraction of the environmental measures associated with hydropower licensing. For example, instream flow requirements, tailwater gravel additions, and invasive aquatic species monitoring are other common PME measures that can help improve environmental conditions in aquatic systems (Schramm, Bevelhimer, and DeRolph 2016).

In this chapter, we 1) summarize environmental measures in hydropower licenses using an existing database (Schramm, Bevelhimer, and DeRolph 2016), and 2) provide detailed descriptions of common mitigation measures as documented in the 10 case studies from Appendix C. This chapter only includes mitigation measures associated with FERC licensing and does not discuss the cost of these measures.

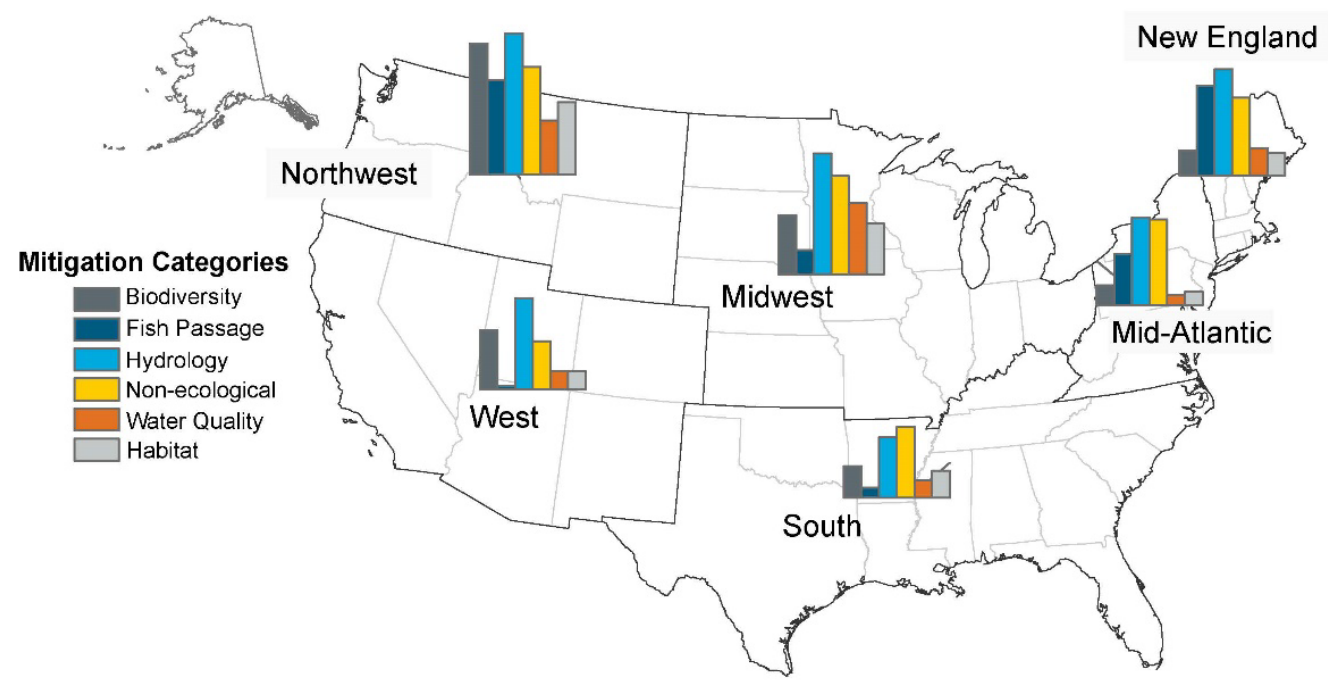

Figure 11. Map showing Tier 1 mitigation measure categories from the Schramm, Bevelhimer, and DeRolph (2016) database by FERC licensing region. Bars show the relative numbers of mitigations for each mitigation category and region. Actual numbers of mitigations depicted in bars are in Table 19.

\subsection{Summary of Existing Information on Mitigation Measures}

To better understand the types of environmental mitigation measures associated with the hydropower licensing and federal authorization process, we summarized a database constructed as part of the DOE-funded Mitigation Prediction Project (Schramm, Bevelhimer, and DeRolph 2016). This database consists of mitigation measures included in all FERC licenses issued from 
1998 to 2013 and contains a total of 309 projects that comprise 442 hydropower plants and 414 dams. Note that this database does not attribute mitigation measures to specific sources in the licensing process (e.g., CWA Section 401 certification, Section 18 fishway prescription, etc.; Appendix D).

There were 5,130 instances of 132 unique mitigation measures listed in this dataset, including 813 biodiversity, 659 fish passage, 490 habitat, 1,491 hydrology, 1,178 recreation, and 499 water quality measures (Figure 11, Table 19). Hydropower plants in the Northwest FERC licensing region had the most mitigation measures reported from licenses $(\mathrm{N}=1146$ measures, 70 licenses) followed by the Midwest $(\mathrm{N}=1043$ measures, 81 licenses $)$, West $(\mathrm{N}=920$ measures, 57 licenses), New England ( $\mathrm{N}=819$ measures, 55 licenses), Mid-Atlantic ( $\mathrm{N}=648$ measures, 44 licenses), and South $(\mathrm{N}=554$ measures, 41 licenses). For more detail on license measures, please see Appendix D.

There was regional variability in the most frequently required type of mitigation measure as well as the distribution of a particular type of measure across regions. For example, fish passage measures were most required in the New England region, although they were also commonly required in licenses issued in the Northwest and Mid-Atlantic regions. Hydrology and nonecological measures were evenly distributed across regions.

\subsubsection{Benefits to Species}

Benefits to species included mitigation measures categorized under the biodiversity, fish passage, habitat, and water quality Tier 1 categories. There were more terrestrial than aquatic biodiversity mitigation measures (terrestrial: 584, aquatic: 229); however, other mitigation measures (e.g., fish passage, aquatic and riparian habitat, hydrologic or water quality) also have a focus on aquatic biodiversity. Measures for monitoring, studying, or planning for benefitting species were common and accounted for 1,581 of 5,130 measures (31\% of all measures).

Table 19. Tallies of Tier-1 (gray highlight) and Tier-2 (bold) Protection, Mitigation, and Enhancement Measures from FERC Licenses From the Database Described by Schramm, Bevelhimer, and DeRolph (2016) by FERC Licensing Region, As Described in Chapter 3.

\begin{tabular}{|c|c|c|c|c|c|c|c|}
\hline & $\begin{array}{c}\text { MA } \\
N=44\end{array}$ & $\begin{array}{c}\text { MW } \\
N=81\end{array}$ & $\begin{array}{c}N E \\
N=45\end{array}$ & $\begin{array}{c}N W \\
N=60\end{array}$ & $\begin{array}{l}\text { South } \\
N=31\end{array}$ & $\begin{array}{l}\text { West } \\
N=47\end{array}$ & $\begin{array}{l}\text { Grand Total } \\
\quad N=308\end{array}$ \\
\hline Biodiversity & 52 & 148 & 59 & 247 & 82 & 225 & 813 \\
\hline Aquatic & 15 & 19 & 25 & 92 & 30 & 48 & 229 \\
\hline Terrestrial & 37 & 129 & 34 & 155 & 52 & 177 & 584 \\
\hline Fish Passage & 123 & 59 & 210 & 152 & 27 & 88 & 659 \\
\hline Downstream Fish Passage & 41 & 17 & 45 & 29 & 6 & 17 & 155 \\
\hline Entrainment & 50 & 9 & 19 & 14 & 8 & 12 & 112 \\
\hline Passage Planning & 15 & 26 & 76 & 74 & 6 & 40 & 237 \\
\hline Upstream Fish Passage & 17 & 7 & 70 & 35 & 7 & 19 & 155 \\
\hline Habitat & 31 & 124 & 52 & 135 & 63 & 85 & 490 \\
\hline Fisheries & 9 & 40 & 7 & 37 & 16 & 34 & 143 \\
\hline Reservoir & 15 & 59 & 24 & 19 & 40 & 7 & 164 \\
\hline Riparian & 0 & 21 & 16 & 35 & 6 & 32 & 110 \\
\hline Wetlands & 7 & 4 & 5 & 44 & 1 & 12 & 73 \\
\hline Hydrology & 212 & 291 & 252 & 285 & 158 & 293 & 1,491 \\
\hline Bypass Minimum Flow & 27 & 19 & 43 & 31 & 17 & 50 & 187 \\
\hline Flow Mitigation & 78 & 68 & 81 & 102 & 41 & 112 & 482 \\
\hline
\end{tabular}




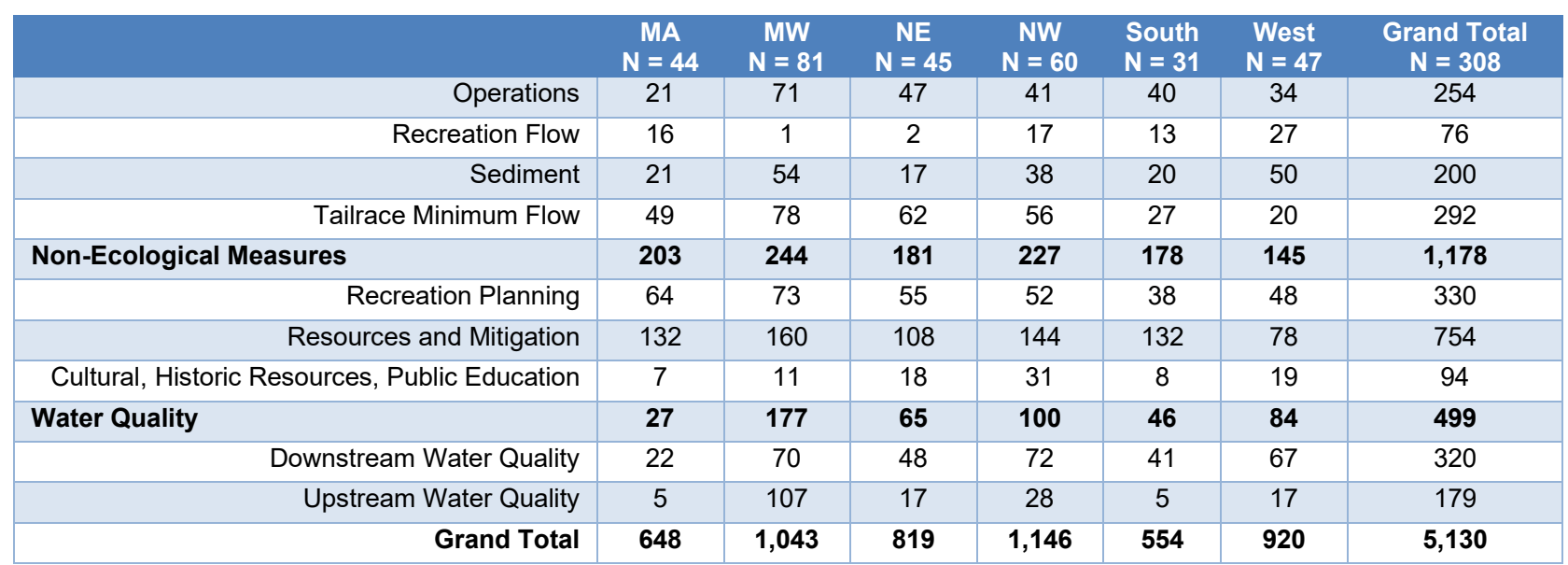

Note: Tier-1 and Tier-2 classifications are as described in Schramm, Bevelhimer, and DeRolph (2016) and derived from major hydropower environmental impacts and associated mitigation measures outlined in Trussart et al. (2002) and Kumar et al. (2012). The $\mathrm{N}=$ below each region indicates the number of licenses in the database.

FERC licenses often list species that are potentially impacted or otherwise of special concern. We summed the number of mitigation measures by fish species listed in licenses to obtain a measure of relative investment in a species. For example, if a license has four biodiversity and six water quality measures and has alewife Alosa pseudoharengus and American shad $A$. sapidissima listed somewhere on the license, alewife would tally four biodiversity and six water quality measures and American shad would also tally four biodiversity and six water quality measures. Because a license will often have multiple mitigation measures, the sum of measures for all species is greater than the total number of mitigation measures in the database. American eel Anguilla rostrata is listed on licenses with more mitigation measures than any other species and was specifically listed on licenses having the most fish passage and hydrology mitigation measures. American shad is listed on licenses with the second highest number of mitigation measures and Chinook salmon Oncorhynchus tshawytscha were associated with licenses having the most biodiversity, habitat, and water quality mitigation measures (Appendix D). Other species that were commonly listed on licenses with large numbers of mitigation measures included rainbow trout and steelhead $O$. mykiss, blueback herring A. aestivalis, Atlantic salmon Salmo salar, and alewife.

Upstream fish passage measures accounted for 155 of 659 (24\%) fish passage measures and were less common than downstream fish passage measures that accounted for 267 of $659(41 \%)$ of fish passage measures. Upstream fish passage measures included construction, implementation or modification of eel passage, fish ladders, locks, lifts, elevators, and trap and transport. Downstream passage measures included downstream passageway construction, entrainment prevention such as installation of barrier nets, fish screens, or trash racks with narrower bar spacing, and fish protection such as installation of fish friendly turbines or strobe lights. Fish species that have a facultative or obligate diadromous life history accounted for 19 of 28 (68\%) species listed on licenses where fish passage was ordered, while nine species $(32 \%)$ listed on licenses where fish passage was required are obligate freshwater species. Examples of specific fish passage mitigations are provided in Box 5.1.

There were 490 aquatic habitat and 131 terrestrial habitat measures. Although terrestrial habitat measures were not detailed in the database, 143 of $490(29 \%)$ of the aquatic habitat measures 
were for fisheries, $164(33 \%)$ were for reservoir aquatic habitat measures, $110(22 \%)$ were for riparian habitat measures, and $73(15 \%)$ were for wetland habitat measures. Examples of measures included additions of in-channel gravel or woody debris (fisheries); noxious aquatic management and shoreline protection (reservoir); buffer establishment and riparian habitat monitoring, planning, or enhancement (riparian); and enhancement, mitigation, monitoring, or protection of wetland habitats (wetland).

Hydrologic measures represented the largest Tier 1 category of mitigation in the database, accounting for 1,491 of 5,103 (29\%) mitigation measures. Mitigations specifying flows accounted for $37 \%$ of mitigation measures including minimum flows (479 of 1,491; 32\%), ramp rate specifications ( 75 of 1,$491 ; 5 \%)$, and recreational flow specifications that often require a specific flow or narrow range of flows $(40$ of 1,$491 ; 3 \%)$. Flow requirements may apply to specific project areas, including bypasses (346 of 1,491; 23\%), tailraces (615 of 1,491; 41\%), and reservoirs ( 49 of 1,$491 ; 3 \%$ ), thus providing a larger number of flow-related measures to parts of the ecosystem downstream of the project. Detailed information on the rationale for specific hydrologic measures were not provided in the ORNL Mitigation Database (Schramm, Bevelhimer, and DeRolph 2016) beyond what is captured in Appendix D. Examples of specific purposes of in-stream flow requirements are provided in Box 5.2.

Water quality mitigation accounted for 499 of the 5,130 measures in the database. Most water quality mitigation measures in this database provided measures downstream of the facility (320 of $499 ; 64 \%$ ) with most of those consisting of some type of monitoring ( 250 of $320 ; 78 \%$ ).

Similarly, most upstream water quality mitigation measures consisted of some form of monitoring (115 of 179; 64\%). Dissolved oxygen was specifically mentioned in 11\% (35 of 320) of the downstream water quality mitigation measures and included dissolved oxygen enhancement planning and installation of aeration infrastructure. 


\section{Box 5.1 Fish Passage and Protection Measures From Selected Case Studies}

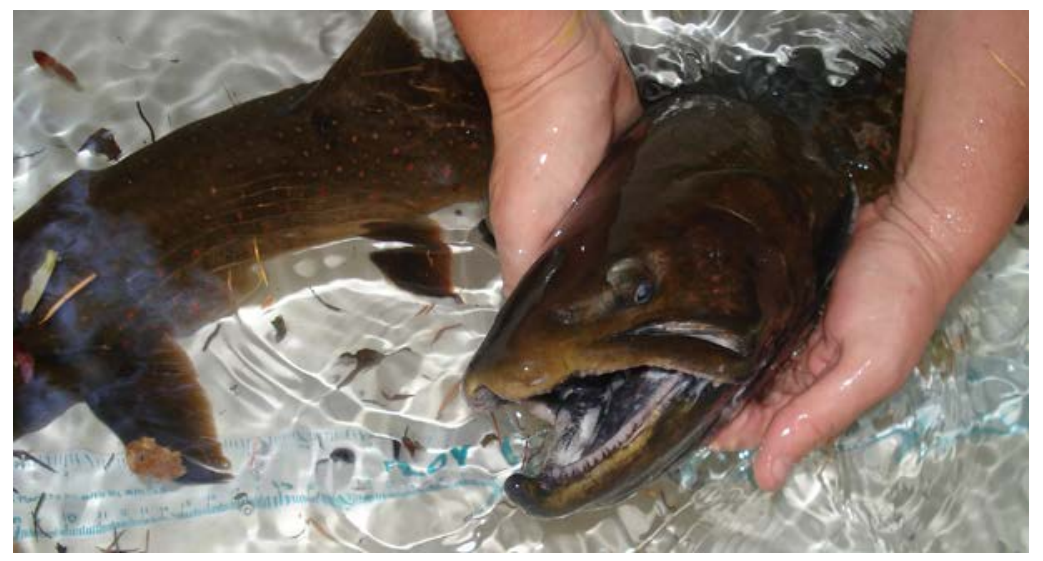

Figure 12. Bull trout (Salvelinus confluentus), Cougar Reservoir. Photo from Garth Wyatt, DOE

Many of the case study projects examined for this report had fish passage mitigation measures in the license. License requirements as described for each project in Appendix B are listed below. The source of each measure is listed in parenthesis. All conditions or measures that originated in the 401 certification, settlement agreement, or BO were included as mitigation measures in the license. Mitigation measures in the license but not listed in the Appendix B description of the 401 certification, settlement agreement, or $\mathrm{BO}$ only have the license as the source of measure origination. For more information, please see full case study write-ups in Appendix C.

- A-drop (P-12549): Collection, transport, and release of Artic grayling from stilling pool downstream of the tailrace at the end of the irrigation season (license)

- Emeryville (P-2810): 1. Install fish protection infrastructure including downstream fish passage (401 certification and settlement agreement), 2. Bypassed reach dredging to facilitate downstream fish passage (401 certification and settlement agreement)

- Merwin (P-935): 1. Installation of surface collectors for downstream salmon and steelhead smolt passage (settlement agreement), 2. Installation of upstream and downstream passage for bull trout if anadromous fish passage is not installed (settlement agreement)

- $\quad$ Spring Gap-Stanislaus (P-2130): 1. Fish screen planning at power tunnel entrance (license), 2. Continued operation and maintenance of diversion fish screen and ladder (license)

- Waterbury (P-2090): Provide upstream and downstream fish passage (401 certification). 


\section{Box 5.2 Environmental Flow Measures From Selected Case Studies}

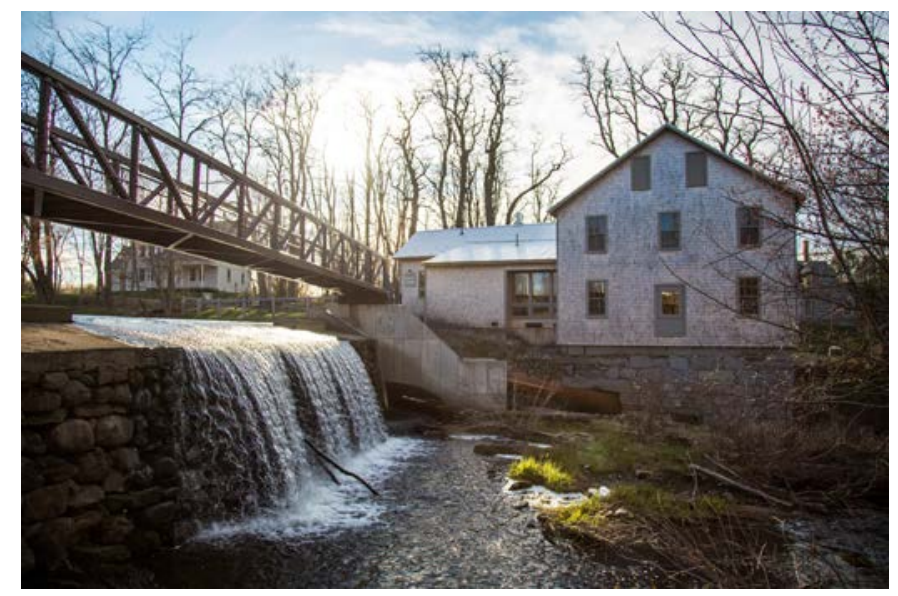

Figure 13. Freedom Falls Hydropower Project, Freedom, Maine. Photo from Andy Baumgartner, DOE

Many of the case study projects examined for this report had environmental flow mitigation measures in the license. License requirements, as described for each project in Appendix $\mathrm{C}$, are listed below. Abbreviations are as in Box 5.1. For more information, please see full case study write-ups in Appendix C.

- Badger-Rapide Croche (P-2677): 1. Run-of-river mode requirement (401 certification), 2. Minimum flow requirements (401 certification), 3. Ramp rate restrictions (401 certification), 4. Walleye spawning flows (license)

- Carver Falls (P-11475): 1. Run-of-river mode requirement (New York [NY] and Vermont [VT] 401 certification), 2. Bypassed reach minimum flow (NY 401 certification), 3. Bypassed reach minimum flow for walleye spawning (settlement agreement), 4. Water quality flows downstream of work sites to meet water quality standards (NY 401 certification), 5. Flow monitoring plan for bypassed reach, headpond, and tailwater (NY and VT 401 certification), 6. Minimum flows during maintenance activities (VT 401 certification), 7. Holiday and weekend aesthetic flows (settlement agreement)

- Emeryville (P-2850): 1. Run-of-river mode requirement (401 certification), 2. Bypassed reach minimum flow (401 certification and settlement agreement), 3. Install bypass flow gages (401 certification and settlement agreement)

- Loup River (P-1256): 1. Bypassed reach minimum flow for aquatic resources, water quality, and endangered interior least tern and piping plover (BO), 2. Power canal flows to enhance endangered interior least tern, piping plover, whooping crane, and threatened rufa red knot habitat (BO), 3. Run-of-canal mode requirement during endangered pallid sturgeon spawning migration (license)

- Merwin (P-935): Seasonal flow requirements (settlement agreement)

- Morgan Falls (P-2237): Flow monitoring (license)

- Spring Gap-Stanislaus (P-2130): 1. Minimum flow requirements and allowance for licensee to propose minimum flow modifications in "critically dry" water years (401 certification), 2. Ramp rate restrictions (401 certification)

- Waterbury (P-2090): 1. Run-of-river mode requirement (401 certification), 2. Bypass minimum flow (401 certification), 3. Develop reservoir flow and management plan including stream gage installation if necessary (401 certification). 


\subsubsection{Measures Related to Non-Ecological Resources Including Recreational, Cultural, and Historic Resources}

Measures related to recreational, cultural, and historic resources were the second most common type of mitigation measures in the database $(1,178$ of 5,$130 ; 23 \%$; Table 1$)$. However, mitigation measures focused on recreation were overwhelmingly the most common in this category compared with cultural, social, and historic resources (recreation: 1,079 of 1,178; 92\%). Measures for recreational management plan, study, or monitoring were common and found in $28 \%$ (330 of 1,178) of all measures in this category. Measures specifically benefitting recreational boating were also common and consisted of $19 \%(225$ of 1,178$)$ of measures in the recreational, cultural, social, and historic resources. More detail on specific recreational measures is provided in Box 5.3.

Benefits to non-ecological, social environmental resources included appointing a historic cultural resource coordinator $(2$ of 1,$178 ;<1 \%)$, interpretive education sign and displays ( 73 of 1,178 ; $6 \%$ ), protection of specific historic and/or cultural resource sites (16 of 1,$178 ; 1 \%)$, and public outreach education programs ( 3 of 1,$178 ;<1 \%)$. Although recreational, cultural, and historic resources are not of coequal significance, these types of mitigation measures were combined into one category to represent the non-ecological, social environmental measures created by the FERC licensing process. 


\section{Box 5.3 Recreational Measures From Selected Case Studies}

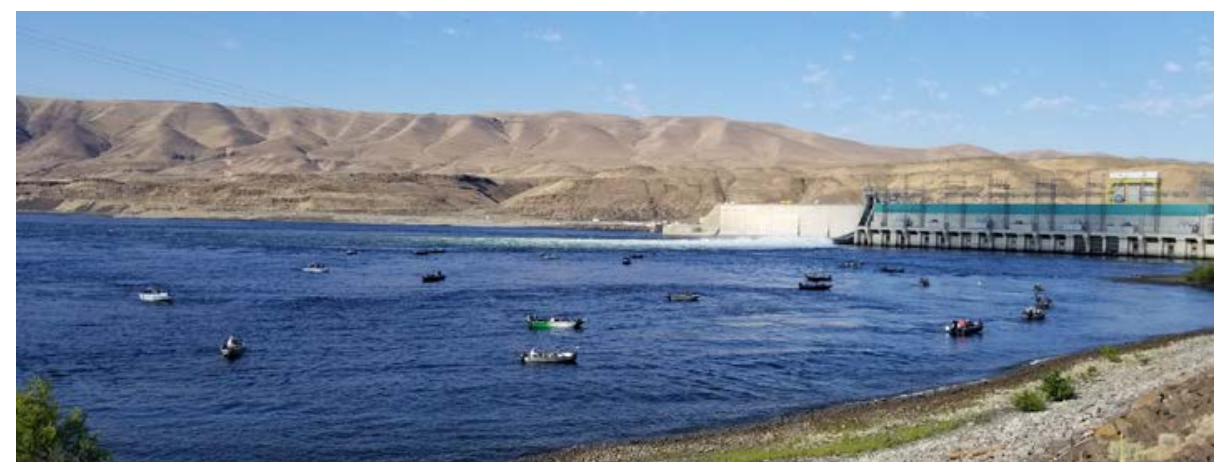

Figure 14. Salmon fishing in front of Wanapum Dam, Columbia River, Washington. Photo from Dave Dempsey, DOE

Many of the case study projects examined for this report had recreation mitigation measures in the license. License requirements as described for each project in Appendix $\mathrm{C}$ are listed below. For more information, please see full case study write-ups in Appendix C.

- Badger-Rapide Croche (P-2677): 1. Development and implementation of a recreation plan (license), 2. Development of new boat ramp and whitewater boat launch areas (license), 3 . Whitewater flows (license)

- Carver Falls (P-11475): 1. Provide recreational access and canoe/kayak portage (401 certification), 2. Improved parking and viewing access opportunities (settlement agreement), 3. Construction, maintenance, operation, and/or modification of recreational facilities considering needs of physically handicapped (license), 4. Free public access (license), 5. Implement recreation plan (license).

- $\quad \mathrm{RC}$ Byrd (P-12796): Site restoration and aesthetics plan (license)

- Emeryville (P-2850): Draft and implement recreation management plan (401 certification and settlement agreement)

- Loup River (P-1256): Continued park and trail operation and maintenance within project boundary (license), 2. Implement recreation plan (license)

- Merwin (P-935): 1. Implement recreation management plan (settlement agreement), 2. Operation and maintenance of parks and trails (license), 3. River access upgrades (license), 4. Bull trout protection public education program (license)

- Morgan Falls (P-2237): 1. Create Visitor Interpretation Program (license), 2. Manage, construct, maintain canoe portage, shoreline angler platform, and barrier-free access (license)

- Spring Gap-Stanislaus (P-2130): 1. Recreation flows (401 certification), 2. Improve recreational facilities (license)

- Waterbury (P-2090): 1. Draft and implement a recreation plan (401 certification), 2. Construction, maintenance, operation, and/or modification of recreational facilities (license), 3 . Free public access to project lands and waters for navigation and outdoor recreation including fishing and hunting (license), 4. Development of recreation plan (license). 


\subsection{Conclusion}

The hydropower licensing and federal authorization process results in a wide range of environmental mitigation measures in FERC licenses to mitigate for the impacts of hydropower projects. These measures can arise through regular license negotiations and be codified by FERC but can also be specified as parts of other processes such as settlement agreements, Section 7 consultation and state Section 401 CWA conditions, State Historic Preservation Office (SHPO) requirements, tribal requirements, and requirements from other governmental entities. Benefits brought about by these processes can include species protection measures, water quality protection and improvement measures, increased recreational access, and recreational infrastructure improvements. The licensing process can also benefit stakeholders and municipal, state, federal, and tribal governments through protection, preservation, and restoration of important historic and cultural sites that may be impacted by the project or are in the project boundary and facilitate public education and interpretation of social, cultural, and natural resources. 


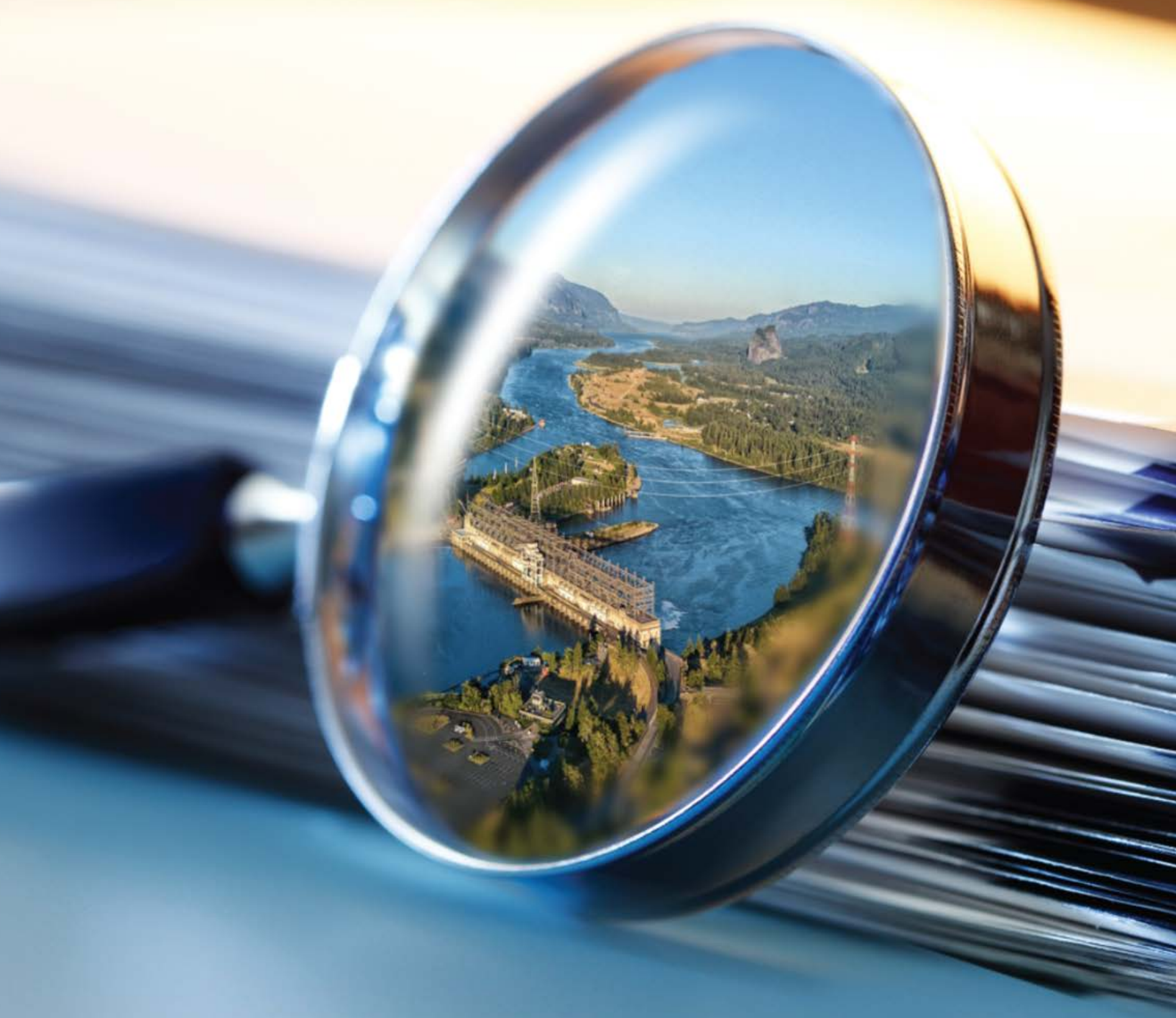

AN EXAMINATION OF THE HYDROPOWER LICENSING AND FEDERAL AUTHORIZATION PROCESS

\section{Stakeholder Elicitations on Licensing Process Challenges}




\section{Stakeholder Elicitations on Licensing Process Challenges}

This chapter documents challenges and perspectives expressed by stakeholders in the hydropower licensing and federal authorization process. It also identifies common themes within and across sectors (i.e., project development, social, cultural, and natural resource interests) and regions (i.e., eastern versus western United States) to provide insight into some of the primary challenges for participants involved in the hydropower licensing and federal authorization process. This chapter serves to document and organize key themes in stakeholder perceptions about the hydropower licensing and federal authorization process including 1) general perspectives, 2) environmental considerations, and 3) other considerations.

\subsection{Stakeholder Email Elicitation and Interview Methods}

To document stakeholder perspectives, ORNL sent email inquiries to a cross section of hydropower stakeholders and followed these inquiries up with phone interviews to determine where in the hydropower licensing and federal authorization process perceived challenges may occur, and what parts of this process may be satisfying to stakeholders. Unless otherwise noted, in this document the term "stakeholder" refers to all those involved with the hydropower licensing and federal authorization process, including regulatory agencies, Indian tribes, NGOs, utilities, project development interests.

Stakeholders were chosen at random from a dataset that included diverse geographic and cross section of hydropower interests contributed by the project Stakeholder Working Group and the project team (Table 20). Although FERC staff are listed in Table 1 with the project development interests, perspectives from FERC staff respondents were noted separately from other project development interest respondents.

Four waves of Delphi-style elicitations, each consisting of three rounds of inquiry, were conducted to document stakeholder challenges and perspectives (see Waves A through D in Figure 15). In Round 1 of each wave of inquiry, up to 13 stakeholders responded via email to two questions regarding their organization's experience with the hydropower licensing and federal authorization process (Table 21; Table 22). Stakeholders from one wave were not reused in another wave. The Inquiry Round 1 responses were then summarized for all respondents. For Inquiry Round 2, these summaries were sent to the same group of stakeholders included in the Inquiry Round 1 along with follow-up questions drafted by the project team that would help us revise and assess the efficacy of our Inquiry Round 1 summaries. Finally, in Inquiry Round 3, we performed semistructured telephone interviews with up to four new and previously unsolicited stakeholders from our database who represented perspectives from project development and social, cultural, and natural resource perspectives to assess the comprehensiveness and accuracy of our revised inquiry summaries and explore any other factors that may not have been identified by the two previous rounds of inquiry. We attempted to contact stakeholders who could provide diverse and balanced stakeholder perspectives, but diverse responses were not always received. For example, we only received one tribal response, although more were contacted. 


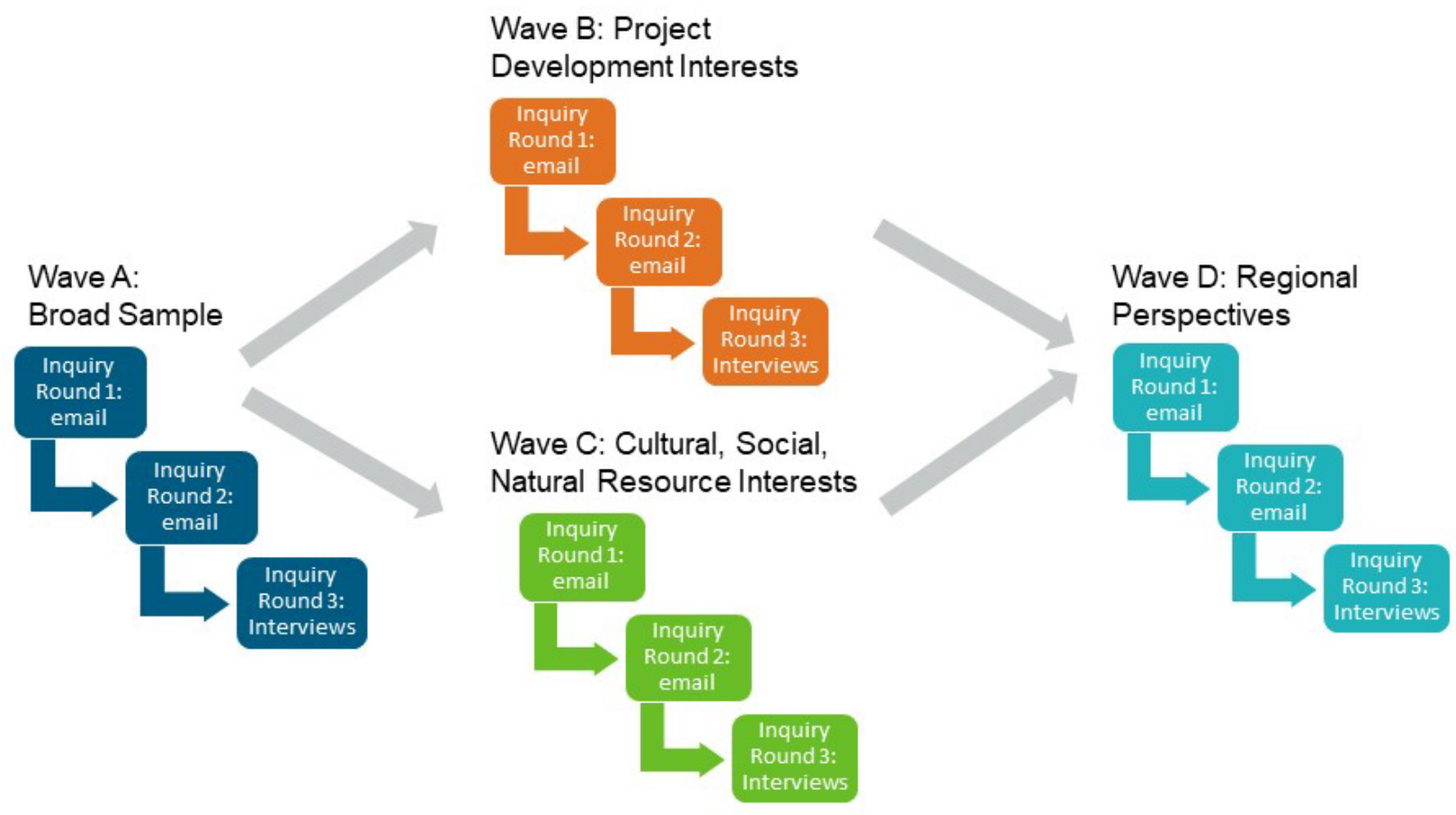

Figure 15. Stakeholder elicitation process and timeline showing Waves $A$ through $D$ and the structure of Rounds 1, 2, and 3 of each wave

Table 20. Taxonomy of Stakeholder Sectors

\begin{tabular}{|l|l|l|}
\hline \multicolumn{1}{|c|}{$\begin{array}{c}\text { Sector } \\
\text { Project Development/Utility }\end{array}$} & Sector Respondent Examples & Wave Sectors \\
\hline & - Electric utilities & A, B, D \\
\hline \multirow{3}{*}{ Social, Cultural, Natural Resource } & - Project developers & \\
\hline & - FERC & \\
\hline & - Indian tribes & A, C, D \\
\hline & - USFWS & \\
\hline & - NOAA Fisheries & \\
\hline & - USACE & \\
\hline & - State water quality/natural \\
& resource/species management agency & \\
\hline & - NGOs & \\
\hline
\end{tabular}

Note: Although FERC was included in the project development category for the purpose of stakeholder elicitation experimental design, FERC feedback is summarized separately from other project development and utility interests. 
Table 21. Total Number of Respondents Including All Three Rounds in Each Wave by Geographic Region

\begin{tabular}{|l|c|c|c|c|c|}
\hline Region & $\begin{array}{c}\text { Wave } \\
\text { A }\end{array}$ & $\begin{array}{c}\text { Wave } \\
\text { B }\end{array}$ & $\begin{array}{c}\text { Wave } \\
\text { C }\end{array}$ & $\begin{array}{c}\text { Wave } \\
\text { D }\end{array}$ & $\begin{array}{c}\text { Total } \\
\text { by } \\
\text { Region }\end{array}$ \\
\hline Northwest & 3 & 4 & 2 & 1 & 10 \\
\hline West & 0 & 1 & 2 & 2 & 5 \\
\hline Midwest & 1 & 1 & 1 & 3 & 6 \\
\hline South & 5 & 3 & 1 & 6 & 15 \\
\hline $\begin{array}{l}\text { New } \\
\text { England }\end{array}$ & 4 & 1 & 5 & 4 & 14 \\
\hline $\begin{array}{l}\text { Mid- } \\
\text { Atlantic }\end{array}$ & 1 & 1 & 0 & 2 & 4 \\
\hline Total & 14 & 11 & 11 & 18 & 54 \\
\hline
\end{tabular}

Table 22. Summary of Respondents for Each Wave by Stakeholder Sector

\begin{tabular}{|l|c|c|c|c|c|}
\hline \multicolumn{1}{|c|}{ Stakeholder Sector } & Wave A & Wave B & Wave C & Wave D & Total by Sector \\
\hline FERC & 1 & 3 & 0 & 4 & 8 \\
\hline $\begin{array}{l}\text { Federal Land/Resource } \\
\text { Agencies }\end{array}$ & 3 & 0 & 4 & 1 & 8 \\
\hline State Agency & 3 & 0 & 2 & 5 & 10 \\
\hline Developer & 1 & 5 & 0 & 3 & 9 \\
\hline Utility & 3 & 3 & 0 & 2 & 8 \\
\hline Environmental NGO & 2 & 0 & 5 & 3 & 10 \\
\hline Tribe & 1 & 0 & 0 & 0 & 1 \\
\hline Total & 14 & 11 & 11 & 18 & 54 \\
\hline
\end{tabular}

\subsection{General Perspectives}

Across all sectors, stakeholders consistently identified the length and complexity of the hydropower licensing and federal authorization process as a challenge. One respondent from the project development sector noted that this complexity, combined with the infrequency with which licensing occurs, leads FERC license applicants to expend substantial resources on educating or re-educating those involved in the licensing proceeding about the process itself.

Respondents from across sectors (i.e., project development and social, cultural, and natural resource interests) also noted staff turnover and bandwidth as key challenge in the licensing process. Challenges fell into three main themes across sectors: 1) new/inexperienced staff taking 
over in the middle of a license proceeding, 2) inadequate agency resources to complete work in a timely fashion, and 3) inadequate NGO resources to stay engaged during a multiyear process.

New and inexperienced staff that take over during a licensing proceeding due to retirements and turnover at FERC, agencies, and NGOs was cited by some stakeholders as challenging as the new staff come up to speed on a particular licensing proceeding or come to a different conclusion than a previous staff member on the same topic. For example, one federal resource agency respondent stated, "As the times change, new rules/laws come out, and people retire, we may lose some relationships that have developed over the years leaving a void where communication breaks down." Some respondents noted that it was especially important to document the terms of a settlement agreement so that new people or fading memories would not lead to the renegotiation of terms. Project development interest stakeholders also stated that new staff at federal and/or state agencies may bring new opinions about project impacts and how they should be studied or mitigated after those matters were previously agreed upon.

A utility sector respondent also noted that the time involved in FERC license negotiations presents a challenge to keeping stakeholders engaged with the process. A different respondent from the same sector noted that there may also be a lack of agency resources to complete an ESA Section 7 BO in a timely manner. Similarly, some state resource agency respondents cited inadequate staff bandwidth to engage with all licensing projects under their purview.

Some environmental NGO respondents indicated that although they provide an important perspective during the hydropower licensing and federal authorization process, they often lack the resources to have a seat at the table because of limited financial and labor resources and short timelines relative to available resources. They explained that this is particularly the case for smaller, local NGO groups that may have multiple projects simultaneously going through licensing that are important to their organizational mission. These stakeholders also described difficulty accessing sufficient technical expertise to understand, interpret, and comment on technical studies.

\subsubsection{License Process Type}

Although some stakeholder sector perspectives were specifically elicited by license process type (i.e., ALP, ILP, TLP), there were crosscutting challenges noted by stakeholders from both project development and social, cultural, and environmental perspectives. ALP and ILP schedules were noted by several stakeholders across sectors - sometimes positively, sometimes negatively — when they were asked about these licensing processes. Some stakeholders perceived challenges particular to each license process type; others were not familiar enough with all three types to draw distinctions among them. We discuss challenges and benefits of individual license process types below.

\subsubsection{Alternative Licensing Process}

Core challenges identified by respondents from the project development sector associated with the ALP were found to be a lack of schedule and study certainty. A state regulatory agency respondent noted that aggressive timelines do not "allow for much discussion of difficult issues," and can force study completion outside of recommended timelines. An environmental NGO respondent indicated that resource commitment can be significant in terms of the time it takes to agree on engagement protocols "which either shortens the pre-filing environmental study 
opportunity or requires a much earlier start than other licensing processes." In addition, it can take a substantial amount of time to implement the process. One project development sector respondent suggested that early consensus building can increase costs for licensees due to the increased time involved in ALP implementation.

The ALP was described by a FERC respondent as running "pretty smoothly due to all of the stakeholders being on board with the collaborative pre-filing process." Additionally, one federal natural resource agency respondent noted some advantages of the ALP process were that the Communication Protocol, agreed to by all ALP participants "allows interactions throughout [the] study phase and resolves issues in timely fashion" and that the process "is adaptable .... and builds trust and relationships that help during post-filing, construction, and implementation phases."

\subsubsection{Integrated Licensing Process}

The ILP is a schedule-driven process and one electric utility stakeholder noted that having deadlines built into the process can "keep the process from dragging on longer than necessary." However, this stakeholder went on to explain that this schedule can also involve challenges because "resource agencies and other licensing participants tend to be unsupportive" of using this process. Additionally, they noted that having a short turnaround time when a project has many "studies that are in dispute among the applicant and stakeholders... it is challenging for FERC staff to adequately address all of the issues in such a short amount of time." An environmental NGO respondent noted that the ILP can impede trust-building because they find it difficult "to build trusting relationships with resource agencies if the agencies believe that the process is stacked against them."

Other challenges highlighted by respondents from the project development sector were that only agencies with mandatory conditioning authority can request a study dispute resolution while the licensee cannot. It was also noted by a federal natural resource regulatory agency that the ILP reduces the study phase "effectively diminish[ing] record of decision for the project."

\subsubsection{Traditional Licensing Process}

From a project development sector perspective, the TLP offers a flexible schedule early in the process, although a state regulatory agency respondent stated that, "late scoping and FERC's limited role in the up-front process are the most challenging aspects." This same state agency respondent also noted that the TLP was found to add the risk of "additional costs late in the process, potential delays, and unpredicted outcomes associated with the potential for identification of additional studies after the filing of the final license application."

The staggered involvement of different parties can also create delays and uncertainties. This is challenging for all licensing participants because they need as much certainty as possible when, as one environmental NGO respondent put it, they are "pursuing a project as time-consuming and expensive as a FERC hydro licensing."

\subsection{Environmental Considerations}

Stakeholders from across sectors noted that a variety of environmental considerations present challenges during the process. These challenges can be generally categorized into: 1) conducting 
studies and the study determination process, and 2) compliance with state and federal processes required for issuing a FERC license.

\subsubsection{Environmental Studies and the Study Plan Determination Process}

A cross section of stakeholders identified the study plan determination process as a challenge. At least some respondents from each sector perceived the actions of opposing-view stakeholders as self-serving, working to leverage environmental studies and the study plan determination portions of the licensing process to meet their own sector priorities. Respondents from both the social, cultural, and natural resource sector and the project development sector described how positional bargaining during this phase leads to worse outcomes compared to stakeholders working together to identify win-wins.

Many respondents representing the project development sector reported that the length and complexity of the study plan determination process is, according to one project development respondent, "burdensome," and, according to another project development respondent, results in "too much time talking about what to study and not enough time actually studying it." Project developer respondents also consistently indicated that stakeholder requests for studies were not consistent with project relevance, commonly referred to as project nexus. Some project development sector respondents perceive FERC expectations as "unreasonable" or FERC as "micromanaging" the study plan determination process.

A respondent from the project development sector also mentioned that the study plan determination process can be challenging when a stakeholder's proposed study or comments are insufficient to fully understand the nature of the study. "Without this information, the applicant, stakeholders, and agencies might not be able to assess the need for additional information, the nexus between project operation and effects, the adequacy of the methodology, or the costs of the study."

Respondents representing the social, cultural, and natural resource sector found a different set of challenges with the study determination process. One respondent noted that FERC has been found to not "accept resource agency study plan requests that relate to information that FERC and the resource agency can use to support determinations in consultations" nor accept "study plan requests that relate to information that a resource agency can use to support a decision regarding whether and how to issue mandatory license conditions."

As a result, respondents from this sector believe that they must perform their own studies or rely on more generally available information, "which results in a less efficient process." Another challenge identified by this sector is the resolution of differences between resource agency study requests and FERC's ultimate determination on studies in which "agencies may request studies or study approaches that FERC later dismisses, sometimes at the expense of information or data that could be important to understanding a project's impacts." In addition, when "agencies do independently conduct studies, it also creates a situation where independently gathered information is discredited because it is independently gathered." These sector respondents also indicated that FERC does not provide "adequate explanations of its rationale in study plan determinations, which makes it unclear what more support the requesters need to provide for FERC to approve their study plan requests." 
The most prevalent theme noted in responses between both project development and social, cultural, and natural resource sectors was acknowledgement of substantial power imbalances between sectors. In general, responses suggest that project development stakeholders sometimes rely on their greater financial resources to achieve their goals instead of seeking collaborative solutions. Some respondents noted that although initial notification of a potential license proceeding was relatively straightforward, there are substantial barriers for meaningful engagement with the FERC licensing process. They described challenges accessing the technical expertise necessary to interpret studies and a perception that consultants and license applicants may not present the best available science but instead interpret the results of studies such that they are consistent with the goals of the project.

Responses suggest that the project development sector sometimes perceives other stakeholders as behaving opportunistically, using the study plan determination process and requests for license conditions to meet their agency or organization goals. Respondents from this sector also perceive some social, cultural, and natural resource stakeholders as using the licensing process to try to stop a project from going forward. The mistrust embodied by this perception was expressed by respondents from the social, cultural, and natural resource sector as well, who noted that because the same consultants are utilized "over and over in relicensing and are paid millions of dollars in each relicensing, they have had the opportunity to refine their arguments to keep unwelcome subject matter out of the study plan." This same sector also noted that rather than focusing on "strictly answering the known environmental questions in the study plan determination process," the process has become one in which "lawyers make legal arguments as to why the study plan should not reach to issues, topics, and features of the environment." That can "turn the relationship adversarial and/or political" among stakeholders of opposing sectors.

Social, cultural, and natural resource sector respondents generally acknowledge heterogeneity in license applicant strategies for interactions with project stakeholders, with some interactions occurring in a relatively straightforward manner and other behaving less collaboratively. One respondent described different "categories" of license applicants:

A straightforward licensee will allow study of topics it doesn't think belong in relicensing. It will allow the study to meet the interests of relicensing participants. This licensee may dispute the value of study results and their relevance to license conditions at a later time but won't use the study as a proxy for the later argument. An intransigent licensee will do anything to defend its perceived interests at any step in the process. This means full-blown combat science and legal advocacy to keep studies out of licensing if the results of those studies could inform license conditions.

This is consistent with another social, cultural, and natural resource interest respondent perception:

The study plan process in relicensing and original licensing has become a proxy battle for the outcome of the entire relicensing process.... the technical aspects of developing the study plan have become secondary to the quasi-legal battle that now underlies study plan development.... Over time, licensees and consultants to the licensees have learned how to game the study plan system to limit the subject matter that goes into studies.... as veterans of relicensing, the consultants often 
shape the worldview of licensees, particularly those licensees that don't operate multiple hydropower projects.

However, not all respondents mentioned mistrust between stakeholder sectors and highlighted where the process is collaborative and leads to positive outcomes for the cross-section of stakeholders. Some project development sector respondents discussed how they have worked to build strong relationships with their stakeholders, which they find helps reduce controversy in the licensing process. For example, a representative for a utility described strategies they have used to engage stakeholders.

I think the fact that we have such strong relationships [with our stakeholders] and we make them such a huge priority has really softened a lot of the things. And we care... We legitimately put a lot of concern and value on what's best for the resource, so it seems to make our path easier than some of our peers.

Likewise, some social, cultural, and natural resource sector respondents described relationships with project development/utility stakeholders to be trustworthy, with one respondent stating that, in their experience, some issues could be dealt with without having submitted a formal request for a study plan. In this scenario, the respondent described a situation in which "applicants produced a plan based on my recommendations and guidance in the accessibility field or have taken on the responsibility to improve accessibility outside of the FERC process."

Respondents from FERC also noted challenges in the study determination process, such as shortcomings in study plans submitted by license applicants. One respondent stated that, " $[\mathrm{P}]$ roject proponents ... often don't have their project proposals at a design level that is adequate to assess project effects, and this can lead to delays." They noted that "without sufficient information, stakeholders and agencies might not know the purpose of the study, the proposed methodology, or the nexus between project operation and effects." FERC respondents identified licensee inexperience as a contributor to shortcomings in study plans, stating that "the licensing process is complex but infrequent for individual projects, and so individual stakeholders may have limited experience with the process as a result. This causes shortcomings in the study plans, primarily in that the proposed study plans lack certain required details."

\subsubsection{State and Federal Hydropower Authorization Processes}

Respondents also commented on other state and federal authorization processes outside of FERC's licensing process. These processes include State Section 401 CWA certification; ESA Section 7 Consultation process; USACE Section 404 and 408 permits, which generally apply to hydropower retrofits of non-powered USACE dams; completion of Section 106 of the NHPA; and other required state, local, or tribal requirements such as the California Environmental Quality Act. In some cases, respondents from across sectors were generally in agreement that these processes can be challenging steps in the hydropower licensing and federal authorization process. Respondents also noted broad challenges across stakeholder groups not specific to a particular process, such as disagreements between FERC and federal or state agency staff on the level of information needed to make decisions under agency regulations. One federal agency respondent summed up the challenges with these processes.

Clean Water Act Certificates and the Endangered Species Act Certificates, if somehow, if they could blend the information. Do you know, for example, the 
Clean Water Act information - and this was just litigated with some deadlines but, FERC will have its licensing process and then the states will impose additional requests for information - if you could integrate those, it might expedite things. Similarly, under the ESA consultation, if folks could clearly articulate what they need to see and if FERC understands that and requires that as a study, then... the responsible agency can say to the Fish and Wildlife Service, 'don't bring me another rock' and go argue over the interpretation of the results versus saying go get more data because that's what's delaying both the Clean Water Act and ESA consultation. They never have enough information. 'Bring me another rock.' And if they could integrate those, you know, legislatively or legally so the entity to do that would be FERC, but then resource agencies are not going to be amused at that. But if you could integrate those information request into one under the ILP or whatever - that would help.

Although more processes were noted as challenging by respondents, the state Section 401 CWA Certification and the ESA Section 7 Consultation process were mentioned most often and are further discussed below.

\subsubsection{Section 401 Clean Water Act Certification}

Respondents across sectors acknowledged substantial overlap between the FERC licensing process and USACE authorization processes. One state regulatory stakeholder noted that their state waives 401 certifications for hydropower licensing "because we do it through the Corps anyways." Project development sector respondents expressed frustration when FERC and the USACE each require studies that are functionally the same, or when these same studies come to opposite conclusions on the same issue related to species protection or water quality.

Both project development and state water quality agency sector respondents also noted challenges with the Section 401 CWA certification timelines, although the project development respondent generally thought the process was "too long, subjective, and too expensive." On the other hand, state water quality agency sector respondents indicated that new certification timeline requirements were too restrictive and expectations of when the timeline starts were unclear. For example, one project development sector respondent from the eastern United States said, "I had a project in [an eastern state] where the 401 process delayed license issuance by $8-$ 10 years, and that's just unacceptable for, again, a project that's been there for a hundred years." Another project development respondent described challenges with inconsistencies between expectations from FERC and those from the state water quality authority.

I think the one crosscutting thing [is] FERC's authority versus the state's within the 401 process. ... FERC may say, "no, no, no," and then a state agency, specifically those with the 401 authority will say "yes" and FERC has to accept [the 401 condition]. So even though the record through the relicensing shows opposition to [the 401 condition], the 401 authority still puts [the disputed condition] in [the requirements for 401 certification] and FERC can't say "no" to that.... That's a recent frustration we have and that it appears that with some of the agencies - well, certainly state agencies — can say “well, if FERC won't to say yes to my study request, if FERC won't say yes to what I want in the new license even though we had 100 meetings, I'm just going to go to my sister agency, [state 
water quality authority], and say those requirements need to be in their 401." FERC can't say "no" then, even though you have this record of [the disputed requirement] not making any sense, the state agency can just find somebody else with authority that will do what they want to do.

State water quality agency respondents also identified challenges associated with the Section 401 CWA certification. For example, one of the state water quality agency respondents stated that their agency does not have the resources to conduct a thorough WQC, so they just waive their authority. This respondent said, "Then there were budget cuts and etcetera and with that we reduced our certification of FERC licenses and waived those typically. That's our biggest challenge-resources." Another respondent from the same sector discussed challenges in the WQC process related to receiving incomplete information from applicants and how that affects timelines.

And then the other issue is the 401 timeline. I think FERC has a different definition for when it starts than the definition that we incorporate or use.... In these three projects we've [kind of] hit this sort of disagreement between FERC and ourselves. FERC tends to start the timeline when they receive the application. And we start it when we receive a complete application - that's a subtle difference. So, it could be the difference between two weeks or three months or whatever... Because having that one-year timeline that we're supposed to act, that decides when we're [going to] act on the project, when we're [going to] submit the 401 certification, and so if we submit the 401 certification on our time frame that could be outside FERC's time frame and thus the 401 certification would be waived then we've lost all, I guess all direction within that particular project.

Another state water quality agency described challenges with meeting timelines required by the recent changes to 401 certifications.

One of our major challenges is the proposed amendments or changes to how Water Quality Certification occurs.... Some applicants don't follow the schedule and that's usually related to TLP projects as opposed to ILP projects and getting information back to us in a timely manner that we can have sufficient time to understand it, ask questions, and digest the data so that we can produce a good quality certification.

\subsubsection{Endangered Species Act Section 7 Consultation}

Most respondents citing challenges with the ESA Section 7 Consultation process were from the project development sector perspective. Endangered species were listed by one utility respondent as "really the number one" issue in the hydropower licensing and federal authorization process. Respondents representing the project development sector discussed inconsistencies in ESA requirements among hydropower facilities as being particularly challenging and further described frustration with having to do studies to inform mitigation measures rather than just moving right to discussion of the measures themselves.

I'm going to give you an example. So, I have endangered species act listed fish in my reservoir and, you know, the resource agencies want me to do an entrainment 
study. So, I asked the question, "how many fish can I entrain before you will make me put fish screens on the intakes?" OK, and they say "well, it's one," so "if I entrain one fish, I have to put fish screens on?" "Yes." "Well, I can tell you right now, without doing, you know, a \$2 million study, is that I'm entraining one fish, so let's just jump to the end, let's talk about fish screens and how we're going to deal with that."

Regulators and respondents from the social, cultural, and natural resource sector did not necessarily list the ESA as being particularly challenging; however, one respondent noted challenges with bringing projects up to compliance with new environmental requirements set forth by ESA and NEPA. That respondent pointed out that the process to make some facilities compliant with these new requirements was sometimes controversial, requiring extensive negotiations and adjustments to facility operations. A state agency respondent also noted how these regulatory requirements may present insurmountable challenges for some relicense applicants.

But within the last license term, the regulatory landscape has changed dramatically with environmental acts not only for water quality but also for endangered species, the NEPA process, everything. So, within the last wave of hydropower relicensing, most of these projects needed to become compliant with a number of federal acts. So, that necessitated a lot of negotiation and a lot of adjustment to their operations to become compliant. There are some facilities that simply cannot become compliant with Clean Water Act, Endangered Species Act, or any of the other federal acts that comprise the federal licensing process. I'm thinking specifically of the [name of specific hydropower project redacted] which is scheduled for license surrender and decommissioning. And we do see a number of projects that simply cannot meet that threshold of federal relicensing, and it becomes necessary to remove outdated projects.

\subsection{Other Considerations}

The sections above only represent the most commonly discussed perspectives from the email elicitations and phone interviews. Below, we summarize other respondents' perspectives.

\subsubsection{Considerations Across Sectors}

- Respondents stated that individuals matter in licensing outcomes. They indicated goals, negotiated terms, and other matters that had been settled earlier in the licensing process may end up being revisited. These items may be revisited as the individuals involved in the licensing process turn over leading to new interpretations of studies and information in addition to communication challenges among stakeholders. They explained that this occurs because the licensing process relies on interpretation of technical studies and balancing competing objectives, all of which may change as the makeup of the pool of engaged stakeholders' changes.

- Respondents described a changing energy landscape, particularly in the West. They explained that this results in part from increased concern about climate change and new incentives for renewable energy sources. They noted that some environmental and natural resource stakeholders are beginning to acknowledge that hydropower development is an 
important component of any climate change mitigation effort despite the potential for local environmental impacts.

\subsubsection{Considerations From Project Developer Sector}

- Respondents suggested that stakeholders in a licensing proceeding may not understand the impact of licensing timelines on financing and capital for developing a new project. They also noted that may not be the case, however, for relicensed projects that can continue generating revenue during the relicensing process.

- One sector respondent noted that the "inherently different perspectives and mandates" of stakeholders "inevitably" leads to delays, particularly when stakeholders wait to voice their concerns until later in the process. The respondent suggested that a stakeholder may have "divined that this project is counter to their own aspirations for the project area," while others "desire to exert bureaucratic oversight and perceived power."

- Project developer sector respondents also noted that hydropower competes with wind and solar energy as an energy source, and the cost, uncertainty, and duration of the licensing process is a significant impediment to investment in hydropower relative to wind and solar.

\subsubsection{Considerations From Natural, Social, and Cultural Resource Sector}

- These respondents expressed concern with ex parte rules imposed by FERC that may lead to a lack of agency coordination which can, in turn, cause delays and confusion. In reference to these rules, one sector respondent stated, "agencies and resource NGOs would coordinate issues and present a united front in the licensing process. This approach would limit confusion. However, recently some hydro companies have been calling this 'collusion,' and have requested to be present during these meetings... resource Agencies must have the ability to coordinate independent from the companies (and outside NGOs should also be independent from Agency coordination)."

- Resource agency sector respondents indicated that they can face challenges when the license applicant is designated as FERC's non-federal representative and the BA the license applicant produces does not adequately address agency concerns or does not use the best available science. Specifically, the respondents explained that, when FERC requests initiation of formal consultation with the resource agency and the information from the license applicant is incomplete or otherwise unacceptable, the agency may not be able to provide concurrence upon FERC's request, leading to delays.

- Resource agency respondents acknowledged that project developers perceive them as inflexible but write that the "perception of inflexibility is due to the legal constraints that are largely written into law by Congress/legislature or the legal interpretations that the agency must follow."

- Respondents stated that project developers may not always have a good understanding of the physical, social, and energy landscapes in the region in which they propose to build and operate.

\subsection{Conclusions}

Broadly, as well as specifically, stakeholders from across sectors (e.g., federal and state agencies, tribes, NGOs, development interests) identified the length and complexity of the licensing process as presenting challenges. For stakeholders who are not frequently engaged in licensing 
proceedings or have not personally been engaged in a licensing process, procedural complexities result in substantial time being devoted to educating unfamiliar stakeholders with the process.

Stakeholders also noted that because the process for licensing one project can take several years, turnover of staff involved in a license proceeding can lead to the need to renegotiate terms of settlement and other agreements because of the loss of established relationships and understandings.

Issues of scientific data relevance, accuracy, and availability with respect to project impacts were reported by both project development and social, cultural, and natural resource sectors as being at the root of disagreements during the licensing process, particularly during the environmental study negotiation process. Project developers generally felt that data collected by outside organizations or already existing data were too frequently discounted by stakeholders from social, cultural, and natural resource perspectives without regard for economic implications of conducting new studies. On the other hand, the social, cultural, and natural resource sector reported challenges with license applicants submitting studies with conclusions that do not necessarily use the best available science nor provide enough information to make informed decisions. Underpinning these challenges is the perception shared across sectors that there is a lack of trust among stakeholders with differing perspectives because each sector views stakeholders with other perspectives as engaging in positional bargaining to advance their agenda without any real intent to compromise. 


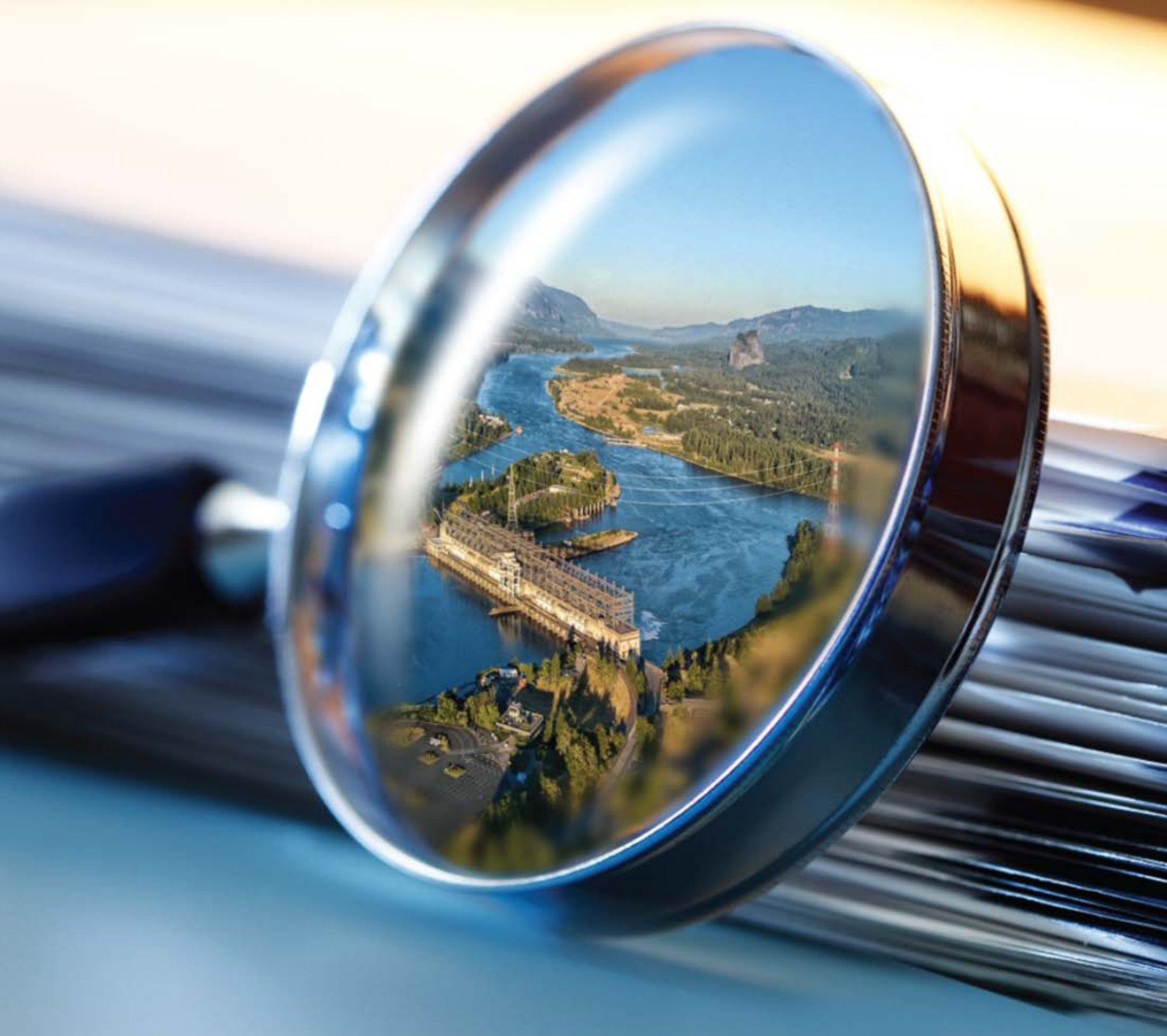

AN EXAMINATION OF THE HYDROPOWER LICENSING AND FEDERAL AUTHORIZATION PROCESS

\section{Comparison to Previous Reports Analyzing the Hydropower Licensing and Federal Authorization Process}




\section{Comparison to Previous Reports Analyzing the Hydropower Licensing and Federal Authorization Process}

This chapter provides a summary and comparison of issues related to hydropower licensing identified in previously published FERC licensing reports as well as academic and market reports. In addition, this chapter compares the findings of these previous reports to key findings identified in this current report.

\subsection{Summary of Previous Federal Energy Regulatory Commission Licensing Reports}

This section contains a summary of issues identified in the 2001 FERC Section 603 report, which analyzed policies, procedures, and regulations relating to the licensing of non-federal hydropower projects to reduce time and costs associated with licensing. In addition, this section contains a summary of FERC's 2017 2-year hydroelectric licensing process for non-powered dams and closed-loop pumped storage projects report, which analyzed the effectiveness of FERC's efforts to implement a pilot 2-year licensing process.

\subsubsection{Federal Energy Regulatory Commission 2001 Section 603 Report}

In May 2001, FERC staff prepared a report pursuant to Section 603 of the Energy Act of 2000 (Section 603 report). In the Section 603 report, FERC undertook a comprehensive review of the licensing procedures for hydropower projects to identify current cost and time impacts as well as strategies to reduce the cost and time of obtaining a license under the FPA (FERC 2001).

To identify the factors influencing the timeliness and cost of hydropower licensing, FERC compared application timelines for license applications filed between 1980 and 1992 to applications filed between 1993 and 2000. FERC ultimately found that for applications filed between 1993 and 2000, the median time from application to issuance took 13 months longer than for applications filed between 1980 and 1992. FERC determined that increased processing time was attributable to 1) a greater volume of applications, 2) post-filing disputes over the scope of necessary studies, 3) efforts to promote settlement agreements, 4) a 1993 policy requiring the issuance of draft EAs, 5) a 1994 policy requiring additional NEPA scoping procedures, 6) an increased number of joint NEPA documents with other federal agencies, 7) agency delays in providing conditions, ${ }^{34}$ and 8) increased issuance of state CWA Section 401 WQCs as opposed to waivers of certification (FERC 2001).

FERC also analyzed whether the introduction of the ALP had reduced the time and costs of licensing and relicensing. ${ }^{35}$ After review, FERC determined that use of the ALP resulted in a faster overall process than the TLP. Although the ALP requires more pre-filing activity than the

\footnotetext{
34 The greatest costs associated with license terms and conditions were related to fish protection measures. FERC also noted that the costs of preparing a license application and implementing terms and conditions were relatively greater for smaller projects.

${ }^{35}$ Notably, when FERC published the Section 603 report in 2001, the ALP and TLP were the only licensing procedures available. The ILP was adopted in 2003.
} 
TLP, the median time to complete all post-filing milestones for the ALP (16-29 months) was considerably shorter than the TLP. FERC noted that unresolved disputes between license applicants and resource agencies over the need for additional post-filing studies significantly increased the time and costs of obtaining a license using the TLP (FERC 2001).

In addition, FERC determined that the untimely receipt of CWA Section 401 WQCs from state resource agencies was creating licensing delays. In analyzing the effect of untimely receipt of WQCs, FERC determined that 39\% of applications filed between 1994 and 2000 experienced WQC delays. FERC noted that of 129 licensing cases pending at the time the Section 603 report was released, 73 were held up from normal processing, and, of those $73,71 \%$ were held up by WQC issues (FERC 2001).

Further, FERC found that the time it took to complete PAs pursuant to Section 106 of the NHPA increased delays because the agreements often linked non-controversial projects to controversial projects in multiproject river basin proceedings (FERC 2001).

As a result of its findings, FERC prepared a list of legislative, regulatory, and policy recommendations for licensing reform. Although some of FERC's recommended reforms were enacted in full, others were not enacted or were enacted with modifications.

The following are FERC's 2001 recommended legislative reforms:

- Establish a FERC issued license as the only required federal authorization for hydropower licenses. Under this recommendation, FERC would have authority to reject or modify agency conditions based on inconsistency with FERC's public interest determination. In addition, FERC would establish a single administrative process to address all federal agency issues in a licensing case and prepare a single NEPA document.

- Require agencies to consider the public interest in drafting license conditions.

- Establish an administrative appeals process for agency license conditions.

- Enact a congressional amendment limiting WQCs to physical and chemical water quality parameters related to the hydropower facility.

- Provide a statutory definition of the term "fishway." Under this recommendation, FERC suggests that any definition of fishway should be consistent with the definition established by Congress in EPAct of 1992 and should require the concurrence of FERC.

- Amend the FPA to permit FERC to remit the portion of administrative annual charges attributable to the costs of agencies with FPA Part I responsibilities and specify that such remittances are to be used for the purposes of implementing FPA Part I.

The following are FERC's 2001 regulatory and policy recommendations:

- Require license applicants to submit a status report focusing on study requests during the pre-filing consultation to enable FERC staff to determine if pre-filing involvement is warranted (FERC 2001). Under this recommendation, all applicants would be required to file a report on the status of consultations to FERC 1 year after the initial consultation package is released (approximately 2 years before the application is filed). 
- Require FERC approval for agency revisions of license terms, recommendations, and conditions. Under this recommendation, the option to provide draft conditions and an open-ended schedule for submitting final conditions would be eliminated. Agencies would only be permitted to revise their conditions within a reasonable period of time following first environmental analysis and only if FERC agrees to accept the revisions.

- Require applicants to include public and NGOs in pre-filing consultation.

- Allow applicants to maintain public information electronically.

- Continue to promote the ALP.

- Continue to encourage the settlement of disputes during the licensing process.

- Eliminate draft EAs unless they are necessary.

- Eliminate issuances of a second NEPA scoping document.

- Increase the standard new ${ }^{36}$ licensing term to 50 years.

For a detailed overview of FERC's legislative, regulatory, and policy recommendations; the status of recommendations (e.g., whether the recommendation was enacted); and the final form of the recommendation (e.g., incorporated into statutes, regulations, or executive orders), see Appendix E.

\subsubsection{Federal Energy Regulatory Commission 2017 Section 6 Report: 2-Year Licensing Process}

In May 2017, FERC staff prepared a report pursuant to Section 6 of the Hydropower Regulatory Efficiency Act of 2013 (Section 6 report). In the Section 6 report, FERC investigates the feasibility of the issuance of a license for hydropower development at non-powered dams and closed-loop pumped storage projects in a 2-year period (pilot 2-year licensing process) as a solution to reduce the time required to obtain a license under the FPA for certain projects (FERC 2017b).

To assess the feasibility of a 2-year licensing process, FERC solicited public comments and recommendations, engaged stakeholders, analyzed existing statutory and regulatory requirements of the licensing process, conducted a 2-year licensing time and motion pilot study, and examined the processing times for projects that were issued original licenses or small hydropower exemptions (FERC 2017b).

FERC analyzed existing statutory and regulatory requirements of the non-hydropower licensing process, as well as official records, to ascertain whether there was sufficient flexibility within the current regulations to facilitate a 2 -year process. FERC used the criteria developed and the analysis of the existing licensing processes to develop a pilot licensing process for hydropower development at non-powered dams and closed-loop pumped storage projects (FERC 2017b). On May 5, 2014, Rye Development filed its NOI, PAD, and request to test the pilot 2-year licensing process, setting in motion the pilot 2-year licensing process. On May 5, 2016, FERC issued an original license to Rye Development for the L\&D 11 Project, meeting the 2-year target date for completing the licensing process (FERC 2017b).

\footnotetext{
36 "New license" refers to a license issued to replace a project's expiring license during relicensing.
} 
To assess the feasibility of a 2-year licensing process, FERC also examined the processing times for 83 projects that completed pre-filing and post-filing activities and were issued original licenses or small hydropower exemptions between 2003 and 2016. Table 23 below provides a summary of FERC's findings.

\subsubsection{Processing Times for New Projects}

Of the 83 projects examined, 19 projects were granted a small hydropower exemption, and the remaining consisted of 52 TLPs, 7 ILPs, 4 ALPs, and the pilot 2-year project. For these projects, the median time from the filing of the NOI and PAD until license issuance was 3.34 years and the median time to receive an exemption was 1.86 years. The median time spent in the pre-filing phase for these projects was 1.55 years and the median time from license application to license issuance was 1.86 years. FERC found that during the 13 -year period examined, 22 projects $(27 \%)$ received a license or exemption in 2 years or less, all of which used the TLP or ILP. For those 22 projects that received a license or exemption within 2 years, FERC noted that the median process time, including pre-filing consultation, was 1.36 years. The L\&D 11 Project was also licensed in 2 years, using the pilot 2-year process (FERC 2017b).

\subsubsection{Characteristics of Projects Processed in 2 Years}

FERC further examined the 23 projects ( 22 that received a license or exemption within 2 years, as well as the L\&D 11 Project, which was licensed using the pilot 2-year process) to compare the characteristics of these projects with the 60 projects licensed (or exempted) in more than 2 years, to determine what, if any, factors contribute to or hinder expedited processing.

FERC analyzed a number of project characteristics, including project capacity; the quality of the applicant's filings determined by the need for AIRs; the filings of FPA 4(e) conditions; Section 18 prescriptions and 30(c) conditions; and compliance with NEPA, CWA Section 401, ESA Section 7, and NHPA Section 106. FERC found that $74 \%$ of the projects licensed within 2 years were $1 \mathrm{MW}$ or less, and $13 \%$ of the projects were $5 \mathrm{MW}$ or less. Conversely, FERC found that $15 \%$ of the projects with licensing timelines longer than 2 years were more than $5 \mathrm{MW}$ and $25 \%$ were more than $10 \mathrm{MW}$. FERC reported that of the projects licensed within 2 years, 30\% had no AIRs or deficiencies and only $8 \%$ of those licensed in more than 2 years had no AIRs or deficiencies (FERC 2017b).

FERC's analysis found $100 \%$ of the projects licensed in 2 years or less met FERC-set deadlines for FPA 4(e) conditions and Section 18 prescriptions, while only 33\% with licensing timelines longer than 2 years met FERC-set 4(e) deadlines and only 78\% met Section 18 prescription deadlines. FERC also determined that NEPA EAs for projects licensed in 2 years or less took approximately 4 months, but EAs for projects with licensing timelines longer than 2 years averaged 10 months. Similarly, FERC noted that all projects licensed in 2 years or less received a CWA Section 401 WQC or waiver within 1 year, while only $80 \%$ of the projects with licensing timelines of more than 2 years received a WQC or waiver within 1 year. FERC also found that $70 \%$ of the projects licensed in 2 years or less required no ESA consultation, while $53 \%$ of projects with licensing timelines more than 2 years required informal or formal ESA consultation. FERC also reported that only $23 \%$ of projects licensed in less than 2 years had adverse effects on historic properties requiring a programmatic agreement or memorandum of agreement under NHPA, while $37 \%$ of projects with licensing timelines more than 2 years had adverse effects on historic properties (FERC 2017b). 
Table 23. Characteristics of Projects Licensed or Exempted From Licensing in More Than 2 Years and 2 Years or Less

\begin{tabular}{|c|c|c|}
\hline Characteristic & More Than 2 Years & 2 Years or Less \\
\hline Number of Projects & 60 & 23 \\
\hline \multirow[t]{3}{*}{ Process } & $83 \%$ TLP license or exemption & 91\% TLP license or exemptions \\
\hline & $5 \%$ ALP & $4 \%$ ALP \\
\hline & $12 \%$ ILP & $4 \%$ Pilot 2-year process \\
\hline Median Processing Time & 3.91 years & 1.36 years \\
\hline \multirow[t]{4}{*}{ Project Capacity } & $30 \% 1 \mathrm{MW}$ or less & $74 \% 1 \mathrm{MW}$ or less \\
\hline & $30 \%>1$ and $\leq 5 \mathrm{MW}$ & $13 \%>1$ and $\leq 5 \mathrm{MW}$ \\
\hline & $15 \%>5$ and $\leq 10 \mathrm{MW}$ & $13 \%>5$ and $\leq 10 \mathrm{MW}$ \\
\hline & $25 \%>10 \mathrm{MW}$ & $0 \%>10 \mathrm{MW}$ \\
\hline \multirow[t]{3}{*}{ Post-Filing AIRS or Deficiencies } & $87 \%$ required AIR & $65 \%$ required AIR \\
\hline & $\begin{array}{l}67 \% \text { had one or more } \\
\text { deficiencies }\end{array}$ & $\begin{array}{l}43 \% \text { had one or more } \\
\text { deficiencies }\end{array}$ \\
\hline & $8 \%$ no AIRs or deficiencies & $30 \%$ no AIRs or deficiencies \\
\hline $\begin{array}{l}\text { Median Time From Application Filed } \\
\text { to REA Notice }\end{array}$ & 8.5 months & 2.3 months \\
\hline $\begin{array}{l}\text { Median Time From REA Notice to } \\
\text { Final EA Issuance }\end{array}$ & 9.7 months & 4.3 months \\
\hline FPA 4(e) Conditions & $\begin{array}{l}33 \% \text { received before FERC-set } \\
\text { deadline }\end{array}$ & $\begin{array}{l}100 \% \text { received before FERC-set } \\
\text { deadline }\end{array}$ \\
\hline FPA Section 18 Prescriptions & $\begin{array}{l}78 \% \text { received before FERC-set } \\
\text { deadline }\end{array}$ & $\begin{array}{l}100 \% \text { received before FERC-set } \\
\text { deadline }\end{array}$ \\
\hline CWA 401 Certification or Waiver & $\begin{array}{l}80 \% \text { certifications or waivers } \\
\text { within } 1 \text { year }\end{array}$ & $\begin{array}{c}100 \% \text { certifications or waivers } \\
\text { within } 1 \text { year }\end{array}$ \\
\hline \multirow[t]{3}{*}{ ESA Consultation } & $\begin{array}{l}43 \% \text { required informal } \\
\text { consultation }\end{array}$ & $\begin{array}{l}26 \% \text { required informal } \\
\text { consultation }\end{array}$ \\
\hline & $10 \%$ required formal consultation & $4 \%$ required formal consultation \\
\hline & $47 \%$ required no consultation & $70 \%$ required no consultation \\
\hline \multirow[t]{2}{*}{ NHPA Section 106} & $28 \%$ no historic properties & $35 \%$ no historic properties \\
\hline & $35 \%$ no adverse effects & $43 \%$ no adverse effects \\
\hline
\end{tabular}

Note: Adapted from FERC's 2017 report

In 2017, FERC held a final workshop to solicit public comment on an expedited license process and the effectiveness of the 2-year licensing process. FERC also provided an opportunity for the public to submit written comments after the workshop. In general, the commenters and workshop participants supported the assumption that an expedited licensing process had multiple benefits, was feasible and practicable, and would encourage greater investment in hydropower development.

Developers, industry, and resource agency staff provided comment that there were multiple benefits to an expedited licensing process. Developers and the NHA asserted that the length of 
time it takes to license new projects under FERC's existing licensing process is a barrier to investment, and that an expedited licensing process could reduce this barrier. Resource agency staff also commented that an expedited licensing process for specific projects could increase the relevancy of data collected for a project, reduce the potential for agency turnover during the licensing process, and aid in better retention of process- and project-specific information for members of the public involved in the licensing process (FERC 2017b).

Commenters and workshop participants also highlighted a number of best practices and recommendations that could enhance the feasibility of a 2-year licensing process for certain projects. These best practices and recommendations included:

- Early and frequent consultation by applicants with agencies and other stakeholders

- Flexible licensing process to be able to address unforeseen issues

- Adequate baseline data at the start of pre-filing to facilitate agency and stakeholder review

- Tiered FERC NEPA documents when possible (a practice employed by USFS)

- Access to licensing guidance

- Deference to agencies with regard to study requests

- Ability to process multiple projects in a river basin in a comprehensive, integrated way

- Refinement of existing memoranda of understanding and an exploration of opportunities for new memoranda of understandings to facilitate parallel agency processing

- Consultations with Congress about reducing FERC and USACE duplicative authorities

- Development of more stringent criteria for preliminary permits

- Development of formatted and automated document preparation templates (e.g., an electronic form for initial EAs) (FERC 2017b).

\subsection{Summary of Other Hydropower Licensing Reports}

This section contains a summary of two academic reports and one market report: 1) "Sources of Bureaucratic Delay: A Case Study of FERC Dam Relicensing" (Kosnik 2006), 2) "Does Collaboration Affect the Duration of Environmental Permitting Processes?" (Ulibarri 2017), and 3) "2017 DOE Hydropower Market Report" (ORNL 2017). Each of these reports analyzes licensing timelines for specific hydropower criteria (e.g., relicensing, non-powered dam development, licensing process type). These reports date back to the early 2000s and each report is limited in scope (e.g., relicensing, non-powered dam development, specific license process types).

\subsubsection{Summary of Other Reports}

The 2006 Kosnik report reviewed 222 hydropower relicensing proceedings for FERC licensed dams from 1982 to 1998 . The report found that $27 \%$ of hydropower relicenses, from NOI/PAD filing to license issuance, were issued in more than 5 years, with the longest licensing timeline taking 21 years. Kosnik found that project characteristics, such as dam height, gross storage capacity, project size, and drainage area size, correlate to longer relicensing timelines. The report also observed several reasons for longer timelines based on intervenor comments, including delays from hydropower interests (e.g., dam owners and power intervenors), environmental interests (e.g., endangered species), and quasi-environmental interests (e.g., sportfishing and historical intervenors) (Kosnik 2006). 
The "2017 Hydropower Market Report" analyzed 53 non-powered dam projects with FERC original license dockets opened from 2000 to 2016. The report found that the median licensing timeline for the 53 projects was 2.5 years from license application to license issuance, but that the timeline ranged from 6 months to 7 years across the projects (Uría-Martínez, Johnson, and O'Connor 2018).

Another 2017 report analyzed 24 FERC hydropower projects relicensed between 2007 and 2012 that used the ALP or ILP (Ulibarri 2017). The relicensing proceedings analyzed included run-ofriver, storage, and conventional dam projects distributed across 12 states. The report found the mean relicensing timeline for the 24 projects was 5.9 years with a standard deviation of 1.5 years. Ulibarri found that the presence of aquatic endangered species and project size correlate to longer relicensing timelines, but that stakeholder collaboration did not (Ulibarri 2017).

\subsection{Comparison of Previously Published Federal Energy Regulatory Commission, Academic, and Market Reports to Current Report}

This section compares the findings of the previously published FERC, academic, and market reports to key findings in this current report, including similarities and distinctions.

\subsubsection{Comparison of Previous Federal Energy Regulatory Commission Reports to Current Report}

A number of similarities were found between the two previously published FERC reports and our current report. First, the 603 report identified post-filing disputes over necessary studies in the TLP process to be a factor in increased processing time. Although not quantified in our report, our qualitative elicitation results identified post-filing TLP study disputes as a challenge within the current process. Second, both the 603 report and the 2-year pilot report identified untimely/late receipt of CWA 401 certifications to be a cause of increased processing timelines.

Similarly, our statistical timeline analysis showed the CWA 401 process to be a statistically significant driver of licensing timelines and a review of FERC's list of projects with expired licenses/licensing delays highlighted a number of projects held up by 401 certifications. Third, the 603 Report stated that efforts to promote settlement agreements/the use of settlement agreements were associated with increased processing times. Similarly, our report found that projects with settlement agreements had longer processing times than projects without settlement agreements. However, it is worth noting that we were unable to ascertain how long these licensing timelines would have been without settlement agreements and that, generally, projects with settlement agreements have more environmental complexity.

In addition, a number of distinctions can be made between the two FERC reports and our current report. First, the FERC 603 report predated the ILP and, as a result, we are unable to make any comparisons with our ILP data. Second, the 2-year pilot study had a specific focus on projects that could complete the post-filing process in 2 years and included a collection of exemptions from licensing. In contrast, our report had a broader focus on both pre-filing and post-filing activities and did not include any exemptions. Third, both FERC reports included additional criteria that were not analyzed as part of our report: (1) the 603 report addressed federal agency delays in providing license conditions and the 2-year pilot report specifically looked at the timeliness of FPA 4(e) mandatory conditions, while our report reviewed neither of these aspects; (2) both FERC reports analyzed timelines related to the NHPA 106 consultation process while 
our report did not ascertain quantitative data on the NHPA 106 consultation process, but instead reviewed these as applicable for the licensing case studies presented in Appendix $\mathrm{C}$ and through qualitative elicitations; (3) the 2-year pilot report analyzed the impacts of post-filing AIRs or other license application deficiencies, but our study did not include any criteria related to the quality of the license application.

\subsubsection{Comparison of Other Previous Studies to Current Study}

A number of similarities were found between our report results and other previous reports. Like Kosnick and Ulibarri, our study identified a correlation between longer licensing timelines and the presence of endangered species as well as longer licensing timelines and project size (i.e., capacity in megawatts) once we accounted for license type. In addition, our sample of ILP projects had the same overall timeline of 5.9 years found in the Ulibarri study.

However, like the previous FERC reports, other licensing reports reviewed as part of this report had a narrower focus. For example, Kosnick and Ulibarri only reviewed relicensing efforts, with Ulibarri focusing on the ILP and Kosnick only reviewing ALP and TLP projects (due to the study period being prior to creation of the ILP). In addition, the licensing timeline data gleaned from the "2017 Hydropower Market Report" were focused only on powering non-powered dams. In addition, these other reports focused on additional criteria not reviewed as part of our report, including intervener comments, impacts of collaboration, additional physical project attributes, and recreational activities such as sportfishing. 


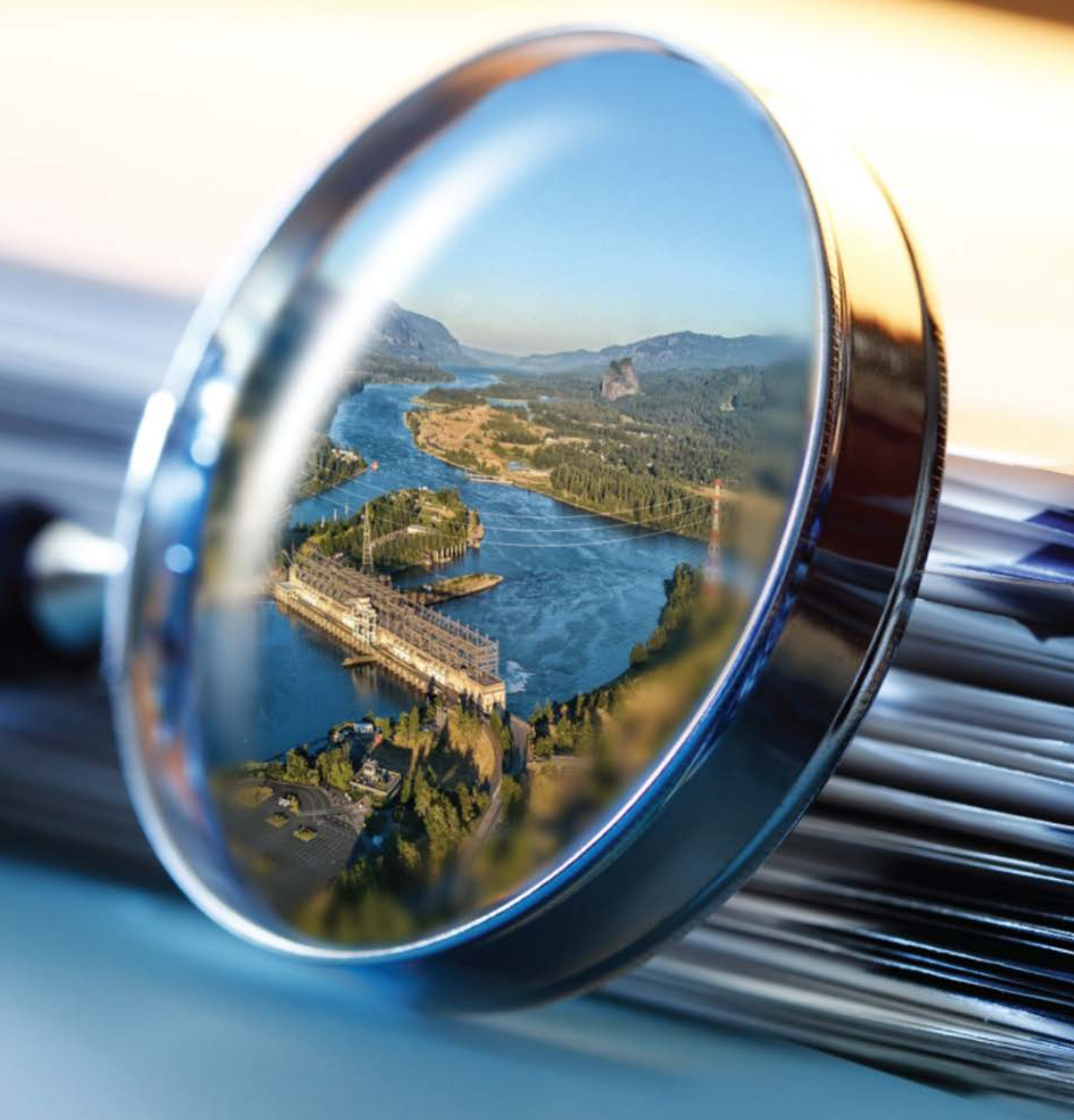

AN EXAMINATION OF THE HYDROPOWER LICENSING AND FEDERAL AUTHORIZATION PROCESS

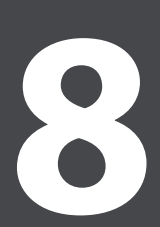 \\ Hydropower Licensing and Federal Authorization Process: Conclusions and Discussion}




\section{Hydropower Licensing and Federal Authorization Process: Conclusions and Discussion}

This chapter provides a discussion of key takeaways synthesized from the report as a whole, with respect to hydropower project regulatory timelines, costs, and benefits as well as the complexities of the non-federal hydropower licensing and federal authorization process in the United States. Although each hydropower project has unique project characteristics and environmental concerns, much can still be gleaned from our quantitative and qualitative analysis of hydropower licensing and federal authorization process.

\subsection{Discussion of Key Report Takeaways}

The key takeaways presented in this chapter were identified based on:

- A comprehensive review of literature and policy including but not limited to statutes, regulations, NEPA documents (i.e., EISs and EAs), license orders, settlement agreements, ESA consultation documents (i.e., biological opinions), water quality certification documents, federal agency reports (e.g., FERC 2001 Section 603 Report), and other domestic and international publications

- Email elicitations and interviews from a wide assortment of international and domestic industry and agency experts and personnel, non-governmental organizations, and other stakeholders

- Statistical timeline analysis, associated case studies, and licensing cost analysis.

\subsubsection{Licensing Timelines, Environmental Complexity, Environmental Measures}

\section{Length and Complexity of the Licensing Process is Challenging for All Stakeholder Sectors, Including Regulatory Agencies}

The average length of an original $(5.0+2.9$ years $)$ or relicense $(7.6+3.3$ years $)$ process constitutes a relatively long-term time and monetary investment by all sectors of the hydropower community. ${ }^{37}$ Responses to email elicitations and phone interviews with stakeholders from all sectors point to turnover and bandwidth among state and federal agency staff and NGOs as a primary source of these challenges. Specifically, these responses included new/inexperienced staff taking over in the middle of licensing/authorization process; agencies not having adequate staff resources to complete work in timely fashion; and NGOs, especially those with a local focus, not having adequate staff bandwidth or technical expertise to stay engaged throughout the licensing process.

\section{Longer Licensing Timelines Are Associated With Greater Environmental Complexity}

The potential for environmental impacts from hydropower development and operation to significant or sensitive cultural or natural resources, endangered species, critical habitat, and recreation may require more time and consideration to determine how best to evaluate and

\footnotetext{
${ }^{37}$ For context, per FERC regulations (18 C.F.R. $\S 5.5$ ) the anticipated time for relicensing a project is 5 to 5.5 years, as determined by when a licensee must file the NOI and Pre-Application Document to relicense the hydropower project.
} 
mitigate potential impacts. Projects having indicators of environmental complexity, that is, projects with larger dams, that involve longer CWA Section 401 certifications or ESA Section 7 consultations, presence of endangered species, need for an EIS NEPA document, presence of a settlement agreement, and/or projects that have not been relicensed since passage of environmental protection legislation such as amendments to the Federal Power Act tend to have longer NOI/POD to license issuance timelines than those that do not have those indicators.

Moreover, our analyses found that relicensing timelines were 2.6 years longer than those for original licenses. We have interpreted shorter original licensing timelines as an effect of reduced environmental complexity at these sites because projects with original licenses included in the timeline analyses only rarely had the indicators of environmental complexity listed above. Projects being relicensed, in contrast, often had one or more indicators of environmental complexity. This suggests that site selection for original licenses and choosing sites where hydropower development will have fewer impacts can play an important role in reducing their licensing timeline.

In addition, even if operations or project works have not changed since the previous license was issued, new environmental regulations such as ECPA amendments to the FPA have effectively increased the level of environmental compliance on many projects, which also may contribute to longer timelines. These amendments included changes to FPA 4(e), which require giving equal consideration to the purposes of energy conservation; the protection, mitigation of damages to, and enhancement of, fish and wildlife; the protection of recreational opportunities; and the preservation of other aspects of environmental quality and amendments to resource agency consultation requirements in FPA 10(a) and 10(j). In addition, changing water quality conditions and the listing of new species under the ESA since the previous licensing may also require more time to determine how best to mitigate potential impacts.

\section{Environmental Measures Resulting From the Licensing Process Are Important to Ecosystems and Stakeholders}

The hydropower licensing and federal authorization process can lead to improved environmental outcomes and stakeholder relationships. Settlement agreements may result in greater environmental benefits than would have been otherwise realized, such as expanded fish passage across dams in a watershed, increased protections for species of concern, improvements in recreational facilities, and other benefits that are difficult to quantify in a statistical analysis. Examples of common PME measures are summarized here and presented more fully in Chapter 5 and the case studies in Appendix C.

The following is a list of common licensing outcomes/non-power benefits (PME measures) synthesized from the 10 licensing case studies presented in Appendix C:

- Water quality and species protection measures:

- Establishment of minimum instream flows and ramping rates to enhance aquatic habitat

○ Construction of fish screens and other species protection measures

- Development and implementation of species monitoring and conservation plans, including invasive species management plans 
- Monitoring dissolved oxygen and water temperature levels upstream and downstream of the project

- Development of soil erosion and sedimentation control plans to protect water quality and aquatic habitat.

- Recreation measures

- Implementation of recreational resources management plans requiring rehabilitation and improvement of existing recreational facilities (e.g., boat ramps, beaches, picnic areas, parking areas, trail systems) to enhance recreational activities at the project site.

- Cultural/Historic Resources Measures

- Implementation of a Historic Protection Management Plan via a programmatic agreement with the SHPO requiring the licensee to consult with the SHPO prior to making any additions or alterations to properties listed or eligible for listing on the National Register of Historic Places.

\subsubsection{Licensing Costs Generally Disproportionately Impact Both Smaller Projects and Projects Seeking Original Licenses}

The burden of costs associated with licensing disproportionately impacts smaller projects even though regression analyses showed that smaller projects have shorter timelines. Despite larger projects having higher licensing costs overall, smaller projects on average had higher licensing costs under a costs $/ \mathrm{kW}$ metric, likely due to fixed costs associated with various aspects of license application development and associated studies. The lower costs $/ \mathrm{kW}$ associated with the licensing process for larger projects suggests that these larger projects can absorb licensing costs through economies of scale in a way that is not possible for smaller projects.

In addition, although the costs are higher and the timelines are longer for projects being relicensed than for those seeking original licenses, projects being relicensed can continue to generate electricity during the licensing process. Projects seeking original licenses, in contrast, must wait until the license is issued and the project is constructed before generating electricity/revenue. There may also be a viability component for projects seeking original licenses in that projects exceeding a certain cost are not viable and are abandoned during the licensing process. Approximately $90 \%$ of projects seeking original licenses abandon pursuit of a license prior to license issuance, but how the environmental complexity and/or costs associated affected abandonment of these projects is not known (Uria-Martinez et al. 2021). However, protracted relicensing proceedings for existing hydropower projects can also drive-up costs and increase project economic uncertainty through compounding interest costs over long time periods coupled with an unclear risk profile. 


\subsubsection{Environmental Impact Determination and Authorizations Are the Primary Source of Stakeholder Disagreements in Licensing}

\section{Environmental Study Negotiations Are a Source of Stakeholder Disagreement in the Licensing Process}

Stakeholders from across sectors described the process of determining project impacts and how to study them as a primary source of disagreement in the licensing process. There are frequent and sometimes protracted disagreements on what environmental impacts are relevant to the project and whether existing information or studies conducted by outside organizations are appropriate to inform protection, mitigation, enhancement, or other measures. License applicants feel that the value of existing studies is often too quickly discounted, while agencies feel that existing information presented by license applicants may not be current or does not use the best available science. License applicants also expressed frustration with agency proposals of new studies because the applicants believe the time and money spent on those studies could be better spent planning and executing mitigation measures. NGO stakeholders expressed feeling disadvantaged relative to other stakeholders in the licensing process because of limited access to information or expertise.

Stakeholders from all sectors described a lack of trust among stakeholders with different perspectives, particularly during the study negotiation process. Stakeholders from across sectors suggested that other stakeholders involved in the study negotiation process use positional bargaining to achieve their sector or group mission without any real intent to compromise. This lack of trust can lead to further communication breakdowns that can draw-out study negotiations.

Many subsequent steps in the licensing process hinge on which environmental studies are conducted. For example, states may request that the license applicant conduct studies to inform the CWA 401 certification issuance. If the license applicant does not agree to conducting these studies and these studies are not required by FERC, this could result in longer licensing timelines because of insufficient information. In addition, in some cases, the options available for agencies to collect needed information are, at best, uncertain.

Stakeholders expressed that the individuals involved in a licensing process matter can bring about more positive as well as negative outcomes to the licensing process. They further noted that relationships built between and among individuals involved in a licensing process can influence the terms of a license and the time it takes to issue that license.

Incomplete and/or Inadequate Information for Authorization Processes Results in Longer Licensing Timelines and Disagreements Among Some Stakeholders

State water quality authorizations required in the hydropower licensing process are completed within statutorily required time frames in $64 \%$ of the case studies while $17 \%$ of state water quality certifications took longer than 2-years. Anecdotal information from state water quality agencies suggests that incomplete and/or inadequate information is one source of longer timelines in this process. Similarly, documentation provided by NOAA Fisheries and USFWS states that receipt of incomplete packages of information needed to begin the ESA Section 7 Consultation process leads to additional months to years added to licensing proceedings. However, it is important to note that what constitutes complete and adequate information for 
these authorizations is also a source of disagreement between agencies and some license applicants.

\subsubsection{The ILP Had the Shortest and Least Variable Timeline of the Three Licensing Processes}

The ILP may minimize the time spent in the licensing process and provide lower variability, which equates to greater timeline certainty compared to other licensing processes. Specifically, while there was no statistical difference in NOI/PAD to LI timeline among the three license processes (ALP: $6.7+2.8$ years, ILP: $6.0+1.5$ years, TLP: $6.9+4.0$ years), the ILP has significantly shorter post-filing timelines $(2.6+0.2$ years $)$ than projects using the TLP $(4.2+0.4$ years) as well as overall greater certainty (i.e., lower standard deviation values) in the licensing timeline compared to the ALP and TLP. The ILP's "schedule-driven" process keeps the licensing timeline from taking longer than necessary and may be advantageous to projects seeking original licenses or those proposing new construction that may not begin until the license is issued. On the other hand, the schedule of the ILP can also create challenges related to tight timelines and turnaround times for comments and the meeting of other licensing milestones.

\subsubsection{Compared to Other Types of Energy and Water Infrastructure, Both Nationally and Internationally, the U.S. Licensing Process Includes More Federal and State Agencies As Well As Opportunities for Stakeholder Engagement}

In comparing the statutory and regulatory frameworks governing hydropower development to other energy and non-energy infrastructure project types, all of the infrastructure projects we analyzed required the consideration of project impacts to biological resources, cultural resources, and the environment (including water quality as applicable) prior to project construction and operation. Although most infrastructure projects must consider potential impacts to the environment through applicable resource protection statutes and the NEPA review process, hydropower licensing is distinct from other types of infrastructure projects (including nuclear energy and interstate natural gas pipelines) in that the FPA requires additional opportunities for federal and state agencies to weigh into the licensing process, specifically through sections 4(e), 10(a), 10(j), and 18. In addition, section 4(e) requires FERC to give equal consideration to the benefits of development and environmental concerns, a standard that other infrastructure projects included in this review were not subject to.

Some members of our Stakeholder Working Group highlighted that, in part, these differences between how other types of energy and non-energy infrastructure projects are regulated may be attributed to river systems being a public trust resource and the scale of impacts associated with hydropower development compared to the other infrastructure project types analyzed in this report. See Appendix A for a description of common environmental impacts associated with each type of energy and non-energy infrastructure project analyzed in this report based on a review of NEPA documents.

In comparing the statutory and regulatory framework for hydropower projects in the United States, Canada, Norway, and Sweden, we found that all require a project proponent to consider project impacts on biological resources, water quality, cultural resources, and the general environment. However, as noted above, the United States hydropower licensing and authorization process requires the participation and engagement of up to 11 federal agencies as 
well as state agencies throughout the licensing and authorization process. By comparison, the other countries analyzed in this report only required a handful of federal agencies to participate in the authorization process (e.g., the authorization process in Norway may involve the participation of 5-6 federal agencies) or their authorization processes were primarily delegated to provincial or local jurisdiction with minimal federal involvement. Again, the distinction with respect to the number of agencies involved in the United States hydropower authorization process is due in part to FPA requirements under Sections 4(e), 10(a), 10(j), and 18.

In addition, although Canada, Sweden, and Norway all provide some opportunities for agency, tribal, and public engagement within their hydropower licensing processes, in the United States, the hydropower authorization process includes more opportunities for tribal and public engagement through built-in statutory requirements (e.g., NEPA and the FPA require federal and state agency participation as well as tribal and public engagement). By contrast, in Sweden and Norway, the public may participate informally or formally by consulting with a project proponent or engaging in stakeholder meetings, hearings, or appeal processes. Recent amendments to Canadian federal statutes require that project proponents engage with the public and Aboriginal peoples throughout the EA process. This distinction may result from the fact that in the United States, multiple statutes involved in the hydropower licensing process require agency, tribal, and public engagement.

\subsection{Future Focus Areas for Additional Research and Collaboration}

Although we tried to be comprehensive within our study design and methodology in this study and associated report, a number of areas of study were not considered within the scope of our report. Members of our Stakeholder Working Group posed the following additional areas of study for future research:

- A quantitative analysis of environmental benefits associated with hydropower licensing conditions, which could include a cost analysis of ecosystem services and risks to the environment

- A quantitative analysis of how AIRs influence licensing timelines

- Qualitative analysis on licensing success stories to inform best practices for future hydropower licensing

- An analysis of the benefits and challenges associated with basin-scale assessments for the hydropower licensing and federal authorization process.

Finally, the analysis contained in this report and areas for future research may be useful to Stanford University's Uncommon Dialogue surrounding U.S. Hydropower: Climate Solution and Conservation Challenge. The Uncommon Dialogue effort represents an important step to help address climate change by both advancing renewable energy and storage benefits of hydropower and the environmental and economic benefits of healthy rivers. In the Joint Statement released by Stanford, the parties were motivated by these two urgent challenges:

“To rapidly and substantially decarbonize the nation's electricity system, the parties recognize the role that U.S. hydropower plays as an important renewable energy resource and for integrating variable solar and wind power into the U.S. electric grid. At the same time, our nation's waterways, and the biodiversity and ecosystem services they sustain, are vulnerable to the compounding factors of a changing climate, habitat loss, and alteration of river processes. 
Our shared task is to chart hydropower's role in a clean energy future in a way that also supports healthy rivers." (Stanford 2020).

The Uncommon Dialogue Joint Statement identified seven areas for joint collaboration. This report may be particularly useful to future Uncommon Dialogue efforts surrounding topic area 6: Improve Federal Hydropower Licensing, Relicensing, and License Surrender Processes. 


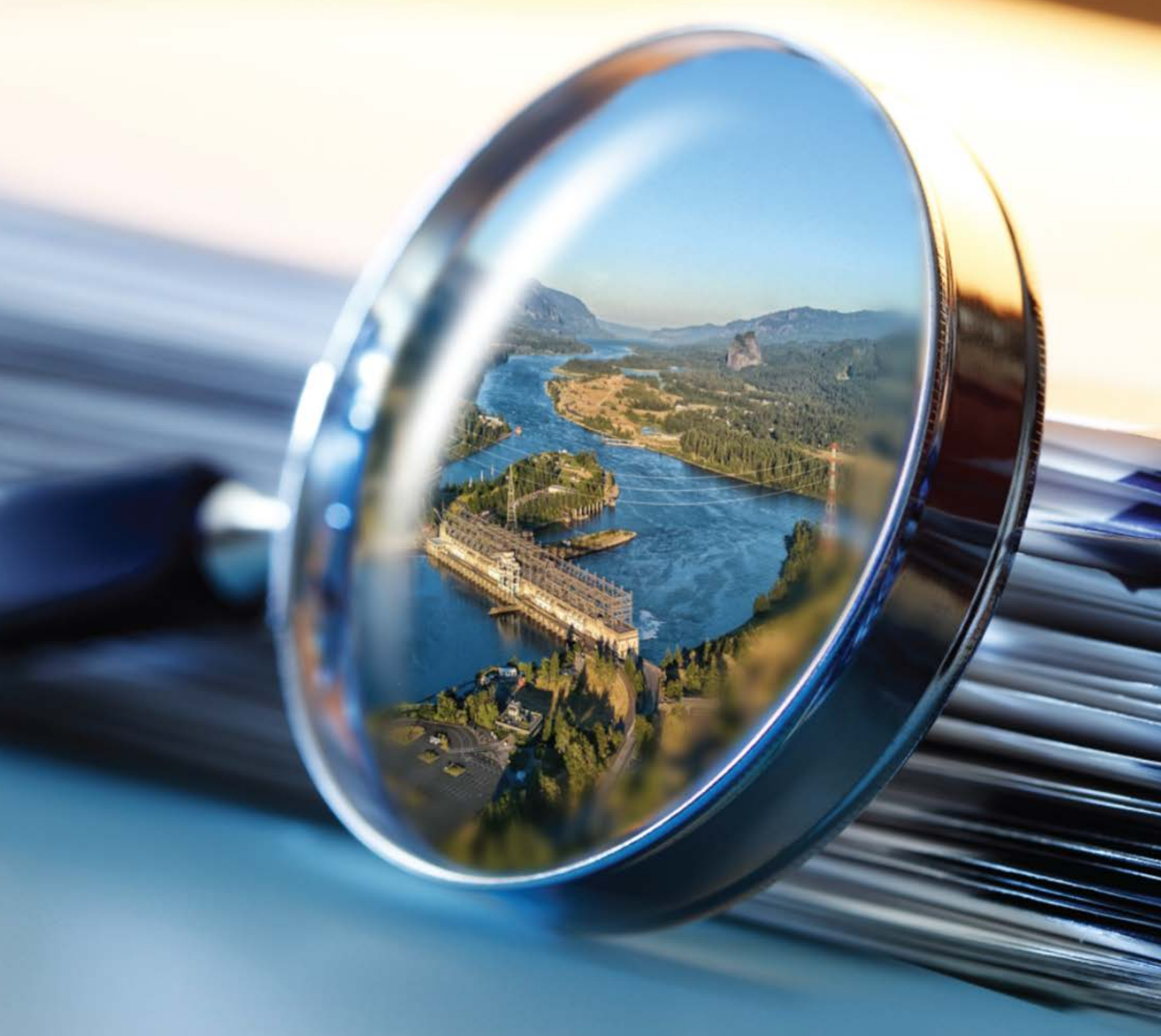

AN EXAMINATION OF THE HYDROPOWER LICENSING AND FEDERAL AUTHORIZATION PROCESS

\section{References}




\section{References}

American Whitewater Affiliation and New England Flow. 2002. Comments on The Application Ready for Environmental Analysis and Soliciting Comments, Recommendations, Terms and Conditions, And Prescriptions Submitted by American Whitewater Affiliation and New England Flow. Filed November 20, 2002. Green Mountain Hydropower Corporation. Project no. 2090003.

American Whitewater, New England Flow, and Vermont Paddling Club. 2004. Comments on the Draft Water Quality Certification for the Green Mountain Power Waterbury Hydroelectric Project. FERC No. 2090-003. Filed December 12, 2004.

American Whitewater. 2008. Badger-Rapide Croche Hydroelectric Project. FERC No. 2677019. Filed February 7, 2008. City of Kaukauna, Wisconsin. Project no. 2677-019.

Ball, Christopher J. 2016. "A View of Canadian Hydroelectric Generation Markets." Hydro Review. Accessed December 23, 2019. https://www.hydroreview.com/2016/01/29/a-view-ofcanadian-hydroelectric-generation-markets/\#gref.

Bill C-69. 2019. An Act to enact the Impact Assessment Act and the Canadian Energy Regulator Act, to amend the Navigation Protection Act and to make consequential amendments to other Acts. June 21, 2019. https://www.parl.ca/DocumentViewer/en/42-1/bill/c-69/royal-assent.

Carter, Emily. 2015. "FERC Licensing Process.” Presentation. February 24, 2015. https://www.fws.gov/northeast/ecologicalservices/pdf/hydro/Carter Licensing Processes and N EPA Feb 2015.pdf.

CCWD (Calaveras County Water District). 2004. FERC Project Nos. 2130, 2005, 2067, and 2118. December 7, 2004.

Central Vermont Public Service Corporation (CVPS). 1994. Application for Initial License for Major Water Power Project 5 Megawatts or Less. Filed April 28, 1994. Central Vermont Public Service Corporation. Project no. 11475-000.

CVPS. 1996. Settlement Offer, Central Vermont Public Service Corporation, Carver Falls Hydroelectric Project. FERC Project no. 11475. Filed December 12, 1996. Central Vermont Public Service Corporation. Project no. 11475-0000.

Curtis, Taylor, and Heather Buchanan. 2019. Basin-Wide Approaches to Hydropower Relicensing: Case Studies and Considerations. Golden, CO: National Renewable Energy Laboratory. NREL/TP-6A20-71979. January 2019. https://www.nrel.gov/docs/fy19osti/71979.pdf.

Clean Water Act. 1972. PL 92-500, 86 Stat. 47 (33 U.S.C. $\$ \oint 1251$ - 1376 [October 18, 1972]). 
DOI (U.S. Department of the Interior). 1995. Motion to Intervene, Carver Falls Hydroelectric Project, FERC Project no. 11475. Filed December 1, 1995. Central Vermont Public Service Corporation. Project no. 11475-000.

DOI. 2002. Comments on the Notice of Application Ready for Environmental Analysis and Soliciting Comments, Recommendations, Terms and Conditions, and Prescriptions for the Waterbury Project, FERC No. 2090-003. Filed November 25, 2002. Green Mountain Hydropower Corporation. Project no. 2090-003.

DOI. 2004. Morgan Falls Hydroelectric Project (P-2237) Notice of Study Dispute. December 16, 2004.

DOI. 2007. Comments on the Notice of Availability of Environmental Assessment for the Licensing of the Morgan Falls Hydroelectric Project, P-2237. December 10, 2007.

DOI. 2008a. Review of Historic Properties Management Plan for Hydrodynamics, Inc. Project no. 12549-002. August 22, 2008.

DOI. 2008b. Comments, recommendations, terms and conditions, and prescriptions on Hydrodynamics, Inc. Project no. 12549-002. October 10, 2008.

European Commission (EC). 2016. A Starter's Guide: Overview on the Main Provisions of the Water Framework Directive, the Marine Strategy Framework Directive, the Birds and Habitats Directives, and the Floods Directive: Similarities and Differences. Technical Report 2016-103. https://ec.europa.eu/environment/nature/natura2000/management/docs/starter_guide.pdf.

EC. 2018. Guidance on the Requirements for Hydropower in Relation to Natura 2000. https://ec.europa.eu/environment/nature/natura2000/management/docs/Hydro\%20final\%20May \%202018.final.pdf.

EC. 2019a. "Types of EU Law." Accessed December 23, 2019. https://ec.europa.eu/info/law/law-making-process/types-eu-law_en.

EC. 2019b. "Our Oceans, Seas and Coasts Legislation: The Marine Strategy Framework Directive." Accessed December 23, 2019. https://ec.europa.eu/environment/marine/eu-coast-andmarine-policy/marine-strategy-framework-directive/index en.htm.

EPA (U.S. Environmental Protection Agency). 1995. Motion to Intervene, Carver Falls Project, Poultney, Vermont and New York, Major License Application, Central Vermont Public Service Corporation. Project no. 11475-000 FERC Project no. 11475. Filed December 5, 1995. Central Vermont Public Service Corporation. Project no. 11475-000.

EPA. 2005. Draft Environmental Impact Statement (DEIS) for the Stanislaus River Projects (FERC Nos. 2130, 2005, 2118 and 2067), Tuolumne and Calaveras Counties, California (CEQ \#040470). January 5.

EPA. 2009. EPA Comments on the EA for the A-Drop Hydroelectric Project. FERC 12549-002. January 26, 2008. 
Federal Energy Regulatory Commission (FERC). 1977. Order Issuing License (Major). Issued June 7, 1977. City of Kaukauna, Wisconsin. Project no. 2677-019. FERC. 2011. Order Issuing New License. Issued May 18, 2011. City of Kaukauna, Wisconsin. Project no. 2677-019.

FERC. 2011. Order Issuing New License. Issued May 18, 2011. City of Kaukauna, Wisconsin. Project no. 2677-019.

FERC. 1988. Order Finding Hydroelectric Project Jurisdiction. Issued September 29, 1988. Central Vermont Public Service Corporation. Docket no. UL88-12-000.

FERC. 1991. Order Denying Rehearing. Issued January 25, 1991. Central Vermont Public Service Corporation. Docket no. UL88-12-002.

FERC. 1995. Scoping Document for the Carver Falls Hydroelectric Project. Issued November 30, 1995. Central Vermont Public Service Corporation. Project no. 11475-000.

FERC. 1997. Environmental Assessment for Hydropower License. Issued March 13, 1997. Central Vermont Public Service Corporation. Project no. 11475-000.

FERC. 2000. Notice of Intent to File Application for New License. Filed November 6, 2000.

FERC. 2001. Report on Hydroelectric Licensing Policies, Procedures, and Regulations Comprehensive Review and Recommendations Pursuant to Section 603 of the Energy Act of 2000. May 8, 2001.

FERC. 2004. Notice of Settlement Agreement, Application and Applicant Prepared EAs Accepted for Filing, Soliciting Motions to Intervene and Protests, and Soliciting Comments, and Final Recommendations, Terms, and Conditions, and Prescriptions. December 9, 2004.

FERC. 2005a. Order Accelerating License Expiration Date. Issued May 11, 2005. City of Kaukauna, Wisconsin. Project no. 2677-017.

FERC. 2005b. Programmatic Agreement Among the Federal Energy Regulatory Commission and the Washington State Historic Preservation Officer for Managing Historic Properties that May be Affected by a License Issuing to PacifiCorp for the Continued Operation of the Swift no. 1 (Project no. 2111) Swift No. 2 (Project no. 2213) Yale (Project no. 2071) Merwin (Project no. 935). December 27, 2005.

FERC. 2005c. Letter Requesting Formal Consultation with FWS Under Section 7 of the Endangered Species Act for the Relicensing of the Lewis River Projects. September 30, 2005.

FERC. 2005d. Letter Requesting Formal Consultation with NOAA Under Section 7 of the Endangered Species Act and Section 305 of the Magnuson-Stevens Conservation and Management Act for the Relicensing of the Lewis River Projects. September 30, 2005.

FERC. 2005e. Findings and Recommendations of the Study Dispute Resolution Panel for the Morgan Falls Hydroelectric Project (P-2237). February 4, 2005. 
FERC. 2005f. Director's Formal Dispute Resolution Determination (P-2237). February 24, 2005.

FERC. 2005g. Director's Formal Dispute Resolution Determination (P-2237). April 11, 2005.

FERC. 2005h. Environmental Impact Statement. March 1. 2005.

FERC. 2005i. Notice of Availability of Final Environmental Assessment. Issued August 15, 2005. Green Mountain Hydropower Corporation. Project no. 2090-003.

FERC. 2006a. Policy Statement on Hydropower Licensing Settlements. Docket No. PL06-5-000. September 21, 2006. https://ferc.gov/sites/default/files/2020-06/PL06-5-000.pdf.

FERC. 2006b. Final Environmental Impact Statement for Hydropower Licenses Swift No. 1 (Project no. 2111) Swift No. 2 (Project no. 2213) Yale (Project no. 2071) Merwin (Project no. 935). March 2006.

FERC. 2007. Notices of Intent to File License Applications; Filing of Pre-Application Documents; and Notices of, and Soliciting Comments on, the Request to Use the Traditional Licensing Process and to Waive Certain Pre-Filing Consultation Requirements. December 18, 2007.

FERC. 2007a. Notice of Availability of Environmental Assessment. November 9, 2007.

FERC. 2008. Water Quality Certification for the Morgan Falls Hydroelectric Project (P-2237). March 12, 2008.

FERC. 2008a. Deficiency of License Application and Request for Additional Information for ADrop Hydroelectric Project (P-12549). May 7, 2008.

FERC. 2008b. Environmental Assessment of Hydrodynamics, Inc. Project no. 12549-002. Issued December 19, 2008.

FERC. 2008c. Finding of No Adverse Effect to Historic Properties by Proposed Project. November 21, 2008.

FERC. 2009. Order Issuing Original Minor License. Hydrodynamics, Inc. 129 FERC $962,042$. October 19, 2009.

FERC. 2009a. Order on Offer of Settlement and Issuing Original License. Issued February 25, 2009. Central Vermont Public Service Corporation. Project no. 11475-000.

FERC. 2009b. Authorization to Use the Traditional Licensing Process for RC Byrd Hydroelectric Project. City of Wadsworth, Ohio. August 7, 2009.

FERC. 2010a. Notice of Availability of Environmental Assessment. Issued January 20, 2010. City of Kaukauna, Wisconsin. Project no. 2677-019. 
FERC. 2010b. Notice of Availability of Environmental Assessment. Issued August 12, 2010. City of Kaukauna, Wisconsin. Project no. 2677-019.

FERC. 2011. Notice of Availability of Environmental Assessment. Issued May 6, 2011. Hampshire Paper Company. Project no. 2850-015.

FERC. 2012. Order Issuing New Major License. Issued January 6, 2012. Hampshire Paper Company. Project no. 2850-015.

FERC. 2012a. Notice of Application Ready for Environmental Analysis and Soliciting Comments, Recommendations, Terms and Conditions, and Prescriptions for City of Wadsworth, Ohio (P-2796-004). Filed October 25, 2012.

FERC. 2013. Order Terminating License. Hydrodynamics, Inc. 145 FERC $₫$ 62,140. November $25,2013$.

FERC. 2015. Notice of Availability of Environmental Assessment for City of Wadsworth, Ohio. Project no. 12796-004. January 23, 2015.

FERC. 2016. Final Environmental Assessment for Hydropower License for Loup River Hydroelectric Project (P-1256). June 2016.

FERC. 2016a. Order Issuing New License. Issued February 19, 2016. Green Mountain Hydropower Corporation. Project no. 2090-003.

FERC. 2017.. Hydropower Primer: A Handbook of Hydropower Basics. February 2017. https://www.ferc.gov/sites/default/files/2020-05/hydropower-primer.pdf.

FERC. 2017a. Request for Concurrence Using Streamlined Framework for Northern LongEared Bat. March 16, 2017.

FERC. 2017b. Report on the Pilot Two-Year Hydroelectric Licensing Process for Non-Powered Dams and Closed-Loop Pumped Storage Projects and Recommendations Pursuant to Section 6 of the Hydropower Regulatory Efficiency Act of 2013. May 2017.

https://www.ferc.gov/sites/default/files/2020-05/final-2-year-process.pdf.

FERC and BOR (Federal Energy Regulatory Commission and Bureau of Reclamation). 1992. Memorandum of Understanding Between the Federal Energy Regulatory Commission and Department of Interior, Bureau of Reclamation. November 6, 1992.

https://www.usbr.gov/recman/fac/fac04-08-AppA.pdf.

Federal Permitting Improvement Steering Committee. n.d. "Fast-41 for Infrastructure Permitting: A Coordinated Framework for Improving the Federal Environmental Review and Authorization Process." https://www.permits.performance.gov/sites/permits.dot.gov/files/202005/FAST_41_FS 20200325.pdf. 
GAO (U.S. Government Accountability Office). 2001. Licensing Hydropower Projects - Better Time and Cost Data Needed to Reach Informed Decisions About Process Reforms. GAO-01-499. May 2, 2001. https://www.gao.gov/assets/240/231349.pdf.

GDNR (Georgia Department of Natural Resources). 2007. Comments to the environmental assessment for the Morgan Falls Hydroelectric Project (P-2237). December 7, 2007.

Glachant, Jean-Michel, Marcelo Saguan, Vincent Rious, Sebastien Douguet, and Emmanuella Gentzoglanis. 2014. "Regimes for Granting Rights to Use Hydropower in Europe." European University Institute.

https://cadmus.eui.eu/bitstream/handle/1814/33653/2014_RR_Hydropower.pdf.

GMPC (Green Mountain Power Corporation). 2003. Green Mountain Power Corporation, Waterbury Project, FERC No. 2090-003: Responses to Comments, Recommendations, Terms and Conditions, and Prescriptions. Filed January 8, 2003. Green Mountain Hydropower Corporation. Project no. 2090-003.

GPC (Georgia Power Company). 2006. Preliminary License Proposal (P-2237). September 21, 2006.

GPC. 2007. Agreement Resolving Matters Concerning the Morgan Falls Hydroelectric Project and the Chattahoochee River National Recreation Area. September 13, 2007.

GPC. 2008. 123 ๆ 62, 152, Order Issuing New License.

HPC (Hampshire Paper Company). 2010. Hampshire Paper Company - Emeryville Hydroelectric Project. FERC Project \#2850-NY. License Application. Filed June 3, 2010. Hampshire Paper Company. Project no. 2850-015.

Hydrodynamics, Inc. 2007a. Pre-Application Document and NOI to File for a TLP for five hydroelectric projects - FERC Project Nos. 12549 (A-Drop), 12548 (Greenfield), 12545 (Johnson) and 12540 (Woods). Filed November 14, 2007. Received November 27, 2007.

Hydrodynamics, Inc. 2007b. Pre-Application Document of a Small Hydroelectric Power Project of 5 MW or Less, FERC 12549 -A-Drop. Received November 27, 2007.

Hydrodynamics, Inc. 2008a. License Application for a Small Hydroelectric Power Project FERC Project no. (A-Drop) P-12539 under the traditional licensing process. Filed March 31, 2008.

Hydrodynamics, Inc. 2008b. Deficiency corrections for four projects - FERC Project nos. 12549 (A-Drop), 12548 (Greenfield), 12545 (Johnson) and 12540 (Woods). Filed August 7, 2008.

Irvin, William Robert. 2017. Testimony of Wm. Robert Irvin President and Chief Executive Officer American Rivers, Inc., Hearing: "Legislation Addressing Pipeline and Hydropower Infrastructure Modernization," Subcommittee on Energy Committee on Energy and Commerce, United States House of Representatives. May 2, 2017. https://docs.house.gov/meetings/IF/IF03/20170503/105916/HHRG-115-IF03-Wstate-IrvinW20170503.pdf. 
IAA (Impact Assessment Agency of Canada). 2019. "Tailored Impact Statement Guidelines Template for Designated Projects Subject to the Impact Assessment Act and the Canadian Energy Regulatory Act." (Last Updated July 15, 2019). https:/www.canada.ca/en/impactassessment-agency/services/policy-guidance/practitioners-guide-impact-assessment-act/tailoredimpact-statement-guidelines-template-impact-assessment-canadian-energy-regulator-act.html.

IAEA (International Atomic Energy Association). 2014. "Country Nuclear Power Profiles: Sweden." https://wwwpub.iaea.org/MTCD/Publications/PDF/cnpp2018/countryprofiles/Sweden/Sweden.htm.

IHA (International Hydropower Association). 2018. "Hydropower Status Report." https://hydropower-assets.s3.eu-west-2.amazonaws.com/publicationsdocs/iha 2018 hydropower_status_report 4.pdf.

INAC (Indigenous and Northern Affairs Canada). 2019. "Water Management.” Accessed December 12, 2019. https://www.aadnc-aandc.gc.ca/eng/1100100037427/1100100037428.

IVA (Royal Swedish Academy of Engineering Sciences). 2016. "Electricity Production in Sweden.” IVA Report R-489. https://www.iva.se/globalassets/201604-iva-vagvalelelproduktion-Johnson, Megan, Shih-Chieh Kao, Nicole Samu, and Rocio Uria-Martinez. 2020. "Existing Hydropower Assets Plant Dataset FY20." HydroSource. Oak Ridge National Laboratory, Oak Ridge, TN. DOI: https://doi.org/10.21951/EHA FY20.

Johnson, M.M, S.-C. Kao, N.M. Samu, and R. Uria-Martinez. "Existing Hydropower Assets, 2019” HydroSource. Oak Ridge National Laboratory, Oak Ridge, TN. Accessed January 14, 2020. https://hydrosource.ornl.gov/market-info-and-data/existing-hydropower-assets.

Kern, Rebecca. 2018. "Permit Delays Dam Up Hydro Projects, Relicensing Costs Millions." Bloomberg Environment. October 30, 2018. https://news.bloomberglaw.com/environment-andenergy/permit-delays-dam-up-hydro-projects-relicensing-costs-millions.

Knudsen, Jargen Kjetil, and Audun Ruud. 2011. "Changing currents in Norwegian Hydropower Governance: The Challenge of Reconciling Conflicting Interests." SINTEF Energy Research. June 6, 2011. https://www.sintef.no/globalassets/upload/642bcd01.pdf/.

Kohler, Berit, and Audun Ruud. "How are Environmental Measures Realized in European Hydropower: A Case Study of Austria, Switzerland and Sweden." HydroCen Report 6 (February 2019):1-77.

https://www.ntnu.edu/documents/1270500170/1284338302/HydroCen+rapport+6+Berit+Kohler +og+Audun+Ruud.pdf/5b024dca-3008-4d7d-8269-08ea6e5aefe6.

Kosnik, Lea. 2006. "Sources of Bureaucratic Delay: A Case Study of FERC Dam Relicensing." Journal of Law Economics and Organization 22(1): 258-288. DOI:10.1093/jleo/ewj004.

Kumar, Arun, Tormod Schei, Alfred Ahenkorah, Rodolfo Caceres Rodriguez, Jean-Michel Devernay, Marcos Freitas, Douglas Hall, Ånund Killingtveit, and Zhiyu Liu. 2012. Chapter 5, Hydropower, in: Edenhofer, Ottmar., Ramón Pichs-Madruga, Youba Sokona, Kristin Seyboth, Patrick Matschoss, Suzanne Kadner, Timm Zwickel, Patrick Eickemeier, Gerritt Hansen, Steffen 
Schlömer, and Christof von Stechow (Eds.), Renewable Energy Sources and Climate Change Mitigation. New York, NY: Cambridge University Press. Special Report of the Intergovernmental Panel on Climate Change. https://www.ipcc.ch/site/assets/uploads/2018/03/SRREN_Full_Report-1.pdf.

Leahey, Jeffrey. 2017. Written Testimony of Jeffrey Leahey, Deputy Executive Director on Behalf of the National Hydropower Association Before the House Energy and Commerce Committee Subcommittee on Energy Hearing on Legislation Addressing Pipeline and Hydropower Infrastructure Modernization. May 3, 2017. https://docs.house.gov/meetings/IF/IF03/20170503/105916/HHRG-115-IF03-Wstate-LeaheyJ20170503.pdf.

Levine, Aaron, and Austin Flanagan. 2019. FERC Hydropower Licensing: A Review of Utilization of the ILP, TLP, and ALP. Golden, CO: National Renewable Energy Laboratory. NREL/TP-6A20-71982. https://www.nrel.gov/docs/fy19osti/71982.pdf.

Levine, Aaron, Taylor Curtis, and Laura Shields. 2018. Negotiating Terms and Conditions: An Overview of the Federal Energy Regulatory Commission Hydropower Settlement Agreement Process. Golden, CO: National Renewable Energy Laboratory. NREL/TP-6A20-71093. https://www.nrel.gov/docs/fy18osti/71093.pdf.

Lindstrom, Andreas, and Audun Ruud. 2017. Swedish Hydropower and the EU Water Framework Directive. Stockholm, Sweden: Stockholm Environment Institute. Project Report 2017-01. https://mediamanager.sei.org/documents/Publications/SEI-PR-2017-01-SwedenHydropower-WFDa.pdf.

Loup River Public Power District. 2008. Notice of Intent to File and Pre-Application Document for Relicense of Loup River Hydroelectric Project (P-1256). October 16, 2008.

Loup River Public Power District. 2012a. Request for 401 Water Quality Certification for Relicense of Loup River Hydroelectric Project (P-1256). October 18, 2012.

Loup River Public Power District. 2012b. Final License Application for Relicense of Loup River Hydroelectric Project (P-1256). Volume 3 of 5. Final Study Report. April 13, 2012.

Loup River Public Power District. 2017. 159 FERC \ 62,198 Order Issuing New License.

Mead Hunt (MH). 2009. Proof of Date of Service - 401 Water Quality Certification Request, Badger-Rapide Croche Hydroelectric Project. FERC Project no. 2677. Kaukauna Utilities.

Myers, Joe. 2015. "Which Countries Produce the Most Hydroelectric Power." World Economic Forum. Accessed December 23, 2019. https://www.weforum.org/agenda/2015/10/whichcountries-produce-the-most-hydroelectric-power/.

National Park Service (NPS). 2008. National Park Service comments on the Notice of Tendering of Application and Soliciting Additional Study Requests on the A-Drop Hydro Project Located on BR Lands, MT. Filed May 28, 2008. 
Nebraska Department of Environmental Quality. 2013. State Water Quality Certification for the Loup River Hydroelectric Project (P-1256). January 2, 2013.

New York Department of Environmental Conservation. 2011. 401 Water Quality Certification Emeryville Hydroelectric Facility DEC I.D.\#6-4038-00078/00001 FERC \#2850. Filed June 8, 2011. Hampshire Paper Company. Project no. 2850-015.

Norwegian Ministry of Petroleum and Energy (NMPE). 2015. Facts: Energy and Water Resources in Norway. Report Y-0102/9E.

https://www.regjeringen.no/contentassets/fd89d9e2c39a4ac2b9c9a95bf156089a/facts_2015_ener gy and water_web.pdf.

NMPE. 2019. "Energy Facts Norway: The Legal Framework.” Accessed December 29, 2019. https://energifaktanorge.no/en/regulation-of-the-energy-sector/det-juridiske-rammeverket/.

NOAA (National Oceanic Atmospheric Administration Fisheries, formally known as National Marine Fisheries Service). 2006a. Extension of Timeline for Formal Consultation Under the Endangered Species Act and under Section 305 of the Magnuson-Stevens Fisheries Conservation and Management Act - Lewis River Hydroelectric Projects (FERC No. 935), Yale (FERC No. 2071), Swift No. 1 (FERC No. 2111), and Swift No. 2 (FERC No. 2213). Filed February 10, 2006.

NOAA. 2006b. Extension of Time for Formal Consultation Under the Endangered Species Act and under Section 305 of the Magnuson-Stevens Fisheries Conservation and Management ActLewis River Hydroelectric Projects (FERC No. 935), Yale (FERC No. 2071), Swift No. 1 (FERC No. 2111), and Swift No. 2 (FERC No. 2213). Filed June 20, 2006.

NOAA. 2007. Biological Opinion for ESA Consultation for the Operation of PacifiCorp and Cowlitz PUD's Lewis River Hydroelectric Projects (Merwin (Project no. 935 Swift No. 1 (Project no. 2111) Swift No. 2 (Project no. 2213) Yale (Project no. 2071)). Filed August 27, 2007.

Ohio Environmental Protection Agency (Ohio EPA). 2012. Incomplete Section 401 Water Quality Certification Application for RC Byrd Hydropower Project. January 4, 2012.

Ohio EPA. 2013. Submission of Additional Information, Re: Section 401 Certification Decision. February 6, 2013.

PacifiCorp. 2004. Final Application for New License for Major Project. Received April 28, 2004.

PacifiCorp. 2005. Biological Evaluation of FWS Listed, Proposed, and Candidate Species, As Related to PacifiCorp and Cowlitz PUD's Lewis River Hydroelectric Projects. January 15, 2005.

Pacific Gas and Electric Company (PG\&E). 2005. Spring Gap-Stanislaus Project, FERC Project no. 2130-033 Transmittal of Draft Recreation Settlement Agreement and Clarification of Comments on Draft EIS. January 24.

PG\&E. 2009. 127 FERC \ 62,070, Order Issuing New License. 
Rudberg, Peter M., Marisa Escobar, Julie Gantenbein, and Nicholas Niiro. 2015. "Mitigating the Adverse Effects of Hydropower Projects: A Comparative Review of River Restoration and Hydropower Regulation in Sweden and the United States." Georgetown International Environmental Law Review 252 (2015): 251-73.

https://www.waterpowerlaw.com/sites/default/files/team/publications/rudberg_escobar_gantenbe in niiro final pdf 27-2.pdf.

Schramm, Michael P., Mark S. Bevelhimer, and Chris R. DeRolph. 2016. "A synthesis of environmental and recreational mitigation requirements at hydropower projects in the United States." Environmental Science \& Policy 61(Suppl. 3): 87-96.

DOI:10.1016/j.envsci.2016.03.019.

Swedish Environmental Code (SEC). 2000. Ds 2000:61. https:/www.government.se/legaldocuments/2000/08/ds-200061/.

Sensiba, Charles R., Michael A. Swiger, and Sharon L. White. 2018. "Deep Carbonization and Hydropower." Environmental Law Reporter 48(4): 10309-0333. 2018.

https://www.vnf.com/webfiles/48.10309.pdf.

Sheehan, Greg. 2018. Testimony of Greg Sheehan, Principal Deputy Director, U.S. Fish and Wildlife Service, Department of the Interior before the House Committee on Energy and Commerce, Subcommittee on Energy on Improving the Hydropower Licensing Process. June 7, 2018. https://www.doi.gov/ocl/hydropower-licensing-process.

Stanford (Stanford University). 2020. "Executive Summary - U.S. Hydropower: Climate Solution and Conservation Challenge." Stanford University Uncommon Dialogue. October 13, 2020. https://woods.stanford.edu/sites/g/files/sbiybj5821/f/hydropower-

uncommon dialogue executive summary.pdf.

Swaminathan, Ramya. 2017. Written Testimony of Ramya Swaminathan, CEO, Rye Development, Before the U.S. House of Representatives Subcommittee on Energy Regarding "Modernizing Energy Infrastructure: Challenges and Opportunities to Expanding Hydropower Generation. March 15, 2017.

https:/energycommerce.house.gov/sites/democrats.energycommerce.house.gov/files/TestimonySwaminathan-EP-Hrg-Hydro-2017-03-15.pdf.

Swedish Environmental Protection Agency. 2017. "Swedish Environmental Law: An Introduction to the Swedish Legal System for Environmental Protection." Report 6790 (October 2017): 1-38. http://www.swedishepa.se/Documents/publikationer6400/978-91-620-6790-

8.pdf?pid=21184.

SWRCB (State Water Resources Control Board). 2009. Order Granting Petitions for Reconsideration and Authorizing Issuance of a Revised Water Quality Certification. Order WR 2009-0039. June 16.

Trout Unlimited, Friends of the River, Central Sierra Environmental Resource Center (TU et al.). 2004. Comments submitted for FERC/DEIS-0171D for the Stanislaus River Projects. December 7. 
Trussart, Serge, Danielle Messier, Vincent Roquet, and Shuichi Aki. 2002. "Hydropower projects: a review of most effective mitigation measures." Energy Policy 30(14): 1251-1259. DOI: $10.1016 / \mathrm{S} 0301-4215(02) 00087-3$.

Ulibarri, Nicola. 2017. "Does Collaboration Affect the Duration of Environmental Permitting Processes?" Journal of Environmental Planning and Management 61(4): 617-634.

https://www.researchgate.net/publication/317587223 Does_collaboration_affect the duration_o f_environmental_permitting_processes.

Uria-Martinez, Rocio, Megan Johnson, and Patrick O’Connor. 2018. 2017 Hydropower Market Report. Water Power Technologies Office, Office of Energy Efficiency and Renewable Energy, U.S. Department of Energy. https://www.energy.gov/eere/water/downloads/2017-hydropowermarket-report.

Uria-Martinez, Rocio, Megan M. Johnson, and Rui Shan. 2020. "Challenges in the PostLicensing Stage of U.S. Hydropower Development: Current Status and Some Potential Solutions." The Electricity Journal 33(4): 106729. https://www.sciencedirect.com/science/article/pii/S104061902030021X?via\%3Dihub.

U.S. Department of Energy. 2016. Hydropower Vision. Washington, DC: U.S. Department of Energy. https://www.energy.gov/eere/water/downloads/hydropower-vision-report-full-report.

USFS (U.S. Forest Service). 2003. "Forest Service Manual 2700 - Special Uses Management." October 14, 2003. https://www.fs.fed.us/cgi-bin/Directives/get_dirs/fsm?2700!.

U.S. Fish and Wildlife Service (USFWS). 1993. 340 FW 3, Rights-of-Way and Road Closing Policy. July 28, 1993. https://www.fws.gov/policy/340fw3.html.

USFWS. 2006a. Extension of Timeline for Formal Consultation Under the Endangered Species Act-Lewis River Hydroelectric Projects (FERC No. 935), Yale (FERC No. 2071), Swift No. 1 (FERC No. 2111), and Swift No. 2 (FERC No. 2213). Filed March 14, 2006.

USFWS. 2006b. Biological Opinion for the FERC Relicensing of the Lewis River Hydroelectric Projects: Merwin (No. 935), Yale (FERC No. 2071), Swift No. 1 (FERC No. 2111), and Swift No. 2 (FERC No. 2213). Filed September 15, 2006.

USFWS. 2006c. Extension of Timeline for Formal Consultation Under the Endangered Species Act-Lewis River Hydroelectric Projects (FERC No. 935), Yale (FERC No. 2071), Swift No. 1 (FERC No. 2111), and Swift No. 2 (FERC No. 2213). Filed June 12, 2006.

USFWS. 2011. FWS Response to Notice of Tendering of Application; Additional Study Requests for the Robert C. Byrd Hydroelectric Project. FERC No. 12796-004. Filed May 9, 2011.

USFWS (Nebraska Field Office). 2016. Loup River Hydroelectric Project (P-1256) Final Biological Opinion. December 16, 2016.

USFWS. 2017. Biological Opinion and Incidental Take Statement for the Fanshell (Cyprogenia stegaria), Pink Mucket Pearly Mussel (Lampsilis abrupta), Sheepnose (Plethobasus cyphyus), and 
Snuffbox (Epioblasma triquetra) for the Robert C. Byrd Hydroelectric Project and Navigation Channel Maintenance Dredging at the existing Robert C. Byrd Locks and Dam in Gallia County, Ohio and Mason County, West Virginia. City of Wadsworth, Ohio. Project no. 12796004. Filed June 17, 2017.

USFS. 2011. Forest Service Administration of Special Use Program. Audit Report 08601-55-SF. June 2011. https://www.usda.gov/sites/default/files/08601-55-SF.pdf.

USFS. 2015. Pinecrest Area Campground Improvements Conceptual Design Summary. http://pinecrestlakeupdate.com/images/uploads/Pinecrest Area Campgrounds Conceptual Desi gn Summary.pdf.

Vermont Agency of Natural Resources (VANR). 1995. Project no. 11475 - VT/NY Carver Falls Project Central Vermont Public Service. Filed November 8, 1995. Central Vermont Public Service Corporation. Project no. 11475-000.

VANR. 2002. Comments Recommendations Terms and Conditions Waterbury Project Number 2090-003 Green Mountain Power Corporation. Filed November 25, 2002. Green Mountain Power Corporation. Project no. 2090-003.

VANR. 2014. Draft Water Quality Certification Project Number 2090-003 Green Mountain Power Corporation. Issued December 11, 2014. Green Mountain Power Corporation. Project no. 2090-003.

Wadsworth (The City of Wadsworth, Ohio). 2009. Notice of Intent to file an Application for Original License and Request for Designation as Non-Federal Representative; Request to use the Traditional Licensing Process (TLP); and Pre-Application Document (PAD) for the R.C. Byrd Hydroelectric Project no. 12796. June 16, 2009.

Wadsworth. 2010. Draft License Application for City of Wadsworth, Ohio. FERC Project no. 12796. November 2010.

Wadsworth. 2011. Application for License of a Major Project-Existing Dam Robert C. Byrd Hydroelectric Project no. 12796. Filed March 28, 2011.

Wadsworth. 2012. Section 401 Water Quality Certification (WQC) Application for RC Byrd Hydropower Project. October 18, 2012.

Washington Department of Ecology. 2006. Section 401 Water Quality Certification for the Merwin Project (P-935). Filed October 9, 2006.

Water Authorities. 2019. "Water Management in Sweden.” Accessed December 18, 2019. https://www.vattenmyndigheterna.se/vattenforvaltning/vattenforvaltning-i-sverige.html.

West Coast Environmental Law Group. 2009. "Improving the Opportunities for Public Involvement in the Crown Land Tenure and Water License Approval Process for Run-of-River Electrical Generation Projects in British Columbia." IPP Projects Series. https://www.wcel.org/sites/default/files/publications/IPP $\% 20$ water $\% 20$ license $\% 20$ and $\% 201$ land $\%$ 20leases.pdf. 
West Virginia Department of Environmental Protection. 2014. State 401 Water Quality Certification. City of Wadsworth, RC Byrd Hydroelectric Project, FERC License No. 12796, hydroelectric project at existing RC Locks and Dam, near Gallipolis Ferry, Mason County, WV. January 23, 2014.

West Virginia Division of Natural Resources. 2011. Robert $C$.

Byrd Hydroelectric Project, FERC no. P-12796, FERC notice of application tendered for filing with the Commission and soliciting additional study requests. Filed May 10, 2011.

Wisconsin Department of Natural Resources. 2008. Badger-Rapide Croche Hydroelectric Project. Filed March 6, 2008. City of Kaukauna, Wisconsin. Project no. 2677-019.

Wisconsin Department of Natural Resources. 2011. State Water Quality Certification for Badger-Rapide Croche, Hydropower FERC License Application (P-2677-019). Kaukauna Utilities, Kaukauna, WI. Filed February 23, 2011. City of Kaukauna, Wisconsin. Project no. 2677-019. 


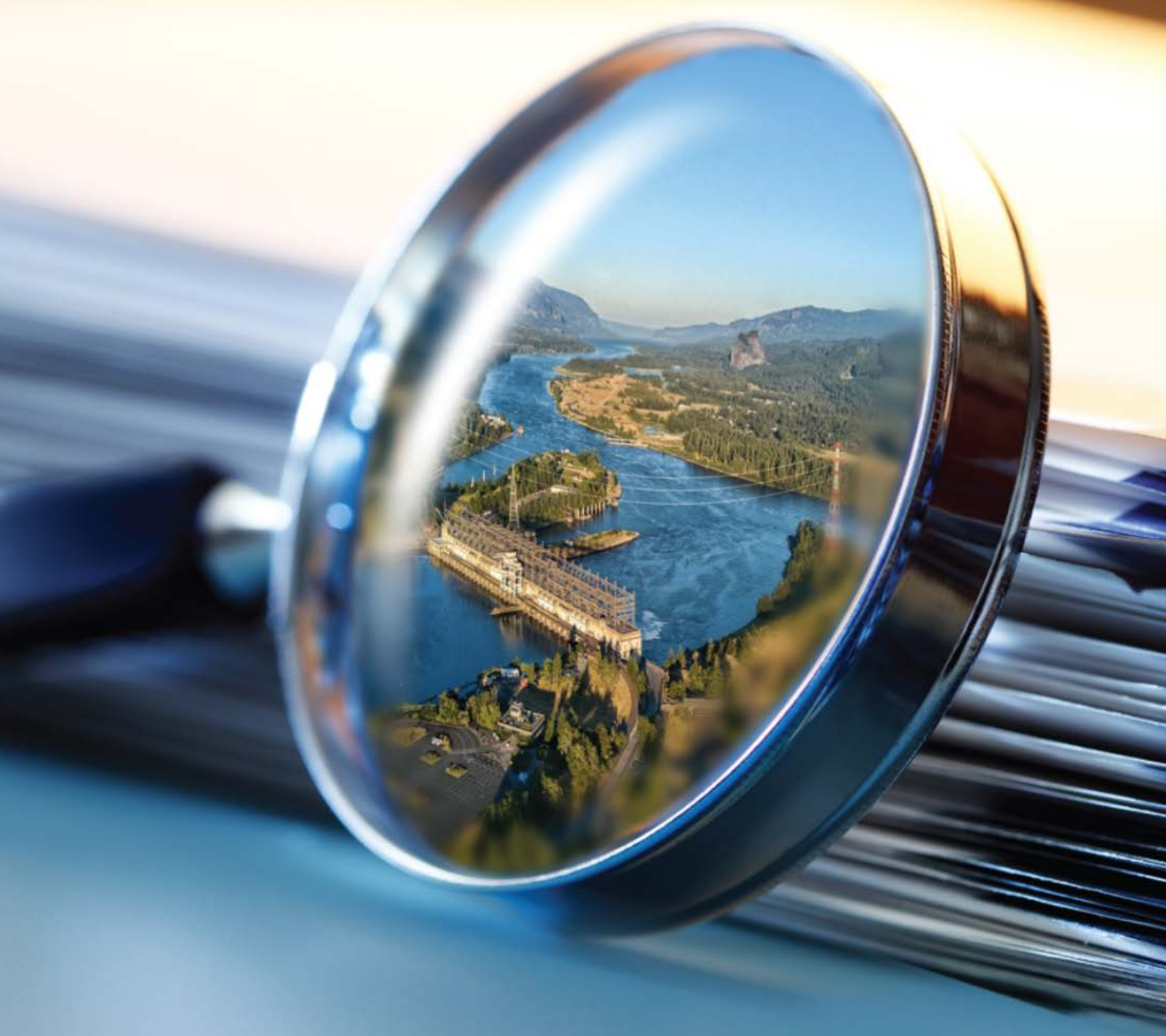

AN EXAMINATION OF THE HYDROPOWER LICENSING AND FEDERAL AUTHORIZATION PROCESS

\section{APPENDIX $\mathbf{A}^{\cdot 1}$ \\ Infrastructure Project Review: Environmental Impacts and Regulatory Approvals for Infrastructure Projects in the United States}




\section{Appendix A.1. Infrastructure Project Review: Environmental Impacts and Regulatory Approvals for Infrastructure Projects in the United States}

This appendix provides additional information to supplement the comparisons between hydropower and other types of infrastructure projects in Chapter 2 of this report. To begin, this appendix provides an overview of the common potential environmental impacts associated with infrastructure project construction and operation. Next, this appendix includes an overview the regulatory and permitting requirements under federal law $^{38}$ associated with other types of infrastructure projects in the United States.

To determine applicable regulatory and permitting requirements and common potential environmental impacts associated with different infrastructure projects, National Renewable Energy Laboratory (NREL) staff reviewed and analyzed approximately 10 National Environmental Policy Act of 1969 (NEPA) documents for each project type (86 total), including a relatively even distribution of environmental assessments and environmental impact statements, to identify potential environmental impacts associated with construction and operation activities of each of the nine infrastructure project types discussed in Chapter 2 and this appendix. In addition, NREL staff analyzed the NEPA documents to identify relevant permits, authorizations, and approvals required under federal law for each type of infrastructure project. Upon completion of the review, NREL staff compiled associated data, including:

- Common potential environmental impacts associated with construction and operation activities of each infrastructure project type

- Relevant federal permits, authorizations, or approvals identified during the NEPA document literature review

- Relevant federal statutory authority and enabling acts associated with each permit, authorization, or approval

- Relevant federal and state agencies and actors relevant to each permit, authorization, or approval

- A list of all infrastructure project types subject to each identified permit, authorization, or approval under federal law.

\section{Common Potential Environmental Impacts Associated with Infrastructure Project Construction and Operation}

Infrastructure project construction and operation may cause impacts to a number of different resources. This section discusses the potential impacts of infrastructure project construction and operation on biological resources, cultural resources, water quality resources, and preexisting land use and natural resource protection.

\footnotetext{
${ }^{38}$ This chapter does not include a detailed discussion of regulatory and permitting requirements solely under state or local law. In addition, to the specific regulatory and permitting requirements discussed in this chapter, an infrastructure project developer may need to comply with other regulatory requirements or receive approvals from a state or local authority.
} 


\section{Biological Resources}

Infrastructure project construction and operation may cause impacts to biological resources (e.g., species and species habitat). Typical impacts to biological resources as a result of infrastructure project construction and operation may include:

- Noise producing activities during construction and operation, such as drilling, blasting, and increased vehicle traffic can lead to disruption of species' feeding and reproduction habits as well as species and habitat degradation

- Construction activities, such as land clearing and development of access roads can lead to vegetation alteration or loss and species habitat fragmentation

- Development of permanent structures and associated infrastructure, such as energy facilities and power plants, well pads, transmission lines, pipelines, dams, access roads, and parking areas can lead to species depredation and displacement, disruption of species migration routes as well as loss of habitat and food sources.

\section{Cultural Resources}

Infrastructure project construction and operation may cause impacts to cultural resources (e.g., historic properties or resources that are eligible for listing or are listed on the National Register of Historic Places). Typical impacts to cultural resources as a result of infrastructure project construction and operation may include:

- Destruction of cultural resources present in areas undergoing surface disturbance

- Degradation or destruction of cultural resources on- and off-site resulting from topographic or hydrological pattern changes or soil movement

- Unauthorized removal of artifacts or vandalism to the site as a result of increased human access to previously inaccessible areas

- Visual impacts resulting from vegetation clearing, increases in dust, and the presence of large-scale equipment, machinery, and vehicles.

\section{Water Quality Resources}

Infrastructure project construction and operation may cause impacts to water quality and water resources (e.g., surface water and groundwater quality). Typical impacts to water resources as a result of infrastructure project construction and operation may include:

- Soil erosion caused by construction and operation activities that could increase turbidity and suspended sediment (or other constituents/chemicals) transport within navigable waters

- Untreated groundwater used to control dust during project construction could deposit dissolved salts on the surface allowing the salts to enter surface water systems

- Discharges of loose soil, debris, chemicals, and other products stored on project sites during project construction that could enter sewer systems, rivers, lakes or coastal waters

- Discharges of pollutants or fill materials that could enter navigable waters during project operation. 


\section{Preexisting Land Use and Natural Resource Protection}

Infrastructure project construction and operation may cause impacts to preexisting land uses (e.g., U.S. Army Corp of Engineers [USACE] structures and installations or areas set aside for recreational use) present at or surrounding a project site. Typical impacts to preexisting land uses as a result of infrastructure project construction and operation may include:

- Interference, modification, alteration, or obstruction of navigable waters during project construction or operation that may impact the preexisting uses of federally managed structures and resources

- Impacts to recreational opportunities as well as other preexisting uses within sensitive environments including rivers and coastal areas as a result of project construction and operation.

\section{Infrastructure Specific Licenses, Permits, and Authorizations}

Infrastructure projects have the potential to impact different resources depending on the type of infrastructure project at issue (e.g., coal and natural gas power plants have the potential to impact air quality because they release air pollutants during operation activities). Accordingly, project developers may be required to comply with specific federal licenses, permits, authorizations, or other approvals and procedures, depending on the type of infrastructure project. The following section contains a discussion of the environmental impacts and licenses, permits, authorizations, and other approvals that are applicable to the construction and operation of specific infrastructure projects including:

- Non-hydropower water infrastructure projects

- Nuclear power projects

- Geothermal power projects

- Land-based wind power projects

- Solar power projects

- Bulk electric transmission projects

- Natural gas pipeline projects

- Natural gas and coal power plant projects.

In addition to the infrastructure specific approvals listed below, an infrastructure project developer must obtain a Rivers and Harbors Act (RHA) Section 10 Construction Permit from USACE to obstruct the navigable capacity of the waters of the United States or to excavate, fill, alter, or modify the course, location, condition, or capacity of any port, roadstead, haven, harbor, canal, lake, harbor or refuge, or enclosure of any navigable water of the United States pursuant to the Rivers and Harbors Act of 1899 (RHA) (33 U.S.C. § 403).

\section{Non-Hydropower Water Infrastructure Project Permits and Authorizations}

In the United States, water infrastructure projects (e.g., dams, conduits, water conveyance systems) must comply with federal and state statutes prior to commencing construction and operation. The following contains a discussion of relevant environmental impacts associated with water infrastructure projects as well as the federal permits, licenses, and authorizations required for water infrastructure project construction and operation. 
Non-Hydropower Water Infrastructure Project Potential Environmental Impacts

A typical water infrastructure project raises environmental issues that require permitting and/or regulatory approval from federal and state agencies. Potential environmental impacts from water infrastructure development include but are not limited to:

- Potential water quality impacts (e.g., dissolved oxygen levels, increased water temperatures, sediment buildup) due to altered flow rates, water loss due to evaporation, and interruption of natural sediment flows during construction activities and operation

- Potential impacts to groundwater composition, quality, and hydrology as a result of changes to water flow during operation

- Potential impacts to recreation activities (e.g., boating, swimming, fishing, and camping activities) due to altered reservoir and flow conditions from construction and operation activities

- Potential impacts to fish (including eel) and other aquatic species populations as a result of inhibited migratory patterns during construction and operation

- Potential impact as a result of loss of habitat after land inundation and altered surface water hydrology, including permanent removal or alteration of aquatic wildlife habitat during construction activities and operation

- Potential impacts to near-surface cultural resources from topographic or hydrological pattern changes or from soil movement or disturbance (e.g., removal, erosion, sedimentation, excavation) during construction and operation activities

- Alterations to rivers, streams, and other bodies of water due to construction of intakes and dams

- Potential impacts to scenic and aesthetic qualities of landscapes and rivers due to construction activities and addition of permanent operation structures.

Required Permits and Authorizations for Water Infrastructure Projects

Authority for water infrastructure project permitting resides with the relevant federal or state agency with jurisdiction. The following federal permits, licenses, and authorizations are applicable to water infrastructure project construction and operation:

\section{Rivers and Harbors Act Section 14 Authorization (Section 408 Authorization)}

A water infrastructure project may require a "Section 408 " authorization from USACE for a project to use or alter USACE infrastructure (e.g., dam, conduit) pursuant to Section 14 of the RHA (33 U.S.C. $§ 408(a)$ ). Section 408 grants USACE the authority to authorize the alteration or use of any USACE infrastructure when it will not be injurious to the public interest or impair the infrastructure's usefulness (33 U.S.C. § 408(a)).

\section{Fish and Wildlife Coordination Act Consultation}

A water infrastructure project developer must consult with U.S. Fish and Wildlife Service and/or National Oceanic and Atmospheric Administration (NOAA) Fisheries, and the relevant state resource agency before proposing or authorizing any project that will cause a stream or other body of water to be impounded, diverted, the channel deepened or otherwise controlled, or modified for any purpose pursuant to the Fish and Wildlife Coordination Act (16 U.S.C. § 662(a)). 


\section{Nuclear Power Project Licenses, Permits, and Authorizations}

In the United States, the Atomic Energy Act of 1946 is the primary statute governing nuclear power project construction and operation (42 U.S.C. $\S \S 2011-2297 \mathrm{~h}-13$ ). The following contains a discussion of relevant environmental impacts associated with nuclear projects generally as well as the federal permits, licenses, and authorizations required for construction and operation of nuclear infrastructure projects.

\section{Nuclear Power Project Potential Environmental Impacts}

A typical nuclear power project raises environmental issues that require regulatory and permitting approval from federal and state agencies. Potential environmental impacts from nuclear power development include but are not limited to:

- Potential air quality impacts due to volatile organic compound, particulate matter, and greenhouse gas emissions such as hydrocarbons, carbon monoxide, radioactive gases, and sulfur oxides from diesel generators and boilers, combustion turbines, and cooling towers from operation activities

- Potential water quality impacts from volatile organic compound, particulate matter, and greenhouse gas emissions such as hydrocarbons, carbon monoxide, radioactive gases, and sulfur oxides from diesel generators and boilers, combustion turbines, and cooling towers from operation activities

- Potential impacts to surface water hydrology due to water withdrawal and discharge of cooling water

- Potential impacts to recharge of groundwater and associated aquifers because of the use of water as a cooling agent for operation activities

- Potential impacts from thermal discharge into surface water from operation activities

- Potential impacts to fish (including eel) and other aquatic species from entrainment and impingement at cooling water intake structures

- Potential impacts to migratory birds from collisions with and noise coming from mechanical cooling towers and the addition of other permanent structures for operation.

\section{Required Licenses, Permits, and Authorizations for Nuclear Power Projects}

The Nuclear Regulatory Commission (NRC) is the primary licensing authority for nuclear power projects. The NRC works with other federal agencies; state, local, and tribal governments; and the public to issue licenses for nuclear power projects. The following permits, licenses, and authorizations are required for nuclear power project construction and operation.

\section{Combined Nuclear License}

The NRC has authority to issue licenses to construct and operate a nuclear power plant within the United States pursuant to the Atomic Energy Act (42 U.S.C. $\S \S 2011-2297$-13; 10 C.F.R. $\S$ 52.75(a)). A Combined Nuclear License authorizes the licensee to construct and (with specified conditions) operate a nuclear power plant at a specific site, in accordance with established laws and regulations (10 C.F.R. $\S 52.1(\mathrm{a})$ ). The NRC may issue a combined nuclear license for a 40year licensing term, after which a nuclear project operator may apply for a 20 -year relicensing term from the NRC (10 C.F.R. $\S \S 51.1-51.125$; 10 C.F.R. $\S \S 54.1-54.43)$. 
When evaluating an application for a nuclear power license, the NRC takes into account a multitude of health, safety, environmental, and other relevant standards/criteria (10 C.F.R. $\S$ 52.81). Specific to nuclear reactor siting, the NRC considers factors related, but not limited to:

- Population density, population distribution, societal risk of potential plant accidents, and unique characteristics that could pose impediments to the development of emergency plans

- Proximity to human-related hazards (e.g., airports, dams, transportation routes, and military and chemical facilities

- Physical site characteristics (e.g., seismology, meteorology, geology, and hydrology) (10 C.F.R. $\S 100.20)$.

\section{NRC Combined Nuclear License Prerequisites}

Prior to NRC issuing a combined nuclear license, a nuclear project developer must comply with the following processes and obtain the following certifications, approvals, permits, and authorizations:

- 401 Water Quality Certification

- ESA Section 7 Consultation Process

- Essential Fish Habitat Consultation Process

- Coastal Zone Management Act Consistency Determination

- National Historic Preservation Act (NHPA) Section 106 Consultation Process.

\section{Clean Air Act Title V Operating Permit}

A nuclear project developer must obtain a Clean Air Act (CAA) Title V Operating Permit from the U.S. Environmental Protection Agency (EPA) or state agency with EPA delegated authority to construct or operate a power plant that: 1) is a major source, ${ }^{39} 2$ ) is a new source performance standards source, ${ }^{40} 3$ ) is a hazardous air pollutant, ${ }^{41} 4$ ) is an affected source, ${ }^{42} 5$ ) requires a Prevention of Significant Deterioration Permit, or 6) is any other source designated by EPA pursuant to the CAA (42 U.S.C. $\S 7661 a(a)$ ).

\section{Acid Rain Permit}

A nuclear power project developer with an affected unit ${ }^{43}$ must obtain an acid rain permit to operate that source or unit from the EPA or a state agency with EPA delegated authority as part

\footnotetext{
39 "Major source" means any stationary source (or any group of stationary sources located on one or more continuous or adjacent properties, and under common control of the same person) belonging to a single major industrial grouping described in 40 C.F.R. $\S \S 70.2$ (1)-(3) (40 C.F.R. $\S 70.2)$.

40 "New source" means any stationary source, the construction or modification of which is commenced after the publication of regulations prescribing a standard of performance under this section that will be applicable to such source (42 U.S.C. $\$ 7411(2)$ ).

41 "Hazardous air pollutant" means any air pollutant listed in 42 U.S.C. § 7412 (b) (42 U.S.C. § 7412(6)). "Affected source" means a source that includes one or more affected units (40 C.F.R. $\S 72.2$ ).

42 "Affected source" means a source that includes one or more affected units (40 C.F.R. $\S 72.2$ ).

43 "Affected unit" means a unit that is subject to emission reduction requirements or limitations under this subchapter (42 U.S.C. § 7651a(2)).
} 
of a CAA Title V Operating Permit pursuant to the CAA (42 U.S.C. $\S \S 7401-7671$ q; 40 C.F.R. $\S$ 72.30(a)).

\section{Notice of Proposed Construction or Alteration}

A nuclear developer must provide the Federal Aviation Administration notice of a proposed construction or alteration that exceeds $200 \mathrm{ft}$ above ground level or that exceeds an imaginary surface extending upwards and outward at any of the following slopes: 100 to 1 for a horizontal distance of $20,000 \mathrm{ft}$ from the nearest point of the nearest runway of each airport with its longest runway more than 3,200 ft in actual length; 50 to 1 for a horizontal distance of 10,000 from the nearest point of the nearest runway of each airport with its longest runway no more than 3,200 ft; or 25 to 1 for a horizontal distance of $5,000 \mathrm{ft}$ from the nearest point of the nearest landing and takeoff area of each heliport.

\section{Geothermal Power Project Licenses, Permits, and Authorizations}

In the United States, the Geothermal Steam Act of 1970 is the primary statute governing geothermal project construction and operation. The following contains a discussion of relevant environmental impacts associated with geothermal projects generally as well as the federal permits, licenses, and authorizations required for geothermal infrastructure projects.

\section{Geothermal Power Project Potential Environmental Impacts}

A typical geothermal project raises environmental issues that require regulatory and permitting approval from federal and state agencies. Potential environmental impacts from geothermal development include but are not limited to:

- Potential air quality impacts due to minimal emissions from naturally occurring noncondensable gases, such as carbon dioxide, nitrogen, and methane from operation of geothermal plant

- Potential air quality impacts from emissions of hydrogen sulfide, mercury, arsenic, and boron from drilling operations

- Potential air quality impacts from binary working fluid emissions, typically pentane or butane isomers, released into the atmosphere from gaskets, rotating seals, and flanges or from refilling during construction and operation activities

- Potential water quality and quantity impacts due to reduced spring discharge rates, decreasing groundwater supply, or interference with groundwater recharge caused by construction activities (e.g., soil compaction, vegetation clearing) and geothermal plant operation (e.g., water pumping, water injection, and evaporation)

- Potential water quality impacts from geothermal waters mixing with shallow connected groundwater aquifers and consumption of geothermal fluid, leading to lower pressures in geothermal reservoirs and altered water supply by reducing spring flow or water levels of connecting groundwater aquifers during operation activities

- Potential groundwater and surface water impacts from contaminants (e.g., drilling mud, geothermal fluid, lubricants, fuels) leaking from pipeline transport during operation activities

- Potential impacts to recreation from a project's potential to be seen, heard, or smelled from nearby recreational lands during specific operations (e.g., well site drilling, exploration, steam plume emissions). 


\section{Required Licenses, Permits, and Authorizations for Geothermal Power Projects}

The U.S. Bureau of Land Management(BLM) is the primary permitting authority, and works with other federal agencies as well as state, local, and tribal governments as well as the public to issue leases and permits for geothermal projects pursuant to the Geothermal Steam Act of 1970 (30 U.S.C. § 1002). The BLM manages the federal government's subsurface mineral estates underlying land managed by the BLM, U.S. Forest Service (USFS), or other federal agencies as well as other non-federal surface owners. The following permits are required for geothermal project construction and operation.

\section{Geothermal Lease}

A geothermal project developer must obtain a geothermal lease from the BLM to use subsurface mineral resources for geothermal use, such as commercial generation of electricity or direct use (e.g., heating) of the resource pursuant to the Geothermal Steam Act of 1970 (30 U.S.C. § 1003).

\section{Notice of Intent to Conduct Geothermal Resource Exploration Operations}

A geothermal project developer must obtain a Notice of Intent to Conduct Geothermal Resource Exploration Operations (NOI) from the BLM to conduct "exploration operations": 1) on BLM administered public lands or 2) on lands whose surface is managed by another federal agency (e.g., USFS), where BLM has leased the subsurface geothermal resources and the lease operator seeks to conduct exploration pursuant to the Geothermal Steam Act of 1970 (30 U.S.C. § 1003; 43 C.F.R. § 3251.10).The USFS has authority to issue an NOI to conduct exploration operations on unleased parcels on lands whose surface estate is managed by the USFS.

\section{Geothermal Drilling Permit}

A geothermal project developer must obtain a drilling permit from the BLM to drill wells and conduct related activities for the purpose of performing flow tests, producing geothermal fluids, or injecting fluids into a geothermal reservoir pursuant to the Geothermal Steam Act of 1970 (30 U.S.C. $\S 1003 ; 43$ C.F.R. $\S 3260.10$ ).

\section{Geothermal Utilization Permits}

A geothermal project developer must obtain a site license and an approved utilization plan from the BLM prior to commencing construction of a utilization facility for commercial operations pursuant to the Geothermal Steam Act (30 U.S.C. § 1003; 43 C.F.R. § 3274.10; 43 C.F.R. § 3271.15). In addition, any geothermal project developer must obtain a commercial use permit approved by the BLM to sell the electricity pursuant to the Geothermal Steam Act of 1970 (30 U.S.C. § 1003; 43 C.F.R. § 3274.10; 43 C.F.R. § 3271.15)

\section{Underground Injection Control Permit}

A geothermal project developer must obtain an underground injection control permit from the EPA or relevant state agency with EPA delegated authority to undertake any underground 
injection ${ }^{44}$ pursuant to the Safe Drinking Water Act of 1974 (42 U.S.C. $\S \S 300 f-300 j-27 ; 40$ C.F.R. $\S 144.11)$.

\section{Land-Based Wind Power Project Permits and Authorizations}

In the United States, land-based wind projects must comply with federal and state statutes prior to commencing construction and operation activities. The following contains a discussion of relevant environmental impacts associated with wind projects as well as the federal permits, licenses, and authorizations required for wind project construction and operation.

\section{Land-Based Wind Power Project Potential Environmental Impacts}

A typical wind project raises environmental issues that require regulatory and permitting approval from federal and state agencies. Potential environmental impacts from wind project development include but are not limited to:

- Potential impacts to mineral resources from permanently removing mineral exploration opportunities as a result of the addition of permanent structures for operation

- Potential impacts to near-surface cultural resources from topographical changes from soil movement or other disturbance during construction activities and operation activities

- Potential impacts to surface water from periodic turbine cleanings and associated hazardous waste discharge or sediment runoff into the underlying surface from operation activities

- Potential impacts to recreation as a result of scenic and aesthetic changes of landscapes from ground grading construction activities and addition of permanent structures for operation

- Potential impacts to birds and bats from collision and wind shear resulting in injury or death as a result of the addition of permanent structures for operation activities

- Other potential direct and indirect effects to wildlife (including federally or state protected species) related to wind project construction and operation, including habitat fragmentation and loss.

Required Permits and Authorizations for Land-Based Wind Power Projects

Authority for wind project permitting resides with the relevant federal or state agency with jurisdiction over the project site. The following federal permits, licenses, and/or authorizations are required for wind project construction and operation.

\section{Notice of Proposed Construction or Alteration}

See Section 1.2.2 for a description of the aforementioned permit.

\section{Bureau of Land Management Wind and Solar Lease}

A wind project developer may need to obtain a lease from the BLM if a project is located on BLM managed land through a competitive leasing process established by the BLM pursuant to

\footnotetext{
44 "Underground injection" means subsurface emplacement of fluids by well injection excluding the underground injection of natural gas for purposes of storage or the underground injection of fluids or propping agents pursuant to fracking operations related to oil, gas, or geothermal production activities (42 U.S.C. $\S 300 \mathrm{~h}(\mathrm{~d})(1)$ ).
} 
the Federal Land Policy \& Management Act of 1976 (43 U.S.C. $\S \S 1701-1787 ; 30$ C.F.R. $\S 2809.10)$.

\section{Solar Power Project Permits and Authorizations}

In the United States, solar projects must comply with federal and state statutes prior to commencing construction and operation activities. The following contains a discussion of relevant environmental impacts associated with solar projects as well as the federal permits, licenses, and authorizations required for solar project construction and operation.

\section{Solar Power Project Potential Environmental Impacts}

A typical solar project raises environmental issues that require regulatory and permitting approval from federal and state agencies. Potential environmental impacts from solar project development include but are not limited to:

- Potential air quality impacts from soil disturbance during vegetation clearing, digging, and soil grading from construction activities

- Potential impacts to near-surface cultural resources from topographical changes from soil movement or other disturbance during construction activities and operation activities

- Potential impacts to surface water from periodic photovoltaic panel cleanings and associated hazardous waste discharge or sediment runoff into the underlying surface from operation activities

- Potential impacts to wildlife and migratory birds (including federally and state protected species) from transmission line collision, habitat fragmentation and reduction, vegetation loss, introduction and spread of invasive species, and topsoil removal due to construction activities and addition of permanent structures for operation.

\section{Required Permits and Authorizations for Solar Power Projects}

Authority for solar project permitting resides with the relevant federal or state agency with jurisdiction over the project site. The following federal permits, licenses, and/or authorizations are required for solar project construction and operation.

\section{Bureau of Land Management Wind and Solar Lease}

See Section 1.2.4 for a description of the aforementioned permit.

\section{Bulk Electric Transmission Project Permits and Authorizations}

In the United States, bulk electric transmission projects must comply with federal and state statutes prior to commencing construction and operation activities. The following contains a discussion of relevant environmental impacts associated with bulk transmission projects as well as the federal permits, licenses, and authorizations required for bulk transmission project construction and operation.

\section{Bulk Electric Transmission Project Potential Environmental Impacts}

A typical bulk transmission project raises environmental issues that require regulatory and permitting approval from federal and state agencies. Potential environmental impacts from bulk transmission development include but are not limited to: 
- Potential air quality impacts from soil disturbance during vegetation clearing, digging, and soil grading from construction activities

- Potential impacts to near-surface cultural resources from vegetation clearing, soil erosion, habitat fragmentation, alteration of site-specific natural quality, or destruction of property during construction and operation activities

- Potential surface and groundwater impacts from runoff, particulate matter, wastewater, and other materials that may leach into ground or surface water during operation activities

- Potential impacts to wildlife as a result of vegetation and habitat fragmentation and loss from construction activities (e.g., land clearing) and addition of permanent structures for operation (e.g., rights-of-way, access roads, poles, wires)

- Potential impacts to migratory birds from increased collision into poles and wires resulting in injury or death because of the addition of permanent structures for operation activities.

\section{Required Permits and Authorizations for Bulk Electric Transmission Projects}

Authority for bulk transmission project permitting resides with the relevant federal or state agency with jurisdiction over the project site. The following federal permits, licenses, and/or authorizations are required for bulk transmission construction and operation.

\section{Federal Energy Regulatory Commission Construction or Modification Permit}

Under the Federal Power Act (FPA), the Federal Energy Regulatory Commission (FERC) has the authority to issue permits for the construction or modification of electric transmission facilities in national interest electric transmission corridors used for the transmission of energy in interstate commerce under specific circumstances, including where:

- A state in which the transmission facility is to be constructed or modified does not have authority to approve the siting of the facility

- A state in which the transmission facility is to be constructed or modified does not have authority to consider the interstate benefits expected to be achieved by the proposed construction or modification of the facility

- The applicant for a permit is a transmitting utility under the FPA but does not qualify to apply for a permit or siting approval for the proposed project in a state because the applicant does not serve end-use customers in the state

- A state commission or other entity that has authority to approve the siting of the transmission facility has withheld approval for more than 1 year after the filing of an application seeking approval pursuant to applicable law or 1 year after the designation of the relevant National Interest Electric Transmission Corridors, whichever is later (note that this does not give FERC permitting authority when a state has affirmatively denied a permit application within the 1-year deadline (see Piedmont Envtl. Council v. FERC, 558 F.3d 304 (4th Cir. 2009))

- A state commission or other entity that has authority to approve the siting of the transmission facility has conditioned its approval in such a manner that the proposed construction or modification will not significantly reduce transmission congestion in interstate commerce or is not economically feasible (16 USC $\S 824 \mathrm{p}(\mathrm{b})$; FERC Order No. 689). 


\section{Notice of Proposed Construction or Alteration}

See Section 1.2.2 for a description of the aforementioned permit.

\section{Natural Gas Pipeline Project Authorizations}

In the United States, the Natural Gas Act of 1938 is the primary statute governing interstate ${ }^{45}$ natural gas pipeline project construction and operation (15 U.S.C. $\S \S 717-717 \mathrm{z}(1938)$ ). The following contains a discussion of relevant environmental impacts associated with natural gas pipeline projects generally as well as the federal permits, licenses, and authorizations required for interstate natural gas pipeline projects.

\section{Natural Gas Pipeline Project Potential Environmental Impacts}

A typical natural gas pipeline project raises environmental issues that require regulatory and permitting approval from federal and state agencies. Potential environmental impacts from natural gas pipeline development include but are not limited to:

- Potential wildlife impacts from habitat disruption, habitat fragmentation, or animal mortality from addition of permanent infrastructure for operation activities (e.g., pipelines and transportation corridors)

- Potential air quality impacts as a result of the release of particulate matter in the form of fugitive dust generated by ground grading, vegetation removal, and drilling during construction activities

- Potential surface water resource impacts from periodic right-of-way clearings for operating activities

- Potential impacts to air quality, wildlife, and ecological resources from hazardous and flammable fluid and vapor releases during operation activities.

\section{Required Authorizations for Natural Gas Pipeline Projects}

FERC is the primary permitting authority that issues permits for interstate natural gas pipeline projects pursuant to the Natural Gas Act of 1938 (15 U.S.C. $\S \S 717-717$ z (1938)). The following permits are required for natural gas project construction and operation.

\section{Federal Energy Regulatory Commission Certificate of Public Convenience and Necessity}

An interstate natural gas pipeline developer must obtain a certificate of public convenience and necessity from FERC to sell or transport natural gas or construct, extend, acquire, or operate any such facility (15 U.S.C. $\S 717 \mathrm{f}(\mathrm{c})(1)(\mathrm{A})$ ). The certificate of public convenience and necessity is effective so long as the applicant continues authorized operations (18 C.F.R. $\S 157.20$ ).

FERC must determine that the proposed natural gas pipeline project is within the "public interest" to issue a certificate of public convenience and necessity. In making a public interest determination FERC must balance "the public benefit against the potential adverse

\footnotetext{
45 "Interstate commerce" means commerce between any point in a State and any point outside thereof, or between points within the same State but through any place outside thereof, but only insofar as such commerce takes place within the United States (15 U.S.C. $§ 717$ a (7))
} 
consequences" of the proposed project by evaluating economic, public, and environmental factors, which include:

- Adverse impacts on potentially affected interests of the applicant's (developer's) existing customers, competing existing pipelines and their customers, landowners, and surrounding communities affected by the route of the new pipeline, which could include environmental impacts, private property impacts, and market demand impacts

- Public benefits of the proposed project

- Potential environmental impacts.

(Certification of New Interstate Natural Gas Pipeline Facilities, 88 FERC $\uparrow$ 61,227 (1999), clarified, 90 FERC \ 61,128, further clarified, 92 FERC \ 61,094 (2000) (Certificate Policy Statement)).

\section{FERC Certificate of Public Convenience and Necessity Prerequisites}

Prior to FERC issuing a certificate of public convenience and necessity, a natural gas pipeline developer must comply with the following processes and obtain the following certifications, approvals, permits, and authorizations from the relevant authority with jurisdiction:

- 401 Water Quality Certification

- Endangered Species Act (ESA) Section 7 Consultation Process.

\section{Natural Gas and Coal Power Plant Project Permits and Authorizations}

In the United States, natural gas and coal power plants must comply with federal and state statutes related to air quality prior to commencing construction and operation activities. The following contains a discussion of relevant environmental impacts associated with power plants generally as well as the federal permits, licenses, and authorizations required for construction and operation of power plant projects.

\section{Natural Gas and Coal Power Plant Projects Potential Environmental Impacts}

A typical power plant project raises environmental issues that require regulatory and permitting approval from federal and state agencies. Potential environmental impacts from power plant development include but are not limited to:

- Potential air quality impacts from volatile organic compound, particulate matter, and greenhouse gas emissions such as carbon monoxide, carbon dioxide, nitrogen oxides, sulfur dioxide, and heavy metals like mercury, beryllium, sulfuric acid mist, hydrochloric acid, hydrofluoric acid, benzene, and arsenic from operation activities

- Potential water quality impacts from gasifier slag, fine solids, elemental sulfur, fly ash, landfill runoff, and sludges from water and wastewater treatment contaminating the water supply, and spent catalysts, absorbents, resins, and filtration materials leaching into groundwater or surface water during operation activities

- Potential water quality impacts from stormwater runoff impacts collected from the facilities, coal piles, and other areas with oil and grease and other contaminants during operation activities 
- Potential impacts cooling water discharges, including water temperature and water quality impacts from proprietary biocides, corrosion and scale inhibitors (such as phosphates), chlorine, and other substances from operation activities

- Potential impacts to fish (including eel) and other aquatic species populations as a result of impingement and entrainment from cooling water withdrawals

- Potential impacts from habitat disruption or animal mortality from addition of permanent infrastructure for operation activities (e.g., transmission lines, utility pipelines, and transportation corridors).

\section{Required Permits Authorizations for Natural Gas and Coal Power Plant Projects}

The EPA and state resource agencies with EPA delegated authority have primary authority to issue permits related to air quality for power plants pursuant to the Clean Air Act of 1970 (CAA) (42 U.S.C. $\S \S 7401-7671 q$ ). The following permits are required for natural gas and coal power plant project construction and operation.

\section{Clean Air Act Title V Operating Permit}

See Section 1.2.2 for a description of the aforementioned permit.

\section{Acid Rain Permit}

See Section 1.2.2 for a description of the aforementioned permit.

\section{Minor New Source Review Permit}

A natural gas or coal power plant project developer must obtain a minor new source review permit to construct or modify a minor stationary source that would interfere with attainment or maintenance of the National Ambient Air Quality Standard or violate the control strategy in nonattainment areas if a Prevention of Significant Deterioration permit or Nonattainment New Source Review permit is not required pursuant to the CAA (42 U.S.C. $\S 7410(\mathrm{a})(2)(\mathrm{C})$ ).

\section{National Emission Standards for Hazardous Air Pollutants Approval}

A natural gas or coal power plant project developer must obtain a National Emission Standards for Hazardous Air Pollutants approval of a major source ${ }^{46}$ or area source ${ }^{47}$ of any listed hazardous air pollutants must obtain written approval prior to constructing or modifying any stationary source and must operate that major source or area source in compliance with all applicable national emission standards for hazardous air pollutants pursuant to the CAA (40 C.F.R. $\S 61.05(a)-(b))$.

\footnotetext{
46 "Major source" means any stationary source or group of stationary sources located within a contiguous area and under common control that emits or has the potential to emit 10 tons per year or more of any hazardous air pollutant or 25 tons per year or more of any combination of hazardous air pollutants (42 U.S.C. $\S 7412$ (a)(1).

47 "Area Source" means any stationary source of hazardous air pollutants that is not a major source (42 U.S.C. $\S$ 7412 (a)(4).
} 


\section{New Source Performance Standards}

A power plant project developer of any stationary source that contains an affected facility ${ }^{48}$ may need to comply with the new source performance standards (40 C.F.R. $§ 60.1(a)$ ).

\section{Non-Attainment New Source Review Permit}

A developer of any new major source or major modifications at existing sources for pollutants must obtain a non-attainment new source review permit when the source is located in an area that is not in attainment ${ }^{49}$ with the National Ambient Air Quality Standards (42 U.S.C. $§ 7503(a)$ ).

\section{Prevention of Significant Deterioration Permit}

Any major emitting facility ${ }^{50}$ must obtain a Prevention of Significant Deterioration permit to construct a new major stationary source or major modifications of an existing major stationary source facility in an area designated as attainment or unclassifiable National Ambient Air Quality Standard (40 C.F.R. § 52.21(a)(2)).

\section{Notice of Proposed Construction or Alteration}

See Section 1.2.2 for a description of the aforementioned permit.

Table A1 provides a summary of the regulatory and permitting requirements across each infrastructure project type.

\footnotetext{
${ }^{48}$ Affected Facility" means with reference to a stationary source, any apparatus to which a standard is applicable (40 C.F.R. $\S 60.2$ ). "Stationary Source" means any building, structure, facility, or installation which emits or may emit any air pollutant (40 C.F.R. § 60.2).

49 "Nonattainment area" means for any air pollutant, an area which is designated "nonattainment" with respect to that pollutant within the meaning of (42 U.S.C. 7407(d); any area that does not meet (or that contributes to ambient air quality in a nearby area that does not meet) the national primary or secondary ambient air quality standard for the pollutant (42 U.S.C. 7501 (2)).

50 "Major emitting facility" refers to a variety of listed categories of stationary sources found in 42 U.S.C. $\$ 7479(1)$ that emit or have the potential to emit 100 tons per year or more of any pollutant, or any other source with the potential to emit 250 tons per year or more (42 U.S.C. $\S 7479(1)$ ).
} 
Table A1. Infrastructure Comparison Table

\begin{tabular}{|c|c|c|c|c|}
\hline Infrastructure Type & $\begin{array}{c}\text { Required Permits, Approvals, } \\
\text { and Authorizations }\end{array}$ & Relevant Agency & $\begin{array}{l}\text { Common Potential } \\
\text { Environmental Impacts }\end{array}$ & $\begin{array}{l}\text { Regulatory } \\
\text { Considerations }\end{array}$ \\
\hline \multirow[t]{4}{*}{$\begin{array}{l}\text { Non-Hydropower } \\
\text { Water Infrastructure }\end{array}$} & $\begin{array}{l}\text { Land Access } \\
\text { BLM Right-of-Way (ROW) } \\
\text { Military Land ROW } \\
\text { National Park System ROW } \\
\text { National Wildlife Refuge ROW } \\
\text { Special Use Authorization } \\
\text { Tribal Land ROW }\end{array}$ & $\begin{array}{l}\text { Land Access } \\
\text { BLM } \\
\text { U.S. Department of } \\
\text { Defense (DOD) } \\
\text { National Park Service } \\
\text { (NPS) } \\
\text { USFWS } \\
\text { USFS } \\
\text { Bureau of Indian Affairs } \\
\text { (BIA)/Tribe }\end{array}$ & & \\
\hline & $\begin{array}{l}\text { Biological Resources } \\
\text { Eagle Non-Purposeful Take Permit } \\
\text { Essential Fish Habitat Consultation } \\
\text { ESA Section } 7 \text { Consultation } \\
\text { Marine Mammal Incidental Take } \\
\text { Authorizations } \\
\text { Migratory Bird Special Purpose } \\
\text { Permit } \\
\text { Fish and Wildlife Coordination Act } \\
\text { (FWCA) Consultation }\end{array}$ & $\begin{array}{l}\text { Biological Resources } \\
\text { USFWS } \\
\text { NOAA Fisheries/USFWS } \\
\text { NOAA Fisheries/USFWS } \\
\text { NOAA Fisheries/USFWS } \\
\text { USFWS } \\
\text { USFWS/NOAA } \\
\text { Fisheries/State Agency }\end{array}$ & $\begin{array}{l}\text { Biological Resources Impacts } \\
\text { - } \\
\text { sish, eel, and other aquatic } \\
\text { species affected by inhibited } \\
\text { migratory patterns } \\
\text { - Wildlife and nesting bird habitat } \\
\text { inundated due to altered } \\
\text { hydrology } \\
\text { - Habitat and species } \\
\text { fragmentation due to addition of } \\
\text { permanent structures }\end{array}$ & \\
\hline & $\begin{array}{l}\text { Cultural Resources } \\
\text { NHPA Section } 106 \text { Consultation } \\
\text { Process }\end{array}$ & $\begin{array}{l}\text { Cultural Resources } \\
\text { State Historic Preservation } \\
\text { Office (SHPO), Tribal } \\
\text { Historic Preservation Office } \\
\text { (THPO), Advisory Council } \\
\text { on Historic Preservation } \\
\text { (ACHP) }\end{array}$ & & \\
\hline & $\begin{array}{l}\text { Water Quality } \\
\text { Clean Water Act (CWA) Section } 401 \\
\text { Water Quality Certification } \\
\text { CWA Section } 404 \text { Dredge and Fill } \\
\text { Permit }\end{array}$ & $\begin{array}{l}\text { Water Quality } \\
\text { State Agency/EPA } \\
\text { USACE/Michigan/New } \\
\text { Jersey/Florida }\end{array}$ & $\begin{array}{l}\text { Water Quality Impacts } \\
\text { Reduced reservoir elevations } \\
\text { affecting groundwater quality } \\
\text { Flow rate changes leading to } \\
\text { dissolved oxygen levels, water } \\
\text { loss, sediment buildup, } \\
\text { increased temperatures to } \\
\text { surface water }\end{array}$ & \\
\hline
\end{tabular}




\begin{tabular}{|c|c|c|c|c|}
\hline Infrastructure Type & $\begin{array}{c}\text { Required Permits, Approvals, } \\
\text { and Authorizations }\end{array}$ & Relevant Agency & $\begin{array}{l}\text { Common Potential } \\
\text { Environmental Impacts }\end{array}$ & $\begin{array}{l}\text { Regulatory } \\
\text { Considerations }\end{array}$ \\
\hline & $\begin{array}{l}\text { Preexisting Land Use } \\
\text { Rivers and Harbors Act of } 1899 \\
\text { (RHA) Section } 10 \text { Construction } \\
\text { Permit } \\
\text { CZMA Consistency Determination } \\
\text { Wild and Scenic River Act Section } 7 \\
\text { Consultation }\end{array}$ & $\begin{array}{l}\text { Preexisting Land Use } \\
\text { USACE } \\
\text { State Agency } \\
\text { BLM/USFWS/NPS/USFS }\end{array}$ & $\begin{array}{l}\text { Preexisting Land Use Impacts } \\
\text { Construction and operation of } \\
\text { intakes, dams, and other project } \\
\text { facilities affecting recreation, habitat, } \\
\text { and scenic and aesthetic qualities of } \\
\text { rivers and streams }\end{array}$ & \\
\hline & $\begin{array}{l}\text { Environmental Review } \\
\text { NEPA Environmental Review } \\
\text { Process } \\
\text { RHA Section } 408 \text { Authorization }\end{array}$ & $\begin{array}{l}\text { Environmental Review } \\
\text { USACE/U.S. Bureau of } \\
\text { Reclamation (BOR) }\end{array}$ & & \\
\hline & & $\frac{\text { Infrastructure Specific }}{\text { USACE }}$ & & \\
\hline \multirow[t]{3}{*}{ Nuclear Power } & $\begin{array}{l}\text { Air Quality } \\
\text { CAA Title V Operating Permit } \\
\text { Acid Rain Permit }\end{array}$ & $\frac{\text { Air Quality }}{\text { State Agency/EPA }}$ & $\begin{array}{l}\text { Air Quality Impacts } \\
\text { Emission of volatile organic } \\
\text { compounds, particulate matter, and } \\
\text { radioactive gases affecting air } \\
\text { quality }\end{array}$ & \\
\hline & $\frac{\text { Land Access }}{\mathrm{N} / \mathrm{A}}$ & $\frac{\text { Land Access }}{\mathrm{N} / \mathrm{A}}$ & & \\
\hline & $\begin{array}{l}\text { Biological Resources } \\
\text { Eagle Non-Purposeful Take Permit } \\
\text { Essential Fish Habitat Consultation } \\
\text { Endangered Species Section } 7 \\
\text { Consultation } \\
\text { Marine Mammal Incidental Take } \\
\text { Authorizations } \\
\text { Migratory Bird Special Purpose } \\
\text { Permit }\end{array}$ & $\begin{array}{l}\text { Biological Resources } \\
\text { USFWS } \\
\text { NOAA Fisheries/USFWS } \\
\text { NOAA Fisheries/USFWS } \\
\text { NOAA Fisheries/USFWS } \\
\text { USFWS }\end{array}$ & $\begin{array}{l}\text { Biological Resources Impacts } \\
\text { - } \quad \text { Migratory bird morbidity from } \\
\text { collisions resulting from the } \\
\text { addition of other permanent } \\
\text { structures } \\
\text { Habitat and species } \\
\text { fragmentation resulting from the } \\
\text { addition of permanent } \\
\text { structures } \\
\text { Fish and other aquatic species } \\
\text { impacts from entrainment and } \\
\text { impingement at cooling water intake } \\
\text { structures }\end{array}$ & $\begin{array}{l}\text { Biological Resources } \\
\text { - } \quad \text { Essential Fish Habitat } \\
\text { Consultation is a } \\
\text { prerequisite to a } \\
\text { combined nuclear } \\
\text { license. } \\
\text { - Endangered Species } \\
\text { Section } 7 \text { Consultation is } \\
\text { a prerequisite to a } \\
\text { combined nuclear } \\
\text { license. }\end{array}$ \\
\hline
\end{tabular}




\begin{tabular}{|c|c|c|c|c|}
\hline Infrastructure Tyре & $\begin{array}{c}\text { Required Permits, Approvals, } \\
\text { and Authorizations }\end{array}$ & Relevant Agency & $\begin{array}{l}\text { Common Potential } \\
\text { Environmental Impacts }\end{array}$ & $\begin{array}{l}\text { Regulatory } \\
\text { Considerations }\end{array}$ \\
\hline & $\begin{array}{l}\text { Cultural Resources } \\
\text { NHPA Section } 106 \text { Consultation } \\
\text { Process }\end{array}$ & $\frac{\text { Cultural Resources }}{\text { SHPO, THPO, ACHP }}$ & $\begin{array}{l}\text { Cultural Resources Impacts } \\
\text { Near-surface cultural resource } \\
\text { damages from topographic changes, } \\
\text { soil movement, or disturbance }\end{array}$ & $\begin{array}{l}\text { Cultural Resources } \\
\text { NHPA Section } 106 \\
\text { Consultation is a prerequisite } \\
\text { to a combined nuclear } \\
\text { license. }\end{array}$ \\
\hline & $\begin{array}{l}\text { Water Quality } \\
\text { CWA Section } 401 \text { Water Quality } \\
\text { Certification } \\
\text { CWA Section } 402 \text { NPDES Permit } \\
\text { CWA Section } 404 \text { Dredge and Fill } \\
\text { Permit }\end{array}$ & $\begin{array}{l}\text { Water Quality } \\
\text { State Agency/EPA } \\
\text { State Agency/EPA } \\
\text { USACE/Michigan/New } \\
\text { Jersey/Florida }\end{array}$ & $\begin{array}{l}\text { Water Quality Impacts } \\
\quad \text { Recharge of groundwater and } \\
\text { aquifers affected by use for } \\
\text { cooling agent for operation } \\
\text { activities } \\
\text { Surface water affected by thermal } \\
\text { discharge from operation activities }\end{array}$ & $\begin{array}{l}\text { Water Quality } \\
401 \text { Water Quality } \\
\text { Certification is a prerequisite } \\
\text { to a combined nuclear } \\
\text { license. }\end{array}$ \\
\hline & $\begin{array}{l}\text { Preexisting Land Use } \\
\text { RHA Section } 10 \text { Construction } \\
\text { Permit } \\
\text { CZMA Consistency Determination }\end{array}$ & $\begin{array}{l}\text { Preexisting Land Use } \\
\text { USACE } \\
\text { State Agency }\end{array}$ & $\begin{array}{l}\text { Preexisting Land Use Impacts } \\
\text { Recreation as well as scenic and } \\
\text { aesthetic qualities of landscapes } \\
\text { affected by addition of permanent } \\
\text { operation structures }\end{array}$ & $\begin{array}{l}\text { Preexisting Land Use } \\
\text { Coastal Zone Management } \\
\text { Act (CZMA) Consistency } \\
\text { Determination is a } \\
\text { prerequisite to a combined } \\
\text { nuclear license. }\end{array}$ \\
\hline & $\begin{array}{l}\text { Environmental Review } \\
\text { NEPA Environmental Review } \\
\text { Process }\end{array}$ & $\frac{\text { Environmental Review }}{\text { NRC }}$ & & \\
\hline & $\begin{array}{l}\text { Infrastructure Specific } \\
\text { Combined Nuclear License } \\
\text { Notice of Proposed Construction or } \\
\text { Alteration }\end{array}$ & $\begin{array}{l}\text { Infrastructure Specific } \\
\text { NRC } \\
\text { Federal Aviation } \\
\text { Administration }\end{array}$ & $\begin{array}{l}\text { Infrastructure Specific Impacts } \\
\text { Emission of volatile organic } \\
\text { compounds, particulate matter and } \\
\text { radioactive gases affecting air } \\
\text { quality }\end{array}$ & $\begin{array}{l}\text { Infrastructure Specific } \\
\text { Combined nuclear } \\
\text { license is subject to 40- } \\
\text { year term. } \\
\text { NRC's authority under } \\
\text { the Atomic Energy Act is } \\
\text { not limited by surface } \\
\text { owner or manager. NRC } \\
\text { must evaluate factors to } \\
\text { determine whether the } \\
\text { site is acceptable for a } \\
\text { stationary power reactor. }\end{array}$ \\
\hline Geothermal Power & $\begin{array}{l}\text { Land Access } \\
\text { BLM ROW } \\
\text { DOD Enhanced Use Lease } \\
\text { National Park System ROW }\end{array}$ & $\begin{array}{l}\text { Land Access } \\
\text { BLM } \\
\text { DOD } \\
\text { NPS }\end{array}$ & & \\
\hline
\end{tabular}




\begin{tabular}{|c|c|c|c|c|}
\hline Infrastructure Tуре & $\begin{array}{c}\text { Required Permits, Approvals, } \\
\text { and Authorizations }\end{array}$ & Relevant Agency & $\begin{array}{l}\text { Common Potential } \\
\text { Environmental Impacts }\end{array}$ & $\begin{array}{l}\text { Regulatory } \\
\text { Considerations }\end{array}$ \\
\hline & $\begin{array}{l}\text { National Wildlife Refuge ROW } \\
\text { Special Use Authorization } \\
\text { Tribal Land ROW } \\
\text { Tribal Energy Resources } \\
\text { Agreement Land ROW }\end{array}$ & $\begin{array}{l}\text { USFWS } \\
\text { USFS } \\
\text { BIA/Tribe } \\
\text { BIA/Tribe }\end{array}$ & & \\
\hline & $\begin{array}{l}\text { Biological Resources } \\
\text { Eagle Non-Purposeful Take Permit } \\
\text { Essential Fish Habitat Consultation } \\
\text { Migratory Bird Special Purpose } \\
\text { Permit } \\
\text { ESA Section } 7 \text { or Section } 10 \\
\text { Consultation }\end{array}$ & $\begin{array}{l}\text { Biological Resources } \\
\text { USFWS } \\
\text { NOAA Fisheries/USFWS } \\
\text { USFWS } \\
\text { NOAA Fisheries/USFWS }\end{array}$ & $\begin{array}{l}\text { Biological Resources Impacts } \\
\text { Habitat fragmentation and species } \\
\text { displacement from the addition of } \\
\text { permanent structures }\end{array}$ & \\
\hline & $\begin{array}{l}\text { Cultural Resources } \\
\text { NHPA Section } 106 \text { Consultation } \\
\text { Process }\end{array}$ & $\frac{\text { Cultural Resources }}{\text { SHPO, THPO, ACHP }}$ & $\begin{array}{l}\text { Cultural Resources Impacts } \\
\text { Cultural resources affected by } \\
\text { topographical changes and drilling } \\
\text { activities }\end{array}$ & \\
\hline & $\begin{array}{l}\text { Water Quality } \\
\text { CWA Section } 401 \text { Water Quality } \\
\text { Certification } \\
\text { CWA Section } 404 \text { Dredge and Fill } \\
\text { Permit }\end{array}$ & $\begin{array}{l}\text { Water Quality } \\
\text { State Agency/EPA } \\
\text { USACE/Michigan/New } \\
\text { Jersey/Florida }\end{array}$ & $\begin{array}{l}\text { Water Quality Impacts } \\
\text { Reduced groundwater supply and } \\
\text { groundwater quality as a result of } \\
\text { geothermal waters mixing with } \\
\text { shallow connected groundwater } \\
\text { aquifers }\end{array}$ & \\
\hline & $\frac{\text { Preexisting Land Use }}{\text { CZMA Consistency Determination }}$ & $\frac{\text { Preexisting Land Use }}{\text { State Agency }}$ & $\begin{array}{l}\text { Preexisting Land Use Impacts } \\
\text { Project's potential to be seen, heard, } \\
\text { or smelled, affecting nearby } \\
\text { recreational lands }\end{array}$ & \\
\hline & $\begin{array}{l}\text { Environmental Review } \\
\text { NEPA Environmental Review } \\
\text { Process }\end{array}$ & $\frac{\text { Environmental Review }}{\text { BLM/USFS }}$ & & \\
\hline
\end{tabular}




\begin{tabular}{|c|c|c|c|c|}
\hline & $\begin{array}{l}\text { Infrastructure Specific } \\
\text { Underground Injection Control } \\
\text { Permit } \\
\text { Geothermal Lease } \\
\text { NOI to Conduct Geothermal } \\
\text { Resource Exploration Operations } \\
\text { Geothermal Drilling Permit } \\
\text { Geothermal Utilization (i.e., } \\
\text { Construction Permit, Site License, } \\
\text { and Commercial Use Permit) }\end{array}$ & $\begin{array}{l}\text { Infrastructure Specific } \\
\text { State Agency/EPA } \\
\text { BLM } \\
\text { BLM/USFS } \\
\text { BLM } \\
\text { BLM }\end{array}$ & & $\begin{array}{l}\text { Infrastructure Specific } \\
\text { Phased development } \\
\text { approach. Generally, } \\
\text { leasing, exploration } \\
\text { operations, drilling, and } \\
\text { utilization are distinct } \\
\text { phases that require } \\
\text { separate approvals. } \\
\text { Development phases } \\
\text { (exploration through } \\
\text { utilization) may combine } \\
\text { NEPA analysis. } \\
\text { BLM Geothermal Site } \\
\text { Licenses have a primary } \\
\text { term of } 30 \text { years, with a } \\
\text { preferential right to } \\
\text { renew. } \\
\text { BLM Geothermal Lease is } \\
\text { only applicable to BLM } \\
\text { managed mineral estates. }\end{array}$ \\
\hline \multirow[t]{2}{*}{ Land-Based Wind Power } & $\begin{array}{l}\text { Land Access } \\
\text { BLM ROW } \\
\text { DOD Enhanced Use Lease } \\
\text { National Park System ROW } \\
\text { National Wildlife Refuge ROW } \\
\text { Special Use Authorization } \\
\text { Tribal Land ROW } \\
\text { Tribal Energy Resources } \\
\text { Agreement Land ROW }\end{array}$ & $\begin{array}{l}\text { Land Access } \\
\text { BLM } \\
\text { DOD } \\
\text { NPS } \\
\text { USFWS } \\
\text { USFS } \\
\text { BIA/Tribe } \\
\text { BIA/Tribe }\end{array}$ & & \\
\hline & $\begin{array}{l}\text { Biological Resources } \\
\text { Eagle Non-Purposeful Take Permit } \\
\text { Essential Fish Habitat Consultation } \\
\text { Marine Mammal Incidental Take } \\
\text { Authorizations } \\
\text { Migratory Bird Special Purpose } \\
\text { Permit } \\
\text { ESA Section } 7 \text { or Section } 10 \\
\text { Consultation }\end{array}$ & $\begin{array}{l}\text { Biological Resources } \\
\text { USFWS } \\
\text { NOAA Fisheries/USFWS } \\
\text { NOAA Fisheries/USFWS } \\
\text { USFWS } \\
\text { NOAA Fisheries/USFWS }\end{array}$ & $\begin{array}{l}\text { Biological Resources Impacts } \\
\text { Impacts to birds and bats from } \\
\text { collision and wind shear } \\
\text { resulting in injury or death } \\
\text { Habitat fragmentation and species } \\
\text { displacement from addition of } \\
\text { permanent structures }\end{array}$ & \\
\hline
\end{tabular}




\begin{tabular}{|c|c|c|c|c|}
\hline Infrastructure Tyре & $\begin{array}{c}\text { Required Permits, Approvals, } \\
\text { and Authorizations }\end{array}$ & Relevant Agency & $\begin{array}{l}\text { Common Potential } \\
\text { Environmental Impacts }\end{array}$ & $\begin{array}{l}\text { Regulatory } \\
\text { Considerations }\end{array}$ \\
\hline & $\begin{array}{l}\text { Cultural Resources } \\
\text { NHPA Section } 106 \text { Consultation } \\
\text { Process }\end{array}$ & $\frac{\text { Cultural Resources }}{\text { SHPO, THPO, ACHP }}$ & $\begin{array}{l}\text { Cultural Resources Impacts } \\
\text { Impacts to near-surface cultural } \\
\text { resources from topographical } \\
\text { changes from soil movement or } \\
\text { other disturbance }\end{array}$ & \\
\hline & $\begin{array}{l}\text { Water Quality } \\
\text { CWA Section } 401 \text { Water Quality } \\
\text { Certification } \\
\text { CWA Section } 404 \text { Dredge and Fill } \\
\text { Permit }\end{array}$ & $\begin{array}{l}\text { Water Quality } \\
\text { State Agency/EPA } \\
\text { USACE/Michigan/New } \\
\text { Jersey/Florida }\end{array}$ & $\begin{array}{l}\text { Water Quality Impacts } \\
\text { Impacts to surface water from } \\
\text { periodic turbine cleanings and } \\
\text { associated hazardous waste } \\
\text { discharge or sediment runoff }\end{array}$ & \\
\hline & $\frac{\text { Preexisting Land Use }}{\text { CZMA Consistency Determination }}$ & $\frac{\text { Preexisting Land Use }}{\text { State Agency }}$ & $\begin{array}{l}\text { Preexisting Land Use Impacts } \\
\text { - Impacts to mineral resources } \\
\text { from permanently removing } \\
\text { mineral exploration } \\
\text { opportunities } \\
\text { Impacts to recreation due to scenic } \\
\text { and aesthetic changes of landscape }\end{array}$ & \\
\hline & $\begin{array}{l}\text { Environmental Review } \\
\text { NEPA Environmental Review } \\
\text { Process }\end{array}$ & $\begin{array}{l}\text { Environmental Review } \\
\text { BLM }\end{array}$ & & \\
\hline & $\begin{array}{l}\text { Infrastructure Specific } \\
\text { BLM Wind and Solar Lease } \\
\text { Notice of Proposed Construction or } \\
\text { Alteration }\end{array}$ & $\begin{array}{l}\text { Infrastructure Specific } \\
\text { BLM } \\
\text { Federal Aviation } \\
\text { Administration }\end{array}$ & & $\begin{array}{l}\text { Infrastructure Specific } \\
\text { BLM Wind and Solar } \\
\text { Leases subject to an } \\
\text { adjustable term with a } \\
\text { 30-year maximum } \\
\text { BLM lease only applicable on } \\
\text { BLM-managed surface } \\
\text { estates }\end{array}$ \\
\hline Solar Power & $\begin{array}{l}\text { Land Access } \\
\text { BLM ROW } \\
\text { DOD Enhanced Use Lease } \\
\text { National Park System ROW } \\
\text { National Wildlife Refuge ROW } \\
\text { Special Use Authorization } \\
\text { Tribal Land ROW } \\
\text { Tribal Energy Resources } \\
\text { Agreement Land ROW }\end{array}$ & $\begin{array}{l}\text { Land Access } \\
\text { BLM } \\
\text { DOD } \\
\text { NPS } \\
\text { USFWS } \\
\text { USFS } \\
\text { BIA/Tribe } \\
\text { BIA/Tribe }\end{array}$ & & \\
\hline
\end{tabular}




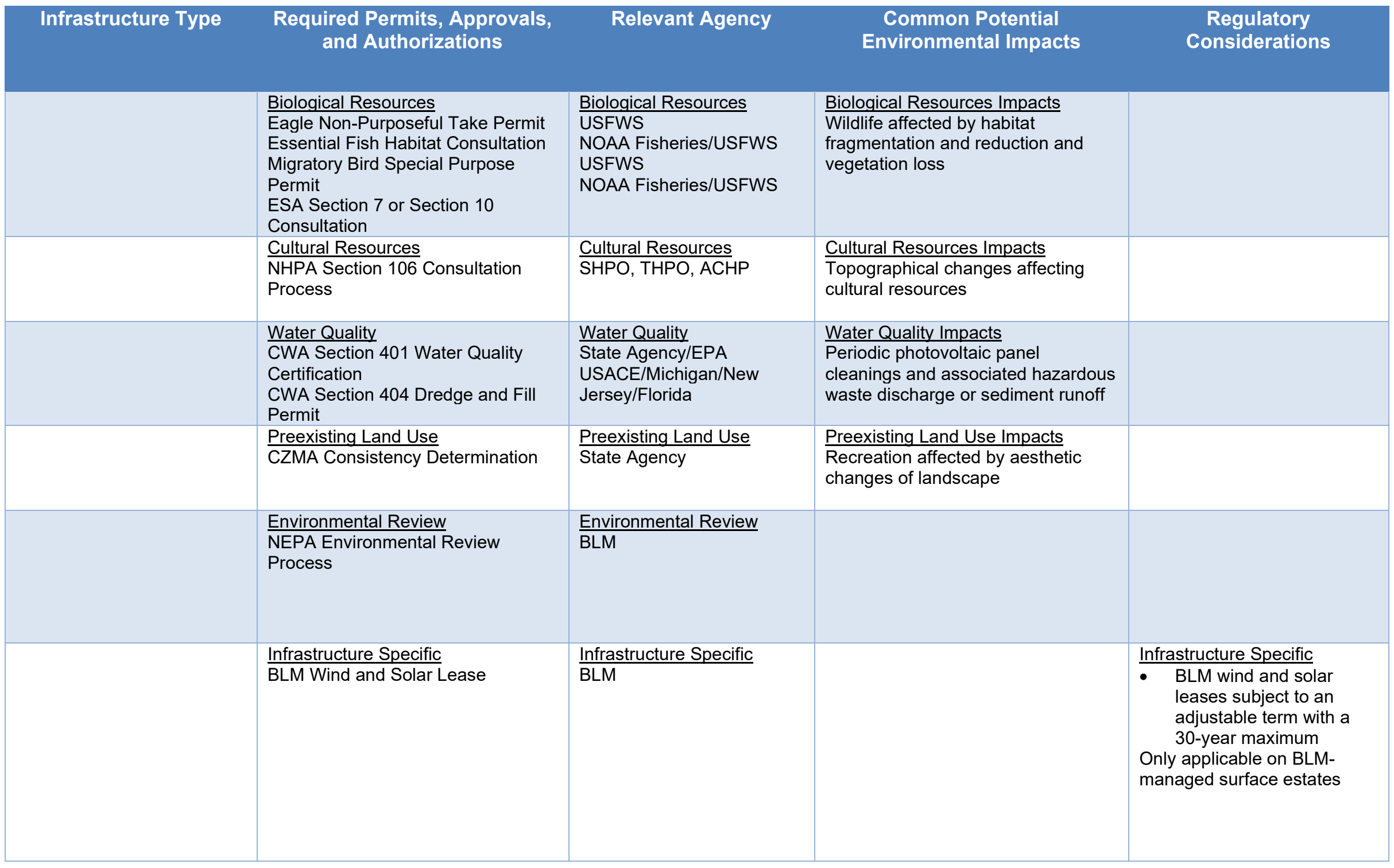




\begin{tabular}{|c|c|c|c|c|}
\hline Infrastructure Tyрe & $\begin{array}{c}\text { Required Permits, Approvals, } \\
\text { and Authorizations }\end{array}$ & Relevant Agency & $\begin{array}{l}\text { Common Potential } \\
\text { Environmental Impacts }\end{array}$ & $\begin{array}{l}\text { Regulatory } \\
\text { Considerations }\end{array}$ \\
\hline \multirow[t]{5}{*}{$\begin{array}{l}\text { Bulk } \\
\text { Electric Transmission }\end{array}$} & $\begin{array}{l}\text { Land Access } \\
\text { BLM ROW } \\
\text { Military Land ROW } \\
\text { National Park System ROW } \\
\text { National Wildlife Refuge ROW } \\
\text { Special Use Authorization } \\
\text { Tribal Land ROW } \\
\text { Tribal Energy Resources } \\
\text { Agreement Land ROW }\end{array}$ & $\begin{array}{l}\text { Land Access } \\
\text { BLM } \\
\text { DOD } \\
\text { NPS } \\
\text { USFWS } \\
\text { USFS } \\
\text { BIA/Tribe } \\
\text { BIA/Tribe }\end{array}$ & & $\begin{array}{l}\text { Land Access } \\
\text { BLM ROW, Military Land } \\
\text { ROW, National Wildlife } \\
\text { Refuge ROW, Special } \\
\text { Use Authorization, Tribal } \\
\text { Land ROW subject to } \\
\text { variable term periods } \\
\text { determined by } \\
\text { agency/tribe with } \\
\text { jurisdiction } \\
\text { National Park System } \\
\text { ROW 50-year maximum } \\
\text { term } \\
\text { Tribal Energy Resources } \\
\text { Agreement Land ROW 30- } \\
\text { year maximum term }\end{array}$ \\
\hline & $\begin{array}{l}\text { Biological Resources } \\
\text { Eagle Non-Purposeful Take Permit } \\
\text { Essential Fish Habitat Consultation } \\
\text { Marine Mammal Incidental Take } \\
\text { Authorizations } \\
\text { Migratory Bird Special Purpose } \\
\text { Permit } \\
\text { ESA Section } 7 \text { or Section } 10 \\
\text { Consultation }\end{array}$ & $\begin{array}{l}\text { Biological Resources } \\
\text { USFWS } \\
\text { NOAA Fisheries/USFWS } \\
\text { NOAA Fisheries/USFWS } \\
\text { USFWS } \\
\text { NOAA Fisheries/USFWS }\end{array}$ & $\begin{array}{l}\text { Biological Resources Impacts } \\
\text { Migratory bird morbidity from } \\
\text { collision into poles and wires } \\
\text { Wildlife affected by habitat } \\
\text { fragmentation and reduction and } \\
\text { vegetation loss }\end{array}$ & \\
\hline & $\begin{array}{l}\text { Cultural Resources } \\
\text { NHPA Section } 106 \text { Consultation } \\
\text { Process }\end{array}$ & $\frac{\text { Cultural Resources }}{\text { SHPO, THPO, ACHP }}$ & $\begin{array}{l}\text { Cultural Resources Impacts } \\
\text { Land clearing and soil erosion } \\
\text { affecting cultural resources }\end{array}$ & \\
\hline & $\begin{array}{l}\text { Water Quality } \\
\text { CWA Section } 401 \text { Water Quality } \\
\text { Certification } \\
\text { CWA Section } 404 \text { Dredge and Fill } \\
\text { Permit }\end{array}$ & $\begin{array}{l}\text { Water Quality } \\
\text { State Agency/EPA } \\
\text { USACE/Michigan/New } \\
\text { Jersey/Florida }\end{array}$ & $\begin{array}{l}\text { Water Quality Impacts } \\
\text { Runoff of particulate matter, } \\
\text { wastewater, and other materials that } \\
\text { may leach into ground or surface } \\
\text { water }\end{array}$ & \\
\hline & $\begin{array}{l}\text { Preexisting Land Use } \\
\text { CZMA Consistency Determination } \\
\text { Wild and Scenic River Act Section } 7 \\
\text { Consultation } \\
\text { RHA Section } 10 \text { Construction } \\
\text { Permit }\end{array}$ & $\begin{array}{l}\text { Preexisting Land Use } \\
\text { State Agency } \\
\text { BLM/USFWS/NPS/USFS }\end{array}$ & & \\
\hline
\end{tabular}




\begin{tabular}{|c|c|c|c|c|}
\hline Infrastructure Tуре & $\begin{array}{c}\text { Required Permits, Approvals, } \\
\text { and Authorizations }\end{array}$ & Relevant Agency & $\begin{array}{l}\text { Common Potential } \\
\text { Environmental Impacts }\end{array}$ & $\begin{array}{c}\text { Regulatory } \\
\text { Considerations }\end{array}$ \\
\hline & $\begin{array}{l}\text { Environmental Review } \\
\text { NEPA Environmental Review } \\
\text { Process }\end{array}$ & $\frac{\text { Environmental Review }}{\text { Lead Federal Agency }}$ & & \\
\hline & $\begin{array}{l}\text { Infrastructure Specific } \\
\text { Notice of Proposed Construction or } \\
\text { Alteration } \\
\text { FERC Construction or Modification } \\
\text { Permit }\end{array}$ & $\begin{array}{l}\text { Infrastructure Specific } \\
\text { Federal Aviation } \\
\text { Administration } \\
\text { FERC }\end{array}$ & & \\
\hline \multirow[t]{4}{*}{ Natural Gas Pipeline } & $\begin{array}{l}\text { Land Access } \\
\text { BLM ROW } \\
\text { Military Land ROW } \\
\text { National Park System ROW } \\
\text { National Wildlife Refuge ROW } \\
\text { Special Use Authorization } \\
\text { Tribal Land ROW } \\
\text { Tribal Energy Resources } \\
\text { Agreement Land ROW }\end{array}$ & $\begin{array}{l}\text { Land Access } \\
\text { BLM } \\
\text { DOD } \\
\text { NPS } \\
\text { USFWS } \\
\text { USFS } \\
\text { BIA/Tribe } \\
\text { BIA/Tribe }\end{array}$ & & \\
\hline & $\begin{array}{l}\text { Biological Resources } \\
\text { Eagle Non-Purposeful Take Permit } \\
\text { Essential Fish Habitat Consultation } \\
\text { ESA Section } 7 \text { Consultation } \\
\text { Marine Mammal Incidental Take } \\
\text { Authorizations } \\
\text { Migratory Bird Special Purpose } \\
\text { Permit }\end{array}$ & $\begin{array}{l}\text { Biological Resources } \\
\text { USFWS } \\
\text { NOAA Fisheries/USFWS } \\
\text { NOAA Fisheries/USFWS } \\
\text { NOAA Fisheries/USFWS } \\
\text { USFWS }\end{array}$ & $\begin{array}{l}\text { Biological Resources Impacts } \\
\text { Wildlife affected by habitat } \\
\text { fragmentation and reduction } \\
\text { and vegetation loss } \\
\text { Wildlife morbidity and injury from } \\
\text { hazardous and flammable liquid and } \\
\text { vapor release }\end{array}$ & \\
\hline & $\begin{array}{l}\text { Cultural Resources } \\
\text { NHPA Section } 106 \text { Consultation } \\
\text { Process }\end{array}$ & $\frac{\text { Cultural Resources }}{\text { SHPO, THPO, ACHP }}$ & $\begin{array}{l}\text { Cultural Resources Impacts } \\
\text { Topographical changes affecting } \\
\text { cultural resources }\end{array}$ & \\
\hline & $\begin{array}{l}\text { Water Quality } \\
\text { CWA Section } 401 \text { Water Quality } \\
\text { Certification } \\
\text { CWA Section } 404 \text { Dredge and Fill } \\
\text { Permit }\end{array}$ & $\begin{array}{l}\text { Water Quality } \\
\text { State Agency/EPA } \\
\text { USACE/Michigan/New } \\
\text { Jersey/Florida }\end{array}$ & $\begin{array}{l}\text { Water Quality Impacts } \\
\quad \text { Periodic ROW clearings } \\
\quad \text { affecting water quality } \\
\text { Hazardous and flammable fluid and } \\
\text { vapor releases affecting water } \\
\text { quality }\end{array}$ & $\begin{array}{l}\text { Water Quality } \\
\text { Section } 401 \text { Water Quality } \\
\text { Certification is a prerequisite } \\
\text { to a FERC Certificate of } \\
\text { Public Convenience and } \\
\text { Necessity }\end{array}$ \\
\hline
\end{tabular}




\begin{tabular}{|c|c|c|c|c|}
\hline Infrastructure Туре & $\begin{array}{c}\text { Required Permits, Approvals, } \\
\text { and Authorizations }\end{array}$ & Relevant Agency & $\begin{array}{l}\text { Common Potential } \\
\text { Environmental Impacts }\end{array}$ & $\begin{array}{l}\text { Regulatory } \\
\text { Considerations }\end{array}$ \\
\hline & $\begin{array}{l}\text { Preexisting Land Use } \\
\text { CZMA Consistency Determination } \\
\text { RHA Section } 10 \text { Construction } \\
\text { Permit }\end{array}$ & $\begin{array}{l}\text { Preexisting Land Use } \\
\text { State Agency } \\
\text { USACE }\end{array}$ & & \\
\hline & $\begin{array}{l}\text { Environmental Review } \\
\text { NEPA Environmental Review } \\
\text { Process }\end{array}$ & $\begin{array}{l}\text { Environmental Review } \\
\text { FERC }\end{array}$ & & \\
\hline & $\begin{array}{l}\text { Infrastructure Specific } \\
\text { FERC Certificate of Public } \\
\text { Convenience and Necessity }\end{array}$ & $\frac{\text { Infrastructure Specific }}{\text { FERC }}$ & & 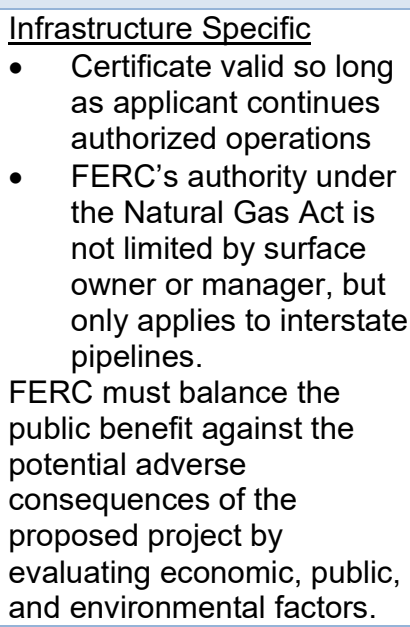 \\
\hline $\begin{array}{l}\text { Coal and Natural Gas } \\
\text { Power Plants }\end{array}$ & $\begin{array}{l}\text { Air Quality } \\
\text { Clean Air Act Title V Operating } \\
\text { Permit } \\
\text { Acid Rain Permit } \\
\text { Minor New Source Review Permit } \\
\text { National Emission Standards for } \\
\text { Hazardous Air Pollutants Approval } \\
\text { New Source Performance } \\
\text { Standards } \\
\text { Non-Attainment New Source } \\
\text { Review Permit } \\
\text { Prevention of Significant } \\
\text { Deterioration Permit }\end{array}$ & $\begin{array}{l}\text { Air Quality } \\
\text { State Agency/EPA } \\
\text { State Agency/EPA } \\
\text { State Agency/EPA } \\
\text { State Agency/EPA } \\
\text { State Agency/EPA } \\
\text { State Agency/EPA } \\
\text { State Agency/EPA }\end{array}$ & $\begin{array}{l}\text { Air Quality Impacts } \\
\text { Impacts to air quality from volatile } \\
\text { organic compound and particulate } \\
\text { matter }\end{array}$ & \\
\hline
\end{tabular}




\begin{tabular}{|c|c|c|c|c|}
\hline \multirow[t]{2}{*}{ Infrastructure Tyрe } & \multicolumn{2}{|l|}{$\begin{array}{c}\text { Required Permits, Approvals, } \\
\text { and Authorizations }\end{array}$} & \multirow[t]{2}{*}{$\begin{array}{l}\text { Common Potential } \\
\text { Environmental Impacts }\end{array}$} & \multirow[t]{2}{*}{$\begin{array}{l}\text { Regulatory } \\
\text { Considerations }\end{array}$} \\
\hline & $\begin{array}{l}\text { Land Access } \\
\text { BLM ROW } \\
\text { Military Land ROW } \\
\text { National Park System ROW } \\
\text { National Wildlife Refuge ROW } \\
\text { Special Use Authorization } \\
\text { Tribal Land ROW } \\
\text { Tribal Energy Resources } \\
\text { Agreement Land ROW }\end{array}$ & $\begin{array}{l}\text { Land Access } \\
\text { BLM } \\
\text { DOD } \\
\text { NPS } \\
\text { USFWS } \\
\text { USFS } \\
\text { BIA/Tribe } \\
\text { BIA/Tribe }\end{array}$ & & \\
\hline & $\begin{array}{l}\text { Biological Resources } \\
\text { Eagle Non-Purposeful Take Permit } \\
\text { Essential Fish Habitat Consultation } \\
\text { Marine Mammal Incidental Take } \\
\text { Authorizations } \\
\text { Migratory Bird Special Purpose } \\
\text { Permit } \\
\text { ESA Section } 7 \text { or Section } 10 \\
\text { Consultation }\end{array}$ & $\begin{array}{l}\text { Biological Resources } \\
\text { USFWS } \\
\text { NOAA Fisheries/USFWS } \\
\text { NOAA Fisheries/USFWS } \\
\text { USFWS } \\
\text { NOAA Fisheries/USFWS }\end{array}$ & $\begin{array}{l}\text { Biological Resources Impacts } \\
\quad \text { Wildlife affected by habitat } \\
\text { fragmentation and reduction } \\
\text { and vegetation loss } \\
\text { Fish and other aquatic species } \\
\text { impacts from entrainment and } \\
\text { impingement at cooling water intake } \\
\text { structures. }\end{array}$ & \\
\hline & $\begin{array}{l}\text { Cultural Resources } \\
\text { NHPA Section } 106 \text { Consultation } \\
\text { Process }\end{array}$ & $\frac{\text { Cultural Resources }}{\text { SHPO, THPO, ACHP }}$ & & \\
\hline & $\begin{array}{l}\text { Water Quality } \\
\text { CWA Section } 401 \text { Water Quality } \\
\text { Certification } \\
\text { CWA Section } 402 \text { NPDES Permit } \\
\text { CWA Section } 404 \text { Dredge and Fill } \\
\text { Permit }\end{array}$ & $\begin{array}{l}\text { Water Quality } \\
\text { State Agency/EPA } \\
\text { State Agency/EPA } \\
\text { USACE/Michigan/New } \\
\text { Jersey/Florida }\end{array}$ & $\begin{array}{l}\text { Water Quality Impacts } \\
\text { Potential impacts cooling water } \\
\text { discharges, including water } \\
\text { temperature and water quality } \\
\text { impacts from proprietary biocides, } \\
\text { corrosion and scale inhibitors (such } \\
\text { as phosphates), chlorine, and other } \\
\text { substances from operation activities }\end{array}$ & \\
\hline & $\frac{\text { Preexisting Land Use }}{\text { CZMA Consistency Determination }}$ & $\frac{\text { Preexisting Land Use }}{\text { State Agency }}$ & & \\
\hline & $\begin{array}{l}\text { Environmental Review } \\
\text { NEPA Environmental Review } \\
\text { Process }\end{array}$ & $\frac{\text { Environmental Review }}{\text { Lead Federal Agency }}$ & & \\
\hline
\end{tabular}




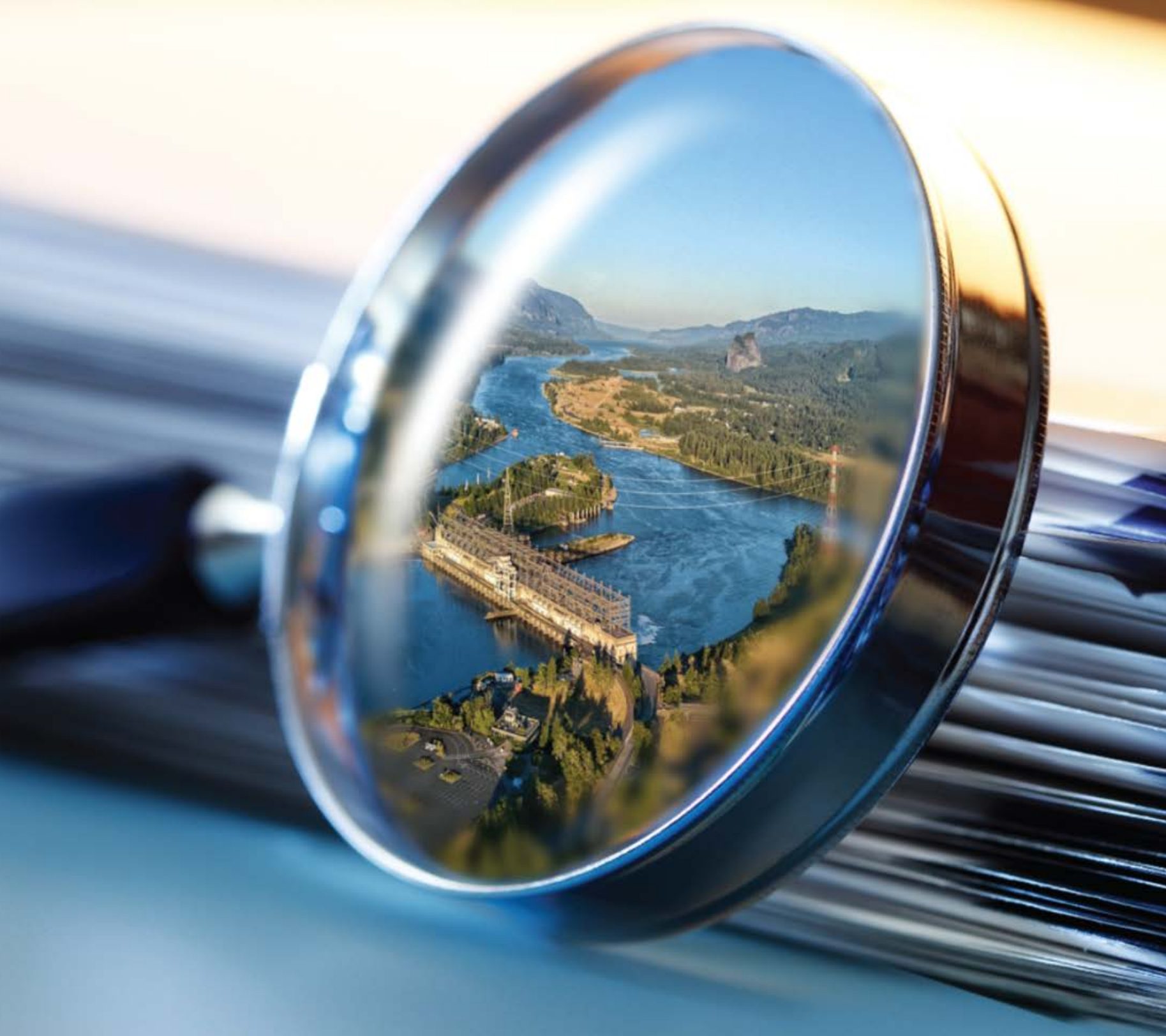

AN EXAMINATION OF THE HYDROPOWER LICENSING AND FEDERAL AUTHORIZATION PROCESS

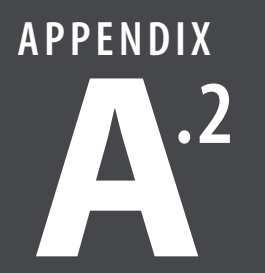

International Hydropower Project Review: Regulatory Approvals for Hydropower Projects in Canada, Sweden, and Norway 


\section{Appendix A.2. International Hydropower Project Review: Regulatory Approvals for Hydropower Projects in Canada, Sweden, and Norway}

This appendix provides an overview of the statutory and regulatory frameworks governing hydropower development in Canada, Sweden, and Norway, which are among the world's top producers of hydroelectric power internationally (Myers 2015). In addition, because Sweden is a member state of the European Union and Norway is part of the European Economic Agreement, this appendix also contains a synopsis of the European Union directives related to hydropower development, which Sweden and Norway have incorporated into their national statutory schemes.

Specifically, this appendix discusses statutory and regulatory frameworks governing hydropower development within the aforementioned countries as they relate to the following:

- Land access and energy facility licensing laws

- Environmental review laws

- Biological resources protection laws

- Cultural resources protection laws

- Water quality laws

- Other development restriction laws.

For a discussion and summary table that compares the statutory and regulatory frameworks governing hydropower development within the aforementioned countries to those found in the United States, see Chapter 2 of this report.

\section{Canada}

Canada is the fourth-largest hydropower producer in the world with a total installed capacity of 81 GW (International Hydropower Association [IHA] 2018). Hydropower accounts for approximately $64 \%$ of total electricity generation in Canada (IHA 2018). Most hydropower facilities in Canada are owned and operated by crown corporations; however, it is estimated that Canada has over 1,000 independent owners of hydropower installations (Ball 2016).

\section{Canadian Regulatory Framework}

Hydropower development in Canada is regulated by the federal government, provinces, and certain territories within their respective jurisdictions (Indigenous and Northern Affairs Canada [INAC] 2019). Canada's federal government is responsible for managing hydropower development on federal lands, First Nation reserves, and the Nunavut and Northwest Territories (INAC 2019). Canada's ten provinces own — and have legislative authority over-hydropower development within their jurisdictions (INAC 2019). In addition, the Yukon Territory has responsibility for hydropower development within its jurisdiction (INAC 2019). ${ }^{51}$ Generally, authority for hydropower development falls within provincial jurisdiction; however, federal

\footnotetext{
${ }^{51}$ For the purposes of this chapter, the Yukon Territory is included in references to provincial authority to regulate hydropower.
} 
participation may be required if the project requires the use of federally managed resources (e.g., water navigation and shipping areas, coastal areas, or federally managed fisheries).

\section{The Role of Public Participation}

In Canada, the public has a growing role in the authorization process for hydropower projects. Most provinces and territories have enacted their own environmental assessment statutes and regulations, which require public participation throughout the assessment process. In addition, since 2019, hydropower projects may be subject to a federal environmental assessment process through the Impact Assessment Act (IAA), which requires public participation throughout the assessment process. Specifically, the IAA requires that a project proponent consult with the public prior to submitting assessment documentation and provide an opportunity for the public to comment on a project's potential environmental, health, social, and economic impacts (IAA 2019).

\section{Key Canadian Statutes}

Canadian hydropower development is governed by several federal statutes, which require that project proponents consider impacts to land, biological resources, cultural resources, and water quality. In addition to federal law, each Canadian province and certain territories have enacted laws that apply to hydropower development within their respective jurisdiction. Both federal and provincial governments may be required to consult with and accommodate Aboriginal peoples prior to authorizing hydropower projects. Federal and provincial governments may delegate procedural aspects of Aboriginal consultation and accommodation requirements to project proponents.

\section{Land Access and Energy Facility Licensing Laws}

In Canada, there is no federal facility licensing process for hydropower projects. Rather, each province or territory has its own laws governing hydropower project licensing, construction, operation, and maintenance. Accordingly, hydropower licensing terms vary by province. ${ }^{52}$ Hydropower project proponents may need to obtain land access rights from a provincial agency if a project will be on public land under its jurisdiction.

\section{Crown Land Tenure}

Hydropower project proponents may need to obtain Crown Land Tenure (i.e., land access rights) from the provincial/territorial agency with jurisdiction if a project is planned on Crown Land (West Coast Environmental Law Group [WCEL] 2009). Crown Land is public land, which is owned by the federal or provincial government (R.S., c. 114, s. 1). Crown Land Tenure includes occupation licenses, leases, rights-of-way, and easements to access Crown Land (WCEL 2009).

\footnotetext{
${ }^{52}$ In Canada, license terms for hydropower projects may vary by province. For example, pursuant to the Manitoba Water Power Act, the provincial government of Manitoba may issue a hydropower license for a 30-50 year term before a project proponent must seek a renewal (C.C.S.M. c. W60). However, in Ontario, pursuant to the Water Sustainability Act, the maximum licensing term for a hydropower project is 40 years before a project proponent must seek a renewal (S.B.C. 2014, c. 15). By contrast, in Quebec, pursuant to the Hydro-Quebec Act, hydropower licenses are granted in perpetuity; however, provincial authorities have the power to suspend an operator's license if operating conditions are not met (C.Q.L.R. c. H-5).
} 
Most Canadian hydropower projects are proposed on public land and therefore require Crown Land Tenure prior to development (WCEL 2009).

\section{Environmental Review Laws}

In Canada, hydropower project proponents must comply with an environmental review process to take into account project impacts on human health and the environment prior to project construction pursuant to the IAA. ${ }^{53}$ The project proponent is responsible for initiating IAA review with the Impact Assessment Agency of Canada. In addition to federal law, many Canadian provinces and territories, including Quebec, Ontario, and British Columbia, have also enacted environmental laws that apply to hydropower development within their respective jurisdiction. Accordingly, environmental protection may fall under concurrent federal and provincial/territorial government jurisdiction depending on a project's location.

\section{Impact Assessment Act}

Hydropower project proponents must initiate IAA review with the Impact Assessment Agency prior to commencing project construction (S.C. 2019, c. 28, s. 1). The purpose of the IAA is to protect the environment, health, social and economic conditions of Canada (S.C. 2019, c. 28, s. 1). The Impact Assessment Agency is responsible for guiding hydropower projects through the IAA review process and coordinating environmental review with other federal agencies and indigenous groups (S.C. 2019, c. 28, s. 1). IAA review may result in an Impact Assessment Report, which analyzes hydropower project impacts on biological, cultural, Indigenous and economic resources (S.C. 2019, c. 28, s. 1).

\section{Biological Resources Protection Laws}

In Canada, hydropower project proponents must consider the potential impacts of a project on biological resources prior to commencing project construction pursuant to the Species At Risk Act (SARA), Migratory Birds Convention Act, and Fisheries Act. The project proponent is responsible for consulting with Canadian federal resource agencies to consider the project's impacts on endangered species, birds, and fisheries. In addition to federal law, many Canadian provinces and territories have enacted environmental laws to protect biological resources that apply to hydropower development within their respective jurisdictions. Accordingly, protection of biological resources may fall under concurrent federal and provincial/territorial jurisdiction depending on a project's location.

\section{Species At Risk Act}

Hydropower project proponents must consult with the Department of Environment and Climate Change Canada, Parks Canada Agency, and/or Department of Fisheries and Oceans Canada if a project may affect a listed species at risk pursuant to SARA (S.C. 2002, c. 29, s. 1). ${ }^{54}$

\footnotetext{
${ }^{53}$ In June 2019, Canada's Bill C-69 amended the Impact Assessment Act, the Canadian Energy Regulatory Act, and the Navigable Water Act (also known as the Navigation Protection Act) (Bill C-69; IAA 2019). The IAA became law on August 28, 2019 (IAA 2019).

${ }^{54}$ Canada's Bill C-69 that amended the Impact Assessment Act, the Canadian Energy Regulatory Act, and the Navigable Water Act (also known as the Navigation Protection Act) also requires regulatory changes to SARA and these regulatory changes are still pending (Bill C-69; IAA 2019).
} 
The purpose of SARA is to prevent wildlife species from becoming extinct, provide for the recovery of wildlife species ${ }^{55}$ that are endangered or threatened, and to manage species of special concern. (S.C. 2002, c. 29, s. 6). The SARA consultation process may result in an environmental assessment that contains an analysis of a project's impacts on listed species (S.C. 2002, c. 29, s. 32). Following the conclusion of the SARA consultation process, a project proponent may need to obtain a SARA Section 73 permit if a project may affect a listed wildlife species or critical habitat (S.C. 2002, c. 29, s. 73).

\section{Migratory Birds Convention Act}

Hydropower project proponents may need an authorization or permit from Environment and Climate Change Canada and/or the provincial government agency with jurisdiction if a project may disturb, harm, or kill migratory birds pursuant to the Migratory Birds Convention Act (S.C. 1994, c. 22, s. 12). The purpose of the Migratory Birds Convention Act is to protect and conserve migratory birds and their nests (S.C. 1994, c. 22, s. 4).

\section{Fisheries Act}

Hydropower project proponents must consult with Fisheries and Oceans Canada if a project may result in the alteration, disruption, or destruction of fish habitat pursuant to the Fisheries Act (R.S.C. 1985, c. F-14, s. 1). The purpose of the Fisheries Act is to provide a framework for the proper management and control of fisheries and the conservation and protection of fish and fish habitat (R.S.C. 1985, c. F-14, s. 2.1). Fisheries and Oceans Canada may impose conditions and/or modifications to a hydropower project's plans or operations to prevent and/or mitigate impacts to fisheries and/or fishery resources (R.S.C. 1985, c. F-14, s. 1).

\section{Cultural Resources Protection Laws}

In Canada, hydropower project proponents must consider the potential impacts of a project on cultural resources prior to commencing project construction pursuant to the IAA. An analysis of impacts on cultural resources is included as a component of the IAA environmental review process. The project proponent is responsible for initiating IAA review with the Impact Assessment Agency of Canada.

\section{Impact Assessment Act}

Hydropower project proponents may need to conduct an assessment of project impacts to structures, sites, or things of historic, archaeological, paleontological, or architectural significance pursuant to the IAA (S.C. 2019, c. 28, s. 1). The purpose of the IAA is to protect the environment, health, social, and economic conditions of Canada (S.C. 2019, c. 28, s. 1). IAA review may result in an Impact Assessment Report that must contain a description and analysis

\footnotetext{
${ }^{55}$ Wildlife means "a species, subspecies, variety, or geographically or genetically distinct population of animal, plant or other organism, other than a bacterium or virus, that is wild by nature and: (a) is native to Canada; or (b)has extended its range into Canada without human intervention and has been present in Canada for at least 50 years." S.C. 2002 , c. 29 , s. 2.
} 
of potential hydropower project impacts on cultural resources, including indigenous cultural resources (S.C. 2019 , c. 28 , s. 1$){ }^{56}$

\section{Water Quality Laws}

In Canada, hydropower project proponents must consider the impacts of projects on navigable waters prior to commencing project construction pursuant to the Canadian Navigable Waters Act. The project proponent is responsible for consulting with Transport Canada to determine whether an approval or permit is required for project activities.

\section{Canadian Navigable Waters Act}

Hydropower project proponents may need an approval or permit from Transport Canada to dredge and fill navigable waters or to construct or alter any structure, device, or thing (e.g., dam, conduit) located in, on, over, under, through, or across navigable water pursuant to the Canadian Navigable Waters Act (R.S.C., 1985, c. N-22). ${ }^{57}$ The Canadian Navigable Waters Act protects the public's right to navigation and marine safety in the navigable waters of Canada and applies to any body of water that is navigable by a floating canoe (R.S.C., 1985, c. N-22).

\section{Other Development Restriction Laws}

In Canada, hydropower project proponents may be restricted from developing projects in certain areas that are designated as national wildlife areas pursuant to the Wildlife Act. The project proponent is responsible for consulting with Environment and Climate Change Canada to determine whether an approval or permit is required for project activities in national wildlife areas.

\section{Wildlife Act}

Hydropower project proponents may need a permit from Environment and Climate Change Canada if a project takes place on federally-owned or leased lands established as national wildlife areas pursuant to the Wildlife Act (R.S.C., 1985, c. W-9, s. 1). The purpose of the Wildlife Act is to protect national wildlife areas from environmental degradation and require permits for certain activities conducted within national wildlife areas (R.S.C., 1985, c. W-9, s. 1).

\section{European Union}

The European Union (EU) has enacted directives, which are applicable to hydropower development in EU member countries pursuant to the Treaty on the Functioning of the European Union. ${ }^{58}$ EU Directives are binding legal acts that require member countries to achieve a certain result but leave countries free to choose how to do so (European Commission [EC] 2019a). EU

\footnotetext{
${ }^{56}$ Canada is currently in the process of developing new statutory and regulatory procedures for analyzing project impacts to cultural resources. A hydropower project proponent should consult with the Impact Assessment Agency and/or provincial agency with jurisdiction to determine whether a project requires consultation and/or an assessment with respect to protection of cultural resources pursuant to the IAA or other applicable federal statute.

${ }^{57}$ Canada's Bill C-69 amended the Navigable Water Act (also known as the Navigation Protection Act) and these regulatory changes are still pending (Bill C-69; IAA 2019).

${ }^{58}$ Consolidated Version of the Treaty on the Functioning of the European Union, 26.10.2012, pt. 6, tit. 1, ch. 2 , s. 1.
} 
countries must adopt measures to incorporate directives into their national law schemes (EC 2019a).

\section{EU Directives Applicable to Hydropower Development}

There are several EU Directives aimed at protecting Europe's freshwater and marine environments that are applicable to hydropower, including:

- Habitats Directive

- Birds Directive

- Water Framework Directive

- Marine Strategy Framework Directive

- Floods Directive

- Environmental Assessments Directives.

\section{Birds and Habitats Directive}

The Birds Directive establishes a framework to protect wild birds and their habitats (EC 2016). The Habitats Directive establishes a framework to protect threatened or endangered wildlife, plants, and habitat (EC 2016). Together, these two directives establish a network of protected sites and provide a strict regime to protect listed species (EC 2016). The Birds and Habitats directives ensure that protected species and their habitats are maintained and restored to a specified conservation status throughout their natural range within the EU (EC 2016).

\section{Marine Strategy Framework Directive}

The Marine Strategy Framework Directive establishes a framework to protect marine environments across Europe (EC 2019b). The Marine Strategy Framework Directive protects marine biodiversity and creates an ecosystem-based framework to manage human activities that have an impact on the European marine environment (EC 2019b). The Marine Strategy Framework Directive integrates the concepts of environmental protection and sustainable use in its framework and requires that each member state create a strategy for its marine waters (EC 2019b).

\section{Water Framework Directive}

The Water Framework Directive establishes a framework to protect and manage inland surface waters, estuaries, coastal waters, groundwater, and wetlands and their ecosystems (EC 2019b). The Water Framework Directive requires that each EU member country establish a river basin management plan for each river basin district and assess the impacts of hydropower development on all water bodies (EC 2019b).

\section{Floods Directive}

The Floods Directive establishes a framework to reduce and manage the risks that floods pose to human health, the environment, cultural heritage, and economic activity (EC 2016). The Floods Directive requires that EU member countries design flood risk management plans that take into account the characteristics of specific river basins and develop measures for flood prevention and preparedness (EC 2016). 


\section{Environmental Assessments Directives}

The Environmental Assessments Directives provide a framework to protect the European environment (EC 2018). The Environmental Assessments Directives require that member states consider environmental consequences of public and private projects before any action is taken (EC 2018).

\section{Sweden}

Sweden is the $15^{\text {th }}$ largest hydropower producer in the world with a total installed capacity of $16.5 \mathrm{GW}$ (IHA 2018). Hydropower accounts for approximately 50\% of total electricity generation in Sweden (IVA 2016). Approximately 50\% of Swedish hydropower production is owned by public entities (International Atomic Energy Association 2014).

\section{Swedish Regulatory Framework}

Hydropower development in Sweden is primarily regulated at the regional level through five Land and Environment Courts and five County Administrative Boards (Water Authorities 2019; Kohler and Ruud 2019; Rudberg et al. 2015). Sweden's water resources are divided into five river basin districts (Water Authorities 2019; Kohler and Ruud 2019; Rudberg et al. 2015). Land and Environment Courts and County Administrative Boards share jurisdiction over hydropower development within each of the five river basin districts (Water Authorities 2019; Kohler and Ruud 2019; Rudberg et al. 2015). Land and Environment Courts have authority to issue licenses for the construction, operation, and maintenance of hydropower projects within their jurisdiction (Water Authorities 2019; Kohler and Ruud 2019; Rudberg et al. 2015). County Administrative Boards are responsible for water use and management within their jurisdictions, including the creation and implementation of river basin management plans (Water Authorities 2019; Kohler and Ruud 2019; Rudberg et al. 2015).

\section{The Role of the Public Participation}

In Sweden, the public plays a key role in the authorization process for hydropower projects. The public may participate formally or informally in the hydropower licensing process by consulting with the project proponent, providing public opinion, and engaging in approval hearings. For example, the Swedish Environmental Code (SEC) requires that the project proponent consult with members of public who may be affected by the development of a hydropower project (SEC 2000, Ds 2000:61, c. 6, s. 4; Swedish EPA 2017). In addition, the SEC also provides an opportunity for the public to comment on a permit to construct, operate, or maintain a hydropower project and to participate during related hearings (SEC 2000, Ds 2000:61, c. 11, s. 9; Swedish EPA 2017).

\section{Key Swedish Statutes}

As a member state of the EU, Sweden is subject to the EU environmental directives discussed in Section 4.2. In 1999, Sweden enacted the SEC to implement the EU's environmental directives (Swedish EPA 2017). 
The SEC is Sweden's primary statute governing hydropower development (SEC 2000, Ds 2000:61). ${ }^{59}$ The SEC requires that hydropower project proponents obtain a permit from the Land and Environment Court with jurisdiction to construct, operate, and maintain a hydropower project (SEC 2000, Ds 2000:61, c. 11, s. 9). The SEC also requires that hydropower project proponents conduct a review of project impacts to environmental resources prior to obtaining a license (SEC 2000, Ds 2000:61, c. 6, s. 1). Moreover, the SEC limits and/or prohibits hydropower development on specific water bodies that have cultural significance and/or contain protected biological resources (SEC 2000, Ds 2000:61, c. 4, s. 1). In addition to SEC requirements, hydropower project proponents should consult with the County Administrative Board with jurisdiction to ensure that projects are in compliance with the applicable river basin management plan in place (Rudberg et al. 2015).

At the direction of the EU, Sweden is currently in the process of developing a more comprehensive hydropower licensing procedure ${ }^{60}$ that takes into account project impacts to biological, wildlife, and cultural resources and establishes a license review and renewal procedure (SwAM 2019a; SwAM 2019b; Rudberg et al. 2015).

\section{Land Access and Energy Facility Licensing Laws}

In Sweden, there is no national facility licensing process for hydropower projects. Rather, each of the five regional Land and Environment Courts is responsible for permitting hydropower project construction, operation, and maintenance within their respective jurisdictions (SEC 2000, Ds 2000:61, c. 11, s. 9). A hydropower project proponent may need a water operations permit from a Land and Environment Court to construct, operate, and maintain a project. water operations permits are granted in perpetuity (Lindstrom and Ruud 2017). In addition, hydropower project proponents should consult with the County Administrative Board with jurisdiction to ensure that the hydropower project is in compliance with any applicable river basin management plan (Rudberg et al. 2015).

\section{Swedish Environmental Code Chapter 11}

Hydropower project proponents must obtain a water operations permit from the Land and Environment Court with jurisdiction to construct, operate and, maintain a hydropower facility pursuant to SEC Chapter 11 (SEC 2000, Ds 2000:61, c. 11, s. 9). The purpose of SEC Chapter 11 is to ensure that the economic and social benefits of a hydropower project outweigh any associated impacts to environmental, social, and biological resources (SEC 2000, Ds 2000:61, c. 11, s. 6). The Land and Environment Courts grant Water Operations Permits in perpetuity and have discretion to impose conditions related to environmental and biological resource protection and conservation (e.g., implementation of resource protection and mitigation measures) (Lindstrom and Ruud 2017; Glachant et al. 2014).

\footnotetext{
${ }^{59}$ Swedish Environmental Code, Ds 2000:61, https://www.government.se/legal-documents/2000/08/ds-200061/. ${ }^{60}$ Prior to the enactment of the Environmental Code, hydropower development in Sweden was licensed pursuant to the Water Law, which did not require consideration of project impacts on environmental resources. In addition, all hydropower licenses in Sweden are granted in perpetuity. Accordingly, 90\% of Sweden's hydropower facilitieswhich were licensed under the Water Law - are exempt from environmental considerations under the Environmental Code. Sweden is currently in the process of drafting hydropower legislation, which would establish term limits for licenses and comprehensive environmental review procedures (Lindstrom and Ruud 2017).
} 


\section{Environmental Review Laws}

In Sweden, hydropower project proponents must comply with an environmental review process to consider project impacts on human health and the environment before a Land and Environment Court issues a water operations permit pursuant to SEC Chapter 6 (SEC 2000, Ds 2000:61, c. 6, s. 1). The project proponent is responsible for conducting environmental review and initiating consultation with the County Administrative Board with jurisdiction and any private individual who may be affected by the project. (Ds 2000:61, c. 6, s. 4).

\section{Swedish Environmental Code Chapter 6}

Hydropower project proponents must conduct an environmental review analyzing project impacts on human health and the environment pursuant to SEC Chapter 6 (SEC 2000, Ds 2000:61, c. 6, s. 1). The purpose of SEC Chapter 6 is to establish a process to review projects likely to have significant impacts on the environment, including hydropower projects (SEC 2000, Ds 2000:61, c. 6, s. 2, 3). Environmental review conducted pursuant to SEC Chapter 6 may result in an EIS that analyzes project impacts on biological, environmental. and cultural resources as well as any project alternatives and may provide measures to avoid and/or mitigate any impacts to resources (SEC 2000, Ds 2000:61, c. 6, s. 2, 3 and 7). SEC Chapter 6 review is managed by the project proponent, who is responsible for consulting and coordinating review with the County Administrative Board with jurisdiction and/or any individuals who may affected by the project (SEC 2000, Ds 2000:61, c. 6, s. 5).

\section{Biological Resources Protection Laws}

Sweden is currently in the process of developing a comprehensive hydropower licensing procedure, which takes into account project impacts to biological resources (Lindstrom and Ruud 2017; SwAM 2019b). A hydropower project proponent should consult with the County Administrative Board with jurisdiction to ensure that the hydropower project is in compliance with any applicable river basin management plan with respect to protection of biological resources (Rudberg et al. 2015).

\section{Cultural Resources Protection Laws}

Sweden is currently in the process of developing a comprehensive hydropower licensing procedure, which takes into account project impacts to cultural resources (Lindstrom and Ruud 2017; SwAM 2019b).

\section{Water Quality Laws}

Sweden is currently in the process of developing a comprehensive hydropower licensing procedure, which takes into account project impacts to water quality (Lindstrom and Ruud 2017; SwAM 2019b). A hydropower project proponent should consult with the County Administrative Board with jurisdiction to ensure that the hydropower project is in compliance with any applicable river basin management plan with respect to water quality (Rudberg et al. 2015).

\section{Other Development Restriction Laws}

In Sweden, hydropower project proponents may be restricted from developing projects in certain rivers and waterways, which are defined and listed in SEC Chapter 4. 


\section{Swedish Environmental Code Chapter 4}

Hydropower project proponents are prohibited from developing projects in certain rivers and waterways pursuant to SEC Chapter 4 (SEC 2000, Ds 2000:61, c. 4, s. 6). The purpose of SEC Chapter 4 is to protect specific rivers and waterways that have national and cultural significance because of their natural assets (SEC 2000, Ds 2000:61, c. 4, s. 1). The Swedish Environmental Protection Agency is responsible for enforcing the prohibitions within SEC Chapter 4. SEC Chapter 4 specifically prohibits any hydropower development within 4 national rivers and 20 water areas as well as their source rivers and tributaries (SEC 2000, Ds 2000:61, c. 4, s. 6).

\section{Norway}

Norway is the $9^{\text {th }}$ largest hydropower producer in the world with a total installed capacity of 31.8 GW (IHA 2018). Hydropower accounts for more than $95 \%$ of total electricity generation in Norway (IHA 2018). Approximately $90 \%$ of Norwegian hydropower production is owned by public entities (Norwegian Ministry of Petroleum and Energy [NMPE] 2015).

\section{Norwegian Regulatory Framework}

Hydropower development in Norway in primarily regulated at a national level through the King in Council, the Ministry of Petroleum and Energy (MPE), and Norwegian Water Resources and Energy Directorate (NVE) (NMPE 2015). Pursuant to the Constitution, the King in Council is the monarch exercising executive authority in Norway (NMPE 2015). The NVE is the national regulatory authority responsible for managing Norway's water and energy resources and reports to the MPE (NMPE 2015).

The King in Council has primary licensing authority over hydropower projects that have an installed capacity exceeding 10 MW (NMPE 2015). In some instances, for large projects or projects of major public interest, the Parliament must be consulted before the King in Council can issue a license. The King in Council delegates licensing authority to the NVE for hydropower projects that have an installed capacity of less than 10 MW (NMPE 2015). Regardless of project size, the NVE is the primary regulatory entity responsible for guiding hydropower projects through the licensing application process in Norway, which may include initiating environmental review and consultation procedures with national resource agencies, local government bodies, and individuals affected by a hydropower project (NMPE 2015). For projects with an installed capacity of more than $10 \mathrm{MW}$, NVE provides recommendations to the MPE, which subsequently presents a proposal to the King in Council for a decision.

\section{The Role of Public Participation}

In Norway, the public plays a key role in the authorization process for hydropower projects. The public may participate formally or informally in the hydropower licensing process by consulting with the project proponent, providing public comment, and engaging in stakeholder meetings, hearings, and appeal processes. For example, the Planning and Building Act provides an opportunity for the public to comment on the impacts a hydropower project may have on biological, environmental, and cultural resources and to participate during related meetings and hearings (Act No. 71 of 27 June 2008; NMPE 2015). In addition, the Water Resources Act and the Watercourse Regulation Act regulations require that the proponent consult with members of the public who may be affected by the development of a hydropower project, and both acts provide an opportunity for the public to comment on the license to construct, operate, and 
maintain a hydropower project (Act No. 17 of 14 December 1917; NMPE 2019; Act No. 82 of 24 November 2000; NMPE 2015).

\section{Key Norwegian Statutes}

Norway is associated with the EU through its inclusion in the European Economic Area Agreement (NMPE 2015). Accordingly, Norway is subject to certain EU directives discussed in Section 4.2, including the Water Framework Directive (NMPE 2019). The Water Framework Directive has been implemented in Norwegian law through several statutes, which require that hydropower project proponents consider impacts to land, biological resources, cultural resources, and water quality (NMPE 2019).

\section{Land Access and Energy Facility Licensing Laws}

In Norway, a hydropower project proponent may need a license from the King in Council and/or NVE to construct, operate, and maintain a project. Hydropower projects with an installed capacity that exceeds $10 \mathrm{MW}$ require a license from the King in Council pursuant to the Watercourse Regulation Act. Pursuant to the Watercourse Regulation Act, hydropower projects with an installed capacity that exceeds $10 \mathrm{MW}$ may be issued a license for a 30-50 year term (Knudsen and Ruud 2011). ${ }^{61}$ Hydropower projects with an installed capacity of $10 \mathrm{MW}$ or less require a license from the NVE pursuant to the Water Resources Act. NVE licensing decisions may be appealed to the MPE. Hydropower projects with an installed capacity of $10 \mathrm{MW}$ or less are generally granted licenses in perpetuity; however, the NVE has the authority to revoke a license or impose additional terms on a license if the NVE determines that the project is causing adverse, unforeseen environmental impacts not contemplated in the original licensing process (Knudsen and Ruud 2011). In addition, a hydropower project proponent may need a license from NVE to gain access rights to waterfalls pursuant to the Waterfall Rights Act.

\section{Watercourse Regulation Act}

Hydropower project proponents may need to obtain a license from the King in Council to construct, operate, and maintain hydropower projects with an installed capacity exceeding 10 MW, or with $40 \mathrm{GWh}$ of mean annual production, pursuant to the Watercourse Regulation Act (Act No. 17 of 14 December 1917). ${ }^{62}$ The purpose of the Watercourse Regulation Act is to establish a licensing procedure for larger hydropower projects to ensure sustainable use of water resources and regulate access to river systems used for hydropower development (Act No. 17 of 14 December 1917; NMPE 2019). The King in Council may prescribe a variety of hydropower license conditions related to permissible water usage as well as environmental conditions, fees, and taxes on the local and national level (NMPE 2015).

\footnotetext{
${ }^{61}$ The time frame for licenses granted pursuant to the Watercourse Regulation Act varies depending on the date the original license was granted. Hydropower licenses granted prior to 1972 are subject to 50-year terms. Licenses granted after 1992 are subject to 30-year terms (Knudsen and Ruud 2011).

${ }^{62}$ Watercourse Regulation Act, No. 17 of 14 December 1917. https://www.regjeringen.no/globalassets/upload/oed/vedlegg/lover-og-reglement/act_no 17of 14 december 1917.pdf.
} 


\section{Water Resources Act}

Hydropower project proponents may need to obtain a license from the NVE to construct, operate, and maintain small hydropower projects, which have an installed capacity of less than $10 \mathrm{MW}$ pursuant to the Water Resources Act (Act No. 82 of 24 November 2000). ${ }^{63}$ The purpose of the Water Resources Act is to establish a licensing procedure for small hydropower projects to ensure socially proper use and management of river systems and groundwater (Act No. 82 of 24 November 2000). NVE may prescribe hydropower license conditions to ensure compensation for damage or to mitigate environmental damage caused by the project (Act No. 82 of 24 November 2000; NMPE 2019). NVE licensing decisions may be appealed to the MPE.

\section{Waterfall Rights Act}

Hydropower project proponents may need to obtain a license from the King in Council if a hydropower project, with an installed capacity that exceeds $10 \mathrm{MW}$, requires access rights to a waterfall pursuant to the Waterfall Rights Act (Act No. 16 of 14 December 1917). ${ }^{64}$ In certain circumstances (e.g., large projects or projects of public interest), the Parliament must be consulted before the King in Council may issue a license. The purpose of the Waterfall Rights Act is to ensure that hydropower resources are managed in the country's best interest through public ownership of hydropower resources at national, county, and municipal levels (NMPE 2019). Only publicly owned hydropower projects (e.g., hydropower projects of which $2 / 3$ ownership is vested in the state, county, or municipality) are eligible for waterfall access licenses granted pursuant to the Waterfall Rights Act (NMPE 2019).

\section{Environmental Review Laws}

In Norway, hydropower project proponents must comply with an environmental review process to take into account project impacts on human health and the environment prior to obtaining a license to construct, operate and maintain a project pursuant to the Planning and Building Act. The project proponent is responsible for initiating consultation with the Ministry of Local Government and Modernization and NVE.

\section{Planning and Building Act}

Hydropower project proponents must conduct an environmental review analyzing project impacts on human health and the environment pursuant to the Planning and Building Act (Act No. 71 of 27 June 2008). ${ }^{65}$ The purpose of the Planning and Building Act is to safeguard land resources, landscape qualities, and the conservation of valuable landscapes and cultural environments (Act No. 71 of 27 June 2008). Environmental review conducted pursuant to the Planning and Building Act may result in an EIA, which analyzes project impacts on biological, environmental, and cultural resources as well as any project alternatives, and may provide

\footnotetext{
${ }^{63}$ Water Resources Act, No. 82 of 24 November 2000. https:/www.regjeringen.no/globalassets/upload/oed/vedlegg/lover-ogreglement/act no 82 of 24 november_2000.pdf.

${ }^{64}$ Waterfall Rights Act, $\bar{N}$. 16 of 14 December 1917.

https:/www.regjeringen.no/globalassets/upload/oed/vedlegg/lover-ogreglement/act no 16 of 14 december_1917.pdf.

${ }^{65}$ Planning and Building Act, No. 71 of 27 June 2008. https://www.regjeringen.no/en/dokumenter/planningbuilding-act/id570450/.
} 
measures to avoid and/or mitigate any impacts to resources (Act No. 71 of 27 June 2008). Planning and Building Act review is managed by the project proponent, who is responsible for consulting and coordinating review with the NVE and the Ministry of Local Government and Modernization, local government bodies, and individuals who may be affected by the project (Act No. 71 of 27 June 2008). The Ministry of Local Government and Modernization is a national agency responsible for implementing the Planning and Building Act (NMPE 2019).

\section{Biological Resources Protection Laws}

In Norway, hydropower project proponents must take into account project impacts to biological resources prior to obtaining a license to construct, operate, and maintain a project pursuant to the Nature Diversity Act. The project proponent is responsible for initiating and coordinating review with the NVE and the Ministry of Climate and the Environment.

\section{Nature Diversity Act}

Hydropower project proponents must consult with the Ministry of Climate and the Environment and NVE to consider the potential impacts of a project on biological resources pursuant to the Nature Diversity Act (Act No. 100 of 19 June 2009). ${ }^{66}$ The purpose of the Nature Diversity Act is to protect biological, geological, and landscape diversity and ecological processes through conservation and sustainable use (Act No. 100 of 19 June 2009). The Nature Diversity Act process may result in a BA, which contains an analysis of a project's impacts on listed species as well as any conditions or permits that may be required prior to the commencement of a project (Act No. 100 of 19 June 2009).

\section{Cultural Resources Protection Laws}

In Norway, hydropower project proponents must take into account project impacts to cultural resources prior to obtaining a license to construct, operate, and maintain a project pursuant to the Cultural Heritage Act. The project proponent is responsible for initiating and coordinating review with the Directorate of Cultural Heritage.

\section{Cultural Heritage Act}

Hydropower project proponents must consult with the Directorate of Cultural Heritage to consider project impacts to cultural resources pursuant to the Cultural Heritage Act (Act No. 50 of 9 June 1978). The purpose of the Cultural Heritage Act is to protect heritage sites and cultural environments, including sites, monuments, or other areas with cultural or architectural value throughout Norway (Act No. 50 of 9 June 1978). The Directorate of Cultural Heritage may issue recommendations for inclusion in a hydropower license if a project may impact protected buildings and cultural landscapes pursuant to the Cultural Heritage Act consultation process (Act No. 50 of 9 June 1978).

\section{Water Quality Laws}

In Norway, hydropower project proponents may be required to obtain a permit from the Ministry of Climate and the Environment prior to obtaining a license to construct a project pursuant to the

\footnotetext{
${ }^{66}$ Nature Diversity Act, No. 100 of 19 June 2009. https://www.regjeringen.no/en/dokumenter/nature-diversityact/id570549/.
} 
Pollution Control Act. The project proponent is responsible for consulting with the Ministry of Climate and the Environment to determine whether an approval or permit is required for project activities.

\section{Pollution Control Act}

Hydropower project proponents may be required to obtain a permit from the Ministry of Climate and the Environment if a project requires excavating or dredging a watercourse pursuant to the Pollution Control Act (Act No. 6 of 13 March 1981). ${ }^{67}$ The purpose of the Pollution Control Act is to establish water quality standards and prevent pollution of water resources related to construction activities such as excavation and dredging (Act No. 6 of 13 March 1981).

\section{Other Development Restriction Laws}

In Norway, hydropower project proponents may be restricted from developing projects in certain areas, pursuant to the Svalbard Environmental Protection Act. In addition, the Norway Parliament has approved two plenary resolutions, the Hydropower Development Protection Plans and the Master Plan for Watercourses (Protection Plan for Watercourses), which may restrict areas of potential hydropower development.

\section{Svalbard Environmental Protection Act}

Hydropower project proponents may be restricted from developing projects or subject to stringent license conditions within the Svalbard archipelago pursuant to the Svalbard Environmental Protection Act (Act No. 79 of 15 June 2000). The purpose of the Svalbard Environmental Protection Act is to preserve Svalbard archipelago's environment (Act No. 79 of 15 June 2000). ${ }^{68}$ The Svalbard Environmental Protection Act is administered by the Ministry of Climate and Environment.

\section{Protection Plan for Watercourses}

Hydropower project proponents may be restricted from developing projects within certain river systems pursuant to the Hydropower Development Protection Plans and the Master Plan for Watercourses (Protection Plan for Watercourses 2009). The purpose of the Protection Plan for Watercourses is to restrict the development of power production on specific river systems (Protection Plan for Watercourses 2009). The Plan for Watercourses is administered by the Parliament (Protection Plan for Watercourses 2009).

\footnotetext{
${ }^{67}$ Pollution Control Act, No 6 of 13 March 1981. https://www.regjeringen.no/en/dokumenter/pollution-controlact/id171893/.

${ }^{68}$ Svalbard Environmental Protection Act, No. 79 of 15 June 2000.

https://www.regjeringen.no/en/dokumenter/svalbard-environmental-protection-act/id173945/.
} 
Table A2. International Hydropower Development Comparison Table

\begin{tabular}{|c|c|c|c|}
\hline Country & Statutes & Agencies & Public Participation \\
\hline \multirow[t]{7}{*}{ Canada } & $\begin{array}{l}\text { Land Access } \\
\text { Crown land tenure }\end{array}$ & $\begin{array}{l}\text { Land Access } \\
\text { Province/territorial agency }\end{array}$ & \multirow{7}{*}{$\begin{array}{l}\text { Appeals } \\
\text { Consultation } \\
\text { Comment }\end{array}$} \\
\hline & $\begin{array}{l}\text { Energy Facility Licensing } \\
\text { N/A }\end{array}$ & $\begin{array}{l}\text { Energy Facility Licensing } \\
\text { N/A }\end{array}$ & \\
\hline & $\begin{array}{l}\text { Environmental Review } \\
\text { Impact Assessment Act }\end{array}$ & $\begin{array}{l}\text { Environmental Review } \\
\text { Impact Assessment Agency }\end{array}$ & \\
\hline & $\begin{array}{l}\text { Biological Resources Protection } \\
\text { Species At Risk Act } \\
\text { Migratory Birds Convention Act } \\
\text { Fisheries Act }\end{array}$ & $\begin{array}{l}\text { Biological Resources Protection } \\
\text { Department of Environment and } \\
\text { Climate Change Canada } \\
\text { Parks Canada Agency } \\
\text { Department of Fisheries and Oceans } \\
\text { Canada }\end{array}$ & \\
\hline & $\frac{\text { Cultural Resources Protection }}{\text { Impact Assessment Act }}$ & $\frac{\text { Cultural Resources Protection }}{\text { Impact Assessment Agency }}$ & \\
\hline & $\frac{\text { Water Quality }}{\text { Canadian Navigable Waters Act }}$ & $\frac{\text { Water Quality }}{\text { Transport Canada }}$ & \\
\hline & $\begin{array}{l}\text { Other Development Restrictions } \\
\text { Wildlife Act }\end{array}$ & $\begin{array}{l}\text { Other Development Restrictions } \\
\text { Department of Environment and } \\
\text { Climate Change Canada }\end{array}$ & \\
\hline \multirow[t]{7}{*}{ Sweden } & $\frac{\text { Land Access }}{\mathrm{N} / \mathrm{A}}$ & $\frac{\text { Land Access }}{\text { N/A }}$ & \multirow{7}{*}{$\begin{array}{l}\text { Consultation } \\
\text { Comment } \\
\text { Hearings }\end{array}$} \\
\hline & $\begin{array}{l}\text { Energy Facility Licensing } \\
\text { Swedish Environmental Code }\end{array}$ & $\begin{array}{l}\text { Energy Facility Licensing } \\
\text { Land and Environment Court } \\
\text { County Administrative Board }\end{array}$ & \\
\hline & $\begin{array}{l}\text { Environmental Review } \\
\text { Swedish Environmental Code }\end{array}$ & $\begin{array}{l}\text { Environmental Review } \\
\text { Land and Environment Court } \\
\text { County Administrative Board }\end{array}$ & \\
\hline & $\frac{\text { Biological Resources Protection }}{\text { N/A }}$ & $\frac{\text { Biological Resources Protection }}{\text { N/A }}$ & \\
\hline & $\frac{\text { Cultural Resources Protection }}{\text { N/A }}$ & $\begin{array}{l}\text { Cultural Resources Protection } \\
\text { N/A }\end{array}$ & \\
\hline & $\frac{\text { Water Quality }}{\text { N/A }}$ & $\frac{\text { Water Quality }}{\text { N/A }}$ & \\
\hline & $\frac{\text { Other Development Restrictions }}{\text { Swedish Environmental Code }}$ & $\begin{array}{l}\text { Other Development Restrictions } \\
\text { Land and Environment Court } \\
\text { County Administrative Board }\end{array}$ & \\
\hline \multirow[t]{2}{*}{ Norway } & $\frac{\text { Land Access }}{\text { N/A }}$ & $\frac{\text { Land Access }}{\text { N/A }}$ & \multirow{2}{*}{$\begin{array}{l}\text { Consultation } \\
\text { Comment } \\
\text { Meetings }\end{array}$} \\
\hline & Energy Facility Licensing & Energy Facility Licensing & \\
\hline
\end{tabular}




\begin{tabular}{|c|c|c|c|}
\hline Country & Statutes & Agencies & Public Participation \\
\hline & $\begin{array}{l}\text { Watercourse Regulation Act } \\
\text { Water Resources Act } \\
\text { Waterfall Rights Act }\end{array}$ & $\begin{array}{l}\text { King in Council } \\
\text { Norwegian Water Resources and } \\
\text { Energy Directorate }\end{array}$ & $\begin{array}{l}\text { Hearings } \\
\text { Appeals }\end{array}$ \\
\hline & $\frac{\text { Environmental Review }}{\text { Planning and Building Act }}$ & $\begin{array}{l}\text { Environmental Review } \\
\text { Norwegian Water Resources and } \\
\text { Energy Directorate } \\
\text { Planning Department } \\
\text { Local government bodies }\end{array}$ & \\
\hline & $\frac{\text { Biological Resources Protection }}{\text { Nature Diversity Act }}$ & $\begin{array}{l}\text { Biological Resources Protection } \\
\text { Norwegian Water Resources and } \\
\text { Energy Directorate } \\
\text { Ministry of the Environment }\end{array}$ & \\
\hline & $\frac{\text { Cultural Resources Protection }}{\text { Cultural Heritage Act }}$ & $\frac{\text { Cultural Resources Protection }}{\text { Directorate of Cultural Heritage }}$ & \\
\hline & $\frac{\text { Water Quality }}{\text { Pollution Control Act }}$ & $\begin{array}{l}\text { Water Quality } \\
\text { Ministry of the Environment }\end{array}$ & \\
\hline & $\begin{array}{l}\text { Other Development Restrictions } \\
\text { Svalbard Environmental } \\
\text { Protection Act }\end{array}$ & $\frac{\text { Other Development Restrictions }}{\text { Ministry of Climate and Environment }}$ & \\
\hline \multirow[t]{3}{*}{$\begin{array}{l}\text { United } \\
\text { States }\end{array}$} & $\begin{array}{l}\text { Land Access } \\
\text { Federal Land Policy and } \\
\text { Management Act } \\
\text { National Wildlife Refuge System } \\
\text { Act } \\
\text { Act of February 15, } 1901\end{array}$ & $\begin{array}{l}\text { Land Access } \\
\text { Bureau of Land Management } \\
\text { Forest Service } \\
\text { Fish and Wildlife Service } \\
\text { National Park Service } \\
\text { Bureau of Indian Affairs } \\
\text { Indian Tribe }\end{array}$ & \multirow[t]{3}{*}{$\begin{array}{l}\text { Consultation } \\
\text { Comment } \\
\text { Meetings } \\
\text { Hearings } \\
\text { Appeals }\end{array}$} \\
\hline & $\begin{array}{l}\text { Energy Facility Licensing } \\
\text { Federal Power Act } \\
\text { Town-Sites and Power } \\
\text { Development Act }\end{array}$ & $\begin{array}{l}\text { Energy Facility Licensing } \\
\text { Federal Energy Regulatory } \\
\text { Commission } \\
\text { Bureau of Reclamation }\end{array}$ & \\
\hline & $\frac{\text { Environmental Review }}{\text { National Environmental Policy Act }}$ & $\begin{array}{l}\text { Environmental Review } \\
\text { Federal Energy Regulatory } \\
\text { Commission } \\
\text { Bureau of Reclamation } \\
\text { U.S. Army Corps of Engineers } \\
\text { Bureau of Land Management } \\
\text { Forest Service } \\
\text { Fish and Wildlife Service } \\
\text { National Park Service } \\
\text { Bureau of Indian Affairs } \\
\text { National Oceanic and Atmospheric } \\
\text { Administration (NOAA) Fisheries }\end{array}$ & \\
\hline
\end{tabular}


Biological Resources Protection

Endangered Species Act

Magnuson-Stevens Fishery

Conservation and Management

Act

Migratory Bird Treaty Act

Bald and Golden Eagle Protection

Act

Marine Mammal Protection Act

Fish and Wildlife Coordination Act

Cultural Resources Protection

National Historic Preservation Act

Water Quality

Clean Water Act

Other Development Restrictions

Rivers and Harbors Act

Coastal Zone Management Act

Wild and Scenic Rivers Act

National Park Service Organic Act
Biological Resources Protection

NOAA Fisheries

Fish and Wildlife Service

Federal Energy Regulatory

Commission

State Fish and Wildlife Agencies
Cultural Resources Protection

State Agency

Water Quality

State or Tribal Agency

Environmental Protection Agency

U.S. Army Corps of Engineers

Other Development Restrictions

U.S. Army Corps of Engineers

Federal Energy Regulatory

Commission

National Park Service

Bureau of Land Management

Fish and Wildlife Service

Forest Service

State Agency 


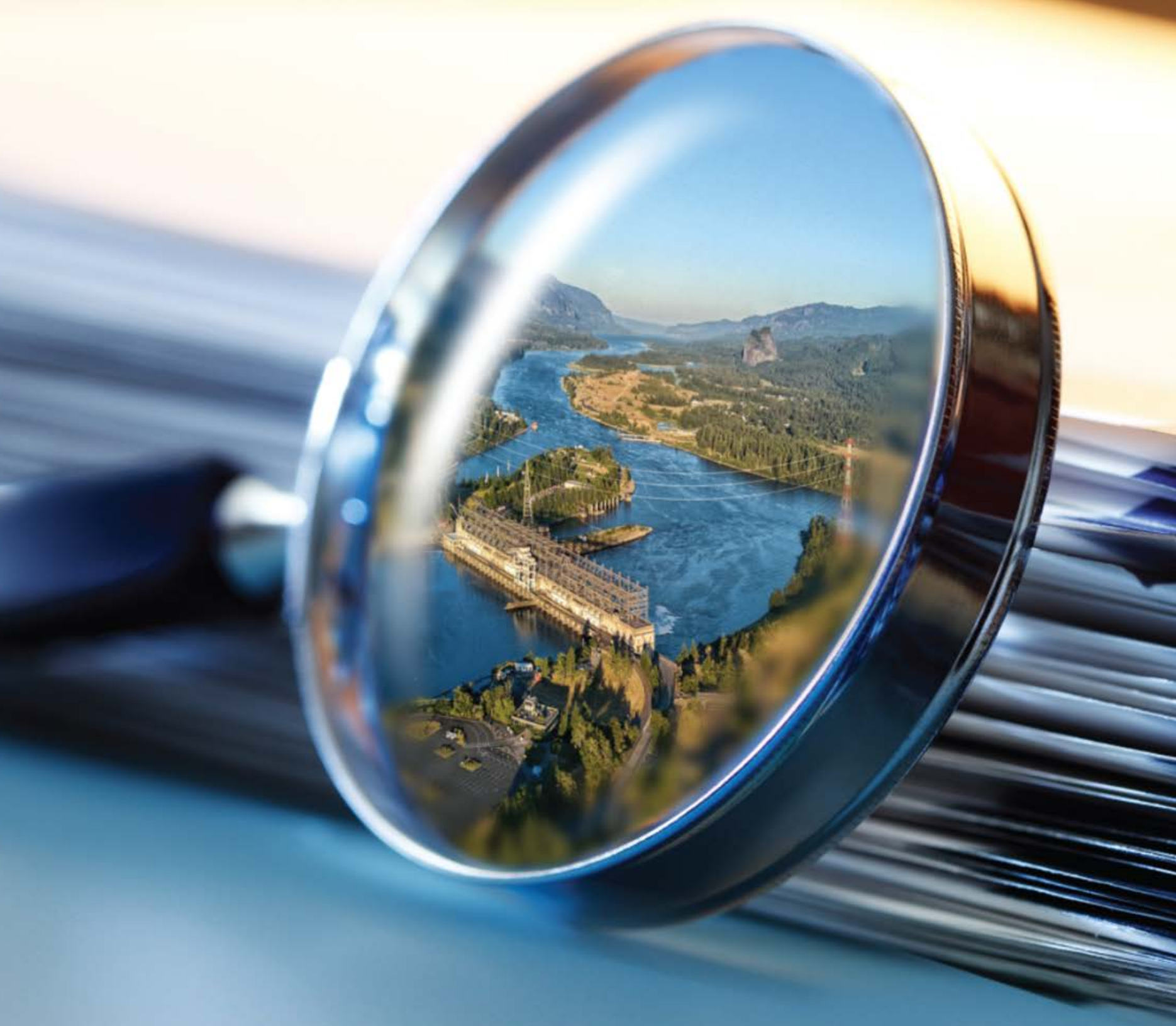

AN EXAMINATION OF THE HYDROPOWER LICENSING AND FEDERAL AUTHORIZATION PROCESS

APPENDIX

D.

D
Supplemental Information and Results for Statistical Analyses Used in Timeline and Cost Chapters 


\section{Appendix B. Supplemental Information and Results for Statistical Analyses Used in Timeline and Cost Chapters}

This appendix provides supplemental methods and test statistics for Chapter 3 on licensing timelines and Chapter 4 on licensing costs.

\section{Methods}

\section{Data collection}

We created a dataset of dates and characteristics of original and relicensed hydropower project licenses by extracting information from Federal Energy Regulatory Commission (FERC) hydropower licensing documents such as license orders and National Environmental Protection Act (NEPA) documents (https://hydrosource.ornl.gov/dataset/hydropower-licensing-timelineand-cost-dataset). Initially, we randomly selected 129 hydropower projects from a FERC maintained list of 296 licensed projects that have been issued licenses since 1 October 2005. We then used the Existing Hydropower Assets Database (Johnson et al. 2020) to ascribe project characteristics to each project and filtered out projects that did not fit our criteria including marine hydrokinetic, transmission line, and pumped storage projects as well as projects that contained more than one type of hydropower facility. We also filtered out one project that had its FERC license vacated by a U.S. District Court (i.e., Coosa River Project) for a final sample size of 107 licensed hydropower projects.

In coordination with the project Stakeholder Working Group, a list of hypotheses about factors that could influence licensing timelines was generated (Table B1) to direct the information extracted from the 107 licenses that could be used to test these hypotheses. Information from licenses was then extracted such as filing dates, type of license acquired (original or relicense), license process used (Alternative, Traditional or Integrated), project nameplate capacity (MW), number of hydropower plants in the facility, and whether or not a project had endangered species present (Table B2).

There were often milestones listed in FERC licensing documents that pertained to timeline information that was collected; thus, the following protocols were followed to make sure that the correct date for the milestone was recorded. Because milestone dates sometimes differ among documents in a FERC docket, the date published in the final license order was used where possible.

To calculate the timeline for compliance with Section 7 of the Endangered Species Act (ESA), we first reviewed FERC license orders to determine if ESA formal consultation was required for the project. If formal consultation was required, we then recorded the date in which FERC staff requested formal consultation and the date the U.S. Fish and Wildlife Service (USFWS) and/or National Oceanic and Atmospheric Administration (NOAA) Fisheries issued the biological opinion (BO), which serves as the endpoint in the Section 7 Consultation process. An example of text that signaled the beginning of the Section 7 Consultation process was, "Staff requested consultation with the FWS on September 30, 2005, " whereas an example of text that signaled the end of this process was, "FWS issued a Biological Opinion on September 15, 2006." 
We also included dates provided by USFWS and/or NOAA Fisheries of complete application packet receipt in our dataset and analysis although additional dates were not provided for all projects that required Section 7 Consultation. The agencies have a 135-day period in which to complete the Section 7 Consultation plus a 60-day extension (or longer with consent of the applicant), but there is often disagreement between the agencies and the applicant on when a complete application packet has been received and whether the agencies have met the 135-day requirement. To better understand where and how frequently delays in the Section 7 Consultation process occur, two sets of dates were used in analyses: 1) the date from when FERC requested Section 7 Consultation to the date of issuance of the last BO or Letter of Concurrence issued by either USFWS or NOAA Fisheries (represents the time the entire Section 7 process takes) and 2) the date from when each service received a complete biological assessment from the license applicant to when each agency issued its final BO or Letter of Concurrence (represents the actual time each service takes to complete consultation).

Table B1. A Priori Hypotheses and Predicted Direction of Effect of Variables on FERC Licensing Timelines

\begin{tabular}{|c|c|}
\hline Variables & Hypothesized Effect on License Timelines \\
\hline \multicolumn{2}{|l|}{ Project Characteristics } \\
\hline Project Size & Larger project size, longer timeline \\
\hline Number of Facilities & More facilities, longer timeline \\
\hline FERC Region & Northwest and New England regions, longer timeline \\
\hline $\begin{array}{l}\text { Project Type } \\
\end{array}$ & Adding power to non-powered dam, shortest timeline \\
\hline \multicolumn{2}{|l|}{ License Characteristics } \\
\hline $\begin{array}{ll}\text { License Type } \\
\end{array}$ & $\begin{array}{l}\text { Relicense: longer timeline; Original license = shorter } \\
\text { timeline }\end{array}$ \\
\hline License Process Type & $\begin{array}{l}\text { Alternative }=\text { longest timeline; } \text { Integrated = shortest } \\
\text { timeline }\end{array}$ \\
\hline \multicolumn{2}{|l|}{ Environmental Characteristics } \\
\hline Settlement Agreement & Presence of settlement agreement $=$ longer timeline \\
\hline NEPA Document Type & EIS = longer timeline \\
\hline Presence of Endangered Species & Endangered species present $=$ longer timeline \\
\hline Fishway Requirement & Presence of fishway requirement $=$ longer timeline \\
\hline \multicolumn{2}{|l|}{ Environmental Process Timelines } \\
\hline $\begin{array}{r}\text { State Clean Water Act (CWA) } 401 \\
\text { Certification }\end{array}$ & Longer CWA 401 timeline $=$ longer timeline \\
\hline NEPA Process & Longer NEPA timeline $=$ longer timeline \\
\hline Section 7 Consultation Timeline & Longer ESA Section 7 timeline $=$ longer timeline \\
\hline
\end{tabular}


Table B2. Variables Extracted from Licensing Documents From 107 U.S. Federal Energy Regulatory Commission (FERC) Licensed Projects Used in Analyses Including the Variable Name and Variable Description. Italicized Variables Are Response Variables and Bolded Variables Are Included as Predictor Variables in Linear Regression Analyses.

\begin{tabular}{|c|c|}
\hline Variable & Variable Description \\
\hline \multicolumn{2}{|l|}{ Response Variables } \\
\hline $\begin{array}{l}\text { Days Notice of Intent (NOI) to License Application } \\
\text { (LA) }\end{array}$ & Number of days from NOI to LA filings \\
\hline Days LA to License Issuance (LI) & Number of days from LA filing to LI \\
\hline Days NOI to LI & Number of days from NOI filing to LI \\
\hline Licensing Cost/kWh & $\begin{array}{l}\text { Reported costs per kilowatt-hour updated to } 2019 \text { dollars using the Consumer Price } \\
\text { Index based on the year the final license application was submitted. }\end{array}$ \\
\hline \multicolumn{2}{|l|}{ Project Characteristics } \\
\hline Capacity & Project nameplate generation capacity in megawatts \\
\hline Number of Facilities & $\begin{array}{l}\text { Number of hydropower facilities included in project license; this does not include, for } \\
\text { instance, dams that are used to produce head but do not directly generate power }\end{array}$ \\
\hline Project Type & $\begin{array}{l}\text { Type of hydropower project on a license (four levels: existing conventional, new stream } \\
\text { reach, in-canal conventional, retrofitting a non-powered dam) }\end{array}$ \\
\hline U.S. Region & $\begin{array}{l}\text { Eastern or Western United States where states including and to the west of North } \\
\text { Dakota, South Dakota, Nebraska, Kansas, Oklahoma, and Texas were considered } \\
\text { Western States and states to the east of those states were considered Eastern states }\end{array}$ \\
\hline Mode of Operation & Mode of operation used at project (two levels: storage/ peaking, run of river) \\
\hline Licensee Type & $\begin{array}{l}\text { Licensee type as reported in Oak Ridge National Laboratory Hydropower Market Report } \\
\text { data }\end{array}$ \\
\hline \multicolumn{2}{|r|}{ Nota } \\
\hline License Process Type & Type of license process used (three levels: alternative, integrated, traditional) \\
\hline License Type & Type of license issued (two levels: original, relicense) \\
\hline Settlement Agreement Presence & Whether settlement agreement was negotiated by stakeholders (two levels: yes, no) \\
\hline \multicolumn{2}{|l|}{ Environmental Complexity Indicators } \\
\hline $\begin{array}{l}\text { Ready for Environmental Analysis (REA) to } \\
\text { Environmental Impact Statement (EIS) Timeline }\end{array}$ & Years from when project was REA to final NEPA document \\
\hline Endangered Species Presence & Whether endangered species were present at project (two levels: yes, no) \\
\hline Endangered Species Consultation Timeline & Years from ESA Section 7 Consultation request to final BO \\
\hline Environmental Assessment (EA) or EIS & Type of NEPA document filed (two levels: EA, EIS) \\
\hline Fishway Order Presence & Whether fishway construction was required (two levels: yes, no) \\
\hline
\end{tabular}


To calculate the timeline for compliance with the CWA Section 401, we reviewed the FERC license orders to determine the date on which the license applicant first submitted a water quality certification request to the relevant state agency and the date the relevant state agency issued the final water quality certification or waiver. An example of text that signaled the beginning of the CWA Section 401 application process was, "On February 3, 2005 PacifiCorp applied to Washington Ecology for water quality certification, " and an example of text that signaled issuance of the CWA certification was, "On October 26, 2006, Washington Ecology issued the certification."

To calculate the timeline for compliance with NEPA, we reviewed the project license to determine the date on which the project was deemed ready for environmental analysis (REA) and the date on which FERC issued the final NEPA document (i.e., an environmental assessment [EA] or environmental impact statement [EIS]).

To calculate the timeline for the FERC licensing process, the project team reviewed the FERC project dockets and recorded the following dates: date the license applicant filed the notice of intent/pre-application document (NOI/PAD), date the license applicant filed the final license application (LA), and date of FERC license issuance (LI).

To determine whether a Section 18 Fishway Prescription was issued by the USFWS or NOAA Fisheries, we reviewed the FERC license orders and recorded a defined fishway prescription as a "yes." All other projects, including those where USFWS and/or NOAA Fisheries reserved authority to provide fishway prescriptions at a later date were recorded as a "no." Reserved authority to provide fishway prescriptions was recorded as a "no" because to date, reserved authority has never been exercised (Frankie Green, Personal Comm.).

To determine whether a Settlement Agreement was in place for a project, FERC licenses were searched for the term "Settlement Agreement" and the entire FERC docket for each project was examined for the presence of a Settlement Agreement.

To gain insight on whether conflicts among stakeholders negotiating environmental impact studies led to longer timelines, we collected information on whether FERC required a disputed study as proposed (hereafter, approved), required a disputed study with modification, or did not require a study (hereafter, rejected), from Study Determination Letters from the 20 Integrated Licensing Process (ILP) hydropower projects in our sample of 107 projects used for timeline analysis with study determination letters. Only ILP projects were used for this analysis because projects using the Traditional Licensing Process (TLP) and Alternative Licensing Process (ALP) do not have Study Determination Letters.

\section{Data Analysis}

Regression analyses (R, $l m$ function) were used to test hypotheses laid out in Table B1 using bolded variables in Table B2 and overall timeline (NOI/PA D to LI) and licensing cost and licensing cost $/ \mathrm{kWh}$. NOI/PAD to LA and LA to LI timelines were also used as response variables to examine the relationship between license process type and timelines due to pre-filing and post-filing time requirements in the ALP and ILP. 
Assumptions of normality and homogeneity of variance were tested prior to running regression models using comparison of mean and median for each treatment group, visual inspection of quantile-quantile plots (for normality assumptions), and Levene's test (for homogeneity of variance assumptions). We included license type in each model because it had a statistically significant association with NOI/PAD to LI timeline and licensing costs. We did not examine effects of license type on information collected from Study Determination Letters because of the small sample size of original licenses $(\mathrm{N}=4)$ compared to relicenses $(\mathrm{N}=16)$. A Tukey test was used in cases where a post-hoc test was conducted.

We controlled Type I error using the Benjamini-Hochberg procedure. This procedure controls for a low proportion of false null hypothesis rejections by adjusting the p-value of each individual test based on the number of comparisons, the ranking of the p-value for an individual test among other individual test p-values, and acceptable false-discovery rate of those tests. Statistical tests were considered significant at $\alpha=0.05$ level (i.e., a false-discovery rate of 5\%).

\section{Results}

Including license type in models improved model fit in all cases. Model results reported below include predictor variable listed in addition to license type (i.e., original or relicense) in all cases.

\section{Project Characteristics: Timeline}

While there was no statistically significant overall relationship between project capacity and licensing timelines, there was a statistically significant relationship between project capacity and licensing timelines within license types where projects with higher nameplate capacity had longer NOI/PAD to LI timelines (Table B3; $\left.F_{2,95}=7.869, p<0.001\right)$. There was no statistically significant difference in overall, pre-filing, or post-filing timelines for original or relicenses among existing conventional, in-canal conventional, adding power to non-powered dams, or new stream reach development. There was also no statistically significant effect of project mode-ofoperation (i.e., run of river, peaking), licensee type (i.e., public, private, public/private), or geographic region (i.e., east, west) on NOI/PAD to LI licensing timelines. A summary of all regression results are provided in Table B4.

\section{License Characteristics: Timeline}

Projects undergoing relicensing had significantly longer timelines than projects seeking an original license (overall model $\mathrm{F}_{1,96}=28.23, \mathrm{p}<0.001$ ). There was no statistically significant difference among NOI to LI timelines of ALP, ILP, or TLP license process types, however, the LA to LI (post-file) timeline for projects using the ILP was significantly shorter than for projects using the TLP (post-file model $\mathrm{F}_{3,103}=6.392, \mathrm{p}<0.001$ ).

\section{Environmental Characteristics: Timeline}

The Clean Water Act (CWA) Section 401 certification timeline was statistically significant and was positively associated with overall licensing timelines. However, the relationship between $\mathrm{NOI} / \mathrm{PAD}$ to LI timelines for projects seeking original and relicenses were significantly different with relicenses taking longer (overall model $\mathrm{F}_{2,74}=107.5, \mathrm{p}<0.001$ ). Timelines for CWA Section 401 certifications were longer for projects being relicensed than for those applying for an original license. The mean \pm SD CWA Section 401 timeline for projects seeking original licenses was $1.2 \pm 2.4$ years versus $2.8 \pm 3.3$ years for those seeking a relicense. 
The project NEPA timeline had a statistically significant association with licensing timelines where projects with longer NEPA timelines also had longer NOI/PAD to LI timelines (overall model $\mathrm{F}_{3,94}=17.47 ; \mathrm{p}<0.001$ ). Timelines for the NEPA process were longer for projects being relicensed than for projects obtaining an original license. The mean \pm SD length of the NEPA process was $0.9 \pm 0.5$ years for a project seeking an original license and $1.3 \pm 0.9$ years for a project being relicensed.

Projects with EA documents had significantly shorter timelines than those with EIS documents and for both types of documents, relicenses had significantly longer NEPA timelines than projects seeking original licenses (overall model $\mathrm{F}_{2,95}=10.32, \mathrm{p}<0.001$ ).

Projects with endangered species present had significantly longer timelines than projects where there were no endangered species for both original and relicenses (overall model $F_{2,51}=13.08, p$ $<0.001)$. There was also a significant relationship between the length of the Section 7 Consultation timeline and the NOI/PAD to LI timeline for both original and relicenses (overall model $F_{2,51}=13.08, p<0.001$ ). However, when dates that USFWS and NOAA Fisheries received complete application packages were instead used as the start date for the Section 7 Consultation clock, the relationship between Section 7 consultation timeline for either agency and NOI to LI timeline was not significant (USFWS: $\mathrm{F}_{1,36}=2.696, \mathrm{p}=0.109$; NOAA: $\mathrm{F}_{1,9}=$ $4.609, \mathrm{p}=0.0646)$.

Projects with settlement agreements had significantly longer timelines both for projects seeking original and relicenses (overall model $\mathrm{F}_{2,99}=0.26, \mathrm{p}<0.001$ ). Project size was removed from the model because it was not significant.

The number of disputed studies from the 20 ILP projects with Study Determination Letters included in our dataset was statistically significant in relation to licensing timelines (overall model $)$ and the number of disputed studies approved $\left(\mathrm{F}_{1,18}=12.27\right.$, Adjusted $\mathrm{R}^{2}=0.372, \mathrm{p}=$ $0.003)$ and the number of accepted disputed studies $\left(\mathrm{F}_{1,18}=12.03\right.$, Adjusted $\mathrm{R}^{2}=0.367, \mathrm{p}=$ 0.003 ) were significantly related to licensing timelines. There was no significant relationship between the number of rejected disputed studies and NOI to LI timelines. Project size was removed from the models because it was not significant. 
Table B3. Summary of Results of Regression Analyses for Factors Hypothesized to be Related to NOI/PAD to License Issuance Timelines. All Models Also Included a Term for License Type. Model p-values Shown Have Been Adjusted for Multiple Comparisons Using the Benjamini-Hochberg Procedure.

\begin{tabular}{|c|c|c|c|c|}
\hline Model Predictor Variable & $F_{\text {num, denom }}$ & $\begin{array}{l}\text { Adjusted } \\
\mathbf{R}^{2}\end{array}$ & $\begin{array}{l}\text { Model } \\
\text { P. } \\
\text { Value }\end{array}$ & Direction of Effect \\
\hline \multicolumn{5}{|l|}{ Project Characteristics } \\
\hline Project Capacity (MW) & $F_{2,95}=7.869$ & 0.28 & $<0.001$ & Larger projects longer timeline \\
\hline Number of Facilities & NS & NS & NS & NA \\
\hline Project Type & NS & NS & NS & NA \\
\hline Mode of Operation & NS & NS & NS & NA \\
\hline $\begin{array}{r}\text { East vs. West Geographic } \\
\text { Region }\end{array}$ & NS & NS & NS & NA \\
\hline Licensee Type & NS & NS & NS & NA \\
\hline \multicolumn{5}{|l|}{ License Characteristics } \\
\hline $\begin{array}{r}\text { License Type } \\
\end{array}$ & $F_{1,96}=28.23$ & 0.22 & $<0.001$ & Relicense longer timeline \\
\hline License Process Type & NS & NS & NS & NA \\
\hline \multicolumn{5}{|l|}{$\begin{array}{l}\text { Environmental } \\
\text { Characteristics }\end{array}$} \\
\hline NEPA Document Type & $\begin{array}{l}F_{2,95}= \\
10.32\end{array}$ & 0.16 & $<0.001$ & EIS longer timeline \\
\hline Endangered Species (Y/N) & $F_{2,51}=13.08$ & 0.31 & $<0.001$ & ESA species present longer timeline \\
\hline Settlement Agreement (Y/N) & $F_{2,99}=0.26$ & 0.27 & $<0.001$ & $\begin{array}{l}\text { Settlement agreement is related to } \\
\text { longer NOI to LI timeline }\end{array}$ \\
\hline Fishway Prescription (Y/N) & NS & NS & NS & NA \\
\hline \multicolumn{5}{|l|}{$\begin{array}{l}\text { Required Authorizations } \\
\text { and Procedural Steps }\end{array}$} \\
\hline $\begin{array}{r}\text { Time NOI/PAD to Final } \\
\text { License Application }\end{array}$ & $F_{1,96}=29.07$ & 0.22 & $<0.001$ & $\begin{array}{l}\text { Longer NOI/PAD to final license } \\
\text { application, longer NOI to LI timeline }\end{array}$ \\
\hline $\begin{array}{r}\text { Time Final License } \\
\text { Application to Notice REA }\end{array}$ & $F_{1,94}=15.79$ & 0.13 & $<0.001$ & $\begin{array}{l}\text { Longer final license application to REA, } \\
\text { longer NOI to LI timeline }\end{array}$ \\
\hline $\begin{array}{r}\text { Time Notice REA to Final } \\
\text { EA or EIS }\end{array}$ & $F_{2,95}=26.22$ & 0.34 & $<0.001$ & $\begin{array}{l}\text { Longer NEPA timeline is related to } \\
\text { longer NOI to LI timeline }\end{array}$ \\
\hline $\begin{array}{r}\text { Time Final License } \\
\text { Application to License } \\
\text { Issuance }\end{array}$ & $F_{1,96}=927.6$ & 0.91 & $<0.001$ & $\begin{array}{l}\text { Longer NOI/PAD to final license } \\
\text { application, longer NOI to LI timeline }\end{array}$ \\
\hline $\begin{array}{r}\text { Time Section } 7 \\
\text { Consultation }\end{array}$ & $F_{2,51}=13.08$ & 0.31 & $<0.001$ & $\begin{array}{l}\text { Longer Section } 7 \text { consultation timeline } \\
\text { is related to longer NOI to LI timeline }\end{array}$ \\
\hline $\begin{array}{r}\text { Time Section } 7 \\
\text { Consultation Complete } \\
\text { USFWS Package }\end{array}$ & NS & NS & NS & NA \\
\hline $\begin{array}{r}\text { Time Section } 7 \\
\text { Consultation Complete } \\
\text { NOAA Package }\end{array}$ & & NS & NS & NA \\
\hline Time 401 Certification & $\begin{array}{l}F_{2,74}= \\
107.50\end{array}$ & 0.74 & $<0.001$ & $\begin{array}{l}\text { Longer } 401 \text { certification timeline is } \\
\text { related to longer NOI to LI timeline }\end{array}$ \\
\hline Number Disputed Studies & $F_{2,17}=8.82$ & 0.45 & 0.002 & $\begin{array}{l}\text { Having more disputed studies is related } \\
\text { to longer NOI to LI timeline }\end{array}$ \\
\hline
\end{tabular}

\section{Project Characteristics: Cost}

There was a statistically significant relationship between project capacity and total licensing cost where larger projects incurred higher total costs (Adjusted $\mathrm{R}^{2} 0.79, \mathrm{~F}_{1,79}=150.30, \mathrm{p}<0.001$; 
Table B4). There was also a statistically significant effect of licensee type licensing costs (overall model $\left.F_{4,77}=3.44, p=0.012\right)$ where publicly owned utilities $(\$ 318 / \mathrm{kW} \pm \$ 600 / \mathrm{kW}$ ) had higher costs than independently owned utilities $(\$ 246 / \mathrm{kW} \pm \$ 512 / \mathrm{kW})$ which had higher costs than private non-utilities $(\$ 205 / \mathrm{kW} \pm \$ 385 / \mathrm{kW})$. There were no statistically significant differences in costs among project types.

\section{License Characteristics: Cost}

Projects undergoing relicensing $(\$ 281 / \mathrm{kW} \pm \$ 509 / \mathrm{kW})$ had significantly higher costs than projects seeking an original license $\left(\$ 196 / \mathrm{kW} \pm \$ 432 / \mathrm{kW}\right.$; overall model $\left.\mathrm{F}_{1,80}=8.22, \mathrm{p}=0.005\right)$. There was no statistically significant difference in costs among license processes.

\section{Environmental Characteristics: Cost}

Projects with more complex environmental characteristics were found to have higher total costs. Projects with an EIS $(\$ 6,171,000 \pm \$ 3,789,000$ and $\$ 145 / \mathrm{kW} \pm \$ 247)$ had higher overall costs but lower $\$ / \mathrm{kW}$ than those with an $\mathrm{EA}(\$ 1,717,000 \pm \$ 2,693,000$ and $\$ 257 / \mathrm{kW} \pm \$ 501 / \mathrm{kW}$; overall model $\left.\mathrm{F}_{2,79}=17.75, \mathrm{p}<0.001\right)$. Similarly, projects with fishway requirements $(\$ 4,871,000 \pm \$ 4,470,000$ and $\$ 151 / \mathrm{kW} \pm \$ 191)$ had higher total but lower $\$ / \mathrm{kW}$ costs than those without $\left(\$ 1,353,000 \pm \$ 1,881,000\right.$ and $\$ 278 / \mathrm{kW} \pm \$ 545 / \mathrm{kW}$; overall model $\mathrm{F}_{2,79}=6.53$, $\mathrm{p}$ $=0.002)$. Alternatively, both total and $\$ / \mathrm{kW}$ costs were higher for projects with endangered species $(\$ 3,188,000 \pm \$ 3,799,000$ and $\$ 288 / \mathrm{kW} \pm \$ 622)$ than those without them $(\$ 1,411,000 \pm$ $\$ 2,180,000$ and $\$ 185 / \mathrm{kW} \pm \$ 180 / \mathrm{kW}$; overall model $\mathrm{F}_{2,79}=6.85, \mathrm{p}=0.002$ ). Relative costs for projects with or without settlement agreements depend on the project license type, and original license projects with settlement agreements had lower costs than those without settlement agreements, while relicense projects with settlement agreements had higher costs than those without (overall model $\mathrm{F}_{2,79}=10.45, \mathrm{p}<0.001$ ).

Table B4. Summary of Results of Regression Analyses for Factors Hypothesized to be Related to Licensing Costs Based on Variables Hypothesized to Influence Licensing Timelines. Model pvalues Shown Have Been Adjusted for Multiple Comparisons Using the Benjamini-Hochberg (B-H) Procedure. The B-H p-values Presented here Only Included Analyses Conducted for the Cost Chapter Including Regressions With Cost and Cost/kW.

\begin{tabular}{|c|c|c|c|c|}
\hline Model Predictor Variable & $F_{\text {num, denom }}$ & $\begin{array}{l}\text { Adjusted } \\
\qquad \mathbf{R}^{2}\end{array}$ & $\begin{array}{c}\text { Model } \\
\text { P. } \\
\text { value }\end{array}$ & Direction of Effect \\
\hline \multicolumn{5}{|l|}{ Project Characteristics } \\
\hline Project Capacity (MW) & $F_{1,79}=150.30$ & 0.79 & $<0.001$ & Larger projects higher cost \\
\hline Project Type & NS & NS & NS & NA \\
\hline Licensee Type & $F_{4,77}=3.44$ & 0.11 & 0.012 & $\begin{array}{c}\text { Private-owned utility }>\text { Investor-owned utility } \\
>\text { Private non-utility }\end{array}$ \\
\hline \multicolumn{5}{|l|}{ License Characteristics } \\
\hline License Type & $\mathrm{F}_{1,80}=8.22$ & 0.08 & 0.005 & Relicense higher cost \\
\hline License Process & NS & NS & NS & NS \\
\hline \multicolumn{5}{|l|}{ Environmental Characteristics } \\
\hline NEPA Document Type & $F_{2,79}=17.75$ & 0.29 & $<0.001$ & EIS higher cost \\
\hline $\begin{array}{r}\text { Endangered Species Act (ESA) } \\
\text { (Y/N) }\end{array}$ & $F_{2,79}=6.85$ & 0.13 & 0.002 & ESA species present higher cost \\
\hline $\begin{array}{r}\text { Settlement Agreement (SA) } \\
(\mathrm{Y} / \mathrm{N})\end{array}$ & $F_{2,79}=10.45$ & 0.19 & $<0.001$ & $\begin{array}{l}\text { Cost original license: SA without > SA with } \\
\text { Cost relicense: SA with > SA without }\end{array}$ \\
\hline Fishway Prescription (Y/N) & $F_{2,79}=6.53$ & 0.12 & 0.002 & Fishway prescription higher cost \\
\hline
\end{tabular}




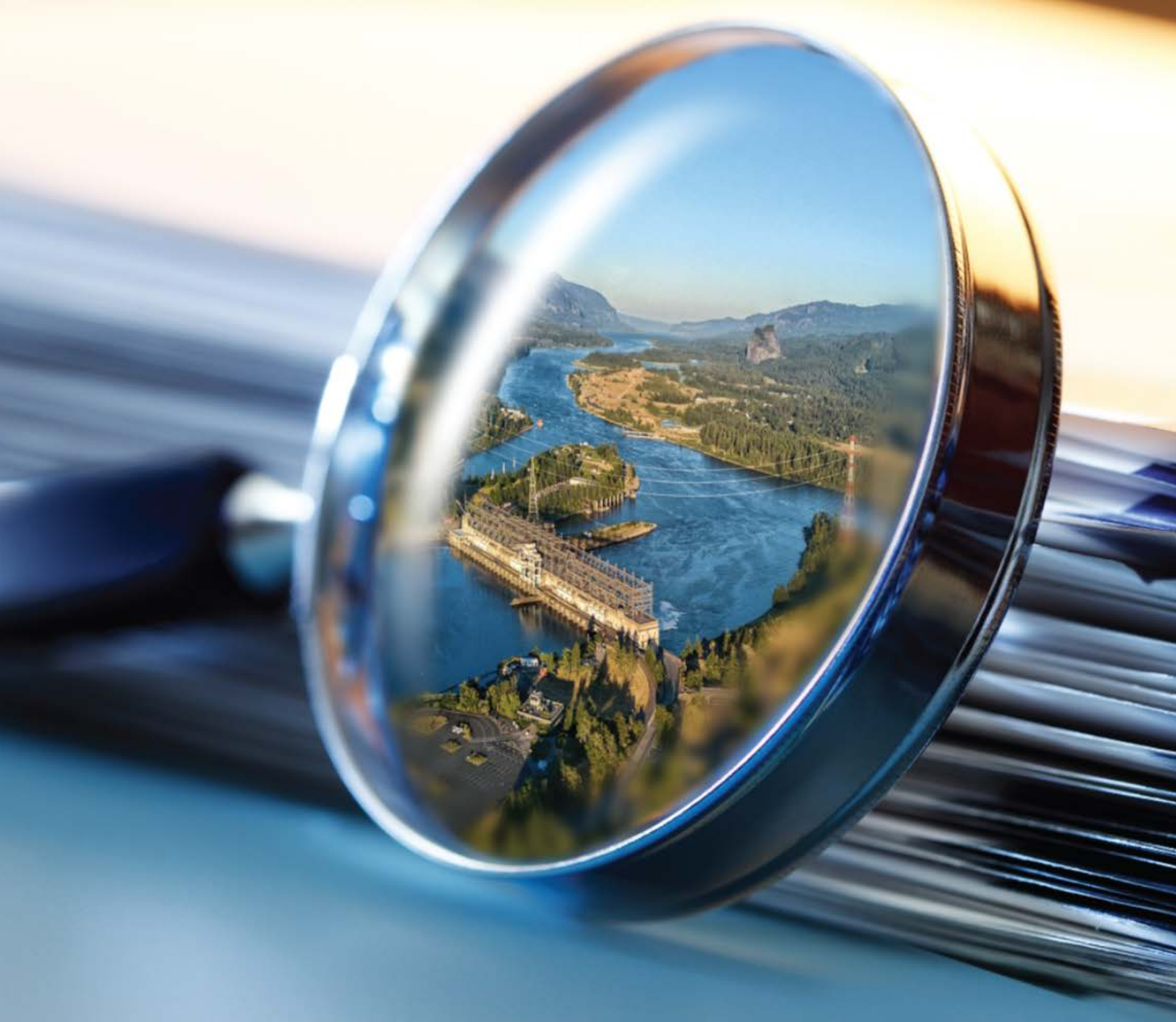

AN EXAMINATION OF THE HYDROPOWER LICENSING AND FEDERAL AUTHORIZATION PROCESS

\section{APPENDIX}

\section{Case Studies}




\section{Appendix C. Case Studies}

This appendix presents 10 case studies documenting hydropower licensing and federal authorization timeline lengths; compliance with statutory and regulatory processes; and protection, mitigation, and enhancement measures for a selection of original and new (relicense) hydropower licenses. The 10 case studies presented in this appendix were selected from the sample of 107 projects that served as the basis for the statistical timeline analysis presented in Chapter 3 of this report. The case studies were selected to illustrate the potential resource issues and other causes that may lead to differences in hydropower licensing and federal authorization timeline lengths. Each of the case studies presented in this appendix includes:

- A table containing percentiles to illustrate the licensing timeline length of the selected case study in relation to the overall sample of 107 projects

- A timeline of major licensing milestones (e.g., notice of intent (NOI)/pre-application document (PAD), 401 Certification, license issuance)

- A map of the project/project area

- An overview of the project and the project's compliance with statutory and regulatory requirements (e.g., Clean Water Act [CWA], Endangered Species Act [ESA], National Environmental Policy Act of 1969 [NEPA], National Historic Preservation Act [NHPA])

- A list of protection, mitigation, and enhancement measures included within the license.

The 10 case studies presented here include:

- A-Drop Hydroelectric Project, P-12549, Montana

- Badger-Rapide Croche Hydroelectric Project, P-2677, Wisconsin

- Carver Falls Hydroelectric Project, P-11475, New York and Vermont

- Emeryville Hydroelectric Project, P-2850, New York

- Loup River Hydroelectric Project, P-1256, Nebraska

- Merwin Hydroelectric Project, P-935, Washington

- Morgan Falls Project, P-2237, Georgia

- RC Byrd Hydroelectric Project, P-12796, Ohio and West Virginia

- Spring Gap-Stanislaus Project, P-2130, California

- Waterbury Hydroelectric Project, P-2090, Vermont. 


\section{A-Drop Hydroelectric Project, Hydrodynamics, Inc. - P-12549 Case Study}

\section{Table C1. Description of Project Key Characteristics and Timeline Lengths}

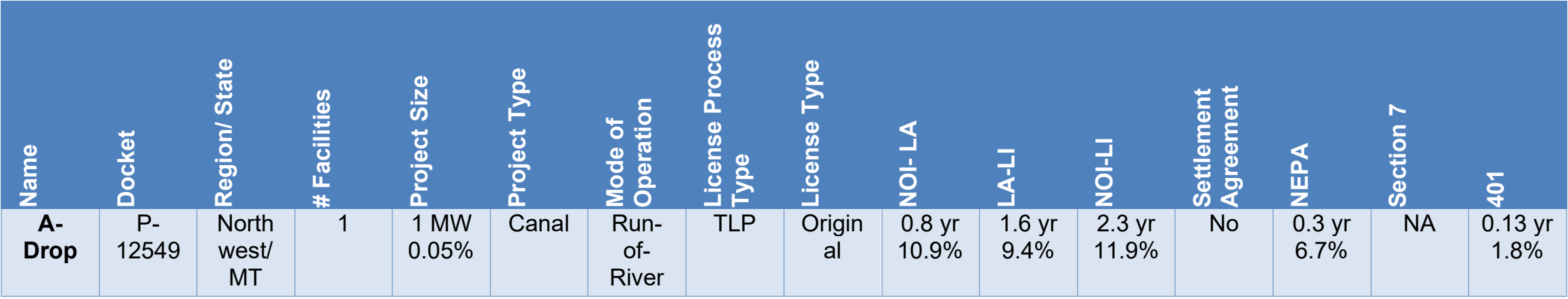

Notes: NOI-LA: Notice of intent to license application timeline. LA-LI: License application to license issuance timeline. NOI-LI: Notice of intent to license issuance timeline. NEPA: National Environmental Policy Act timeline. Section 7: Endangered Species Act Section 7 Consultation timeline. 401 : State Clean Water Act Section 401 Certification timeline. TLP: Traditional Licensing Process. Percent values on the bottom row of some cells represent the percentile the timeline for this project represents in the overall sample of 107 projects used in Chapter 3: Statistical Description and Analysis of Hydropower Licensing Timelines. 


\section{A-Drop P-12549}

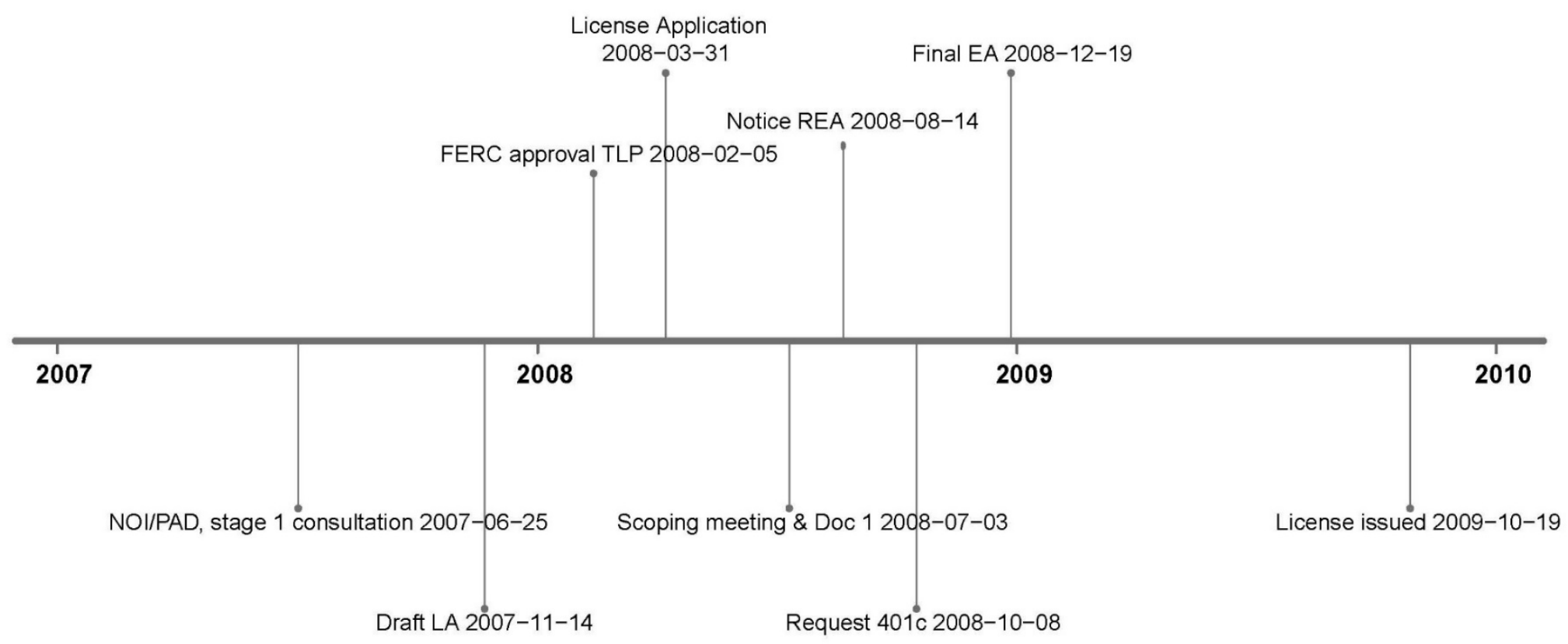

Figure C1. Timeline of some major licensing milestones 


\section{A-Drop Project Overview}

The A-Drop Project was proposed to be located on the Greenfields Main Canal, which is part of the Bureau of Reclamation's (BOR's) Sun River Irrigation Project in Teton County, Montana. ${ }^{69}$ The project would not have occupied any federally managed lands, however BOR holds an easement over the private lands in which the project was to be located. The project proposed to use irrigation flows from the Sun River Project's Greenfields Main Canal, which diverts water from the Sun River (a tributary of the Missouri River) and its tributaries below the Gibson Dam into the Pishkun Supply Canal, which flows into the Pishkun Reservoir (Hydrodynamics, Inc. 2008a; Hydrodynamics, Inc., 129 Federal Energy Regulatory Commission (FERC) $\uparrow 62,042$ Order Issuing Original Minor License [October 19, 2009]). From the Pishkun Reservoir, water flows into the Sun River Slope Canal that becomes the Spring Valley Canal and finally the Greenfields Main Canal (Hydrodynamics, Inc. 2008a).

The proposed A-Drop Project was to consist of a new inflatable weir that would divert water from the Greenfields Main Canal into a new powerhouse containing a 1 MW Francis or propeller turbine generator unit. A new tailrace would have been buried to discharge flows back into the drop structure' $\mathrm{s}^{70}$ stilling pool. The project proposed to realign a section of the existing canal access road to accommodate the proposed project intake. The project did not plan to impound water and was to operate strictly as a run-of-release project. All flows would have been returned to the canal system downstream of the tailrace. The project as proposed did not contain recreation facilities (Hydrodynamics, Inc. 2008a; Hydrodynamics, Inc., 129 FERC 9 62,042 Order Issuing Original Minor License (October 19, 2009).

The A-Drop Project was issued an original minor license in 2009. For the original licensing process being analyzed in this case study, Hydrodynamics, Inc. (licensee) submitted the NOI and PAD in November 2007 and elected to use the Traditional Licensing Process (TLP) (Hydrodynamics, Inc. 2007a; Hydrodynamics, Inc. 2007b; FERC 2007). In December 2007, the licensee requested that the PAD serve as the draft license application (Hydrodynamics, Inc. 2007b). The licensee submitted a final license application in March 2008, and FERC provided a notice of deficiency of license application and request for additional information to the licensee in May 2008 (FERC 2008a). The licensee submitted a revised final license application in August 2008 (Hydrodynamics, Inc. 2008b). In October 2009, FERC issued 40-year original license for the construction, operation, and maintenance of the 1-MW A-Drop Project (Hydrodynamics, Inc., 129 FERC 962,042 Order Issuing Original Minor License [2009]).

\footnotetext{
${ }^{69}$ The A-Drop Project, FERC No. 12549 license was terminated on November 25, 2013, for failure to commence construction in accordance with Article 301 of the license and section 13 of the FPA (Hydrodynamics, Inc., 145 FERC 962,140 Order Terminating License [2013]).

${ }^{70}$ The "drop structure" was proposed to be located at the upstream end of the A-Drop Project canal and is a narrow, lined section of the earthen Greenfields Main Canal that conveys canal flows down to a topographic gradient. A stilling pool is located between the downstream end of the drop structure and the canal. The drop structure and the stilling pool are part of BOR's Sun River Project and operated by the Greenfields Irrigation District (Hydrodynamics, Inc., 129 FERC $\uparrow$ 62,042 Order Issuing Original Minor License [October 19, 2009]).
} 


\section{A-Drop Project Participants and Comment Themes}

The A-Drop Project had 19 participants, none of which filed for intervenor status (i.e., an official party to the proceeding). The majority of comments filed in the FERC record were from federal agencies, specifically, the U.S. Department of the Interior (DOI), U.S. Environmental Protection Agency (EPA), and National Park Service (NPS) (FERC 2009). Comments were generally focused on three main themes: 1) impacts of project operations on potential historic properties; 2) impacts of project operations on recreational areas; and 3) water quality and fisheries (DOI 2008a; DOI 2008b; EPA 2009; NPS 2008).

\section{Statutory and Regulatory Compliance}

The following subsections address both substantive and procedural aspects of the NEPA process administere by FERC, the CWA Section 401 Water Quality Certification process administered by the Montana Department of Environmental Quality (DEQ), the ESA Section 7 consultation process administered by the U.S. Fish and Wildlife Service (USFWS), and the NHPA 106 consultation process administered by the Montana State Historic Preservation Office (SHPO).

\section{National Environmental Policy Act}

FERC conducted scoping to determine what issues and alternatives should be addressed in the environmental assessment (EA). Based on the comments filed in relation to the proposed project, FERC decided not to hold public scoping and instead distributed a scoping document (SD1) to interested agencies and others on July 3,2008, with a request to provide written comments within 30 days (FERC 2008b). On August 7, 2008, FERC indicated that a second scoping document would not be issued, and that the EA would be prepared based on the issues identified in SD1 (FERC 2008b). On August 14, 2008, after accepting the licensee's final license application, FERC issued notice that the A-Drop Project was ready for environmental analysis (REA) (FERC 2008b). On December 19, 2008, FERC issued an EA for the A-Drop Project addressing comments filed in SD1, along with a finding of no significant impact (FONSI) (FERC 2008b).

The relicensing of the A-Drop Project raised a few cultural/historic, environmental, and natural resource concerns requiring analysis primarily under the Federal Power Act (FPA), NEPA, CWA, ESA, and NHPA.

The A-Drop Project EA provides an overview of the key issues analyzed during the A-Drop Project original licensing process. At a high level, the primary issue analyzed in the EA was the effect of project operation on:

- The Arctic grayling population in the canals

- Impact to historic properties (FERC 2018b).

In addition to the primary issue analyzed in the EA, a few other potentially significant impacts were analyzed, including:

- Erosion and sedimentation from construction activities

- Turbidity and sedimentation from construction activities or when water is turned back into the canals 
- Fish entrainment and turbine mortality

- Loss of vegetation (FERC 2018b).

\section{Clean Water Act Section 401}

On September 15, 2008, Montana DEQ received a request to grant or waive a water quality certification (WQC) for the operation of the A-Drop Project. On October 27, 2008, Montana DEQ waived WQC for the A-Drop Project's operation (Hydrodynamics, Inc., 129 FERC 9 62,042 Order Issuing Original Minor License [2009]).

\section{ESA Section 7 Consultation}

During the NEPA review process, FERC concluded that there were no listed species or designated critical habitat in the project area and therefore ESA Section 7 formal consultation was not required (Hydrodynamics, Inc., 129 FERC $\$$ 62,042 Order Issuing Original Minor License [2009]).

\section{NHPA Section 106}

To comply with Section 106 of the NHPA (16 U.S.C. $\S 306108$ ), FERC designated the licensee as the non-federal representative for the purposes of conducting consultation. The licensee consulted with BOR, the Montana SHPO, and five Indian tribes - the Blackfeet, the Confederated Salish and Kootenai Tribes, the Chippewa Cree Tribe, and Gros Ventre (Fort Belknap Indian Community) about the potential adverse effects to historical properties associated with the project and the preparation of the Historic Properties Management Plan (HPMP) (FERC 2008b; FERC 2008c). In November 2008, the Montana SHPO found there were no adverse effects to historic properties involving the proposed project (FERC 2008b; FERC 2008c). The licensee's responsibility to implement the HPMP is included in Article 414 of the FERC license order (Hydrodynamics, Inc., 129 FERC 1 62,042 Order Issuing Original Minor License [2009]).

\section{Settlement Agreement}

Stakeholders in the A-Drop Project did not attempt to reach a settlement agreement.

\section{A-Drop Project Outcomes: Non-Power Benefits (Protection, Mitigation, and Enhancement)}

This section highlights project outcomes that resulted in non-power benefits associated with the A-Drop Project original licensing. For the purposes of this case study, non-power benefits are defined as the measures included as conditions to the FERC license order.

These license conditions were the result of measures proposed by the licensee, FERC staff recommendations within NEPA analysis, and the Montana DEQ's CWA 401 Water Quality Certification process. These license conditions include those associated with species and historic/cultural resources.

\section{Species Protection Measures}

The FERC license order for the A-Drop Project contained the following protection, mitigation, and enhancement (PME) measures applicable to aquatic species protection: 
- Required annual collection, transportation, and subsequent release of Arctic graylings from BOR's stilling pool downstream of the tailrace at the end of the irrigation season (Hydrodynamics, Inc., 129 FERC 92,042 Order Issuing Original Minor License [2009]).

Cultural and Historic Resources Measures

The FERC license order for the A-Drop Project required the licensee to implement a HPMP. The FERC license order requires the licensee to consult with the Montana SHPO prior to making any additions or alterations to properties listed or eligible for listing on the National Register of Historic Places (Hydrodynamics, Inc., 129 FERC $\$$ 62,042 Order Issuing Original Minor License [2009]).
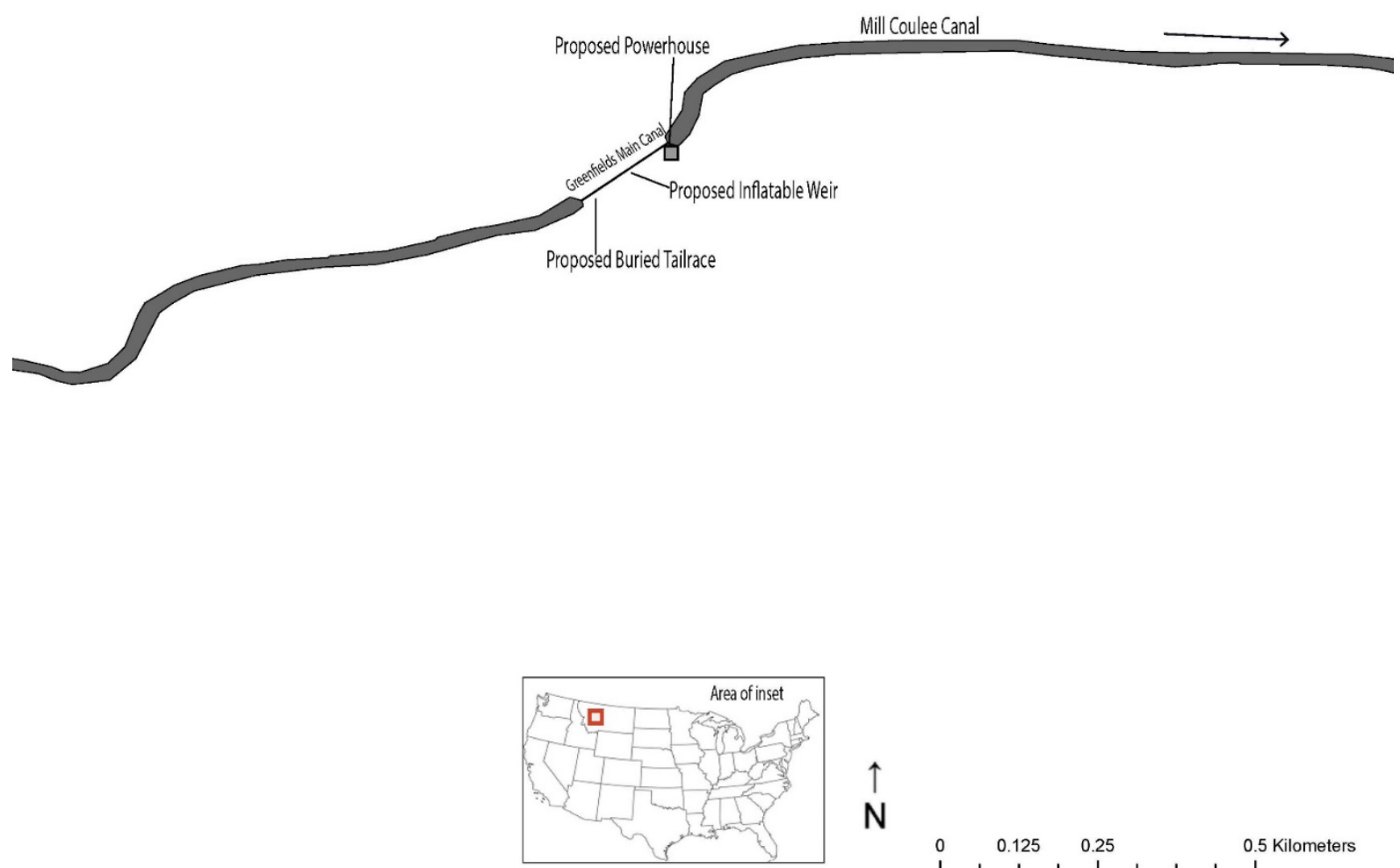

\section{$\uparrow$ \\ $\mathrm{N}$}

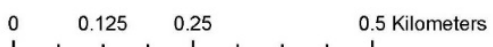

Figure C2. Map indicating major landmarks and features mentioned in project license. Arrow indicates direction of flow. 


\section{Badger-Rapide Croche Hydroelectric Project - P-2677 (Relicensing) Case Study}

\section{Table C2. Description of Project Key Characteristics and Timeline Lengths}

\begin{tabular}{|c|c|c|c|c|c|c|c|c|c|c|c|c|c|c|c|}
\hline$\frac{\stackrel{9}{E}}{\frac{10}{2}}$ & $\begin{array}{l}\text { 형 } \\
\frac{0}{0} \\
8 \\
0\end{array}$ & 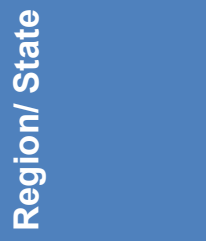 & 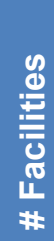 & 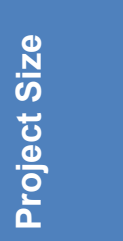 & 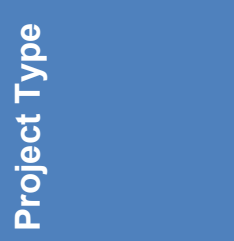 & 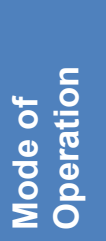 & 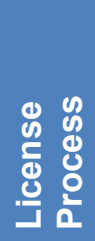 & 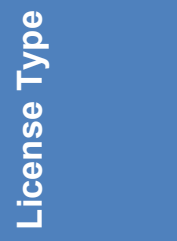 & $\frac{4}{\frac{1}{2}}$ & $\frac{\bar{y}}{5}$ & $\begin{array}{l}\overline{7} \\
\frac{1}{2}\end{array}$ & 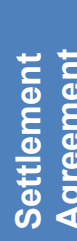 & $\frac{\nwarrow}{\frac{\alpha}{2}}$ & 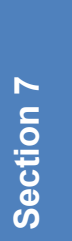 & ร \\
\hline $\begin{array}{l}\text { Badger- } \\
\text { Rapide } \\
\text { Croche }\end{array}$ & $\begin{array}{c}\text { P- } \\
2677\end{array}$ & Midwest/WI & 3 & $\begin{array}{c}9.4 \\
\text { MW } \\
0.45 \%\end{array}$ & $\begin{array}{c}\text { Existing } \\
\text { Conventional }\end{array}$ & $\begin{array}{l}\text { Run- } \\
\text { of- } \\
\text { River }\end{array}$ & TLP & Relicense & $\begin{array}{l}2.3 \mathrm{yr} \\
32.5 \%\end{array}$ & $\begin{array}{l}3.7 \mathrm{yr} \\
22.6 \%\end{array}$ & $\begin{array}{c}6 \mathrm{yr} \\
30.8 \%\end{array}$ & No & $\begin{array}{c}1.4 \mathrm{yr} \\
26.5 \%\end{array}$ & NA & $\begin{array}{l}1.9 \mathrm{yr} \\
12.3 \%\end{array}$ \\
\hline
\end{tabular}

Notes: NOI-LA: Notice of intent to license application timeline. LA-LI: License application to license issuance timeline. NOI-LI: Notice of intent to license issuance timeline. NEPA: National Environmental Policy Act timeline. Section 7: Endangered Species Act Section 7 Consultation timeline. 401 : State Clean Water Act Section 401 Certification timeline. Percent values on the bottom row of some cells represent the percentile the timeline for this project represents in the overall sample of 107 projects used in Chapter 3: Statistical Description and Analysis of Hydropower Licensing Timelines.

Badger-Rapide Croche P-2677

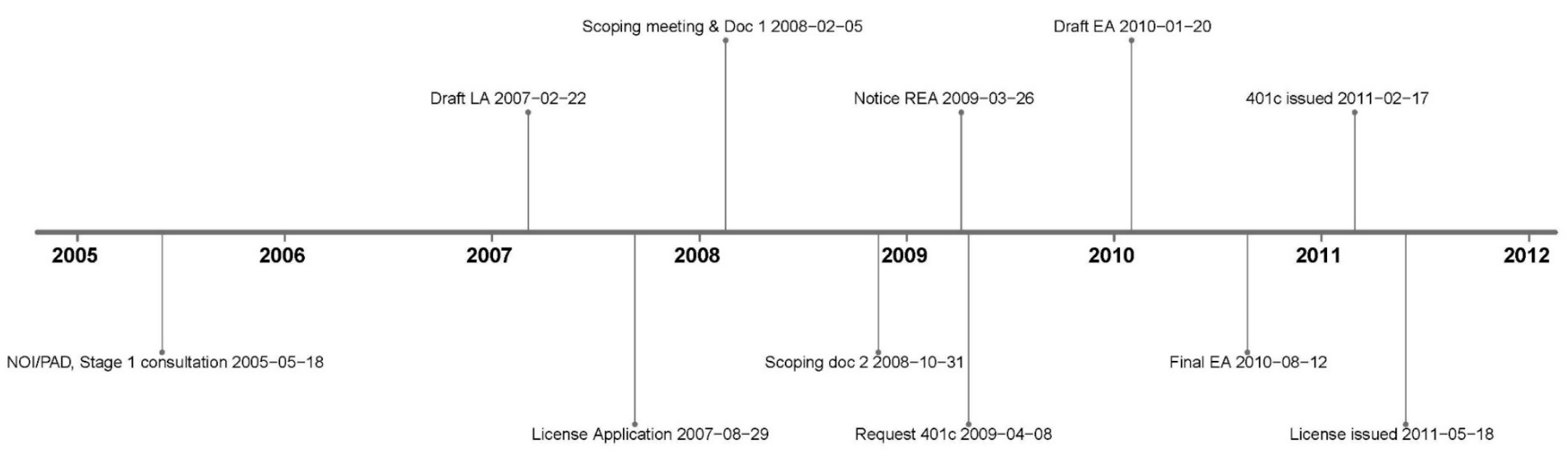

Figure C3. Timeline of some major licensing milestones 


\section{Badger-Rapide Croche Project Overview}

The Badger-Rapide Croche Hydroelectric Project (Badger-Rapide Croche Project) is located in Outagamie County, Wisconsin, and consists of the Badger and Rapide Croche Developments. The project does not occupy any federally managed lands. The Badger Development is located in the City of Kaukauna at the U.S. Army Corp of Engineer's (USACE's) Kaukauna dam. The Rapide Croche Development is located in the Town of Buchanan at USACE's Rapide Croche dam. USACE operates the dams for navigation, recreation, water quality, and flood control purposes. There are no minimum flow releases at either dam (FERC 2011).

Although this relicense proposed a number of upgrades to the Badger Development, the original facility utilized the head created by the Kaukauna dam and flashboards installed atop the dam and consisted of a power canal that bifurcates into a canal leading to the Old Badger powerhouse and a power canal that led to the New Badger powerhouse. A bypassed reach extended from the Kaukauna dam downstream to the impoundment of the City Plant Dam Project No. 1510 (FERC 2011). ${ }^{71}$ Hydropower generation at this original facility was conducted at the $2 \mathrm{MW}$ rated capacity Old Badger Powerhouse and the 3.6 MW rated capacity New Badger Powerhouse.

The Rapide Croche Development is located approximately 4.5 miles downstream of the Badger Development and is integral to the Rapide Croche dam. This facility utilizes the head created by the Rapide Croche dam and flashboards atop the dam. Hydropower generation at this development is conducted at the 2.4 MW rated capacity Rapide Croche Powerhouse (FERC 2011).

The new license proposed upgraded project facilities at the Badger Development, including decommissioning of the Old Badger powerhouse; decommissioning, demolition, and removal of the New Badger powerhouse; and construction of a new 7-MW powerhouse for a total project installed generation capacity of $9.4 \mathrm{MW}$. The new license also proposed modifying the power canal and increasing the hydraulic capacity from 3,096 cubic feet per second (cfs) to 5,260 cfs. No significant changes to project operation or facilities were proposed for the Rapide Croche Development.

The license includes Rapide Croche Park. Amenities provided at the park include drinking water, a parking area, restroom facilities, picnic tables and grills, hiking trails, and protective fencing (FERC 2011).

The Badger-Rapide Croche Project was originally licensed in 1977 for a 50-year term effective in $1938,{ }^{72}$ and went through a previous relicensing, receiving a second license in 1989 for a 30year term (FERC 2011). For the relicensing process being analyzed in this case study, Kaukauna

\footnotetext{
${ }^{71}$ In 2018, the capacity of the Badger-Rapide Croche project was reduced by an amendment to the license (165 FERC ๆ 62,115 November 21, 2018 (P-2677-037)).

72 The Fox River was determined to be navigable in an order issued on November 30, 1938, so the 50-year term was effective on November 1, 1938 and expired on October 31, 1988 (FERC 1977).
} 
(licensee) submitted a request to accelerate the expiration date ${ }^{73}$ of its license in January 2005, proposing no major modifications to the existing infrastructure and electing to use TLP (FERC 2011). In May 2005, FERC granted the request to accelerate the expiration date, and by doing so, deemed the licensee's January 2005 request as the licensee's NOI (FERC 2011; FERC 2005a). The license for the Badger-Rapide Croche Project expired on August 9, 2010. Prior to completing relicensing, the project operated under an annual license from 2010 until receiving its new license in 2011 (FERC 2011).

\section{Badger-Rapide Croche Project Participants and Comment Themes}

The Badger-Rapide Croche Project had 36 participants, 3 of which filed for intervenor status (i.e., an official party to the proceeding) with FERC. The bulk of comments filed in the FERC record were from state and federal agencies, specifically, DOI and the Wisconsin Department of Natural Resources (DNR). In addition, American Whitewater, a non-profit river conservation group with a mission to conserve and restore whitewater resources and enhance opportunities to enjoy them safely, filed a timely motion to intervene. Comments were generally focused on three main themes of project impacts: 1) recreation in the form of paddle boating, 2) impacts of project operations on flows that subsequently affect fisheries and other aquatic life, and 3) fish impingement and entrainment (American Whitewater 2008; DNR 2008).

\section{Statutory and Regulatory Compliance}

The following subsections address both substantive and procedural aspects of the NEPA process administered by FERC, the CWA Section 401 Water Quality Certification process administered by the Wisconsin DNR, the ESA Section 7 consultation administered by USFWS, and the NHPA 106 consultation process administered by the Wisconsin SHPO.

\section{National Environmental Policy Act}

FERC conducted scoping to determine what issues and alternatives should be addressed in the EA. A scoping document (SD1) was initially distributed to interested project stakeholders on February 5, 2008. Following release of the SD1, FERC conducted a site visit on August 5, 2008, and provided an opportunity for written comment. FERC issued a revised scoping document (SD2), addressing the comments received on SD1, on October 31, 2008. On March 26, 2009, after accepting the licensee's final license application, FERC issued notice that the BadgerRapide Croche Project was REA (FERC 2011). On January 20, 2010, FERC issued a draft EA for the Badger-Rapide Croche Project requiring comments to be filed on the draft EA by February 30, 2010 (FERC 2010a). On August 12, 2010, FERC issued the final EA, addressing comments filed on the draft EA.

The relicensing of the Badger-Rapide Croche Project raised a number of cultural, historic, environmental, natural resource, and recreational concerns requiring analysis primarily under FPA, NEPA, CWA, ESA, and NHPA. The Badger-Rapide Croche Project EA provides an

\footnotetext{
73 The licensee requested an accelerated expiration date in order to begin repairing aging facilities, to decommission the Old Badger powerhouse, and to build a new Badger powerhouse that would increase the project's overall installed capacity (FERC 2011).
} 
overview of the key issues of the Badger-Rapide Croche Project relicensing process. At a high level, the primary issues analyzed in the EA included:

- Minimum instream flows in the Badger Development bypass reach for whitewater boating

- Fish entrainment and impingement at the project intakes

- Invasive species control

- Recreation areas, including whitewater boating

- Aesthetic values that could be affected by proposed new construction

- Protection of cultural resources (FERC 2010b).

In addition to the primary issues analyzed in the EA, a number of other issues were analyzed, including:

- Sediment control and disposal during demolition and construction

- Water temperature and minimum instream flow rates to support walleye spawning from mid-March to mid-April

- Operation of the project in a run-of-river mode, with minimal reservoir fluctuations

- Enhancements to recreational facilities

- Continuation of routine maintenance of the Old Badger powerhouse without altering the exterior

- Designing the proposed powerhouse to complement the Old Badger powerhouse

- Options for reusing salvaged stone to minimize the visual impact of filling portions of the canal

- Erosion sites around the Rapide Croche impoundment

- Implementation of a Historic Resources Management Plan (FERC 2010b).

\section{Clean Water Act Section 401}

On April 1, 2009, the licensee submitted a request to the Wisconsin DNR to grant or waive a WQC for the continued operation of the Badger-Rapide Croche Project (FERC 2011; DNR 2011), which was received on April 6, 2009 (MH 2009). On February 19, 2010, the licensee withdrew its request and submitted a new request for a WQC to the Wisconsin DNR received on February 22, 2010 (FERC 2011). The licensee proposed continued operation of the BadgerRapide Croche Project in accordance with historic operating procedures with only one minor change to existing project operations - to increase capacity of the Badger Development from 3,096 to $5,260 \mathrm{cfs}$ using two identical generating units with a capacity of 2,630 cfs each (FERC 2011; DNR 2011).

The primary water quality issues associated with the continued operation of the Badger-Rapide Croche Project that were identified and studied included run-of-river operation in accordance with the water level and flow management plan of USACE, limitation of impoundment fluctuations, minimum flow and spawning flow releases, ramping rates, fish protection, water quality monitoring, invasive species monitoring, and recreational facilities (FERC 2011; WNDR 2011). The Wisconsin DNR subsequently concluded that the Badger-Rapide Croche Project operation, as proposed in the final license application, would comply with Section 401 of the CWA (DNR 2011). On February 17, 2011, Wisconsin DNR issued a WQC for the Badger- 
Rapide Croche Project's continued operation with the following 14 additional conditions, which were incorporated into the license:

- Condition 1 required the licensee to notify the Wisconsin DNR of construction projects at least 5 days prior to the beginning of construction and 5 days after completion of construction

- Condition 2 required the project to operate in run-of-river mode and in cooperation with the water level and flow management plan of USACE for the Fox River

- Conditions 3 and 4 required the project to maintain minimum flow rates using a discharge conduit or, with permission, another facility or device

- Conditions 5 and 6 required the project to maintain set intake velocities at the power intake trash rack, which must not exceed 1-inch clear spacing (and the licensee must replace the trash rack at the Rapide Croche plant no later than 2021)

- Condition 7 required that changes in generation flow should not exceed more than $10 \%$ of the total inflow per hour unless otherwise agreed upon

- Conditions 8, 9, and 10 required the development and implementation of an invasive species plan, a recreation plan, and a wildlife and land management plan

- Condition 11 required the project to meet the most current state water quality standards at any time under the license term and develop a water quality monitoring plan that described the methodology used to conduct periodic water quality monitoring in accordance with a schedule approved by the Wisconsin DNR

- Conditions 12, 13, and 14 required the development of a compliance plan for flow delivery and flow monitoring in the spillway channel, an erosion plan and large woody debris passage plan, and a reservoir drawdown plan approved by the Wisconsin DNR to minimize the impact of project maintenance on aquatic and wetland resources (FERC 2011).

\section{ESA Section 7 Consultation Overview}

During the scoping process, FERC found that no federally listed species or critical habitats for such species were present in the project boundary (FERC 2011). FERC concluded that issuing a new license for the project would have no effect on federally listed species because no federally listed species or critical habitats for such species were present within the project boundary (FERC 2011). Therefore, Section 7 consultation was deemed unnecessary (FERC 2011).

\section{NHPA Section 106}

To comply with Section 106 of the NHPA (16 U.S.C. § 306108), FERC executed a statewide programmatic agreement (PA) with the Advisory Council on Historic Preservation (ACHP) and the Wisconsin and Michigan SHPOs on December 30, 1993 (FERC 2011). The licensee concurred with the PA, which required it to implement an HPMP for the 50-year license term (FERC 2011). The licensee filed the HPMP for the project on August 21, 2007, and consulted with the SHPO on December 12 and 13, 2007 (FERC 2011). The SHPO agreed that the HPMP addressed its concerns via an email dated January 14, 2008 (FERC 2011). The licensee's responsibilities under the PA, including the HPMP, were included in article 410 of the FERC license order (FERC 2011). 


\section{Settlement Agreement}

Stakeholders in the Badger-Rapide Croche project relicense did not agree to terms on a settlement agreement.

\section{Badger-Rapide Croche Project Outcomes: Non-Power Benefits}

This section highlights project outcomes that resulted in non-power benefits associated with the Badger-Rapide Croche relicensing. For the purposes of this case study, non-power benefits are generally PME measures included as conditions to the FERC license. These conditions were the result of measures proposed by the licensee, FERC recommendations within NEPA analysis, and the Wisconsin DNR's CWA 401 Water Quality Certification process. These conditions include those associated with water quality, species and habitat protection, recreation, and historic/cultural resources.

\section{Water Quality and Species Protection Measures}

The FERC license order for the Badger-Rapide Croche project contained the following PME measures applicable to water quality and aquatic species protection:

- Required the construction, maintenance, and operation of facilities for the conservation and development of fish and wildlife resources

- Required the allowance of the United States or its designated agency to use, free of cost, the licensee's lands and interests in lands, reservoirs, waterways, and project works as may be required to complete facilities or improvements there for the protection of wildlife and fisheries

- Required responsibility for and prevention of soil erosion on lands adjacent to streams or other waters, stream sedimentation, and any form of water or air pollution during construction, maintenance, or operation of the project

- Required that material only be dredged, excavated, or placed as fill in project lands or waters if the licensee was continuing work specifically authorized under the license, in the maintenance of the project, or after obtaining FERC approval

- Required cooperation with the Lower Green Bay Remedial Action Plan by allowing the Wisconsin DNR or other agencies involved with the implementation of that plan reasonable access to the project boundary or temporarily modify the project's instantaneous run-of-river operation mode to facilitate removal or treatment of contaminated sediments in the Fox River

- Required the development of a plan to conduct subsurface testing for contaminated soils in areas proposed for ground disturbance

- Required the development of a plan to conduct water quality monitoring for a period of 3 years to evaluate the effects of year-round and walleye spawning flow releases on water temperature and dissolved oxygen immediately upstream of the Badger intake, at the downstream end of the Badger bypassed reach, and in the tailrace

- Required the development of a plan to document compliance with the operational provisions required by WQC conditions $2,3,5$, and 7, including a requirement to continuously record water temperature (via a logger located in the Badger powerhouse or other appropriate location) to determine the start/stop dates of the walleye spawning flow releases (FERC 2011). 


\section{$\underline{\text { Recreation Measures }}$}

The FERC license order for the Badger-Rapide Croche project contained the following PME measures applicable to recreation:

- Implementation of a recreation plan that included:

- Development of public access with parking areas near the railroad bridge and Elm Street in the natural diversion channel

- Development of a new boat launch area on the southern shoreline of the Rapide Croche impoundment to include an access road, boat ramp, parking area, pier, and accessible American Disabilities Act compliant fishing pier with signage and lighting

- Enhancements at the existing Rapide Croche Park to include construction of a pavilion with accessible restrooms, display kiosk, replacement of existing picnic tables and grills, and development of an approved fishing access trail

- Incorporation of Hydro Park into the project boundary and development of new facilities including the installation of interpretive kiosks, trail surfacing, landscaping, a picnic area, and restrooms

- Development of a new whitewater boater access site to the bypass channel in Central Park, including the installation of fencing, gate, and lock system with keys available for purchase

- Maintenance of a website and staff gauge to provide flow information for those planning on boating in the bypass reach

- Four whitewater flow releases of 3,340 cfs annually with ramping rates with annual monitoring for 3 years following the first release (FERC 2011).

\section{$\underline{\text { Cultural/Historic Resources Measures }}$}

The FERC license order for the Badger-Rapide Croche Project required the licensee to implement an HPMP via PA with the Wisconsin SHPO. The PA requires the licensee to consult with the Wisconsin SHPO prior to making an additions or alterations to properties listed or eligible for listing on the National Register of Historic Places (FERC 2011). 


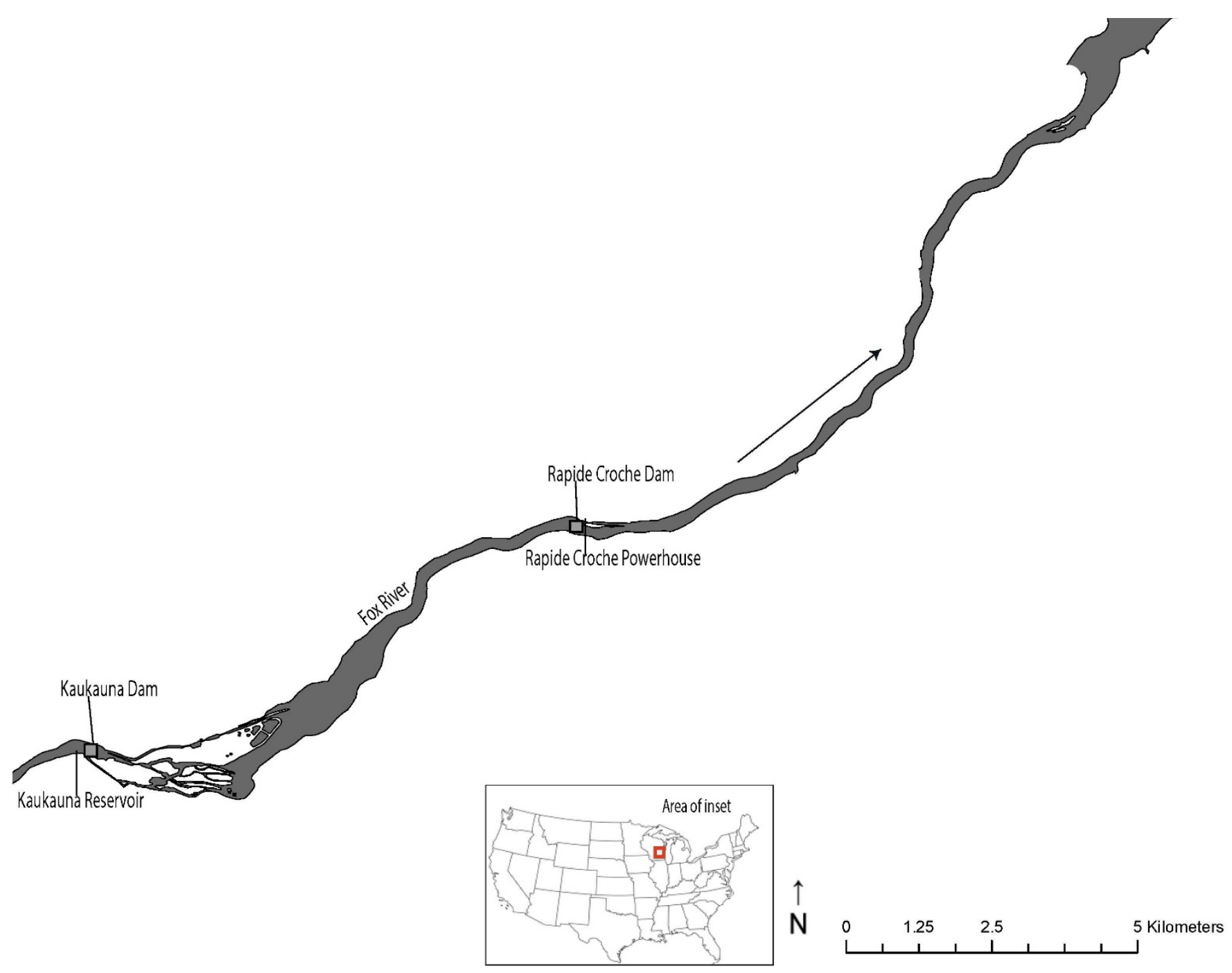

Figure C4. Map indicating major landmarks and features mentioned in project license. Arrow indicates direction of flow. 


\section{Carver Falls Hydroelectric Project - P-11475 (Licensing) Case Study}

\section{Table C3. Description of Project Key Characteristics and Timeline Lengths}

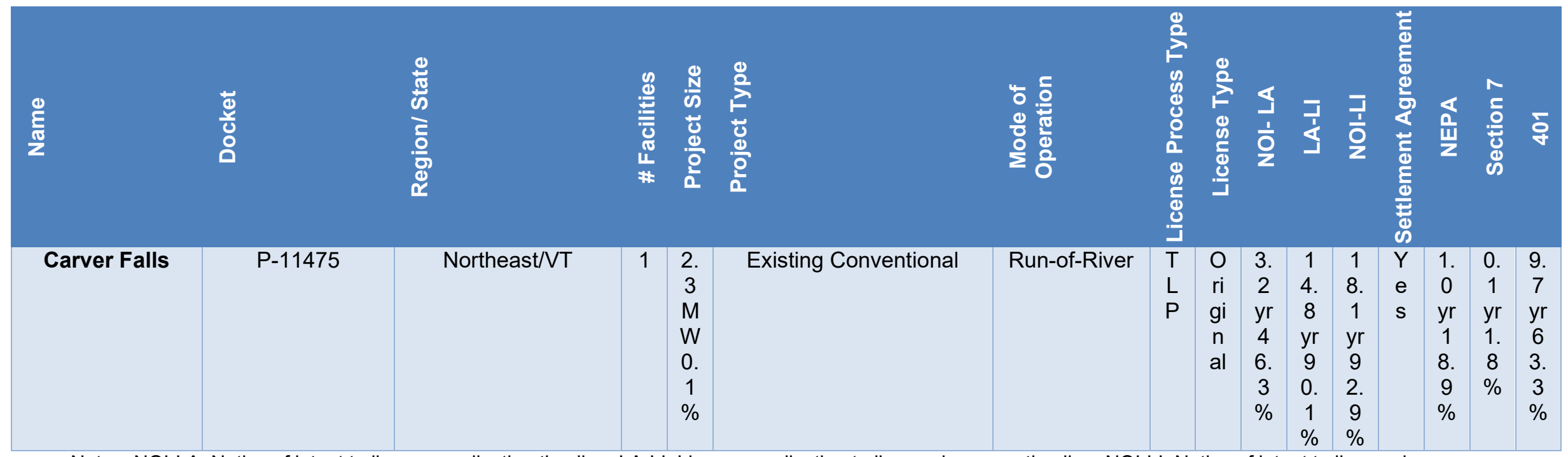

Notes: NOI-LA: Notice of intent to license application timeline. LA-LI: License application to license issuance timeline. NOI-LI: Notice of intent to license issuance timeline. NEPA: National Environmental Policy Act timeline. Section 7: Endangered Species Act Section 7 Consultation timeline. 401: State Clean Water Act Section 401 Certification timeline. Percent values on the bottom row of some cells represent the percentile the timeline for this project represents in the overall sample of 107 projects used in Chapter 3: Statistical Description and Analysis of Hydropower Licensing Timelines. 
Carver Falls P-11475

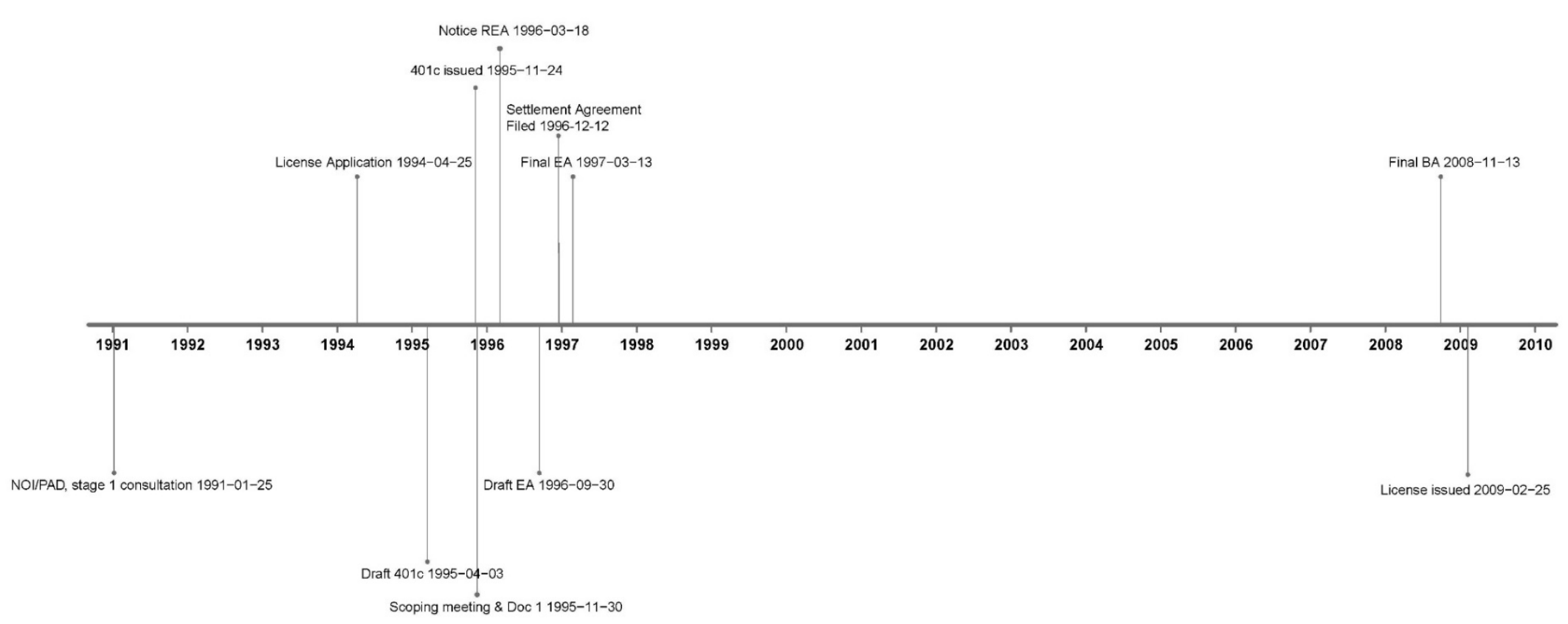

Figure C5. Timeline of some major licensing milestones 


\section{Carver Falls Project Overview}

The Carver Falls Hydroelectric Project (Carver Falls Project) is located in the town of Hampton in Washington County, New York, and the town of West Haven in Rutland County, Vermont (FERC 1995). The project does not occupy any federally managed lands. The project consists of a concrete-and-stone masonry dam that spans the Poultney River. Hydropower generation at the project is conducted at the 1.9-MW rated capacity Carver Falls Powerhouse. The project has one reservoir, the Carver Falls impoundment. The powerhouse discharges water directly into the Poultney River (FERC 2009a).

Recreation facilities at the project are located on the New York side of the river and radiate out from a parking area located near the southern end of the dam. On the upstream side of the parking area, an approximately 600 -foot long trail runs east through a meadow to an informal canoe launch on the impoundment. On the downstream side of the parking area is a fence and gate leading to the powerhouse service road and a trail that runs north to two overlooks to the dam and falls. One is a small viewing platform (overlook) located on top of the penstock, and the second is located nearby on a steep promontory. A trail runs southwest from the powerhouse access road to the river downstream from the dam; this is used as an informal downstream portage trail. Vehicular access beyond the parking area is currently restricted to licensee service vehicles (FERC 2009a).

The Carver Falls Project began unlicensed power generation in 1894 (FERC 2009a). On January 25, 1991, FERC issued an order stating that the Carver Falls Project portion of the Poultney River had been determined ${ }^{74}$ to be a navigable waterway of the United States and that the Central Vermont Public Service Corporation (CVPS) (licensee) would need to file a license application or an exemption within 36 months of the order (FERC 1988; FERC 1991). Thus, for the original licensing being analyzed in this case study, the licensee did not submit an NOI or a PAD (FERC 2009a). The licensee proposed no major modifications to the existing infrastructure and selected the TLP (CVPS 1994). In February 2009, FERC issued an original 30-year hydropower license for the continued operation and maintenance of the 1.9 MW Carver Falls Project (FERC 2009a).

\section{Carver Falls Project Participants and Comment Themes}

The Carver Falls Project had 35 participants, 7 of which filed for intervenor status (i.e., an official party to the proceeding) with FERC. The bulk of comments filed in the FERC record were from state and federal agencies, specifically, DOI, EPA, New York State Department of Environmental Conservation (DEC), Vermont Agency of Natural Resources (VANR), Vermont Natural Resources Council (VNRC) and the Lower Poultney River Committee (known jointly as VNRC). In addition, New York Rivers United (NYR) and American Rivers, Inc., Nongovernmental organizations (NGOs) that lobby for the conservation-focused, recreational use of America's rivers and streams, also provided comments. Comments were generally focused on four main themes of project impacts: 1) impacts to walleye spawning in the bypassed reach, 2) impacts of project operations on recreational activities, 3 ) impacts of project operations on

\footnotetext{
${ }^{74}$ A navigation status report by FERC in September 1988 indicated that a portion of the Poultney River that included the Carver Falls Project segment was a navigable waterway under Section 3(8) of the Federal Power Act (FERC 1988). In this report, FERC determined that the Poultney River had been used to transport timber and log shipments above, at, and below the site of the Carver Falls Project (FERC 1988).
} 
threatened and endangered species, 4) impacts to water quality and quantity, and 5) aesthetics and aesthetics of spill (DOI 1995; EPA 1995; VANR 1995).

\section{Statutory and Regulatory Compliance}

The following subsections address both substantive and procedural aspects of the NEPA process administered by FERC, the CWA Section 401 WQC processes administered by New York DEC and VANR, the ESA Section 7 consultation administered by USFWS, and the NHPA 106 consultation process administered by the New York and Vermont SHPOs.

\section{National Environmental Policy Act}

FERC conducted scoping to determine what issues and alternatives should be addressed in the EA. A scoping document was initially distributed to interested project stakeholders on November 30, 1995. Comments from project stakeholders were to be in written form and were due no later than February 9, 1996. No revised scoping document was issued. On March 18, 1996, after accepting the licensee's final license application, FERC issued notice that the Carver Falls Project was REA. On September 30, 1996, FERC issued a draft EA for the Carver Falls Project requiring comments to be filed on the draft EA by October 15, 1996. On March 13, 1997 FERC issued the final EA, addressing comments filed on the draft EA, along with a FONSI (FERC 1997).

The licensing of the Carver Falls Project raised a number of cultural, historic, environmental, natural resource, and recreational concerns requiring analysis primarily under FPA, NEPA, CWA, ESA, and NHPA.

The Carver Falls Project EA provides an overview of the key issues of the Carver Falls Project licensing process. At a high level, the main issues analyzed in the EA included the effects of project operation on:

- Walleye spawning in the bypassed reach

- Development of a flow monitoring plan

- Operation of the project in instantaneous run-of-river mode

- Aesthetic flow releases on certain holidays and Sundays

- Minimizing drawdown and turbidity via a flashboard removal and replacement plan

- Removal of abandoned penstocks and cradles to enhance project aesthetics

- Improvement of recreational access and facilities via a final recreation plan, including measures to control soil erosion and sedimentation during construction

- Development of a trashrack debris disposal plan

- Development of a cultural resources management plan

- Cooperation in the New York DEC's sea lamprey control project

- Participation in the Carver Falls Advisory Committee (FERC 1997).

\section{Clean Water Act Section 401}

New York State Department of Environmental Conservation Water Quality Certification On April 22, 1994, the licensee submitted a request to New York DEC to grant or waive a WQC for the continued operation of the Carver Falls Project (FERC 2009a). The licensee proposed 
continued operation of the Carver Falls Project in accordance with historic operating procedures (FERC 2009a).

The primary water quality issues analyzed by the New York DEC associated with the continued operation of the Carver Falls Project included water quantity for aesthetics; water quantity for recreation; water quality during construction, operation, and maintenance; water quantity for walleye spawning; and study plan development (FERC 2009a). New York DEC received the request and subsequently determined that the Carver Falls Project operation, as proposed in the final license application, would comply with Section 401 of the CWA. On April 21, 1995, New York DEC issued a WQC for the Carver Falls Project's continued operation with several additional conditions incorporated into the license order (FERC 2009a). The WQC included the following conditions:

- Condition 1 required the licensee to allow an authorized representative of the New York DEC to inspect the project, including relevant records such as a copy of this WQC, at reasonable hours and intervals upon reasonable notice to the licensee

- Condition 2 required the project to operate in run-of-the-river mode that does not allow the elevation of the project impoundment to drop below one inch above the top of the flashboards or below one inch above the crest of the dam

- Condition 3 required the project to provide continuous release to the bypassed reach at a minimum of $18.5 \mathrm{cfs}$

- Condition 4 required the licensee to submit a flow monitoring plan to determine project flows through the bypassed reach and the project headpond and tailwater elevations

- Condition 5 required the project to curtail generation and install stoplogs or otherwise shut off flow through the turbine(s) before commencing any maintenance dredging activities

- Condition 6 required the licensee to submit and comply with a sediment analysis and disposal plan

- Condition 7 required the licensee to submit and comply with an erosion and sediment control plan

- Condition 8 required the licensee to obtain approval of the design and placement of any temporary structures that would encroach upon the bed or banks of the river, including any cofferdams or temporary access roads or ramps

- Condition 9 required the project to maintain adequate flows immediately downstream of the work sites to ensure water quality standards are met

- Condition 10 required the licensee to measure and compare the turbidity of the water immediately upstream and no more than 100 feet downstream of the project for changes and addressing them appropriately

- Condition 11 required the licensee to provide at least 2 weeks' notice to New York DEC before performing any work required by the certificate

- Condition 12 required the licensee to provide recreational access, including a cartop boat access, parking for at least 5 cars, and a canoe portage route to a point downstream of the powerhouse (FERC 2009a).

New York DEC modified the WQC to make it consistent with the settlement agreement conditions (FERC 2009a). For more details on the settlement agreement conditions, see Section 4 below. 


\section{Vermont Agency of Natural Resources Water Quality Certification}

On December 5, 1995, VANR filed a motion to intervene, asserting that the licensee must obtain WQC from it, because the project would result in a discharge into Vermont waters from a dam spillway located on the Vermont side of the Poultney River. FERC subsequently issued a letter ${ }^{75}$ directing the licensee to request WQC from VANR. On April 7, 1999, the licensee submitted a request to VANR for a WQC for the continued operation of the Carver Falls Project (FERC 2009a). The licensee proposed continued operation of the Carver Falls Project in accordance with historic operating procedures (FERC 2009a). Each year from 1999 to 2007, the licensee withdrew and refiled its WQC application (FERC 2009a). On December 7, 2007, the licensee submitted its most recent request to grant or waive a WQC for the continued operation of the Carver Falls Project (FERC 2009a).

The primary water quality issues analyzed by VANR associated with the continued operation of the Carver Falls Project included water quantity for aesthetics; water quantity for recreation; water quality during construction, operation, and maintenance; and water quantity for walleye spawning (FERC 2009a). VANR subsequently determined that the Carver Falls Project operations, as proposed in the final license application, would comply with Section 401 of the CWA (FERC 2009a). On December 5, 2008, VANR (through the Vermont DEC) issued a WQC for the Carver Falls Project's continued operation containing the following operating conditions:

- Condition A required the licensee to operate and maintain the Carver Falls project consistent with the findings and conditions of the WQC

- Condition B required the project to operate in a run-of-the-river mode that maintains minimum bypass flows at all times

- Condition $\mathrm{C}$ required the project to meet at least $90 \%$ of the instantaneous inflow requirements during refilling of the project impoundment after flashboard replacement, an approved dam maintenance operation, or an emergency drawdown

- Condition D required the licensee to develop and file a flow management plan

- Condition E required the licensee to develop an impoundment and flow management monitoring plan

- Condition F required the licensee to provide the Vermont DEC with a copy of the turbine rating curbs within 1 year of the license issuance

- Condition $\mathrm{G}$ required the licensee to replace the flashboards on the north spillway within 2 years of the license issuance

- Condition H required the licensee to develop and file a debris disposal plan

- Condition I required the licensee to file all proposals for project or maintenance or repair work with the Vermont DEC for approval if the work may have an adverse effect on water quality or cause less-than-full support of an existing use or beneficial value of state waters

- Condition $\mathrm{J}$ required the licensee to allow public access to the project lands to use public resources, subject to reasonable safety and liability limitations

\footnotetext{
75 The Director's decision was upheld in a December 22, 1998, FERC order (FERC 2009a).
} 
- Condition $\mathrm{K}$ required the licensee to remove the concrete cradles and the section of abandoned steel penstocks following consultation with the VDHP within 2 years of license issuance

- Condition L required the licensee to develop and file a recreation plan to construct and maintain recreational facilities

- Condition M required the licensee to contribute $\$ 250,000$ to the Lake Champlain and Tributaries Fund that will be used to protect, restore, and enhance the integrity and connectivity of ecosystems and aquatic life, including but not limited to lake sturgeon and self-sustaining land-locked Atlantic salmon, and protect the riparian zones along Lake Champlain for ecological and recreational resource benefits through land or easement purchases

- Condition $\mathrm{N}$ required the licensee to design and implement erosion control measures as necessary at the Vermont DEC's written request

- Condition O required the licensee to allow the Vermont DEC to inspect the project at any time to check for compliance with the WQC conditions

- Condition $\mathrm{P}$ required the licensee to prominently post a copy of the WQC within the project's powerhouse

- Condition Q required the licensee to obtain approval from the Vermont DEC before making any changes to the project that would have a significant or material effect on the findings, conclusions, or conditions of the WQC

- Conditions $\mathrm{R}$ and $\mathrm{S}$ allowed the Vermont DEC to request that FERC reopen the license to consider modifications to the license conditions as necessary to ensure compliance with the state water quality standards and to add or alter the WQC conditions as necessary (FERC 2009a).

\section{Endangered Species Act Section 7 Consultation Overview}

In a letter dated June 17, 2002, USFWS stated that the federally listed endangered Indiana bat (Myotis sodalis) was likely to occur at the Carver Falls Project (FERC 2009a). FERC issued a BA to USFWS on November 13, 2008, concluding that licensing the project was not likely to adversely affect the Indiana bat so long as the licensee did not conduct tree ${ }^{76}$ removal activities $^{-}$ during the Indiana bat roosting period (between April 15 and September 15) without first surveying for potential roosting trees and consulting with FERC and USFWS (FERC 2009a). On December 29, 2008, USFWS filed a letter in support of a time-of-year restriction but recommended a longer restriction of April 1 through October 31 and that the licensee should also provide survey results, if required, to the New England Field Office of USFWS and the Vermont Department of Fish and Wildlife (FERC 2009a). USFWS also recommended the use of an Indiana bat protection plan that required surveys and consultations be concluded and filed with FERC before tree removal during the non-hibernation season (FERC 2009a). With the amended measures, USFWS concurred with the biological assessment (BA) that the project was not likely to adversely affect the Indiana bat and that no further ESA Section 7 consultation with USFWS was required (FERC 2009a). The licensee's responsibilities under the BA, including the time-of-

\footnotetext{
76 The licensee was only required to conduct surveys if trees with a diameter at breast height greater than 10 inches must be removed during the restricted period. Otherwise, surveys were not required.
} 
year restrictions for tree removal and the Indiana bat protection plan requirements, were included in article 405 of the FERC license order (FERC 2009a).

\section{National Historic Preservation Act Section 106}

To comply with Section 106 of the NHPA (16 U.S.C. $\S 306108$ ), FERC executed a PA with the Advisory Council on Historic Preservation, New York SHPO, and Vermont SHPO on August 8, 1997. FERC invited the licensee to concur with the stipulations in the PA. The licensee concurred to the $\mathrm{PA}$, which required it to implement a cultural resources management plan (CRMP), which would include completion, if necessary, of identification of historic properties at the project for the 30-year license term. This agreement also included stipulations regarding the interim treatment of historic properties, dispute resolution, and amendment and termination of the PA. In addition, the PA required the licensee to file the CRMP within 1 year of license issuance. The licensee's responsibilities under the PA, including the CRMP, were included in article 406 of the FERC license order (FERC 2009a).

\section{Settlement Agreement}

The licensee, New York DEC, VNRC, New York Rivers United, the Poultney River Committee, the Vermont Chapter of the National Wildlife Federation, and VANR participated in settlement agreement negotiations beginning in November 1995 (CVPS 1996). Only the licensee, New York DEC, and New York Rivers United were signatories on the final agreement ${ }^{77}$ (CVPS 1996; FERC 2009a). The settlement agreement was filed on December 12, 1996, and provides that the licensee shall ensure the following:

- A continuous flow to the bypassed reach of $50 \mathrm{cfs}$, or inflow, if less, from April 1 through May 15 every year to protect walleye spawning in the bypassed reach

- Removal of the site's two abandoned above ground penstocks and concrete cradles

- Improved parking and viewing access opportunities for the general public at Carver Falls

- Flow releases over the southern spillway of 2.5 inches, or inflow, if less, for aesthetic purposes on Memorial Day, the Fourth of July, Labor Day, and every Sunday in July and August during the daylight hours, commencing at 9 a.m.

- Establishment of the Carver Falls Advisory Council, chaired by New York DEC, to represent various interests in the project and meet ${ }^{78}$ at least annually to make project management recommendations (FERC 2009a).

\section{Carver Falls Project Outcomes: Non-Power Benefits}

This section highlights project outcomes that resulted in non-power benefits associated with the Carver Falls licensing. For the purposes of this case study, non-power benefits are generally PME measures included as conditions to the FERC license. These conditions were the result of measures proposed by the licensee, FERC staff recommendations within NEPA analysis, New York DEC's CWA 401 Water Quality Certification process, Vermont DEC's CWA 401 Water Quality Certification process, USFWS's ESA Section 7 consultation, and the settlement

\footnotetext{
77 VNRC stated in a letter filed on December 13, 1996, that it did not oppose the settlement agreement but would not be a signatory (FERC 2009a).

78 The licensee must also contribute a maximum of $\$ 200$ each year to defray the costs of the Carver Falls Advisory Council (e.g., travel expenses) (FERC 2009a).
} 
agreement. These conditions include those associated with water quality, species and habitat protection, recreation, and historic/cultural resources.

Water Quality and Species Protection Measures

The final license order for the Carver Falls project contained the following PME measures applicable to water quality and aquatic species protection:

- Required the construction, maintenance, operation, or modification of project structures and operation for the conservation and development of fish and wildlife resources, as ordered by FERC or upon the recommendation of the Secretary of the Interior, fish and wildlife agency, or agencies of any state in which the project was located

- Allowed the United States or its designated agency to use, free of cost, the licensee's lands and interests in lands, reservoirs, waterways, and project works to construct facilities or perform improvements to existing fish and wildlife facilities

- Required the licensee to be responsible for and take measures to prevent soil erosion on lands adjacent to streams or other waters, stream sedimentation, and any form of water or air pollution during construction, maintenance, or operation of the project

- Required the removal or deposit of dredged/excavated material in such manner as to preserve the environmental values of the project and not to interfere with traffic on land or water

- Required the project to operate in a run-of-river mode and release minimum flows, which could be temporarily modified if required by operating emergencies beyond the control of the licensee or for short periods upon agreement among the licensee, VANR, New York DEC, and USFWS

- Reserved authority to DOI to require the licensee to construct, operate, and maintain fishways as may be prescribed by the Secretary of the Interior pursuant to Section 18 of the FPA

- Required the removal of the 1.5-foot-high flashboards from the southern spillway section of the dam on or before September 15 annually to minimize any water quality impacts downstream and in the reservoir (the licensee was permitted to reinstall the flashboards in mid to late April)

- Required the licensee to avoid removing trees (of 10-inch-diameter-breast-height or larger) April 1 through October 31 of each year. If tree removal needed to occur in that period for the purpose of access to project recreation sites, facilities, or routine vegetation management, the licensee was to file an Indiana bat protection plan at least 30 days before the tree removal activities that included:

- Results of a survey by a professional wildlife biologist of all areas to be disturbed by tree removals, including documentation of all potential Indiana bat roosting trees within the areas

- Documentation of consultation with USFWS, Vermont Department of Fish and Wildlife, and New York DEC concerning whether additional surveys for Indiana bat presence were required and any additional comments and recommendations

- An implementation schedule for the tree removal and specific descriptions of how the agencies' comments and recommendations were accommodated by the plan FERC 2009a). 


\section{Recreation Measures}

The FERC license order for the Carver Falls Project contained the following PME measures applicable to recreation:

- Required the construction, maintenance, operation, and/or modification of recreational facilities such as access roads, wharves, launching ramps, beaches, picnic and camping areas, sanitary facilities, and utilities, giving consideration to the needs of the physically handicapped

- Required free public access to project waters and project lands for the purpose of navigation and outdoor recreational purposes, including fishing and hunting

- Implemented a recreation plan that included erosion control measures as well as the provisions required in New York DE's and VANR's WQCs (FERC 2009a).

\section{Cultural/Historic Resources Measures}

The FERC license order for the Carver Falls Project required the licensee to implement a CRMP via a PA with the Advisory Council on Historic Preservation, the New York SHPO, and the Vermont SHPO (FERC 2009a). The PA requires the licensee to identify historic properties at the project and comply with the applicable stipulations regarding the interim treatment of historic properties, dispute resolution, and amendment and termination of the PA (FERC 2009a).

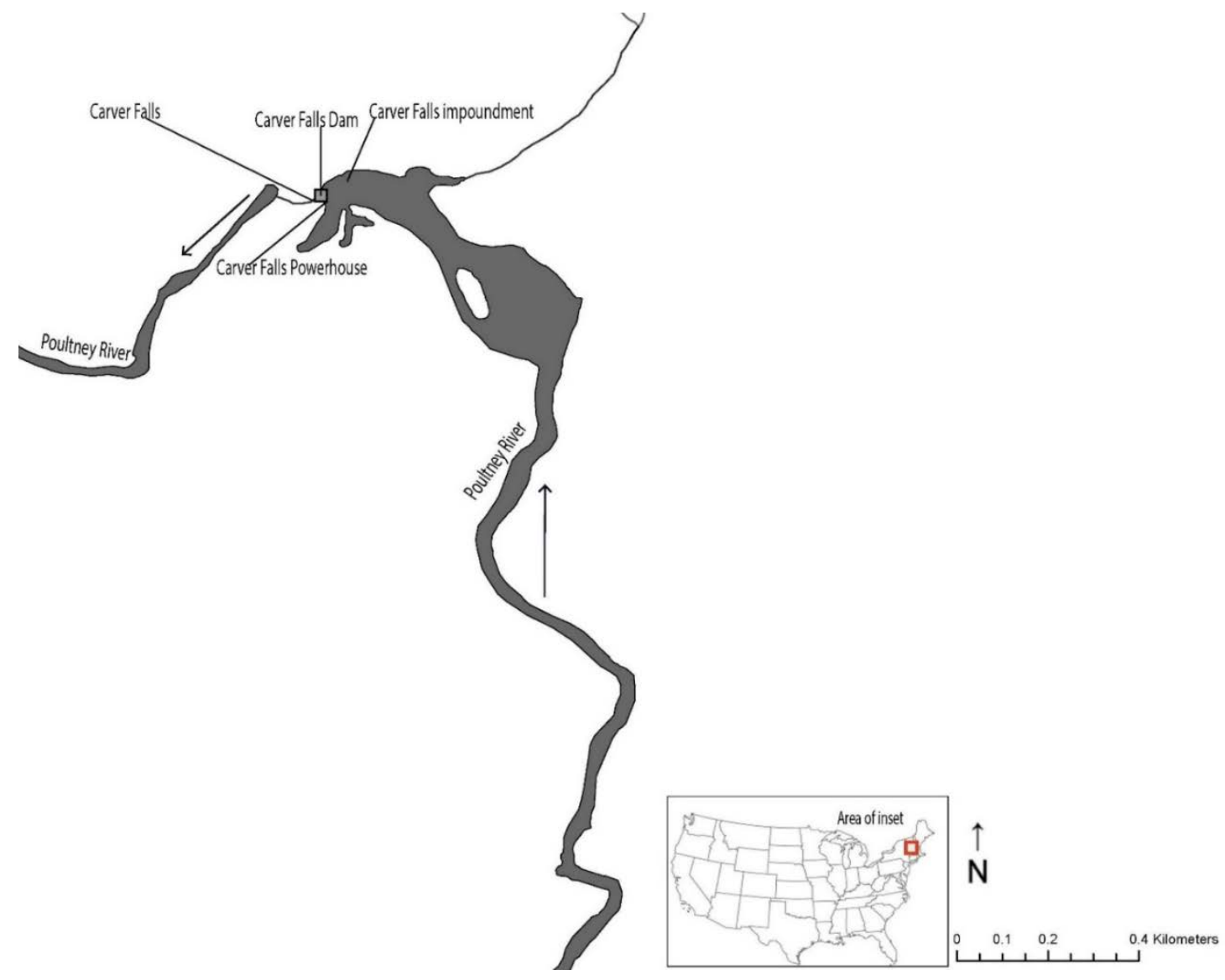

Figure C6. Map indicating major landmarks and features mentioned in project license. Arrow indicates direction of flow. 


\section{Emeryville Project-P-2850 (Relicensing) Case Study}

\section{Table C4. Description of Project Key Characteristics and Timeline Lengths}

\begin{tabular}{|c|c|c|c|c|c|c|c|c|c|c|c|c|c|c|c|}
\hline$\frac{\stackrel{5}{\frac{1}{N}}}{2}$ & $\begin{array}{l}\text { t] } \\
\frac{0}{0} \\
8 \\
0\end{array}$ & 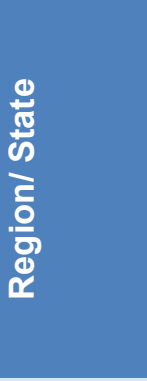 & 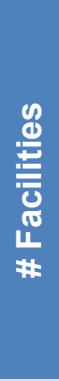 & 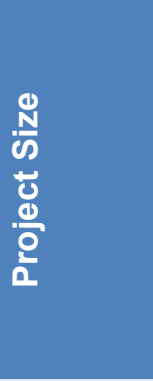 & 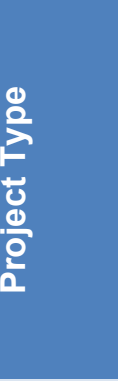 & 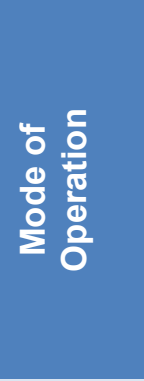 & 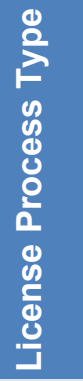 & 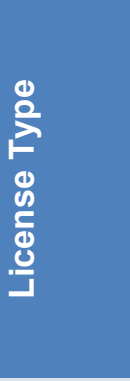 & $\frac{4}{\frac{1}{0}}$ & $\frac{\bar{J}}{4}$ & $\frac{\overline{7}}{\overline{0}}$ & 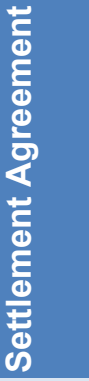 & $\frac{\nwarrow}{\frac{1}{2}}$ & 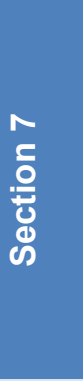 & 5 \\
\hline Emeryville & $\begin{array}{c}\text { P- } \\
2850\end{array}$ & $\begin{array}{c}\text { Mid- } \\
\text { Atlantic/ } \\
\text { NY }\end{array}$ & 1 & $\begin{array}{c}3.5 \mathrm{MW} \\
82 \%\end{array}$ & Conv & $\begin{array}{l}\text { Run-of- } \\
\text { river }\end{array}$ & ILP & Relic & $\begin{array}{c}3.0 \mathrm{yr} \\
43 \%\end{array}$ & $\begin{array}{c}1.6 \mathrm{yr} \\
17 \%\end{array}$ & $\begin{array}{c}4.6 \mathrm{yr} \\
24 \%\end{array}$ & Yes & $\begin{array}{c}0.5 \mathrm{yr} \\
5 \%\end{array}$ & NA & $\begin{array}{c}1.0 \mathrm{yr} \\
7 \%\end{array}$ \\
\hline
\end{tabular}

Notes: NOI-LA: Notice of intent to license application timeline. LA-LI: License application to license issuance timeline. NOI-LI: Notice of intent to license issuance timeline. NEPA: National Environmental Policy Act timeline. Section 7: Endangered Species Act Section 7 Consultation timeline. 401: State Clean Water Act Section 401 Certification timeline. ILP: Integrated Licensing Process. Percent values on the bottom row of some cells represent the percentile the timeline for this project represents in the overall sample of 107 projects used in Chapter 3: Statistical Description and Analysis of Hydropower Licensing Timelines. 
Emeryville P-2850

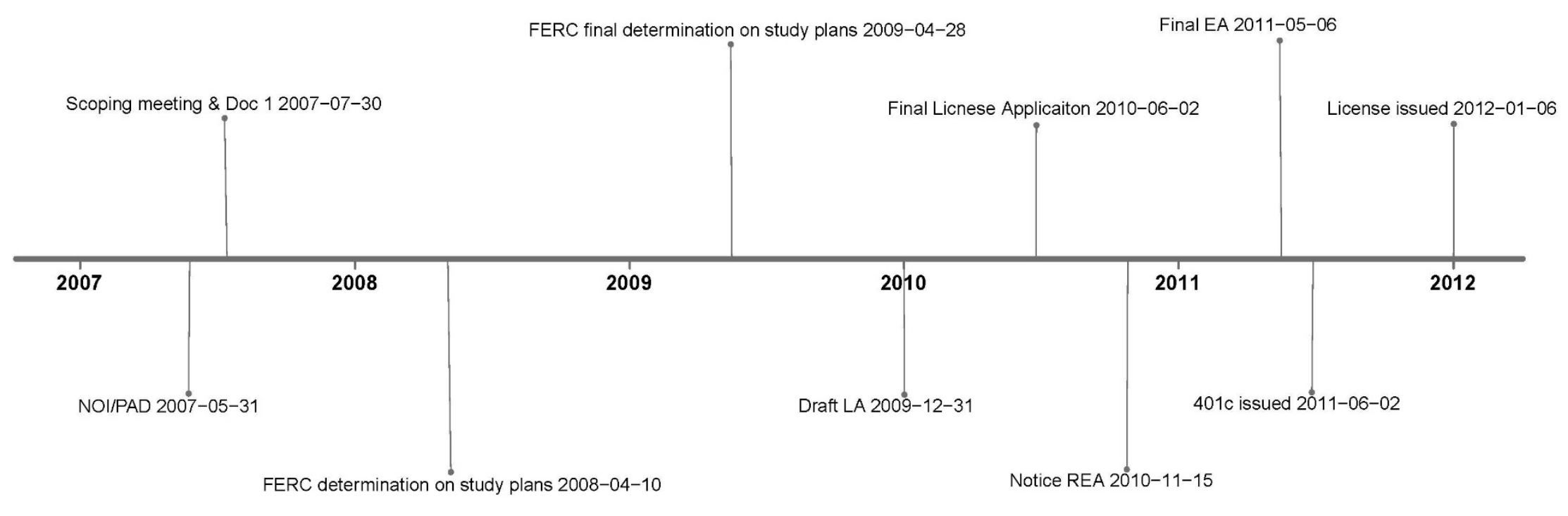

Figure C7. Timeline of some major licensing milestones 


\section{Emeryville Project Overview}

The Emeryville Project is located in the town of Fowler in St. Lawrence County, New York. The project does not occupy any federally managed lands. The project consists of a concrete-capped timber and earth fill gravity dam that spans the Oswegatchie River and a 250-foot-long bypassed reach. Hydropower generation at the project is conducted at the $3.449 \mathrm{MW}$ rated capacity Emeryville Powerhouse. The project has a single 35-acre impoundment (FERC 2012). Hampshire Paper Company (HPC) operates and maintains several recreational facilities at the project, including two parking areas, two boat ramps, a portage trail, a picnic area, a boat barrier, and signage (FERC 2012).

The Emeryville Project was originally licensed in 1982 (HPA 2010a). In 1987, an amendment to the original license was issued as part of a facility renovation (HPC 2010). For the relicensing process being analyzed in this case study, HPC (licensee) submitted the NOI and PAD in May 2007 proposing no major modifications to the existing infrastructure and selected the default Integrated Licensing Process (ILP) (FERC 2011; HPC 2010). On January 6, 2012, FERC issued a new 40-year hydropower license (relicense) for the continued operation and maintenance of the 3.449 MW Emeryville Project (FERC 2012).

\section{Emeryville Project Participants and Comment Themes}

The Emeryville Project had 25 participants, 4 of which filed for intervenor status (i.e., an official party to the proceeding) with FERC. The bulk of comments filed in the FERC record were from state and federal agencies, specifically, DOI, Hydro Development Group, Inc., and St. Lawrence County, New York. In addition, the New York DEC filed a late motion to intervene, which was granted on February 23, 2011. Comments were generally focused on three main themes of project impacts: 1) fish passage, the weir, and excavation in the bypassed reach; 2) invasive species management; and 3) ensuring the project stays in run-of-river mode (FERC 2011).

\section{Statutory and Regulatory Compliance}

The following subsections address both substantive and procedural aspects of the NEPA process administered by FERC, the CWA Section 401 Water Quality Certification process administered by New York DEC, and the NHPA 106 consultation process administered by the New York SHPO. During the NEPA review process, FERC determined that ESA Section 7 consultation was not required for the Emeryville Project.

\section{National Environmental Policy Act}

FERC conducted scoping to determine what issues and alternatives should be addressed in the EA. A scoping document (SD1) was distributed to interested project stakeholders on July 30, 2007. Following release of the SD1, FERC held two scoping meetings to solicit comments from project stakeholders on August 28 and 29, 2007, and also provided an opportunity for written comment. The licensee submitted a final license application to FERC on June 17, 2010. On November 15, 2010, FERC issued notice that the Emeryville Project was REA. On May 6, 2011, FERC issued the final EA, addressing comments filed in the SD1, NOI, and PAD, along with a FONSI. 
The relicensing of the Emeryville Project raised a number of cultural/historic, environmental and natural resource, and recreational concerns requiring analysis primarily under the FPA, NEPA, CWA, and NHPA.

The Emeryville Project EA provides an overview of the key issues analyzed during Emeryville Project relicensing process. At a high level, the issues analyzed in the EA included the effect of project operation on:

- Water quality and quantity in the Oswegatchie River upstream and downstream of the project

- Aquatic and terrestrial resources, including forested shoreline and wildlife and botanical species habitat

- Fisheries resources, including seventeen species of warm and cool water fish present in the vicinity of the project

- Land use and recreational resources, including impacts to two recreational facilities located within the project area

- Impacts to wildlife, including mammals and birds commonly found in the project area

- Impacts of invasive species in terrestrial habitat in the vicinity of the project boundary, specifically pale swallow-wort

- Impacts to potentially present archeological and historical sites listed or eligible for listing on the National Register of Historic Places

- Impacts to threatened and endangered species, specifically, the Indiana Bat (FERC 2011).

\section{Clean Water Act Section 401}

On June 2, 2010, the New York DEC received a request to grant or waive a WQC for the continued operation of the Emeryville Project (FERC 2011). The licensee proposed continued operation of the Emeryville Project in accordance with historic operating procedures and construction of an in-river weir (FERC 2012).

The primary water quality issues identified and studied that were associated with the continued operation of the Emeryville Project included maintenance of minimum flows in the bypass reach, modification of the bypass reach for fish passage, maintenance of existing public access and recreational facilities, and implementation of erosion and sediment control measures during operation, construction, or maintenance activities (NYDEC 2011; FERC 2011; FERC 2012). On June 2, 2011, New York DEC issued a WQC for the Emeryville Project's continued operation containing the following 14 operating conditions:

- Condition 8 required the licensee to operate the project in run-of-river mode

- Condition 9 required the licensee to maintain a bypassed flow of $20 \mathrm{cfs}$

- Condition 10 required the licensee to install bypass flow monitoring gauges/monuments within 18 months of the issuance of the license

- Condition 11 required the licensee install fish protection measures, downstream fish passage facilities, and appropriate channel excavation within 18 months of the issuance of the license

- Condition 12 required the licensee to draft and implement a recreation management plan 
- Condition 13 required the licensee to submit an Invasive Species Management Plan to the New York DEC to prevent the introduction and spread of aquatic and terrestrial invasive species

- Conditions 14 and 15 related to project maintenance and construction work and prohibited the licensee from conducting in-water maintenance activities during specific dates

- Condition 16 prohibited the licensee from impoundment drawdowns during specific dates

- Conditions 17 and 22 required the licensee to install and maintain appropriate turbidity control structures and conduct turbidity monitoring while conducting maintenance dredging activities

- Conditions 18, 20, and 21 required the licensee to submit and implement an erosion and sediment control plan and sample sediment disturbed by work and maintenance operations for contaminants (New York DEC 2011; FERC 2012).

\section{ESA Section 7 Consultation Overview}

During the NEPA review process, FERC noted that the endangered Indiana bat (Myotis sodalis) was the only federally listed threatened or endangered species that might be in the project vicinity. However, FERC concluded that continued project operation would have no effect on this species because the project is located more than 30 miles from known roosts and nesting areas. Therefore, no ESA Section 7 consultation was required for the project (FERC 2011; FERC 2012).

\section{NHPA Section 106}

To comply with Section 106 of the NHPA (16 U.S.C. $§ 306108$ ), FERC designated the licensee as its non-federal representative for the purposes of conducting consultation on July 30, 2007 (FERC 2011; FERC 2012). The licensee invited the New York SHPO as well as the Onondaga Nation, Oneida Nation, Tuscarora Nation, Cayuga Nation, Tonawanda Seneca Nation, Seneca Nation of Indians, and the St. Regis Mohawk Tribe to consult to determine and assess potential adverse effects to historic properties associated with the project (FERC 2011). On February 7, 2007, the SHPO concluded that the project would have no effect upon properties in or eligible for inclusion in the National Register of Historic Places (FERC 2011; FERC 2012). However, FERC found that it was possible that previously unidentified cultural resources could be discovered during construction, operation, or maintenance activities (FERC 2011; FERC 2012). Therefore, Article 404 of the licensing order requires the licensee notify FERC and SHPO immediately if previously undiscovered cultural resources are found during the course of the project (FERC 2011; FERC 2012).

\section{Settlement Agreement}

The licensee, New York DEC, New York State Council of Trout Unlimited, USFWS, and St. Lawrence County participated in a settlement agreement negotiation, which was executed on April 2, 2010 (HPC 2010; FERC 2011; FERC 2012). All parties except St. Lawrence County were signatories to the final settlement agreement (HPC 2010). The settlement agreement was submitted to FERC on May 14, 2010, and provides that the licensee shall ensure the following:

- Maintain the impoundment between elevations 586.6 feet and 586.3 feet National Geodetic Vertical Datum 
- Replace the existing spillway minimum flow weir with a new downstream fish passage flume and install a new weir in the bypassed reach

- Excavate the bypassed reach to facilitate downstream fish passage

- Maintain a year-round minimum flow of $20 \mathrm{cfs}$ or inflow in the bypassed reach

- Install staff gauges or monuments on the spillway, bypassed reach, and the plunge pool

- Install overlays over the full length and height of the existing trashracks

- Implement a recreation management plan that includes procedures for operating and maintaining the existing recreational facilities

- Develop an invasive species management plan (FERC 2011).

Emeryville Project Outcomes: Non-Power Benefits (Protection, Mitigation, and Enhancement)

This section highlights project outcomes that resulted in non-power benefits associated with the Emeryville Project relicensing. For the purposes of this case study, non-power benefits are defined as PME measures included as conditions to the FERC license order. These license conditions were the result of measures proposed by the licensee, FERC staff recommendations within the NEPA analysis, the NHPA Section 106 process, and the New York DEC's CWA 401 Water Quality Certification process. These license conditions include those associated with water quality, species and habitat protection, recreation, and historic/cultural resources.

\section{$\underline{\text { Water Quality and Species Protection Measures }}$}

The FERC license order for the Emeryville Project contained the following PME measures applicable to water quality and aquatic species protection:

- Required the project to operate in run-of-river mode, established a minimum flow in the bypassed reach, install staff gauges or monuments to measure bypass flow, and develop a stream flow and water monitoring plan to protect water quality and aquatic species

- Installation of new trashracks or overlays, a weir, downstream fish passage facilities, and modification of the bypassed reach for downstream fish movement to protect fisheries resources

- Installation of turbidity control structures while conducting any dredging activities and sampling of sediment for contaminants prior to disturbing it or removing it from project waters

- Required the licensee to file an invasive species management plan to prevent the introduction and spread of invasive species

- Required the licensee to submit a design plan before installing any structures that encroach on the Oswegatchie River banks and file an erosion and sediment control plan 60 days prior to conducting any major construction or maintenance activities to protect water quality and aquatic habitat

- Required the licensee to monitor turbidity and implement erosion and sediment control measures during operation, construction, or maintenance activities to protect water quality and aquatic habitat (NYDEC 2011; FERC 2012). 


\section{$\underline{\text { Recreation Measures }}$}

The FERC license order for the Emeryville Project contained the following PME measures applicable to recreation:

- Implementation of a recreation management plan to enhance recreational activities at the project and maintain existing project recreational facilities including two parking areas, two boat ramps, a portage trail, picnic area, boat barrier, and signage (FERC 2012).

\section{$\underline{\text { Cultural/Historic Resources Measures }}$}

The FERC license order for the Emeryville Project contained the following PME measures applicable to cultural resources:

- Required the licensee to notify FERC and the New York SHPO immediately if historic resources are encountered or suspected during the course of constructing, maintaining, or developing project works or other facilities at the project

- Required the licensee to consult with the SHPO prior to implementing any project modifications not specifically authorized by the license that could affect cultural resources (FERC 2012).
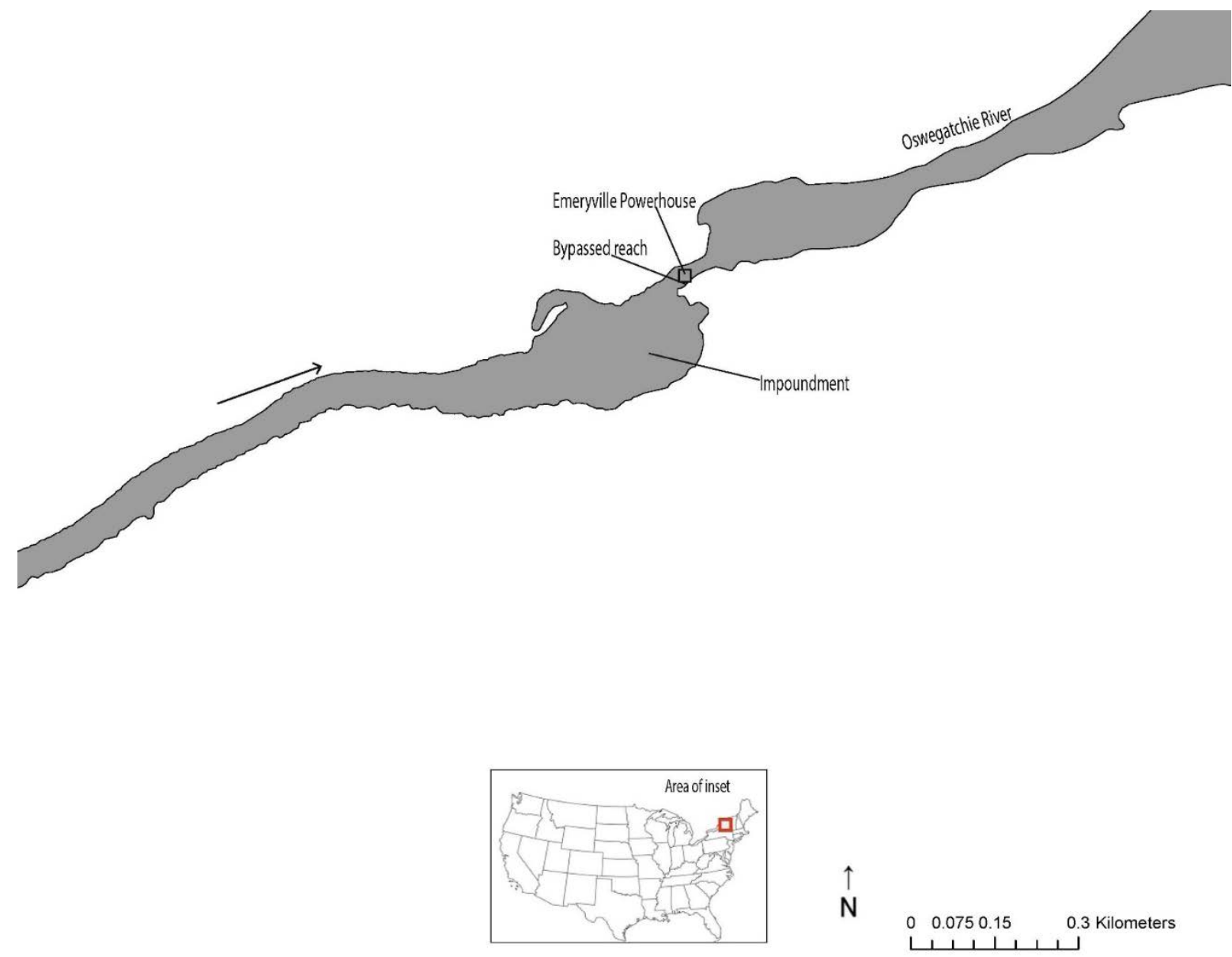

Figure C8. Map indicating major landmarks and features mentioned in project license. Arrow indicates direction of flow. 


\section{Loup River Hydroelectric Project - P-1256 (Relicensing) Case Study}

Table C5. Description of Project Key Characteristics and Timeline Lengths

\begin{tabular}{|c|c|c|c|c|c|c|c|c|c|c|c|c|c|c|c|}
\hline$\frac{\text { है }}{\text { काँ }}$ & 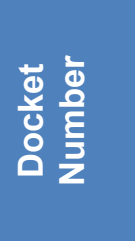 & 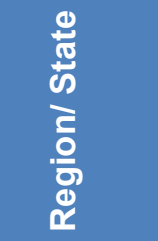 & 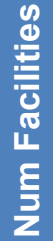 & $\begin{array}{l}\stackrel{N}{N} \\
\text { क } \\
\frac{\mathrm{d}}{0} \\
\frac{0}{2} \\
\frac{2}{2}\end{array}$ & 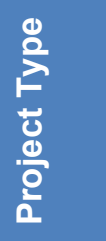 & 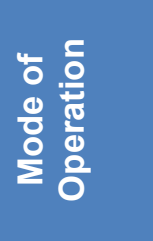 & 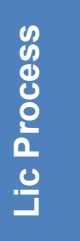 & 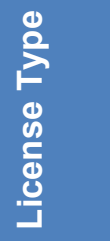 & $\frac{4}{\frac{1}{2}}$ & $\begin{array}{l}5 \\
\end{array}$ & $\frac{7}{\frac{1}{2}}$ & 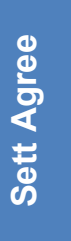 & $\frac{\overleftarrow{a}}{\frac{0}{2}}$ & 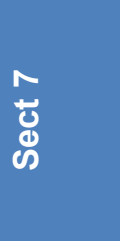 & 웜 \\
\hline $\begin{array}{l}\text { Loup } \\
\text { River }\end{array}$ & P-1256 & $\begin{array}{c}\text { Midwest/ } \\
\text { NE }\end{array}$ & 2 & $\begin{array}{c}50.9 \mathrm{MW} \\
(82 \%)^{*}\end{array}$ & Conv & Peaking & ILP & Relic & $\begin{array}{c}3.5 \mathrm{yr} \\
(85 \%) \\
*\end{array}$ & $\begin{array}{c}5.1 \mathrm{yr} \\
(80 \%) \\
*\end{array}$ & $\begin{array}{c}8.6 \mathrm{yr} \\
(77 \%) \\
*\end{array}$ & No & $\begin{array}{c}3.9 \mathrm{yr} \\
(99 \%) \\
*\end{array}$ & $\begin{array}{c}2.5 \mathrm{yr} \\
(90 \%) \\
*\end{array}$ & $\begin{array}{c}0.2 \mathrm{yr} \\
(11 \%) \\
*\end{array}$ \\
\hline
\end{tabular}

* Percentile within sample of 107 FERC hydropower licenses issued after October 1, 2005.

Notes: NOI-LA: Notice of intent to license application timeline. LA-LI: License application to license issuance timeline. NOI-LI: Notice of intent to license issuance timeline. NEPA: National Environmental Policy Act timeline. Section 7: Endangered Species Act Section 7 Consultation timeline. 401 : State Clean Water Act

Section 401 Certification timeline. Percent values on the bottom row of some cells represent the percentile the timeline for this project represents in the overall sample of 107 projects used in Chapter 3: Statistical Description and Analysis of Hydropower Licensing Timelines. 
Loup River Hydro P-1256

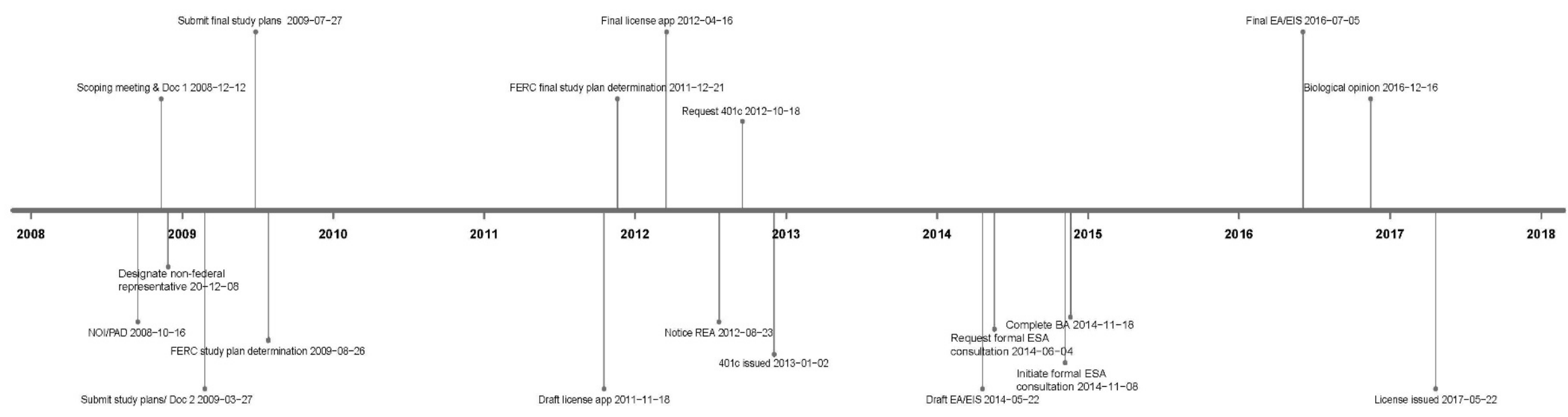

Figure C9. Timeline of major points in relicensing of Loup River Hydroelectric Project P-1256 


\section{Loup River Project Overview}

The Loup River Project is located in Nance and Platte counties, Nebraska, near the towns of Genoa, Monroe, and Columbus. The project does not occupy any federally managed lands. The project consists of a diversion weir that diverts water from the lowest 34.2 miles of the Loup River into a 35-mile-long canal where the Loup River Project is located (Figure C10). Hydropower generation at the project is conducted at the 7.46 MW rated capacity Monroe Powerhouse, and the 43.6 MW rated capacity Columbus Powerhouse. The project also contains two reservoirs, Lake Babcock and Lake North, that support peaking at the Columbus Powerhouse. The canal outlet weir discharges canal water into the Platte River two miles downstream of its confluence with the Loup River (FERC 2016). In addition, five recreation facilities are located within the project boundary: Headworks Park, which is located near the diversion weir and includes East Camp, Headworks Park, Park Camp, Trailhead Camp, Weir Park Camp, and Headworks Off-Highway Vehicle (OHV) Park; Lake Babcock Park, located on the north and west shores of Lake Babcock; Lake North Park, located adjacent to Lake North; Columbus Powerhouse Park, located adjacent to the Columbus powerhouse; and Tailrace Park, located at the confluence of the tailrace canal and the Platte River. In addition, three trails are located within the project boundary (Two Lakes Trail, Bob Lake Trail, and Robert White Trail) with a cumulative length of 5.2 miles located along the north, west, and south perimeters of the Lake Babcock and Lake North Parks (FERC 2016).

The Loup River Project was originally licensed in 1934 and went through a previous relicensing, receiving a second license in 1982. For the relicensing process being analyzed in this case study, the Loup River Public Power District (licensee) submitted the NOI and PAD in October 2008, proposed no major modifications to the existing infrastructure, and selected the default ILP. In May 2017, FERC issued a new 30-year hydropower license (relicense) for the continued operation and maintenance of the 51 MW Loup River Hydroelectric Project (Loup River Project). Prior to completing relicensing, the Loup River Project operated on an annual license from 2014 until receiving its new license in 2017 (Loup River Power District 2008; Loup River Public Power District 2012b;159 FERC \ 62,198 (2017).

\section{Loup River Project Participants and Comment Themes}

The Loup River Project had 66 participants file for intervenor status (i.e., an official party to the proceeding) with FERC. The majority of comments filed in the FERC record were from state and federal agencies, specifically the Nebraska Game and Parks Commission, the Nebraska Department of Natural Resources, and USFWS. In addition, the Tern and Plover Conservation Partnership, an NGO that conducts conservation focused research for terns and plovers, also provided comments. Comments were generally focused on three main themes of project impacts: 1) impacts to the bypassed reaches of the Loup and Platte rivers including water temperatures, sediment availability, and threatened and endangered species habitats; 2) direct impacts of project operations on threatened and endangered species, including hydrocycling and sediment disruption; and 3) indirect impacts of project operations on threatened and endangered species including degradation of threatened and endangered species habitats in the bypassed reach of Loup River due to off-highway vehicle use. 


\section{Statutory and Regulatory Compliance}

The following subsections address both substantive and procedural aspects of the NEPA process administere by FERC, the CWA Section 401 Water Quality Certification process administered by the Nebraska DEQ, the ESA Section 7 consultation process administered by the USFWS, and the NHPA 106 consultation process administered by the Nebraska SHPO.

\section{National Environmental Policy Act}

FERC conducted scoping to determine what issues and alternatives should be addressed in the EA. A scoping document (SD1) was initially distributed to interested project stakeholders on December 12, 2008. Following release of the SD1, FERC held two scoping meetings to solicit comments from project stakeholders on January 12 and 13, 2009, and also provided an opportunity for written comment. FERC issued a revised scoping document (SD2), addressing the comments received on SD1, on March 27, 2009. On August 23, 2012, after accepting the licensee's final license application, FERC issued notice that the Loup River Project was REA. On May 22, 2014, FERC issued a draft EA for the Loup River Project requiring comments to be filed on the draft EA by June 21, 2014. On July 5, 2016, FERC issued the final EA, addressing comments filed on the draft EA, along with a FONSI.

The relicensing of the Loup River Project raised a number of cultural/historic, environmental and natural resource, and recreational concerns requiring analysis primarily under the FPA, NEPA, CWA, ESA, and NHPA.

The Loup River Project EA provides an overview of the key issues analyzed during the Loup River Project relicensing process. At a high level, the primary issues analyzed in the EA included the effect of project operation on:

- Water quality in the Loup River bypassed reach

- Aquatic habitat in the Loup River bypassed reach and in project-affected portions of the lower Platte River (release point of the water after traveling through the power canal)

- Threatened and endangered species, most notably, the interior least tern, piping plover, whooping crane, and rufa red knot in the Loup River bypassed reach and in portions of the lower Platte River (FERC 2016).

In addition to the primary issues analyzed in the EA, a number of other potentially significant impacts were analyzed, which included:

- Erosion of shoreline and canal banks

- Sediment control and disposal

- Dissolved oxygen levels during maintenance drawdowns in the power canal

- Water temperature in the power canal

- Impacts to migratory bird foraging and nesting activities during project maintenance

- Impacts to six archeological and historical sites listed or eligible for listing on the National Register of Historic Places (FERC 2016). ${ }^{79}$

\footnotetext{
${ }^{79}$ In addition, the Loup River itself is eligible for listing as a historic district (FERC 2016).
} 


\section{Clean Water Act Section 401}

On October 22, 2012, the Nebraska DEQ received a request to grant or waive a WQC for the continued operation of the Loup River Project and discharge to the lower Platte River (Loup River Public Power District, 159 FERC $\mid$ 62,198 (2017)). The licensee proposed continued operation of the Loup River Project in accordance with historic operating procedures with only one minor change to existing project operations - to increase flow from 50 to $75 \mathrm{cfs}$ in the Loup River bypassed reach when ambient temperatures are forecasted to reach $98^{\circ} \mathrm{F}$ or higher (Loup River Public Power District 2012a; Loup River Power District 2008).

The primary water quality issues identified and studied that are associated with the continued operation of the Loup River Project included water temperature in both the Loup River bypassed reach and the Platte River bypassed reach, and elevated polychlorinated biphenyl (PCB) levels in fish. The Nebraska DEQ subsequently determined that the Loup River Project operation, as proposed in the final license application, would comply with Section 401 of the CWA (Nebraska DEQ 2013). On January 2, 2013, the Nebraska DEQ issued a WQC for the Loup River Project's continued operation with no additional conditions to the FERC license order (Loup River Public Power District, 159 FERC \ 62,198 (2017)).

\subsection{Endangered Species Act Section 7 Consultation Overview}

During the ESA Section 7 consultation process, USFWS identified and considered the effects of the Loup River Project (including water quantity) on the following threatened and endangered species: interior least tern, pallid sturgeon, piping plover, rufa red knot, whooping crane, northern long-eared bat, and western prairie fringed orchid. This section provides details on the ESA Section 7 consultation process, beginning with preliminary meetings prior to initiating information consultation through the final biological opinion (BO).

\section{Endangered Species Act Informal Consultation, Study Development, Draft License Application}

On May 7, 2008, the licensee (and its contracted representatives), USFWS, U.S. Geological Survey, NPS, Nebraska DNR, Nebraska DEQ, Nebraska Game and Parks Commission, Lower Loup Natural Resources District, Central Platte Resources District, and local, county, and city municipalities conducted an agency orientation meeting to discuss agency roles necessary to complete the ESA Section 7 consultation process for the proposed FERC relicensing of the Loup River Project (USFWS 2016). Between May and August of 2008, the licensee, USFWS, and FERC held meetings to identify project impacts on threatened and endangered species and identify necessary studies (USFWS 2016). On December 16, 2008, FERC published a NOI of the licensee's application for a new license for the Loup River Project and designated the licensee as the non-federal representative for carrying out informal ESA Section 7 consultation (initiating the informal consultation process with USFWS [USFWS 2016]).

Between December 2008 and March 2009, the licensee, USFWS, and other interested state agencies conducted scoping meetings to identify environmental issues, concerns, and project alternatives, in part related to ESA listed species (USFWS 2016). On March 27, 2009, the licensee submitted a study plan to FERC and USFWS. Four months later, on July 27, the licensee submitted a revised study plan to encompass additional sedimentation studies requested by USFWS. The study plan was finalized on August 26, 2009 (USFWS 2016). 
On October 20, 2010, the licensee submitted an initial study report to FERC. USFWS submitted comments regarding whether the study adequately assessed potential project effects to the interior least terns, piping plovers, and pallid sturgeons. In February 2011, the licensee submitted a second initial study report to FERC addressing the USFWS comments (USFWS 2016). On April 7, 2011, USFWS submitted comments on the second initial study report to FERC, which noted that studies indicated that the Loup River Project would have adverse effects on the interior least tern, piping plover, and pallid sturgeon populations (USFWS 2016).

On November 18, 2011, the licensee filed a draft license application with FERC, which concluded that the project was not likely to adversely affect the pallid sturgeon, interior least tern, piping plover, or whooping crane (USFWS 2016). On February 16, 2012, USFWS submitted comments on the draft license application to FERC concluding that the USFWS did not concur with the licensee's conclusions regarding project effects on the pallid sturgeon, interior least tern, piping plover, or whooping crane. The USFWS recommended avoidance and minimization measures to FERC (USFWS 2016).

$\underline{\text { Final License Application and Draft Biological Opinion }}$

On August 23, 2012, the licensee filed a Final License Application and Draft Biological Assessment with FERC (USFWS 2016).

\section{ESA Section 7 Formal Consultation}

On June 4, 2014, FERC requested formal Section 7 consultation and provided a draft EA and formal Section 7 consultation package. The draft EA included a no action alternative under which the project would continue to operate under the terms and conditions of the existing license at the time. The draft EA explained that the purpose of the no action alternative was to establish baseline environmental conditions for comparison with other alternatives. On July 2, 2014, the USFWS determined the package was incomplete because differences between USFWS' and FERC's definitions of the environmental baseline made it difficult to evaluate how the proposed project would affect federally listed species. Specifically, in the view of the USFWS the no action alternative (i.e., the environmental baseline) should have been the project "without issuance of the new permit" resulting in "no diversion for power." In a teleconference held on August 13, 2014, FERC staff explained to USFWS that the USFWS' definition of the no action alternative described a future condition resulting from a FERC decommissioning action and that decommissioning was not identified as a viable action alternative for consideration in the relicensing proceeding. FERC staff reiterated that the environmental baseline for comparison with the Proposed Action with which FERC staff requested formal Section 7 consultation, was the existing operations and conditions at the project as the project was then licensed. On October 20, 2014, FERC staff sent USFWS an environmental effects matrix summarizing how the proposed relicensing action would change the existing conditions at the project, and again requested that the USFWS initiate formal Section 7 consultation. On November 18, 2014, USFWS accepted the resubmitted request as a complete consultation package and estimated delivery of a final BO by March 4, 2015 (USFWS 2016).

After initiating formal ESA Section 7 consultation, the process encountered multiple delays and requests for extension related to needing missing hydrology data from $\mathrm{FERC}$, unexpected 
USFWS staff shortages, newly listed species (rufa red knot and northern long-eared bat), and substantial differences between information contained in FERC's draft EA (2014) compared to the final EA (2016). Specifically, the final EA did not include USFWS's request for effect determinations for the rufa red knot and whooping crane and the final EA included changes in project operations when compared to the draft EA. These material changes required the USFWS to withdraw a draft BO on July 29, 2016, and reinitiate formal consultation on August 25, 2016, after receiving additional information from FERC.

\section{$\underline{\text { Final Biological Opinion }}$}

On December 16, 2016, USFWS submitted a final BO to FERC. Ultimately, USFWS concurred with FERC that the Loup River Project was not likely to adversely affect the rufa red knot or whooping crane. In addition, USFWS concurred that the project would have no effect on the northern long-eared bat or western prairie fringed orchid. Finally, USFWS concurred that the project was likely to adversely affect the pallid sturgeon, interior least tern, and piping plover (USFWS 2016).

USFWS's final BO contained an incidental take statement and analyzed and concurred with implementing the following conditions for inclusion in the FERC license order for the Loup River Project:

- License Article 404, Seasonal Minimum Flows in the Loup River Bypassed Reach

- License Article 406, Maximum Diversion of Flow into the Power Canal

- License Article 412, Interior Least Tern, Piping Plover, and Rufa Red Knot Management Plan (USFWS 2016).

\section{NHPA Section 106}

To comply with Section 106 of the NHPA (16 U.S.C. § 306108), FERC executed a PA with the Nebraska SHPO on June 16, 2014. FERC invited the licensee, Nebraska SHPO, the Omaha Tribe of Nebraska, the Pawnee Nation of Oklahoma, and the Santee Sioux Nation to concur with the stipulations in the PA. The licensee concurred to the PA, which required it to implement an HPMP for the 30-year license term. The licensee's responsibilities under the PA, including the HPMP, were included in article 414 of the FERC license order (159 FERC 9 62,198 [2017]).

\section{Settlement Agreement}

Stakeholders in the Loup River Project relicense did not agree to terms on a settlement agreement. However, between October and November 2011, the USFWS, the licensee, and the Nebraska Game and Parks Commission convened discussions to attempt to reach a settlement agreement; however, the parties failed to reach an agreement (USFWS 2016).

\section{Loup River Project Outcomes: Non-Power Benefits (Protection, Mitigation, and Enhancement)}

This section highlights project outcomes that resulted in non-power benefits associated with the Loup River Project relicensing. For the purposes of this case study, non-power benefits are defined as PME measures included as conditions to the FERC license order. These license conditions were the result of measures proposed by the licensee, FERC staff recommendations within NEPA analysis, the Nebraska DEQ's CWA 401 Water Quality Certification process, and 
the USFWS's ESA Section 7 consultation process. These license conditions include those associated with water quality, species and habitat protection, recreation, and historic/cultural resources.

\section{$\underline{\text { Water Quality and Species Protection Measures }}$}

The FERC license order for the Loup River Project contained the following PME measures applicable to water quality and aquatic species protection:

- Established minimum flows in the Loup River bypassed reach to protect aquatic resources, water quality, and the endangered interior least tern and piping plover

- Required streambank and canal bank monitoring plans as well as an erosion and sediment control plan to limit erosion within the project boundary

- Limited the diversion and rate of water into the power canal to provide downstream habitat enhancement for the endangered interior least tern, piping plover, whooping crane, and threatened rufa red knot

- Suspended project activities in a settling basin during the months of May through August to avoid impacts to interior least tern and piping plover nesting areas

- Facilitated migration of the pallid sturgeon by requiring the project to operate in an instantaneous run-of-canal mode annually from May 1 through June 7

- Required the licensee to conduct additional migratory bird surveys of affected habitats to reduce the potential for "take" of migratory bird species

- Required hot weather fish protection measures, which prevented the licensee from conducting non-emergency maintenance activities that would require drawdown of water in the power canal during times when the water temperature is $90^{\circ} \mathrm{F}$ or warmer (Loup River Public Power District, 159 FERC $\mid$ 62,198). ${ }^{80}$

$\underline{\text { Recreation Measures }}$

The FERC license order for the Loup River Project contained the following PME measures applicable to recreation:

- Required the continued operation and maintenance of five parks (Headworks OHV Park, Lake Babcock Park, Lake North Park, Columbus Powerhouse Park, and Tailrace Park) and three trails (Two Lakes Trail, Bob Lake Trail, and Robert White Trail) within the project boundary

- Implemented a recreation plan that contained the following requirements:

○ Installation of a volleyball court at Park Camp

○ Installation of restroom facility at Headworks OHV Park

○ Construction of a fishing pier at Lake North Park

- Implementation of a no-wake zone in Lake North to enhance fishing opportunities at Lake North Park

\footnotetext{
${ }^{80}$ This measure was included to prevent reduced dissolved oxygen levels that could have a negative impact on aquatic species.
} 
○ Construction of a walking/biking trail along the southeast shore of Lake Babcock

- Upgrades to car camper electrical outlets at Lake North Park and Headworks Park.

○ Continued to prohibit vehicle access to Tailrace Park to minimize vandalism

- Continued to operate Headworks OHV Park with assistance from the State of Nebraska (Loup River Public Power District, 159 FERC \ 62,198).

\section{Cultural/Historic Resources Measures}

The FERC license order for the Loup River Project required the licensee to implement an HPMP via a PA with the Nebraska SHPO. The PA requires the licensee to consult with the Nebraska SHPO prior to making any additions or alterations to properties listed or eligible for listing on the National Register of Historic Places (Loup River Public Power District, 159 FERC 962,198 ).

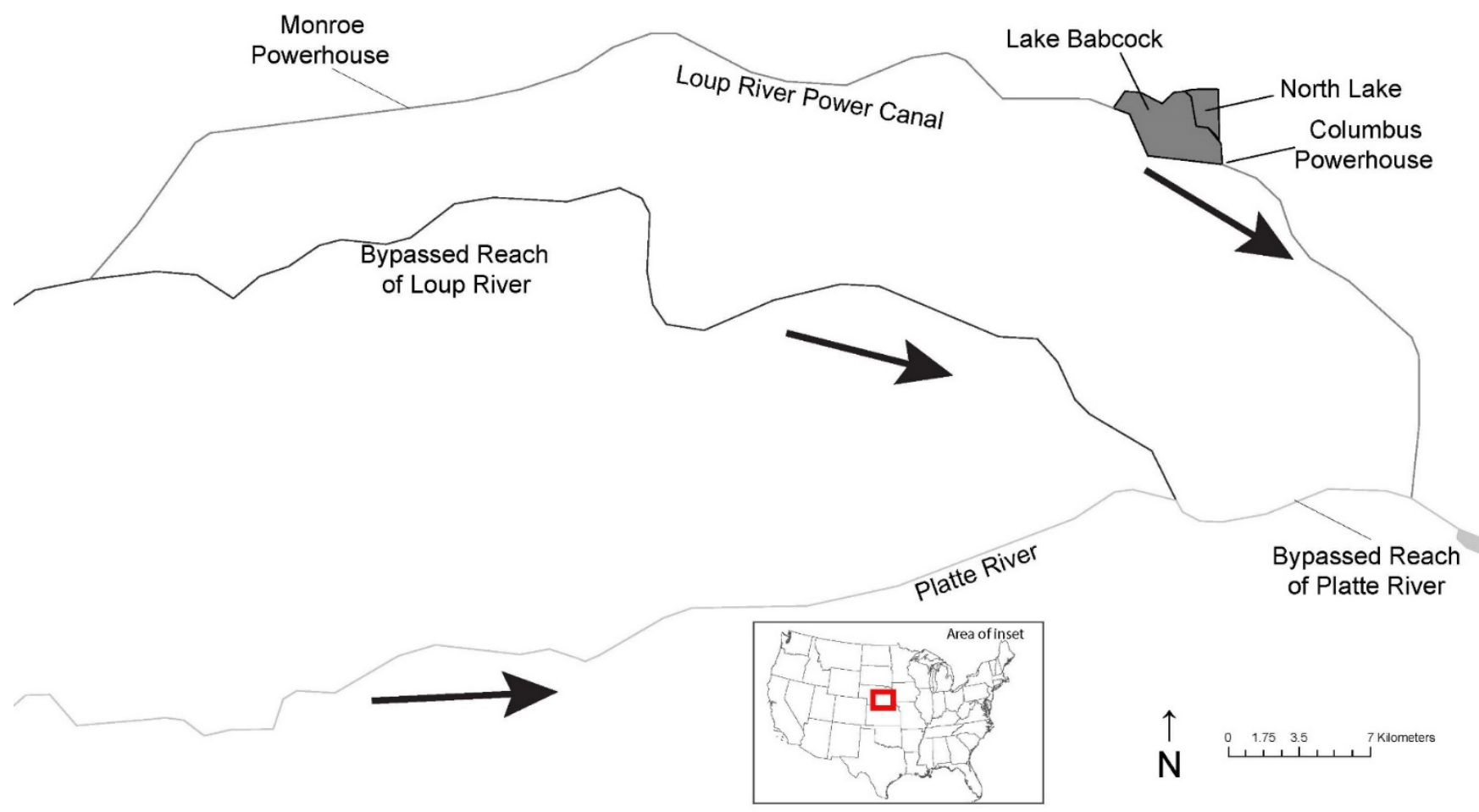

Figure C10. Map of Loup River Hydroelectric Project P-1256 showing the bypassed reaches of the Loup and Platte rivers in Nebraska and the Loup River Power Canal. All hydropower generation takes place within the Loup River Power Canal. The area of inset map shows the location of the project in reference to the continental United States. Arrows indicate direction of flow. 


\section{Merwin Hydroelectric Project - P-935 (Relicensing) Case Study}

\section{Table C6. Description of Project Key Characteristics and Timeline Lengths}

\begin{tabular}{|c|c|c|c|c|c|c|c|c|c|c|c|c|c|c|c|}
\hline 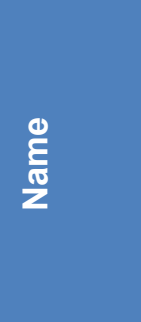 & $\begin{array}{l}\text { 엉 } \\
\frac{0}{0} \\
8 \\
0\end{array}$ & 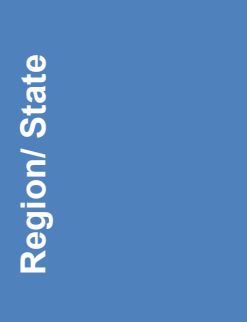 & 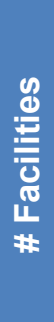 & 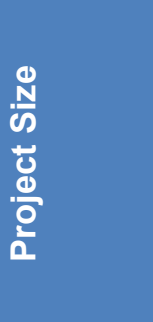 & 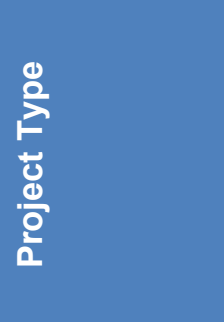 & 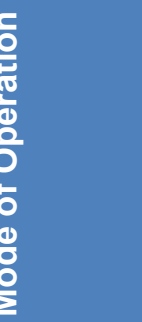 & 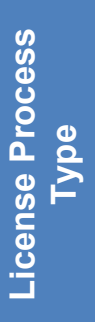 & 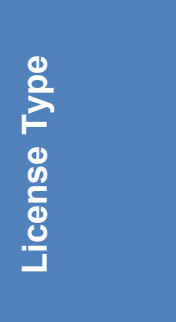 & $\begin{array}{l}\frac{4}{2} \\
\frac{1}{2}\end{array}$ & $\frac{\bar{J}}{5}$ & $\begin{array}{l}\overline{7} \\
\frac{1}{2}\end{array}$ & 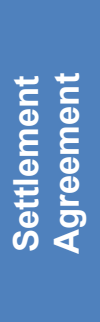 & $\frac{\overleftarrow{\alpha}}{\frac{u}{2}}$ & 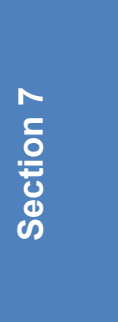 & ㅇ \\
\hline Merwin & P-935 & Northwest/WA & 1 & $\begin{array}{c}136 \mathrm{MW} \\
6.2 \%\end{array}$ & $\begin{array}{c}\text { Existing } \\
\text { Conventional }\end{array}$ & $\begin{array}{l}\text { Run-of- } \\
\text { River }\end{array}$ & ALP & Relicense & $\begin{array}{l}3.5 \mathrm{yr} \\
49.6 \%\end{array}$ & $\begin{array}{l}4.2 \mathrm{yr} \\
25.3 \%\end{array}$ & $\begin{array}{l}7.6 \mathrm{yr} \\
39.2 \%\end{array}$ & Yes & $\begin{array}{l}1.3 \mathrm{yr} \\
24.7 \%\end{array}$ & $\begin{array}{l}1.9 \mathrm{yr} \\
27.9 \%\end{array}$ & $\begin{array}{l}1.7 \mathrm{yr} \\
11.3 \%\end{array}$ \\
\hline
\end{tabular}

Notes: NOI-LA: Notice of intent to license application timeline. LA-LI: License application to license issuance timeline. NOI-LI: Notice of intent to license issuance timeline. NEPA: National Environmental Policy Act timeline. Section 7: Endangered Species Act Section 7 Consultation timeline. 401 : State Clean Water Act Section 401 Certification timeline. ALP: Alternative Licensing Process. Percent values on the bottom row of some cells represent the percentile the timeline for this project represents in the overall sample of 107 projects used in Chapter 3: Statistical Description and Analysis of Hydropower Licensing Timelines.

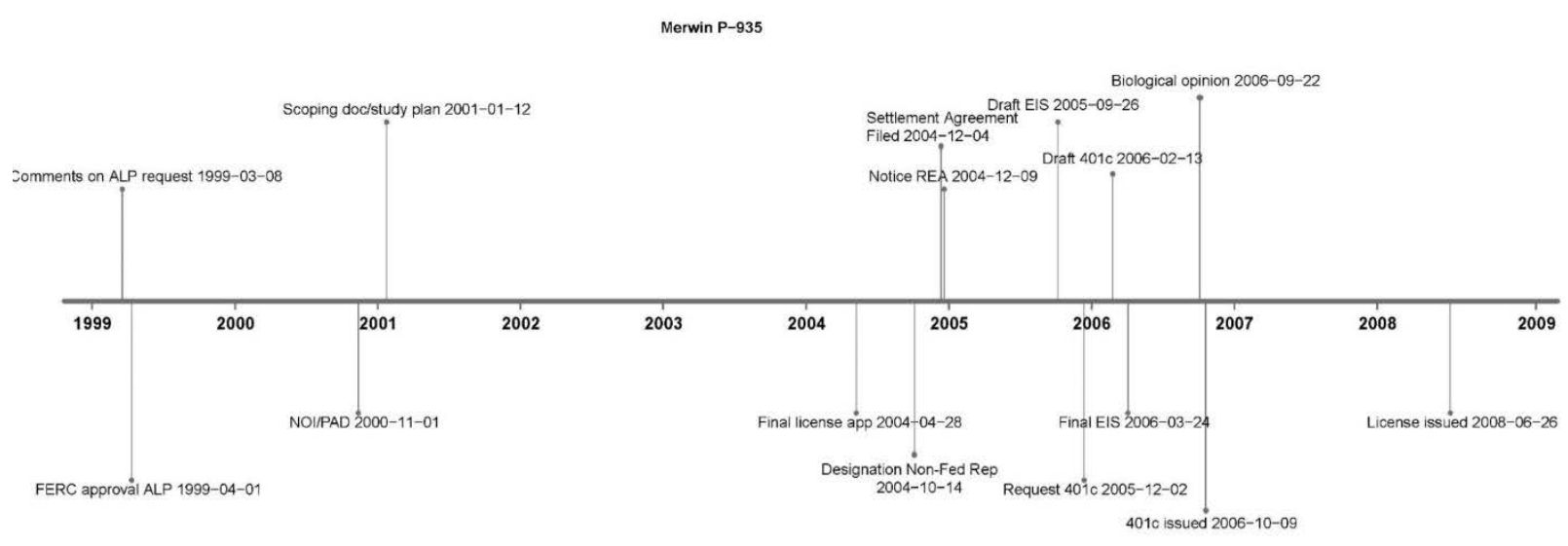

Figure C11. Timeline of some major licensing milestones 


\section{Merwin Project Overview}

The Merwin Project is located on the North Fork Lewis River in Clark and Cowlitz counties, Washington, near the town of Woodland. The project occupies 142.15 acres of federal lands administered by the Bureau of Land Management (BLM) in addition to other non-federal lands (FERC 2006b). The project consists of a concrete dam extending across the Lewis River and deepwater inlets that lead to three short penstocks that enter a powerhouse downstream of the Merwin dam. The powerhouse contains three $45 \mathrm{MW}$ generating units and $1 \mathrm{MW}$ house generating unit with a total installed capacity of $136 \mathrm{MW}$. Flows in excess of powerhouse capacity are controlled by five taintor gates situated above the spillway. The project impounds Lake Merwin, with a surface area of about 4,000 acres at full pool. Lake Merwin's usable storage is managed for power generation, flood management, recreation, and downstream fish habitat enhancement. The Merwin Project boundary includes all shoreline recreational sites (Merwin Park, Speelyai Bay Park, Cresap Bay Campground); a narrow shoreline buffer around the reservoir; the Lower Speelyai Creek diversion and Speelyai Fish Hatchery; all project development facilities (dam, powerhouse, switchyard); the Merwin Fish Hatchery; the Hydro North Control Center; and lands downstream of the dam along the Lewis River that include the Merwin fishing access on the north shore of the river and the PacifiCorp fishing easement on the south shore (FERC 2004; PacifiCorp 123 FERC 9 62,258, Order Issuing New License (2008)).

The Merwin Project was originally licensed in 1934 and went through a previous relicensing, receiving a second license in 1983 . The second license expiration date was accelerated from December 11, 2009, to April 30, 2006, in order to facilitate a coordinated relicensing review with three other projects - the Swift No. 1 Project, the Swift No. 2 Project, and the Yale Project - in the Lewis River Basin (PacifiCorp 87 FERC 1 62,033 (1999)). The four Lewis River Basin projects are collectively known as the Lewis River Projects (PacifiCorp 87 FERC 1 62,033 [1999]). For the relicensing process being analyzed in this case study, PacifiCorp (licensee) submitted the NOI and PAD in November 2000 proposing no major modifications to the existing infrastructure and selected the Alternative Licensing Process (ALP) (FERC 2000). In June 2008, FERC issued a new 50-year hydropower license (relicense) for the continued operation and maintenance of the $136 \mathrm{MW}$ Merwin Project. Prior to completing relicensing, the Merwin Project operated on an annual license from 2006 until receiving its new license in 2008 (PacifiCorp 123 FERC \ 62,258, Order Issuing New License [2008]).

\section{Merwin Project Participants and Comment Themes}

The Merwin Project had 22 participants, 10 of which filed for intervenor status (i.e., an official party to the proceeding) with FERC. The majority of comments filed by intervenors in the FERC record were from state and federal agencies, specifically the Washington Department of Fish and Wildlife, Washington Department of Ecology (WDE), USFWS, USFS, the National Oceanic and Atmospheric Administration Fisheries (NOAA Fisheries) (formerly known as the National Marine Fisheries Service), Cowlitz Public Utility District (PUD), Cowlitz Tribe, Yakama Nation, American Rivers, Trout Unlimited, Native Fish Society, and Fish First. Comments were generally focused on three main themes of project impacts: 1) impacts to anadromous salmonids in the Lewis River Basin, 2) impacts to wildlife habitat, and 3) impacts to recreational opportunities (PacifiCorp 123 FERC \ 62,258, Order Issuing New License (2008)). 


\section{Statutory and Regulatory Compliance}

The following subsections address both substantive and procedural aspects of the NEPA process administered by FERC, the CWA Section 401 WQC process administered by WDE, the ESA Section 7 consultation process administered by USFWS and NOAA, and the NHPA 106 consultation process administered by the Washington SHPO.

\section{National Environmental Policy Act}

FERC conducted scoping to determine what issues and alternatives should be addressed in the EIS. A scoping document (SD1) was initially distributed to interested project stakeholders on May 17, 2000. Following release of the SD1, FERC held two scoping meetings to solicit comments from project stakeholders on June 22, 2000, and also provided an opportunity for written comment. FERC issued a revised scoping document (SD2), addressing the comments received on SD1, on January 10, 2001 (PacifiCorp 2004; FERC 2006b). Between January 2001 and March 2002, the licensee held a series of meetings and workshops with relicensing stakeholders to identify potential environmental enhancement measures. The result of the series of meetings and workshops was the Resource Enhancement Alternatives Document (READ), which was used in refining the preliminary alternatives identified in SD2. Following the READ process, consultation efforts focused on a settlement agreement as required by the ALP. From March 2002 to December 2004, the licensee and relicensing stakeholders met monthly to negotiate a settlement (FERC 2006b). On December 3, 2004, the licensee filed a settlement agreement with FERC, which included a preliminary draft EA (PacifiCorp 2005; FERC 2006b). On September 23, 2005, FERC issued a draft EIS for the Merwin Project (which incorporated by reference the licensee's preliminary draft EA) and notice for public comment. On March 24, 2006, FERC issued a final EIS, addressing comments filed on the draft EIS. FERC concluded in the final EIS that relicensing the Merwin Project as proposed would continue to have an adverse effect on Chinook and coho essential fish habitat, but that elements of the proposed project, such as improvements to upstream and downstream passage, would reduce these effects compared to current conditions (FERC 2006b; PacifiCorp 123 FERC 9 62,258, Order Issuing New License [2008]).

The relicensing of the Merwin Project raised a number of cultural/historic, environmental and natural resource, and recreational concerns requiring analysis primarily under FPA, NEPA, CWA, ESA, and NHPA.

The Merwin Project EIS provides an overview of the key issues analyzed during the Merwin Project relicensing process. At a high level, the primary issues analyzed in the final EIS included the effect of project operation on:

- Flows and water quality in the lower Lewis River

- Anadromous salmonids in the Lewis River basin

- Fish passage between and through the reservoirs

- Federally listed threatened or endangered species

- Existing recreational uses and facilities (FERC 2006b). 
In addition to the primary issues analyzed in the final EIS, a number of other potentially significant impacts were analyzed including:

- Project operations, maintenance activities, and future construction impacts on cultural resources located near the Merwin Dam

- Socioeconomic impacts associated with potential flood impacts to small rural communities within the project area (FERC 2006b).

\section{Clean Water Act Section 401}

On February 3, 2005, WDE received a request to grant or waive a WQC for the continued operation of the Merwin Project. On December 2, 2005, PacifiCorp withdrew and refiled its application for WQC with WDE. On October 9, 2006, WDE issued a WQC for continued operation of the Merwin Project (WDE 2006). On December 21, 2007, and January 17, 2008, WDE issued amendments to the WQC for the Merwin Project. The amendments to the WQC included:

- Changes to the evaluation requirements for the oil water separators for the project's transformers and turbines (WDE 2006; PacifiCorp 123 FERC \ 62,258, Order Issuing New License [2008]).

The primary water quality issues identified and studied that are associated with the continued operation of the Merwin Project, included:

- Compliance with sediment quality standards

- Prohibition of discharge of any solid or liquid waste to the waters of the United States. (WDE 2006; PacifiCorp 123 FERC 9 62,258, Order Issuing New License [2008]).

WDE determined that the Merwin Project operation, as proposed in the final license application, would comply with Section 401 of the CWA. WDE issued a WQC for the Merwin Project's continued operation with the following conditions:

- Comply with instream flow and ramping rates, identified in the settlement agreement, downstream from Merwin Dam

- Manage, monitor, and report river spill levels from Merwin Dam

- Maintain specified total dissolved gas levels associated with air injected into turbine flows from Merwin Dam

- Maintain specified temperature and dissolved oxygen levels

- Implement best practice measures to protect water quality during construction projects, and miscellaneous discharges

- Maintain specified turbidity standards

- Implement oil spill prevention and control measures

- Implement measures to protect water quality during pesticide applications

- Implement monitoring and reporting measures (WDE 2006; PacifiCorp 123 FERC $\uparrow$ 62,258, Order Issuing New License [2008]). 


\section{ESA Section 7 Consultation Overview}

During the ESA Section 7 consultation process, USFWS and NOAA Fisheries identified and considered the effects of the Merwin Project (including water quantity) on the following threatened and endangered species: bull trout, bald eagle, northern spotted owl, Lower Columbia Chinook salmon, Lower Columbia River coho salmon, Columbia River chum salmon, and the Lower Columbia River steelhead (PacifiCorp 123 FERC $\$$ 62,258, Order Issuing New License [2008]). This section provides details on the ESA Section 7 consultation process, beginning with preliminary meetings prior to initiating information consultation through the final BO.

Endangered Species Act Informal Consultation, Biological Evaluation, Study Development, Biological Assessment

In July 1999, the licensee and FERC conducted a number of meetings with USFWS and NOAA Fisheries to identify studies and develop a proposal for habitat protection for the identified threatened and endangered species (USFWS 2006b). On October 14, 2004, FERC designated the licensee as the non-federal representative for the purpose of conducting informal Section 7 consultation. On December 9, 2004, FERC issued a notice of the settlement agreement and the licensee prepared the preliminary EA and solicited public comment (PacifiCorp 2005; FERC 2006b). On January 14, 2005, the licensee submitted a biological evaluation to FERC that included the potential impacts the Merwin Project, as proposed, may have on threatened and endangered species. As required by the ALP, the biological evaluation was drafted through a coordinated stakeholder process and was memorialized in a comprehensive settlement agreement. The biological evaluation identified studies to conduct and conservation measures that the licensee proposed to implement as conditions for the new license (relicense) for the Merwin Project. On September 23, 2005, FERC issued a draft EIS for the Merwin Project and notice for public comment, which incorporated the biological evaluation by reference and served as FERC's BA for the purposes of ESA Section 7 consultation and essential fish habitat assessment (FERC 2005b; FERC 2005d; PacifiCorp 2005; PacifiCorp 123 FERC \ 62,258, Order Issuing New License [2008]).

\section{ESA Section 7 Formal Consultation}

On September 30, 2005, FERC requested Section 7 formal consultation with NOAA Fisheries on listed salmon and steelhead species and USFWS on bull trout, bald eagle, and northern spotted owl species.

\section{U.S. Fish and Wildlife Service}

In the request for formal consultation with USFWS, FERC also requested concurrence from USFWS on the following determinations:

- May affect, likely to adversely affect the Columbia River Distinct Population Segment of bull trout

- May affect, not likely to adversely affect the northern spotted owl

- May affect, not likely to adversely affect the bald eagle

- May affect, not likely to adversely affect the designated bull trout critical habitat (FERC 2005d; USFWS 2007). 
On March 14, 2006, USFWS requested an extension of timeline for formal consultation and issuance of the final BO from FERC from February 16, 2006, until May 5, 2006 (USFWS 2006a, 2006c). USFWS stated in the request that the extension would enable the agency to complete consultation and incorporate findings of the final EIS and Section 401 WQC (USFWS 2006a). On March 15, 2006, FERC granted USFWS' extension request until May 5, 2006, stating that the licensee had agreed to the extension and that the extension would not affect the licensing schedule (FERC 2006b). On June 12, 2006, USFWS, with concurrence from the licensee, submitted notice to FERC that USFWS revised the timeline for formal consultation until September 1, 2006. USFWS noted the principal reason for rescheduling the issuance of the BO was unusually heavy workload combined with the need to coordinate closely with the licensees and NOAA Fisheries (USFWS 2006c).

\section{National Oceanic and Atmospheric Administration Fisheries}

On February 10, 2006, NOAA Fisheries requested an extension of timeline for formal consultation and issuance on the final BO from FERC from February 16, 2006, until May 5, 2006 (NOAA 2006a). NOAA Fisheries stated in the requests that the extension would enable the agency to complete consultation and incorporate findings of the final EIS and Section 401 WQCs (NOAA 2006a). On March 3, 2006, FERC granted NOAA Fisheries' extension request until May 5, 2006, stating the licensee had agreed to the extension and that the extension would not affect the licensing schedule (FERC 2006b). On June 20, 2006, NOAA Fisheries, with concurrence from the licensee, submitted notice to FERC that NOAA Fisheries revised the timeline for formal consultation until September 1, 2006. NOAA Fisheries noted the principal reason for rescheduling the issuance of the BO was unusually heavy workload combined with the need to coordinate closely with the licensee and USFWS (NOAA 2006b).

\section{$\underline{\text { Final Biological Opinion }}$}

\section{U.S. Fish and Wildlife Service}

On September 15, 2006, USFWS issued a final BO to FERC concluding formal consultation. USFWS noted in the agency's final BO, filed on September 15, 2006, that USFWS did not meet the September 1, 2006, deadline because the agency was receiving "critical information regarding components of the settlement agreement up to the end of August" (USFWS 2006b). The USFWS concurred with FERC that the continued operation of the Merwin Project:

- May affect, likely to adversely affect the Columbia River Distinct Population Segment of bull trout

- May affect, not likely to adversely affect the designated bull trout critical habitat in the Lower Lewis River (USFWS 2006b).

USFWS did not concur with the following FERC determinations:

- May affect, not likely to adversely affect the northern spotted owl. USFWS did not concur with this effect determination stating that the Wildlife Habitat Management Plans allowed for the removal of suitable spotted owl habitat, which results in adverse effects to the spotted owl.

- May affect, not likely to adversely affect the bald eagle. USFWS did not concur with this effect determination stating that the agency anticipated indirect effects of increased 
recreationists associated with recreation facilities upgrades/expansions and increased fisheries associated with the reintroduction of salmon and steelhead would disturb bald eagles (USFWS 2006b).

USFWS's final BO contained an incidental take statement and analyzed and concurred with implementing the following conditions for inclusion in the FERC license order (Appendix E) for the Merwin Project:

- Required the licensee to comply with bull trout species protections (e.g., annual surveys, minimize instream flow construction activities, implement measures for monitoring and handling)

- Required the licensee to monitor and report to FERC annual on the bull trout recovery efforts (PacifiCorp 123 FERC $\mid 62,258$, Order Issuing New License (2008)).

\section{National Oceanic and Atmospheric Administration Fisheries}

On August 27, 2007, NOAA Fisheries issued a final BO to FERC concluding formal consultation. NOAA Fisheries determined that the continued operation of the Merwin Project would not likely adversely jeopardize the continued existence of the Lower Columbia Chinook salmon, Lower Columbia River coho salmon, Columbia River chum salmon, or the Lower Columbia River steelhead. NOAA Fisheries also determined the Merwin Project was not likely to destroy or adversely modify designated critical habitat of the aquatic species listed above (NOAA 2007).

NOAA Fisheries' final BO contained an incidental take statement as well as consultation regarding essential fish habitat under the Magnuson-Stevens Fishery Conservation and Management Act. NOAA Fisheries put forth the following conditions for inclusion in the FERC license order (Appendix D) for the Merwin Project:

- Required the licensee to comply with anadromous fish species protections specified in the settlement agreement, specifically:

- Section 3: Anadromous Fish Reintroduction Outcome Goals

- Section 4: Fish Passage Measures

- Section 6: Flow Releases for Fish and Other Aquatic Species

- Section 7: Aquatic Habitat Enhancement Actions

- Section 8: Hatchery and Supplemental Program

- Section 9: Aquatic Monitoring and Evaluation (PacifiCorp 123 FERC 962,258 , Order Issuing New License [2008]).

- Required licensee to follow best management practices to control sediment, disturbance, and other potential determinantal effects to listed salmonids

- Required licensee to monitor and evaluate conditions identified in the settlement agreement

- Required licensee to observe and report dead or injured salmon or steelhead to NOAA (PacifiCorp 123 FERC 9 62,258, Order Issuing New License [2008]). 


\section{NHPA Section 106}

To comply with Section 106 of the NHPA (16 U.S.C. § 306108), FERC executed a programmatic agreement with the Washington SHPO on December 27, 2005, for the Merwin Project, along with two other Lewis River Projects - the Swift No. 1 Project and the Yale Project. FERC invited the licensee, USFS, Cowlitz Tribe, and Yakama Nation, to concur with the stipulations of the PA. The licensee concurred to the PA, which required it to implement an HPMP for the 50-year license term. The licensee's responsibilities under the PA, including the HPMP, were included in article 412 of the FERC license order (FERC 2005c; PacifiCorp 123 FERC $\uparrow$ 62,258, Order Issuing New License [2008]).

\section{Settlement Agreement}

In January 1999, the licensee and Cowlitz PUD filed a request with FERC for approval to use FERC's ALP and for the simultaneous and coordinated processing of the relicense applications for the Lewis River Projects - the Merwin Project, the Swift No. 1 Project, the Swift No. 2 Project, and the Yale Project. On April 1, 1999, FERC approved the request and issued an order accelerating the expiration of the Merwin Project license to coincide with the other Lewis River Projects (PacifiCorp 2005).

On April 29 and 30, 1999, the licensee and Cowlitz PUD convened meetings to initiate the collaborative process. Following the initial April 1999 meetings, the licensee and Cowlitz PUD held a series of public meetings to establish ground rules for the relicensing process, the goals and objectives of the participants, and, ultimately, establish the Lewis River Project Relicensing Steering Committee and Resource Workgroups (PacifiCorp 2005).

The steering committee was responsible for overseeing the collaborative process and establishing the working groups' goals and objectives. The steering committee established the following resource groups to study and address particular resource issues: 1) aquatics, 2) terrestrial/land use, 3) flood management, 4) recreation/aesthetics, 5) socioeconomics, and 6) cultural. Initially, the resource groups designed studies to evaluate resource issues and project effects, and later devised conservation measures to address identified resource issues. In March 2002, negotiating, policy, and legal groups were formed to develop the Lewis River Settlement Agreement (PacifiCorp 2005).

On November 30, 2004, the licensee and Cowlitz PUD reached a comprehensive settlement agreement with 26 interested parties with regard to the Lewis River Projects (WDE 2006; PacifiCorp 123 FERC 962,258 , Order Issuing New License [2008]). The parties to the settlement agreement included NOAA Fisheries, USFWS, BLM, USFS, NPS, Washington Department of Fish and Wildlife, Washington Interagency Committee for Outdoor Recreation, Cowlitz County, Cowlitz Skamania Fire District No. 7, North Country Emergency Medical Service, City of Woodland, Woodland Chamber of Commerce, Lewis River Community Council, Lewis River Citizens at Large, American Rivers, Fish First, Rocky Mountain Elk Foundation, Trout Unlimited, the Native Fish Society, Confederated Tribes and Bands of the Yakama Nation, Lower Columbia River Fish Recovery Board, Clark County, Skamania County, and the Cowlitz Indian Tribe (PacifiCorp 123 FERC 9 62,258, Order Issuing New License [2008]). 
On December 3, 2004, the licensee filed the settlement agreement with FERC with the purpose of resolving all issues related to the relicensing of the Lewis River Projects. The settlement agreement required several fish passage and aquatic enhancement measures for the Merwin Project, including:

- Improvements to the Merwin Project adult salmon and steelhead collection and transport facility

- Installation of modular surface collectors for downstream passage of salmon and steelhead smolts at the Merwin, Yale, and Swift No. 1 projects (unless the USFWS and NOAA Fisheries determine, based on new information, that passage facilities are inappropriate, in which case the licensee must provide additional funds for projects in lieu of fish passage)

- Installation of upstream and downstream passage facilities for bull trout at the Merwin, Yale, and Swift projects in the event that the anadromous fish passage facilities are not constructed

- Construction of an enhanced habitat side channel next to the Lewis River bypassed reach

- Seasonally adjusted minimum flows, ramping rate restrictions, and plateau operations downstream of Merwin dam

- Habitat enhancement measures, including programs to store and place large woody debris in selected locations

- Upgrades to and continued maintenance of the three Lewis River hatcheries, with an increase in the hatchery production of salmon, steelhead, and resident species

- A supplementation program in which fish in excess of hatchery production are released in the upper watershed to spawn and rear naturally

- A comprehensive monitoring program to review the results and assess the status of the fisheries restoration efforts

- Measures under the Aquatics Fund associated with project effects, to support habitat enhancement and fish recovery efforts

- A gravel augmentation program, to include monitoring to determine baseline gravel availability downstream of Merwin dam, with a program for supplementation if monitoring shows levels are decreasing over the current baseline (FERC 2004; PacifiCorp 123 FERC 92,258 , Order Issuing New License [2008]).

\section{Merwin Project Outcomes: Non-Power Benefits (Protection, Mitigation, and Enhancement)}

This section highlights project outcomes that resulted in non-power benefits associated with the Merwin Project relicensing. For the purposes of this case study, non-power benefits are defined as PME measures included as conditions to the FERC license order. These license conditions were the result of measures proposed by the licensee, FERC staff recommendations within NEPA analysis, the WDE's CWA 401 WQC process, the USFWS and NOAA Fisheries' ESA Section 7 consultation process, and the comprehensive settlement agreement. These license conditions include those associated with water quality, species and habitat protection, recreation, and historic and cultural resources. 


\section{Water Quality and Species Protection Measures}

The FERC license order for the Merwin Project contained the following PME measures applicable to water quality and aquatic species protection:

- Required funding to enhance wetlands, and riparian and riverine habitats

- Required development of a hatchery and supplementation program to support reintroduction of anadromous fish to the watershed upstream of the Merwin dam

- Established minimum instream flows and ramping rates for fish and wildlife in Lewis River basin

- Required acquisition of interest and management of lands for fish, wildlife, and native plant species

- Required the licensee to implement NOAA Fisheries and USFWS facility/handling guidelines for anadromous fish and bull trout

- Required annual evaluation of all Chinook in the lower Lewis River

- Required maintaining road closures through sensitive habitat areas (PacifiCorp 123 FERC $\uparrow 62,258$, Order Issuing New License [2008]).

\section{$\underline{\text { Recreation Measures }}$}

The FERC license order for the Merwin Project contained the following PME measures applicable to recreation:

- Required the licensee to implement a recreational resources management plan consistent with the settlement agreement

- Required the licensee to operate and maintain recreational facilities, including Merwin Park, Cresap Bay Campground and Day Use Area, Marble Creek Trail, and Speelyai Bay Park

- Required upgrades to river access at Speelyai Bay Park and Yale Bridge

- Required the licensee to implement interpretation and public education programs to protect bull trout (PacifiCorp 123 FERC 9 62,258, Order Issuing New License [2008]).

\section{Cultural and Historic Resources Measures}

The FERC license order for the Merwin Project required the licensee to implement a HPMP via a PA with the Washington SHPO. The PA requires the licensee to consult with the Washington SHPO prior to making any additions or alterations to properties listed or eligible for listing on the National Register of Historic Places (PacifiCorp 123 FERC 9 62,258, Order Issuing New License [2008]). 

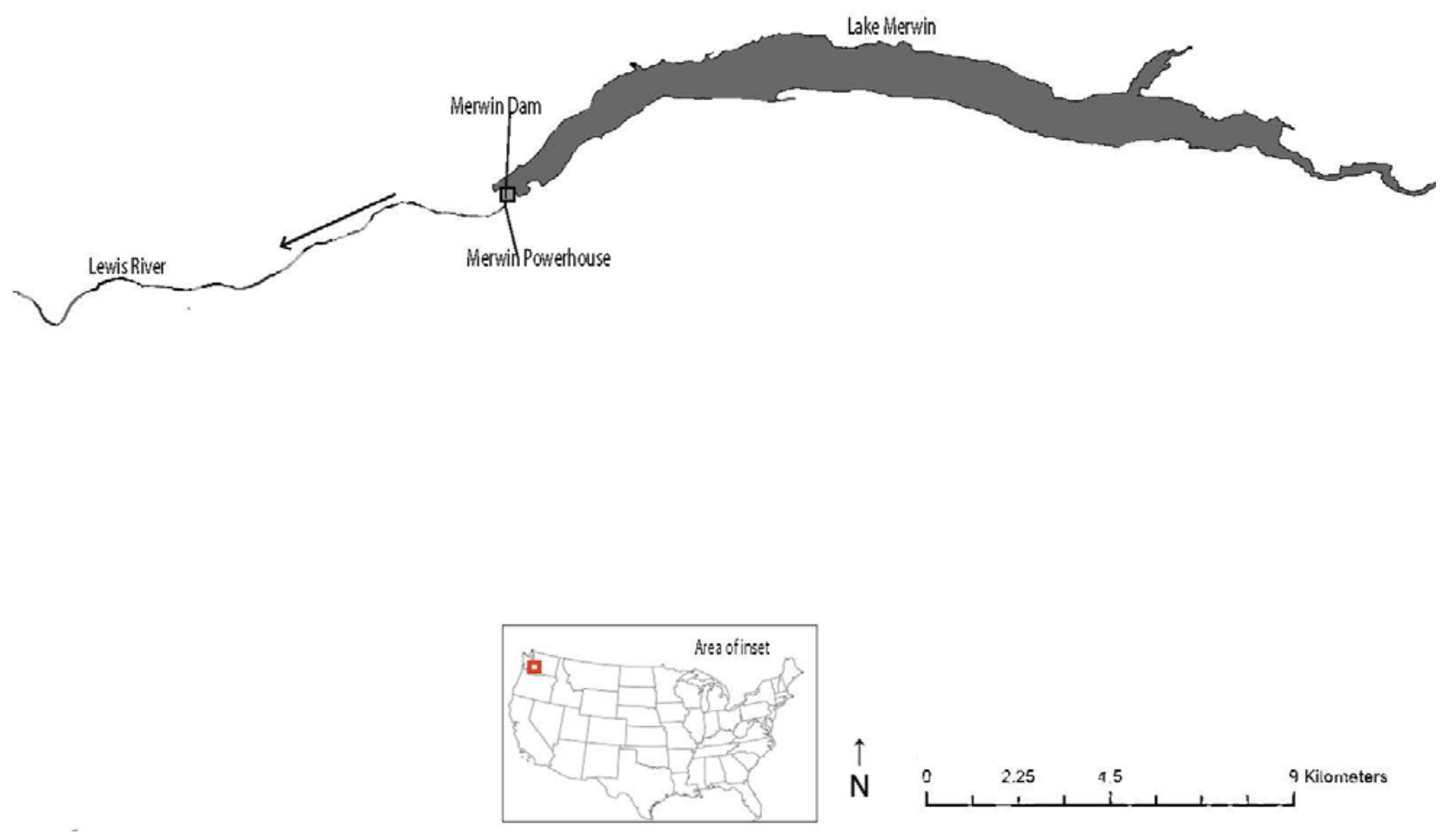

Figure C12. Map indicating major landmarks and features mentioned in project license. Arrow indicates direction of flow. 


\section{Morgan Falls Project-P-2237 (Relicensing) Case Study}

\section{Table C7. Description of Project Key Characteristics and Timeline Lengths}

\begin{tabular}{|c|c|c|c|c|c|c|c|c|c|c|c|c|c|c|c|}
\hline$\frac{\Phi}{\pi}$ & $\begin{array}{l}\text { tᄒ } \\
\frac{1}{0} \\
\frac{0}{0} \\
8 \\
0\end{array}$ & 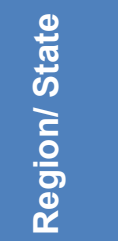 & 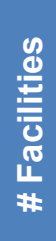 & $\begin{array}{l}\frac{d}{N} \\
\frac{d}{d} \\
\frac{d}{0} \\
\frac{0}{2}\end{array}$ & 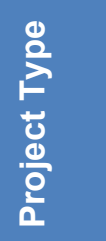 & 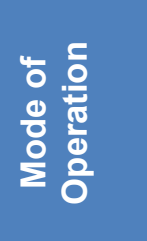 & 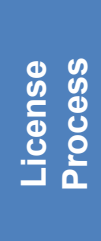 & 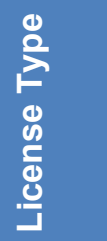 & $\frac{4}{\frac{1}{2}}$ & $\begin{array}{l}\overline{1} \\
\dot{4}\end{array}$ & $\begin{array}{l}\overline{1} \\
\overline{0}\end{array}$ & 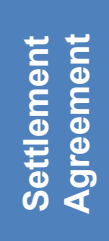 & $\frac{\nwarrow}{\text { 而 }}$ & $\begin{array}{l}\text { 들 } \\
\text { 을 } \\
\text { 혀 }\end{array}$ & б \\
\hline $\begin{array}{c}\text { Morgan } \\
\text { Falls }\end{array}$ & P-2237 & $\begin{array}{c}\text { South/ } \\
\text { GA }\end{array}$ & 2 & $\begin{array}{c}16.8 \mathrm{MW} \\
1.6 \%\end{array}$ & Conv & Peaking & ILP & Relic & $\begin{array}{c}3.1 \mathrm{yr} \\
45 \%\end{array}$ & $\begin{array}{l}1.2 \mathrm{yr} \\
7.5 \%\end{array}$ & $\begin{array}{l}4.4 \mathrm{yr} \\
22.3 \%\end{array}$ & No & $\begin{array}{c}0.5 \\
y r \\
9.5 \%\end{array}$ & NA & $\begin{array}{l}1.0 \mathrm{yr} \\
6.5 \%\end{array}$ \\
\hline
\end{tabular}

Notes: NOI-LA: Notice of intent to license application timeline. LA-LI: License application to license issuance timeline. NOI-LI: Notice of intent to license issuance timeline. NEPA: National Environmental Policy Act timeline. Section 7: Endangered Species Act Section 7 Consultation timeline. 401 : State Clean Water Act Section 401 Certification timeline. Percent values on the bottom row of some cells represent the percentile the timeline for this project represents in the overall sample of 107 projects used in Chapter 3: Statistical Description and Analysis of Hydropower Licensing Timelines.

\section{Morgan Falls P-2237}

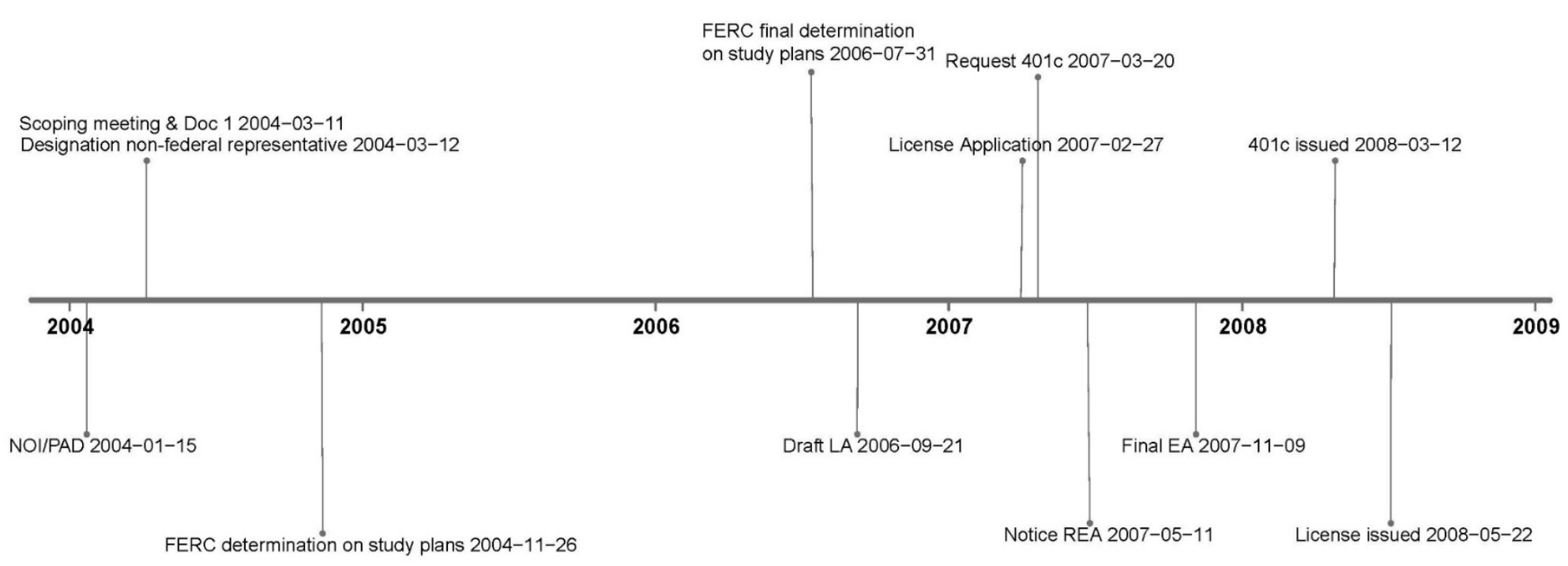

Figure C13. Timeline of some major licensing milestones 


\section{Morgan Falls Project Overview}

The Morgan Falls Project is owned by the Georgia Power Company and is located in Cobb and Fulton counties, Georgia, near the city of Atlanta. The project occupies 14.4 acres of federal lands within the Chattahoochee River National Recreation Area, which was created by public law in 1978 and is managed by NPS. The project consists of a concrete dam that spans the Chattahoochee River. Hydropower generation at the project is conducted at the $16.8 \mathrm{MW}$ rated capacity powerhouse. The project has a single 684-acre impoundment, Bull Sluice Lake, which is about 7 river miles long. There is no bypassed reach. Most of the flow entering the project comes from releases from the USACE's upstream Buford dam and power plant. Because Buford dam's reservoir is substantially larger than Bull Sluice Lake, the amount and timing of Buford dam's water releases directly affect the operation of this project. Recreation facilities within the project boundary include a canoe portage, shoreline angler platform, and barrier-free access (Georgia Power Company [GPC] 2008).

The Morgan Falls Project was originally licensed in 1959 for a 50-year license term. For the relicensing process being analyzed in this case study, the Georgia Power Company (licensee) submitted the NOI and PAD in January 2004, proposing no major modifications to the existing infrastructure, and selected the default ILP. The licensee submitted a final license application to FERC on February 27, 2007 (GPC 2008). In May 2008, FERC issued a new 30-year hydropower license (relicense) for the continued operation and maintenance of the 16.8 MW Morgan Falls Project (FERC 2008).

\section{Morgan Falls Project Participants and Comment Themes}

The Morgan Falls Project had 45 participants, 2 of which filed for intervenor status (i.e., an official party to the proceeding) with FERC. The bulk of comments filed in the FERC record were from state and federal agencies, specifically Georgia Power Company, the Georgia Department of Natural Resources (DNR), the Georgia Wildlife Resources Division, and DOI. There were several other commenters, including the Hydropower Reform Coalition, the Upper Chattahoochee Riverkeeper, and American Rivers. Comments were generally focused on three main themes of project impacts: 1) impacts to the Chattahoochee River including water temperatures, fisheries, erosion, sedimentation, and recreation; 2) impacts of project operations on aquatic and terrestrial resources; and 3) carbon footprint analysis (Georgia DNR 2007; DOI 2007; UCR and AR 2007).

\section{Statutory and Regulatory Compliance}

The following subsections address both substantive and procedural aspects of the CWA Section 401 Water Quality Certification process administered by Georgia DNR), the ESA Section 7 consultation administered by USFWS, and the NHPA 106 consultation process administered by the Georgia SHPO.

\section{National Environmental Policy Act}

FERC conducted scoping to determine what issues and alternatives should be addressed in the EA. A scoping document (SD1) was initially distributed to interested project stakeholders on March 11, 2004 (GPC 2006). Following release of the SD1, FERC held a scoping meeting to solicit comments from project stakeholders on April 14, 2004, and also provided an opportunity for written comment (GPC 2006). The licensee submitted a final license application to FERC on 
February 27, 2007 (GPC 2008). On May 11, 2007, FERC issued notice that the Morgan Falls Project was REA (GPC 2008). On November 9, 2007, FERC issued an EA for the Morgan Falls Project along with a FONSI (FERC 2007a).

The relicensing of the Morgan Falls Project raised a number of cultural/historic, environmental and natural resource, and recreational concerns requiring analysis primarily under the FPA, NEPA, CWA, ESA, and NHPA.

The Morgan Falls Project EA provides an overview of the key issues analyzed during the Morgan Falls Project relicensing process. At a high level, the issues analyzed in the EA included the effect of project operation on:

- Water quality and quantity in the Morgan Falls impoundment

- Aquatic resources and habitat in the Morgan Falls impoundment and project-affected portions of the Chattahoochee River

- Terrestrial resources including wildlife resources and botanical and vegetative resources within the project boundary

- Land use and recreational resources located within the project area

- Rare, threatened, and endangered species, including seven federally protected species and candidate species potentially occurring in the project area

- Impacts to archaeological and historical sites listed or eligible for listing on the National Register of Historic Places including a historic mill, seven archaeological sites, and an Indian trading and traveling route (FERC 2007a).

\section{Clean Water Action Section 401}

On March 21, 2007, Georgia DNR received a request to grant or waive a WQC for the continued operation of the Morgan Falls Project (Georgia DNR 2008). The licensee proposed continued operation of the Morgan Falls Project in accordance with historic operating procedures (Georgia DNR 2008).

The primary water quality issues identified and studied that were associated with the continued operation of the Morgan Falls Project included construction and maintenance activity effects on water quality and stream buffer zones (Georgia DNR 2008). Georgia DNR subsequently determined that the Morgan Falls Project operation, as proposed in the final license application, would comply with Section 401 of the CWA (Georgia DNR 2008). On March 12, 2008, Georgia DNR issued a WQC for the Morgan Falls Project's continued operation with five additional conditions to the FERC license order, including the following:

- Condition 1 required that work performed during construction not violate applicable water quality standards

- Condition 2 prohibited the discharge of oils, grease, or other pollutants to public waters during construction activities

- Condition 3 required that the licensee submit an application for a stream buffer variance to the Georgia DNR prior to conducting any land disturbing activities in state mandated stream buffers 
- Condition 4 required that the licensee complete mitigation activities prior to final stabilization of permitted land disturbing activities on the project site

- Condition 5 required the licensee to comply with flow and discharge requirements included within the Statement of Policy between the licensee and the Atlanta Regional Commission (Georgia DNR 2008).

\section{ESA Section 7 Consultation Overview}

During the ESA Section 7 consultation process, USFWS identified and considered the effects of the Morgan Falls Project on the following threatened and endangered species: Michaux's sumac, shinrayed pocketbook mussel, gulf moccasinshell mussel, whooping crane, and bald eagle (GPC 2006; FERC 2007a).

\section{ESA Informal Consultation, Study Development, Draft License Application}

FERC distributed a scoping document (SD1) to interested project stakeholders on March 11, 2004 (GPC 2006). On March 12, 2004, FERC designated the licensee as its non-federal representative for the purpose of initiating consultation with the USFWS under Section 7 of the ESA (FERC 2007a). FERC held a scoping meeting to solicit comments from project stakeholders on April 14, 2004, and also provided an opportunity for written comment (GPC 2006).

Subsequently, the licensee consulted with USFWS in developing and implementing a study plan for threatened and endangered species. The licensee issued a proposed study plan on June 26, 2004, which proposed conducting nine studies addressing eight resource areas (GPC 2006). The licensee held study plan meetings to gather initial information and study requests and resolve outstanding issues with regard to a proposed study plan on July 28-30, 2004 (GPC 2006). On October 26, 2004, the licensee issued a revised study plan to take into account feedback, including written comment from stakeholders regarding the proposed study plan (GPC 2006). On November 26, 2004, FERC issued a study plan determination (GPC 2006).

On December 16, 2004, DOI initiated a formal study dispute resolution on behalf of two of its component bureaus, USFWS and NPS (DOI 2004). Specifically, DOI contended that the study plan determination did not fully address USFWS and NPS comments and concerns regarding geology and soils and water resources ${ }^{81}$ (DOI 2004). The DOI requested a sediment contamination study to determine the presence of toxicity in sediments in the Bull Sluice Lake and protect populations of seven species of fish located downstream of the project (primarily concerned with the shoal bass) as well as a site-specific instream flow incremental methodology (IFIM) study to characterize existing fish and aquatic resources in the Morgan Falls reservoir and inform fish passage decision-making (DOI 2004). On January 19, 2005, the dispute resolution panel convened and concluded that the IFIM study was not necessary because the studies proposed in the study plan determination were sufficient to inform a fish passage decision; however, the panel recommended that the licensee conduct the sediment contamination study

\footnotetext{
${ }^{81}$ The original study dispute resolution notice also requested a study concerning recreation and land use below the project dam; however, on January 14, 2005, DOI reduced the number of studies for dispute resolution to include the water resources and geology and soils study.
} 
(FERC 2005e; GPC 2006). On February 24, 2005, FERC issued a formal dispute resolution determination, which concurred that the IFIM study was not required, but requested additional information related to the need for the sediment contamination study (FERC 2005f; GPC 2006). On April 11, 2005, FERC issued a second formal dispute resolution determination, which concluded that a sediment contamination study was not necessary because there was no nexus between project effects and the seven species of fish referenced by the DOI in their request for the study (FERC 2005g; GPC 2006). On June 3, 2005, FERC denied the DOI's request for rehearing of the study plan determination, which rendered the decision final (GPC 2006).

The licensee completed nine resource studies between March 2005 and March 2006. The licensee completed final study reports between December 2005 and April 2006. After completion of the resource studies, it was determined that no federally listed species or critical habitat were found within the project area; therefore, the project would have no effect on listed species and no further ESA section 7 consultation was required for the project (FERC 2007a; GPC 2008).

\section{National Historic Preservation Act Section 106}

To comply with Section 106 of the NHPA (16 U.S.C. § 306108), FERC executed a PA with the Georgia SHPO on January 15, 2008. FERC invited the licensee, Georgia SHPO, NPS, Eastern Band of Cherokee Indians, Seminole Nation of Oklahoma, United Keetoowah Band of Cherokee Indians, Cherokee Nation, Seminole Tribe of Florida, Poarch Band of Creek Indians, Thlopthlocco Tribal Town, Alabama-Quassarte Tribal Town, Muskogee (Creek) Nation, and the Kialegee Tribal Town to concur with the stipulations of the PA. The licensee concurred to the PA, which required it to implement an HPMP for the 30-year license term. The licensee's responsibilities under the PA, including the HPMP, were included in article 409 of the FERC license order (GPC 2008).

\section{Settlement Agreement}

Although no official settlement agreement was filed with FERC, on September 13, 2007, the licensee and DOI (through NPS and USFWS) signed an off-license agreement (OLA) with respect to the Morgan Falls Project. Among other things, the OLA specifically required the licensee to support NPS management activities related to the Chattahoochee River National Recreation Area, and DOI agreed that the OLA would satisfy all of the licensee's statutory and regulatory obligations to DOI related to the relicensing and operation of the Morgan Falls Project. In addition, DOI agreed to not file any 4(e) mandatory conditions in the licensing proceeding but reserved the Secretary of the Interior's authority to prescribe section 18 fishway prescriptions. On October 25, 2004, the licensee filed the OLA with FERC, which resolved all of the environmental, recreational, cultural, and other issues among the signatories that were or could have been raised through the licensing process (GPC 2007).

\section{Morgan Falls Project Outcomes: Non-Power Benefits (Protection, Mitigation, and Enhancement)}

This section highlights project outcomes that resulted in non-power benefits associated with the Morgan Falls Project relicensing. For the purposes of this case study, non-power benefits are defined as PME measures included as conditions to the FERC license order. These license conditions were the result of measures proposed by the licensee, FERC staff recommendations 
within NEPA analysis, the NHPA Section 106 process, and the Georgia DNR's CWA 401 Water Quality Certification process. These license conditions include those associated with water quality, species and habitat protection, recreation, and historic/cultural resources.

Water Quality and Species Protection Measures

The FERC license order for the Morgan Falls Project contained the following PME measures applicable to water quality and species protection:

- Required the licensee to monitor project operations and flows to ensure water level drawdowns in the Bull Sluice Lake and monitor head pond fluctuations and tailrace flows at USGS gauges on the Chattahoochee River

- Required the licensee to ensure that all construction and maintenance work is done in a manner that complies with the applicable water quality standards and 401 WQC conditions

- Required the licensee to install signage to educate project visitors on preventing the spread of invasive aquatic vegetation and other species and file an Invasive Terrestrial Vegetation Management Program with FERC to help manage invasive plants that occur on project lands and restore native plants

- Required the licensee to file an annual bald eagle monitoring report to monitor the presence of bald eagles in the project boundary (GPC 2008).

\section{$\underline{\text { Recreation Measures }}$}

The FERC license order for the Morgan Falls Project contained the following PME measures applicable to recreation:

- Required the licensee to file a Visitor Interpretation Program for the Chattahoochee Nature Center's wetlands boardwalk to enhance the recreational experience within the project boundary

- Required the licensee to manage, construct, and maintain recreation facilities within the project boundary including a canoe portage, shoreline angler platform, and barrier-free access (GPC 2008).

\section{$\underline{\text { Cultural/Historic Resources Measures }}$}

The FERC license order for the Morgan Falls Project required the licensee to implement an HPMP via a PA with the Georgia SHPO. The PA requires the licensee to consult with the Georgia SHPO prior to making any additions or alterations to properties listed or eligible for listing on the National Register of Historic Places (GPC 2008). In addition, the FERC license order required the licensee to install signage at the Hightower Trail to inform the public of the significance of the trail as an Indian trading and traveling route (GPC 2008). 


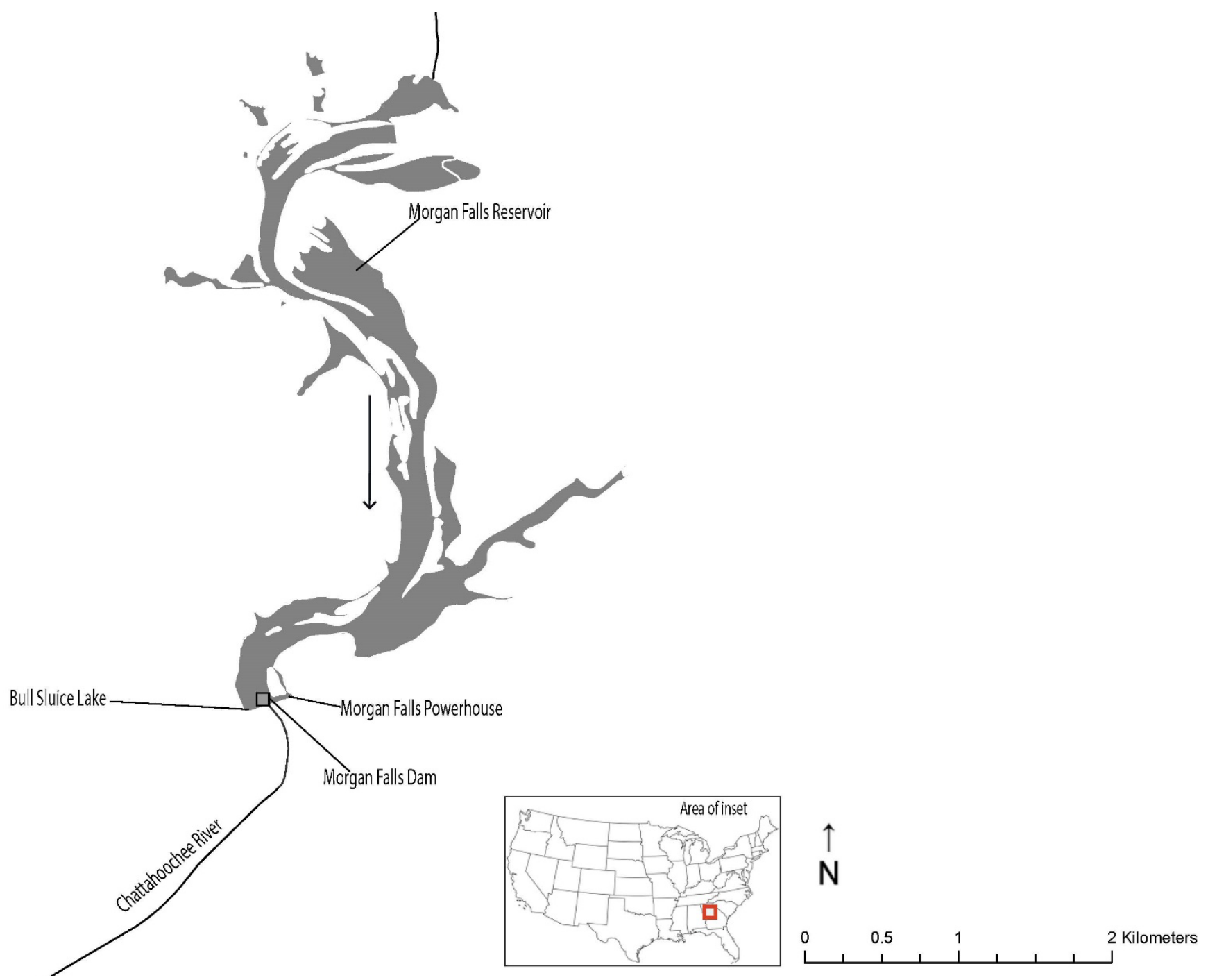

Figure C14. Map indicating major landmarks and features mentioned in project license. Arrow indicates direction of flow. 


\section{City of Wadsworth, Ohio - RC Byrd Hydroelectric Project - P-12796 Case Study}

Table C8. Description of Project Key Characteristics and Timeline Lengths

\begin{tabular}{|c|c|c|c|c|c|c|c|c|c|c|c|c|c|c|c|}
\hline$\frac{\stackrel{g}{\frac{E}{10}}}{z}$ & $\begin{array}{l}\text { बे } \\
\frac{0}{0} \\
8\end{array}$ & 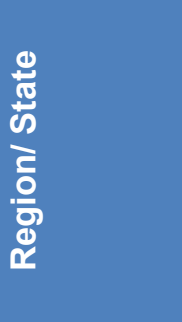 & 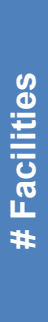 & $\begin{array}{l}\frac{9}{N} \\
\text { क } \\
\frac{d}{0} \\
\frac{0}{0} \\
\frac{2}{2}\end{array}$ & 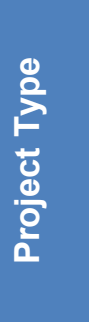 & $\begin{array}{l}\frac{5}{0} \\
\frac{0}{7} \\
\frac{2}{0} \\
\frac{0}{0} \\
0 \\
\frac{0}{0} \\
\frac{0}{8} \\
\frac{0}{2}\end{array}$ & 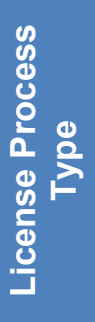 & 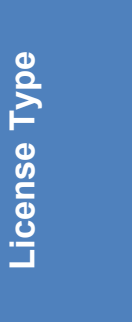 & $\begin{array}{l}\frac{5}{1} \\
\frac{1}{2}\end{array}$ & $\bar{J}$ & $\frac{\overline{1}}{\frac{1}{0}}$ & 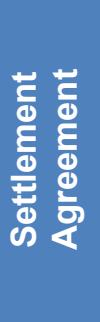 & $\frac{\mathbb{a}}{\frac{u}{z}}$ & 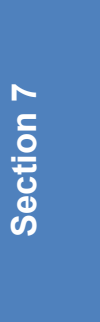 & б \\
\hline $\begin{array}{c}\text { RC } \\
\text { Byrd }\end{array}$ & $\begin{array}{c}\mathrm{P}- \\
12796\end{array}$ & $\begin{array}{c}\text { MidAtlantic/ } \\
\text { WV }\end{array}$ & 1 & $\begin{array}{c}50 \mathrm{MW} \\
2.3 \%\end{array}$ & NPD & $\begin{array}{l}\text { Run- } \\
\text { of- } \\
\text { River }\end{array}$ & TLP & Original & $\begin{array}{l}3.7 \mathrm{yr} \\
52.2 \%\end{array}$ & $\begin{array}{l}6.4 \mathrm{yr} \\
39 \%\end{array}$ & $\begin{array}{l}10.1 \mathrm{yr} \\
51.8 \%\end{array}$ & No & $\begin{array}{l}2.3 \mathrm{yr} \\
43.6 \%\end{array}$ & $\begin{array}{l}6.8 \mathrm{yr} \\
100 \%\end{array}$ & $\begin{array}{l}2.3 \mathrm{yr} \\
14.8 \%\end{array}$ \\
\hline
\end{tabular}

Notes: NOI-LA: Notice of intent to license application timeline. LA-LI: License application to license issuance timeline. NOI-LI: Notice of intent to license issuance timeline. NEPA: National Environmental Policy Act timeline. Section 7: Endangered Species Act Section 7 Consultation timeline. 401 : State Clean Water Act Section 401 Certification timeline. Percent values on the bottom row of some cells represent the percentile the timeline for this project represents in the overall sample of 107 projects used in Chapter 3: Statistical Description and Analysis of Hydropower Licensing Timelines.

\section{RC Byrd P-12796}

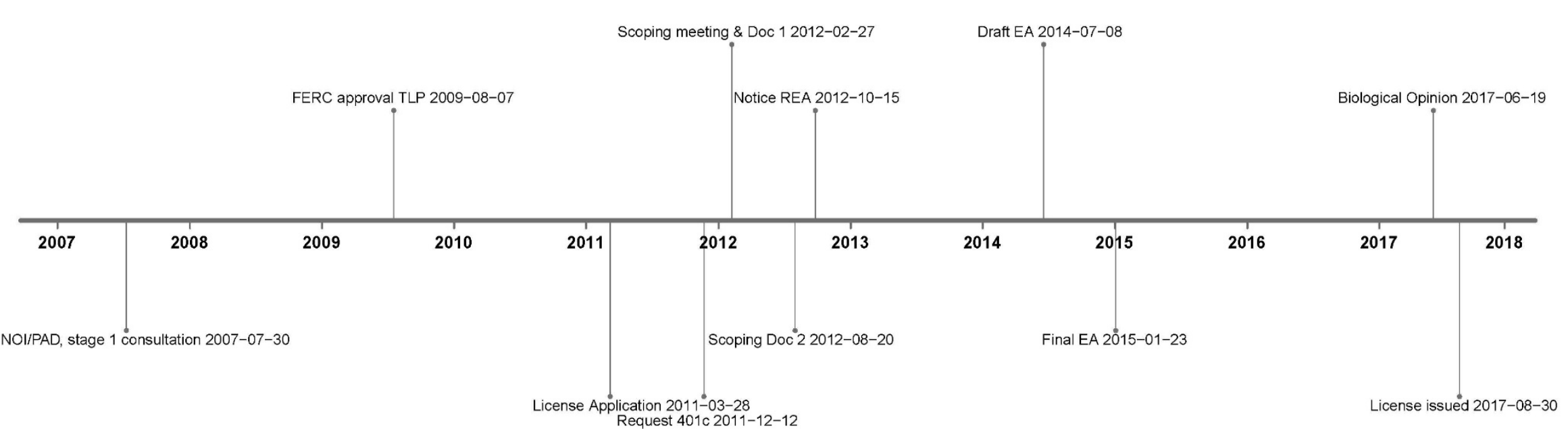

Figure C15. Timeline of some major licensing milestones 


\section{RC Byrd Project Overview}

The Robert C. Byrd Hydroelectric Project (RC Byrd Project) was proposed to be located in Gallia County, Ohio, and Mason County, West Virginia, at the existing USACE RC Byrd Locks and Dam. ${ }^{82}$ The proposed project would have been located on approximately 7.6 acres of federal land under the jurisdiction of USACE. The project proposed to use head created by the existing RC Byrd Locks and Dam, which consists of a concrete, high-lift, gate dam; two active parallel locks; and two deactivated locks. The RC Byrd Locks and Dam operates in a run-of-river mode to maintain a reservoir that extends 41.7 miles upstream on the Ohio River to the Racine Locks and Dam. The Greenup Pool is located downstream of the RC Byrd Locks and Dam and extends 61.8 miles downstream to the USACE Greenup Locks and Dam. The project would have consisted of a new 1,200-foot intake channel conveying flow to two intakes connected to a new $50 \mathrm{MW}$ total installed capacity powerhouse located on the Ohio shoreline of the Ohio River adjacent to the existing RC Byrd Locks and Dam, and a new tailrace that would lead water from the powerhouse back to the downstream Greenup Pool. In addition, the project would have consisted of the following new recreation facilities: a fishing platform; a multilevel walkway along the shoreline; picnic sites with an open play area; tailwater and bank fishing access points; an access road to a parking area; informational signage; lighting; trash receptacles; a potable water supply; and restrooms (Wadsworth 2011; City of Wadsworth, Ohio 160 FERC § 62,191 Order Issuing Original License [2017]).

The RC Byrd Project was issued an original major license in 2017. For the original licensing process being analyzed in this case study, the City of Wadsworth, Ohio (applicant) submitted the NOI and PAD in June 2009 and selected to use the TLP (Wadsworth 2009; FERC 2009b). The applicant submitted a final license application in March 2011 (Wadsworth 2011). In August 2017, FERC issued 50-year original license for the construction, operation, and maintenance of the 50 MW RC Byrd Project (City of Wadsworth, Ohio 160 FERC $\S 62,191$ Order Issuing Original License (2017)).

\section{RC Byrd Project Participants and Comment Themes}

The RC Byrd project had 83 participants, one of which filed for intervenor status (i.e., an official party to the proceeding). The majority of comments filed in the FERC record were from state and federal agencies, specifically, the West Virginia Division of Natural Resources (West Virginia DNR), Ohio Department of Natural Resources (Ohio DNR), West Virginia Department of Environmental Protection (WVDEP), West Virginia State Historic Preservation Office (West Virginia SHPO), Ohio State Historic Preservation Office (Ohio SHPO), USACE, DOI, and the West Virginia and Ohio field offices of the USFWS. Comments were generally focused on three main themes of project impacts: 1) sedimentation, erosion, and turbidity caused by construction, 2) direct impacts of project operations on threated and endangered species, and 3) recreational disruption due to construction (West Virginia DNR 2011

\footnotetext{
${ }^{82}$ On December 3, 2019 FERC approved the applicant's application to surrender its license for the RC Byrd Project, FERC No. 12796 before construction of the project on an existing USACE lock and dam, citing that the project was no longer financially advantageous (City of Wadsworth, Ohio 169 FERC \ 62,128 [2019]).
} 


\section{Statutory and Regulatory Compliance}

The following subsections address both substantive and procedural aspects of the NEPA process administered by FERC, the CWA Section 401 Water Quality Certification process administered by the Ohio Environmental Protection Agency (Ohio EPA) and the WVDEP, the ESA Section 7 consultation process administered by the USFWS, and the NHPA 106 consultation process administered by the Ohio SHPO and the West Virginia SHPO.

\section{National Environmental Policy Act}

FERC conducted scoping to determine what issues and alternatives should be addressed in the EA. A scoping document (SD1) was initially distributed to interested project stakeholders on February 27, 2012. Following release of the SD1, FERC conducted an environmental site review and held two scoping meetings on March 28, 2012, as well as provided an opportunity for written comments. Based on discussions during the site visit, scoping meetings, and written comments received during the comment period, FERC issued a revised scoping document (SD2) on August 20, 2012. On October 15, 2012, after accepting the applicant's final license application, FERC issued notice that the RC Byrd Project was REA. On July 8, 2014, FERC issued a draft EA for the RC Byrd Project requiring comments to be filed on the draft EA by August 8, 2014. On January 23, 2015, FERC issued the final EA, addressing comments filed on the draft EA, along with a FONSI (FERC 2012a; FERC 2015; City of Wadsworth, Ohio 160 FERC ๆ 62,191 [2017]).

The original license of the RC Byrd Project raised a number of cultural/historic, environmental and natural resource, and recreational concerns requiring analysis primarily under the FPA, NEPA, CWA, ESA, and NHPA.

The RC Byrd Project EA provides an overview of the key issues analyzed during the RC Byrd Project original licensing process. At a high-level, the primary issues analyzed in the EA, included the effect of project operation on:

- Changes in flow patterns on water quality; and

- Effects of changes in flow patterns on fisheries, native mussels and federally listed species (FERC 2015).

In addition to the primary issues analyzed in the EA, a number of other potentially significant impacts were analyzed, which included:

- Effects of project construction and operation on recreational fishing opportunities, bottomland hardwood forests and riparian habitat, land use and cultural resources (FERC 2015).

\section{Clean Water Act Section 401}

On July 20, 2011, WVDEP received a request to grant or waive a WQC for the operation of the RC Byrd Project. On July 17, 2012, WVDEP requested that the applicant withdraw its application to allow time for the agency to review additional information. The applicant withdrew its certification application on July 17, 2012 and resubmitted the application on October 24, 2012. On January 23, 2014, WVDEP provided notice to the applicant that the agency declined to act (grant or deny) on the applicant's application for certification within 1- 
year after receipt, and the certification was deemed waived. WVDEP stated that the agency had anticipated using the information in the EA and response to the agency's 10(j) recommendations to prepare the certification but had not yet received those two documents and therefore would not act on the application. WVDEP also noted that they anticipated receipt of a second 401 certification application in relation to the USACE $404^{83}$ application, which they had not yet received (WVDEP 2014; City of Wadsworth, Ohio 160 FERC § 62,191 Order Issuing Original License (2017)).

On December 13, 2011, the Ohio EPA received a request to grant or waive a WQC for the operation of the RC Byrd Project. On January 4, 2012, the Ohio EPA provided notice to the applicant that the application for certification was incomplete and requested additional information (Ohio EPA 2012). On October 18, 2012, the applicant provided Ohio EPA with the additional information requested for a complete certification application (Wadsworth 2012). On February 6, 2013, the Ohio EPA provided notice to the applicant that the agency completed review of the certification application. The Ohio EPA noted that after discussions with FERC, it was the agency's "understanding that because more than 1-year had passed since receipt of the original certification application and the agency had not acted (denied or granted) the application that FERC was of the opinion the certification was waived" (Ohio EPA 2013). The Ohio EPA stated that although they "did not agree with FERC's opinion, given the Ohio EPA and FERC did not deem the application for certification complete until February 7, 2012, that the agency would not take further action" (Ohio EPA 2013). The Ohio EPA also noted that they anticipated receipt of a second 401 certification application in relation to the USACE 404 application, which they had not yet received (Ohio EPA 2012; City of Wadsworth, Ohio 160 FERC $§ 62,191$ Order Issuing Original License [2017]).

\section{ESA Section 7 Consultation}

During the ESA Section 7 consultation process, USFWS identified and considered the effects of the RC Byrd Project and the USACE Navigation Channel Maintenance Dredge Program (Dredge Program) at the existing RC Byrd Locks and Dams on the following threatened and endangered species: Indiana bat, northern long-eared bat, pink mucket pearly mussel, eastern fanshell mussel, snuffbox mussel, and sheepnose mussel. USFWS evaluated both the RC Byrd project and the USACE Dredge Program in the same Section 7 consultation and $\mathrm{BO}$ because the construction and operation of the proposed RC Byrd Project had the potential to interfere with USACE's ability to protect federally listed mussels during dredging operations in the lower approach to the dam locks (USFWS 2017). This section provides details on the ESA Section 7 consultation process (focusing only on the RC Byrd project), beginning with preliminary meetings prior to initiating informal consultation through the final BO.

\section{ESA Informal Consultation, Study Development, Draft License Application}

In June 2009, the applicant filed the NOI and PAD with FERC and requested designation as the non-federal representation for carrying out informal ESA Section 7 consultation with USFWS

\footnotetext{
${ }^{83}$ This project was required to obtain additional USACE approvals (i.e., CWA Section 404 permit and CWA Section 408 approval) after license issuance, but those approvals are outside the scope of this study (City of Wadsworth, Ohio 160 FERC § 62,191 Order Issuing Original License [2017]).
} 
(Wadsworth 2009; FERC 2009b). On October 1, 2009, the applicant (and its contracted representatives) held an initial consultation meeting with federal and state agencies, affected tribal entities, and members of the public to discuss the ESA Section 7 consultation process for the original license of the RC Byrd Project (Wadsworth 2011; USFWS 2017). Between February 2010 and November 2010, the applicant, USFWS, and FERC held meetings and consulted with stakeholders to identify project impacts on threatened and endangered species and identify necessary studies (Wadsworth 2011; USFWS 2017). On November 5, 2010 the applicant filed a draft license application with FERC and published notice to solicit comments and additional study requests (Wadsworth 2010). In February 2011, the applicant, USFWS, USACE and FERC held a joint meeting with state and federal regulators, affected tribal entities, and the public to further discuss the draft license application and potential project impacts on threatened and endangered species (Wadsworth 2011; USFWS 2017).

\section{Final License Application}

In April 2011, FERC provided notice of the applicant's final license application and solicited comments and additional study requests (USFWS 2017). In February 2012, FERC distributed SD1 and conducted scoping meetings in March 2012 to identify potential impacts to threatened and endangered species (USFWS 2017). Based on discussions during the site visit, scoping meetings, and written comments received during the comment period FERC issued a revised scoping document on August 20, 2012 (FERC 2012a; FERC 2015; USFWS 2017; City of Wadsworth, Ohio 160 FERC \ 62,191 [2017]).

On October 15, 2012, FERC issued a notice that the RC Byrd Project was REA. On December 11, 2012, DOI sent FERC a "no comment response" to the notice of REA. On July 14, 2014, FERC submitted the draft EA for the project to USFWS stating that the draft EA served as the biological assessment for the purposes of ESA Section 7 consultation and requesting concurrence that the proposed project was "not likely to adversely affect" the Indiana bat, eastern fanshell, pink mucket pearly, sheepnose and snuffbox mussels. On July 24, 2014, and August 7, 2014, the USFWS Ohio Field Office and West Virginia Field Office provided non-concurrence letters to FERC citing the lack of bat and mussel conservation plans and the lack of an operating agreement with USACE to support the effect determinations. USFWS also stated that the northern long-eared bat had been proposed for listing and recommended that conservation measures for the species be incorporated into the project. On September 23, 2014, USFWS, FERC, and the applicant held a meeting to discuss Section 7 consultation process and potential species impacts for the RC Byrd Project (USFWS 2017).

On January 30, 2015, FERC submitted the final EA to USFWS requesting concurrence that the proposed project was "not likely to adversely affect" the Indiana bat, northern long-eared bat, eastern fanshell, pink mucket pearly, sheepnose and snuffbox mussels. On March 13, 2015, USFWS requests that USACE provide a timeline for development and completion of an operating agreement between the applicant and USACE. On February 26, 2015, USFWS provided a non-concurrence letter to FERC again citing the lack of bat conservation plan, an operating agreement with USACE to support the effect determinations, a water quality monitoring plan, an erosion and sediment control plan, a mussel relocation and monitoring plan, and a contaminated sediment testing and disposal plan (USFWS 2017). 


\section{ESA Section 7 Formal Consultation}

On March 12, 2015, FERC submitted a request for initiation of formal consultation to USFWS for the Indiana bat, eastern fanshell, pink mucket pearly, sheepnose and snuffbox mussels. On April 9, 2015, USFWS sent a letter to FERC denying the request for formal consultation due to the receipt of an incomplete initiation package citing the lack of project details necessary for USFWS to determine the action area and conduct a project effect analysis. USFWS also notified FERC that due to the April 2, 2015, publication of a final rule listing the northern long-eared bat as a threatened species, consultation on the northern long-eared bat would also be necessary for the project. Between April 2015 and September 2016 FERC, USACE, the applicant, USFWS Ohio and USFWS West Virginia consulted to identify information needed to determine the potential scope and effect of the proposed project on listed bat and mussel species (USFWS 2017; City of Wadsworth, Ohio 160 FERC § 62,191 Order Issuing Original License [2017]).

On February 6, 2017, USFWS received a letter from FERC requesting concurrence with a "not likely to adversely affect" determination for the Indiana bat, eastern fanshell, pink mucket pearly, sheepnose, and snuffbox mussels. FERC also requested that if USFWS could not concur with a "not likely to adversely affect" determination, that formal consultation be initiated for the project. The concurrence request did not include the northern long-eared bat. On March 3, 2017, USFWS concurred with FERC's determinations that the RC Byrd Project was "not likely to adversely affect" the Indiana bat and that the Indiana bat protection plan supported USFWS's determination. USFWS did not concur with a "not likely to adversely affect" determination for the eastern fanshell, pink mucket pearly, sheepnose, and snuffbox mussels due to a lack of data provided to support the determination and instead granted the request for formal consultation for these mussel species. USFWS also informed FERC that consultation for the northern long-eared bat would be necessary for the project. In response, USFWS received a completed northern longeared bat 4(d) Rule Streamlined Consultation Form from FERC on March 21, 2017, which fulfilled FERC's consultation obligation for this species for the project (USFWS 2017).

In May 2017, USFWS sent the draft BO to USACE and FERC for review. In June 2017, the applicant provided comments on the draft BO to USFWS and FERC (USFWS 2017).

\section{Final Biological Opinion}

On June 19, 2017, USFWS issued a final BO to FERC and USACE concluding formal consultation. The final BO concluded that the RC Byrd Project and USACE's Navigation Channel Dredging Maintenance Project, as proposed, was not likely to jeopardize the continued existence of the eastern fanshell, pink mucket pearly, sheepnose, and snuffbox mussels (USFWS 2017).

USFWS's final BO contained an Incidental Take Statement and analyzed and concurred with implementing the following conditions for inclusion in the FERC license order for the RC Byrd Project:

- License Article 402, Operation Compliance and Monitoring

- License Article 403, Physical Hydraulic Modeling

- License Article 405, Erosion and Sediment Control 
- License Article 406, Timing of In-Water Construction to Avoid Spawning Season

- License Article 407, Sediment Testing and Disposal

- License Article 408, Sediment Transport Modeling Plan for Eastern Fanshell, Pink Mucket Pearly, Sheepnose, and Snuffbox Mussels

- License Article 409, Water Quality Monitoring

- License Article 410, Spill Prevention, Containment and Countermeasures

- License Article 412, Mussel Protection Plan for Eastern Fanshell, Pink Mucket Pearly, Sheepnose, and Snuffbox Mussels (USFWS 2017)

- License Article 413, Site Restoration and Aesthetics.

\section{NHPA Section 106}

To comply with Section 106 of the NHPA (16 U.S.C. $\S 306108)$, FERC executed a PA with West Virginia and Ohio SHPOs on March 20, 2015, and May 27, 2015, respectively. FERC invited the applicant and USACE to concur with the stipulations in the PA. The applicant and USACE concurred to the PA, which required the implementation of a HPMP for the 50-year license term. The applicant's responsibilities under the PA, including the HPMP were included in Article 418 of the FERC license order (City of Wadsworth, Ohio 160 FERC $\S 62,191$ Order Issuing Original License [2017]).

\section{Settlement Agreement}

Stakeholders in the RC Byrd Project did not attempt to reach a settlement agreement.

\section{FAST $-41^{84}$}

On September 22, 2016, the Federal Permitting Improvement Steering Council selected the RC Byrd Project as a covered project under the FAST-41 framework. After participating in several informatory conference calls with FAST-41 staff about hydropower permitting and the RC Byrd Project, the applicant experienced increased transparency, predictability, and accountability within the licensing process. One example of these benefits was the facilitation of the approval of the final BO from USFWS, which led FERC to issue a letter to USFWS that explained FERC's EA and requested concurrence within 30 days (FERC 2017a). FERC also indicated that if USFWS failed to respond, FERC would consider its responsibilities met and would resolve the matter. Other benefits the FAST-41 program had on the RC Byrd Project include increasing agency accountability by making agency actions and timeliness more visible and informally resolving longstanding disputes and guiding the license through to issuance.

\footnotetext{
${ }^{84}$ The Fixing America's Surface Transportation Act (FAST), commonly referred to as the FAST Act was signed into law on December 4, 2015. Title 41 of FAST established a new framework to improve the federal environmental review and authorization process for covered infrastructure projects that promotes early stakeholder consultation and enhanced coordination amongst agencies. The new framework includes the designation of a lead federal agency and a coordinated project plan and timetable for environmental reviews and authorizations. The plan may also include approaches and schedules for public and tribal outreach and coordination as well as stakeholder discussions regarding potential avoidance, minimization, and mitigation strategies (Federal Permitting Improvement Steering Council n.d.).
} 


\section{RC Byrd Project Outcomes: Non-Power Benefits (Protection, Mitigation, and Enhancement)}

This section highlights project outcomes that resulted in non-power benefits associated with the RC Byrd Project original licensing. For the purposes of this case study, non-power benefits are defined as the PME measures included as conditions to the FERC license order. These license conditions were the result of measures proposed by the applicant, FERC staff recommendations within NEPA analysis, the WVDEP and Ohio EPA CWA 401 Water Quality Certification processes, and USFWS's ESA Section 7 consultation process.

These license conditions include those associated with water quality, species and habitat protection, recreation, historic and cultural resources.

\section{Water Quality and Species Protection Measures}

The FERC license order for the RC Byrd Project contained the following PME measures applicable to water quality and aquatic species protection:

- Required development of an erosion and sedimentation control plan to protect water quality

- Required applicant to monitor dissolved oxygen and water temperature upstream and downstream of project

- Required development and implement of a wildlife protection plan

- Required applicant to implement mussel monitoring and conservation plan

- Required applicant to implement a myotid bat conservation plan (City of Wadsworth, Ohio 160 FERC \& 62,191 Order Issuing Original License [2017]).

\section{$\underline{\text { Recreational Measures }}$}

The FERC license order for the RC Byrd Project contained the following PME measures applicable to recreation:

- Required applicant to implement a site restoration and aesthetics plan; and

- Required applicant to implement recreational plan that includes construction, maintenance, and monitoring of new recreation facilities (fishing platform, walkways along shoreline, access road and parking area, potable water supply, restrooms, trash receptacles, picnic tables, play area) (City of Wadsworth, Ohio 160 FERC $\S 62,191$ Order Issuing Original License [2017]).

\section{Cultural and Historic Resources Measures}

The FERC license order for the RC Byrd Project required the applicant to implement a HPMP via a PA with West Virginia and Ohio SHPOs. The PA requires the applicant to consult with the West Virginia and Ohio SHPOs prior to making any additions or alterations to properties listed or eligible for listing on the National Register of Historic Places (Loup River Public Power District, 159 FERC 962,198$)$. 


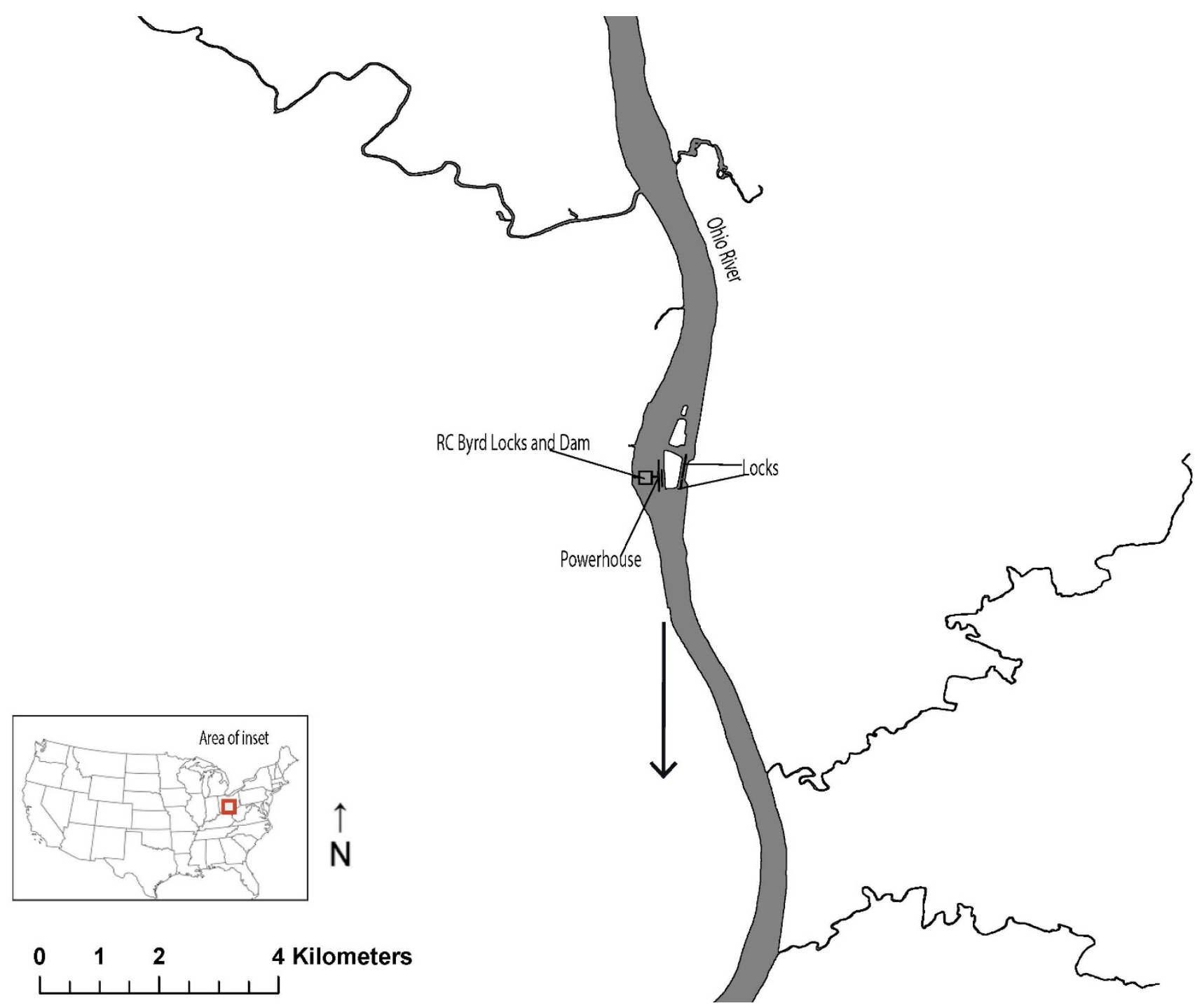

Figure C16. Map indicating major landmarks and features mentioned in project license. Arrow indicates direction of flow. 


\section{Spring Gap- Stanislaus Project-P-2130 (Relicensing) Case Study}

\section{Table C9. Description of Project Key Characteristics and Timeline Lengths}

\begin{tabular}{|c|c|c|c|c|c|c|c|c|c|c|c|c|c|c|c|}
\hline 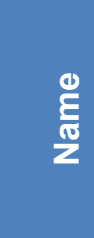 & $\begin{array}{l}\text { to } \\
\frac{0}{\delta} \\
\frac{0}{0} \\
\text { 을 } \\
0\end{array}$ & 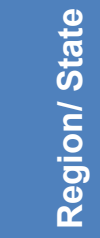 & 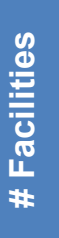 & $\begin{array}{l}\frac{9}{N} \\
\frac{D}{0} \\
\frac{d}{d} \\
\frac{d}{0}\end{array}$ & 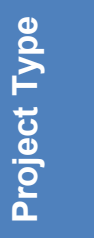 & 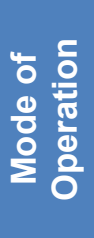 & 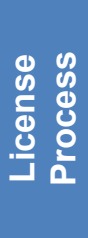 & 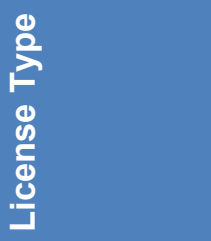 & $\frac{5}{\frac{1}{2}}$ & $\begin{array}{l}J \\
\end{array}$ & $\begin{array}{l}\overline{1} \\
\frac{1}{2}\end{array}$ & 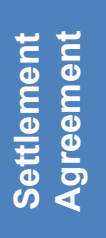 & $\frac{⿱ 亠}{\frac{1}{u}}$ & 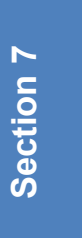 & ร \\
\hline $\begin{array}{c}\text { Spri } \\
\text { ng } \\
\text { Gap } \\
- \\
\text { Stan } \\
\text { isla } \\
\text { us }\end{array}$ & $\begin{array}{c}P_{-} \\
2130\end{array}$ & $\begin{array}{l}\text { Wes } \\
\text { t/ CA }\end{array}$ & 2 & $\begin{array}{c}87.9 \\
\mathrm{MW} \\
0.5 \\
\%\end{array}$ & $\begin{array}{c}\text { Con } \\
\text { v }\end{array}$ & $\begin{array}{l}\text { Pea } \\
\text { king }\end{array}$ & TLP & Relic & $\begin{array}{l}3.4 \mathrm{yr} \\
48.5 \%\end{array}$ & $\begin{array}{c}6.3 \\
y r \\
38.2 \\
\%\end{array}$ & $\begin{array}{c}9.7 \\
\mathrm{yr} \\
5.6 \\
\%\end{array}$ & Yes & $\begin{array}{c}1.2 \\
\mathrm{yr} \\
23.0 \\
\%\end{array}$ & NA & $\begin{array}{l}5.8 \\
y r \\
37.9 \\
\%\end{array}$ \\
\hline
\end{tabular}

Notes: NOI-LA: Notice of intent to license application timeline. LA-LI: License application to license issuance timeline. NOI-LI: Notice of intent to license issuance timeline. NEPA: National Environmental Policy Act timeline. Section 7: Endangered Species Act Section 7 Consultation timeline. 401 : State Clean Water Act Section 401 Certification timeline. Percent values on the bottom row of some cells represent the percentile the timeline for this project represents in the overall sample of 107 projects used in Chapter 3: Statistical Description and Analysis of Hydropower Licensing Timelines.

\footnotetext{
Stanislaus $\mathrm{P}-\mathbf{2 1 3 0}$
}

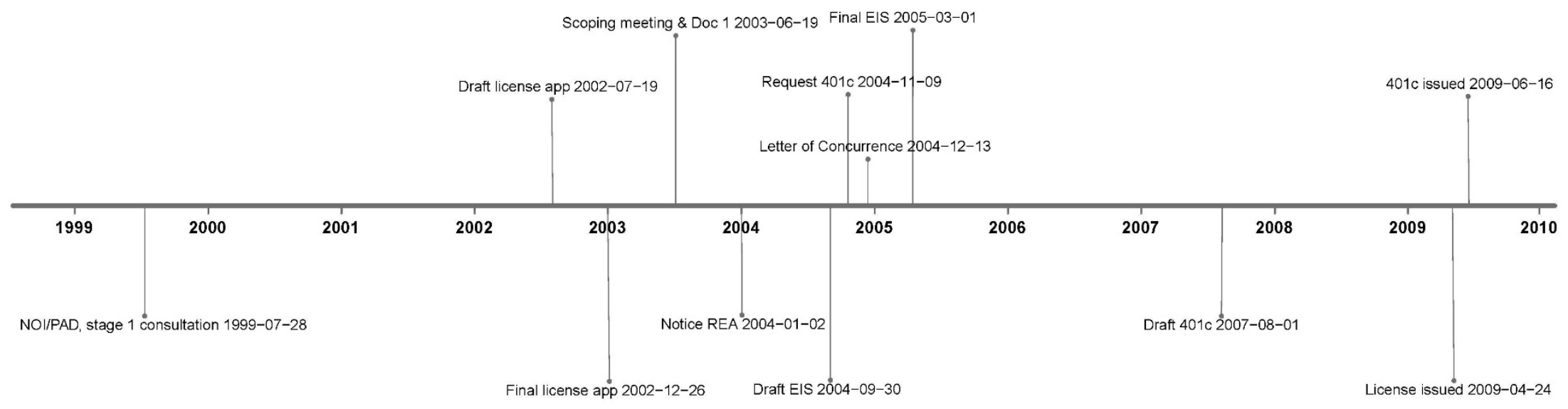

Figure C17. Timeline of some major licensing milestones 


\section{Spring Gap-Stanislaus Project Overview}

The Spring Gap-Stanislaus Project is owned by Pacific Gas \& Electric (PG\&E) and is located in Calaveras and Tuolumne counties, California, on the Middle and South Forks of the Stanislaus River. The project occupies approximately 1,060 acres within the Stanislaus National Forest, managed by USFS. The Spring Gap-Stanislaus Project consists of four developments: the nonpowered Relief and Strawberry Developments that serve as water storage for powered developments in the project, and the powered Spring Gap and Stanislaus developments. The project has a total installed capacity of 87.9 MW.

The Relief Development is located on the Middle Fork Stanislaus River and is the upstream most development in the project. This development includes the non-powered Relief Dam-a 144.5foot-high, 560-foot-long cam with a 63-foot-long spillway controlled by 15-foot flashboards, which forms the 223-acre Relief Reservoir. All land at this development is within the Stanislaus National Forest.

Water released from Relief Reservoir flows downstream into the South San Joaquin and Oakdale Irrigation District's (Irrigation Districts) Beardsley/Donnells Project with some being diverted through Tri-Dam Power's Sand Bar power tunnel and powerhouse. Water not diverted through the Tri-Dam Power facility that remains in the bypassed reach of the Middle Fork Stanislaus River converges with the diverted water from the South Fork Stanislaus River through the Spring Gap Development. Two miles downstream, water from the Sand Bar Project discharges back into the Middle Fork Stanislaus River just upstream of the Spring Gap-Stanislaus Project's Sand Bar Diversion Dam. This diversion dam diverts water from the Middle Fork Stanislaus River into the 11.4-mile-long Stanislaus Power Tunnel (that bypasses approximately 14 miles of the Middle Fork Stanislaus River) carrying water into the Stanislaus Development's forebay and powerhouse. Water from the diversion discharges back into the Middle Fork Stanislaus River two miles downstream of its confluence with the North Fork Stanislaus River. Water then flows over the breached Stanislaus Afterbay Dam - the final piece of the Spring Gap-Stanislaus Project on the Middle Fork Stanislaus River-into New Melones reservoir.

The Strawberry Development is located on the upper reaches of the South Fork Stanislaus River at the confluence of Herring Creek and the South Fork and consists of the non-powered Strawberry Dam, which is a 133-foot-high, 720-foot-long dam with a 108-foot-long spillway controlled by 6-foot-high flashboards, which forms 300 -acre Pinecrest Lake. The project license specifies that Pinecrest Lake be kept as full as possible during the summer recreation season and water releases from this development are made to meet project operational needs, including power generation, water supply, and minimum instream flow requirements. All land at this development is within the Stanislaus National Forest.

The Spring Gap Development is located on the South Fork Stanislaus River and includes Philadelphia Diversion Dam - an 11-foot-high, 56-foot-long overflow spillway dam that forms a 0.25-acre impoundment with 1 acre-foot of storage capacity and includes a fish screen, fish ladder, and associated facilities. This diversion dam diverts water into the forebay of Spring Gap Dam via the 4.7-mile-long Philadelphia Ditch. Water diverted into the Spring Gap forebay flows through the Spring Gap powerhouse before discharging into the Middle Fork Stanislaus River. The Spring Gap forebay has a storage capacity of less than 1 acre-foot and is impounded by a 
13.5-foot-high, 220-foot-long concrete header box with an 80-foot-long concrete overtop spillway. The 7,249 foot long Spring Gap penstock leads water into the Spring Gap powerhouse, which contains one generating unit with $6 \mathrm{MW}$ of installed capacity. Water from the South Fork Stanislaus River that is not diverted into the Spring Gap forebay flows downstream into Lyons Reservoir - a part of the Phoenix Project, which is also owned by PG\&E.

The Spring Gap-Stanislaus Project was originally licensed in 1955. For the relicensing process being analyzed in this case study, PG\&E (licensee) submitted the NOI and PAD in July 1999, proposing no major modifications to the existing infrastructure. The licensee requested, and received permission from FERC, to use TLP. On July 19, 2002, the licensee filed a draft license application with FERC. On December 26, 2002, the licensee submitted a final license application. In 2009, FERC issued a new 38-year hydropower license (relicense) for the continued operation and maintenance of the 87.9 MW Spring Gap-Stanislaus Project. Prior to completing relicensing, the Spring Gap-Stanislaus Project operated on an annual license from 2004 until receiving its new license in 2009 (PG\&E, 127 FERC \ 62,070 [2009]).

\section{Spring Gap-Stanislaus Project Participants and Comment Themes}

The Spring Gap-Stanislaus Project had 45 participants, 11 of which filed for intervenor status (i.e., an official party to the proceeding) with FERC. The bulk of comments filed in the FERC record were from American Whitewater Affiliation, California State Water Resources Control Board (SWRCB), Friends of the River, Central Sierra Environmental Resources Center, Trout Unlimited, County of Tuolumne, Tuolumne Public Power Agency, Tuolumne Utilities District, and USFS. Untimely motions to intervene were filed by Calaveras Public Power Agency and the County of Calaveras. Late interventions were granted in a notice issued July 18, 2005. None of the intervenors opposed the project. Comments were generally focused on four main themes of project impacts: 1) drinking water supply, 2) funding and protection for the Stanislaus National Forest, 3) mitigation for impaired waters, and 4) impacts of dredging on water quality (EPA 2005; PG\&E 2005; CCWD 2004; TU et al. 2004).

\section{Statutory and Regulatory Compliance}

The following subsections address both substantive and procedural aspects of the NEPA process administered by FERC, the CWA Section 401 Water Quality Certification process administered by the California SWRCB, the ESA Section 7 consultation process administered by USFWS, and the NHPA 106 consultation process administered by the California SHPO.

\section{National Environmental Policy Act}

FERC conducted scoping to determine what issues and alternatives should be addressed in the EIS. ${ }^{85}$ A scoping document (SD1) was initially distributed to interested project stakeholders on May 21, 2003. Following release of the SD1, FERC held two scoping meetings to solicit comments from project stakeholders on June 18 and 19, 2003, and provided an opportunity for written comment. FERC issued a revised scoping document (SD2), addressing the comments

\footnotetext{
85 The EIS contained an analysis of three projects located on the Stanislaus River in addition to the Spring GapStanislaus Project. The other projects analyzed in the final EIS include the Beardsley/Donnells Hydroelectric Project (P-2005), Tulloch Hydroelectric Project (P-2067), and Donnells-Curtis Transmission Line Project (P-2118). For the purposes of this case study, all key issues discussed in Section 3.1 relate only to the Spring Gap-Stanislaus Project.
} 
received on SD1, on December 30, 2003. On January 2, 2004, FERC issued notice that the Spring Gap-Stanislaus Project was REA. On September 30, 2004, FERC issued a draft EIS for the Spring Gap-Stanislaus Project, requiring comments to be filed on the draft EIS by December 7, 2004. On March 1, 2005, FERC issued the final EIS, addressing comments filed on the draft EIS (FERC 2005h).

The relicensing of the Spring Gap-Stanislaus Project raised a number of cultural/historic, environmental and natural resource, and recreational concerns requiring analysis primarily under the FPA, NEPA, CWA, ESA, and NHPA.

The Spring Gap-Stanislaus Project EIS provides an overview of the key issues of the Spring Gap-Stanislaus Project relicensing process. At a high level, the issues analyzed in the EIS included:

- Coordination of operations at the Spring-Gap Project with other hydroelectric projects located downstream

- Water quantity and quality within the Stanislaus River watershed, water temperature profiles, suspended sediment levels, and dissolved oxygen content in reservoirs contained within the project area

- Aquatic resources, including fish species that historically occurred within the Stanislaus River, reservoirs contained within the project area, and various stream segments located off of the Stanislaus River

- Terrestrial resources including vegetation cover and wildlife including amphibians, reptiles, birds, and mammals within the project area

- Threatened and endangered species including the valley elderberry longhorn beetle and bald eagle ${ }^{86}$

- Recreational resources located within the project area

- Archeological and historic sites listed or eligible for listing on the National Register of Historic Places (FERC 2005h).

\section{Clean Water Act Section 401}

On December 10, 2002, the SWRCB received a request to grant or waive a WQC ${ }^{87}$ for the continued operation of the Spring Gap-Stanislaus Project. The licensee withdrew and refiled its application each year between 2003 and 2007 for a total of five times. The licensee proposed continued operation of the Spring Gap-Stanislaus Project in accordance with historic operating procedures with one change, to remove the Stanislaus Afterbay Dam, which had been nonfunctional since 1997 (SWRCB 2008).

\footnotetext{
${ }^{86}$ In 2007, the USFWS removed the bald eagle from the list of threatened and endangered species.

${ }^{87}$ In California, a request to grant or waive a WQC also requires compliance with the California Environmental Quality Act (CEQA). CEQA is a state required environmental review, analysis, and disclosure process, which is similar to the federal NEPA process. CEQA requirements apply to " discretionary projects proposed to be carried out or approved by public agencies, including, but not limited to, the enactment and amendment of zoning ordinances, the issuance of zoning variances, the issuance of conditional use permits, and the approval of tentative subdivision maps unless the project is exempt from this division" (Cal. Pub. Res. Code $\S 21080(a)$ ).
} 
The primary water quality issues identified and studied that were associated with the continued operation of the Spring Gap-Stanislaus Project included water quantity and temperature levels within the Relief Reservoir, water quantity levels within the Pinecrest Lake, water quality impacts due to removal of the Stanislaus Afterbay Dam, coordination with other hydrologically connected projects, and aquatic resources preservation and enhancement measures (SWRCB 2008). The SWRCB subsequently determined that the Spring Gap-Stanislaus Project operation, as proposed in the final license application, would comply with Section 401 of the CWA (SWRCB 2008). On September 15, 2008, the SWRCB issued a WQC ${ }^{88}$ for the Spring GapStanislaus Project's continued operation containing the following 33 operating conditions:

- Condition 1 required the licensee to determine water-year type and maintain a 5-year record of its water-year type determinations to provide to the SWRCB annually

- Condition 2 required the licensee to develop a "best fit" drawdown curve for Relief Reservoir based on yearly hydrological conditions to meet minimum and maximum streamflow requirements for the water-year type

- Conditions 3 and 4 required the licensee to maintain minimum streamflows made up of minimum daily flows and minimum supplemental flows according to a specified schedule and established a minimum target level of 5,608 feet for Pinecrest Lake

- Condition 5 allowed the licensee to propose modifications to the minimum streamflow requirements in "critically dry" water years

- Condition 6 required that minimum streamflow requirements were subject to temporary modifications if required by equipment malfunction or system emergencies

- Condition 7 required that the licensee conduct facility modification necessary to implement streamflow requirements as soon as reasonably practicable

- Condition 8 required the licensee to prepare detailed plans for construction, operation, and testing of a fish screen at the entrance to Stanislaus Power Tunnel

- Condition 9 required the licensee to annually make recreation streamflow information available to the public

- Condition 10 required the licensee to provide a recreation streamflow event according to a specified schedule

- Condition 11 required the licensee to obtain all necessary permits prior to beginning construction of the Stanislaus Power Tunnel Fish Screen or removal of the Stanislaus Afterbay Dam

- Condition 12 required the licensee to collect sediment samples for selected trace metal analysis from sediment deposited after the removal of the Stanislaus Afterbay Dam

- Condition 13 required the licensee to prepare plans to minimize soil erosion and loss of topsoil prior to beginning construction of the Stanislaus Power Tunnel Fish Screen or removal of the Stanislaus Afterbay Dam

\footnotetext{
${ }^{88}$ On May 21, 2009, the licensee filed an Application for Rehearing, Request for Clarification of New License, and Request for Stay in which they requested that FERC stay several provisions of the WQC that were included in the license orders issued on April 24, 2008. The SWCRB issued an order with a modified WQC on June 16, 2009 (SWRCB 2009).
} 
- Condition 14 required monitoring and proper disposal and transport of any hazardous materials used during the construction of the Stanislaus Power Tunnel Fish Screen or removal of the Stanislaus Afterbay Dam

- Condition 15 required the licensee to submit a spill channel management plan to the SWRCB to minimize use of spill channels and reduce spill magnitude and duration

- Condition 16 required the licensee to coordinate project operations with other hydrologically connected hydropower projects located downstream

- Condition 17 noted that the WQC did not convey any consumptive water rights to the licensee

- Condition 18 required that the licensee limit increase or decrease of regulated minimum streamflows and daily flows to result in a stage change of six inches or less per hour

- Conditions 19 and 20 required the licensee continue to maintain and operate the Philadelphia Diversion fish screen and fish ladder

- Condition 21 required the licensee to pay the cost for fish stocking in Pinecrest Lake

- Conditions 22-25 $5^{89}$ noted that the WQC was contingent on compliance with all applicable requirements for the Sacramento and San Joaquin River Basins, all water quality standards and implementation plans approved pursuant to Section 303 of the CWA, and payment of all fees to the SWRCB

- Condition 26 required the licensee to comply with the ESA

- Condition 27 related to the process for sanctions and penalties for any violation of the conditions of the WQC

- Condition 28 required the licensee to submit any proposed change to the project to the SWRCB for review and written approval

- Conditions 29-33 related to authority of the SWRCB to add or modify conditions of the WQC (SWRCB 2008).

\section{Endangered Species Act Section 7 Consultation}

In June 2003, the licensee and other interested stakeholders conducted scoping meetings to identify environmental issues, concerns, and project alternatives. During the NEPA review process, FERC evaluated the potential effects of relicensing on two federally listed threatened species - the valley elderberry longhorn beetle and the bald eagle. On September 30, 2004, FERC submitted a draft EIS, which served as FERC's BA for the purposes of ESA Consultation. In the draft EIS, FERC determined that relicensing would have no effect on either species because no suitable habitat was present. FERC sought concurrence from USFWS by a letter dated October 5, 2004. On December 13, 2004, USFWS concurred with FERC's findings. The project did not require further ESA Section 7 consultation (FERC 2005h).

\section{National Historic Preservation Act Section 106}

To comply with Section 106 of the NHPA (16 U.S.C. $\S 306108$ ), FERC executed a PA with the California SHPO on September 25, 2005. FERC invited the licensee, California SHPO, BLM, USFS, the Irrigation Districts (as Tri-Dam Project), BIA, Chicken Ranch Tribal Council,

\footnotetext{
${ }^{89}$ Condition 25 specified that the WQC did not apply to the issuance of any FERC license or amendment other than the FERC license specifically identified in the licensee's application for WQC. This language is a standard condition required in all WQCs issued in California.
} 
Washoe Tribe of Nevada and California, Calaveras Band of MiWuk Indians, American Indian Council of Mariposa County, and the Tuolumne Me-Wuk Tribe to concur with the stipulations in the PA. The licensee was the only party to concur with the PA as no other party responded to FERC's request for concurrence. The PA required the licensee to implement an HPMP for the 38-year license term. The licensee's responsibilities under the PA, including the HPMP, were included in License Article 407 (PG\&E, 127 FERC 9 62,070 [2009]).

\section{Settlement Agreements}

In 1999, a group of stakeholders, known as the Stanislaus Planning Action Team (SPLAT) formed and met on more than 40 occasions during the next 5 years in plenary or subgroup meetings to determine mutually acceptable environmental measures for relicensing of the project. SPLAT participants included representatives of the following groups: the licensee, the California Department of Fish and Game, Central Sierra Environmental Resources Center, USFS, Friends of the River, the SWRCB, the Tuolumne Utilities District, Tri-Dam Project, Trout Unlimited, USFWS, NPS, and American Whitewater. The primary discussions related to the project were focused on a collaborative review of information contained in the NOI/PAD, study plan development and review, water and power model runs, stream temperature models, fish and amphibian survey data, and a habitat time series analysis to examine different flow regimes. In late 2003 and early 2004, SPLAT participants reached a consensus on recommended resource measures for the Spring Gap-Stanislaus project and requested that FERC consider including the SPLAT recommendations in the EIS (FERC 2005h; PG\&E, 127 FERC 92,070 [2009]). The measures included in the SPLAT settlement agreement addressed the following issues:

- Water-year types

- Maximum and minimum flows

- Ramping rates

- Implementation of fish screens and ladders

- Fish stocking and monitoring

- Special status species

- Vegetation rejuvenation

- Ground disturbing activities

- Noxious weed management

- Monitoring of potentially occurring listed threatened and endangered species

- Recreation streamflow information and implementation plans

- HPMP (PG\&E, 127 FERC \ 62,070 [2009]).

On March 1, 2004, the licensee filed an agreement with FERC entitled: SPLAT-Recommended Resource Measures for the Spring Gap-Stanislaus Project (SPLAT Agreement). Signatory parties to the SPLAT Agreement included the licensee, USFS, the Tuolumne Utilities District, NPS, TriDam, Central Sierra Environmental Resources Center, Friends of the River, American Whitewater, and Trout Unlimited. In the final EIS, FERC determined that the SPLAT Agreement represented the proposed measures of the licensee and signatories. The SPLAT Agreement's recommended measures were analyzed within the final EIS and incorporated within the final licensing order issued by FERC (PG\&E, 127 FERC 9 62,070 [2009]). 
In addition, between 2003 and 2004, the licensee and the USFS met numerous times and agreed to terms on an off-license settlement agreement to address recreation facilities consisting of access trails, campgrounds, and infrastructure improvement located within the Stanislaus National Forest, outside of the project boundary (FERC 2005h). In 2006, the parties entered into the off-license settlement agreement to fund trail work at the Relief Reservoir and rehabilitate and improve three existing campgrounds within the USFS (USFS 2015).

\section{Spring Gap-Stanislaus Project Outcomes: Non-Power Benefits (Protection, Mitigation, and Enhancement)}

This section highlights project outcomes that resulted in non-power benefits associated with the Spring Gap-Stanislaus Project relicensing. For the purposes of this case study, non-power benefits are defined as PME measures included as conditions to the FERC license order. These license conditions were the result of measures proposed by the licensee, FERC staff

recommendations within NEPA analysis, the SPLAT Agreement, and the California SWRCB's CWA 401 Water Quality Certification process. These license conditions include those associated with water quality, species and habitat protection, recreation, and historic/cultural resources.

\section{Water Quality and Species Protection Measures}

The FERC license order for the Spring Gap-Stanislaus Project contained the following PME measures applicable to water quality and species protection:

- Required the licensee to develop annual drawdown curves for Relief Reservoir and Pinecrest Lake and provide minimum instream flows for reaches that are dependent on the time frame and water-year type to enhance aquatic habitat

- Required the licensee to implement a ramping rate in the Relief, Sand Bar, Pinecrest, and Philadelphia reaches of no more than 6 inches per hour for increases and decreases in regulated minimum instream flows and daily flows to avoid stranding or displacement of aquatic species during licensee-controlled changes in regulated streamflow

- Required the licensee to develop and implement a Spill Channel Management Plan approved by USFS for the Spring Gap spill channel and the Stanislaus Forebay spill channel to minimize environmental impacts to USFS land over which spills occur

- Required the licensee to develop and implement a plan to minimize soil erosion and loss of topsoil associated with construction of the Stanislaus Power Tunnel Fish Screen or removal of the Stanislaus Afterbay Dam

- Required the licensee to construct a fish screen at Stanislaus power tunnel, continue to maintain the fish screen and ladder at the Philadelphia diversion dam to prevent fish from entering the power funnel, and contribute to the wild trout fishery in the Stanislaus River Spring Gap

- Required the licensee to develop and implement land resource plans for monitoring environmental resources to ensure water quality and aquatic and terrestrial resources (PG\&E, 127 FERC \ 62,070 [2009]). 


\section{$\underline{\text { Recreation Measures }}$}

The FERC license order for the Spring Gap-Stanislaus Project contained the following PME measures applicable to recreation:

- Required the licensee to provide minimum supplemental flow releases and occasional 2day recreational boating streamflow events

- Required the licensee to annually make recreational streamflow data available to the public

- Required the licensee maintain a target surface water level of 5,608 feet at Pinecrest Lake to sufficiently support recreation activities

- Required the licensee to fund fish stocking to sufficiently support recreation activities

- Required the licensee to rehabilitate and improve recreational facilities associated with the day-use area at Pinecrest Lake including specific improvements to the boat ramp, beaches, picnic area, parking areas, fishing pier, and trail system to enhance public access to project lands and water (PG\&E, 127 FERC 162,070 [2009]).

\section{$\underline{\text { Cultural/Historic Resources Measures }}$}

The FERC license order for the Spring Gap-Stanislaus Project required the licensee to implement an HPMP via a PA with the California SHPO. The PA requires the licensee to consult with the California SHPO prior to making any additions or alterations to properties listed or eligible for listing on the National Register of Historic Places (PG\&E, 127 FERC 962,070 [2009]). 


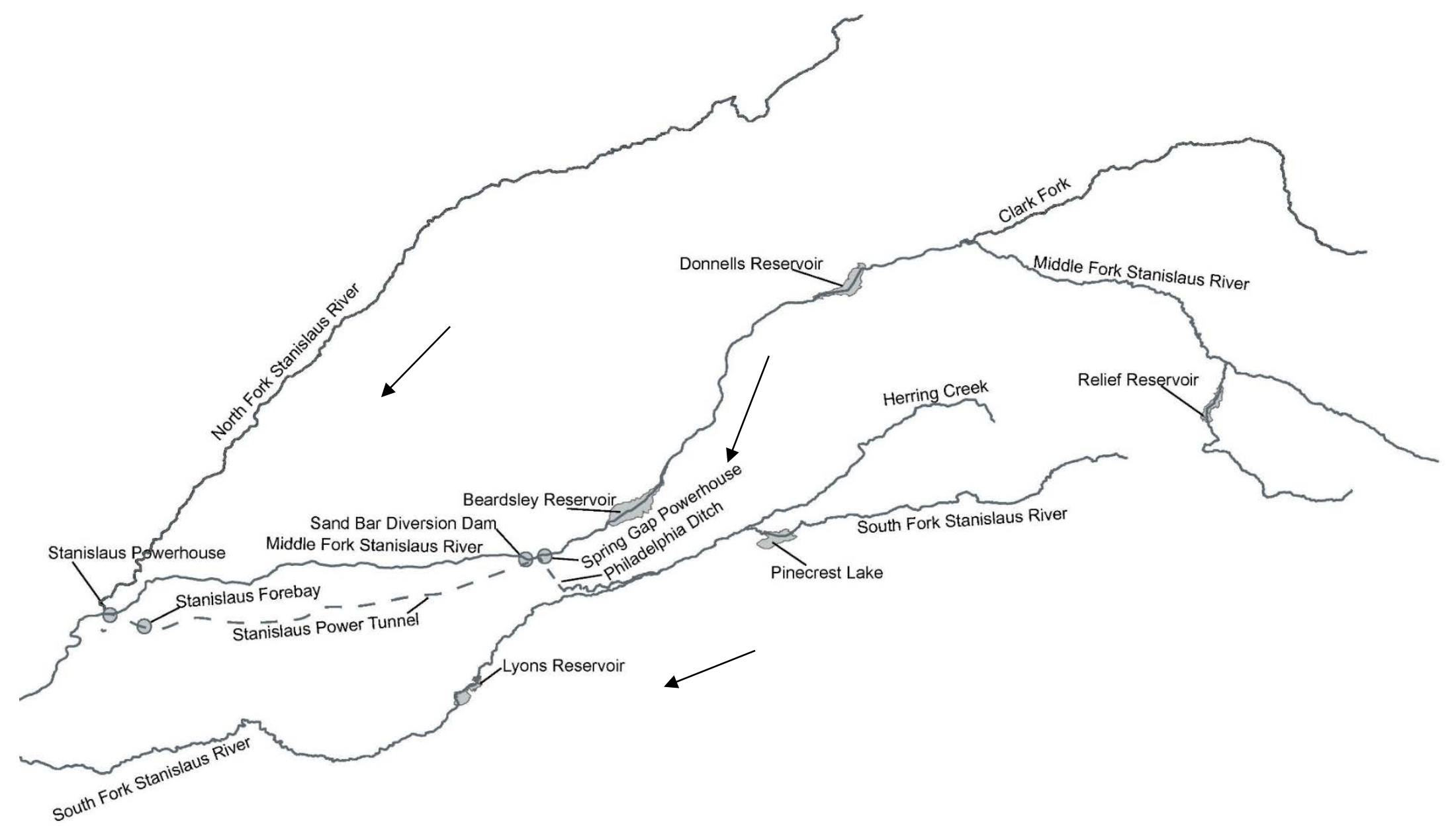

Figure C18. Map indicating major landmarks and features mentioned in project license. Arrow indicates direction of flow. 


\section{Waterbury Hydroelectric Project - P-2090 (Relicensing) Case Study}

Table C10. Description of Project Key Characteristics and Timeline Lengths

\begin{tabular}{|c|c|c|c|c|c|c|c|c|c|c|c|c|c|c|c|}
\hline 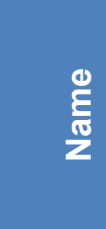 & 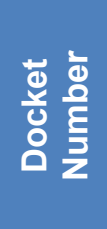 & 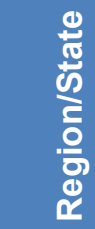 & 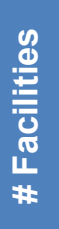 & $\begin{array}{l}\frac{9}{N} \\
\frac{N}{0} \\
\frac{d}{0} \\
\frac{0}{2}\end{array}$ & 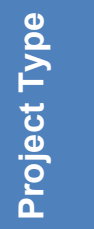 & 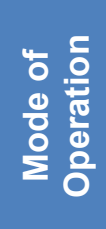 & 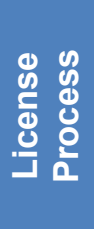 & & & $\frac{5}{5}$ & $\begin{array}{l}\overline{1} \\
\frac{1}{2}\end{array}$ & 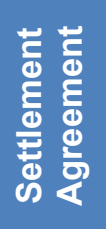 & $\frac{\nwarrow}{\frac{\pi}{2}}$ & 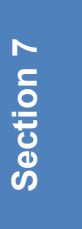 & ㅇ \\
\hline $\begin{array}{c}\text { Wat } \\
\text { erbu } \\
\text { ry }\end{array}$ & $\begin{array}{c}\text { P- } \\
2090\end{array}$ & $\begin{array}{c}\text { New } \\
\text { Eng/ } \\
\text { VT }\end{array}$ & 2 & $\begin{array}{c}5.5 \\
\mathrm{MW} \\
0.5 \%\end{array}$ & $\begin{array}{c}\text { Con } \\
\text { v }\end{array}$ & $\begin{array}{c}\text { Peak } \\
\text { ing }\end{array}$ & TLP & Relic & $\begin{array}{c}3.0 \mathrm{yr} \\
43 \%\end{array}$ & $\begin{array}{c}16.5 \\
\mathrm{yr} \\
100 \\
\%\end{array}$ & $\begin{array}{c}19.5 \\
y r \\
100 \\
\%\end{array}$ & No & $\begin{array}{c}2.9 \\
\mathrm{yr} \\
55 \%\end{array}$ & NA & $\begin{array}{c}15.3 \\
100 \\
\%\end{array}$ \\
\hline
\end{tabular}

Notes: NOI-LA: Notice of intent to license application timeline. LA-LI: License application to license issuance timeline. NOI-LI: Notice of intent to license issuance timeline. NEPA: National Environmental Policy Act timeline. Section 7: Endangered Species Act Section 7 Consultation timeline. 401 : State Clean Water Act Section 401 Certification timeline. Percent values on the bottom row of some cells represent the percentile the timeline for this project represents in the overall sample of 107 projects used in Chapter 3: Statistical Description and Analysis of Hydropower Licensing Timelines.

Waterbury P-2090

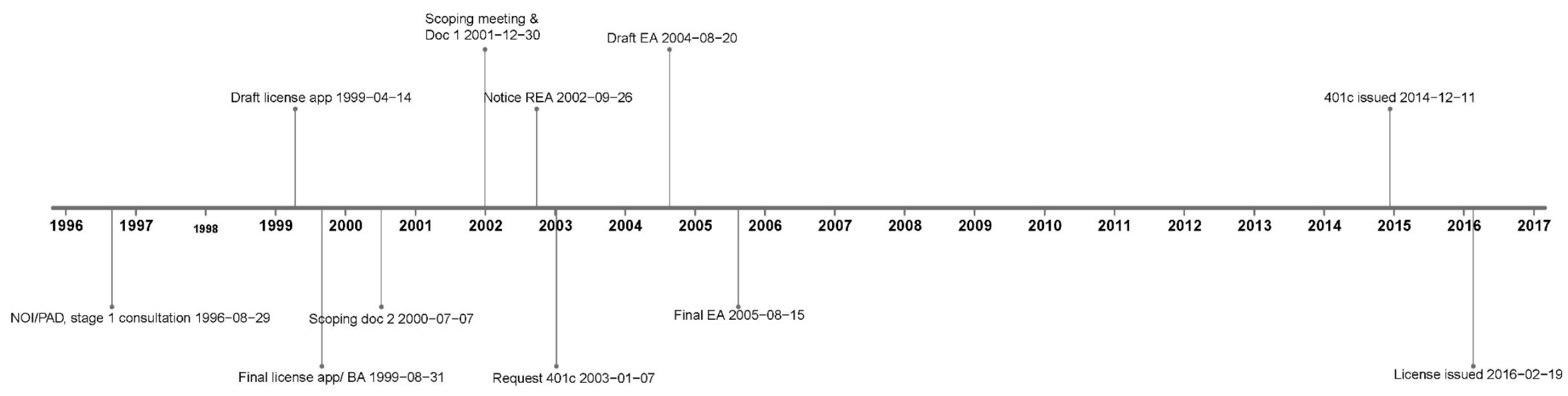

Figure C19. Timeline of some major licensing milestones 


\section{Waterbury Project Overview}

The Waterbury Project is located at Waterbury Dam on the Little River in the town of Waterbury, in Washington County, Vermont. The project does not occupy any federally managed lands. Waterbury Dam was constructed to reduce flooding in the Winooski Valley and consists of a rolled earth embankment and spillway. The spillway includes an ungated concrete ogee weir. Hydropower generation at the project is conducted at the $5.52 \mathrm{MW}$ rated capacity Waterbury Powerhouse. The project also contains a single reservoir, Waterbury Reservoir. From the project area, the Little River flows in a southerly direction for about 2.5 miles before joining the Winooski River. From its confluence with the Little River, the Winooski River flows about 90 miles in a northwesterly direction to Lake Champlain which is located on the border between New York and Vermont. There are no recreation facilities in the project boundary (FERC 2016a). Although Green Mountain Power Corporation (GMPC) (licensee) operates Waterbury Dam for flood control and power generation, federal oversight of Waterbury Dam is continuing and significant. The United States, through USACE, dictates dam operations for flood control purposes. In addition, USACE inspects the dam twice a year (once jointly with the state) and, pursuant to those inspections, issues operational recommendations, including a dam and reservoir regulation manual for Waterbury Dam, and has twice directed and funded extensive remedial construction at the dam. Consequently, Green Mountain does not have to pay annual charges for its use.

The Waterbury Project was originally licensed in 1954 for a 50 -year term effective in 1951. For the relicensing process being analyzed in this case study, GMPC submitted the NOI and PAD in August 1996, proposing no major modifications to the existing infrastructure and using the TLP. In February 2016, FERC issued a new 40-year hydropower license (relicense) for the continued operation and maintenance of the 5.52 MW Waterbury Hydroelectric Project (Waterbury Project). Prior to completing relicensing, the Waterbury Project subsequently operated on an annual license from 2001 until receiving its new license in 2016 (FERC 2016a).

\section{Waterbury Project Participants and Comment Themes}

The Waterbury Project had 19 participants, 8 of which filed for intervenor status (i.e., an official party to the proceeding with FERC). The bulk of comments filed in the FERC record were from American Whitewater; Champlain Valley Canoe and Kayak Series; Trout Unlimited and Central Vermont Chapter of Trout Unlimited (filing jointly); Umiak, LTD and Friends of Little River (filing jointly); VNRC; Vermont Paddlers Club; VANR; American Whitewater and New England Flow (filing jointly); USFWS; and GMPC. DOI filed a late motion to intervene, which was granted. Comments were generally focused on three main themes of project impacts: 1) elimination of the winter drawdown and the recreational, water quality, and flood control impacts of the elimination; 2) direct impacts of project operations on fisheries via flow management; and 3) impacts of project operations on recreation (GMPC 2003; DOI 2002; VANR 2002; American Whitewater Affiliation and New England Flow 2002).

\section{Statutory and Regulatory Compliance}

The following subsections address both substantive and procedural aspects of the NEPA process administered by FERC, the CWA Section 401 Water Quality Certification process administered 
by the Vermont DEC, ESA Section 7 consultation administered by USFWS, and NHPA 106 consultation process administered by the Vermont SHPO.

\section{National Environmental Policy Act}

FERC conducted scoping to determine what issues and alternatives should be addressed in the EA (FERC 2005i). A scoping document (SD1) was initially distributed to interested project stakeholders on December 22, 1999 (FERC 2005i). Following release of the SD1, FERC held two scoping meetings to solicit comments from project stakeholders in January 2000, and provided opportunity for written comment (FERC 2005i). On July 7, 2000, FERC issued a revised scoping document (SD2), addressing the comments received on SD1 (FERC 2005i). On September 26, 2002, after accepting the licensee's final license application, FERC issued notice that the Waterbury Project was REA (FERC 2005i). On August 20, 2004, FERC issued a draft EA for the Waterbury Project (FERC 2005i). On August 15, 2005, FERC issued the final EA, addressing comments filed on the draft EA, along with a FONSI (FERC 2005i).

The relicensing of the Waterbury Project raised a number of cultural/historic, environmental and natural resource, and recreational concerns requiring analysis primarily under FPA, NEPA, CWA, ESA, and NHPA (FERC 2005i).

The Waterbury Project EA provides an overview of the key issues of the Waterbury Project relicensing process. At a high level, the main issues analyzed in the EA included the effects of project operation on:

- Geological resources, including erosion upstream of the project into the Waterbury Reservoir

- Water quality and quantity in the Little River, upstream and downstream of the project, and in the Winooski River, downstream of the project

- Aquatic and terrestrial resources, including the surrounding wetlands and wildlife habitat

- Impacts to wildlife, including invertebrates, herptiles, and waterfowl

- Impacts of invasive species in terrestrial habitat in the vicinity of the project boundary, including Japanese knotweed and reed canary-grass

- Fishery resources, including migratory salmonids and cold-water fish

- Cultural resources, including impacts to potentially present archeological and historical sites listed or eligible for listing on the National Register of Historic Places

- Recreational resources, including impacts to multiple recreational facilities within the project boundary as well as flow releases for whitewater boating (FERC 2005i).

\section{Clean Water Act Section 401}

On August 31, 1999, the licensee submitted a request to the Vermont DEC to grant or waive a WQC for the continued operation of the Waterbury Project (FERC 2016a). The licensee proposed certain modifications, including replacing a recently installed turbine runner and repairing the tainter gates, that would affect reservoir water levels and outflows under the new license term (VANR 2014). Each year from June 29, 2000, through December 11, 2013, GMPC withdrew and refiled its WQC application (FERC 2016a). On December 12, 2014, the Vermont DEC received the most recent request to grant or waive WQC for the continued operation of the Waterbury Project (FERC 2016a). 
The primary water quality issues identified and studied that are associated with the continued operation of the Waterbury Project, included low dissolved oxygen levels in the Little River downstream of the dam, regulation of flows and ramping rates to improve reservoir and downstream water quality, and fish passage measures (VANR 2014). The Vermont DEC subsequently determined that the Waterbury Project operation, as proposed in the final license application, would comply with Section 401 of the CWA (VANR 2014). On December 11, 2014, the Vermont DEC issued a WQC for the Waterbury Project's continued operation containing the following operating conditions:

- Condition A required the licensee to operate and maintain the Waterbury Project consistent with the findings and conditions of the WQC

- Conditions $\mathrm{B}$ and $\mathrm{C}$ required the licensee to operate the project in run-of-river mode in three progressive stages of reservoir elevation and project discharge limits to account for the time it would take to make the project modifications described in the WQC

- Condition D required the licensee to maintain a bypass flow of $125 \mathrm{cfs}$ (up to $250 \mathrm{cfs}$ if the Vermont DEC determines it is feasible)

- Condition E required the licensee to develop a reservoir flow and management plan to ensure compliance with the flow requirements, including installing an upstream gauge on the Little River (if necessary to enable an accurate estimation of instantaneous flows)

- Conditions F and $\mathrm{G}$ required the licensee to develop plans to meet and monitor dissolved oxygen standards and temperature directly downstream of the project

- Condition $\mathrm{H}$ required the licensee to provide upstream or downstream fish passage facilities or to participate in a trap-and-transport facility that moves migratory fish upstream of the project

- Condition I required the licensee to provide a turbine rating curve depicting flow/production relationship for the record within a year of the federal license issuance

- Condition J required the licensee to seek Vermont DEC approval for project maintenance or repair work that may have a material adverse effect on water quality or cause lessthan-full support of an existing use or beneficial value or use of state waters

- Condition K required the licensee to draft and implement a Recreation Plan (VANR 2014; FERC 2016a).

\section{Endangered Species Act Section 7 Consultation Overview}

During the ESA Section 7 consultation process, USFWS initially determined in August 2000 that no federally listed threatened or endangered species or critical habitat were known to occur within the project area (FERC 2016a). Before the final EA was issued, the USFWS listed the northern long-eared bat as a threatened species (FERC 2016a). However, because the northern long-eared bat was not known to inhabit the project area, no further action pursuant to the ESA was required (FERC 2016a; VANR 2014).

\section{National Historic Preservation Act Section 106}

To comply with Section 106 of the NHPA (16 U.S.C. § 306108), FERC executed a PA with the Vermont SHPO on October 19, 2004 (FERC 2016a). FERC invited the licensee to concur with the stipulations of the PA (FERC 2016a). The licensee concurred to the PA, which required it to implement an HPMP for the 40-year license term (FERC 2016a). The licensee's responsibilities 
under the PA, including the HPMP, were included under article 405 of the FERC license order (FERC 2016a).

\section{Settlement Agreement}

Stakeholders in the Waterbury project relicense did not formalize terms on a settlement agreement. The licensee, in cooperation with American Whitewater and New England Flow, conducted a boating flow study on October 20, 2000. These parties entered settlement discussions during April 2002 in an attempt to resolve issues related to boating needs and balancing those needs with other values. The licensee, American Whitewater, and New England Flow reached an agreement in 2003 that was "not formalized pending FERC staff analysis following the project Environmental Assessment." The proposed agreement would have included 15 scheduled weekend boating flows each year (American Whitewater, New England Flow, and Vermont Paddling Club 2004).

\section{Waterbury Project Outcomes: Non-Power Benefits (Protection, Mitigation, and Enhancement)}

This section highlights project outcomes that resulted in non-power benefits associated with the Waterbury Project relicensing. For the purposes of this case study, non-power benefits are defined as PME measures included as conditions to the FERC license order. These license conditions were the result of measures proposed by the licensee, FERC staff recommendations within NEPA analysis, the Vermont DEC's CWA 401 Water Quality Certification process, and the Vermont SHPO. These license conditions include those associated with water quality, species and habitat protection, recreation, and historic/cultural resources.

\section{Water Quality and Species Protection Measures}

The FERC license order for the Waterbury Project contained the following PME measures applicable to water quality and aquatic species protection:

- Required the development of a dissolved oxygen monitoring plan

- Required the project to maintain minimum flows through the powerhouse and/or the new automated bypass penstock

- Required the development of a soil erosion and sedimentation control plan

- Required the development of an aeration effectiveness monitoring plan

- Required the project to operate in run-of-river mode

- Required the establishment of minimum bypass and reservoir flows

- Required the development of a reservoir flow and management plan, and required the installation of upstream gauges if necessary

- Required upstream and downstream fish passage facilities or participation in a trap-andtransport facility that moves migratory fish upstream of the project

- Required Vermont DEC approval for project maintenance or repair work that may have a material adverse effect on water quality or cause less-than-full support of an existing use or beneficial value or use of state waters (FERC 2016a). 


\section{$\underline{\text { Recreation Measures }}$}

The FERC license order for the Waterbury Project contained the following PME measures applicable to recreation:

- Required the construction, maintenance, operation, and/or modification of recreational facilities, such as access roads, wharves, launching ramps, beaches, picnic and camping areas, sanitary facilities, and utilities

- Required free public access to project waters and adjacent project lands for the purpose of navigation and outdoor recreational purposes, including fishing and hunting

- Required the development of a recreation plan that contained the following requirements, at minimum:

- Establishment of a phone system and website that provided information on flows in the Little River downstream of the project

- Signage for warning boaters of instream hazards and take-out areas in the Little River downstream of the project

O One-time improvements to multiple recreation sites within the project area that were owned and maintained by the town or state (FERC 2016a).

\section{$\underline{\text { Cultural/Historic Resources Measures }}$}

The FERC license order for the Waterbury Project contained the following PME measures applicable to cultural resources:

- Required implementation an HPMP via a PA with the Vermont SHPO

- Required consultation with Vermont SHPO prior to making any additions or alterations to properties listed or eligible for listing on the National Register of Historic Homes (FERC 2016a). 


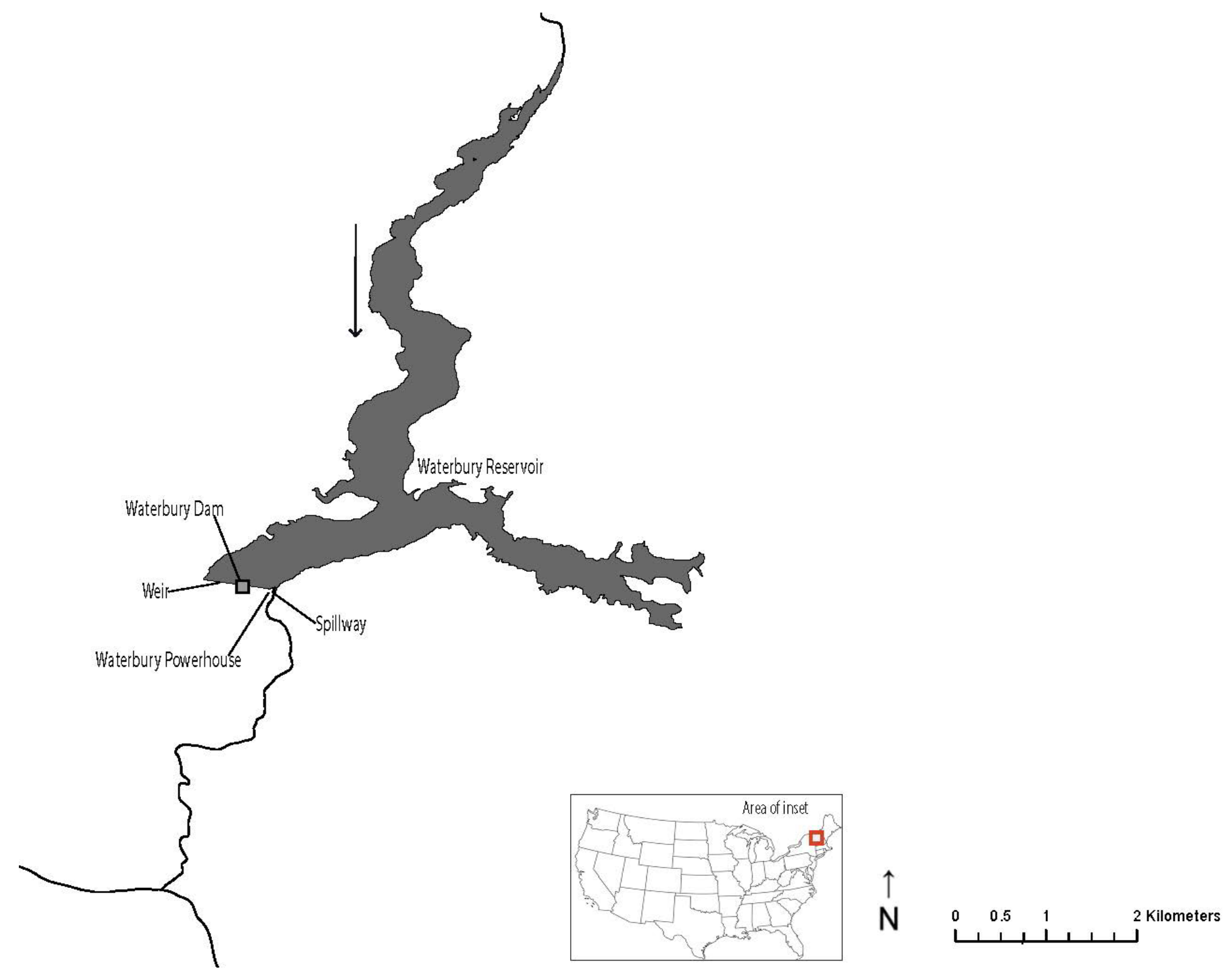

Figure C20. Map indicating major landmarks and features mentioned in project license. Arrow indicates direction of flow. 


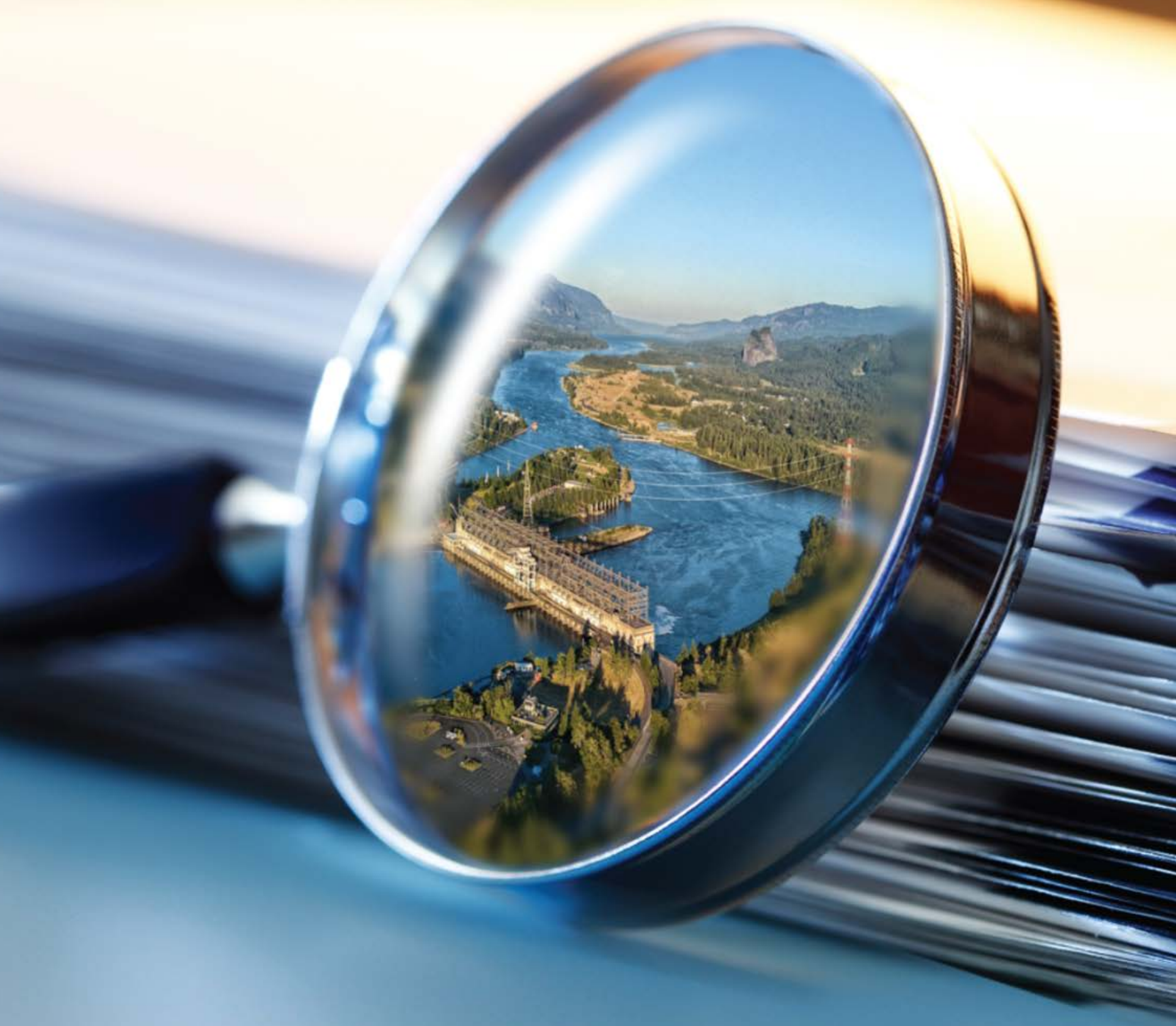

AN EXAMINATION OF THE HYDROPOWER LICENSING AND FEDERAL AUTHORIZATION PROCESS

APPENDIX

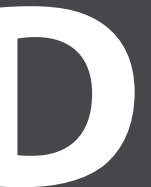

Detailed Mitigation Measure Information From Environmental Measures Chapter 


\section{Appendix D. Detailed Mitigation Measure Information From Environmental Measures Chapter}

Table D1. Tallies of Tier-1 (Gray Highlight and Bold), Tier-2 (Blue Highlight and Italics), and Tier-3 (Bold) Protection, Mitigation, and Enhancement Measures from FERC Licenses From the Database Described by Schramm, Bevelhimer, and DeRolph (2016) by FERC Licensing Region As

Described in Chapter 3 and Are As Follows: Mid-Atlantic (MA), Midwest (MW), New England (NE), Northwest (NW), South, and West

\begin{tabular}{|c|c|c|c|c|c|c|c|}
\hline $\begin{array}{l}\text { Tier-2 Category } \\
\text { Tier-3 Category }\end{array}$ & MA & MW & NE & NW & South & West & $\begin{array}{l}\text { Grand } \\
\text { Total }\end{array}$ \\
\hline Biodiversity & 52 & 148 & 59 & 247 & 82 & 225 & 813 \\
\hline Aquatic & 15 & 19 & 25 & 92 & 30 & 48 & 229 \\
\hline Adaptive fishery management & & 2 & & 13 & 2 & 2 & 19 \\
\hline Aquatic species conservation management monitoring & 6 & 11 & 12 & 39 & 14 & 28 & 110 \\
\hline Diadromous species management monitoring & 1 & & 5 & 20 & 3 & 7 & 36 \\
\hline Invasive aquatic species management (fish and mollusks) & 8 & 6 & 7 & 7 & 9 & 5 & 42 \\
\hline Stocking fish species of concern & & & 1 & 13 & 2 & 6 & 22 \\
\hline Terrestrial & 37 & 129 & 34 & 155 & 52 & 177 & 584 \\
\hline Acquisition easements-conservation or important habitat & & 4 & & 13 & 3 & & 20 \\
\hline Install upgrade monitor wildlife crossings & & & & 1 & & 19 & 20 \\
\hline Noxious terrestrial weed and invasive plant management & 10 & 11 & 1 & 33 & 4 & 48 & 107 \\
\hline Species conservation management monitoring & 16 & 57 & 19 & 22 & 26 & 46 & 186 \\
\hline Threatened and endangered species protection plan & & 5 & 6 & 19 & 1 & 22 & 53 \\
\hline Transmission related avian and bat protection & 2 & 4 & & 30 & 4 & 27 & 67 \\
\hline Wildlife terrestrial habitat management & 9 & 48 & 8 & 37 & 14 & 15 & 131 \\
\hline Fish Passage & 123 & 59 & 210 & 152 & 27 & 88 & 659 \\
\hline Downstream Fish Passage & 41 & 17 & 45 & 29 & 6 & 17 & 155 \\
\hline Bypass facility & 2 & & 3 & 1 & 3 & 1 & 10 \\
\hline Conduit & 2 & & 4 & & & & 6 \\
\hline Downstream passage plan study design & 11 & 14 & 29 & 9 & 3 & 5 & 71 \\
\hline Fish friendly turbine & & & & 1 & & & 1 \\
\hline Flashboard removal or modification & & & & & & 1 & 1 \\
\hline Generation shutdown & 2 & 2 & 6 & & & & 10 \\
\hline Modification of spill or gate operation & 6 & 1 & 2 & 5 & & 2 & 16 \\
\hline Modify bypass facility & & & & 1 & & & 1 \\
\hline Modify intake & & & & & & 1 & 1 \\
\hline Modify sluiceway & 8 & & & & & & 8 \\
\hline Modify spill or gate design & 9 & & 1 & 1 & & 2 & 13 \\
\hline Sluiceway & 1 & & & 1 & & & 2 \\
\hline Surface collector & & & & 5 & & 3 & 8 \\
\hline Trap and transport & & & & 5 & & 2 & 7 \\
\hline Entrainment & 50 & 9 & 19 & 14 & 8 & 12 & 112 \\
\hline Barrier or guidance net & 1 & 3 & & 3 & & 1 & 8 \\
\hline Fish screen & 1 & 1 & & 8 & 2 & 7 & 19 \\
\hline Gatewell exclusion screen & & & & 2 & & & 2 \\
\hline Perforated plate & & & 1 & & & & 1 \\
\hline Solid panel and bar rack & 1 & & 1 & & & & 2 \\
\hline Strobe light & & & & & & 1 & 1 \\
\hline Trash or bar rack & 47 & 5 & 17 & 1 & 6 & 3 & 79 \\
\hline Passage Planning & 15 & 26 & 76 & 74 & 6 & 40 & 237 \\
\hline Design plan entrainment avoidance system & & 7 & & & & 1 & 8 \\
\hline Downstream fish passage monitoring sampling & 6 & 1 & 32 & 16 & 3 & 7 & 65 \\
\hline Entrainment or turbine mortality monitoring & & 3 & & 12 & & 2 & 17 \\
\hline
\end{tabular}




\begin{tabular}{|c|c|c|c|c|c|c|c|c|}
\hline Tier-1 Category & $\begin{array}{c}\text { Tier-2 Category } \\
\text { Tier-3 Category }\end{array}$ & MA & MW & NE & NW & South & West & $\begin{array}{l}\text { Grand } \\
\text { Total }\end{array}$ \\
\hline & Fish passage and operations plan & 3 & 3 & 11 & 6 & & 11 & 34 \\
\hline & Fish passage feasibility assessment & & 1 & 3 & 6 & & 4 & 14 \\
\hline & Fish stranding plan monitoring evaluation & 2 & 10 & 6 & 10 & & 7 & 35 \\
\hline & Fisheries disease management & & & & 2 & & 1 & 3 \\
\hline & Hatchery operations and management & & & & 8 & & 1 & 9 \\
\hline & Upstream fish passage monitoring sampling & 4 & 1 & 24 & 14 & 3 & 6 & 52 \\
\hline & Upstream Fish Passage & 17 & 7 & 70 & 35 & 7 & 19 & 155 \\
\hline & Adult fishway & & 1 & & 1 & & & 2 \\
\hline & Conduit & 1 & & & & & & 1 \\
\hline & Eelway & 9 & & 21 & & 2 & & 32 \\
\hline & Fish ladder & 1 & & 6 & 2 & 1 & 4 & 14 \\
\hline & Lock or elevator & & & 10 & 1 & & & 11 \\
\hline & Modify adult fishway & & & & 1 & & & 1 \\
\hline & Modify fish ladder & & & 1 & 1 & & 2 & 4 \\
\hline & Modify lock or lift & & & 1 & & & & 1 \\
\hline & Modify spill or gate operation & & 1 & & & & & 1 \\
\hline & Modify trap and transport & & & & 2 & & 1 & 3 \\
\hline & Tailrace exclusion device & & 1 & 3 & 4 & & 2 & 10 \\
\hline & Trap and transport & & & 4 & 11 & 2 & 3 & 20 \\
\hline & Upstream passage study plan or design & 6 & 4 & 24 & 12 & 2 & 7 & 55 \\
\hline \multirow[t]{19}{*}{ Habitat } & & 31 & 124 & 52 & 135 & 63 & 85 & 490 \\
\hline & Fisheries & 9 & 40 & 7 & 37 & 16 & 34 & 143 \\
\hline & Downstream gravel and sediment restoration & 1 & & & 9 & & 12 & 22 \\
\hline & Downstream habitat enhancement & 5 & 2 & 7 & 16 & 3 & 8 & 41 \\
\hline & Downstream woody debris restoration or passage & 2 & 37 & & 11 & 4 & 13 & 67 \\
\hline & Reservoir fishery habitat enhancement & 1 & 1 & & 1 & 9 & 1 & 13 \\
\hline & Reservoir & 15 & 59 & 24 & 19 & 40 & 7 & 164 \\
\hline & Noxious invasive aquatic plant management & 11 & 50 & 11 & 8 & 10 & & 90 \\
\hline & Shoreline management plan or program & 4 & 9 & 13 & 11 & 30 & 7 & 74 \\
\hline & Riparian & & 21 & 16 & 35 & 6 & 32 & 110 \\
\hline & Dust control and abatement & & & & 2 & & 1 & 3 \\
\hline & Establish riparian buffers & & 17 & 8 & 8 & 2 & & 35 \\
\hline & Riparian habitat enhancement & & 2 & & 7 & 1 & 13 & 23 \\
\hline & Riparian habitat monitoring or planning & & 2 & 8 & 18 & 3 & 18 & 49 \\
\hline & Wetlands & 7 & 4 & 5 & 44 & 1 & 12 & 73 \\
\hline & Wetland enhancement & & & 1 & 3 & & & 4 \\
\hline & Wetland mitigation & 2 & 1 & 1 & 6 & & 12 & 22 \\
\hline & Wetland monitoring & 1 & & 3 & 10 & & & 14 \\
\hline & Wetland protection & 4 & 3 & & 25 & 1 & & 33 \\
\hline \multirow[t]{13}{*}{ Hydrology } & & 212 & 291 & 252 & 285 & 158 & 293 & 1491 \\
\hline & Bypass Minimum Flow & 27 & 19 & 43 & 31 & 17 & 50 & 187 \\
\hline & Seasonal and type of year bypass & & & & 3 & 2 & 11 & 16 \\
\hline & Seasonal bypass & 7 & 8 & 21 & 16 & 8 & 20 & 80 \\
\hline & Year-round bypass & 20 & 11 & 22 & 12 & 7 & 19 & 91 \\
\hline & Flow Mitigation & 78 & 68 & 81 & 102 & 41 & 112 & 482 \\
\hline & Bypass adaptive flow management & & & & 3 & 1 & & 4 \\
\hline & Bypass flow control device & & & 1 & & 1 & & 2 \\
\hline & Bypass flow monitoring plan & 14 & 6 & 14 & 7 & 5 & 15 & 61 \\
\hline & Bypass flow or stage monitoring equipment & 2 & 3 & 1 & 6 & 3 & 14 & 29 \\
\hline & Bypass flow study & & & 3 & 2 & 1 & 6 & 12 \\
\hline & Bypass flushing or flood flow & & 1 & & 6 & 2 & 16 & 25 \\
\hline & Bypass ramping rate restriction & & 1 & 2 & 10 & 1 & 12 & 26 \\
\hline
\end{tabular}




\begin{tabular}{|c|c|c|c|c|c|c|c|}
\hline $\begin{array}{r}\text { Tier-2 Category } \\
\text { Tier-3 Category }\end{array}$ & MA & MW & NE & NW & South & West & $\begin{array}{l}\text { Grand } \\
\text { Total }\end{array}$ \\
\hline Tailrace adaptive flow management & 2 & & & & 1 & 5 & 8 \\
\hline Tailrace flow control device & 2 & & 1 & 7 & 2 & 1 & 13 \\
\hline Tailrace flow monitoring plan & 46 & 13 & 43 & 17 & 18 & 27 & 164 \\
\hline Tailrace flow or stage monitoring equipment & 11 & 32 & 5 & 9 & 3 & 4 & 64 \\
\hline Tailrace flow studies & 1 & 2 & 2 & 6 & 3 & 2 & 16 \\
\hline Tailrace flushing or flood flows & & & & 9 & & & 9 \\
\hline Tailrace ramping rate restriction & & 10 & 9 & 20 & & 10 & 49 \\
\hline Operations & 21 & 71 & 47 & 41 & 40 & 34 & 254 \\
\hline Flow management plan & & 1 & 22 & 1 & 3 & 1 & 28 \\
\hline Operations compliance monitoring plan & 15 & 66 & 23 & 36 & 27 & 16 & 183 \\
\hline Provide flow or lake levels electronically & 6 & 4 & 2 & 4 & 10 & 17 & 43 \\
\hline Recreation Flow & 16 & 1 & 2 & 17 & 13 & 27 & 76 \\
\hline Maintain recreational lake levels & 2 & 1 & & 7 & 3 & 3 & 16 \\
\hline Provide recreational flow releases or structures & 11 & & 2 & 6 & 8 & 13 & 40 \\
\hline Recreational flow studies & 3 & & & 4 & 2 & 11 & 20 \\
\hline Sediment & 21 & 54 & 17 & 38 & 20 & 50 & 200 \\
\hline Dredging & & & 1 & & & & 1 \\
\hline Install or operate gate to flush sediment & & & & 1 & & 3 & 4 \\
\hline Sediment and erosion control plan or monitoring & 21 & 54 & 16 & 37 & 20 & 45 & 193 \\
\hline Sediment flushing flows & & & & & & 2 & 2 \\
\hline Tailrace Minimum Flow & 49 & 78 & 62 & 56 & 27 & 20 & 292 \\
\hline Run-of-river tailrace & 21 & 55 & 39 & 32 & 14 & 14 & 175 \\
\hline Seasonal and type of year tailrace & & 4 & & 1 & & 1 & 6 \\
\hline Seasonal tailrace & 10 & 14 & 14 & 16 & 5 & 2 & 61 \\
\hline Year-round tailrace & 18 & 5 & 9 & 7 & 8 & 3 & 50 \\
\hline Non-Ecological Benefits & 203 & 244 & 181 & 227 & 178 & 145 & 1178 \\
\hline Recreation Planning & 64 & 73 & 55 & 52 & 38 & 48 & 330 \\
\hline Recreational management plan study or monitoring & 64 & 73 & 55 & 52 & 38 & 48 & 330 \\
\hline Resources and Mitigation & 132 & 160 & 108 & 144 & 132 & 78 & 754 \\
\hline Trail trailhead or camping areas & 9 & 5 & 6 & 25 & 11 & 13 & 69 \\
\hline Boating facilities & 20 & 14 & 15 & 26 & 17 & 15 & 107 \\
\hline Canoe portage launch & 37 & 33 & 24 & 7 & 10 & 2 & 113 \\
\hline Fishing pier & 2 & 15 & 2 & 3 & 17 & 2 & 41 \\
\hline Floating debris removal & 2 & & 3 & & & & 5 \\
\hline Install fish attracting structure for recreational fishing & 2 & 1 & & & 9 & & 12 \\
\hline Navigational aids and improvements & 3 & & & & 2 & & 5 \\
\hline Other day use area improvements & 21 & 41 & 27 & 37 & 15 & 21 & 162 \\
\hline Parking & 26 & 17 & 22 & 23 & 25 & 13 & 126 \\
\hline Shoreline access & 9 & 33 & 7 & 9 & 20 & 8 & 86 \\
\hline Stocking recreational fish species & 1 & 1 & 2 & 14 & 6 & 4 & 28 \\
\hline Cultural and Historic Resources and Public Education & 7 & 11 & 18 & 31 & 8 & 19 & 94 \\
\hline Appoint historic cultural resource coordinator & & & & 2 & & & 2 \\
\hline Interpretive education sign and displays & 5 & 9 & 14 & 26 & 5 & 14 & 73 \\
\hline Public outreach education programs & & & & & & 3 & 3 \\
\hline Protection of specific historic cultural resource sites & 2 & 2 & 4 & 3 & 3 & 2 & 16 \\
\hline Water Quality & 27 & 177 & 65 & 100 & 46 & 84 & 499 \\
\hline Downstream Water Quality & 22 & 70 & 48 & 72 & 41 & 67 & 320 \\
\hline Adaptive water quality management & 1 & 2 & 1 & 4 & 1 & 8 & 17 \\
\hline Benthic macroinvertebrate monitoring & 2 & 1 & 4 & 4 & 3 & 5 & 19 \\
\hline Dissolved oxygen enhancement or mitigation plan & 1 & 4 & 6 & 2 & 10 & & 23 \\
\hline Establish or fund water quality stations and stream gages & & 3 & 1 & 5 & 3 & 3 & 15 \\
\hline Forebay aeration & & & 1 & & & & 1 \\
\hline
\end{tabular}


Tier-2 Category

Tier-3 Category Operational changes Powerhouse aeration

Tailrace structures for aeration Temperature regulating device or structure Temperature regulation or mitigation plan Water quality monitoring plan Upstream Water Quality
Fish tissue sampling and analysis
Impoundment sediment analysis
Impoundment water quality monitoring plan
Inflow water quality monitoring plan
Macroinvertebrate monitoring Upstream Water Quality
Fish tissue sampling and analysis
Impoundment sediment analysis
Impoundment water quality monitoring plan
Inflow water quality monitoring plan
Macroinvertebrate monitoring Upstream Water Quality
Fish tissue sampling and analysis
Impoundment sediment analysis
Impoundment water quality monitoring plan
Inflow water quality monitoring plan
Macroinvertebrate monitoring Upstream Water Quality
Fish tissue sampling and analysis
Impoundment sediment analysis
Impoundment water quality monitoring plan
Inflow water quality monitoring plan
Macroinvertebrate monitoring Upstream Water Quality
Fish tissue sampling and analysis
Impoundment sediment analysis
Impoundment water quality monitoring plan
Inflow water quality monitoring plan
Macroinvertebrate monitoring Upstream Water Quality
Fish tissue sampling and analysis
Impoundment sediment analysis
Impoundment water quality monitoring plan
Inflow water quality monitoring plan
Macroinvertebrate monitoring

$\begin{array}{lllllll}\text { MA } & \text { MW } & \text { NE } & \text { NW } & \text { South } & \text { West } & \begin{array}{l}\text { Grand } \\ \text { Total }\end{array} \\ 3 & 2 & 2 & 3 & 2 & 1 & 13 \\ 1 & 1 & 2 & 2 & 3 & 1 & 10 \\ 1 & & & & & & 1 \\ & & & 1 & 1 & 1 & 3 \\ 1 & & & & & 1 & 2 \\ 12 & 57 & 31 & 51 & 18 & 47 & 216 \\ 5 & 107 & 17 & 28 & 5 & 17 & 179 \\ & 26 & 5 & 2 & & & 33 \\ & 30 & & 1 & & & 31 \\ 3 & 24 & 9 & 18 & 4 & 15 & 73 \\ 2 & 27 & & 7 & 1 & 2 & 39 \\ & & 3 & & & & 3 \\ \mathbf{6 4 8} & \mathbf{1 , 0 4 3} & \mathbf{8 1 9} & \mathbf{1 , 1 4 6} & \mathbf{5 5 4} & \mathbf{9 2 0} & \mathbf{5 , 1 3 0}\end{array}$

Grand Total

.

$\begin{array}{lllll}1,043 & 819 & 1,146 & 554 & 920\end{array}$

Table D2. Number of Mitigation Measures by Tier 1 Category for Species Mentioned in FERC Licenses

\begin{tabular}{|c|c|c|c|c|c|c|c|}
\hline Species Listed in License & $\begin{array}{l}\text { \# Biodiv. } \\
\text { Measures }\end{array}$ & $\begin{array}{c}\text { \# Fish } \\
\text { Pass. } \\
\text { Measures }\end{array}$ & $\begin{array}{l}\text { \# Habitat } \\
\text { Measures }\end{array}$ & $\begin{array}{l}\text { \# Hydrol. } \\
\text { Measures }\end{array}$ & $\begin{array}{l}\text { \# Non- } \\
\text { Ecol. } \\
\text { Measures }\end{array}$ & $\begin{array}{c}\text { \# Water } \\
\text { Quality } \\
\text { Measures }\end{array}$ & Grand Total \\
\hline Alewife & 23 & 147 & 25 & 95 & 92 & 24 & 406 \\
\hline American Eel & 69 & 197 & 50 & 175 & 125 & 37 & 653 \\
\hline American Shad & 62 & 180 & 48 & 142 & 114 & 38 & 584 \\
\hline Arctic Grayling & 1 & 2 & 1 & 7 & & 2 & 13 \\
\hline Atlantic Salmon & 45 & 154 & 35 & 121 & 68 & 29 & 452 \\
\hline Atlantic Sturgeon & 11 & 20 & 3 & 17 & 15 & 9 & 75 \\
\hline Black Buffalo & 4 & & 1 & & 4 & 1 & 10 \\
\hline Blueback Herring & 43 & 151 & 41 & 121 & 98 & 32 & 486 \\
\hline Brown Trout & 2 & 16 & 10 & 18 & 22 & 3 & 71 \\
\hline Bull Trout & 78 & 96 & 34 & 47 & 49 & 32 & 336 \\
\hline Chinook Salmon & 124 & 159 & 59 & 90 & 85 & 52 & 569 \\
\hline Chum Salmon & 10 & 30 & 6 & 16 & 17 & 7 & 86 \\
\hline Coho Salmon & 64 & 92 & 32 & 45 & 50 & 33 & 316 \\
\hline Cutthroat Trout & 41 & 60 & 24 & 36 & 42 & 20 & 223 \\
\hline Dolly Varden & 1 & & & 3 & 1 & & 5 \\
\hline Duskytail Darter & 4 & & 1 & & 4 & 1 & 10 \\
\hline Greater Redhorse & 2 & 6 & 3 & 4 & 3 & & 18 \\
\hline Hickory Shad & 9 & 12 & 3 & 13 & 15 & 9 & 61 \\
\hline Lake Sturgeon & 12 & 12 & 6 & 10 & 9 & 1 & 50 \\
\hline Mountain Whitefish & 37 & 32 & 17 & 11 & 12 & 8 & 117 \\
\hline Pacific Lamprey & 71 & 77 & 25 & 27 & 37 & 28 & 265 \\
\hline Pink Salmon & 2 & 11 & 1 & 8 & 2 & 4 & 28 \\
\hline Rainbow Smelt & 7 & 26 & 3 & 22 & 10 & 1 & 69 \\
\hline $\begin{array}{r}\text { Rainbow Trout or } \\
\text { Steelhead }\end{array}$ & 116 & 154 & 49 & 90 & 91 & 50 & 550 \\
\hline
\end{tabular}




\begin{tabular}{|rccccccc|}
\hline Species Listed in License & $\begin{array}{c}\text { \# Biodiv. } \\
\text { Measures }\end{array}$ & $\begin{array}{c}\text { \# Fish } \\
\text { Pass. } \\
\text { Measures }\end{array}$ & $\begin{array}{c}\text { \# Habitat } \\
\text { Measures }\end{array}$ & $\begin{array}{c}\text { \# Hydrol. } \\
\text { Measures }\end{array}$ & $\begin{array}{c}\text { \# Non- } \\
\text { Ecol. } \\
\text { Measures }\end{array}$ & $\begin{array}{c}\text { \# Water } \\
\text { Quality } \\
\text { Measures }\end{array}$ & Grand Total \\
\hline River Redhorse & 4 & & 1 & & 4 & 1 & 10 \\
\hline Robust Redhorse & & 4 & & 2 & & & 6 \\
\hline Sauger & 4 & & 1 & & 4 & 1 & 10 \\
\hline Sea Lamprey & 9 & 12 & 3 & 13 & 15 & 9 & 61 \\
\hline Smallmouth Buffalo & 4 & & 21 & 64 & 30 & 21 & 226 \\
\hline Smoky Madtom & 4 & & 1 & & 4 & 1 & 10 \\
\hline Sockeye Salmon & 54 & 49 & 19 & 21 & 24 & 12 & 179 \\
\hline Spotfin Chub & 4 & & 1 & & 4 & 1 & 10 \\
\hline Striped Bass & 11 & 33 & 3 & 22 & 20 & 9 & 98 \\
\hline Walleye & 2 & 6 & 3 & 4 & 3 & 17 & 18 \\
\hline White Sturgeon & 19 & 10 & 5 & 7 & 17 & 9 & 67 \\
\hline Yellowfin Madtom & 4 & & 1 & & 4 & 1 & 10 \\
\hline Grand Total & $\mathbf{9 9 5}$ & $\mathbf{1 , 8 0 0}$ & $\mathbf{5 3 7}$ & $\mathbf{1 , 2 5 1}$ & $\mathbf{1 , 0 9 8}$ & $\mathbf{4 8 7}$ & $\mathbf{6 , 1 6 8}$ \\
\hline
\end{tabular}




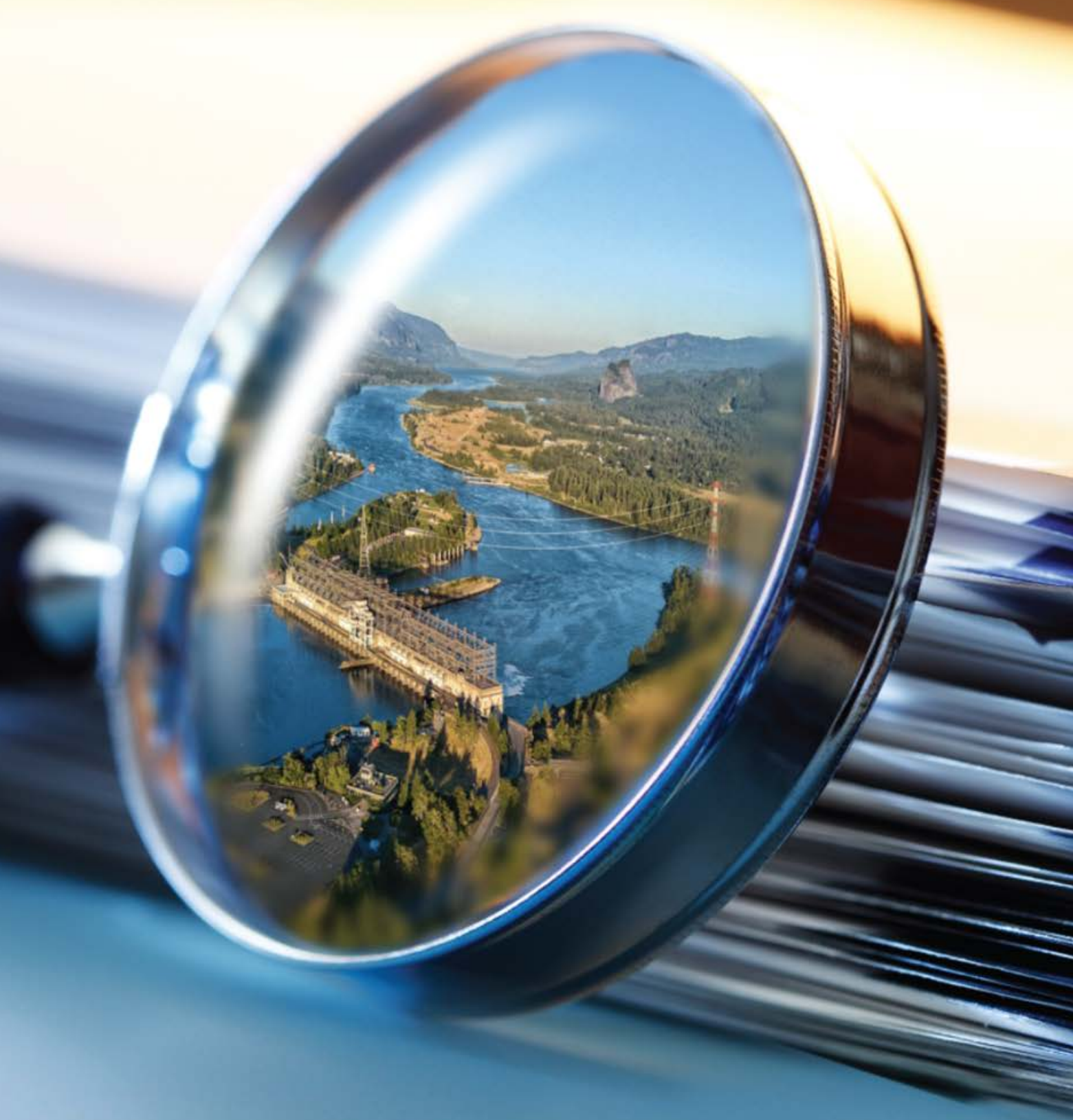

AN EXAMINATION OF THE HYDROPOWER LICENSING AND FEDERAL AUTHORIZATION PROCESS

APPENDIX

Summary and Overview of the Federal Energy

Regulatory Commission's Legislative, Regulatory, and Policy Recommendations From the 2001603 Report 


\section{Appendix E. Summary and Overview of the Federal Energy Regulatory Commission's Legislative, Regulatory, and Policy Recommendations From the 2001603 Report}

This appendix contains two tables that provide an overview and summary of the Federal Energy Regulatory Commissions (FERC's) legislative, regulatory, and policy recommendations from the 2001603 Report. Table E1 provides a summary of FERC's legislative recommendations and the status of the recommendation including whether it was enacted and the final form of the recommendation. Notably, some of FERC's recommendations were implemented only in part or through the invocation of a different mechanism (e.g., executive order instead of congressional amendment).

Table E1. FERC's 2001 Legislative Recommendations

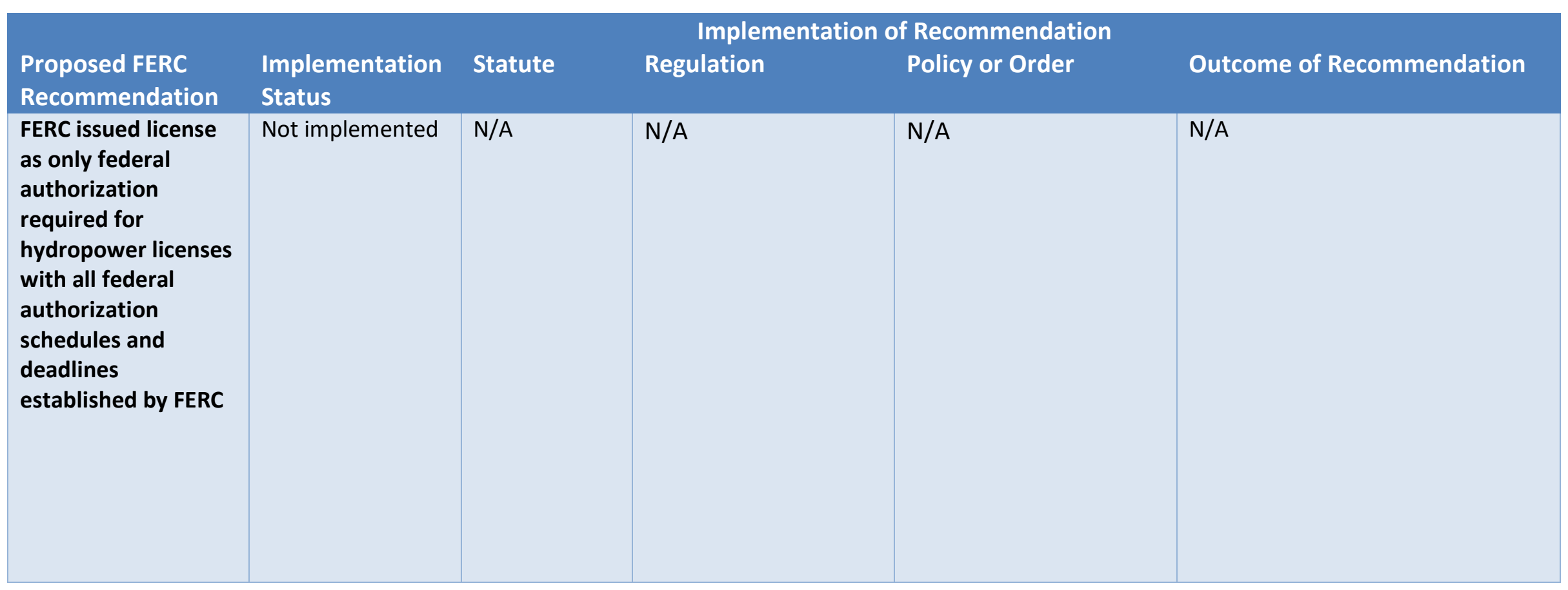




\begin{tabular}{|c|c|c|c|c|c|}
\hline \multirow[b]{2}{*}{$\begin{array}{l}\text { Proposed FERC } \\
\text { Recommendation }\end{array}$} & \multicolumn{5}{|c|}{ Implementation of Recommendation } \\
\hline & $\begin{array}{l}\text { Implementation } \\
\text { Status }\end{array}$ & Statute & Regulation & Policy or Order & Outcome of Recommendation \\
\hline $\begin{array}{l}\text { Preparation of a } \\
\text { single National } \\
\text { Environmental Policy } \\
\text { Act of } 1969 \text { (NEPA) } \\
\text { document for } \\
\text { hydropower projects }\end{array}$ & $\begin{array}{l}\text { Implemented } \\
\text { through executive } \\
\text { order (EO) and } \\
\text { memorandum of } \\
\text { understanding } \\
\text { (MOU) }\end{array}$ & $\mathrm{N} / \mathrm{A}$ & N/A & $\begin{array}{l}\text { Exec. Order 13,807, } 82 \\
\text { Fed. Reg. } 163 \text { (Aug. 15, } \\
\text { 2017) (EO 13807). } \\
\text { MOU between U.S. Army } \\
\text { Corp of Engineers } \\
\text { (USACE) and the Federal } \\
\text { Energy Regulatory } \\
\text { Commission on Non- } \\
\text { Federal Hydropower } \\
\text { Projects 4-5 (2011) }\end{array}$ & $\begin{array}{l}\text { Executive Order } 13807 \text { established } \\
\text { the One Federal Decision approach } \\
\text { which requires that lead federal } \\
\text { agencies navigate major } \\
\text { infrastructure projects through } \\
\text { federal environmental review and } \\
\text { create a single record of decision } \\
\text { encapsulating the decisions of all } \\
\text { involved agencies (EO 13807). } \\
\text { In } 2011, \text { FERC and USACE entered } \\
\text { into a memorandum of } \\
\text { understanding, which designated } \\
\text { FERC as the lead federal agency } \\
\text { with responsibility for preparing a } \\
\text { single NEPA document for non- } \\
\text { federal hydropower licensing } \\
\text { projects for which USACE is a } \\
\text { cooperating agency. }\end{array}$ \\
\hline
\end{tabular}




\begin{tabular}{|c|c|c|c|c|c|}
\hline \multirow[b]{2}{*}{$\begin{array}{l}\text { Proposed FERC } \\
\text { Recommendation }\end{array}$} & \multicolumn{5}{|c|}{ Implementation of Recommendation } \\
\hline & $\begin{array}{l}\text { Implementation } \\
\text { Status }\end{array}$ & Statute & Regulation & Policy or Order & Outcome of Recommendation \\
\hline $\begin{array}{l}\text { Establish an } \\
\text { administrative } \\
\text { appeals process for } \\
\text { agency conditions }\end{array}$ & $\begin{array}{l}\text { Implemented } \\
\text { through the } \\
\text { Energy Policy Act } \\
\text { of } 2005 \text { and } \\
\text { through the jointly } \\
\text { revised rules for } \\
\text { expedited trial- } \\
\text { type hearings of } \\
\text { the U.S. } \\
\text { Departments of } \\
\text { Agriculture, } \\
\text { Interior, and } \\
\text { Commerce }\end{array}$ & $\begin{array}{l}\text { Energy Policy } \\
\text { Act of } 2005, \\
\text { Pub. L. No. } \\
\text { 109-58, § 241, } \\
119 \text { Stat. } 594 \\
\text { (2005) }\end{array}$ & $\begin{array}{l}7 \text { C.F.R. } \S \S 1.601- \\
\text { 1.675, Conditions in } \\
\text { FERC Hydropower } \\
\text { Licenses; } \\
43 \text { C.F.R. } \S \S 45.1 \text { - } \\
\text { 45.75, Conditions and } \\
\text { Prescriptions in FERC } \\
\text { Hydropower Licenses; } \\
50 \text { C.F.R. } \S \S 221.1 \text { - } \\
\text { 221.75, Conditions and } \\
\text { Prescriptions in FERC } \\
\text { Hydropower Licenses }\end{array}$ & N/A & $\begin{array}{l}\text { Section } 241 \text { of the Energy Policy Act } \\
\text { of } 2005 \text { entitles the applicant or } \\
\text { any party to the proceeding to a } \\
\text { "trial-type hearing" on any } \\
\text { disputed issues with respect to } \\
\text { agency-imposed conditions and } \\
\text { prescriptions. In 2016, the U.S. } \\
\text { Departments of Agriculture, } \\
\text { Interior, and Commerce issued } \\
\text { jointly revised final rules for } \\
\text { expedited trial-type hearings } \\
\text { pursuant to the Energy Policy Act of } \\
2005 \text {. }\end{array}$ \\
\hline $\begin{array}{l}\text { Agencies must } \\
\text { consider the public } \\
\text { interest in drafting } \\
\text { conditions }\end{array}$ & Not implemented & N/A & N/A & N/A & N/A \\
\hline $\begin{array}{l}\text { Congressional } \\
\text { amendment to Clean } \\
\text { Water Act (CWA) } \\
\text { clarifying that } \\
\text { Section } 401 \text { water } \\
\text { quality certification } \\
\text { (WQC) be limited to } \\
\text { physical and } \\
\text { chemical water } \\
\text { quality parameters }\end{array}$ & $\begin{array}{l}\text { Implemented } \\
\text { through U.S. } \\
\text { Environmental } \\
\text { Protection Agency } \\
\text { (EPA) updates to } \\
\text { CWA Section } 401 \\
\text { Certification Rule } \\
\text { to establish } \\
\text { procedures to } \\
\text { promote } \\
\text { consistent }\end{array}$ & N/A & N/A & $\begin{array}{l}\text { EPA CWA Section } 401 \\
\text { Guidance for Federal } \\
\text { Agencies, States and } \\
\text { Authorized Tribes (June } \\
\text { 7, 2019). } \\
40 \text { C.F.R. § } 121 \text { (2020) }\end{array}$ & $\begin{array}{l}\text { On June } 1,2020 \text {, the EPA finalized } \\
\text { the CWA Section } 401 \text { Certification } \\
\text { Rule. The new } 401 \text { certification rule } \\
\text { reaffirms the statutory } \\
\text { requirement that action on a } 401 \\
\text { certification must be issued no } \\
\text { later than } 1 \text { year after receipt of } \\
\text { the request, clarifies that the scope } \\
\text { of a certifying authority is limited } \\
\text { to an evaluation of potential water } \\
\text { quality impacts, reaffirms the }\end{array}$ \\
\hline
\end{tabular}




\begin{tabular}{|c|c|c|c|c|c|}
\hline \multirow[b]{2}{*}{$\begin{array}{l}\text { Proposed FERC } \\
\text { Recommendation }\end{array}$} & \multicolumn{5}{|c|}{ Implementation of Recommendation } \\
\hline & $\begin{array}{l}\text { Implementation } \\
\text { Status }\end{array}$ & Statute & Regulation & Policy or Order & Outcome of Recommendation \\
\hline & $\begin{array}{l}\text { implementation of } \\
\text { CWA Section } 401\end{array}$ & & & & $\begin{array}{l}\text { agency's responsibility to provide } \\
\text { technical assistance to parties } \\
\text { requesting a certification, and } \\
\text { promotes early engagement and } \\
\text { coordination among project } \\
\text { proponents. }\end{array}$ \\
\hline $\begin{array}{l}\text { Provide a statutory } \\
\text { definition of the } \\
\text { term "fishway" }\end{array}$ & Not implemented & $\mathrm{N} / \mathrm{A}$ & N/A & $\mathrm{N} / \mathrm{A}$ & $\mathrm{N} / \mathrm{A}$ \\
\hline $\begin{array}{l}\text { Congressional } \\
\text { amendment to } \\
\text { Federal Power Act to } \\
\text { permit FERC to remit } \\
\text { administrative } \\
\text { annual charges } \\
\text { directly to agencies }\end{array}$ & Not implemented & $\mathrm{N} / \mathrm{A}$ & $\mathrm{N} / \mathrm{A}$ & $\mathrm{N} / \mathrm{A}$ & $\mathrm{N} / \mathrm{A}$ \\
\hline
\end{tabular}

Table E2 provides a summary of FERC's regulatory and policy recommendations and status of the recommendation including whether it was enacted and the final form of the recommendation. Notably, some of FERC's recommendations were implemented only in part or through the invocation of a different mechanism. 
Table E2. FERC's 2001 Regulatory and Policy Recommendations

\begin{tabular}{|c|c|c|c|c|c|}
\hline \multirow[b]{2}{*}{$\begin{array}{l}\text { Proposed FERC } \\
\text { Recommendation }\end{array}$} & \multicolumn{5}{|c|}{ Implementation of Recommendation } \\
\hline & $\begin{array}{l}\text { Implementation } \\
\text { Status }\end{array}$ & Statute & Regulation & $\begin{array}{l}\text { Policy or } \\
\text { Order }\end{array}$ & Outcome of Recommendation \\
\hline $\begin{array}{l}\text { License applicants } \\
\text { must report on } \\
\text { status of pre-filing } \\
\text { consultations }\end{array}$ & $\begin{array}{l}\text { Implemented through } \\
\text { FERC's adoption of } \\
\text { the Integrated } \\
\text { Licensing Process } \\
\text { (ILP) in } 2003\end{array}$ & & $\begin{array}{l}18 \text { C.F.R. §§ 5.1- } \\
5.31 \text {, Integrated } \\
\text { License } \\
\text { Application } \\
\text { Process }\end{array}$ & N/A & $\begin{array}{l}\text { The ILP requires that an applicant submit a } \\
\text { plan and schedule to FERC that } \\
\text { incorporates time frames for prefiling } \\
\text { consultations, information gathering, and } \\
\text { studies. } 18 \text { C.F.R. } § 5.6(d)(1) \text {. }\end{array}$ \\
\hline $\begin{array}{l}\text { FERC approval } \\
\text { required for agency } \\
\text { revisions of terms, } \\
\text { recommendations, } \\
\text { and conditions }\end{array}$ & Not implemented & N/A & N/A & $\mathrm{N} / \mathrm{A}$ & N/A \\
\hline $\begin{array}{l}\text { License applicants } \\
\text { required to include } \\
\text { the public and non- } \\
\text { governmental } \\
\text { organizations } \\
\text { (NGOs) in pre-filing } \\
\text { consultations }\end{array}$ & $\begin{array}{l}\text { Implemented through } \\
\text { FERC's adoption of } \\
\text { the ILP in } 2003\end{array}$ & N/A & $\begin{array}{l}18 \text { C.F.R. } \S \S 5.1- \\
5.31, \text { Integrated } \\
\text { License } \\
\text { Application } \\
\text { Process }\end{array}$ & N/A & $\begin{array}{l}\text { The ILP requires that an applicant consult } \\
\text { with all interested parties including local, } \\
\text { regional, and national NGOs and members } \\
\text { of the public prior to filing an application } \\
\text { for a license. } 18 \text { C.F.R. } § 5.1 \text { (d). }\end{array}$ \\
\hline $\begin{array}{l}\text { Allow license } \\
\text { applicants to } \\
\text { maintain public } \\
\text { information } \\
\text { electronically } \\
\text { instead of in paper } \\
\text { form where } \\
\text { appropriate }\end{array}$ & $\begin{array}{l}\text { Implemented through } \\
\text { FERC's adoption of an } \\
\text { e-Filing system and } \\
\text { FERC e-library }\end{array}$ & N/A & N/A & N/A & $\begin{array}{l}\text { FERC has produced guidance for applicants } \\
\text { regarding e-filing requirements for } \\
\text { hydropower license applications: } \\
\text { https://www.ferc.gov/docs- } \\
\text { filing/efiling/filing.pdf and a guide to the e- } \\
\text { filing process generally: } \\
\text { https://www.ferc.gov/docs-filing/efiling- } \\
\text { user-guide.pdf. In addition, the FERC e- } \\
\text { Library provides a tool for the public to } \\
\text { search for application information stored } \\
\text { online. }\end{array}$ \\
\hline $\begin{array}{l}\text { Continue to } \\
\text { promote the }\end{array}$ & Implemented & N/A & N/A & N/A & $\begin{array}{l}\text { The ALP continues to be an option for } \\
\text { license applicants under FERC regulations. }\end{array}$ \\
\hline
\end{tabular}




\begin{tabular}{|c|c|c|c|c|c|}
\hline \multirow[b]{2}{*}{$\begin{array}{l}\text { Proposed FERC } \\
\text { Recommendation }\end{array}$} & \multicolumn{5}{|c|}{ Implementation of Recommendation } \\
\hline & $\begin{array}{l}\text { Implementation } \\
\text { Status }\end{array}$ & Statute & Regulation & $\begin{array}{l}\text { Policy or } \\
\text { Order }\end{array}$ & Outcome of Recommendation \\
\hline \multicolumn{6}{|l|}{$\begin{array}{l}\text { Alternative } \\
\text { Licensing Process } \\
\text { (ALP) }\end{array}$} \\
\hline $\begin{array}{l}\text { Continue to } \\
\text { promote } \\
\text { settlement of } \\
\text { disputes }\end{array}$ & $\begin{array}{l}\text { Promoted through } \\
2006 \text { FERC policy } \\
\text { statement } \\
\text { encouraging } \\
\text { settlement of study } \\
\text { disputes. Also } \\
\text { implemented through } \\
\text { the ILP's built-in } \\
\text { study dispute } \\
\text { resolution process }\end{array}$ & N/A & $\begin{array}{l}18 \text { C.F.R. } \S 5.1- \\
5.31, \text { Integrated } \\
\text { License } \\
\text { Application } \\
\text { Process }\end{array}$ & $\begin{array}{l}\text { Policy } \\
\text { Statement on } \\
\text { Hydropower } \\
\text { Licensing } \\
\text { Settlements, } \\
\text { FERC (2006) } \\
\text { (FERC 2006a) }\end{array}$ & $\begin{array}{l}\text { In } 2006, \text { FERC released a policy statement } \\
\text { noting that it favors settlements in licensing } \\
\text { cases and containing guidance regarding } \\
\text { the circumstances in which settlement is } \\
\text { appropriate and likely to be accepted by } \\
\text { FERC. (FERC 2006a). In addition, the ILP has } \\
\text { a built-in dispute resolution process to } \\
\text { encourage settlement of study disputes. } 18 \\
\text { C.F.R. } \$ 5.14 \text {. }\end{array}$ \\
\hline $\begin{array}{l}\text { Eliminate policy } \\
\text { requiring draft } \\
\text { environmental } \\
\text { assessments }\end{array}$ & $\begin{array}{l}\text { Implemented on a } \\
\text { project-specific basis }\end{array}$ & N/A & N/A & N/A & N/A \\
\hline $\begin{array}{l}\text { Eliminate issuance } \\
\text { of second scoping } \\
\text { document }\end{array}$ & $\begin{array}{l}\text { Implemented on a } \\
\text { project-specific basis }\end{array}$ & N/A & N/A & N/A & N/A \\
\hline $\begin{array}{l}\text { Increase default } \\
\text { licensing term for } \\
\text { new licenses from } \\
30 \text { to } 50 \text { years }\end{array}$ & $\begin{array}{l}\text { Default licensing term } \\
\text { for new licenses } \\
\text { increased from } 30 \text { to } \\
40 \text { years in } 2017\end{array}$ & N/A & N/A & $\begin{array}{l}\text { Policy } \\
\text { Statement on } \\
\text { Establishing } \\
\text { License Terms } \\
\text { for } \\
\text { Hydroelectric } \\
\text { Projects, } 161 \\
\text { FERC } \text { ๆ } 61,078 \\
\text { (2017) (FERC } \\
\text { 2017) }\end{array}$ & $\begin{array}{l}\text { In 2017, FERC issued a policy statement } \\
\text { adopting a } 40 \text {-year default license term for } \\
\text { original and new licenses for hydropower } \\
\text { projects located at non-federal dams (FERC } \\
\text { 2017). }\end{array}$ \\
\hline
\end{tabular}

